\title{
083 ๔isis
}

\section{THE STATUS AND DISTRIBUTION OF FRESHWATER BIODIVERSITY IN THE EASTERN MEDITERRANEAN}

Kevin G. Smith, Violeta Barrios, William R.T. Darwall, and Catherine Numa (Editors)

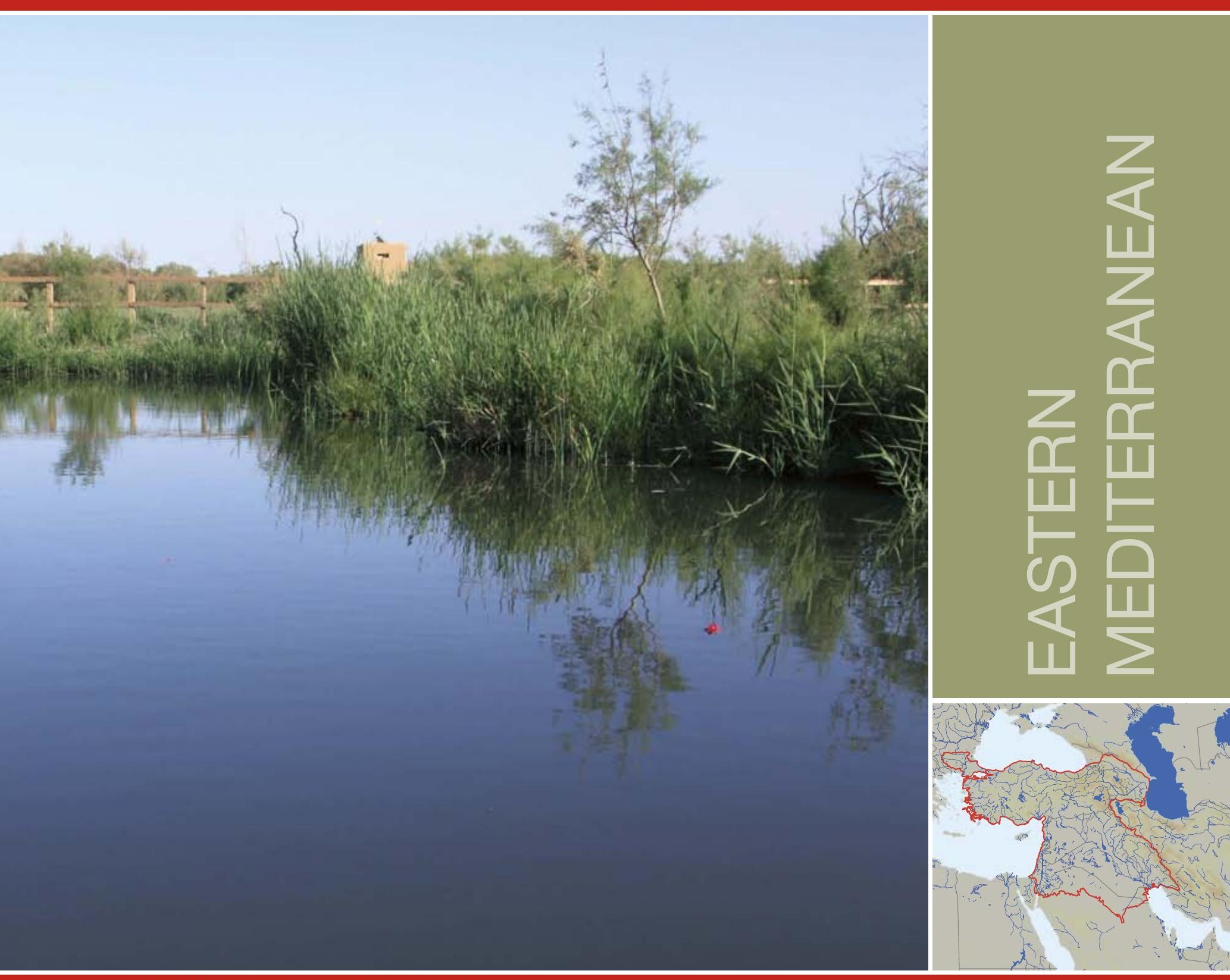




\section{About IUCN}

IUCN, International Union for Conservation of Nature, helps the world find pragmatic solutions to our most pressing environment and development challenges. IUCN's work focuses on valuing and conserving nature, ensuring effective and equitable governance of its use, and deploying nature-based solutions to global challenges in climate, food and development. IUCN supports scientific research, manages field projects all over the world, and brings governments, NGOs, the UN and companies together to develop policy, laws and best practice. IUCN is the world's oldest and largest global environmental organization, with more than 1,200 government and NGO Members and almost 11,000 volunteer experts in some 160 countries. IUCN's work is supported by over 1,000 staff in 45 offices and hundreds of partners in public, NGO and private sectors around the world.

www.iucn.org

\section{IUCN - The Species Survival Commission}

The Species Survival Commission (SSC) is the largest of IUCN's six volunteer commissions with a global membership of 7,000 experts. SSC advises IUCN and its members on the wide range of technical and scientific aspects of species conservation and is dedicated to securing a future for biodiversity. SSC has significant input into the international agreements dealing with biodiversity conservation.

\section{http://www.iucn.org/about/work/programmes/species/who_we_are/about_the_species_survival_commission_/}

\section{IUCN - Global Species Programme}

The IUCN Species Programme supports the activities of the IUCN Species Survival Commission and individual Specialist Groups, as well as implementing global species conservation initiatives. It is an integral part of the IUCN Secretariat and is managed from IUCN's international headquarters in Gland, Switzerland. The Species Programme includes a number of technical units covering Species Trade and Use, the IUCN Red List Unit, Freshwater Biodiversity Unit (all located in Cambridge, UK), the Global Biodiversity Assessment Initiative (located in Washington DC, USA), and the Marine Biodiversity Unit (located in Norfolk, Virginia, USA).

\section{www.iucn.org/species}

\section{IUCN - Centre for Mediterranean Cooperation}

The Centre was opened in October 2001 with the core support of the Spanish Ministry of Agriculture, Fisheries and Environment, the regional Government of Junta de Andalucía and the Spanish Agency for International Development Cooperation (AECID). IUCN has over 172 members in the Mediterranean region, including 15 governments. Its mission is to influence, encourage, and assist Mediterranean societies to conserve and use sustainably the natural resources of the region and work with IUCN members and cooperate with all other agencies that share the objectives of the IUCN.

\section{http://www.iucn.org/about/union/secretariat/offices/iucnmed}




\section{THE STATUS AND DISTRIBUTION OF FRESHWATER BIODIVERSITY IN THE EASTERN MEDITERRANEAN}

Kevin G. Smith, Violeta Barrios, William R.T. Darwall, and Catherine Numa (Editors) 


\section{THE STATUS AND DISTRIBUTION OF FRESHWATER BIODIVERSITY IN THE EASTERN MEDITERRANEAN}

Kevin G. Smith, Violeta Barrios, William R.T. Darwall, and Catherine Numa (Editors)

The designation of geographical entities in this book and the presentation of the material, do not imply the expression of any opinion whatsoever on the part of IUCN concerning the legal status of any country, territory or area, or its authorities, or concerning the delimitation of its frontiers or boundaries.

For improved readability the names of countries have been shortened as below:

The Republic of Armenia as Armenia, the Republic of Azerbaijan as Azerbaijan, the Republic of Iraq as Iraq, the Islamic Republic of Iran as Iran, the State of Israel as Israel, Hashemite Kingdom of Jordan is referred to as Jordan, the Lebanese Republic as Lebanon, the State of Palestine as Palestine, the Syrian Arab Republic as Syria, and the Republic of Turkey as Turkey.

The views expressed in this publication do not necessarily reflect those of IUCN, other participating organizations or donors.

Published by:

IUCN, Cambridge, UK, Malaga, Spain and Gland, Switzerland

Copyright:

\section{(c) 2014 International Union for Conservation of Nature and Natural Resources}

Reproduction of this publication for educational or other non-commercial purposes is authorized without prior written permission from the copyright holder provided the source is fully acknowledged.

Reproduction of this publication for resale or other commercial purposes is prohibited without prior written permission of the copyright holder.

Red List logo: $\quad$ (C) 2008

Citation: $\quad$ Smith, K.G., Barrios, V., Darwall, W.R.T. and Numa, C. (Editors). 2014. The Status and Distribution of Freshwater Biodiversity in the Eastern Mediterranean. Cambridge, UK, Malaga, Spain and Gland, Switzerland: IUCN. xiv+132pp.

ISBN:

$978-2-8317-1699-2$

DOI:

10.2305/IUCN.CH.2014.01.en

Cover design:

NatureBureau

Cover photo:

Azraq Wetland in Jordan dried up in 1992 and the endemic fish Aphanius sirhani had to be rescued and bred in captivity. Now the wetlands are partially restored, though they rely upon pumped water, and Aphanius sirhani has been successfully re-introduced. (c) Kevin Smith

All photographs used in this publication remain the property of the original copyright holder (see individual captions for details). Photographs should not be reproduced or used in other contexts without written permission from the copyright holder.

Layout by:

NatureBureau

Printed by:

Solprint, Mijas (Málaga), Spain

Available from:

IUCN-Centre for Mediterranean Cooperation (International Union for Conservation of Nature), Marie Curie 22, 29590 Málaga, Spain, Tel: +34-952028430

This publication was funded by Critical Ecosystem Partnership Fund (CEPF) and MAVA Foundation.

The Critical Ecosystem Partnership Fund (CEPF) is a joint initiative of l'Agence Française de Développement, Conservation International, the European Union, the Global Environment Facility, the Government of Japan, the MacArthur Foundation and the World Bank. A fundamental goal is to ensure civil society is engaged in biodiversity conservation.

If you have any questions regarding the data and outputs presented in this report, please contact the IUCN Freshwater Biodiversity Unit (Freshwater.Biodiversity @iucn.org). 


\section{Contents}

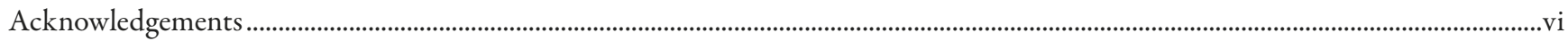

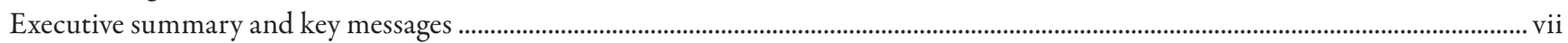

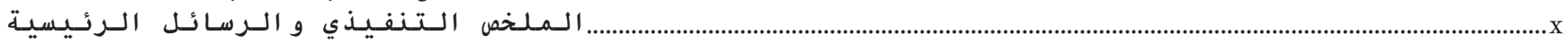

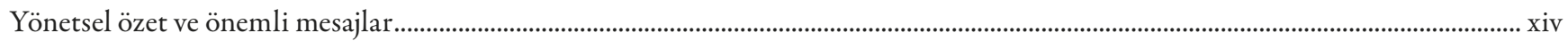

Chapter 1. Background to freshwater biodiversity in the Eastern Mediterranean ................................................................... 1

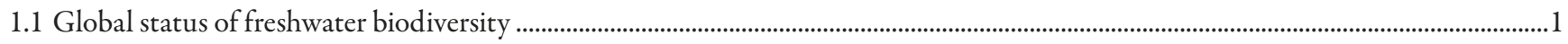

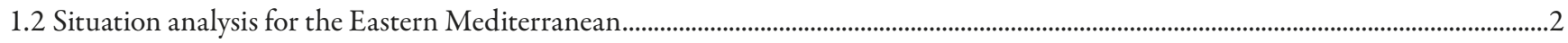

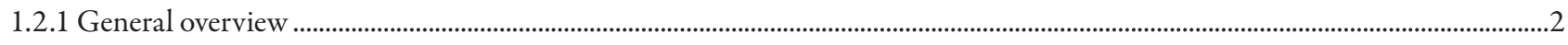

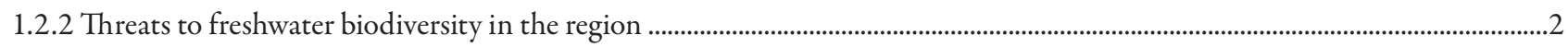

1.2.3 Regional use and value of wetlands and their biodiversity........................................................................................................

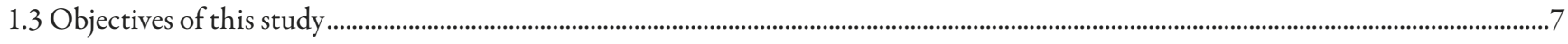

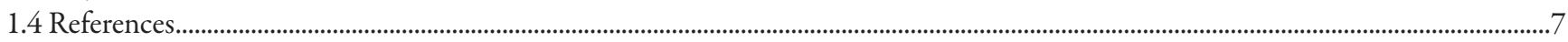

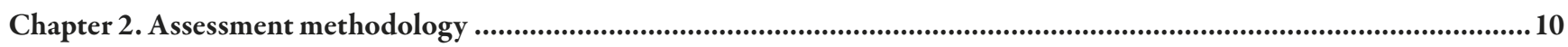

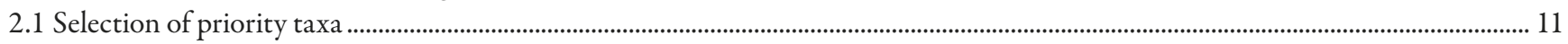

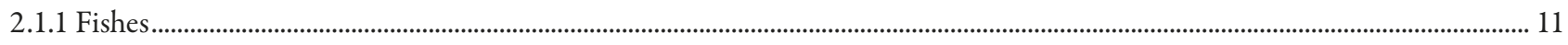

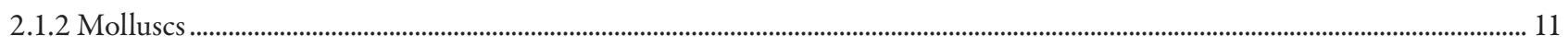

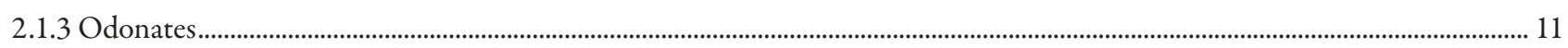

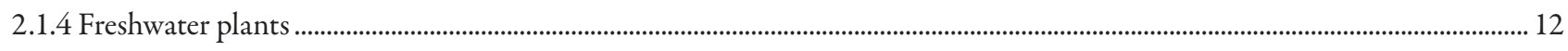

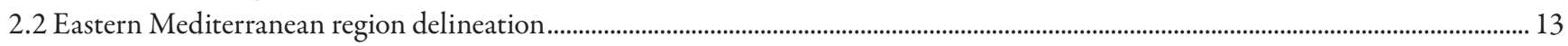

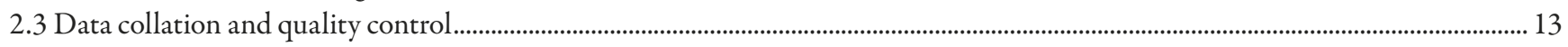

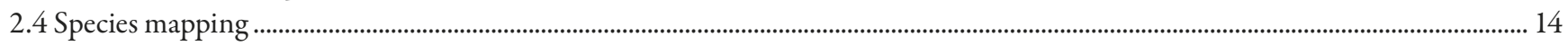

2.5 Overlap with other Red List assessment projects...........................................................................................................................

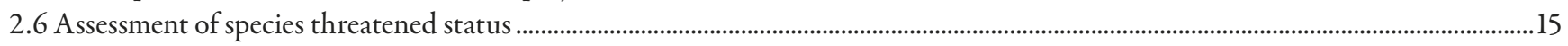

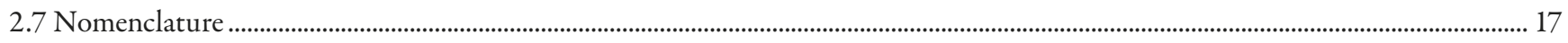

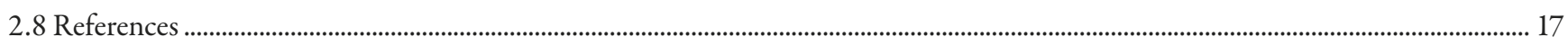

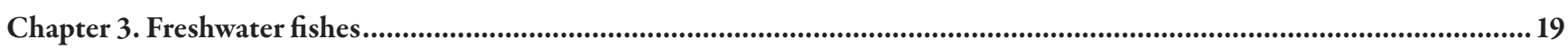

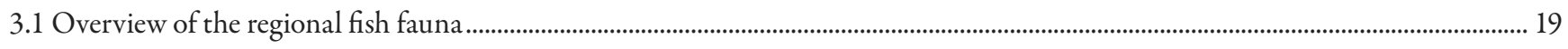

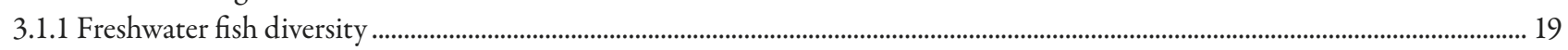

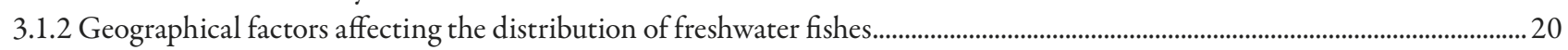

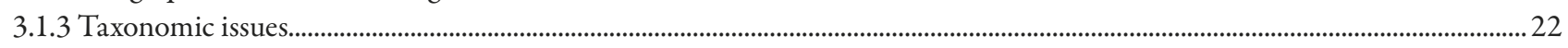

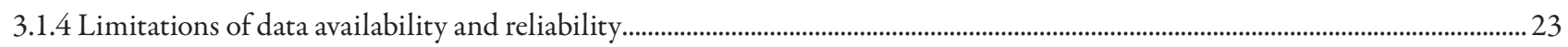

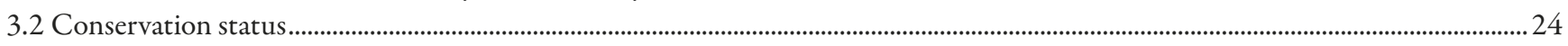

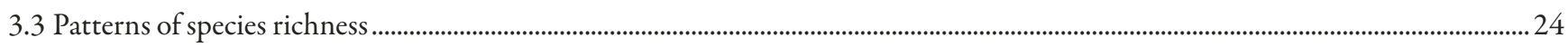

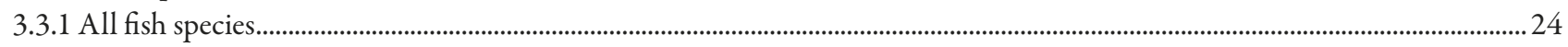

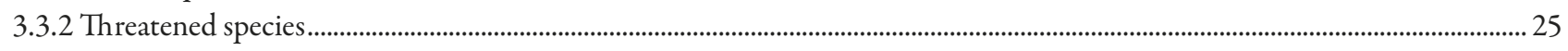

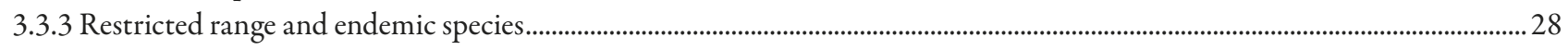

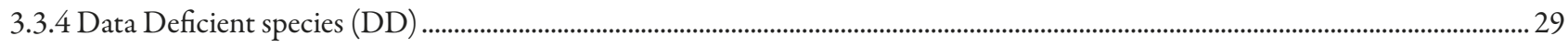

3.3.5 Extinct (EX), Possibly Extinct (CR PE) and Extinct in the Wild (EW) species......................................................................29

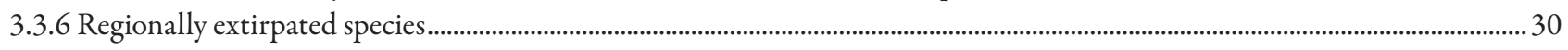

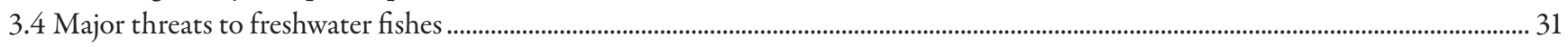

3.4.1 Water extraction and dams (Natural system modification) …................................................................................................. 31

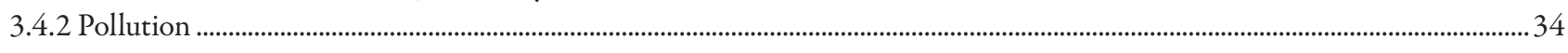

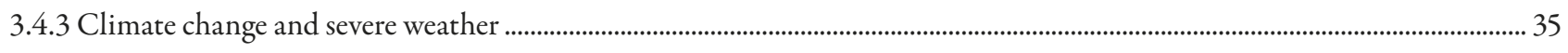

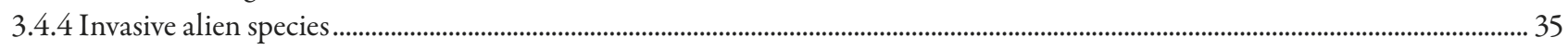

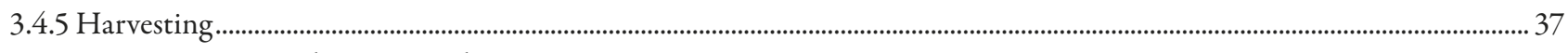

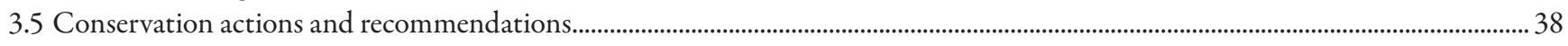

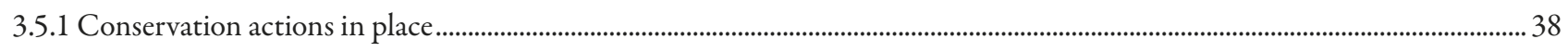

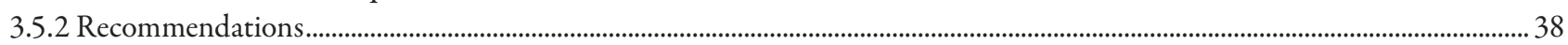




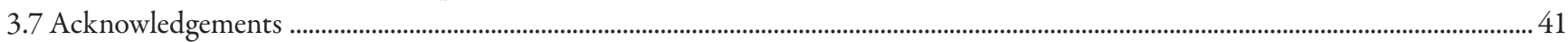

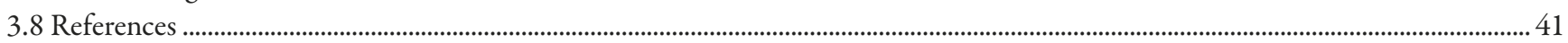

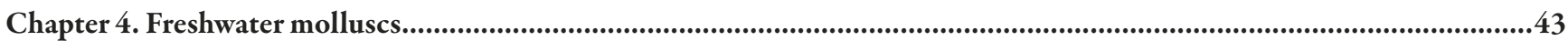

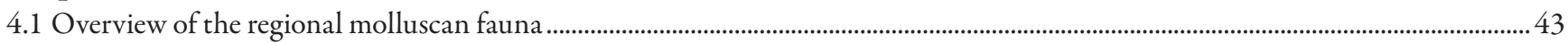

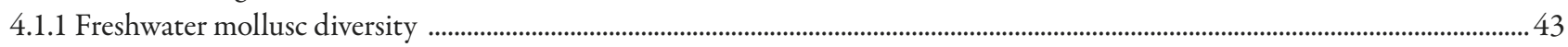

4.1.2 Geographical factors affecting the distribution of freshwater molluscs .....................................................................................46

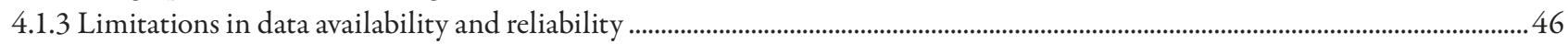

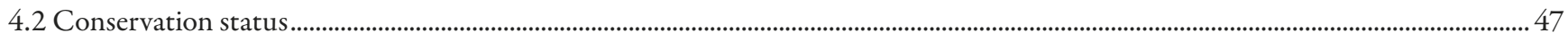

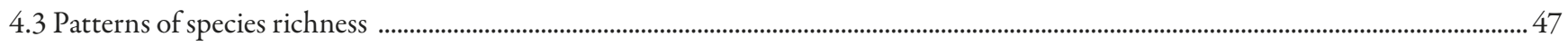

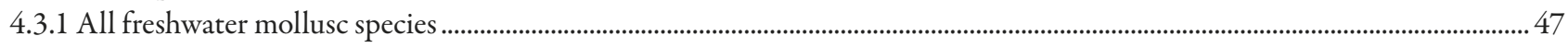

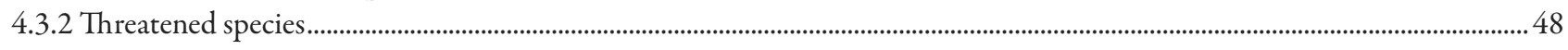

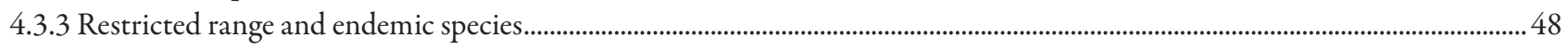

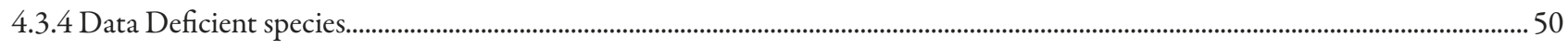

4.3.5 Possibly Extinct (CR PR) and regionally extirpated species .....................................................................................................51

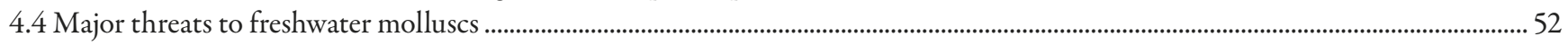

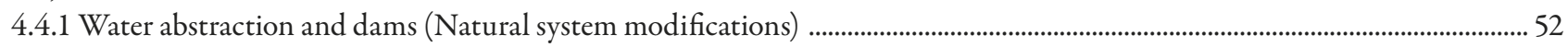

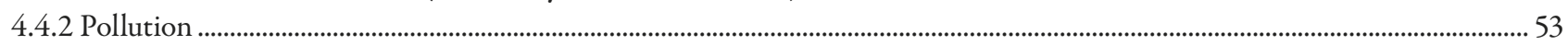

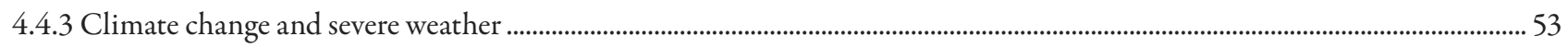

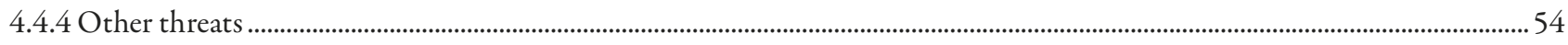

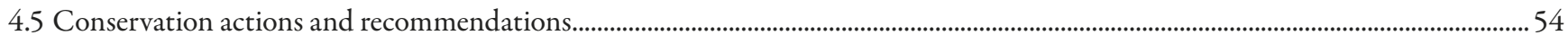

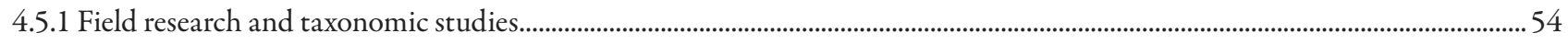

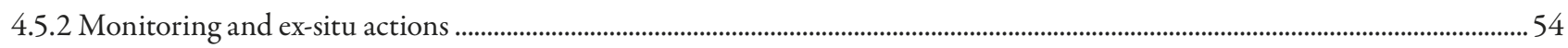

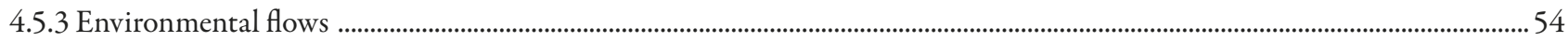

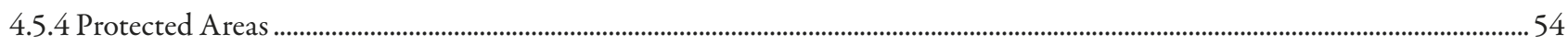

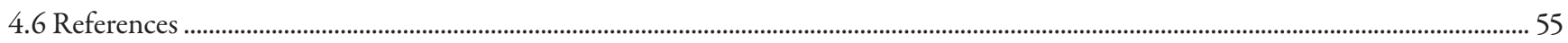

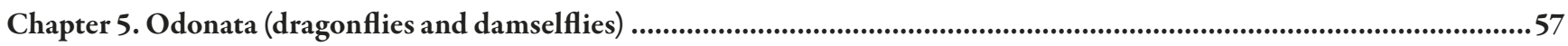

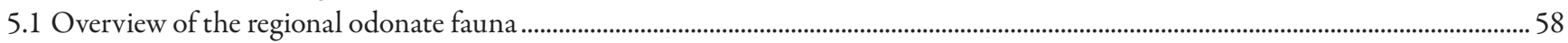

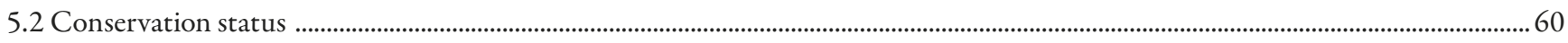

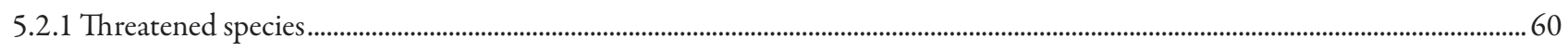

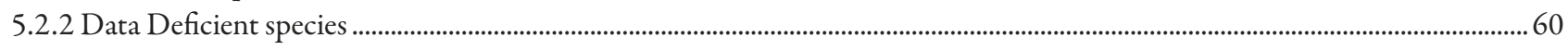

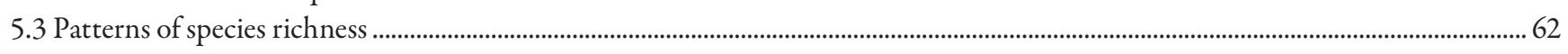

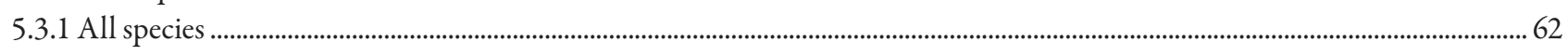

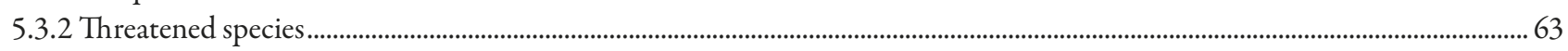

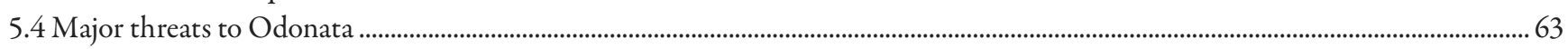

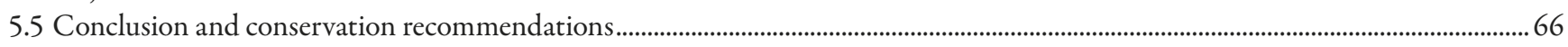

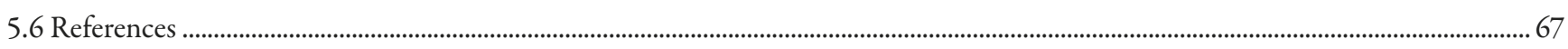

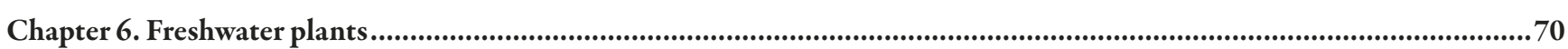

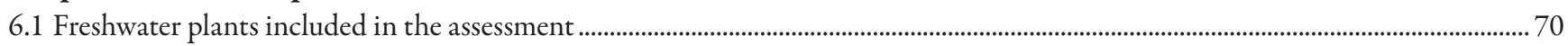

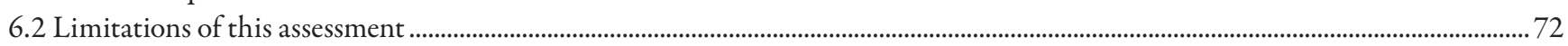

6.3 Wetland dependent plants and wetland habitats in the region ............................................................................................................... 72

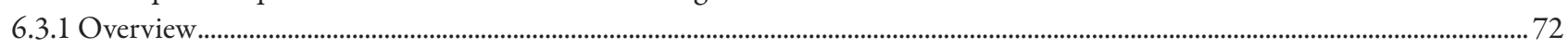

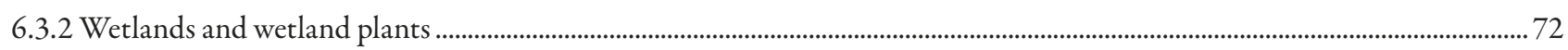

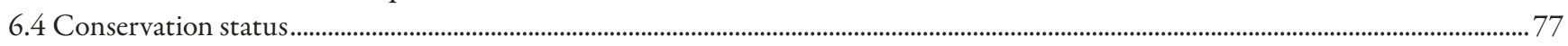

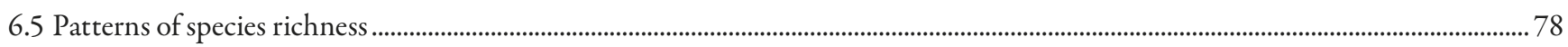

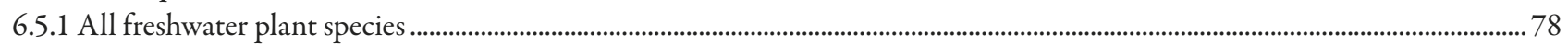

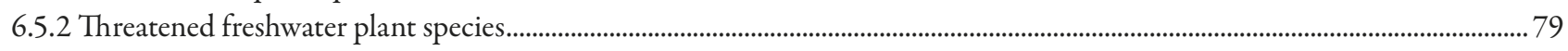

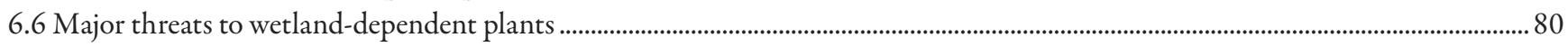

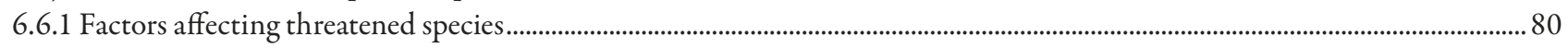

6.6.2 Drainage and conversion to urban or agricultural use ................................................................................................................ 80

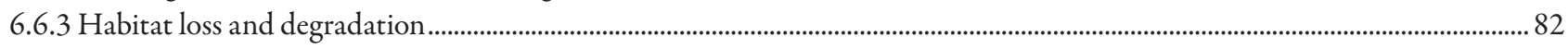

6.6.4 Modification of water courses and hydrological regimes .......................................................................................................... 83

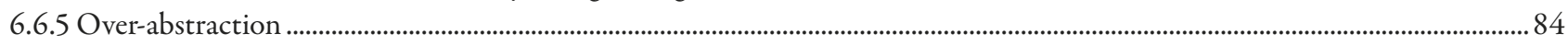


6.6.6 Water pollution

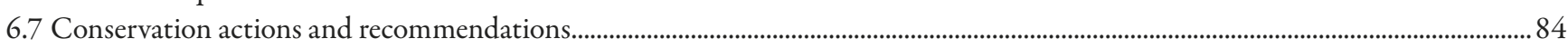

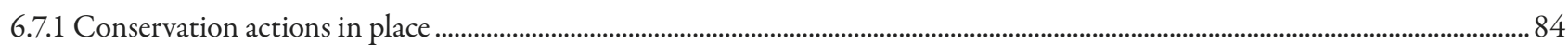

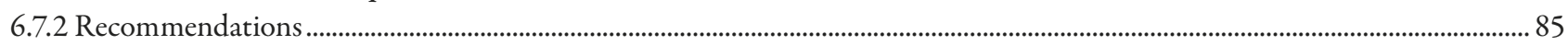

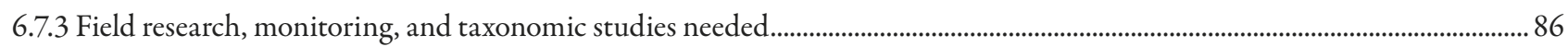

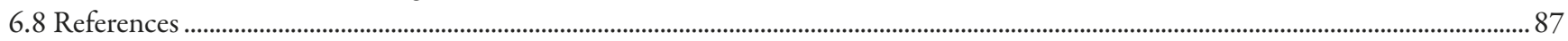

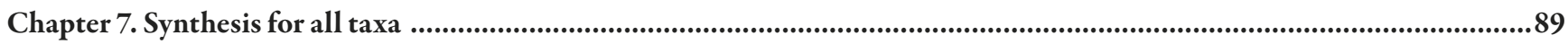

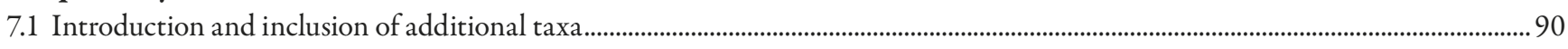

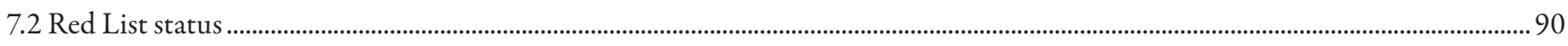

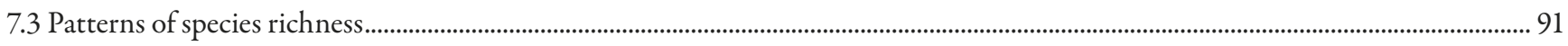

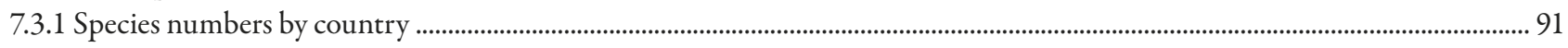

7.3.2 Species numbers by Hotspot within the Eastern Mediterranean ..................................................................................................93

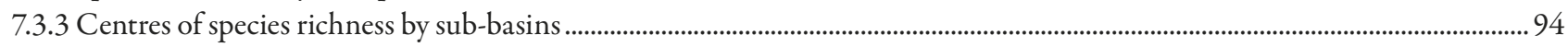

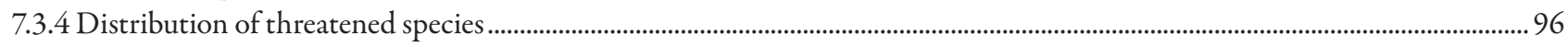

7.3.5 Sub-basins containing high proportions of species and threatened species for all taxonomic groups ......................................... 98

7.4 Important habitats supporting freshwater biodiversity in the Eastern Mediterranean ........................................................................... 100

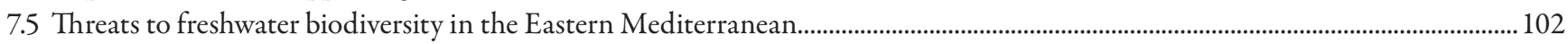

7.6 Provisioning ecosystem services and freshwater biodiversity of the Eastern Mediterranean................................................................. 105

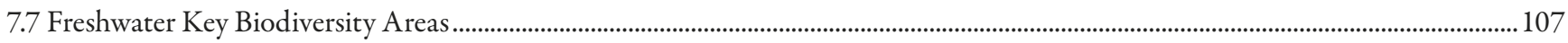

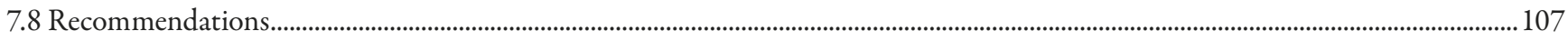

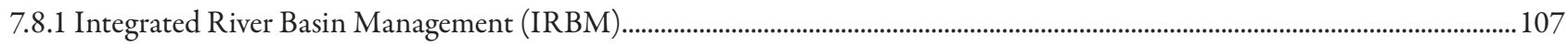

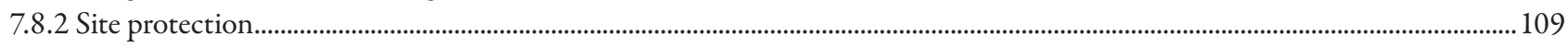

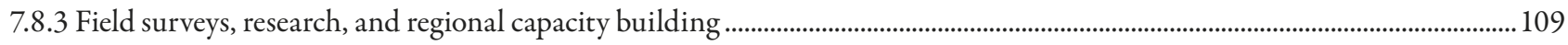

7.8.4 Enforcement of existing legislation and government awareness .................................................................................................109

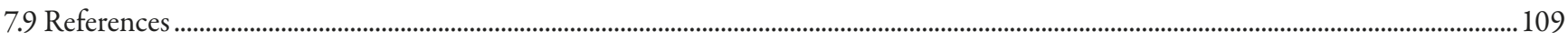

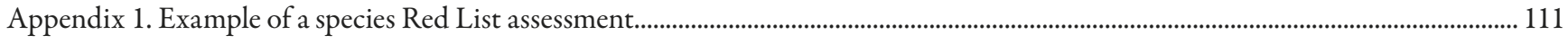

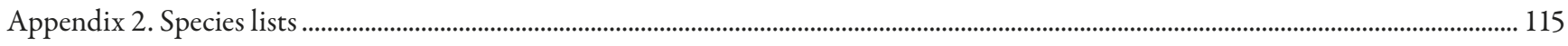

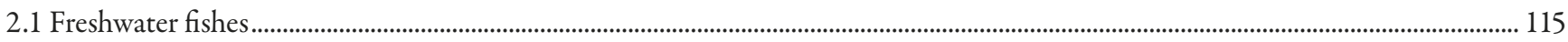

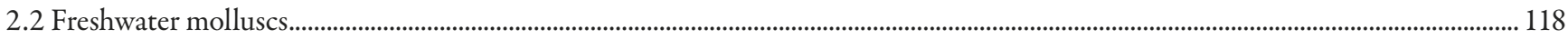

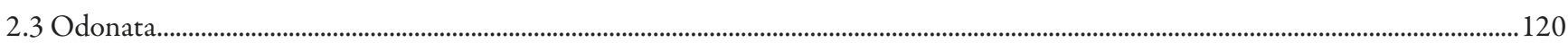

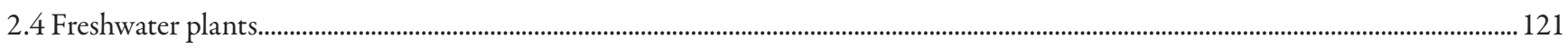

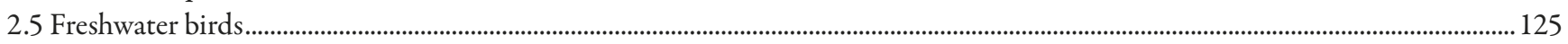

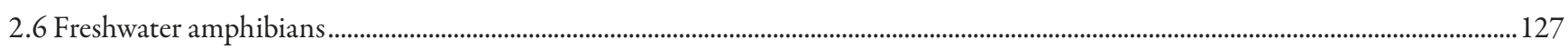

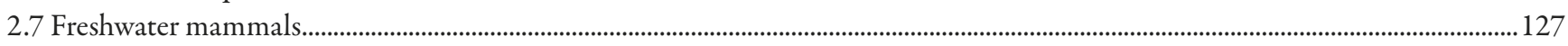

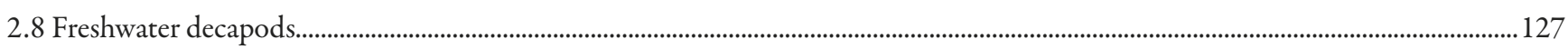

Appendix 3. Number of freshwater species for each taxonomic group by country of the Eastern Mediterranean region......................128 


\section{Acknowledgements}

A very large number of people have provided invaluable assistance to this project throughout its duration, and we would like to express our sincere thanks to all who have contributed, and our apologies if they are omitted here.

All of IUCN's Red List assessment projects rely on the willingness of scientists who are often, but not always, members of the IUCN Species Survival Commission, to pool and contribute their collective knowledge to make the most reliable estimates of a species' conservation status. Without their enthusiastic commitment to species conservation, this kind of assessment project would not be possible. Those scientists are the authors of the various chapters in this report, the contributors to the IUCN Red List species assessments that have been completed through this project and earlier projects, and the experts who provided their time and expertise to review species assessments.

Those experts who contributed directly to the species assessments (as assessors or reviewers) undertaken for this project are: Atheer H. Ali (Iraq), Bahram Zehzad (Iran), Davut Turan (Turkey), Erhan Ünlü (Turkey), F. Güler Ekmekçi (Turkey), Fahrettin Küçük (Turkey), Frank Suhling (Germany), George Nakhutsrishvili (Georgia), Halil Çakan (Turkey), Hamid Reza Esmaeili (Iran), Hossein Akhani (Iran), Ian Harrison (USA), Izolda Matchutadze (Georgia), Jean-Pierre Boudot (France), Jörg Freyhof (Germany), Manuel L. Lima (Portugal), Mary Seddon (UK), Menachem Goren (Israel), Michel Bariche (Lebanon), Müfit Özuluğ (Turkey), Mustafa A. Atalay (Turkey), Mustafa Sari (Turkey), Nashat Hamidan (Jordan), Nina Bogutskaya (Russia), Nisreen Alwan (Lebanon), Richard Lansdown (UK), Salih Kavak (Turkey), Sibel Ergüder (Turkey), Süreyya Isfendiyaroğlu (Turkey), Ümit Kebapçi (Turkey), Vincent Kalkman (Netherlands), Zuhair Amr (Jordan).

We are indebted to the Royal Society for the Conservation of Nature, Jordan and in particular Khaled Younis and Nashat Hamidan who kindly hosted the Red List review workshop and provided technical and scientific expertise throughout the project.

We would like in addition to thank all our colleagues from the IUCN Centre for Mediterranean Cooperation for their invaluable input and support throughout this project. We would also like to thank Haifaa Abdulhalim and her colleagues from the IUCN Regional Office for West Asia, for their contributions to the assessments at the review workshop.
BirdLife International very kindly made spatial data available for the wetland birds of the Eastern Mediterranean region. The mammal, bird, amphibian, and crustacean data could not have been incorporated in this report without the inputs of the very many scientists who contributed to the Red List assessments of these species.

We would like to thank Savrina Carrizo (Global Species Programme, Freshwater Biodiversity Unit) who provided invaluable assistance and support throughout the project, and to David Allen (Red List Unit) for excellent facilitation at the species assessment review workshop. Also to Caroline Pollock, Janet Scott, Catherine Sayer, and Craig Hilton-Taylor (Red List Unit staff) who provided guidance and feedback on the IUCN Red List assessments, and Adrian Hughes and Jemma Able who provided invaluable advice with GIS mapping and analysis. Also, our thanks need to go to Ian Harrison (IUCN-SSC/Wetlands International Freshwater Fish Specialist Group) who helped develop the project proposal. We would like to thank IUCN colleagues Maureen Martindell, Amy Burden, and Aisha Ghauri who have worked tirelessly with all project reporting and financial issues.

The editors would also like to thank Caroline Snow for her amazing attention to detail in proof reading this report, and also to Salih Kavak and Haifaa Abdulhalim for translating the executive summary into Turkish and Arabic respectively.

We are indebted to the Critical Ecosystem Partnership Fund (CEPF, www.cepf.net) who provided financial support for this project, and to Pierre Carret and Antonia Cermak-Terzian, our contact points within CEPF. We would also like to thank BirdLife International who are the regional implementation team for CEPF for the Mediterranean Hotspot, and to our contact Liz Smith for her support.

We would also like to thank the co-funder for this project, the MAVA Foundation.

The freshwater fishes Red List assessments were co-funded by the 'Biodiversity of Freshwater Ecosystems: Trends, Pressures and Conservation Priorities (BioFresh)' FP7 project funded by the European Union (Contract No. 226874). The views expressed herein can in no way be taken to reflect the official opinion of the European Union. 


\section{Executive summary and key messages}

In 2003, the former United Nations Secretary General Boutros Boutros Ghali stated that 'water will be more important than oil this century'. He was referring to the increasing strain being put on water resources in the Middle East and how this may lead to human conflict in the region. While this fear has not yet been realized, it is widely understood to be a real and increasing risk, not just to the Eastern Mediterranean region but to other parts of the world which are also facing major water shortages now and in the future. One aspect of this water crisis that is often overlooked is the impact upon biodiversity that also needs water to survive. This is not setting up a dichotomy between human and biodiversity needs as is often assumed. The availability and quality of water for human use is a service provided by functioning 'healthy' ecosystems and hence biodiversity ${ }^{2}$. Healthy freshwater ecosystems ('natural infrastructure') that support biodiversity not only provide, store, and purify water, but they also provide many other valuable ecosystem services that people rely upon (e.g. food, flood protection, recreation etc.). However, as in many parts of the world, biodiversity needs are rarely incorporated into the decision-making processes governing water resources in the Eastern Mediterranean region which are largely focused upon the provision of water for human needs (primarily for irrigation) and for energy production. The Convention on Biological Diversity (CBD) has stated that it is becoming increasingly critical that policies and management are better informed about how the hydrological cycle functions, and the role of ecosystems and biodiversity in sustaining it $^{2}$.

This IUCN report and accompanying dataset on the status and distribution of freshwater biodiversity in the Eastern Mediterranean, and the associated report and data on the Freshwater Key Biodiversity Areas in the wider Mediterranean Basin $^{3}$ represent major advances in provision of information to help incorporate biodiversity needs into water development planning processes within an Integrated River Basin Management framework, and also, we hope in raising the profile of freshwater biodiversity. This work represents the most comprehensive assessment yet of freshwater biodiversity at the species level for this part of the world. In addition to informing development decision making, the information presented here is fundamental to meeting national obligations for protection and sustainable use of biodiversity under the Convention on Biological Diversity; the Ramsar Convention; and the Millennium Development Goals (MDGs). Information on species status is particularly important for Targets 11 and 12 of the CBD that state: 'By 2020, at least 17 per cent of terrestrial and inland water areas,... especially areas of particular importance for biodiversity and ecosystem services, are conserved...' and '...by 2020 the extinction of known threatened species has been prevented and their conservation status, particularly of those most in decline, has been improved and sustained', respectively. The data provided and analysis presented here also provide an important contribution to help States implement the UN Watercourse Convention (UNWC), which came into force in August 2014, and aims to protect and maintain watercourses in their natural state.

The Eastern Mediterranean region supports just over $4.4 \%$ of the global human population, yet contains only $1.1 \%$ of its renewable water resources ${ }^{4}$. Water withdrawal in the region, primarily for irrigation purposes, is largely unsustainable and has led to a continuing reduction of ground waters at an alarming rate 5 There is also considerable dam development across the region, primarily in Turkey, and pollution from agricultural and domestic sources. Climate change is leading to an increase in mean annual temperatures, and frequency of extremely hot summer days along with decreasing precipitation ${ }^{6}$. The resulting impacts from these compounding threats has been the reduction and alteration of flows in freshwater systems across the region, and in some cases the total loss of a number of water bodies (e.g. Lake Amik in Turkey, and Azraq Oasis in Jordan) and the seasonal drying out of once permanent rivers (e.g. Qweik River in Turkey and Syria). As a major contribution towards the provision of information on the region's freshwater species, IUCN's Global Species Programme, in collaboration with its partners, conducted an assessment of the status (according to the IUCN Red List of Threatened Species ${ }^{\mathrm{TM}}$ ) and distribution of all described species of freshwater fishes, molluscs, odonates, and plants from across the Eastern Mediterranean. Existing information for species of freshwater dependent amphibians, birds, crustaceans, and mammals was also incorporated to present a more comprehensive overview of the status and distribution of freshwater species across the region. In total, information on 1,236 species has been included in this report. With species information compiled for each river or lake sub-basin, this volume represents a major advance in knowledge for informing development actions at a spatial scale appropriate for conservation management. The full dataset, including all species distribution files, will be made available through the IUCN Red List website (www. iucnredlist.org).

Nineteen per cent of all freshwater species assessed here are globally threatened. However, when only those species that are endemic to the region are considered (species which, if lost from the region, will become globally extinct) this level of threat rises to $58.2 \%$. Six species, all fishes, are considered to have become globally Extinct (EX) and 18 species (seven fishes and 11 molluscs) are assessed as Critically Endangered Possibly Extinct - field surveys are urgently required to confirm whether these species are still extant. Major drivers of threat are identified as water abstraction and dams, pollution from agricultural and urban areas, habitat loss/conversion for agriculture, and over-harvesting. Habitats that contain the greatest proportion of threatened species 
are freshwater springs and seepages, and karst systems. Springs often act as refuges for species when rivers and lakes dry (either naturally, or due to excessive water extraction) but are themselves susceptible to groundwater extraction. The highest number of threatened species are found within six distinct areas within the region: the coastal Levant and Gulf of İskenderun catchments from the Orontes to the Litani and the Upper Hula basin and Lake Kinneret/Sea of Galilee, the wider Tigris and Euphrates lower plains including the Hawizah marshes up to the Diyala River in Iraq and lower Karoun in Iran, the Khabur River including the Ras al-Ain springs (Euphrates catchment) in northern Syria, the Lakes Region of Turkey (including the upper Büyük Menderes, the Köprü River, and Kırkgöz Springs), the lower Çoruh River and other Black Sea catchments in north-eastern Turkey, and the lower Aras/Kura River in Azerbaijan and southern Armenia. This distribution largely reflects the overall spatial distribution of recorded species richness and the parts of the region where our knowledge is most complete - other centres of richness and threat may also be detected as further information becomes available. The IUCN Red List is one of the most authoritative global standards supporting policy and action to conserve species. We hope this analysis, based in large part on an assessment of species' Red List status, will provide new information and insights that will motivate actions to help safeguard the diversity of life within the Eastern Mediterranean inland waters.

\section{Key messages}

- High regional diversity of freshwater species. Despite the relatively semi-arid and arid nature of large parts of the region, it supports a diverse set of freshwater species and habitats which provide a wide variety of ecosystem services, including water, food, and income. Of the 1,236 species of freshwater fish, mollusc, odonate (dragonfly and damselfly), freshwater plant, bird, amphibian, crustacean, and mammal, 368 species (29.8\%) are endemic to the Eastern Mediterranean region (i.e. they are found nowhere else in the world).

- Water stress and pollution has led to a high level of threat in freshwater biodiversity. Freshwater biodiversity and habitats are under a great amount of stress caused by excessive water extraction, pollution, and dams which are all compounded by a drying climate. This has caused the loss of many permanent flowing rivers (which now intermittently run dry) and other wetlands such as marshes and lakes. This situation has led to $19.1 \%$ of freshwater biodiversity in the region being assessed as threatened and $58.2 \%$ of the region's endemic freshwater species assessed as threatened. Of the groups assessed for this project, freshwater molluscs and fishes were the highest threatened at $45.5 \%$ and $41 \%$ threatened respectively, followed by dragonflies and damselflies at $6.7 \%$ threatened, and freshwater plants at $2.5 \%$ threatened.

- The role healthy ecosystems and biodiversity play in water provision needs recognition in policy. The critical role ecosystems (and therefore biodiversity) play in the provision of water (quantity and quality) for human use and for biodiversity, needs to be recognized. Biodiversity requirements need to be built into the decision-making processes that govern water management.

- An urgent need for Integrated River Basin Management. Countries within the region need to adopt an Integrated River Basin Management approach (or similar strategy) to ensure that freshwater ecosystems can sustainably provide water, other ecosystem goods, and services in the long term while at the same time supporting biodiversity. This is especially the case for transboundary waters, where it is strongly recommended that the member states fully implement the principles of the UN Watercourse Convention (UNWC) and accept responsibility for protection of connected ecosystems beyond national boundaries.

- Freshwater springs are a key habitat for freshwater biodiversity. Permanent rivers and lakes support the greatest numbers of species and threatened species, however freshwater springs and karst systems have the greatest proportion of threatened species. Freshwater springs and seepages are a key habitat for many threatened species in the region as they often provide refuges during times of drought exacerbated by excessive water extraction.

- Turkey, Israel, and Syria all have seen the greatest number of species extirpated from within their borders. Turkey supports the greatest number of freshwater species, however it also has the highest number (and proportion) of threatened freshwater species in the region. It also has the greatest number of extirpated species (i.e. species lost from within its borders) with some species now globally extinct. Israel has the greatest proportion of extirpated species, followed by Syria and then Turkey.

- There are high levels of species richness, and threatened species across the region. The areas of the highest species richness are found along the Mediterranean coasts of the Levant and Turkey, the Sea of Mamara catchments, Black Sea coast of Turkey, and also within the Aras/Kura catchment in Georgia, Azerbaijan, and Armenia. The areas of the greatest number of threatened species are found in the lower Orontes/Asi catchment in Turkey, the lower and middle Tigris/Euphrates including the Hammar marshes, the Shatt al Arab River, Ras al-Ain spring area and outflowing Khabur/Khabour River (part of the Euphrates catchment) in northern Syria, and the lower Aras/Kura River in Azerbaijan. 
- Freshwater Key Biodiversity Areas can help guide conservation in the region. There are a number of sites across the region of particular importance for the persistence of freshwater biodiversity. These sites, known as freshwater Key Biodiversity Areas are presented in the accompanying report Freshwater Key Biodiversity Areas in the Mediterranean Basin Hotspot. Informing species conservation and development planning in freshwater ecosystems ${ }^{3}$.

a There is an urgent need for collaborative field research and monitoring across the region. There are very few freshwater biodiversity monitoring programmes in the region. If we are to halt the loss of freshwater biodiversity in this region, it is essential that field monitoring and research programmes are established using modern standardized protocols. This will allow changes in populations to be monitored and identification of species that will benefit from ex-situ conservation to help ensure that no more species become extinct. It is recommended that monitoring, field, and taxonomic research programmes are, where appropriate, undertaken through collaboration with international institutions to assist the region in capacity building.

1. Interview with the BBC in 2003. Cited in: International Institute for Sustainable Development (IISD). 2003. Water-L News. 5. http://www.iisd.ca/water-1/ Water-L_News_5.pdf

2. Convention on Biological Diversity, Subsidiary Body on Scientific, Technical and Technological Advice. 2010. In-depth review of the programme of work on the biological diversity of inland water ecosystems: summary of background information and key messages. UNEP/CBD/SBSTTA/INF/3 11 April 2010 https:// www.cbd.int/doc/meetings/sbstta/sbstta-14/information/sbstta-14-inf-03-en.pdf

3. Darwall W., Carrizo S., Numa C., Barrios V., Freyhof J. and Smith K. 2014. Freshwater Key Biodiversity Areas in the Mediterranean Basin Hotspot. Informing species conservation and development planning in freshwater ecosystems. IUCN, Cambridge, UK and Malaga, Spain. www.iucn.org/species/freshwater

4. Frenken, $\mathrm{K}$ (ed.). 2009. Irrigation in the Middle East region in figures. AQUASTAT Survey - 2008. FAO Water Reports \#34, Rome, Italy.

5. Voss, K.A., Famiglietti, J.S., Lo, M., Linage, C., Rodell, M. and Swenseon, S.C. 2013. Groundwater depletion in the Middle East from GRACE with implications for transboundary water management in the Tigris-Euphrates-Western Iran region. Water Resources Research 49(2):904-914.

6. CEPF. 2010. Ecosystem Profile - Mediterranean Basin Biodiversity Hotspot. Critical Ecosystem Partnership Fund. 


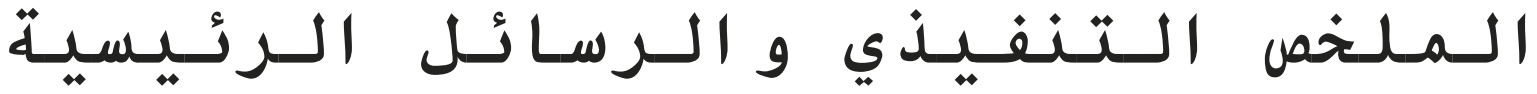

إن تقرير الاتحاد الدولي لحماية الطبيعة (IUCN) هذا، ومجموعة البيانات المرفقة حول توزيع وحالة التنوع الأحيائي في المياه العذبة في شرق البحر الأبيض المتوسط، مع تقرير المناطق الهامة للمياه العذبة في المنطقة الأوسع لثرق حوض البحر الأبيض المتوسط

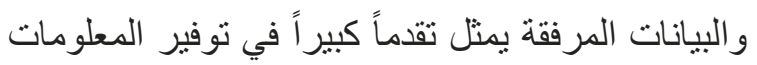
التي تناعد في ادماج احتياجات التنوع الأحيائي في الخطط التنموية للمياه ضمن إطار الإدارة المتكاملة لحوض النهر. كما نأمل من هذا التقرير أيضاً ان يساعد التهد في تحسين المعرفة عن التنوع الأحيائي في المياه العذبة. فيمثل هذا العمل أثمل تقييم على مستوى الأنواع تم إعداده حول التنوع الأحيائي في المياه العذبة في هذا

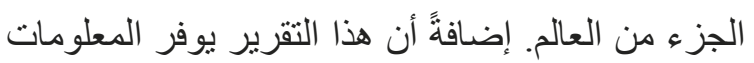

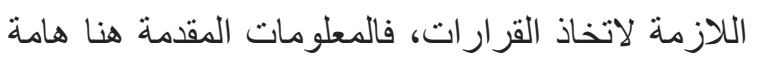
جداً لتحقق كل دولة التزاماتها الوطنية في حماية واستدامة استخدام التنوع الأحيائي في إطار اتفاقية

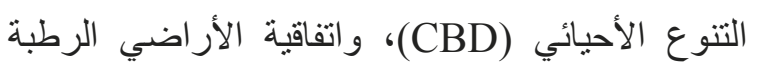
(رامسار)، والأهداف الإنمائية للألفية (MDGs). فالمعلومات المقدمة حول الأنواع ذات أهمية خاصة الإهة لهماته لتحقيق أهداف اتفاقية التنوع الأحيائي (CBD) 11 (CBD)

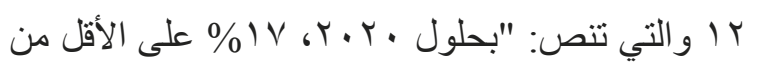

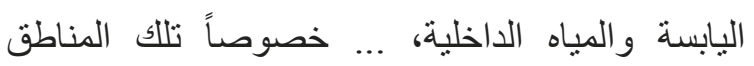
المهمة للتنوع الأحيائي وخدمات النظم البيئية، أصبحت

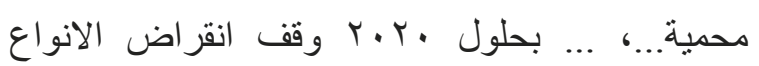
المهددة واستدامة حالة الصون خاصة لتاللك الأكثر تدهوراً " بشكل منوالي. كما تقام هذه المعلومات

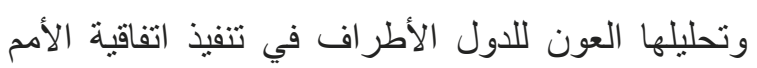
المتحدة لمجاري المياه (UNWC) التي تهدف إلى لى حماية وصيانة المجاري المائية في حالتها الطبيعية وقد

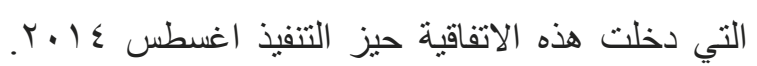

صرَّحَ الأمين العام للأمم المتحدة السابق بطرس بطرس

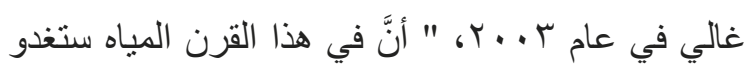
أكثر أهمية من النفط "'، حيث أثشار إلى الضغوط

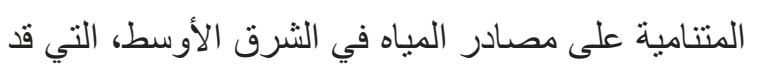
تفضي إلى نز اعات بشرية في المنطقة. فبالر غم من عدم

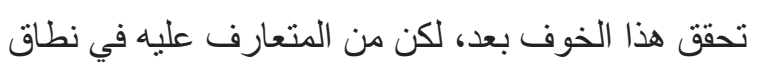

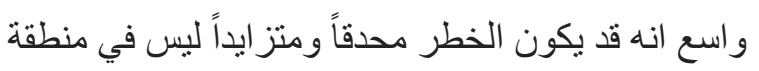
الثرق الأوسط فحسب، لكن في أجزاء أخرى من العالم التي تواجه نفس تحديات نقص المياه في الوقت الحالي و المستقبلي. وفي الغالب ما ينم تجاهل آثار نقص المياه على جو انب التنوع الأحيائي واحتباجاته من أجل البقاء. ليست الغاية هنا التفريق بين حاجة البشر وحاجة التنوع الأحيائي كما يفترض دائماً، لكن! توافر نوعية مياه صالحة للاستخدام البشري هي خدمة يقدمها النظام البيئي "المعافى (الصحي)" وبالتالي تنوع أحيائيخ

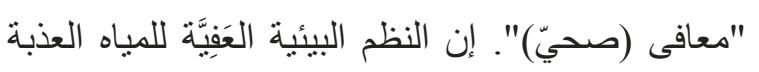
("بنية تحتية طبيعية") لا تقتصر على تخزين وتنقية (كعية

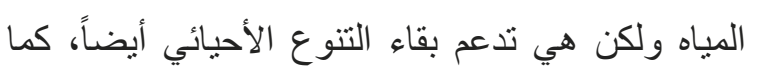
تقدم النظم العفيّة (الصحية) العديد من الخدمات القيّمة

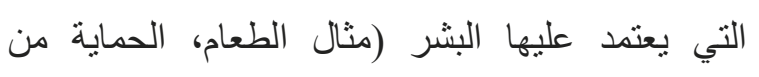
الفيضانات، الاستجمام، الخ.). ففي منطقة شرق البحر الأبيض المنوسط كما هو الحال في العديد من أرجاء

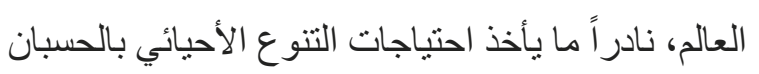

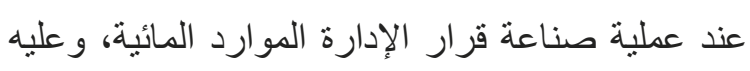
غالباً ما تصنع القرارات لتلبية احتباجات البشر (الري في المقام الأول) وانتاج الطاقة. تتص اتفاقية التنوع الأحيائي (CBD) إلى تزايد ضرورة إلمام السياسات

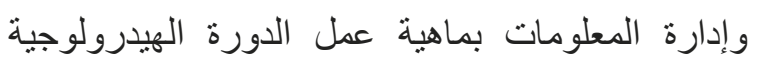
ودور النظم البيئية والتنوع الأحيائي في استدامتهاً. 
حوض بحيرة الفرعية، ويمثل هذا الكم من المعلومات

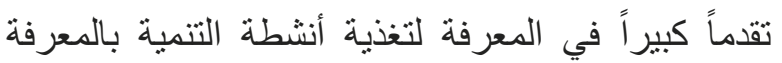
و النطاق المكاني المناسب لإدارة عمليات الصون. وسوف تتاح البيانات الكاملة، بما في ذللك جميع ملفات توزيع الأنواع، من خلال موقع الاتحاد الدولي لحماية الطبيعة للقو ائُ الحمر اء (IUCN) تسعة عشر بالمئة (9 (\%) من أنواع المياه العذبة التي تم تقييمها هي مهددة عالمباً، علماً أنه عند اعتبار ان هذه الأنواع هي أنواع منوطنة لهذه المنطقة - الأنواع إذا هاء

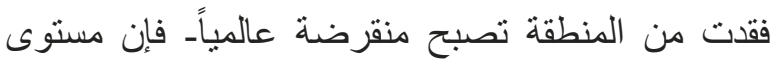
التهديد بالانقراض برتفع ليصل r.0 ,\% في المنطقة،

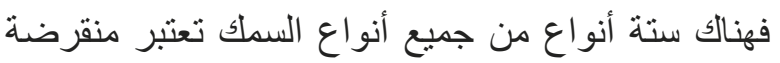

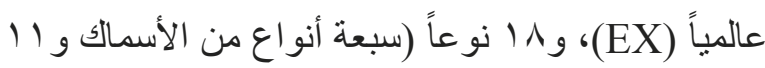
من الرخويات) مهددة بالانقر اض بشكل حرج مع احتمالية انها قد انقرضت فعلياً. لذا هنالك حاجة لمسوحات ميدانية لتأكيد ما إذا كانت هذه الأنواع ما زالت موجودة أو انقرضت فعلاً. كما يحدد التقرير أهم محركات التهديد كاستخراج المياه الجوفية أو بناء السدود، والتلوث من المناطق الزراعية أو الحضرية، وفقدان الموائل/ أو تحويلها لمناطق زر اعية و الإفر اط في حصاد أو جمع هذه الأنواع. فالموائل التي تحوي على الحصة الأكبر من الانواع المهددة بالأنقر اض هي الينابيع العذبة و السيول،

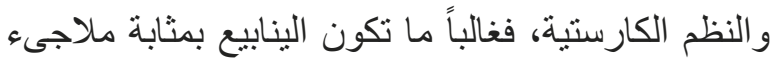
للأنواع عندما تجف الأنهار و البحيرات (إما بشكل طبيعي أو الضخ المفرط/الجائر للمياه) لكن هذه اليناييع هي أيضاً عرضة للضخ الجائر للمياه الجوفية الخاصة بها. فقد تم العثور على أكبر عدد من الأنواع المهددة بالانقر اض في ستة مناطق جلية في الإقليم: ساحل بلاد الثام وخليج اسكندرون من نهر العاصي إلى الليطاني، و أعالي حوض الحولة وبحيرة طبريا، نوسع سهول نهر دلجة و الفرات إلى مصب النهر بما في ذللك أهو ار الحويزة حتى نهر ديالى في العراق، ومصب قارون في إيران،
ان منطقة شرق حوض البحر الأبيض المتوسط تخدم ما

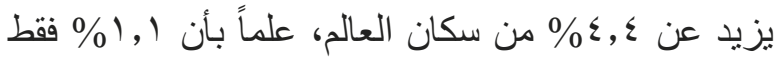
من مصادر المياه فيها متجددة؛. فعمليات سحب المياه في هذه المنطقة من العالم غير مستدامة إلى حد كبير، وهي تستخدم لأغر اض الري في المقام الأول، الأمر الذب أدى إلى إلى انخفاض مستمر لمستويات المياه الجوفية إلى معدلات تنذر بالخطر ْ. كما لوحظ التقدم الكبير في بناء السدود في

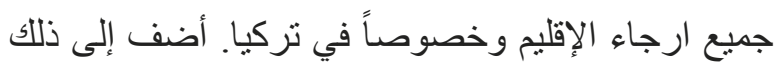
التلوث الناتج من مخلفات الاستخدامات الزراعية والمنزلية، مع آثار التغير المناخي الذي أدى إلى زيادة منوسط درجات الحرارة السنوية، وبالتالي تواتر أيام الصيف الحارة للغاية، و انخفاض معدلات الهطول" . بناءاً على ذلك، فإن تجمع هذه المؤثرات تتذر بتضاعف انخفاض وتغييرات جريان وتدفق المياه العذبة في جميع أنحاء المنطقة، وفي بعض الحالات الخسارة الكلية لعدد من المسطحات المائية (مثل بحيرة العمق في تركيا، واحة الأزرق في الأردن) وجفاف موسمي لأحد الأنهار الدائمة (مثل نهر كويك في تركيا وسوريا).

كمساهمة رئيسية نحو توفير المعلومات عن الأنواع في المياه العذبة في الإقليم، يقوم برنامج الأنواع العالمي لدى رلى الاتحاد الدولي لحماية الطبيعة (IUCN)، بالتعاون مع شركائه، بإجراء تقييم حالة الصون لجميع الأنواع الموصوفة من أسماك المياه العذبة والرخويات، اليعسوبيات، و النباتات في مختلف أنحاء شرق حوض البحر الأبيض المنوسط (وفقا للقوائم الحمراء للانواع المهددة التي يعدها الاتحاد الدولي لحماية الطبيعة) وتحديد توزيعها. كما تم ادماج المعلومات المتوفرة حول الأنواع التي تعتمد في تو اجدها على المياه العذبة من البرمائيات ،

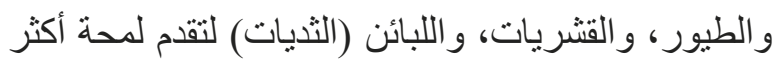
شمولاً لحالة الصون وتوزيعها في جميع أنحاء المنطقة. في المجموع، تم إدراج معلومات عن بسץ، ا نوع في

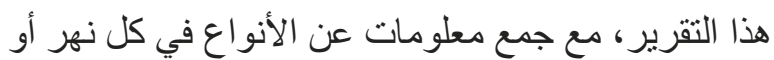


والمهددات التي يمكن ان يتم التحقق منها عندما تتوفر

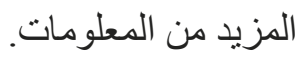

ان قوائم الاتحاد الدولي لحماية الطبيعة (IUCN) هي واحدة من المقاييس العالمبة الأكثر حجيّة لدعم سياسات واجر اءات صون الأنواع، ونحن نأمل أن يكون هذا التقييم هو قاعدة لتقييم أكبر للانواع تبعاً للقوائم الحمر اء للانواع لتواع المهددة، ونوفير معلومات ورؤى جديدة وبالتالي تحفيز

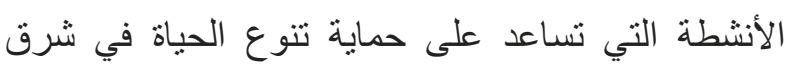

$$
\text { حوض البحر الأبيض المتوسط. }
$$

\section{ثم 0, \% م \% نباتات المياه العذبة مهدداً.}

يجب أن تقدر السياسات الدور الذي تلعبه النظم البيئية

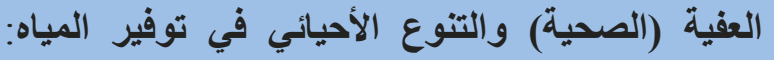

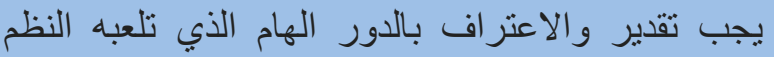

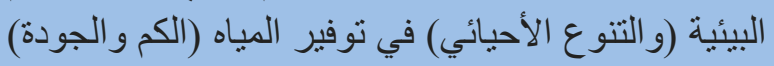

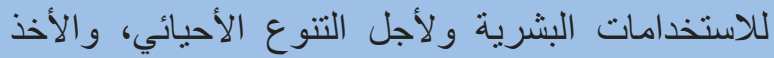

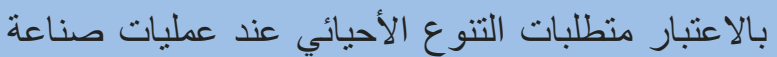
القرار الذي يحكم إدارة الموارد المائية.

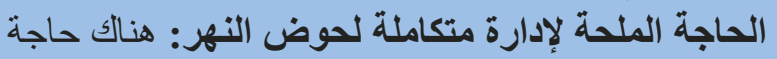

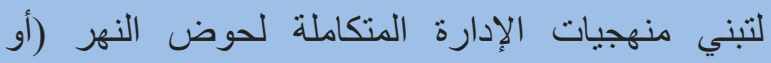

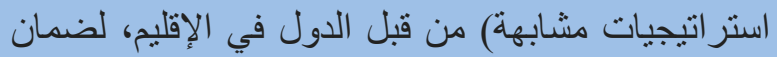

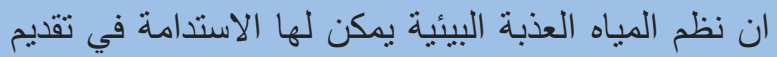

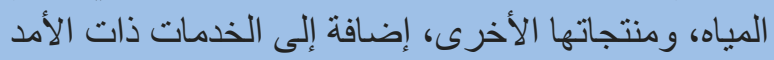

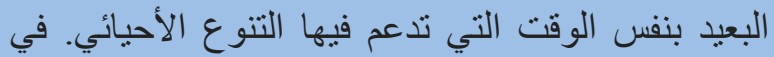

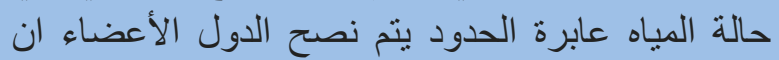
تقوم بنطبيق مبادئ اتفاقية الأمم المتحدة للمجاري الميان المائية

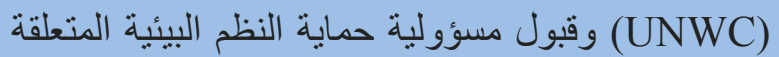
بخارج الحدود الوطنية.

\section{ينابيع المياه العذبة هي موائل مهمة للتنوع التوع الأحيائي في}

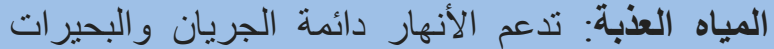

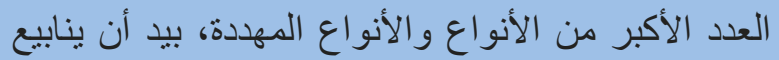

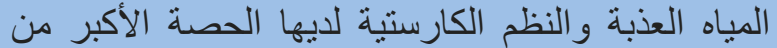

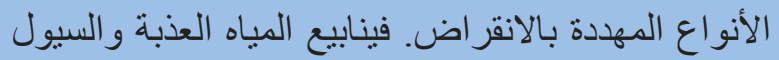

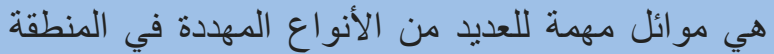

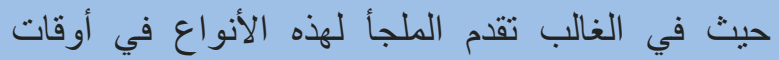
الجفاف بسبب الضخ الجائر (المفرط) للمياه.
ونهر الخابور بما في ذلك ينابيع رأس العين (اماكن تجمع مياه الفرات) في شمال سوريا، في منطقة البحيرات في Büyük ) تركيا (بما في ذلك منبع نهر مندريس العظيم Menderes كرجوز(Kırkgöz)، ومصب شيرو (Çoruh) وتجمعات البحر الأسود الأخرى في شمال شرقي تركيا، ومصب آر اس/نهر كورا في أذربيجان وجنوب أرمينيا. فعيكس هذا التوزيع، التواجد الجغرافي/المكاني الكلي لثراء الأنواع المسجلة في هذا الإقليم فنحن نمتلك القدر الأكبر والأكثر اكتمالاً من المعرفة - مقارنة إلى مراكز ثراء الانواع

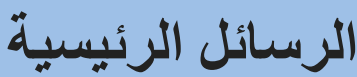

التنوع الثري لأنواع المياه العذبة في الإقليم: بالر غم من

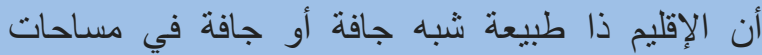

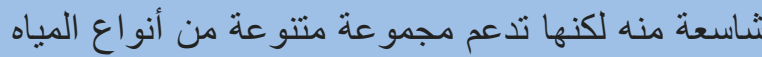

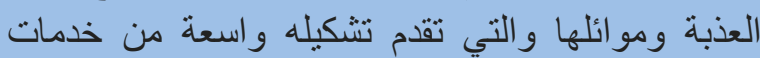

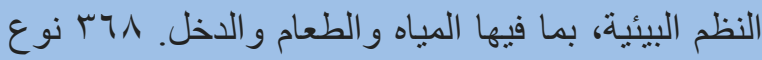

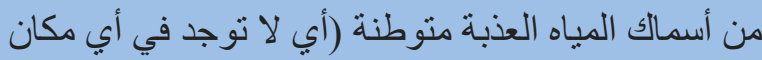

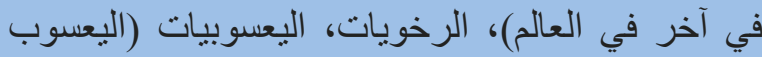

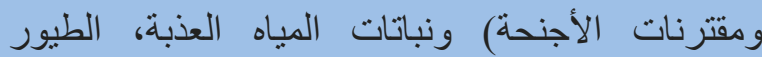

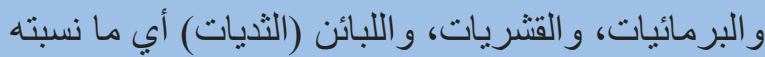

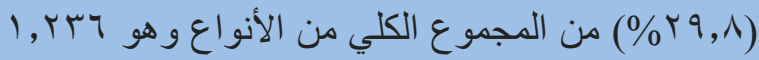
نوع منواجد في إقليم شرق حوض الجر البحر الأبيض المتوسط.

الضغوطات على المياه والتلوث أدى إلى تثكيل تهايد

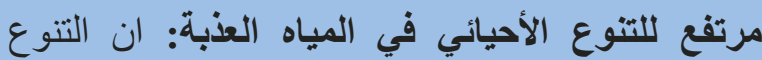

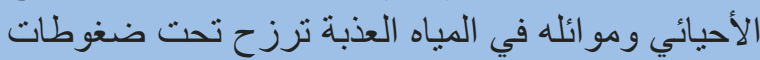
كبيرة بسبيها الاستخر اج المفرط للمياه، والتلوث، وبناء

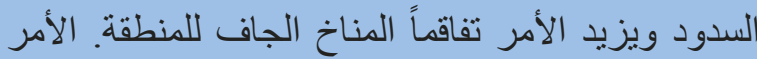

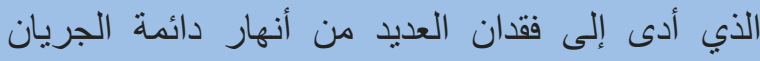

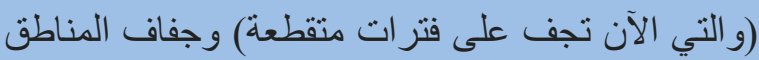

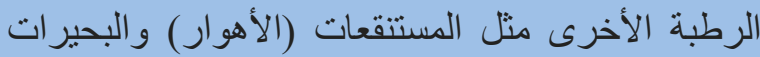

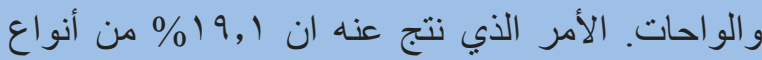

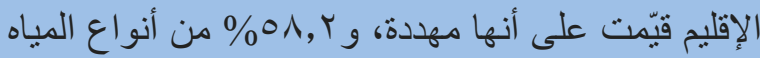

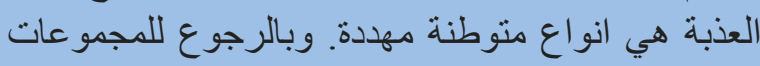

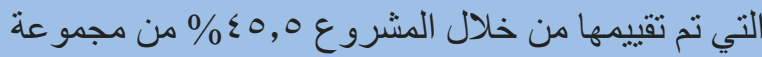

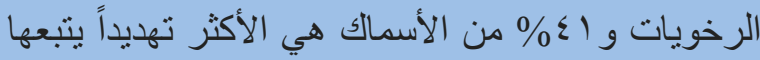

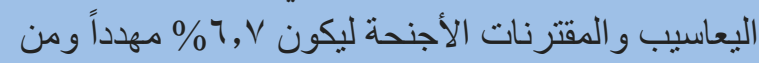


يمكن للمناطق الهامة للتنوع الأحيائي في المياه العذبة

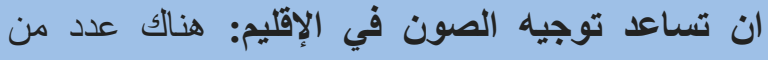

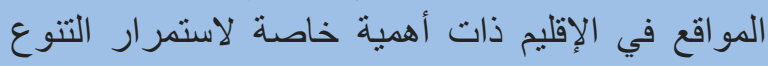

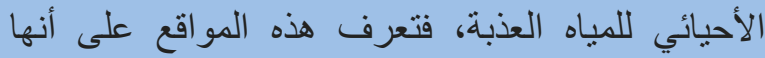

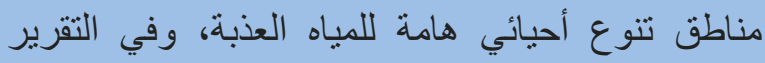
المصاحب مناطق تنوع أحيائي هامة للنقاط الساخنة (hotspots)

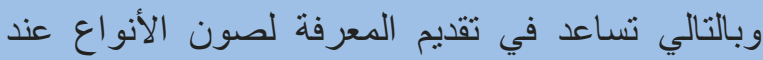

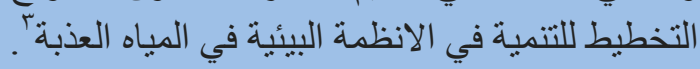

هناك حاجة ملحة للتعاون الإقليمي في مجالات البحث

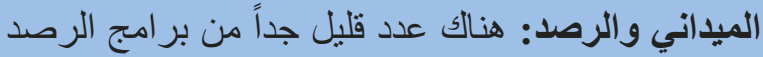

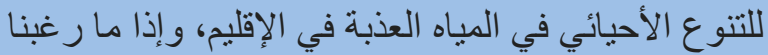

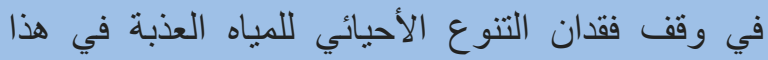

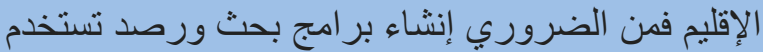

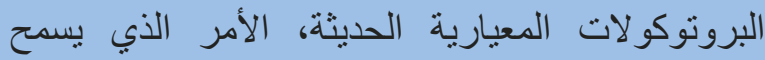

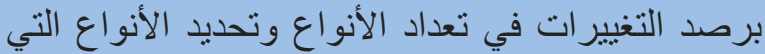

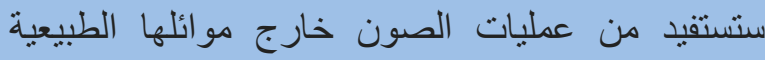

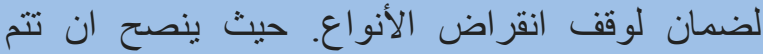

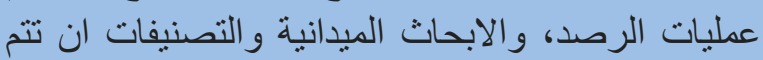
بالتعاون مع جهات دولية عند الحاجة لتقوم بنقديم العون في بناء القدر ات الإقليمية.
- تركيا، وإسرائيل، وسوريا جميعها شهدت أكبر علد

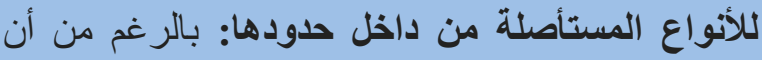

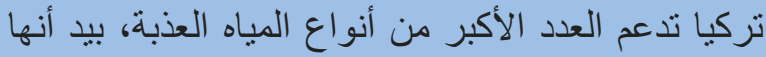

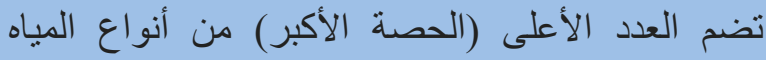

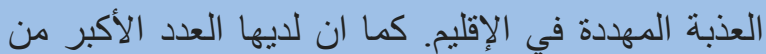

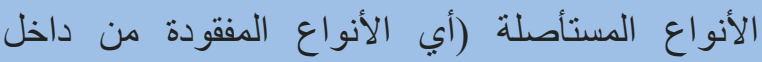

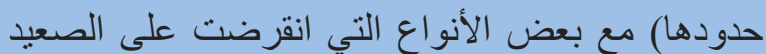

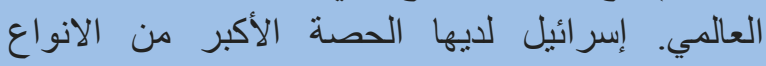
المستأصلة من حدودها تليها سوريا ومن ثم تركيا.

- أكاءك مستوى عالي من ثراء الأنواع، والأنواع المهددة

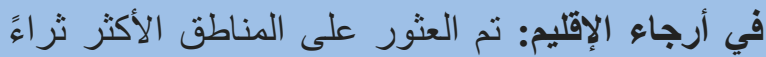

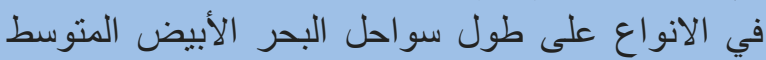

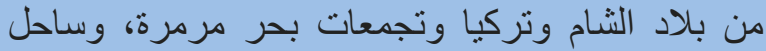

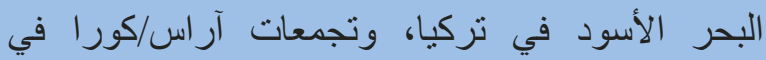

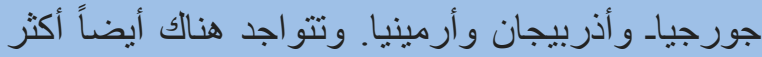

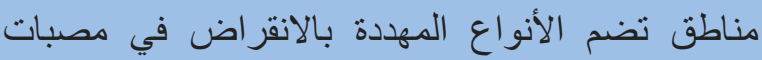

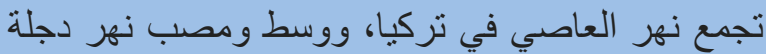
والفرات بما في ذلك هور الحمّار ، شط العرب، ونئ ومنطقة

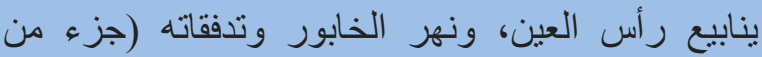

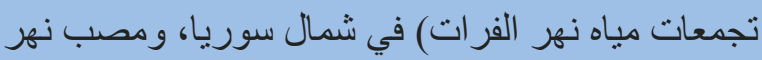

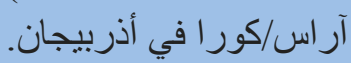

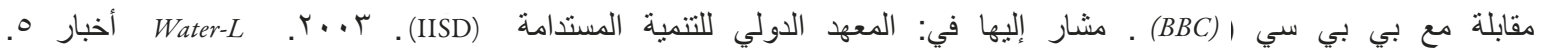
.http://www.iisd.ca/water-1/Water-L_News_5.pdf

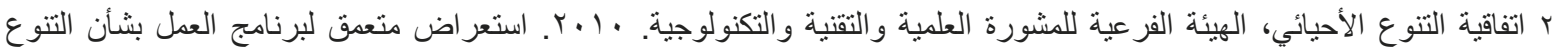

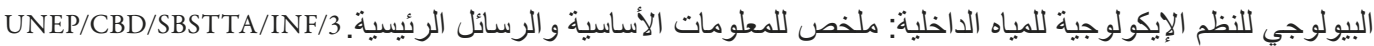

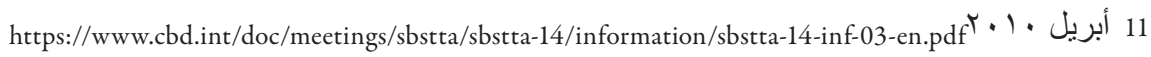

` Darwall W., Carrizo S., Numa C., Barrios V., Freyhof J. and Smith K. 2014. Freshwater Key Biodiversity Areas in the Mediterranean Basin Hotspot. Informing species conservation and development planning in freshwater ecosystems. IUCN, Cambridge, UK and Malaga, Spain. www.iucn.org/species/ freshwater

¿ Frenken, $\mathrm{K}$ (ed.). 2009. Irrigation in the Middle East region in figures. AQUASTAT Survey - 2008. FAO Water Reports \#34, Rome, Italy.

${ }^{\circ}$ Voss, K.A., Famiglietti, J.S., Lo, M., Linage, C., Rodell, M. and Swenseon, S.C. 2013. Groundwater depletion in the Middle East from GRACE with implications for transboundary water management in the Tigris-Euphrates-Western Iran region. Water Resources Research 49(2):904-914.

${ }^{`}$ CEPF. 2010. Ecosystem Profile - Mediterranean Basin Biodiversity Hotspot. Critical Ecosystem Partnership Fund. 


\section{Yönetsel özet ve önemli mesajlar}

2003 yılında, eski Birleşmiş Milletler Genel Sekreteri Butros Butros Gali, bu yüzyılda suyun petrolden daha önemli olacağını belirtti ${ }^{1}$. Ortadoğu da meydana gelen gerginliklerin başında su kaynaklarının paylaşımı gelmekte, bu nedenle bölgedeki insanlar arasında çatışmaların çıkabileceğine değindi. Bu konuda öngörülen endişeler henüz gerçekleşmemiş olmasına rağmen, bu sorunun sadece Doğu Akdeniz bölgesinde değil, dünyanın diğer bölgelerinde de benzer şekilde, günümüzde ve gelecekte önemli su sıkıntıları ile karşı karşıya kalma riskinin var olduğunu göstermektedir.Su krizinin, biyoçeşitlilik üzerine olan olumsuz etkisi genellikle gözden kaçmaktadır. Bu saptamanın amacı insani ve biyoçeşitlilik ihtiyaçları arasında bir ikilem oluşturmak değildir. İnsan kullanımı için uygun miktar ve kalitede suyun mevcudiyeti, iyi işleyen sağlıklı ekosistemler ve dolayısıyla biyoçeşitlilik sayesinde oluşmaktadır ${ }^{2}$. Sağlıklı tatlı sulak alan ekosistemleri (doğal altyapı) sadece biyoçeşitliliği desteklemekle kalmayıp, bu tip ekosistemler temiz suyun depolanmasinda ve aynı zamanda insanlara kendini güvende olmasını hissettiren önemli faydalar (örneğin; gıda, sel baskınından koruma, dinlenme vb.) sunmaktadır. Ancak, dünyanın birçok yerinde olduğu gibi Doğu Akdeniz bölgesinde de büyük ölçüde insani ihtiyaçlar (öncelikle sulama) ve enerji üretimi için suyun temini üzerine odaklanmış olup su kaynakları yönetimi ile ilgili karar alma süreçlerine biyoçeşitlilik ihtiyaçları nadiren dahil edilmiştir. Biyolojik Çeşitlilik Sözleşmesi, hidrolojik döngü fonksiyonlarının nasıl sürdürülmesi gerektiği konusunda ve ekosistemler ve biyoçeşitliliğin rolünün desteklenmesi hakkında daha iyi bilgilendirilmiş politikaların ve yönetimin kritik öneme sahip olduğunu belirtmiştir².

Bu IUCN raporu ile birlikte Doğu Akdeniz' deki tatlı sulak alan biyoçeşitliliğinin dağılımı ve durumu hakkındaki veri seti ve geniş Akdeniz Havzası'ndaki Tatlı Sulak Alan Önemli Biyoçeşitlilik Alanları ile ilgili rapor ${ }^{3}$ sayesinde bir Entegre Nehir Havza Yönetimi çerçevesindeki su kalkınma planlaması kapsamında biyoçeşitlilik ihtiyaçlarını birleştirmeye yardımcı bilgilerin sağlanmasında büyük gelişmeler sunmaktadır. Bu gelişmelerin tatlı sulak alan biyoçeşitliliği ve öneminin anlaşılmasında yardımcı olacağını umuyoruz.

Bu çalışma, dünyanın bu kısmı için tür düzeyinde tatlı sulak alan biyoçeşitliliği ile ilgili şimdiye kadar yapılan en kapsamlı değerlendirmeyi temsil etmektedir. Bu rapor kalkınma konusunda karar vericileri bilgilendirmenin yanında, Biyolojik Çeşitlilik Sözleşmesi, Ramsar Sözleşmesi ve Binyıl Kalkınma Hedefleri kapsamında biyoçeşitliliğin korunması ve sürdürülebilir kullanımı için ulusal yükümlülükleri yerine getirmenin esas olduğu bilgisini de vermektedir. Bu tür alanlarda bulunan canlı türlerinin durumları hakkındaki bilgi özellikle Biyolojik Çeşitlilik Sözleşmesi'nde belirtilen Hedef 11 ve 12 için önem arz etmektedir. "2020 yulına kadar, karasal ve içsulak alanların tamamının, en az \%17'si,... özellikle biyoçesitlilik ve ekosistem hizmetleri için özel öneme sahip alanlar, korunur..." ve "... 2020 yulına kadar bilinen tehdit altındaki türlerin yok olması önlenmiş ve özellikle azalan türlerin koruma durumlar geliştirilmişve sürekli olmuştur.”Bu rapor kapsamında oluşturulan veri ve analizler, su kaynaklarının doğal hallerinde korunarak sürdürülebilmesini amaçlayan, Ağustos 2014 tarihinde yürürlüğe giren BM Su Kaynakları Sözleşmesi'ni uygulamada devletlere yardımcı olmada önemli bir katkı sağlayacaktır.

Doğu Akdeniz bölgesi, dünya nüfusunun \%4,4’ün biraz üzerinde bir nüfusu barındırmasına rağmen yenilenebilir su kaynaklarının sadece \%1,1'ini içermektedir ${ }^{4}$. Özellikle, sulama amaçlı olarak sulak alanlardaki suyun çekilmesi sonucu, yer altı sularının sürdürülebilir kullanımının konusunda endişe verici olarak, büyük oranlarda azalmasına yol açmıştır ${ }^{5}$. Bölge genelinde, özellikle Türkiye'deki su kaynakları, önemli ölçüde baraj yapımlarının artmasının yanında, tarımsal ve evsel kaynaklı kirlilikten de olumsuz yönde etkilenmektedir. İklim değişikliğinden kaynaklanan yıllık ortalama sıcaklıklardaki artışla birlikte azalan yağış nedeniyle yüksek yaz sıcaklığına sahip günlerin sıklığında artışlar ortaya çıkmaktadır ${ }^{6}$. Ortaya çıkan bu tehditlerden kaynaklanan etkiler bölge genelindeki tatlı sulak alan ekosistemlerin azalmasına ve değişmesine neden olurken bazı durumlarda ise suyun tamamen kaybolarak bu tür alanların kurumasına (örneğin; Türkiye'deki Amik Gölü ve Ürdün'deki Azraq Ovası) neden olmuştur. Ayrıca, sürekli akan bazı nehirlerde (örneğin; Türkiye'de doğup Suriye'de devam eden ve Qweik Nehri adını alan Sinnep Deresi) su miktarının azalmasına veya mevsimsel olarak en az bir kez kurumasına neden olmuştur.

IUCN, bölgede bulunan tatlı sulak alanlardaki canlı türleri hakkında bilgi sağlanmak amacıyla, ortaklarıyla işbirliği içinde Küresel Türler Programı çerçevesinde, Doğu Akdeniz genelinde tatlı sulak alan balıkları, yumuşakçaları, kızböcekleri ve bitkilerine ait daha önce tanımlanmış tüm türlerin tehdit durum (IUCN Nesli Tehlike Altındaki Türlerin Kırmızı Listesi’ne göre) ve dağılımına ait bir değerlendirme yapmıştır. Bölge genelinde bulunan tatlı sulak alanlardaki türlerin durum ve dağılımına daha kapsamlı bir bakış sunmak için tatlı sulak alana bağımlı amfibi, kuş, kabuklu ve memeli türleri için daha önceki mevcut bilgiler de dahil edilmiştir. Bu kapsamda, toplam 1236 türe ilişkin bilgiler bu rapora dahil edilmiştir. Bu raporda, koruma yönetimi için uygun bir mekansal ölçek oluşturmak ve kalkınma faaliyetlerine bilgi sağlamak amacıyla, her bir nehir veya göl alt-havzasında bulunan türler için bilgiler hazırlanmıştır. Söz konusu türlerin dağılım dosyaları da dahil olmak üzere tüm veri setleri IUCN Kırmızı Listesi (www.iucnredlist.org) web sitesinde yer almaktadır. .

Burada değerlendirilen tüm tatlı sulak alan türlerin \%19'u küresel anlamda tehdit altındadır. Bunun yanında, sadece bölgeye 
endemik türler dikkate alındığında (eğer tür bölgeden kaybolursa küresel olarak nesli tükenmiş olacak) bu türlerin $\% 58,2$ 'sinin küresel anlamda tehdit altında olduğu görülmektedir. Balık türleri açısından, yapılan değerlendirmede, 6 balık türü küresel olarak Nesli Tükenmiş (EX) olarak kabul edilmişve 18 tür (7 balık ve 11 yumuşakça) Kritik Düzeyde Tehlike kategorisinde yer almakta ve muhtemelen Nesli Tükenmiş olarak değerlendirilmiştir. Bu türlerin yok olup olmadıklarını teyit etmek için acilen arazi çalışmaları gerekmektedir. Tehditlerin başında su çekilmesi ve barajlar, tarımsal ve kentsel kaynaklı kirlilik, yeni tarım alanları açma nedeniyle habitat kaybı/dönüşümü ve aşırı toplayıcılık tanımlanmıştır.

Tehdit altındaki tür sayısı en fazla tatlı sulak alan kaynakları, tatlı sulak alan sızıntıları ve karstik habitatlara sahip sistemlerde bulunmaktadır. Bu tür su kaynakları, suların depolandığ nehirler ve göller kuruduğu zaman (ya doğal olarak ya da aşırı su çekimi nedeniyle) türler için sığınma alanları olarak görev yapar. Ancak yeraltı sularının fazla çekilmesinden bu tür kaynaklar aşırı etkilenen sistemleri oluşturmaktadır. Tehdit altındaki türler baz alındığında, en fazla türün 6 farklı bölgede içerisinde yer aldığı görülmektedir; Levant kıyısı ve İskenderun Körfezi havzaları; Asi Nehri'nden Litani Nehri ve Yukarı Hula havzası ve Kinneret Gölü/Celile Denizi, İran' da Aşağı Karoun ve Irak'ta Diyala Nehri'ne kadar olan Hawizah bataklıklarını içine alan daha geniş Dicle ve Fırat aşağı ovaları, Kuzey Suriye'de Resulayn kaynaklarını (Fırat havzası) içine alan Habur Nehri, Türkiye Göller Bölgesi (Yukarı Büyük Menderes, Köprü Nehri ve Kırkgöz Kaynakları dahil), kuzeydoğu Türkiye' de Aşağı Çoruh Nehri ve diğer Karadeniz Havzaları, Azerbaycan ve güney Ermenistan'da Aşağı Aras Nehri.

Kaydedilen türler, bunların dağılımı ve bölgedeki tür zenginliği şu ana kadar sahip olduğumuz ve tamamladığımız bilgilerin bir yansımasıdır. Bilgi sahibi olduğumuz bölgenin dışındaki çalışmaların tamamlanmasıyla daha fazla bilgi elde edildiğinde zenginliğin ve tehdidin diğer merkezleri de tespit edilebilecektir.

IUCN Kırmızı Listesi türlerin korunması politikasını ve eylemlerini destekleyen en yetkili küresel standartlardan birisidir. Türlerin Kırmızı Liste durumlarının değerlendirmesine dayalı bu analizin Doğu Akdeniz iç sularındaki yaşam çeşitliliğini korumaya yardımcı eylemleri teşvik edecek yeni bilgi ve anlayışları sağlayacağını umuyoruz.

\section{Önemli mesajlar}

- Tatlı sulak alan türlerinin yüksek bölgesel çeşitliliği. Bölgenin büyük kesiminin göreceli olarak yarı-kurak ve kurak doğasına rağmen, tatlı sulak alan türlerinin çeşitliliğini ve geniş bir yelpazede su, gıda ve gelir gibi faydalar sunan habitat çeşitliliğini barındırmaktadır. Tatlı sulak alan balıkları, yumuşakçalar, kızböcekleri (yusufçuk ve küçük kızböcekleri), tatlı sulak alan bitkileri, kuşlar, amfibiler, kabuklular ve memelilerden 1268 türün 368'i $(\% 29,8)$ Doğu Akdeniz bölgesine endemiktir.

- Su stresi ve kirlilik tatlı sulak alan biyoçeşitliliği üzerinde yüksek düzeyde tehdide yol açmıştır. Tatlı sulak alan biyoçeşitliliği ve habitatları, kurak iklimin tüm bileşenleri olan aşırı su alımı, kirlilik ve barajların neden olduğu büyük miktardaki su stresinin etkisi altındadır. Bu durum, sürekli akan birçok nehir (zaman zaman kuruyan) ile bataklıklar ve göller gibi diğer sulak alanların yok olmasına neden olmuştur. Bu nedenle, bölgedeki tatlı sulak alan biyoçeşitliliğinin \%19,1'i ve bölgenin endemik tatlı sulak alan türlerinin \%58,2'si tehdit altında değerlendirilmiştir. $\mathrm{Bu}$ proje için değerlendirilen gruplardan tatlı sulak alan yumuşakçalarının \% 45, 5' i yüksek tehdit altında, balıkların \%41'i, yusufçuklar ve küçük kızböceklerinin \%6,7'si ve tatl sulak alan bitkilerinin $\% 2,5$ 'i tehdit altındadır.

- Sağlıklı ekosistemler ve biyoçeşitlilik, su temininde önemli rol alması nedeniyle politik olarak tanınmaya ihtiyaç duymaktadır. Ekosistemlerin (ve dolayısıyla biyoçeşitliliğin) insani kullanım ve biyoçeşitlilik için suyun temininde (miktar ve kalite) kritik rol alması nedeniyle tanınması gerekmektedir. Bu nedenle biyoçeşitlilik suyun yönetimiyle ilgili karar alma süreçlerine dahil edilmelidir.

- Acil Entegre Nehir Havza Yönetim planı ihtiyacı. Bölgedeki ülkeler aynı zamanda biyoçeşitliliğe destek verirken tatlı sulak alan ekosistemlerine uzun vadede sürdürülebilir su, diğer ekosistem ürünleri ve hizmetleri sağlayabilmek için Entegre Nehir Havza Yönetimi yaklaşımını (ya da benzer bir stratejiyi) benimsemesi gerekir. Bu durum, özellikle BM Su Kaynakları Sözleşmesi'nin prensiplerinin tam olarak uygulanmasında güçlü bir şekilde tavsiye edilen ve ulusal sınırların ötesine geçen ekosistemlerin korunması için sorumluluğu kabul eden üye ülkelerdeki sınır ötesi sular için geçerlidir.

- Tatlı sulak alan kaynakları tatlı sulak alan biyoçeşitliği için önemli bir habitattır. Sürekli akan nehirler ve göller tehlike altındaki türler dahil türlerin çoğunu barındırır, bununla birlikte tatlı sulak alan kaynakları tehlike altındaki türlerin sayısı bakımından en büyük orana sahiptir. Tatlı sulak alan kaynakları ve sızıntıları genellikle aşırı su çekimi sonucu şiddetlenen kurak zamanlarda bölgedeki tehlike altındaki türler için sığınma sağlayan önemli habitatlardır.

- Kaybolan en fazla sayıdaki tür Türkiye, İsrail ve Suriye sınırları içinde görülür. Türkiye en fazla tatlı sulak alan türünü barındıran ülkelerden biridir, aynı zamanda bölgedeki tehdit altındaki tatlı sulak alan türleri bakımından da en yüksek orana ve sayıya sahiptir. Ayrıca, küresel ölçekte nesli tükenmiş bazı türler ile kaybolmuş türler (yani kendi ülke sınırları içindeki kayıp türler) 
bakımından en fazla sayıya sahip ülkedir. İsrail, oransal açıdan, en fazla kaybolan türe sahip ülkedir bunu Suriye ve Türkiye takip etmektedir.

- Tür zenginliğinin ve tehdit altındaki türlerin en yüksek seviyesi bu bölgededir. Tür zenginliğinin en yüksek olduğu alanlar Levant ve Türkiye'nin Akdeniz kıyıları boyunca, Marmara Denizi havzaları, Türkiye'nin Karadeniz kıyılarında ve ayrıca Gürcistan, Azerbaycan ve Ermenistan'daki Aras havzası içinde bulunmaktadır. Tehdit altındaki türlerin büyük çoğunluğu Türkiye'de Aşağ havzasında, Kuzey Suriye'de Hammar bataklığını içine alan Aşağı ve Orta Fırat, Şatt'ül-Arab nehri, Resulayn kaynak alanı ve dışarı akan Habur Nehri (Fırat havzasının parçası) ve Azerbaycan'da Aşağı Aras Nehri'nde bulunmaktadır.

- Tatlı Sulak Alan Önemli Biyoçeşitlilik Alanları bölgede koruma haritasının oluşturulmasında yardımcı olabilir. Tatlı sulak alan biyoçeşitliliğinin devamlılığı için bölge genelinde çok sayıda önemli sulak alan bulunmaktadır. “Tatlı Sulak Alan Önemli Biyoçeşitlilik Alanları” olarak bilinen bu alanlar Akdeniz Havzasi Sıcak Alaninda Tatl
Sulak Alan Önemli Biyoçeşitlilik Alanları raporunda sunulmuştur. Bu rapor tatlı sulak alan ekosistemlerindeki türlerin korunması ve gelişim planlaması hakkında bilgi vermektedir ${ }^{3}$.

- Bölge genelinde işbirliğine dayalı arazi araştırmaları ve izleme çalışmalarına acil olarak ihtiyaç vardır. Bölgede tatlı sulak alanlarla ilgili az sayıda biyoçeşitlilik izleme çalışması bulunmaktadır. Bu bölgedeki tatlı sulak alan biyoçeşitlililik kaybının durdurulması isteniyorsa, modern olarak standardize edilmiş protokoller kullanılarak oluşturulan alan izleme ve araştırma programlarına ihtiyaç bulunmaktadır. Bu durum, daha fazla tür neslinin tehlike altına girmesini engellemeye yardımcı, olmak üzere exsitu korumadan yararlanacak türlerin tanımlanmasına ve popülasyonlardaki değişikliklerin izlenmesine imkan verecektir. Bölgede kapasite geliştirmeye yardımcı olacak uluslararası kuruluşlarla işbirliği yoluyla gerçekleştirilen uygun izleme, arazi ve taksonomik araştırma programları tavsiye edilmektedir.

1. Interview with the BBC in 2003. Cited in: International Institute for Sustainable Development (IISD). 2003. Water-L News. 5. http://www.iisd.ca/water-1/ Water-L_News_5.pdf

2. Convention on Biological Diversity, Subsidiary Body on Scientific, Technical and Technological Advice. 2010. In-depth review of the programme of work on the biological diversity of inland water ecosystems: summary of background information and key messages. UNEP/CBD/SBSTTA/INF/3 11 April 2010 https:// www.cbd.int/doc/meetings/sbstta/sbstta-14/information/sbstta-14-inf-03-en.pdf

3. Darwall W., Carrizo S., Numa C., Barrios V., Freyhof J. and Smith K. 2014. Freshwater Key Biodiversity Areas in the Mediterranean Basin Hotspot. Informing species conservation and development planning in freshwater ecosystems. IUCN, Cambridge, UK and Malaga, Spain. www.iucn.org/species/freshwater

4. Frenken, K (ed.). 2009. Irrigation in the Middle East region in figures. AQUASTAT Survey - 2008. FAO Water Reports \#34, Rome, Italy.

5. Voss, K.A., Famiglietti, J.S., Lo, M., Linage, C., Rodell, M. and Swenseon, S.C. 2013. Groundwater depletion in the Middle East from GRACE with implications for transboundary water management in the Tigris-Euphrates-Western Iran region. Water Resources Research 49(2):904-914.

6. CEPF. 2010. Ecosystem Profile - Mediterranean Basin Biodiversity Hotspot. Critical Ecosystem Partnership Fund. 


\title{
Chapter 1. Background to freshwater biodiversity in the Eastern Mediterranean
}

\author{
Kevin G. Smith¹, William R.T. Darwall1', Violeta Barrios², Catherine Numa², and Süreyya Isfendiyaroğlu³
}

1.1 Global status of freshwater biodiversity

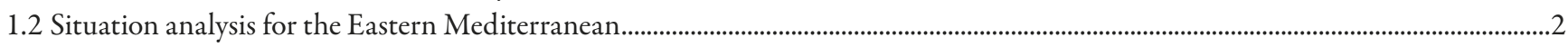

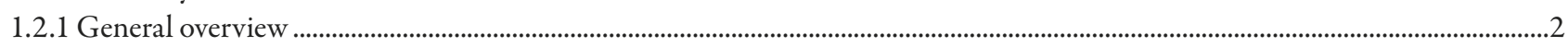

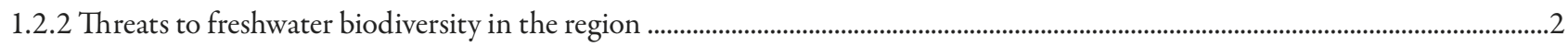

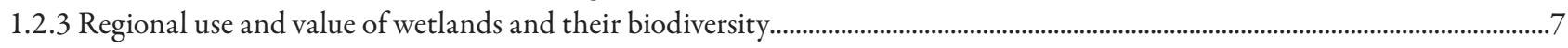

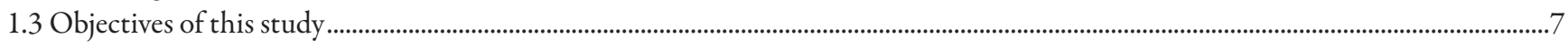

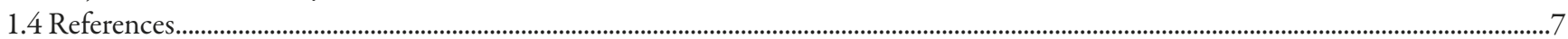

\subsection{Global status of freshwater biodiversity}

While covering less than $1 \%$ of the Earth's surface, freshwater ecosystems provide a home for around $10 \%$ of the world's described species, including a quarter of all vertebrates, and provide humans with a wealth of goods and services (Strayer and Dudgeon 2010). Freshwater biodiversity constitutes a vitally important component of the planet, with a species richness that is relatively higher compared to both terrestrial and marine ecosystems (Gleick 1996). According to the most comprehensive global assessment to date (Balian et al. 2007), there are 125,530 described animal species in freshwaters. This includes almost 5,000 molluscs, 12,740 fishes, 5,680 dragonflies and damselflies (Odonata), and 2,832 decapods. However, the study also highlights the severe lack of knowledge for some geographic regions, in particular for the tropics (areas of high diversity), and taxonomic groups (especially the invertebrate groups), meaning that these figures are likely to be significant underestimates of true diversity.

The value of inland wetlands to human society is easily seen through the direct services they provide, such as fish for food or water for drinking, but they also provide many indirect services - nutrient cycling, flood control, and water filtration. For example tropical inland fisheries alone have been valued at USD 5.58 billion per year (Neiland and Béné 2008). Putting a dollar value on these services is extremely difficult, as many have no market value. However, attempts have been made to estimate the annual value of the direct and indirect services of the world's wetlands, with differing results. For example, the Millennium Ecosystem Assessment (MEA 2005) values the annual total goods and services derived from inland waters globally as up to USD 15 trillion, Schuyt and Brander (2004) estimate a value of
USD 70 billion, whereas Costanza et al. (2014) give a value of just over USD 4 trillion per year.

However, despite its high diversity and importance to humans, freshwater biodiversity has been under threat for many decades, if not centuries. Wetlands have historically been seen as wastelands, with their only value in conversion to more 'profitable' uses such as agriculture. This has led to the loss of $64-71 \%$ of global wetlands since 1900, with the highest losses since the 1980s in Asia (Davidson 2014). Major threats to freshwater biodiversity can be grouped under five interacting categories: overexploitation; water pollution; flow modification; destruction or degradation of habitat; and invasion by exotic species, with global scale environmental changes being superimposed upon all of them (Dudgeon et al. 2006). These globally escalating threats have led to freshwater biodiversity falling into a state of

Tropical inland fisheries alone have been valued at USD 5.58 billion per year. Photo $\odot$ Carsten ten Brink, Online image/Flickr under CC licence 2.0 by-nc-nd

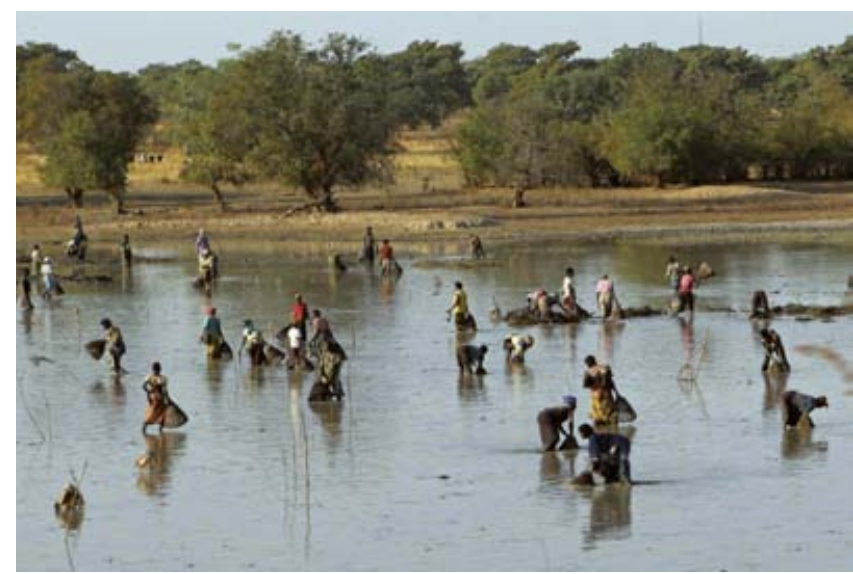

${ }^{1}$ IUCN Global Species Programme, 219c Huntingdon Road, Cambridge, UK. Email: kevin.smith@iucn.org

${ }^{2}$ IUCN Centre for Mediterranean Cooperation, Marie Curie 22, 29590 Málaga, Spain

${ }^{3}$ Doga Dernegi, Kültür Mahallesi, Doktor Mediha Eldem Sokak, 70\10 Çankaya, Ankara, Turkey 
crisis (Vorosmarty et al. 2010), causing a decline greater than is seen in either terrestrial or marine realms with freshwater species populations declining on average by $76 \%$ since 1970 (Strayer and Dudgeon 2010, WWF 2014).

Parties to the Convention on Biological Diversity (CBD) at its Sixth Conference of Parties in The Hague, Netherlands (2002), resolved 'to achieve by 2010 a significant reduction of the current rate of biodiversity loss at the global, regional and national level as a contribution to poverty alleviation and to the benefit of all life on earth' (CBD 2002). Although the '2010 targets' under this CBD commitment were not met (Butchart et al. 2010), the premise of the targets remains fundamentally solid. At the CBD 10th Conference of Parties (2010), the targets were reiterated (as the Aichi 2020 Biodiversity Targets) with more emphasis on achieving them over the next ten years. A mid-term review of progress towards the Aichi biodiversity 2020 targets (the IUCN Red List being one of the key indicators to monitor progress) shows that despite the accelerating policy and management responses to the biodiversity crisis, the impacts of these efforts are unlikely to be reflected in improved trends in the state of biodiversity by 2020 (Tittensor et al. 2014). Therefore in order to meet these targets, and conserve biodiversity, and secure human well-being, additional effort is needed to reduce pressures on biodiversity.

In keeping with the principles of the Convention on Biological Diversity, biodiversity trends and losses can be monitored by assessing the conservation status of species. There are several methods of determining species status, and the most commonly used tool is the IUCN Red List Categories and Criteria (IUCN 2012), which allows consistency in approach across different taxonomic groups. It helps in determining the relative risk of extinction and providing the basis for understanding if a species is Extinct, threatened (Critically Endangered, Endangered or Vulnerable), Near Threatened, of Least Concern, or lacking sufficient basic data for assessment (Data Deficient). The IUCN Red List of Threatened Species ${ }^{\mathrm{TM}}$ publishes the results of the assessments at www.iucnredlist.org. The IUCN Red List also provides basic information on species taxonomy, distributions, habitat and ecology, threats, population trends, use and trade, and research and conservation priorities.

On the IUCN Red List of Threatened Species, only three freshwater obligate taxonomic groups, all crustaceans, have been comprehensively assessed so far and all show a high level of threat (crabs 32\% threatened, crayfish 31.5\% threatened, and shrimps $27.8 \%$ threatened). The amphibians are another comprehensively assessed group which also (mostly) depend upon freshwater to complete their life cycles and are highly threatened (41.2\% threatened), especially when compared to other non-freshwater groups that have been comprehensively assessed, for example birds (13.4\% threatened) and mammals (25.8\% threatened) (Cumberlidge et al. 2009, IUCN 2014). In addition, regional freshwater biodiversity studies (like this one) have shown alarming results, with $21 \%$ of African freshwater biodiversity threatened, $17.8 \%$ of freshwater biodiversity in the Western Ghats
(India), 56\% of the endemic fishes of the Mediterranean basin, $54 \%$ of Madagascan endemic fish, and 38\% of all European fishes are threatened (IUCN 2004, Smith and Darwall 2006, Kottelat and Freyhof 2007, Darwall et al. 2011, Molur et al. 2011).

\subsection{Situation analysis for the Eastern Mediterranean}

\subsubsection{General overview}

The Eastern Mediterranean region (Figure 1.1) extends from the European part of Turkey, across Anatolia and to the KuraAras watershed, and south to the Levant and Mesopotamia. The region covers part of three Biodiversity Hotspots, the Mediterranean Basin, the Irano-Anatolian, and the Caucasus Hotspots. Hotspots are regions that contain at least 1,500 species of vascular plants ( $>0.5 \%$ of the world's total) as endemics, and have lost at least 70\% of their original habitat (Myers et al. 2000; www.cepf.net).

The assessment area also covers 14 freshwater ecoregions, which are large areas that encompass one or more freshwater systems that contain a distinct assemblage of natural freshwater communities and species (Figure 1.2 and Table 1.1) (Abell et al. 2008, WWF and TNC 2013). The ecoregions in the Eastern Mediterranean represent three of the 12 major freshwater habitat types identified in the world: temperate coastal rivers; xeric freshwaters and endorheic (closed) basins; and temperate floodplain rivers and wetlands. In general the region is characterized by riverine ecosystems with small lakes, coastal lagoons, endorheic aquatic systems, and single large river systems.

Within the region there are 27 wetlands of international significance which have been designated as Ramsar sites. One of them, the Azraq Oasis in Jordan, was placed in the Montreux Record (for sites that have changed in ecological character as a result of human interference) in 1990 because unsustainable groundwater extraction led to the almost complete desiccation of the site (http://www.ramsar.org).

\subsubsection{Threats to freshwater biodiversity in the region}

Water provision is a major issue in the Eastern Mediterranean region, which supports $4.4 \%$ of the global population $(140.8$ million people), but contains only $1.1 \%$ of the world's total renewable water resources (AQUASTAT 2009). Water withdrawal in the region, which is mostly used for irrigation, has increased by 20.5\% between 1997 and 2007, and is primarily drawn from surface waters $(71.5 \%)$, with ground waters providing one fifth of the region's needs and the remainder coming from unconventional sources such as desalination (AQUASTAT 2009). However, current levels of water extraction are leading to the reduction of groundwater reserves at an alarming rate, for example between 2003 and 2009 the north-central Middle 


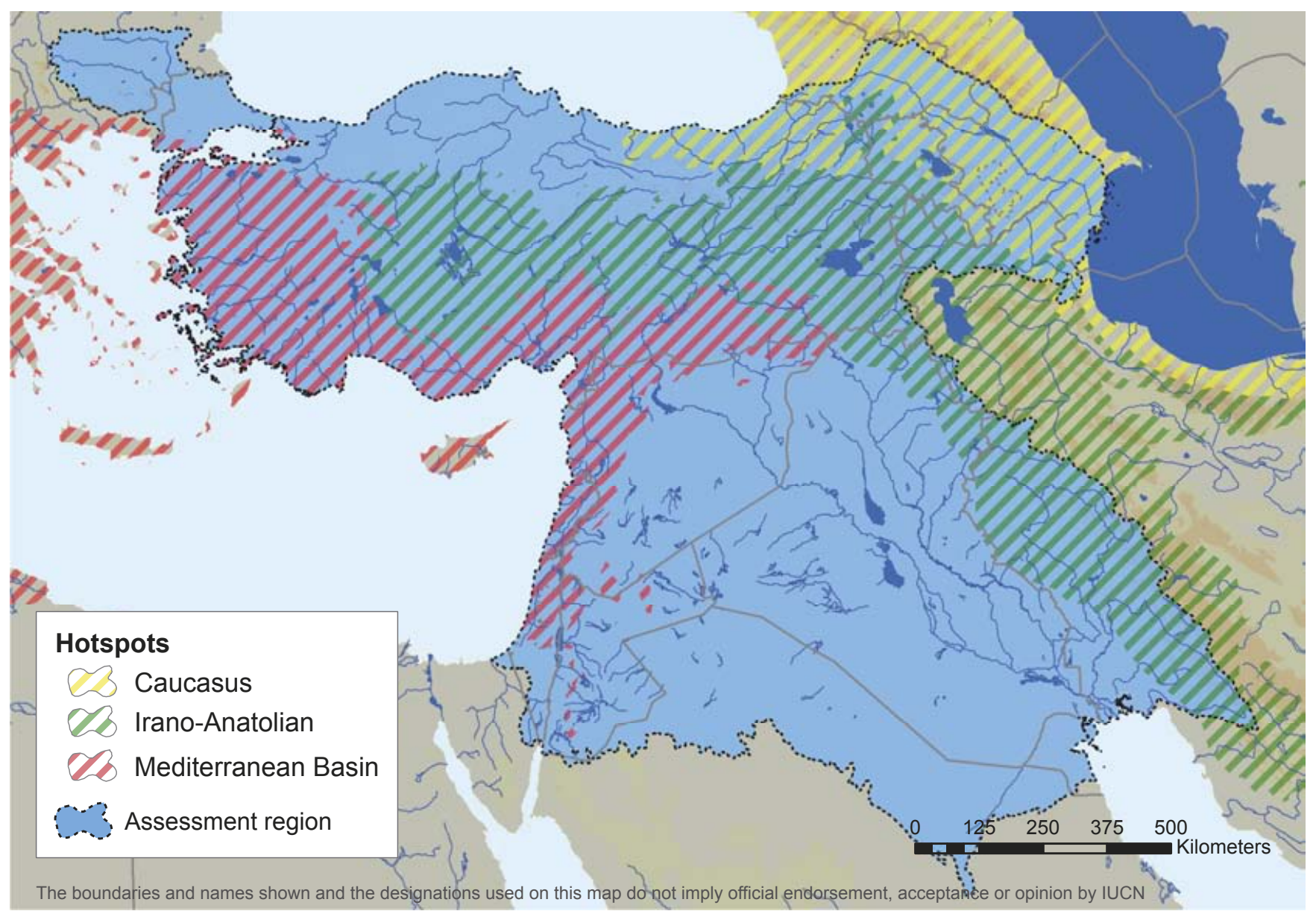

Figure 1.1 Map showing the location of the Eastern Mediterranean assessment region along with the Biodiversity Hotspots.

East lost $17.3 \mathrm{~mm} / \mathrm{yr}$ in ground water height (equivalent to $91.3 \mathrm{~km}^{3}$ in volume) (Vos et al. 2013). The result of this has been reduced flows in the region's rivers and wetlands, with some once permanent rivers becoming intermittent or even totally dry. For example, Aksehir Lake shrunk by $257 \mathrm{~km} 2$ between 1975 and 2006, and dried up completely in 2008 (Sener, Davraz and Sener 2010), and the Qweik River, once the main source of water for the city of Aleppo in Syria, now only flows intermittently and the springs which fed it are dry (UN-ESCWA and BGR 2013). As the population of the region is projected to increase by $61 \%$ between 2010 and 2050 (UN 2012), and only 39\% of the region's potential cultivated land is currently used (AQUASTAT 2009), it raises the question of where is the water going to come from to support these additional people, and irrigation needs?

Water policies within the region are largely dominated by efforts to increase water supply, and multiply the number of large water infrastructures (CEPF 2010). Increasing demand for flood control, irrigation, and electricity generation is fuelling a wave of dam construction. This situation is most severe in Turkey, which is already one of the world's most active dam building nations (International Rivers 2014), and according to GegenStrömung (2011) plans to build an additional 1,700 dams and Hydroelectric Power Plants (HEPPs), on top of the 2,000 that already exist. Turkey, Iraq, and the Syrian Arab Republic contain more than $93 \%$ of the total dam capacity in the region, most of it within the Euphrates-Tigris Basin (AQUASTAT 2009). When dam building or management take place without consideration of the needs of biodiversity and local communities, their impacts can be severe. Dams transform the riverine ecosystem into a lacustrine ecosystem with unnaturally frequent and high water level fluctuations. Dams also affect rivers by changing the flow regime (including flood peaks and seasonal flows) and trapping sediment, physically altering the river channel downstream, water quality can be reduced with changes in temperature, oxygen levels and chemical composition, and they also block migratory routes of fishes.

Water pollution is also a major threat to freshwater biodiversity in the region, and the Asi/Orontes, Gediz and Bakır rivers are examples of extremely polluted water bodies (Minareci et al. 2009, Saç et al. 2012, UN-ESCWA and BGR 2013). The main sources of pollution are from urban sewage and wastewater (often untreated or insufficiently treated), excessive pesticides and nutrients from agricultural activity (primarily nitrogen and phosphorus, and pesticides, fungicides, and herbicides), discharges and accidents from industrial facilities (including heavy metals and oils), toxic chemicals from mining operations, and dumping of solid waste from a variety of sources.

The physical loss of wetlands is also a significant pressure across the region. Coastal wetlands, especially along the Mediterranean 


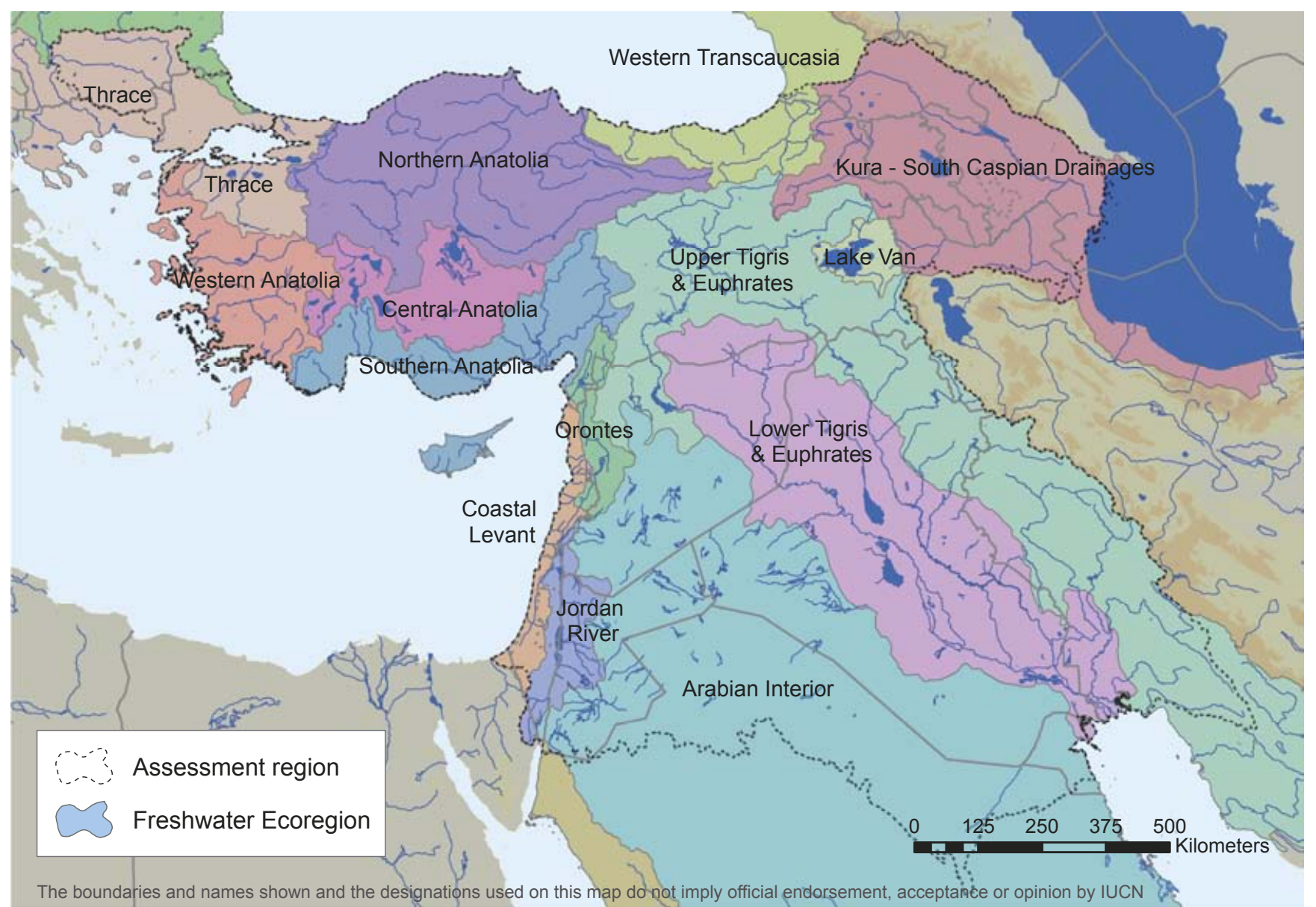

Figure 1.2 Map showing the location of the eastern Mediterranean assessment region along with the freshwater ecoregions Freshwater Ecoregions. (C) WWF and TNC 2013

and Aegean coasts of Turkey are under pressure from urbanization and tourism development. Even officially protected areas such as the Gediz Delta are under immense urbanization pressure causing very rapid to severe deterioration (BirdLife International 2014), and the Göksu Delta which is potentially threatened by tourism development (Middleton 2013). The expansion of agricultural land is one of the major drivers of freshwater habitat loss, which has led to huge wetlands such as Hula Lake, Amik Lake, and Yarma Marshes being drained and converted for agricultural use.

Freshwaters in the Mediterranean basin are reported to be the most invaded systems around the world, leading to high levels of threat amongst native biodiversity (Smith and Darwall 2006, Clavero et al. 2010, Marr et al. 2013, Ilheu, Matono and Bernardo 2014). The spread of invasive species has also been associated with important social and economic impacts. For example, between 1958 and 1961, Pseudophoxinus handlirschi, a fish restricted to Lake Eğirdir in Turkey, accounted for $20.5 \%$ of the total landings in the lake. However the species is now extinct, with no individuals being recorded since the 1980s; it is believed that the introduction of the predatory pike-perch (Sander lucioperca) was the main driver of its extinction (EEA 2011, Freyhof 2014a).
Invasive species are a major threat to freshwater biodiversity across the Mediterranean basin. Introduced tilapia at Azraq Oasis, a Ramsar site in Jordan, which is the only location for the native Azraq toothcarp (Aphanius sirhani). Photo $\odot$ Kevin Smith

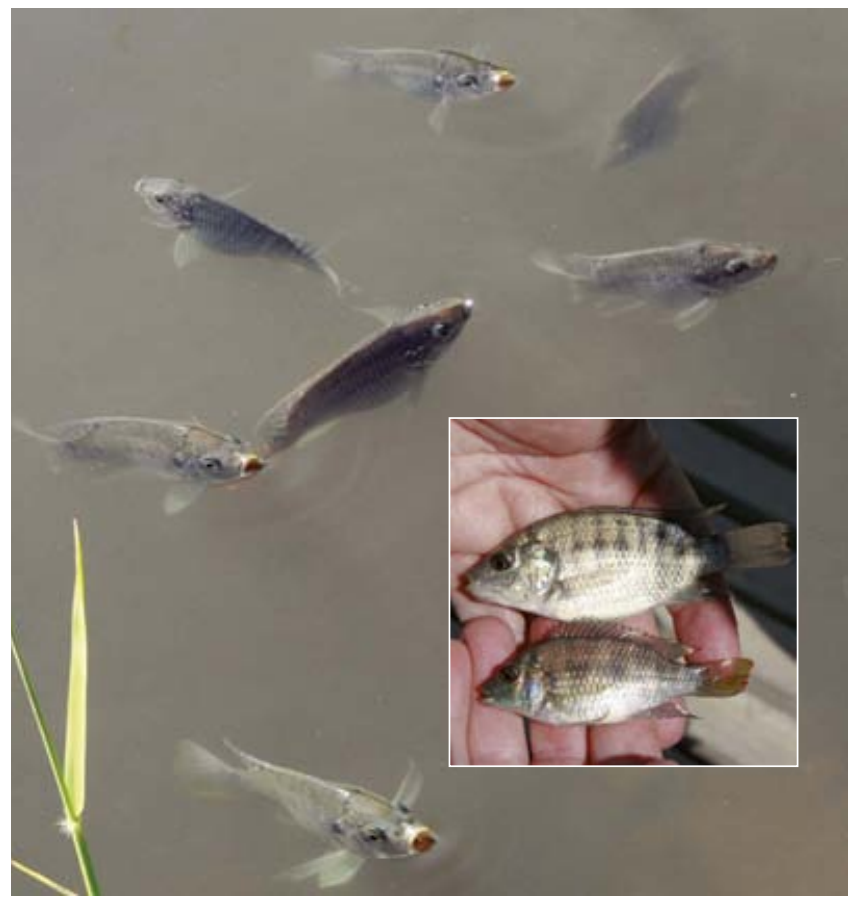


Table 1.1 Ecoregions present in the eastern Mediterranean assessment region (Abell et al. 2008; WWF and TNC 2013).

\begin{tabular}{|c|c|c|c|}
\hline Ecoregion & Major Habitat Type & Delimitation & Justification \\
\hline Thrace & $\begin{array}{l}\text { Temperate coastal } \\
\text { rivers }\end{array}$ & $\begin{array}{l}\text { The junction of Europe and Asia in Turkey, } \\
\text { European Turkey, and eastern Greece. The } \\
\text { ecoregion is bounded by the Balkan Mountains in } \\
\text { the north, the Struma River watershed in the west, } \\
\text { Aegean Sea and Sea of Marmara to the south, and } \\
\text { the Anatolian Plateau to the east. }\end{array}$ & $\begin{array}{l}\text { The diversity and species composition } \\
\text { separates its fauna from those of } \\
\text { neighbouring basins. }\end{array}$ \\
\hline $\begin{array}{l}\text { Southern } \\
\text { Anatolia }\end{array}$ & $\begin{array}{l}\text { Temperate coastal } \\
\text { rivers }\end{array}$ & $\begin{array}{l}\text { The southern area of Anatolian Turkey and } \\
\text { the islands of Cyprus and Crete, including the } \\
\text { drainages of the Aksu, Göksu, Seyhan, and Ceyhan } \\
\text { rivers. Most of the rivers originate in the Taurus } \\
\text { Mountains to the north, and empty into the } \\
\text { Mediterranean Sea in the south. }\end{array}$ & $\begin{array}{l}\text { High levels of endemism in certain genera } \\
\text { and a relatively diverse fauna. }\end{array}$ \\
\hline $\begin{array}{l}\text { Coastal } \\
\text { Levant }\end{array}$ & $\begin{array}{l}\text { Xeric freshwaters and } \\
\text { endorheic (closed) } \\
\text { basins }\end{array}$ & $\begin{array}{l}\text { The coastal strip of the Levant from the western } \\
\text { slopes of the Jabal an Nusayriyah Mountains in } \\
\text { Syria, the Lebanon Mountains in Lebanon and the } \\
\text { Judean Hills in Israel, to the Sinai. }\end{array}$ & $\begin{array}{l}\text { Endemic species and species mix unique in } \\
\text { the Middle East. }\end{array}$ \\
\hline Jordan River & $\begin{array}{l}\text { Xeric freshwaters and } \\
\text { endorheic (closed) } \\
\text { basins }\end{array}$ & The drainage basin of the Jordan River. & $\begin{array}{l}\text { Endemic species, Tethyan relicts, and the } \\
\text { varied (for Southwest Asia) cichlid fauna of } \\
\text { African origin. }\end{array}$ \\
\hline $\begin{array}{l}\text { Central } \\
\text { Anatolia }\end{array}$ & $\begin{array}{l}\text { Xeric freshwaters and } \\
\text { endorheic (closed) } \\
\text { basins }\end{array}$ & $\begin{array}{l}\text { Inland drainage basin, which includes the Lake Tuz } \\
\text { and Konya basins. }\end{array}$ & $\begin{array}{l}\text { High level of endemism and speciation in } \\
\text { the Cyprinidae family in isolated basins. }\end{array}$ \\
\hline $\begin{array}{l}\text { Western } \\
\text { Anatolia }\end{array}$ & $\begin{array}{l}\text { Temperate coastal } \\
\text { rivers }\end{array}$ & $\begin{array}{l}\text { The Aegean coast of Anatolian Turkey, from the } \\
\text { Sea of Marmara in the north to the Mediterranean } \\
\text { Sea in the south. It includes the basins of the Gediz, } \\
\text { Küçük (Lesser) Menderes, and Büyük (Greater) } \\
\text { Menderes rivers. }\end{array}$ & $\begin{array}{l}\text { Endemisms and species diversity with } \\
\text { northern elements, freshwater species } \\
\text { related to those of Europe and to those } \\
\text { of Southwest Asia, and a diverse fauna of } \\
\text { marine origin. }\end{array}$ \\
\hline $\begin{array}{l}\text { Arabian } \\
\text { Interior }\end{array}$ & $\begin{array}{l}\text { Xeric freshwaters and } \\
\text { endorheic (closed) } \\
\text { basins }\end{array}$ & The internal basins of the Arabian Peninsula. & $\begin{array}{l}\text { Relatively high level of endemism and } \\
\text { affinities with Africa. }\end{array}$ \\
\hline $\begin{array}{l}\text { Western } \\
\text { Transcaucasia }\end{array}$ & $\begin{array}{l}\text { Temperate coastal } \\
\text { rivers }\end{array}$ & $\begin{array}{l}\text { The river drainage areas and lakes of the Black } \\
\text { Sea coast in Russia, Georgia, and Turkey from the } \\
\text { Sukko rivulet (north of Novorossiysk) to the Yesil } \\
\text { Irmak (Yesilirmak) River basin (exclusive). }\end{array}$ & $\begin{array}{l}\text { It is clearly distinct from the other } \\
\text { Caucasian ecoregions by the main divided } \\
\text { ridges of the Caucasus. }\end{array}$ \\
\hline $\begin{array}{l}\text { Northern } \\
\text { Anatolia }\end{array}$ & $\begin{array}{l}\text { Temperate coastal } \\
\text { rivers }\end{array}$ & $\begin{array}{l}\text { The drainages of north-central and western } \\
\text { Anatolian Turkey, from the Sakarya basin in the } \\
\text { west to the Kizil and Kelkit basins in the east. }\end{array}$ & $\begin{array}{l}\text { Diversity and species composition separates } \\
\text { its fauna from neighbouring basins. }\end{array}$ \\
\hline $\begin{array}{l}\text { Lower } \\
\text { Tigris and } \\
\text { Euphrates }\end{array}$ & $\begin{array}{l}\text { Temperate floodplain } \\
\text { rivers and wetlands }\end{array}$ & The lower Tigris-Euphrates river system. & $\begin{array}{l}\text { One of the world's major wetlands with } \\
\text { large rivers and formerly extensive marsh } \\
\text { habitats. }\end{array}$ \\
\hline $\begin{array}{l}\text { Upper } \\
\text { Tigris and } \\
\text { Euphrates }\end{array}$ & $\begin{array}{l}\text { Temperate floodplain } \\
\text { rivers and wetlands }\end{array}$ & $\begin{array}{l}\text { The upper sections of the Tigris and Euphrates } \\
\text { rivers and their tributaries, with adjacent drainages } \\
\text { in Iran that flow into the northern Gulf and other } \\
\text { neighbouring internal basins, and the Quwaiq } \\
\text { River basin in Syria. }\end{array}$ & $\begin{array}{l}\text { Mostly riverine fauna comprising species } \\
\text { shared with the Lower Tigris and Euphrates } \\
\text { ecoregion, but with many endemics not } \\
\text { found in these lowlands. }\end{array}$ \\
\hline $\begin{array}{l}\text { Kura South } \\
\text { Caspian } \\
\text { Drainages }\end{array}$ & $\begin{array}{l}\text { Temperate floodplain } \\
\text { rivers and wetlands }\end{array}$ & $\begin{array}{l}\text { The whole Kura-Aras catchment (Lake Sevan } \\
\text { exclusive) and rivers of the Caspian Sea in } \\
\text { southeastern Azerbaijan, as well as the lower reaches } \\
\text { of rivers (Kyzyluzen [Safid Rud]) eastward to the } \\
\text { Taran River (exclusive). }\end{array}$ & High number of endemic taxa. \\
\hline Lake Van & $\begin{array}{l}\text { Xeric freshwaters and } \\
\text { endorheic (closed) } \\
\text { basins }\end{array}$ & The basin of Lake Van. & Its isolation and relict species. \\
\hline Orontes & $\begin{array}{l}\text { Temperate coastal } \\
\text { rivers }\end{array}$ & $\begin{array}{l}\text { The valley of the Orontes River of Lebanon and } \\
\text { Syria, and northern tributaries of Turkey and Syria. }\end{array}$ & $\begin{array}{l}\text { High level of endemism and diverse fauna in } \\
\text { a small basin. Bahrat Homs is an important } \\
\text { wintering and staging area for migratory } \\
\text { waterfowl. }\end{array}$ \\
\hline
\end{tabular}


Overexploitation and illegal and indiscriminate hunting is a serious problem for many Mediterranean species, affecting many threatened plants, reptiles, fishes, and other species (CEPF 2010). This includes unsustainable hunting and egg collecting, logging and wood harvesting, trapping of animals for the pet trade, collection of plants for horticulture, and fishing. Waterfowl poaching is widely practised within the Eastern Mediterranean region, where law enforcement is weak due to insufficient capacity of the local authorities. The sturgeons, occurring in the Black and Caspian seas and their larger catchments, are a high profile example of overharvesting of a species (though they are also impacted by dams blocking their migratory routes), and have become almost extirpated from Turkish rivers (Ustaoglu and Okumus 2004). Another example is the fish Mesopotamichthys sharpeyi, a common commercial species all over the southern part of Euphrates and Tigris drainages a decade ago, it has experienced a population decline of more than $80 \%$ since 1977 due to overfishing and the destruction of marshes (Freyhof 2014b). In some parts of the region, inland waters are open access with no catch controls (FAO 2004) and fishermen use prohibited methods such as toxins and very small mesh-size gill nets to catch fish species (Freyhof 2014b).

A compounding threat upon freshwater biodiversity in the region is climate change. According to CEPF (2010) there is a general consensus in predictions that there will be an increase in mean annual temperatures, and that the frequency of extremely hot summer days is expected to increase by $10 \%$ in coastal areas, and up to $20 \%$ further inland. Precipitation is expected to decrease, particularly over the southern and eastern Mediterranean, and the number of dry summer days and drought spells will increase. These climatic changes will lead to reduced summer flows, which are already impacted by high levels of water abstraction.

It is within transboundary waters such as the Euphrates and Tigris, Jordan River, and Orontes/Asi River that these stressors can often be seen to be the most severe (see Partow 2001, AQUASTAT 2009, Coad and Hales 2013, UN-ESCWA and BGR 2013). The Euphrates River rises in Turkey flowing through Syria and Iraq where it empties into the Arabian/Persian Gulf. According to a UN-ESCWA and BGR (2013) report, water use across the basin is focused on hydropower, irrigation, and drinking provision and as a result water quality and flows have significantly declined, with droughts now forming a major natural hazard affecting water supplies in the basin, and increasing salinity in the lower Euphrates marshes in Iraq. While there are two bilateral agreements in place, there is no basin wide agreement for the Euphrates, and riparian countries hold conflicting positions on International Water Law. According to the UN-ESCWA and BGR (2013) report the outlook, at least in the near term, is not positive with Turkey building the Ilisu dam, political unrest in Syria and Iraq, and water extractions on the rise, concerted efforts will be needed to form a basin-wide

The Ataturk dam on the Euphrates River in Turkey. Due to water abstraction, dams and increasing severity of droughts the Euphrates river flows have significantly declined. Photo $\odot$ Carsten ten Brink, Online image/Flickr under CC licence 2.0 by-nc-nd

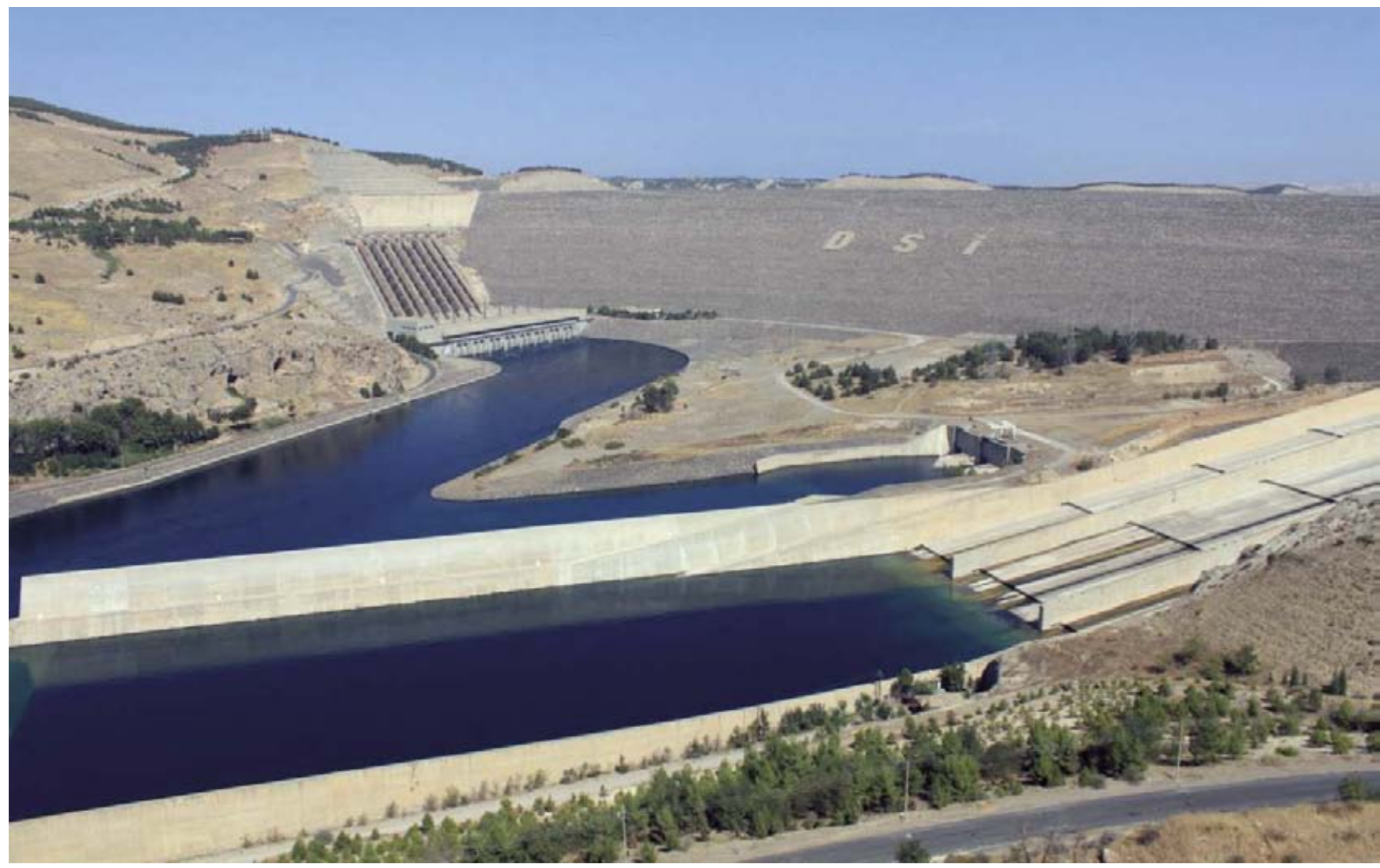


integrated river basin management plan to address the current and future needs of the people and environment.

\subsubsection{Regional use and value of wetlands and their biodiversity}

Wetlands across the Eastern Mediterranean region provide a wide variety of ecosystem services, including water, food, and income. In Turkey, for example at Güney Marshes and Sultan Marshes, reeds (Phragmites australis) and bulrush (Thypha spp.) are used as fodder and roofing material and constitute a key source of income in the area. Reed harvesting in the Sultan Marshes is estimated to be 1,500 tonnes/yr and most (up to 300,000 bundles) is exported (Yeniyurt and Hemmami 2011). The loss of Central Anatolian lakes and marshes has not only impacted hydrological and biological aspects, but also activities like fishing and reed harvesting, which contributed to the economy of local communities, as well as losing the potential opportunities from ecotourism (Karadeniz, Tirıl and Baylan 2009).

Many species of waterfowl are hunted in the region for food and sport, and it is an important socio-economic activity across the region, involving large numbers of people particularly in rural areas, for example in Syria there are an estimated 400,000 sport hunters, 200-300 falcon trappers and 20,000 people who hunt for a living (BirdLife International 2010).

Lagoons in the Eastern Mediterranean, such as the Göksu Delta, Akyatan, and Agyatan lagoons in Turkey, are often managed as sealed fisheries where species such as European eel (Anguilla anguilla) and flathead mullet (Mugil cephalus) are harvested for export (Yeniyurt and Hemmami 2011). However, traditional fisheries are being replaced by the harvesting of the non-native and invasive blue crab (Callinectes sapidus) as it generates a considerable income for local communities.

Sea salt harvesting is also an ancient practice in the Mediterranean. The Gediz Delta in western Anatolia harbours huge saltpans, that provide employment for local communities and the management of the saltpans also secures a safe breeding location for flamingoes (Phoenicopterus roseus) (Eken et al. 2006). Salt harvesting is also found in salt ponds adjacent to the Dead Sea in Jordan and Israel.

The dependence of human populations upon healthy freshwater ecosystems is no more evident than in Iraq. The marshlands in southern Iraq were once among the largest wetlands in the world, covering more than $10,500 \mathrm{~km}^{2}$, supporting a diverse range of flora and fauna and providing freshwater and livelihoods for almost half a million people. The draining of the wetlands in the 1990 s had a very negative impact upon the communities living there, with many having to leave. By 2002, the marshlands had been reduced to less than $10 \%$ of their original size. In 2003, the UN and the World Bank identified the draining as a major environmental and humanitarian disaster and restoration plans were launched (Canada-Iraq Marshlands Initiative 2010). Since then around $4,000 \mathrm{~km}^{2}$ of marshlands have been restored, about
$30-40 \%$ of the original size, and roughly 90,000 'Marsh Arabs' have returned, also in $20131,000 \mathrm{~km}^{2}$ of the marshes were designated as Iraq's first and only National Park (Yeo 2013).

\subsection{Objectives of this study}

A lack of basic information on freshwater species distributions and threatened status in the Eastern Mediterranean region has long been a key obstacle facing freshwater ecosystem managers in the region. Specifically, the Eastern Mediterranean Assessment project, aimed to:

i) Collate information for assessments of conservation status and distributions of freshwater biodiversity (fishes, molluscs, plants, odonates), throughout the inland waters of the Eastern Mediterranean region;

ii) Store, manage, analyze and make widely available the biodiversity information throughout the region and globally, using the IUCN Red List and through the work of IUCN, its members, and partners;

iii) Provide the information so that important sites for freshwater biodiversity, known as Key Biodiversity Areas (Darwall et al. 2014), can be identified.

\subsection{References}

Abell R., Thieme M.L., Revenga C., Bryer M., Kottelat M., Bogutskaya N., Coad B., Mandrak N., Contreras Balderas S., Bussing W., Stiassny M.L.J., Skelton P., Allen G.R., Unmack P., Naseka A., Sindorf R., Ng N., Robertson J., Armijo E., Higgins J.V., Heibel T.J., Wikramanake E., Olson D., Lopez H.L., Reis R.E., Lundberg J.G., Sabaj Perez M.H. and Petry P. 2008. Freshwater ecoregions of the world: a new map of biogeographic units for freshwater biodiversity conservation. BioScience 58:403-414.

AQUASTAT. 2009. Irrigation in the Middle East region in figures. In: K. Frenken (ed.), AQUASTAT survey 2008. FAO Water Reports \#34, Rome, Italy.

Balian, E.V., Leveque, C., Segers, H. and Martens, K. 2007. Freshwater animal diversity assessment. Development in Hydrobiologia 198.

BirdLife International. 2010. Towards sustainable hunting in the Middle East. Presented as part of the BirdLife state of the world's birds website. Accessed: 02/10/2014 http://www.birdlife.org/datazone/ sowb/casestudy/35

BirdLife International. 2014. Important Bird Areas factsheet: Gediz Delta. Downloaded from http://www.birdlife.org on 11/11/2014.

Butchart, S.H.M., Walpole, M., Collen, B., van Strien, A., Scharlemann, J.P., Almond, R.E., Baillie, J.E., Bomhard, B., Brown, C., Bruno, J., Carpenter, K.E., Carr, G.M., Chanson, J., Chenery, A.M., Csirke, J., Davidson, N.C., Dentener, F., Foster, M., Galli, A., Galloway, J.N., Genovesi, P., Gregory, R.D., Hockings, M., Kapos, V., Lamarque, J.F, Leverington, F., Loh, J., McGeoch, M.A., McRae, L., Minasyan, A., Hernández Morcillo, M., Oldfield, T.E., Pauly, D., Quader, S., Revenga, C., Sauer, J.R., Skolnik, B., Spear, D., Stanwell-Smith, D., Stuart, S.N., Symes, A., Tierney, M., Tyrrell, T.D., Vié, J.C. and Watson R. 2010. Global biodiversity: Indicators of recent declines. Science 328:1164-1168.

Canada-Iraq Marshlands Initiative. 2010. Managing for Change: The Present and Future State of the Marshes of Southern Iraq.

CBD. 2002. COP Decision VI/26: Strategic Plan for the Convention on Biological Diversity. 
CEPF. 2010. Ecosystem Profile - Mediterranean Basin Biodiversity Hotspot. Critical Ecosystem Partnership Fund.

Clavero, M., Hermosos, V., Levin, N. and Kark, S. 2010. Geographical linkages between threats and imperilment in freshwater fish in the Mediterranean Basin. Diversity and Distributions 16:744-754.

Coad, B. and Hales, J. 2013. The Jordan River. Freshwater eco-regions of the world. Accessed 16/10/2014 http://www.feow.org/ecoregions/ details/jordan_river

Costanza, R., de Groot, R., Sutton, P., van der Ploeg, S., Anderson, S.J., Kubiszewski, I., Farber, S. and Turner, R.K. 2014. Changes in the global value of ecosystem services. Global Environmental Change 26:152-158.

Cumberlidge, N., Ng, P.K.L., Yeo, D.C.J., Magalhães, C., Campos, M.R., Alvarez, F., Naruse, T., Daniels, S.R., Esser, L.J., Attipoe, F.Y.K., Clotilde-Ba, F.-L., Darwall, W., McIvor, A., Baillie, J.E.M., Collen, M. and Ram, M. 2009. Freshwater crabs and the biodiversity crisis: importance, threats, status, and conservation challenges. Biological Conservation 142:1665-1673.

Darwall W., Carrizo, S., Numa, C., Barrios, V., Freyhof, J. and Smith, K. 2014. Freshwater Key Biodiversity Areas in the Mediterranean Basin Hotspot. Informing species conservation and development planning in freshwater ecosystems. IUCN, Cambridge, UK and Malaga, Spain.

Darwall, W.R.T., Smith, K.G., Allen, D.J., Holland, R.A., Harrison, I.J. and Brooks, E.G.E. (eds.). 2011. The Diversity of Life in African Freshwaters: Under Water, Under Threat. An analysis of the status and distribution of freshwater species throughout mainland Africa. IUCN, Cambridge, UK and Gland, Switzerland.

Davidson, N.C. 2014. How much wetland has the world lost? Long-term and recent trends in global wetland area. Marine and Freshwater Research 65(10):934-941.

Dudgeon, D., Arthington, A.H., Gessner, M.O., Kawabata, Z.-I., Knowler, D.J., Leveque, C., Naiman, R.J., Prieur-Richard, A.-H., Soto, D., Stiassny, M.L.J. and Sullivan, C.A. 2006. Freshwater biodiversity: importance, threats, status and conservation challenges. Biological Reviews, 81:163-182.

EEA.2011. The European environment - state and outlook 2010: assessment of global megatrends. European Environment Agency, Copenhagen.

Eken, G., Bozdoğan, M., İsfendiyaroğlu, S., Kılıç, D.T. and Lise Y. 2006. Key Biodiversity Areas of Turkey (Türkiye'nin Önemli Doğa Alanları.). Doğa Derneği, Ankara, Turkey [in Turkish].

FAO. 2004. Fishery country profile. Republic of Iraq. Accessed: 15/10/2014 http://www.fao.org/fishery/facp/IRQ/en

Freyhof, J. 2014a. Pseudophoxinus handlirschi. The IUCN Red List of Threatened Species. Version 2014.2. www.iucnredlist.org

Freyhof, J. 2014b. Mesopotamichthys sharpeyi. The IUCN Red List of Threatened Species. Version 2014.2. www.iucnredlist.org

GegenStrömung. 2011. Dam construction in Turkey and its impact on economic, cultural and social rights: Parallel report in response to the Initial Report by the Republic of Turkey on the Implementation of the International Covenant on Economic, Social and Cultural Rights. Submission to the UN Committee on Economic, Social and Cultural Rights for its 46th Session, 2-20 May 2011. http://www2.ohchr.org/ english/bodies/cescr/docs/ngos/JointReport_Turkey46.pdf

Gleick, P.H. 1996. Water resources. In: S.H. Schneider, (ed.), Encyclopedia of Climate and Weather, pp. 817-823. Oxford University Press, New York, USA.

Ilheu, M., Matono, P. and Bernardo, J.M. 2014. Invasibility of Mediterranean-climate rivers by non-native fish: the importance of environmental drivers and human pressures. PLOS ONE, DOI: 10.1371/journal.pone.0109694

International Rivers. 2014. Turkey. Accessed 12/11/2014 http://www. internationalrivers.org/campaigns/turkey

IUCN. 2004. Red List assessment of Madagascar endemic freshwater fishes. IUCN, Gland, Switzerland and Cambridge, UK.

IUCN. 2012. IUCN Red List Categories and Criteria: Version 3.1. Second edition. IUCN, Gland, Switzerland and Cambridge, UK.
IUCN. 2014. IUCN Red List of Threatened Species, version 2014.2. www. iucnredlist.org

Karadeniz, N., Tir1l, A. and Baylan, E. 2009. Wetland management in Turkey: Problems, achievements and perspectives. African Journal of Agricultural Research, 4(11):1106-1119.

Kottelat, M. and Freyhoff, J. 2007. Handbook of European Freshwater Fishes. Kottelat, Cornol, Switzerland and Freyhoff, Berlin, Germany.

Marr, S.M., Olden, J.D., Leprieur, F., Arismendi, I., Ćaleta, M., Morgan, D.L., Nocita, A., Sanda, R., Serhan Tarkan, A. and Garcia-Berthou, E. 2013. A global assessment of freshwater fish introductions in Mediterranean-climate regions. Hydrobiologia 719:317-329.

MEA. 2005. Ecosystems and Human Well-Being: A Framework for Assessment. Millennium Ecosystem Assessment. Island Press, Washington DC, USA.

Middleton, N. 2013. The global casino: an introduction to environmental issues. 4th Edition. Routledge.

Minareci, O., Öztürk, M., Egemen, O. and Minareci, E. 2009. Detergent and phosphate pollution in Gediz River, Turkey. African Journal of Biotechnology 8(15):3568-3575.

Molur, S., Smith, K.G., Daniel, B.A. and Darwall, W.R.T. 2011. The status and distribution of freshwater biodiversity in the Western Ghats, India. IUCN, Cambridge, UK and Zoo Outreach Organisation, Coimbatore, India.

Myers, N., Mittermeier, R.A., Mittermeier, C.G., da Fonseca, G.A.B. and Kent, J. 2000. Biodiversity hotspots for conservation priorities. Nature 403:853-858.

Neiland, A.E. and Béné, C. (eds.). 2008. Tropical river fisheries valuation: background papers to a global synthesis. The WorldFish Center Studies and Reviews No.1836. The WorldFish Center, Penang, Malaysia.

Partow, H. 2001. The Mesopotamian Marshlands: Demise of an Ecosystem. United Nations Environment Programme, Nairobi, Kenya.

Saç, M.M., Ortabuk, F., Kumru, M.N., Ichedef, M. and Sert, S. 2012. Determination of radioactivity and heavy metals of Bakirçay river in Western Turkey. Applied Radiation and Isotopes 70(10):2494-2499.

Schuyt, K. and Brander, L. 2004. Living Waters Conserving the Source of Life. The Economic Value of the World's Wetlands. WWF, Gland, Switzerland.

Sener, E., Davraz, A. and Sener, S. 2010. Investigation of Aksehir and Eber Lakes (SW Turkey) coastline change with multi-temporal satellite images. Water Resource Management 24(4):727-745.

Smith, K.G. and Darwall, W.R.T. (eds.). 2006. The Status and Distribution of Freshwater Fish Endemic to the Mediterranean Basin. IUCN, Gland, Switzerland and Cambridge, UK.

Strayer, D.L. and Dudgeon, D. 2010. Freshwater biodiversity conservation: recent progress and future challenges. Journal of the North American Benthological Society 29:344-358.

Tittensor, D.P., Walpole, M., Hill, S.L.L., Boyce, D.G., Britten, G.L., Burgess, N.D., Butchart, S.H.M., Leadley, P.W., Regan, E.C., Alkemade, R., Baumung, R., Bellard, C., Bouwman, L., BowlesNewark, N.J., Chenery, A.M., Cheung, W.W.L., Christensen, V., Cooper, H.D., Crowther, A.R., Dixon, M.J.R., Galli, A., Gaveau, V., Gregory, R.D., Gutierrez, N.L., Hirsch, T.L., Hoft, R., JanuchowskiHartley, S.R., Karmann, M., Krug, C.B., Leverington, F.J., Loh, J., Lojenga, R.K., Malsch, K., Marques, A., Morgan, D.H.W., Mumby, P.J., Newbold, T., Noonan-Mooney, K., Pagad, S.N., Parks, B.C., Pereira, H.M., Robertson, T., Rondinini, C., Santini, L., Scharlemann, J.P.W., Schindler, S., Sumaila, U.R., Teh, L.S.L., van Kolck, J., Visconti, P. and Ye, Y. 2014. A mid-term analysis of progress toward international biodiversity targets. Science, 1257484 . doi:10.1126/science. 1257484

UN. 2012. World population prospects: the 2012 revision. Online database. United Nations, Department of Economic and Social Affairs. Accessed 18/11/2014 http://esa.un.org/wpp/unpp/panel_ population.htm

UN-ESCWA and BGR. 2013. Inventory of Shared Water Resources in Western Asia. United Nations Economic and Social Commission for 
Western Asia; Bundesanstalt für Geowissenschaften und Rohstoffe. Beirut, Lebanon.

Ustaoglu, S. and Okumus, I. 2004. The sturgeons: fragile species need conservation. Turkish Journal of Fisheries and Aquatic Sciences 4:4957.

Vorosmarty, C.J., McIntyre, P.B., Gessner, M.O., Dudgeon, D., Prusevich, A., Green, P., Glidden, S., Bunn, S.E., Sullivan, C.A., Liermann, C.R. and Davies, P.M. 2010. Global threats to human water security and river biodiversity. Nature 467:555-561.

Vos, K.A., Famiglietti, J.S., Lo, M., Linage, C., Rodell, M. and Swenseon. 2013. Groundwater depletion in the Middle East from GRACE with implications for transboundary water management in the Tigris-
Euphrates-Western Iran region. Water Resources Research 49(2):904914.

WWF 2014. The living planet report 2014. Species and spaces, people and places. WWF and Zoological Society of London, UK.

WWF and TNC. 2013. The Freshwater Ecoregions of the World. http:// www.feow.org/

Yeniyurt, C. and Hemmami, M. 2011. Türkiye'nin Ramsar Alanları. Doğa Derneği, Ankara, Turkey.

Yeo, J. 2013. Iraq's First National Park: A Story of Destruction and Restoration in the Mesopotamian Marshlands. Circle of Blue. Accessed 11/11/2014 http://www.circleofblue.org/waternews/2013/world/ iraqs-first-national-park-a-story-of-destruction-and-restoration-inthe-mesopotamian-marshlands/ 


\section{Chapter 2. Assessment methodology}

Kevin G. Smith ${ }^{1}$ and William R.T. Darwall ${ }^{1}$

2.1 Selection of priority taxa.

2.1.1 Fishes..

2.1.2 Molluscs

2.1.3 Odonates...

2.1.4 Freshwater plants

2.2 Eastern Mediterranean region delineation. 13

2.3 Data collation and quality control

2.4 Species mapping

2.5 Overlap with other Red List assessment projects

2.6 Assessment of species threatened status

2.7 Nomenclature

Seasonal flooded mudflats in the Azraq Oasis Ramsar Site, Jordan, the location of the Eastern Mediterranean freshwater biodiversity IUCN Red List assessment workshop. Photo $\Subset$ Kevin Smith

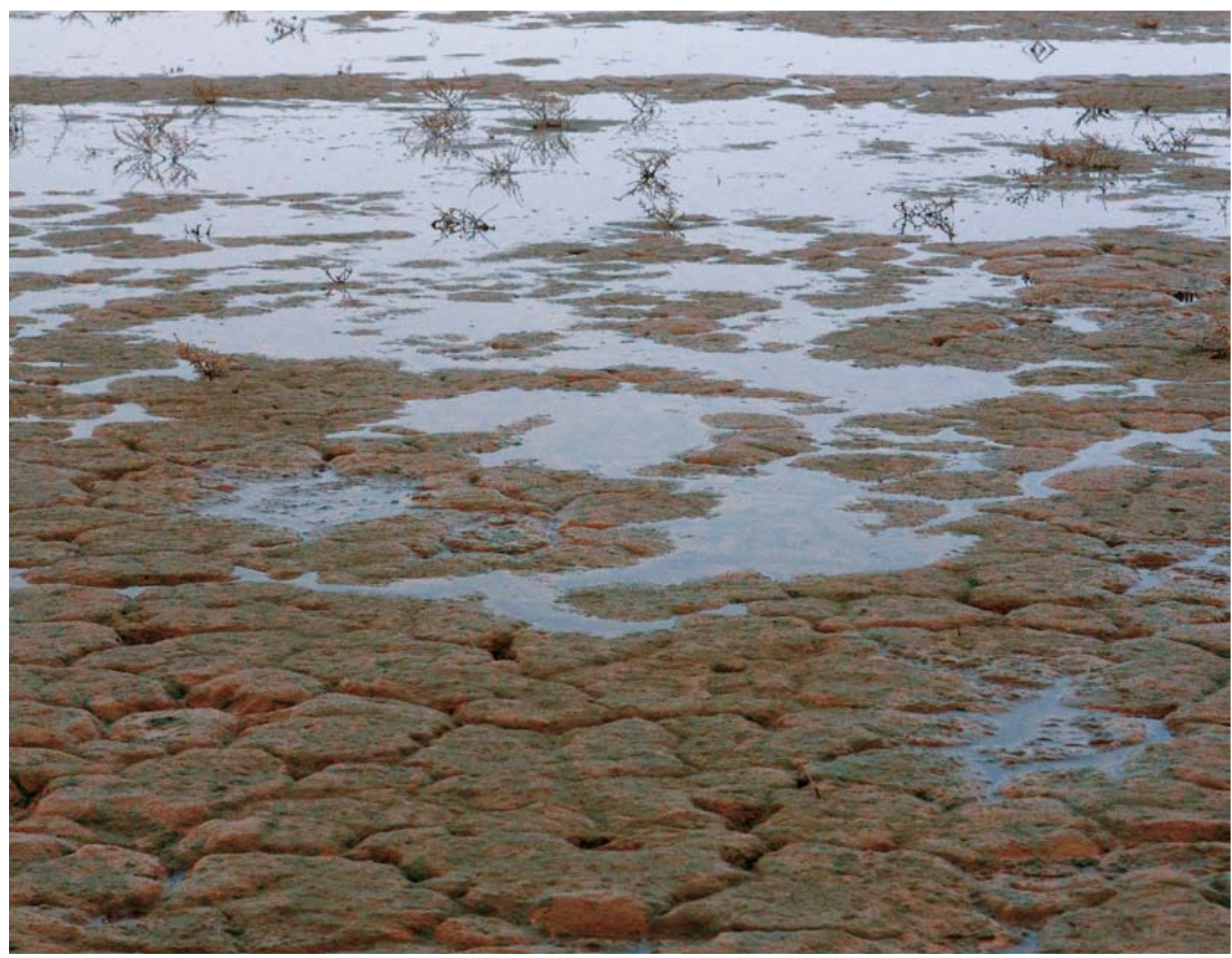

${ }^{1}$ IUCN Global Species Programme, 219c Huntingdon Road, Cambridge, UK. Email: kevin.smith@iucn.org 


\subsection{Selection of priority taxa}

In the majority of cases, large-scale biodiversity assessments have focused on a limited range of taxonomic groups, most often including those groups that provide obvious benefits to humans through direct consumption, or the more charismatic groups, such as mammals and birds. In the case of aquatic systems, it is the wetland birds and fishes that have received most attention. It is, however, important that we take a more holistic approach by collating information to conserve those other components of the food web essential to the maintenance of healthy functioning wetland ecosystems, even if they are neither charismatic nor often noticed. Clearly, it is not practical to assess all species. Therefore, a number of priority taxonomic groups were selected to represent a range of trophic levels within the food webs that underlie and support wetland ecosystems. Priority groups were selected to include those taxa for which there was thought to be a reasonable level of pre-existing information. The taxonomic groups selected were: fishes; molluscs; odonates (dragonflies and damselflies); and aquatic plants.

Although fish and plants provide a clear benefit to the livelihoods of many people throughout the world (Juffe-Bignoli and Darwall 2012), either as a source of income or as a valuable food supply, benefits provided by the other taxa may be indirect and poorly appreciated but nonetheless important. Given the wide range of trophic levels and ecological roles encompassed within these four taxonomic groups, information on their distributions and conservation status, when combined, will provide a useful indication of the overall status of the associated wetland ecosystems.

These same taxonomic groups have also been assessed for other parts of the world, beyond the Eastern Mediterranean region. As such, the assessments presented here through this regionally focused project also contribute towards building global coverage for these groups. Other regional freshwater biodiversity assessments conducted since 2004 include Continental Africa, many regions of Asia (for example see Allen et al. 2010 2012, Darwall et al. 2011, Molur et al. 2011), and Europe (Smith and Darwall 2006, Riservato et al. 2009, Cuttelod, Seddon, and Neubert 2011, Freyhof and Brooks 2011). The reports for these other projects can be downloaded from www.iucn.org All freshwater species of crabs (Cumberlidge et al. 2009), crayfish (Richman et al. In press) and shrimps (De-Grave et al. In prep) have been assessed at the global scale and the data are published on the IUCN Red List of Threatened Species ${ }^{\mathrm{TM}}$ (www.iucnredlist.org).

\subsubsection{Fishes}

Arguably, fishes form the most important wetland product at a global scale, and are often referred to as a 'rich food for poor people' (WorldFish Center 2005). It is estimated that freshwater fishes make up more than $6 \%$ of the world's annual animal protein supplies for humans (FAO 2007) and food security and employment for many more (Coates 1995, Dugan et al. 2010). For the purposes of this assessment, freshwater fishes are defined as those species that spend all or a critical part of their life cycle in fresh waters. Those species entirely confined to brackish waters are also assessed. There are almost 13,000 freshwater fish species in the world, or about 15,000 species if brackish water species are included (Lévêque et al. 2008). Prior to the start of this project in 2013, the risk of global extinction had been assessed for just 74 species of freshwater fish species native to the Eastern Mediterranean region using the IUCN Red List Categories and Criteria.

\subsubsection{Molluscs}

Freshwater molluscs are one of the most diverse and threatened groups of animals (Vaughn, Gido, and Spooner et al. 2004, Lydeard et al. 2004). They are mostly unobtrusive, and are not normally considered as being charismatic creatures, rarely attracting the attention of the popular media, unless in a negative light, as some species play a significant role (as a vector) in the transmission of human and livestock parasites and diseases. However, they play a key role in the provision of ecosystem services and are essential to the maintenance of wetlands, primarily due to their contribution to water quality and nutrient cycling through filter-feeding, algalgrazing and as a food source to other animals (see Strayer 1999, Vaughn, Gido, and Spooner 2004, Vaughn 2010, Prather et al. 2012). Some species are of high commercial importance to humans as food or ornaments (e.g., clams and some mussels and snails). There are just fewer than 5,000 freshwater mollusc species (Bogan 2008; Strong et al. 2008) for which valid descriptions exist, in addition to a possible 4,000 undescribed gastropod species (Strong et al. 2008). Only 41 freshwater mollusc species from the Eastern Mediterranean region had been assessed for the IUCN Red List prior to the initiation of this assessment in 2013.

\subsubsection{Odonates}

Larvae of almost all species of dragonflies and damselflies (order Odonata) are dependent on freshwater habitats. The habitat selection of adult dragonflies strongly depends on the terrestrial vegetation type, and their larvae develop in water where they play a critical role with regards to water quality, nutrient cycling, and aquatic habitat structure. The larvae are voracious predators, often regarded as important in the control of insect pest species. A full array of ecological niches is represented within the group and, as they are susceptible to changes in water flow, turbidity, or loss of aquatic vegetation (Trueman and Rowe 2009), they have been widely used as an indicator for wetland quality. There are approximately 5,680 extant described species. However, even though the group is well studied, it is believed that the actual number is close to 7,000 species (Kalkman et al. 2008). Of these, only 70 species of odonates known from the Eastern Mediterranean region had been assessed for the IUCN Red List prior to the initiation of this assessment in 2013. 


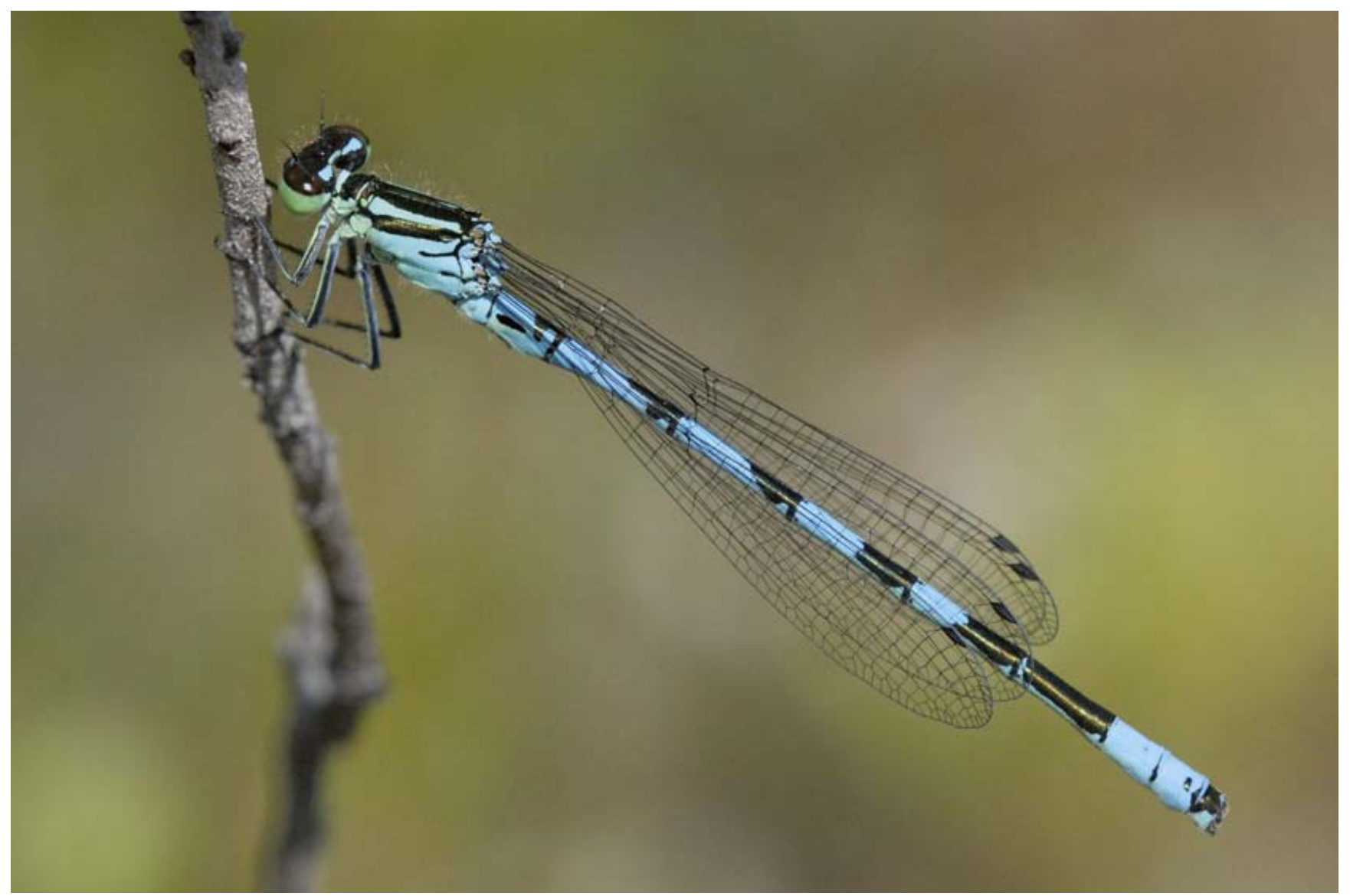

A male Spearhead bluet damselfy (Coenagrion hastulatum). Odonata (dragonflies and damselflies) are susceptible to many types of pressures to wetland ecosystems making them good indicator species. Photo $\odot$ Jean-Pierre Boudot

\subsubsection{Freshwater plants}

Freshwater plants are the building blocks of wetland ecosystems, providing food, oxygen and habitats for many other species. They are also a hugely important natural resource, providing direct benefits to human communities across the world. Numerous species are highly valued for their nutritious, medicinal, cultural, structural, or biological properties. They are also key species in the provision of wetland ecosystem services, such as water filtration and nutrient recycling (Garcia-Llorente et al. 2011). A freshwater plant is defined here as a plant that is dependent upon wetlands, meaning it would not occur if there were no wetlands (permanent or seasonal/intermittent). The number of freshwater plants in the world is unknown, as identifying which plants would qualify as wetland dependent is not an easy task, as some species are even 'wetland dependent' in only parts of their range. There are an estimated 30,000 wetland dependent plant species, including vascular plants, bryophytes, algae, and a small number of lichens (Lansdown, pers. comm. 2014). Cook (1996) estimates that 'aquatic plants' (a more restrictive definition than 'wetland dependent') represent between $1 \%$ and $2 \%$ of all plant species, and Chambers et al. (2008) identify 2,614 'aquatic' (again a more restrictive definition) macrophytes in the world. One hundred and seventeen species of freshwater plants in the Eastern Mediterranean had been assessed for the IUCN Red List prior to the initiation of this assessment in 2013.
Freshwater plants are key providers of ecosystem services such as water filtration and nutrient cycling. Juncus heterophyllus. Photo ${ }^{\circ}$ Richard V. Lansdown

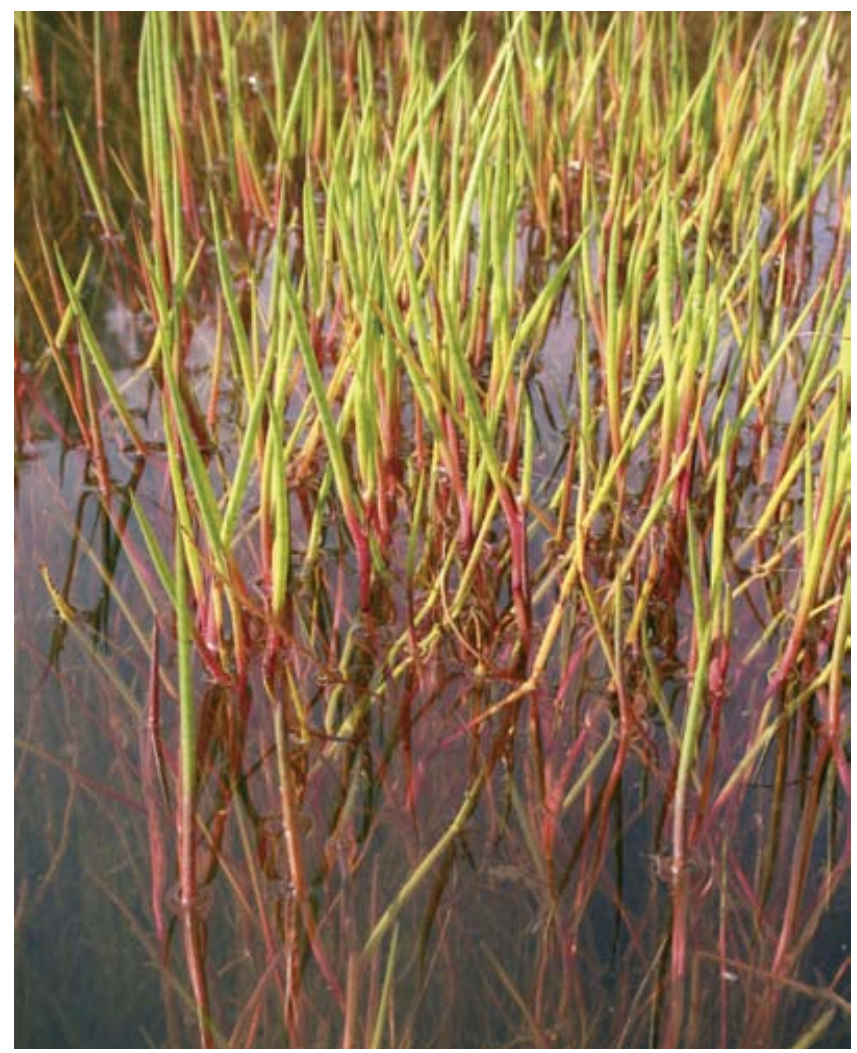




\subsection{Eastern Mediterranean region delineation}

This project focuses on the eastern part of the Mediterranean Hotspot in Turkey, Syria, Lebanon, Israel and Jordan as delineated by Myers et al. (2000), Mittermeier et al. (2004), and CEPF (2010) (see www.conservation.org/How/Pages/Hotspots. aspx and www.cepf.net). We have, however, expanded the project area to incorporate all catchments originating within countries overlapping the Hotspot boundaries, including the Euphrates and Tigris, and all catchments within Turkey (see Figure 2.1). This wider 'catchment' approach takes into consideration the high levels of interconnectivity within freshwater ecosystems, as impacts in one part of a catchment can easily and quickly be transported downstream (or upstream) potentially threatening freshwater biodiversity many miles from the original source of impact. Exclusion of species in those connected parts of catchments outside of the Hotspot boundaries would also not follow the principles of 'Integrated River Basin Management' (IRBM) which call for the management (including conservation) of rivers to be undertaken at the catchment level so the effects of any management proposals are developed with all stakeholders (including biodiversity) throughout the catchment.

\subsection{Data collation and quality control}

Information was sourced and collated for all known species within the priority taxonomic groups (see Section 2.1). Experts from across the Eastern Mediterranean region and beyond (as necessary) were identified by IUCN, the Royal Society for the Conservation of Nature Jordan (project partner), and through consultation with the relevant IUCN Species Survival Commission (SSC) Specialist Groups.

A number of participating experts were contracted to collate species lists for the region for the priority taxonomic groups, and to input within the IUCN species database (Species Information Service - SIS) all available information on each species. Where needed these experts were trained (remotely) in the use of SIS and application of the IUCN Red List Categories and Criteria (IUCN 2001). The required data fields within SIS are summarized in Table 2.2; some are free text fields allowing assessors to add general information such as species distributions, habitat preferences and ecology, whereas other fields are classification schemes using pre-defined lists to record attributes. Standard classification schemes allow for consistency in analysis across other taxonomic groups and geographic regions. For more

Figure 2.1 Project region map. Map showing the Mediterranean Hotspot and the wider project assessment region.

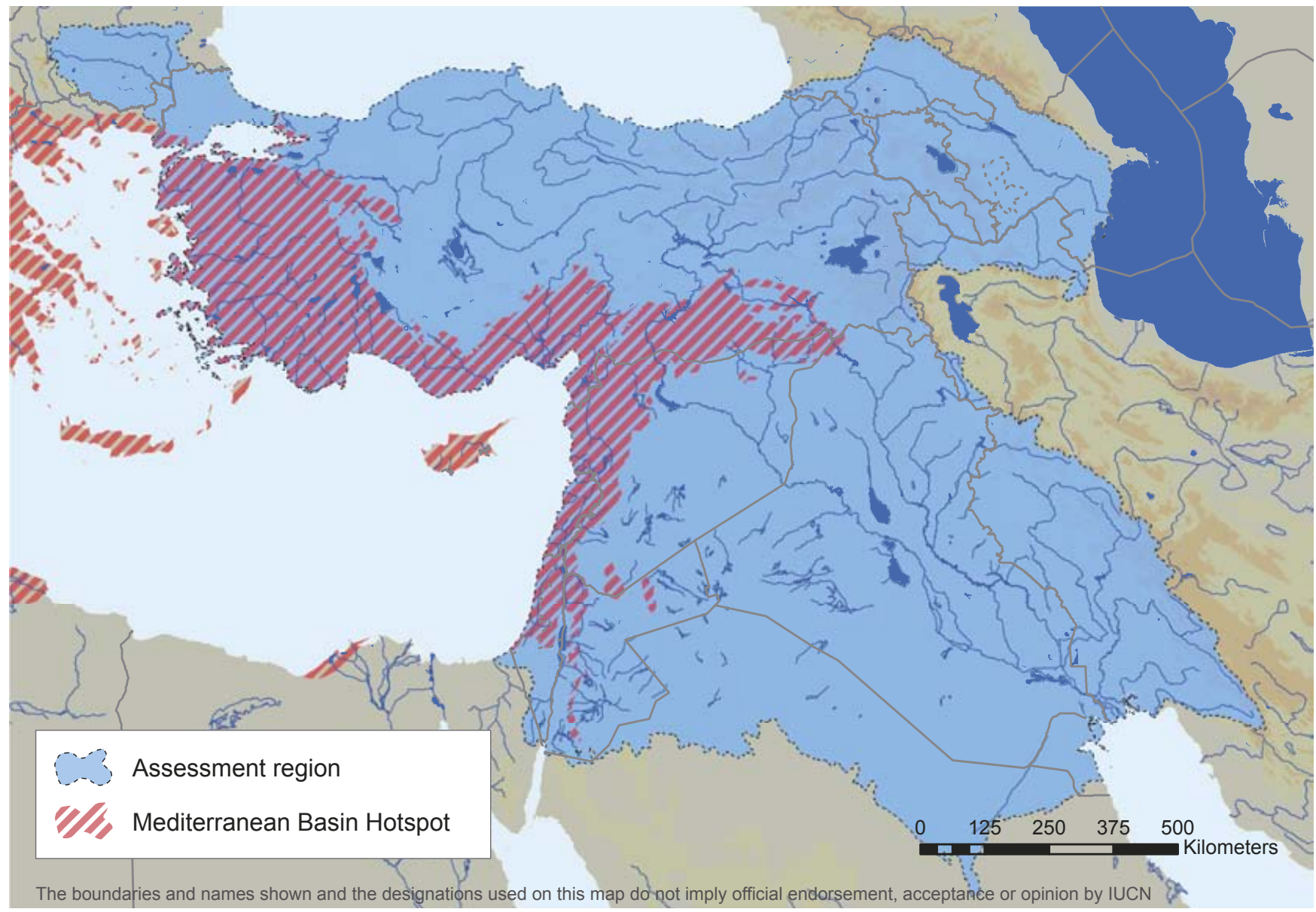


Table 2.2 Data fields within the Species Information Service (SIS) as required to compile a species assessment. Text $=$ text field; CS = predefined Classification Scheme.

\begin{tabular}{|c|c|c|c|c|}
\hline & Fields & & & \\
\hline Taxonomy & Higher taxonomy & Synonyms & Common names & \\
\hline Geographic range & General information (text) & Countries of occurrence (CS) & Biogeographic realm (CS) & \\
\hline Population & General information (text) & Population trend (CS) & & \\
\hline $\begin{array}{l}\text { Habitat and } \\
\text { ecology }\end{array}$ & General information (text) & Habitats (CS) & System (CS) & $\begin{array}{l}\text { Movement } \\
\text { patterns (CS) }\end{array}$ \\
\hline Use and trade & General information (text) & Utilization (CS) & Harvest trends (CS) & \\
\hline Threats & General information (text) & Threats (CS) & & \\
\hline $\begin{array}{l}\text { Conservation } \\
\text { measures }\end{array}$ & General information (text) & $\begin{array}{l}\text { Conservation actions needed and } \\
\text { in-place (CS) }\end{array}$ & $\begin{array}{l}\text { Research needed and } \\
\text { in-place (CS) }\end{array}$ & \\
\hline $\begin{array}{l}\text { Red List } \\
\text { assessment }\end{array}$ & $\begin{array}{l}\text { Red List Category and } \\
\text { Criteria (CS) }\end{array}$ & $\begin{array}{l}\text { Red List assessment rationale } \\
\text { (text) }\end{array}$ & Assessor and Reviewer names & $\begin{array}{l}\text { Assessment and } \\
\text { Review date }\end{array}$ \\
\hline Bibliography & References & & & \\
\hline
\end{tabular}

information on the classification schemes employed visit the IUCN Red List website (http://www.iucnredlist.org/technicaldocuments/classification-schemes).

Spatial data were sourced for the production of species distribution maps (see Section 2.4). All species from the selected taxonomic groups were then assessed for their risk of global extinction according to application of the IUCN Red List Categories and Criteria version 3.1 (IUCN 2012) (see Section 2.5).

The species information and draft Red List assessments were then reviewed at a workshop where each species assessment was evaluated by independent experts to ensure that: i) the information presented was both complete and correct; and ii) the Red List Categories and Criteria had been applied correctly.

\subsection{Species mapping}

Species distributions were mapped to individual river/lake subbasins, as delineated by HydroBASINS which is a digital global coverage of sub-basins at 12 different scales/levels (Lehner and Grill 2013) using GIS software. Most species were mapped to HydroBASIN 'Level 8' and, for restricted range species, 'level 10'. Within the Eastern Mediterranean assessment region there are 3,636 individual sub-basins with an average area of $595 \mathrm{~km}^{2}$ at 'Level 8', and 16,873 sub-basins with an average area of $128 \mathrm{~km}^{2}$ at 'level 10'. All geo-spatial results within this report are presented using the 'Level 8' HydroBASINS layer (Figure 2.2).

Sub-basins were selected as the spatial units for mapping species distributions as, even though it is recognized that

Participants of the Eastern Mediterranean Red List assessment workshop held at Azraq Oasis Lodge, Jordan, April 2013. Left to right: Atheer Ali (fish); Richard Lansdown (plants); Güler Ekmekci (fish); Ümit Kebapçi (molluscs); Hossein Akhani (plants); Kevin Smith (IUCN); Jörg Freyhof (fish); Salih Kavak (plants); David Allen (IUCN); Mary Seddon (molluscs); Catherine Numa (IUCN); Manuel Lima (molluscs); Halil Çakan (plants).

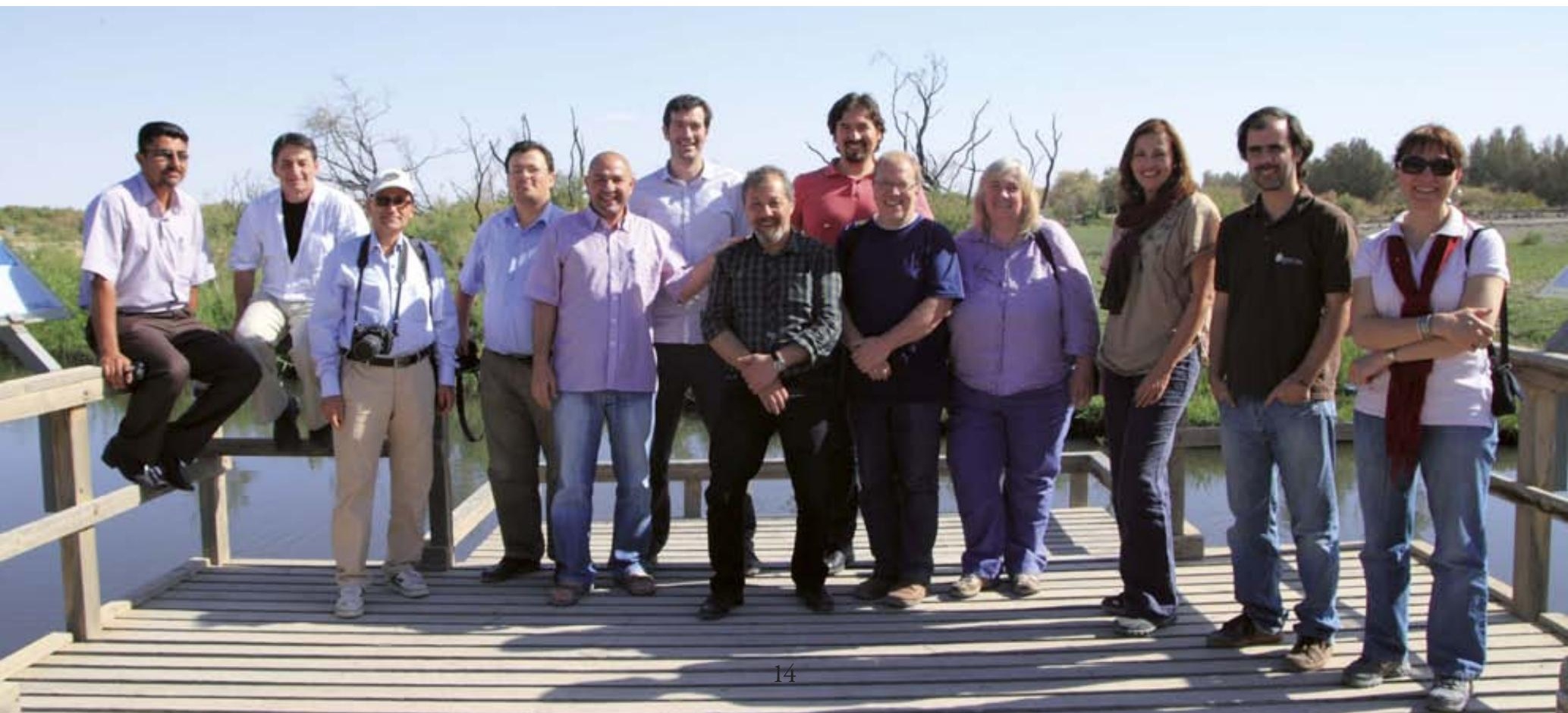


species ranges may not always extend throughout a river subbasin, it is generally accepted that the river/lake basin or catchment is the most appropriate management unit for inland waters (Watson 2004).

Point localities (the latitude and longitude where a species was recorded) and other published data were used in most cases to identify which sub-basins are known to currently contain each species. Using a combination of expert opinion, course scale distribution information and unpublished literature it has also been possible to identify sub-basins where a species is 'probably' present. For many plant species, mainly those with large distribution ranges, the absence of easily accessible information on spatial distributions has limited delineation of range maps to species presences within countries. However, all the threatened plant species have been mapped to HydroBASINS using the same methods as for other taxonomic groups.

\subsection{Overlap with other Red List assessment projects}

The Red List status of a number of species present within the Eastern Mediterranean region has previously been assessed through other IUCN biodiversity assessments. These include the European and Mediterranean assessments (see Smith and Darwall 2006, Riservato et al. 2009, Cuttelod, Seddon, and Neubert 2011, Freyhof and Brooks 2011), the pan-Africa assessment (Darwall et al. 2011) and the Sample Red List Index (SRLI) assessment. The species assessments from these other projects are incorporated into this Eastern Mediterranean assessment and can be found on the IUCN Red List of Threatened Species (www.iucnredlist.org).

\subsection{Assessment of species threatened status}

The risk of extinction for each species was assessed according to the IUCN Red List Categories and Criteria: Version 3.1 (IUCN 2012).

The nine possible Red List Categories are given in Figure 2.3. A species assessed as 'Critically Endangered' is considered to be facing an extremely high risk of extinction in the wild. A species assessed as 'Endangered' is considered to be facing a very high risk of extinction in the wild. A species assessed as 'Vulnerable' is considered to be facing a high risk of extinction in the wild. All taxa listed as Critically Endangered, Endangered or Vulnerable are described as 'threatened'. Species assignment to each of the three threatened Categories is determined according to five criteria with quantitative thresholds (Table 2.3).

Figure 2.2 Sub-basins of the Eastern Mediterranean region, as delineated by HydroBASINS 'Level 8’ (Lehner and Grill 2013), used to map and analyze species distributions.

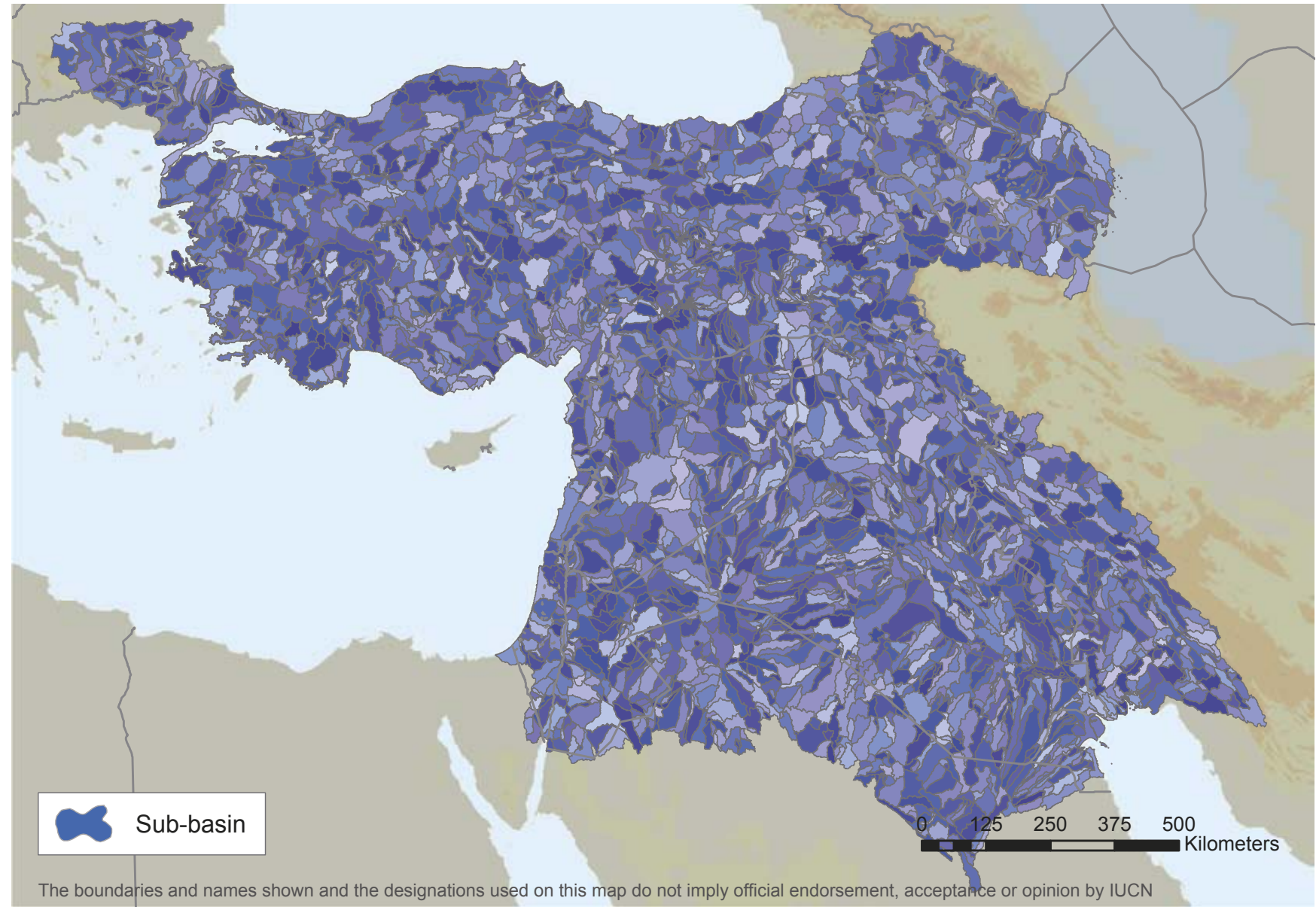


Table 2.3 Summary of the five criteria (A-E) used to determine the category of threat for a species.

A. Population size reduction. Population reduction (measured over the longer of 10 years or 3 generations) based on any of A1 to A4

A1

$A 2, A 3 \& A 4$

A1 Population reduction observed, estimated, inferred, or suspected in the past where the causes of the reduction are clearly reversible AND understood AND have ceased.

A2 Population reduction observed, estimated, inferred, or suspected in the past where the causes of reduction may not have ceased OR may not be understood OR may not be reversible.

A3 Population reduction projected, or suspected to be met in the future (up to a maximum of 100 years) based on (b) to (e) under A1.

A4 An observed, estimated, inferred, projected or suspected population reduction (up to a maximum of 100 years) where the time period must include both the past and the future, and where the causes of reduction may not have ceased OR may not be understood OR may not be reversible, based on (a) to (e) under A1.

\begin{tabular}{|c|c|}
\hline Endangered & Vulnerable \\
\hline$\geq 70 \%$ & $\geq 50 \%$ \\
$\geq 50 \%$ & $\geq 30 \%$ \\
\hline
\end{tabular}

(a) direct observation

(b) an index of abundance appropriate to the taxon

(c) a decline in area of occupancy (AOO), extent of occurrence based on $\quad$ (EOO) and/or habitat quality following: (d) actual or potential levels of following: (d) actual exploitation

(e) effects of introduced taxa, hybridization, pathogens, pollutants, competitors or parasites.

B. Geographic range in the form of either B1 (extent of occurrence) AND/OR B2 (area of occupancy)

B1. Extent of occurrence (EOO)

B2. Area of occupancy (AOO)

AND at least 2 of the following 3 conditions:

(a) Severely fragmented OR Number of locations

Endangered

$<5,000 \mathrm{~km}^{2}$

$<500 \mathrm{~km}^{2}$

Vulnerable

$<20,000 \mathrm{~km}^{2}$

$<2,000 \mathrm{~km}^{2}$

(b) Continuing decline in any of: (i) extent of occurrence; (ii) area of occupancy; (iii) area, extent and/or quality of habitat; (iv) number of locations or subpopulations; (v) number of mature individuals.

(c) Extreme fluctuations in any of: (i) extent of occurrence; (ii) area of occupancy; (iii) number of locations or subpopulations; (iv) number of mature individuals.

C. Small population size and decline

Number of mature individuals

\section{AND either $\mathrm{C} 1$ or $\mathrm{C} 2$}

C1. An estimated continuing decline of at least: (up to a max. of 100 years in future)

C2. A continuing decline AND (a) and/or (b):

(a) (i) Number of mature individuals in each subpopulation (ii) $\%$ of mature individuals in one subpopulation =

(b) Extreme fluctuations in the number of mature individuals

\footnotetext{
(n)

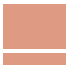

$\leq 50$
$90-100 \%$

$25 \%$ in 3 years or 1 generation (whichever is longer)

\section{$20 \%$ in 5 years or \\ 2 generations} (whichever is longer)
$10 \%$ in 10 years or

3 generations (whichever is longer)

\begin{tabular}{|c|c|c|c|}
\hline & Critically Endangered & Endangered & Vulnerable \\
\hline \multirow[t]{2}{*}{ D. Number of mature individuals } & $<50$ & $<250$ & $<1,000$ \\
\hline & \multicolumn{2}{|c|}{ Restricted area of occupancy } & $\begin{array}{c}\text { AND/OR } \\
\text { typically: } \\
\text { AOO }<20 \mathrm{~km}^{2} \text { or } \\
\text { number of locations } \leq 5\end{array}$ \\
\hline
\end{tabular}

\begin{tabular}{|l|c|c|c|}
\hline E. Quantitative Analysis & Critically Endangered & Endangered & Vulnerable \\
\hline Indicating the probability of extinction in the wild to be: & $\begin{array}{c}\geq 50 \% \text { in } 10 \text { years or } 3 \\
\text { generations, whichever } \\
\text { is longer (100 years } \\
\text { max.) }\end{array}$ \\
\hline$\geq 20 \%$ in 20 years or 5 generations (100 years max.) & $\geq 10 \%$ in 100 years \\
\hline
\end{tabular}

1 Use of this summary sheet requires full understanding of the IUCN Red List Categories and Criteria and Guidelines for Using the IUCN Red List Categories and Criteria. Please refer to both documents for explanations of terms and concepts used here. 


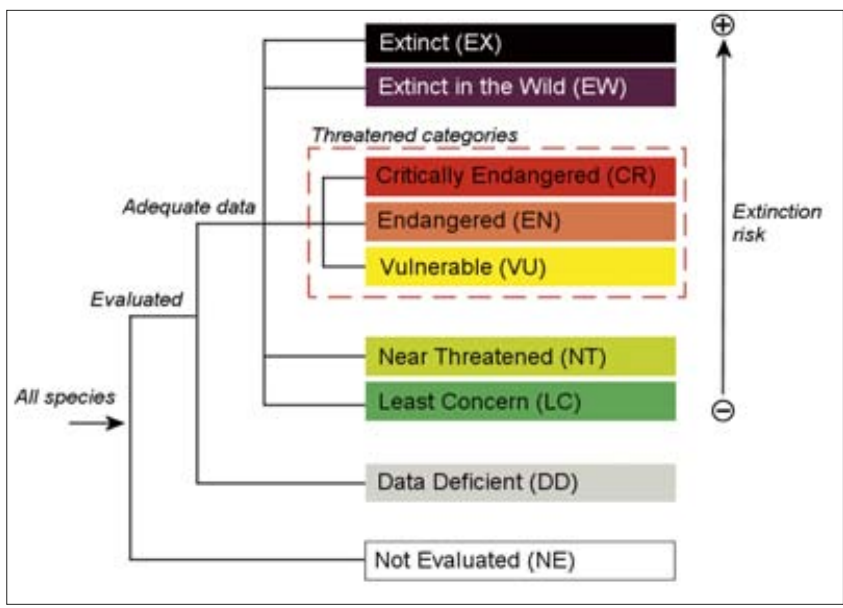

Figure 2.3 IUCN Red List Categories at a global level.

For a more detailed explanation of the Categories and Criteria please refer to the following documentation: The IUCN Red List Categories and Criteria: Version 3.1, which can be downloaded from http://www.iucnredlist.org/technicaldocuments/categories-and-criteria.

Species summaries and global distribution maps are published on the IUCN Red List of Threatened Species website (www. iucnredlist.org). Species spatial can be downloaded as GIS shapefiles from http://www.iucnredlist.org/technicaldocuments/spatial-data. For those who may not have access to the internet the species summaries and GIS shapefiles for the species ranges can be found on an accompanying DVD. Due to space limitations on the DVD species range maps are restricted to those parts of the range within the Eastern Mediterranean region. Please see the IUCN Red List website if you want to view or download species full global ranges. An example output is given in Appendix 1. It is important to note that the information included on the DVD will become outdated as species are re-assessed.

\subsection{Nomenclature}

Taxonomic schemes are constantly changing as results from ongoing studies are made available, in particular with the introduction of molecular techniques. Taxonomy is also a somewhat controversial field and in many cases it is difficult to find a universally agreed taxonomic hierarchy. In this assessment the taxonomy followed is that adopted by the IUCN Red List which, where possible, employs existing published world checklists. Fish classification follows the online Catalog of Fishes maintained at the California Academy of Sciences (Eschmeyer 2014). Odonate classification generally follows the World Odonata List maintained at the University of Puget Sound (Schorr and Paulson 2010). There is currently no widely accepted single taxonomy for molluscs and we therefore follow the standards recommended by the IUCN SSC Mollusc Specialist Group. For plants, where appropriate, we follow the World Checklist of Selected Plant Families hosted by the Royal Botanic Gardens, Kew (WCSP 2014), but other more specialist lists are also followed, such as the Checklist of Ferns and Lycophytes of the World (Hassler and Schmitt 2014) and Algaebase (Guiry and Guiry 2014). For more information on the taxonomic standards of the IUCN Red List visit http://www.iucnredlist.org/technical-documents/ information-sources-and-quality\#standards.

\subsection{References}

Allen, D.J., Molur, S. and Daniel, B.A. (Compilers). 2010. The Status and Distribution of Freshwater Biodiversity in the Eastern Himalaya. IUCN, Cambridge, UK and Gland, Switzerland, and Zoo Outreach Organisation, Coimbatore, India.

Allen, D.J., Smith, K.G. and Darwall, W.R.T. (Compilers). 2012. The Status and Distribution of Freshwater Biodiversity in Indo-Burma. IUCN, Cambridge, UK and Gland, Switzerland.

Bogan, A.E. 2008. Global diversity of freshwater mussels (Mollusca, Bivalvia) in freshwater. In: E.V. Balian, C. Lévêque, H. Segers and K. Martens (eds.), The freshwater animal diversity assessment. Hydrobiologia 595:139-147.

CEPF (Critical Ecosystem Partnership Fund). 2010. Mediterranean Biodiversity Hotspot: Ecosystem profile.

Chambers, P.A., Lacoul, P., Murphy, K.J. and Thomaz, S.M. 2008. Global diversity of aquatic macrophytes in freshwater. In: E.V. Balian, C. Lévêque, H. Segers and K. Martens (eds.), The freshwater animal diversity assessment. Hydrobiologia 595:9-29.

Coates, D. 1995. Inland capture fisheries and enhancement: Status, constraints and prospects for food security. In: International Conference on Sustainable Contribution of Fisheries to Food Security, Kyoto, Japan, 4-9 December 1995. KC/FI/95/TECH/3. Government of Japan, Tokyo, Japan and FAO, Rome, Italy.

Cook, C.D.K. 1996. Aquatic Plant Book. SPB Academic Publishing, Amsterdam/New York.

Cumberlidge, N., Ng, P.K.L., Yeo, D.C.J., Magalhaes, C., Campos, M.R., Alvarez, F., Naruse, T., Daniels, S.R., Esser, L.J., Attipoe, F.Y.K., Clotilde-Ba, F.-L., Darwall, W., Mclvor, A., Ram, M. and Collen, B. 2009. Freshwater crabs and the biodiversity crisis: importance, threats, status, and conservation challenges. Biological Conservation 142:1665-1673.

Cuttelod, A., Seddon, M. and Neubert, E. 2011. European Red List of Non-marine Molluscs. Publications Office of the European Union Luxembourg.

Darwall, W.R.T., Smith, K.G., Allen, D.J, Holland, R.A, Harrison, I.J. and Brooks, E.G.E. (eds.). 2011. The Diversity of Life in African Freshwaters: Under Water, Under Threat. An analysis of the status and distribution of freshwater species throughout mainland Africa. IUCN, Cambridge, United Kingdom and Gland, Switzerland.

De Grave, S., Smith, K.G., Adeler, N.A., Allen, D.J., Alvarez, F., Anker, A., Cai, Y., Carrizo, S., Klotz, W., Mantelatto, F.L., Page, T.J., Shy, J.-Y., Villalobos, J.L. and Wowor, D. In Prep. Dead Shrimp Blues: A global assessment of extinction risk in freshwater shrimp (Decapoda: Caridea).

Dugan, P., Delaporte, A., Andrew, N., O’Keefe, M. and Welcomme, R. 2010. Blue Harvest: Inland Fisheries as an Ecosystem Service. Penang, Malaysia.

Eschmeyer, W.N. (ed.). 2014. Catalog of Fishes: Genera, species, references (Accessed 30 August 2014). Available at: http://research.calacademy. org/ichthyology/catalog/fishcatmain.asp

FAO. 2007. The state of world Aquaculture and Fisheries 2006. Fisheries and Aquaculture Department, Food and Agriculture Organization of the United Nations, Rome, Italy. 
Freyhof, J. and Brooks, E. 2011. European Red List of Freshwater Fishes. Publications Office of the European Union, Luxembourg.

Garcia-Llorente, M., Martin-Lopez, B., Diaz, S. and Montez, C. 2011. Can ecosystem properties be fully translated into service values? An economic valuation of aquatic plant species. Ecological Applications 21(8): 3083-3103.

Guiry, M.D. and Guiry, G.M. 2014. AlgaeBase. World-wide electronic publication, National University of Ireland, Galway. Available at: http://www.algaebase.org

Hassler, M. and Schmitt, B. 2014. Checklist of Ferns and Lycophytes of the World. Available at: http://worldplants.webarchiv.kit.edu/ferns/

IUCN. 2012. IUCN Red List Categories and Criteria: Version 3.1. 2nd Edition. IUCN Species Survival Commission. IUCN, Gland, Switzerland and Cambridge, UK.

Juffe-Bignoli D. and Darwall W.R.T (eds.) 2012. Assessment of the socioeconomic value of freshwater species for the northern African region. IUCN, Gland, Switzerland and Málaga, Spain.

Kalkman, V.J., Causnitzer, V., Dijkstra, K.-D.B., Orr, A.G., Paulson, D.R. and van Tol, J. 2008. Global diversity of dragonflies (Odonata) in freshwater. In: E.V. Balian, C. Lévêque, H. Segers and K. Martens (eds.), The freshwater animal diversity assessment. Hydrobiologia 595: 545-567.

Lansdown, R. 2014. Personal communication from Richard Lansdown, Chair of the IUCN SSC Freshwater Plant Specialist Group.

Lehner, B. and Grill, G. 2013. Global river hydrography and network routing: baseline data and new approaches to study the world's large river systems. Hydrological Processes 27:2171-2186.

Lévêque, C., Oberdorff, T., Paugy, D., Stiassny, M.L.J. and Tedesco, P.A. 2008. Global diversity of fish (Pisces) in freshwater. In: E.V. Balian, C. Lévêque, H. Segers and K. Martens (eds.). The freshwater animal diversity assessment. Hydrobiologia 595: 545-567.

Lydeard, C., Cowie, R.H., Ponder, W.F., Bogan, A.E., Bouchet, P., Clark, S.A., Cummings, K.S., Frest, T.J., Gargominy, O., Herbert, D.G., Hershler, R., Perez, K.E., Roth, B., Seddon, M., Strong, E.E. and Thompson, F.G. 2004. The Global Decline of Nonmarine Mollusks. BioScience 54(4):321.

Mittermeier, R.A., Robles Gil, P., Hoffmann, M., Pilgrim, J., Brooks, T., Mittermeier, C.G., Lamoreux, J. and da Fonseca, G.A.B. 2004. Hotspots revisited: Earth's biologically richest and most endangered ecoregions. CEMEX, Mexico City, Mexico.

Molur, S., Smith, K.G., Daniel, B.A. and Darwall, W.R.T. 2011. The status and distribution of freshwater biodiversity in the Western Ghats, India. IUCN, Cambridge, UK and Gland, Switzerland, and Zoo Outreach Organisation, Coimbatore, India.

Myers, N., Mittermeier, R.A., Mittermeier, C.G., de Fonseca, G.A.B. and Kent, J. 2000. Nature 403:853-858.

Prather, C.M., Pelini, S.L., Laws, A., Rivest, E., Woltz, M., Bloch, C.P., Del Toro, I., Ho, C-K., Kominoski, J., Newbold, T.A.S., Parsons, S. and
Joern, A. 2012 Invertebrates, ecosystem services and climate change. Biological Reviews 88: 327-348.

Richman, N., Böhm, M., Adams, S.B., Alvarez, F., Bergey, E.A., Bunn, J.J.S., Burnham, Q., Cordeiro, J., Coughran, J., Crandall, K.A., Dawkins, K.L., DiStefano, R.J., Doran, N.E., Edsman, L., Eversole, A.G., Füreder, L., Furse, J.M., Gherardi, F., Hamr, P., Holdich, D.M., Horwitz, P., Johnston, K., Jones, C.M., Jones, J.P.G., Jones, R.L., Jones, T.G., Kawai, T., Lawler, S., López-Mejía, M., Miller, R.M., Pedraza-Lara, C., Reynolds, J.D., Richardson, A.M.M., Schultz, M.B., Schuster, G.A., Sibley, P.J., Souty-Grosset, C., Taylor, C.A., Thoma, R.F., Walls, J., Walsh, T.S. and Collen, B. (in press) Multiple drivers of decline in the global status of freshwater crayfish (Decapoda: Astacidea). Philosophical Transactions of the Royal Society of London B.

Riservato, E., Boudot, J.-P., Ferreira, S., Jovic, M., Kalkman, V.J., Schneider, W., Samraoui, B. and Cuttelod, A. 2009. The Status and Distribution of Dragonflies of the Mediterranean Basin. IUCN, Gland, Switzerland and Malaga, Spain.

Schorr, M. and Paulson, D. 2010. World Odonata List. University of Puget Sound. Available at: http://www.pugetsound.edu/academics/ academic-resources/slater-museum/biodiversity-resources/ dragonflies/world-odonata-list/

Smith, K.G. and Darwall, W.R.T. 2006. The Status and Distribution of Freshwater Fish Endemic to the Mediterranean Basin. IUCN, Gland, Switzerland and Cambridge, UK.

Strayer,D.L. 1999. Freshwater mollusks and water quality (editorial).Journal of the North American Benthological Society 18:1.

Strong, E.E., Gargominy, O., Ponder, W.F. and Bouchet, P. 2008. Global diversity of gastropods (Gastropoda; Mollusca) in freshwater. In: E.V. Balian, C. Lévêque, H. Segers and K. Martens (eds.), The freshwater animal diversity assessment. Hydrobiologia 595:149-166.

Trueman, J.W.H. and Rowe, R.J. 2009. Odonata. Dragonflies and Damselflies. Version 16 October 2009. http://tolweb.org/ Odonata/8266/2009.10.16 In: The Tree of Life Web Project, http:// tolweb.org/

Vaughn, C.C. 2010. Biodiversity losses and ecosystem function in freshwaters: emerging conclusions and research directions. BioScience 60(1):25-35.

Vaughn, C.C., Gido, K.B. and Spooner, D.E. 2004. Ecosystem processes performed by unionid mussels in stream mesocosms: Species roles and effects of abundance. Hydrobiologia 527:35-47.

Watson, N. 2004. Integrated river basin management: A case for collaboration. International Journal of River Basin Management. 2(4):243-257.

WCSP. 2014. World Checklist of Selected Plant Families. The Board of Trustees of the Royal Botanic Gardens, Kew. Available at: http://www. kew.org/wcsp/

WorldFish Center. 2005. Fish and Food Security in Africa. The WorldFish Center, Penang, Malaysia. 


\section{Chapter 3. Freshwater fishes}

Jörg Freyhof ${ }^{1}$, F. Güler Ekmekçi², Atheer Ali ${ }^{3}$, Najim R. Khamees ${ }^{3}$, Müfit Özuluğ ${ }^{4}$, Nashat Hamidan ${ }^{5}$, Fahrettin Küçük ${ }^{6}$ and Kevin G. Smith ${ }^{7}$

3.1 Overview of the regional fish fauna 19

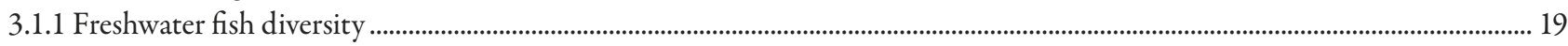

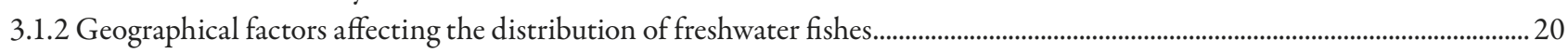

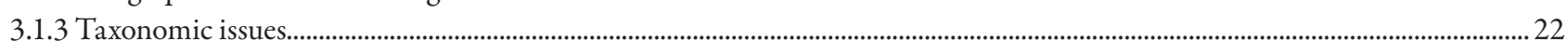

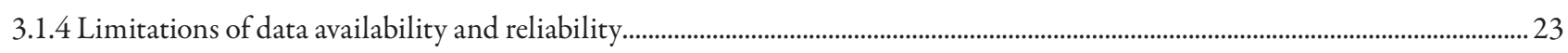

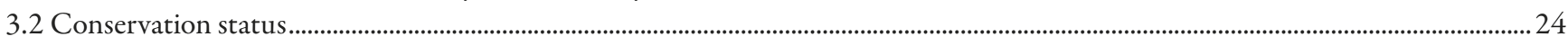

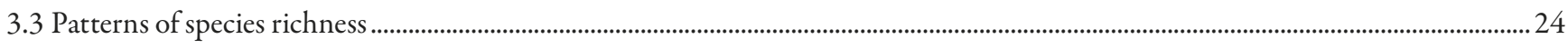

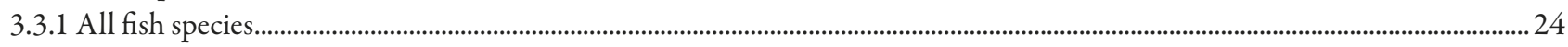

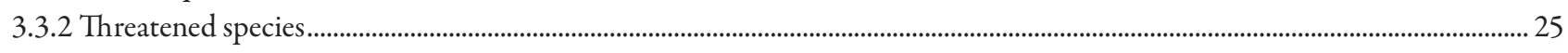

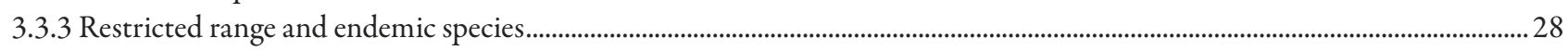

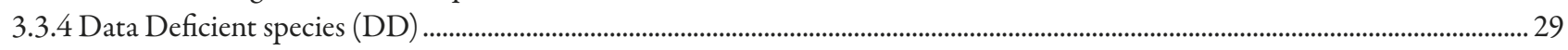

3.3.5 Extinct (EX), Possibly Extinct (CR PE) and Extinct in the Wild (EW) species.......................................................................29

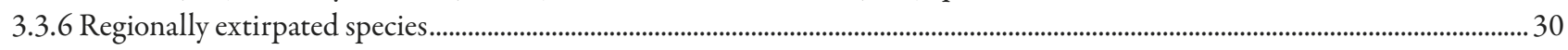

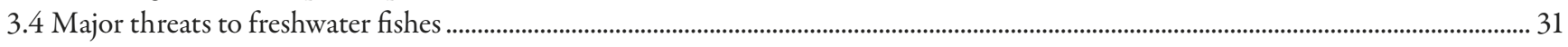

3.4.1 Water extraction and dams (natural system modification) ........................................................................................................ 31

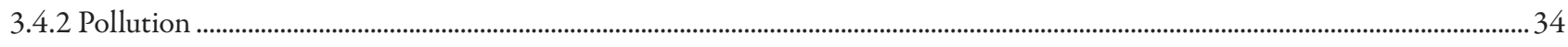

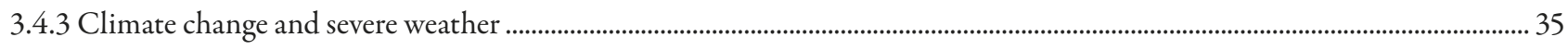

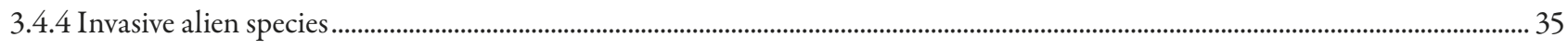

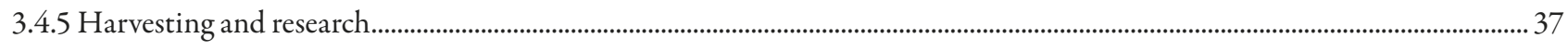

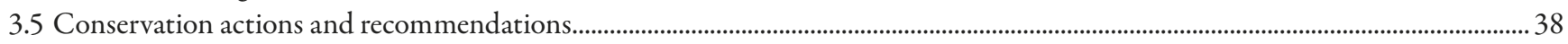

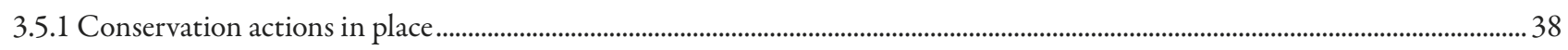

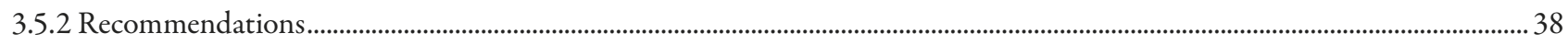

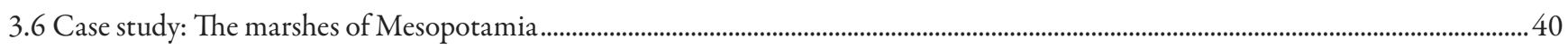

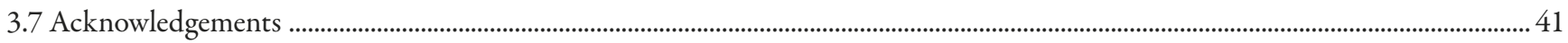

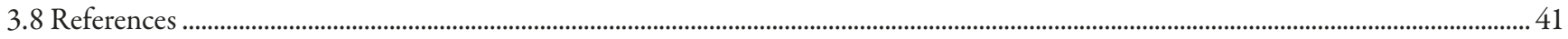

\subsection{Overview of the regional fish fauna}

\subsubsection{Freshwater fish diversity}

The Eastern Mediterranean region covers all of Turkey and the Levant, the southern Caucasus, and Mesopotamia. It overlaps with three Biodiversity Hotspots (Myers et al. 2000, www. cepf.net): the Mediterranean Basin, Irano-Anatolia, and the Caucasus, and incorporates 14 freshwater ecoregions (Abell et al. 2008, WWF/TNC 2013), most of which are only found within the region (see Chapter 1, Figures 1.1 and 1.2).
In terms of IUCN Red List assessments for freshwater fish, this study fills a large geographic gap between Europe, which has been assessed by Freyhof and Brooks (2011), Africa (Darwall et al. 2011), Arabian Peninsula (Freyhof et al. in prep) and the on-going assessment of the freshwater fishes of Iran.

According to this assessment, there are 322 species of freshwater fishes present in the Eastern Mediterranean region, two thirds (66.8\% / 215 species) of which are endemic to the region, with an additional 10 species that are near-endemics (i.e. with only small parts of their range outside the region). There are also at least 84

\footnotetext{
${ }^{1}$ German Centre for Integrative Biodiversity Research (iDiv) Halle-Jena-Leipzig, Deutscher Platz 5a, 04103 Leipzig, Germany, Email: joerg.freyhof@idiv.de

2 Hydrobiology Section, Biology Department, Faculty of Science, Hacettepe University, Beytepe Campus, Ankara 06800, Turkey.

3 Department of Fisheries and Marine Resources, College of Agriculture, University of Basrah, Basrah, Iraq.

${ }^{4}$ Istanbul University, Science Faculty, Department of Biology, 34134 Vezneciler, İstanbul, Turkey.

5 The Royal Society for the Conservation of Nature - Conservation Division, P.O. Box 1215, Jubaiha 11941, Jordan.

${ }^{6}$ Süleyman Demirel University, Fisheries Faculty, 32000, Isparta, Turkey.

IUCN Global Species Programme, 219c Huntingdon Road, Cambridge, UK.
} 
additional 'species' that have been recognized from the area, but most of them currently remain undescribed and therefore have not been included in this assessment.

\subsubsection{Geographical factors affecting the distribution of freshwater fishes}

Biogeographical and hydrological factors are the major drivers of biodiversity patterns in freshwater fishes in the region. With 14 ecoregions, each with its own set of endemic species, the Eastern Mediterranean region is biogeographically highly structured (Küçük et al. 2009). There is a slow but continuous transition from the Mediterranean fauna in Greece and Western Turkey, to the fauna of the Euphrates and Tigris in the east. In Western Anatolia, most genera have close affinities to genera in Greece or to those of the northern Black Sea basin, however there are members of the cyprinid Capoeta present, a genus which is absent from adjacent Europe but widespread all over the Middle East except in the southern Arabian Peninsula (Levin et al. 2012). This is also the case in Central Anatolia, where most species belong to genera in common with Europe except the cyprinid genus Pseudophoxinus, which is almost endemic to the Eastern Mediterranean region and has its highest species diversity in Central Anatolia (Hrbek et al. 2004, Perea et al. 2010, Küçük et al. 2013). Freshwater fishes of the southern Caucasus belong mostly to the same genera as those from the northern Black Sea basin and the Caspian Sea basin, with the Kura-Aras River being mostly inhabited by widespread species of the Caspian Sea basin. However, all these rivers have a considerable number of endemic species indicating their long-lasting biogeographical isolation. The rivers of the Black and Caspian basin also have had recent connections to the upper Euphrates as several species of loaches are found in adjacent headwater streams in the Black Sea basin and in the upper Euphrates (for example Oxynoemacheilus bergianus). Another example is the presence of the Levantine cyprinid genus Acanthobrama in the Kura and Aras drainage (Perea et al. 2010). Mediterranean rivers such as the Seyhan, Asi and Jordan all have a fish fauna which is similar to the Euphrates including typical Mesopotamian species such as the cyprinids Garra rufa and Capoeta damascina, and the killifish Aphanius mento (Krupp 1985). At the species level, a highly endemic fauna inhabits Mesopotamia itself but most species belong to genera that are also found in Europe and Anatolia. Several oriental genera are also represented, for example cyprinids of the genera Barilius, Garra and Cyprinion and a species of Mastacembelid spiny eel, several sisorid and one bagrid catfish, and loaches of the genera Turcinoemacheilus and Paraschistura. Several Mesopotamian species are more widespread in the Arabian / Persian Gulf basin and may occur south to the Gulf of Hormuz in Iran (Abdoli 2000).

In the Eastern Mediterranean, there are many places with locally endemic fishes. The Melendiz River, one of the few streams in Lake Tuz basin, Turkey, is the only habitat of the cyprinids Gobio gymnostethus (CR) and Squalius cappadocicus (CR). Other threatened species such as Capoeta mauricii (EN) and Oxynoemacheilus eregliensis (VU) also occur here making it an important site for fish conservation. Photo $\odot$ Jörg Freyhof 
As in most parts of the world, ecological factors determine freshwater fish diversity within a given biogeographical unit. Species diversity increases with stream order, and in the Eastern Mediterranean region it is typically trouts of the genus Salmo that are found in the mountain streams (Turan, Kottelat, and Engin 2009 2012, Turan, Kottelat, and Bektaş 2011). As these streams become slightly larger and warmer, several loaches of the genus Oxynoemacheilus occur together with cyprinids from the genera Capoeta, Barbus, and Squalius, and in larger streams additional cyprinid species and Cobitis loaches are also found. In the lower sections of streams euryhaline fishes from the families
Clupeidae, Mugilidae, and Gobiidae are common. In the Shatt Al-Basrah canal, in the lower Euphrates drainage, the Bull Shark Carcharbinus leucas (NT) is found (Hussain et al. 2012), however before river regulation, this shark occurred regularly upriver to Baghdad (Coad 2010). Larger rivers in the region, including a number of Black and Mediterranean Sea catchments and the Euphrates/Tigris are (or were historically) visited by anadromous migratory species such as shads of the genera Alosa and Tenualosa, and sturgeons (Huso huso, Acipenser spp.) as well as several migratory cyprinids including Rutilus frisii (LC) and Luciobarbus species.

Loaches of the genus Oxynoemacheilus are widespread but poorly known in the Eastern Mediterranean region. Thirty-four species have been assessed, all but three are endemic to the region, and 13 species are threatened. From the top: O. galilaeus (CR) from Lake Muzarib in Syria, O. seyhanensis (CR) known only from a stream in upper Seyhan in Turkey, and O. tigris (CR) restricted to the upper Qweik in Turkey. Photo @ Jörg Freyhof
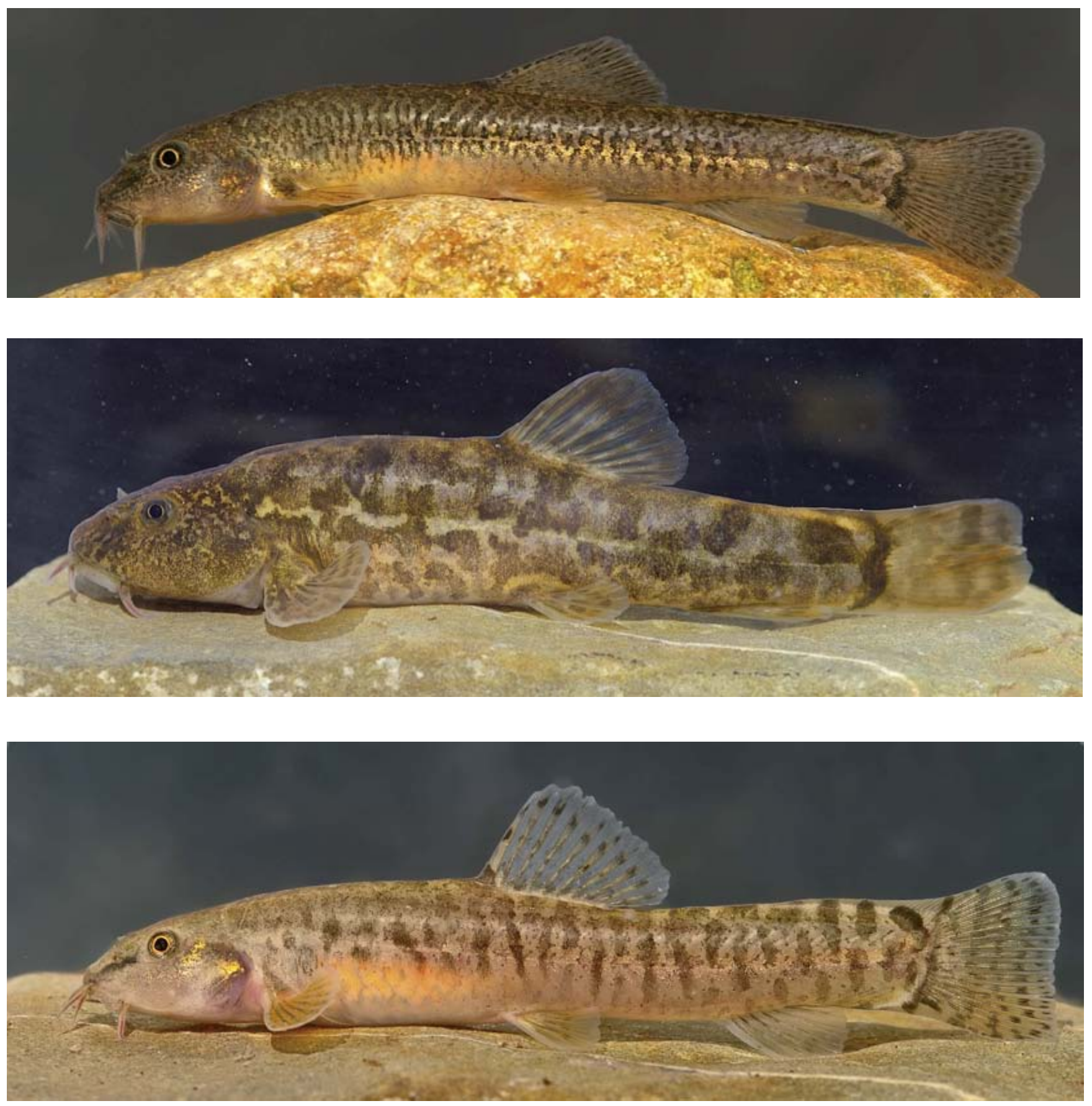
Most lakes in the region are relatively shallow, but they contain a highly endemic fish fauna (especially in Central Anatolia), most of which also occur in the lake tributaries. The truly specialized lacustrine fishes are especially vulnerable to the introduction of non-native invasive fishes (Küçük et al. 2012), and this has led to three species becoming extinct (Alburnus akili, Aphanius splendens, Pseudophoxinus handlirschi). Only two Central Anatolian specialized lacustrine fishes have survived until today, these are Aphanius saldae (not yet assessed but likely to be CR) (in Lake Salda) and Aphanius sureyanus (EN) (in Lake Burdur). In Eastern Anatolia and in the Caucasus, there are still three lakes (Lake Hazer, Lake Van, and Lake Sevan) holding endemic lacustrine fish species. In Central Anatolia several lakes, including Lake Aci, Lake Büget, Lake Gölhisar, Lake Sögüt, and Lake Hotamış, have all dried up, however their fish fauna still survive in the lakes spring-fed tributaries which now have a much higher conservation value than the lakes themselves. Springs (and spring-fed streams) are one of the most important habitats for freshwater fish conservation in the region, as they are often the only permanent waters in arid areas becoming refuges for many freshwater fishes. This can be seen in many places in Central Anatolia, the Ammiq wetland in Lebanon, the Damascus basin in Syria and all along the Syrian and Dead Sea coasts. Also, many lakes in the Eastern Mediterranean region have dried out several times during the
Pleistocene and most fish species are adapted to survive in streams and springs.

\subsubsection{Taxonomic issues}

Incomplete knowledge of biodiversity due to taxonomic uncertainty remains a significant stumbling block for conservation planning in the region, including for the identification of Alliance for Zero Extinction (AZE) sites (Ricketts et al. 2005), and the delineation for freshwater Key Biodiversity Areas (KBAs) (Darwall et al. 2011, Holland, Darwall, and Smith 2012). While the vast barcoding library published recently by Geiger et al. (2014) is a remarkable step forward in tackling this issue, efforts are still urgently needed to resolve many taxonomic problems within the region's fish fauna. Although there has been a reasonable amount of taxonomic research on the freshwater fishes of the Eastern Mediterranean, the species richness of several genera is still not completely resolved and there are many undescribed species. Recently, Geiger et al. (2014) presented an updated list of freshwater fishes of the Mediterranean Biodiversity Hotspot recognizing 526 species, and suggested the occurrence of an additional 64, mostly undescribed species from the area. The lead author's (of this chapter) own unpublished checklist includes 85 undescribed and unresolved 'species', which occur in
The spring Eflatun Pınar with a Hittite temple from 3,500-3,770 years BCE. This small tributary of Lake Beyşehir is of major importance for fish conservation. It is the habitat of Capoeta mauricii (EN), Cobitis battalgili (EN), Pseudophoxinus hittitorum (EN), and Aphanius anatoliae (NT). Photo $\odot$ Jörg Freyhof

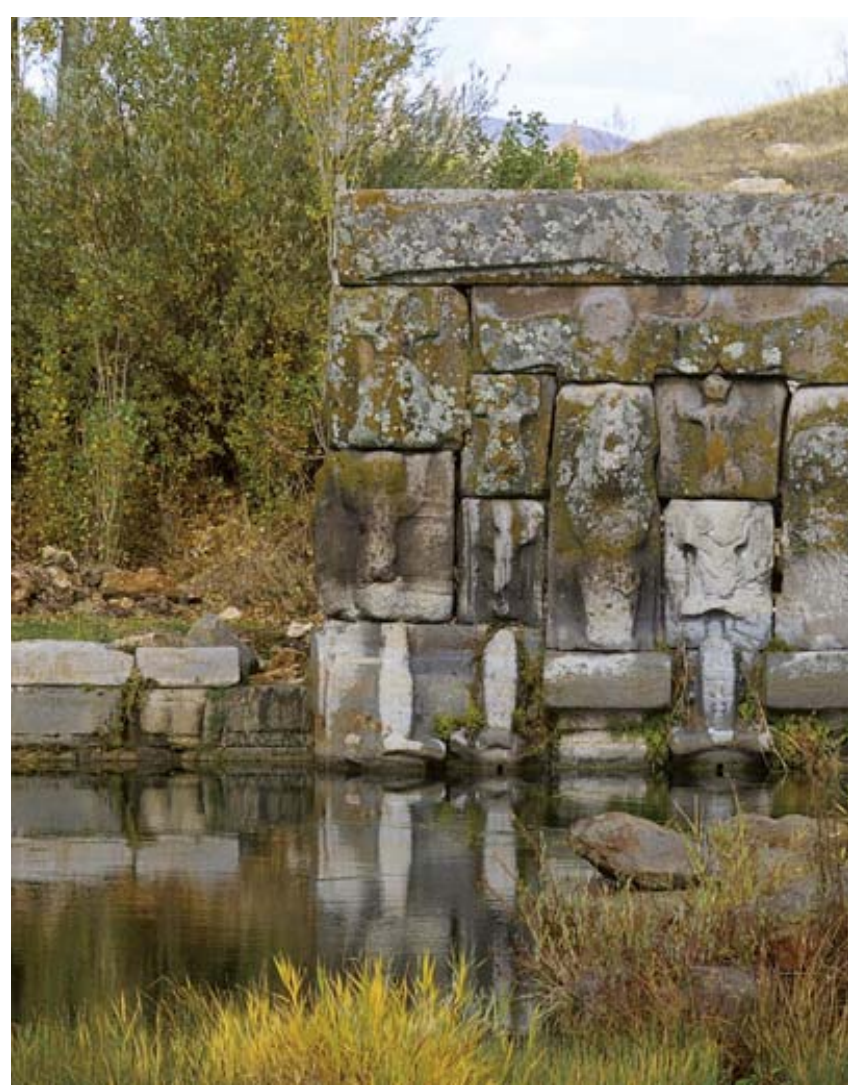

The Şaşal stream, Gümüldür drainage in the Aegean basin, supports the regional endemics Squalius kosswigi (EN), Alburnus demiri (VU), and Chondrostoma holmwoodii (VU). Photo ( Jörg Freyhof

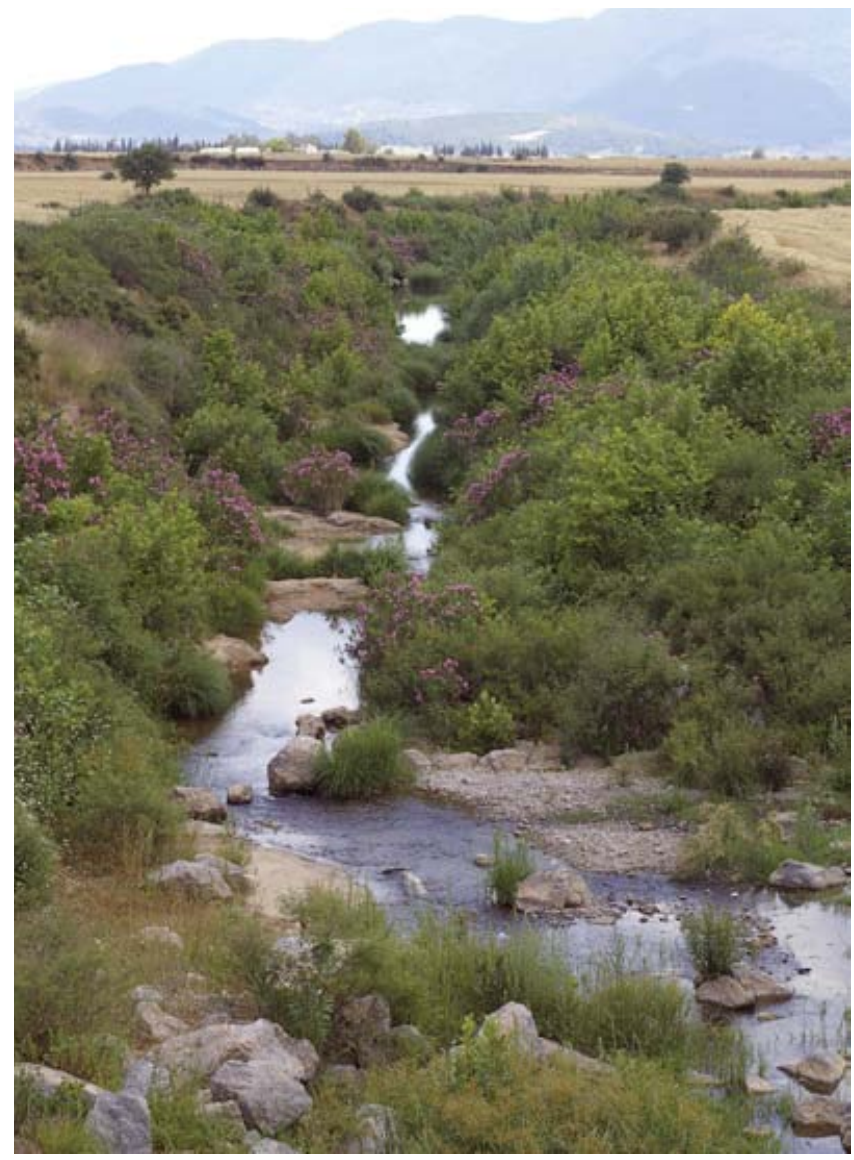




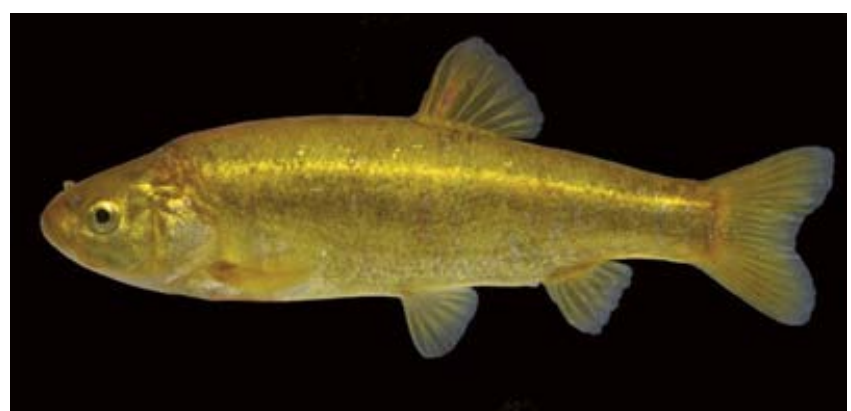

Taxonomic uncertainty is harming conservation of freshwater fishes in the region. Pseudophoxinus elizavetae (CR) is one of five endemic species to the Sultan marshes, three of which are yet to be described. Photo ${ }^{\circ}$ Jörg Freyhof

the assessment region. None of these undescribed or unresolved 'species' have been assessed for this study, which focuses only on currently described species. It is important to note that while these have not been included, they represent $21 \%$ of the freshwater fish fauna known from the area. An example is the Turkish Sultan marshes, which supports five endemic freshwater fishes. This marsh area has been largely drained and only a group of springs from one groundwater aquifer remains. Only two of the five species (Aphanius danfordii, Pseudophoxinus elizavetae) have been described, and both of them have been assessed as CR, but the other three, still undescribed species, occur in the same habitat (Cobitis sp., Oxynoemacheilus sp., and Seminemacheilus sp.) sharing the same level of risk of global extinction with the two named species.

\subsubsection{Limitations of data availability and reliability}

The lack of information is even greater when considering species' ecological needs, and population trends. Such data are virtually absent from the region and we are only aware of very few (e.g. Aphanius sirhani CR, Acanthobrama telavivensis VU) long-term monitoring programmes focusing on threatened, non-commercial freshwater fishes. In vast areas, and for only a few species, statistics of commercial catches are the only longterm source of trend information, which comes with a variety of caveats. Most of the regions ichthyological experts gained their knowledge as a side product from other studies, and there are limited resources within the region to allow for field visits and research on freshwater fishes. There is an urgent need to set up long-term monitoring programmes focused on threatened species particularly in the areas with high threat levels such as Central and Western Anatolia (see 3.3.2). The situation is urgent in some of these areas as several freshwater fishes may become extinct in the near future, largely unnoticed even by the conservation community. For most of the area studied

Will all free-flowing large rivers be lost one day? The Tigris at Hasankeyf is one of the very last habitats of the riverine specialist $L u c i o b a r b u s$ subquincunciatus (CR), and hosts several other threatened fish species. But the Ilisu dam if constructed will submerge not only the 12,000-yearold ancient town but also destroy habitats for all riverine fish species. Photo $@$ Jörg Freyhof

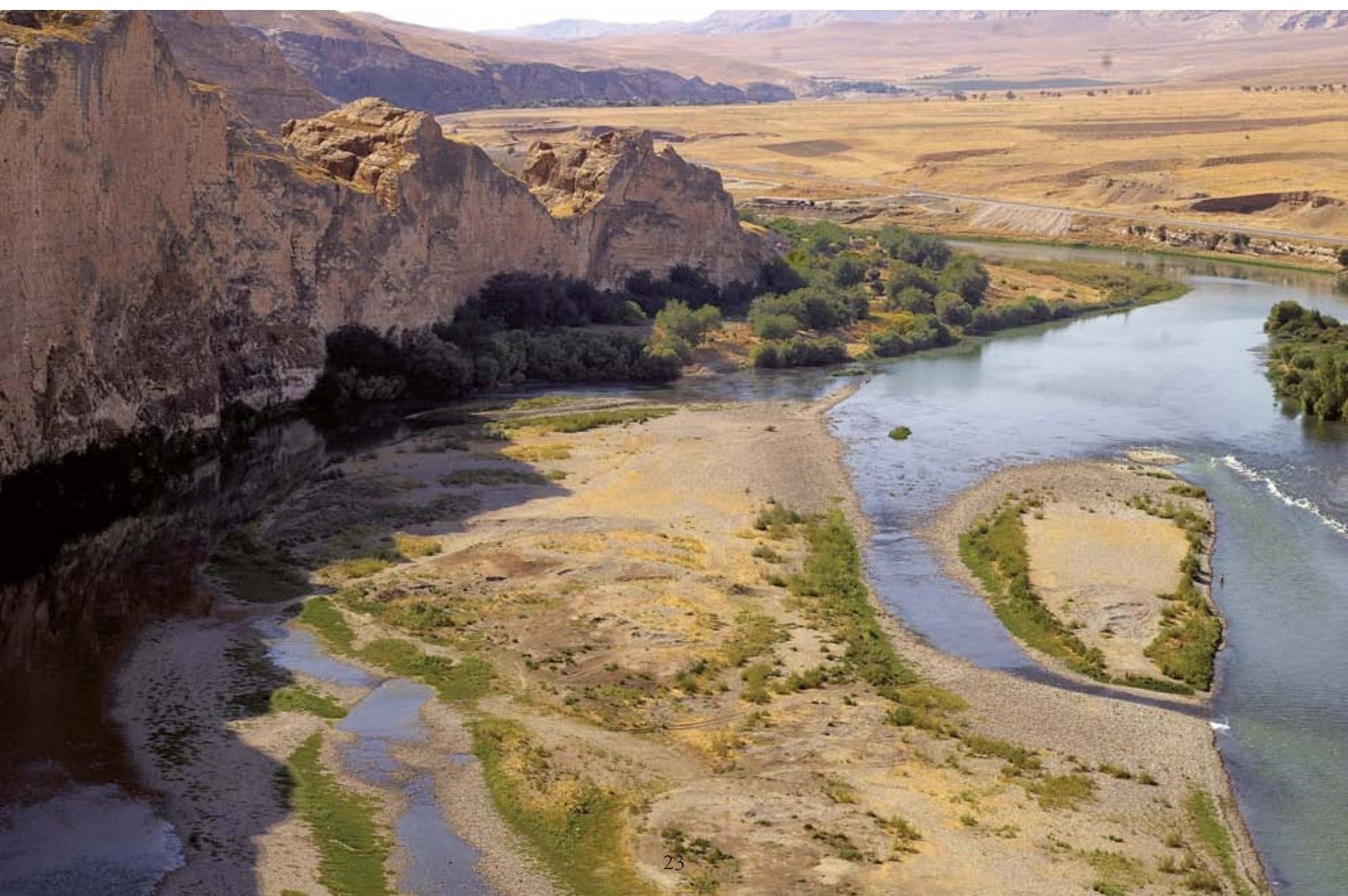




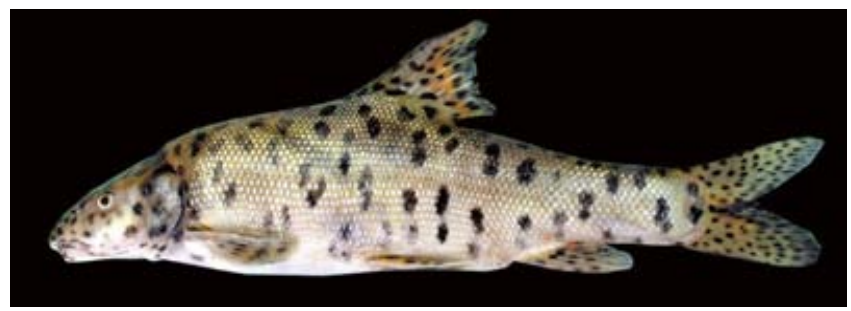

There may be fewer leopard barbels, Luciobarbus subquincunciatus (CR), than leopards in the Euphrates and Tigris drainage basin. This Mesopotamian fish species seems to be at the very border of extinction. Photo $\odot$ E. Ünlü

here, published information is scarce or old, and difficult to access. This presents problems in terms of data availability and reliability. Most current information comes from personal communications and recent fieldwork by the authors and contributors to the species Red List assessments. In addition, recent fieldwork has been virtually impossible in Syria and large parts of Iraq due to political instability. One of the most threatened species in the region is Luciobarbus subquincunciatus (CR), which was once widespread in the Euphrates and Tigris drainage, but there are now very few recent records and the species may be at the very border of extinction. But recent political instability in Syria and Iraq make it impossible to search comprehensively for this species. Contemporary fieldwork is strongly recommended, when security allows, to gain up-to-date data on the conservation status of freshwater fishes especially in these areas. The lack of information is also true for the threats acting upon freshwater systems in the region which are little known in terms of their distribution and severity, especially the extent of water extraction and the construction of new dams. Fisheries statistics for several threatened species such as Luciobarbus esocinus, L. xanthopterus, and Barbus grypus (now in the genus Arabibarbus) (all VU) are only very limited making it difficult to assess the decline of these species, and it is hard to see this situation improving in the future.

\subsection{Conservation status}

This assessment applied the IUCN Red List Categories and Criteria (IUCN 2012) to identify the global risk of extinction for all (322) currently described species of freshwater fishes in the Eastern Mediterranean region.

Of the 322 species assessed, 123 species (41\% of extant species where there is sufficient information to identify an extinction risk) are considered threatened (those assessed as CR, EN, or VU), with an additional 20 species (6.7\%) considered Near Threatened (Appendix 2, Figure 3.1). Just over a half $(52.3 \%$ / 157 species) are assessed as Least Concern being relatively widespread and often inhabiting many independent rivers and streams. Sixteen species ( $5 \%$ of all described species in the region) are considered Data Deficient (meaning there was insufficient information available to make an assessment of extinction risk, due to unresolved taxonomic problems or lack of information),
Figure 3.1 Number of species of Eastern Mediterranean freshwater fish species in each IUCN Red List Category.

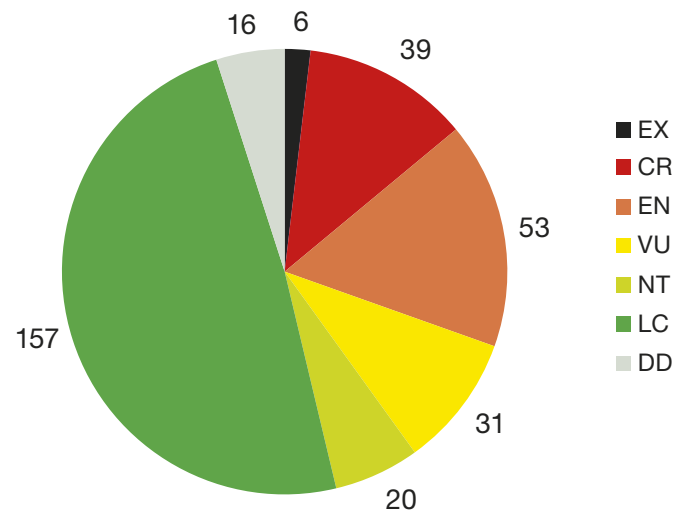

Figure 3.2 Number of Eastern Mediterranean endemic freshwater fish species in each IUCN Red List Category.

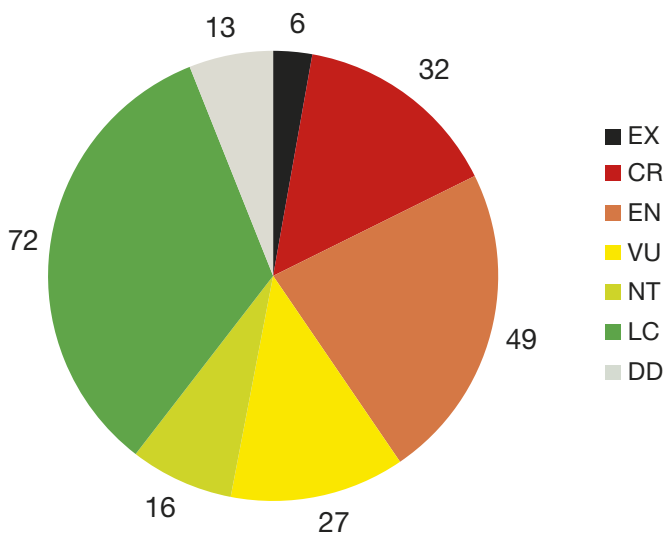

and six species (1.9\%) are classed as Extinct. It is important to note that 13 species assessments are still classed as draft Red List assessments as they are waiting to be passed by the relevant SSC Specialist Group (this includes all nine species of Salmo from the region). Two thirds of all the fish species (66.8\% / 215 species) are endemic to the Eastern Mediterranean region, but this includes 87.8\% (107 species) of all threatened species. When just regional endemics are used, the proportion of threatened species rises to 55.1\% (Figure 3.2).

\subsection{Patterns of species richness}

\subsubsection{All fish species}

From a global perspective, the freshwater fish fauna of the Eastern Mediterranean region is very species rich for a temperate region. From the region 322 species have been described, but when the currently known undescribed species are included this figure is thought to be about 400 . However, at the sub-basin scale (note: species are mapped to sub-basins, see Chapter 2) centres of species richness are much lower when compared to species rich sub-basins in Europe, where up to 94 species are recorded from one sub-basin 
in the lower Danube River (Kottelat and Freyhof 2007, Freyhof and Brooks 2011). As in Europe, the areas of the highest species richness in the Eastern Mediterranean (2743 species per subbasin) are situated along the Black and Caspian Sea coasts (Figure 3.3). The areas with next highest species richness (19-26 per subbasin) are found across the Tigris and Euphrates catchments, and in the middle and upper Aras and Kura drainages in Azerbaijan, Georgia, and Armenia. Most of Central and Mediterranean Anatolia and the Levant have the lowest levels of species richness per sub-basin with between 1 and 18 species per sub-basin, which is similar to Mediterranean areas in Greece, southern and central Italy, North Africa, and the Iberian Peninsula (Garcia, Cuttelod, and Abdul Malak 2010, Freyhof and Brooks 2011). As in these areas, while richness is relative low, local endemism is very high and is mostly due to a few genera, which have many allopatric species endemic to one or few sub-basins. For example, 14 species of Cobitis, 14 species of Aphanius, and 20 (one EX) species of Pseudophoxinus are endemic to Central Anatolia and adjacent southern Anatolia. With very few exceptions, only one species of each genus occurs per basin.

\subsubsection{Threatened species}

The sub-basins with the greatest number of threatened freshwater fishes (between six and eight) in the Eastern Mediterranean region are the lower Orontes/Asi River in Turkey, the drainages of Lake Işıklı and Lake Beyşehir in south-western Anatolia, lower parts of rivers entering the Caspian Sea coast in Azerbaijan, and in the middle Euphrates in Iraq incorporating the Haditha karst system (Figure 3.4).

Most species in the area are threatened by water extraction, and one example is the Orontes/Asi River which has its source (a spring) in northern Lebanon and flows through Syria to Turkey and is subjected to intensive groundwater extraction for agriculture. This has resulted in the depletion of the water storage in the aquifers, lowering of the groundwater table, and considerable reduction of the spring yield (AQUASTAT 2009). The river hosts six threatened species: the loaches Cobitis levantina (EN) and Oxynoemacheilus hamwii (EN), the cyprinids Alburnus orontis (VU), Capoeta barroisi (EN), and Chondrostoma kinzelbachi (EN), and the eel Anguilla anguilla (CR). Also two NT species (Squalius kottelati, Carasobarbus chantrei) occur in the catchment. Furthermore, the CR Possibly Extinct cyprinid Acanthobrama centisquama is (was) endemic to the Asi, known from Lake Amik, a large freshwater lake which is now dry (drained to grow cotton) in southern Turkey. Other permanent water bodies are very rare in its surroundings and the water table has fallen dramatically (Ozelkan, Avcı Uca, and Karaman 2011). In 2007, the Hatay Airport was constructed in the centre of the old lake bed.

In some Syrian parts of the Asi/Orontes River large-scale water extraction has resulted in such a low water table that many

Lake Meyil in the Lake Tuz basin. This fast drying out obruk (sinkhole) lake is the habitat of one of the last populations of Hemigrammocapoeta kemali (now Garra) (EN). Photo @ Jörg Freyhof

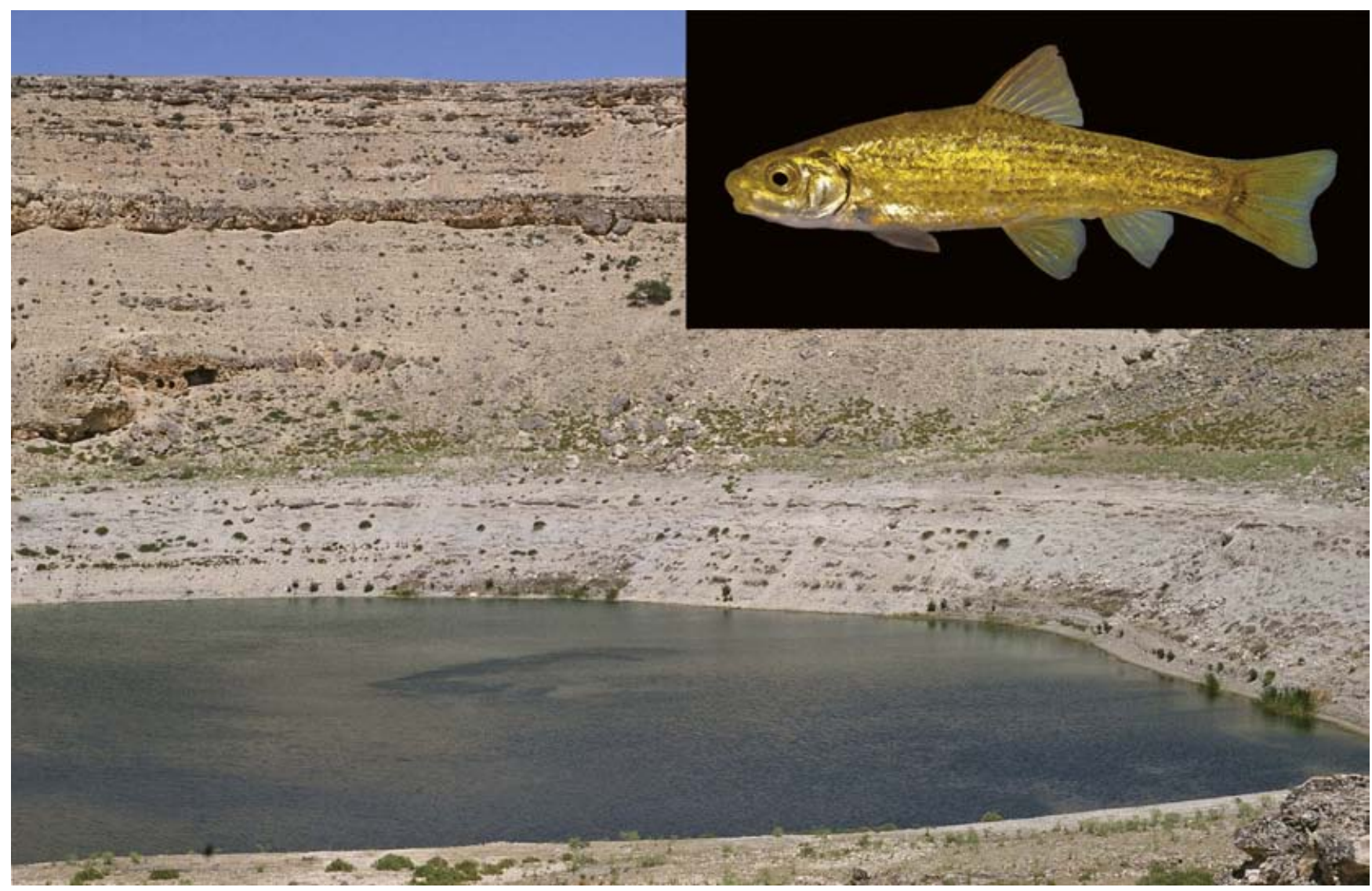




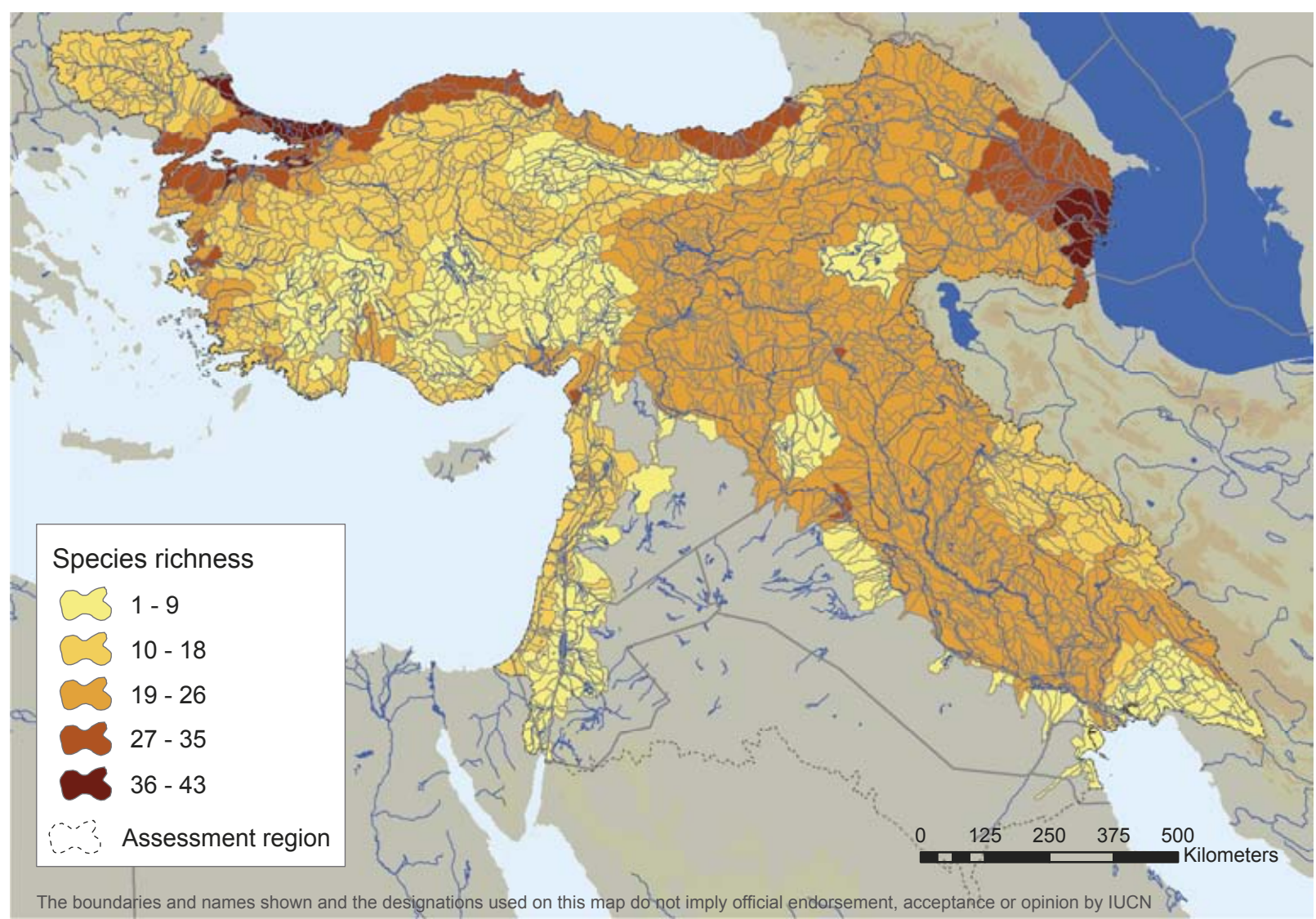

Figure 3.3 Eastern Mediterranean freshwater fish species richness. Species richness = number of species per subbasin (defined by HydroBASINS ‘Level 8’, Lehner and Grill 2013).

Figure 3.4 Eastern Mediterranean threatened freshwater fish species richness. Species richness = number of species per sub-basin (defined by HydroBASINS 'Level 8', Lehner and Grill 2013).

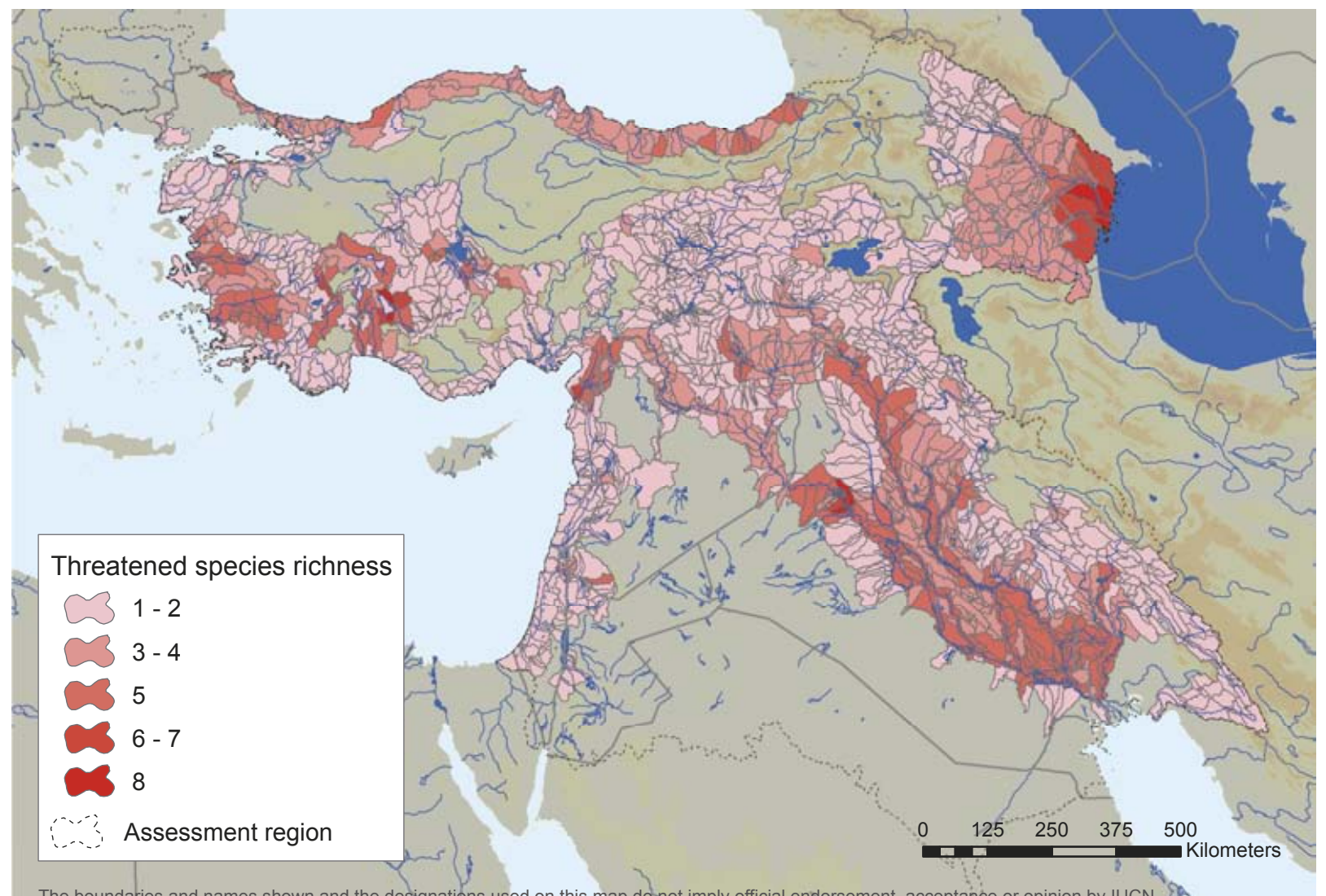

The boundaries and names shown and the designations used on this map do not imply official endorsement, acceptance or opinion by IUCN $\mathfrak{Q}$. 


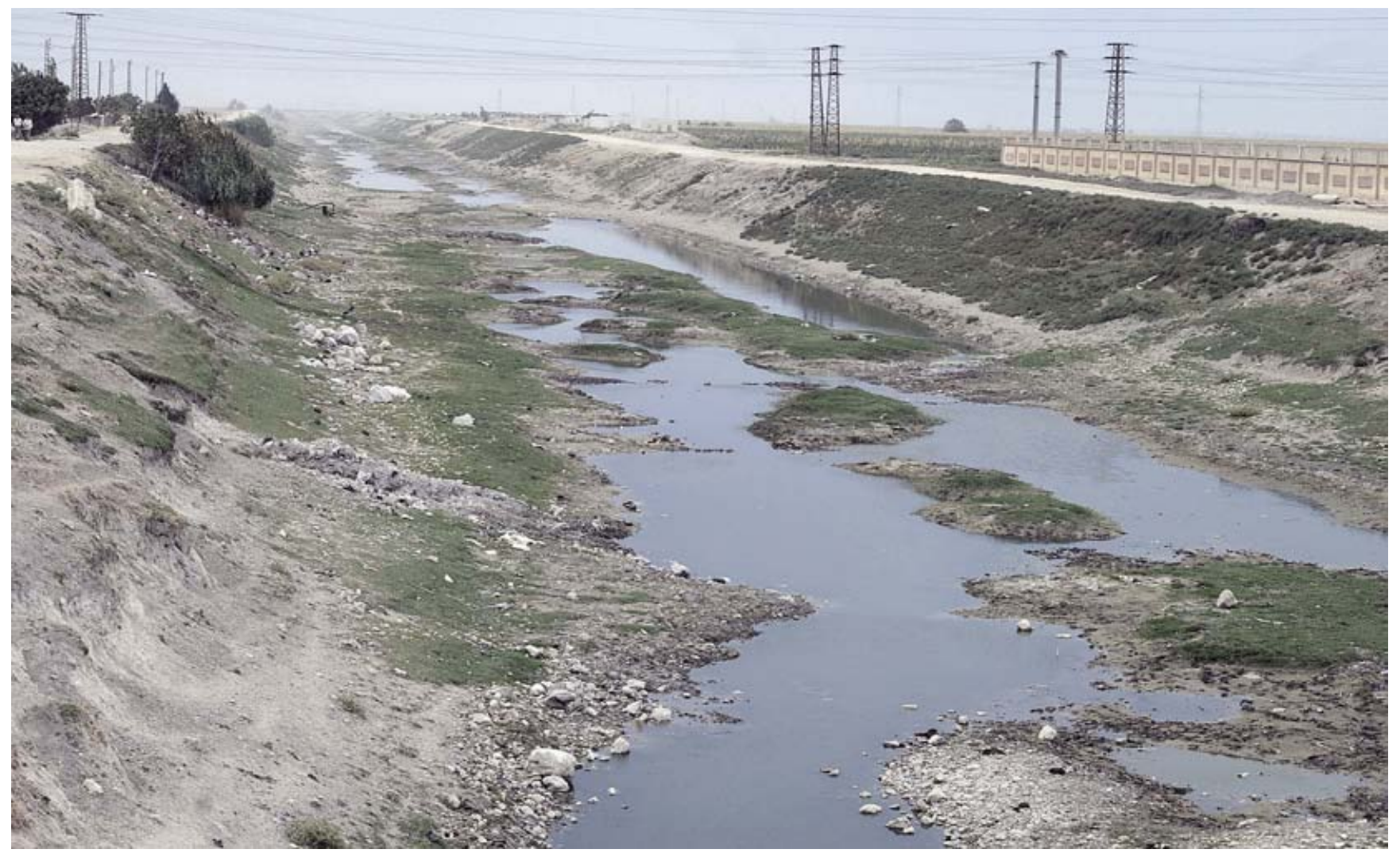

The Lower Asi/Orontes River in the Al Ghab region in Syria. Only a few fish species now occur in this highly polluted and almost dried out stretch of the river. Photo $\odot$ Jörg Freyhof

Lower Asi River downstream of the Al Ghab region in Syria. Large springs feed a clear river full of fishes including several threatened species. Photo $\odot$ Jörg Freyhof

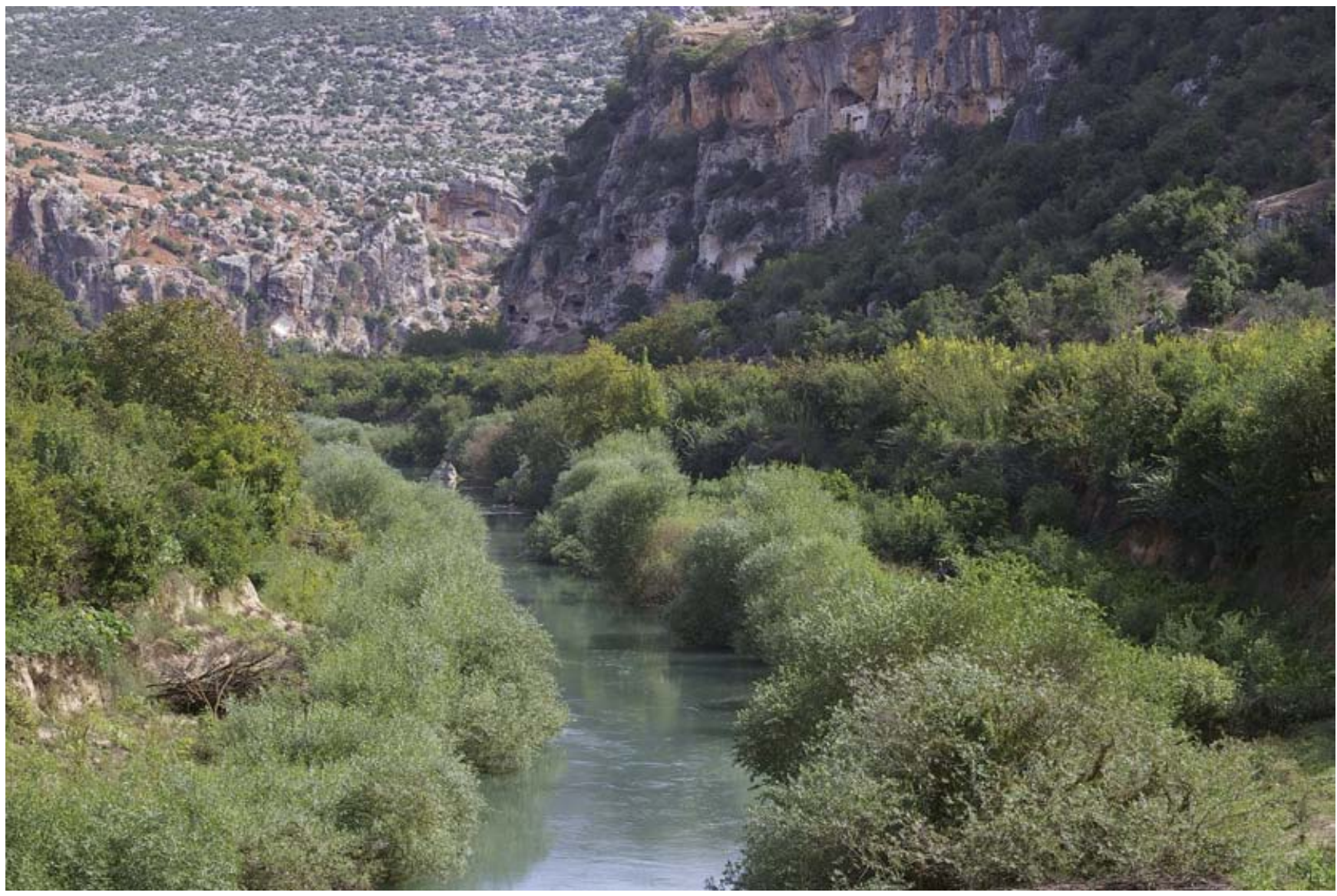


streams have fallen dry and the river itself almost dries out during summer. Furthermore, large cities pollute the waters in the area to such an extent that in some localized areas the river 'water' is mostly sewage. Now only a few areas of large freshwater springs and spring fields along the riverbed of the Asi allow fish to survive, however pressures will only increase in the future with reduced rainfall due to climate change, and the growing economies and populations increasing the demands for water in the area. The situation is so dire that Capoeta barroisi (EN) and Chondrostoma kinzelbachi (EN) mostly exist only in the large reservoirs where water is stored for irrigation, as they can no longer inhabit the polluted river. Such combinations of water stressors are a very common situation in the Mediterranean, Azerbaijan, Mesopotamia, and Central Anatolia, and especially across the Levant. Current rates of water extraction are not sustainable and there are not enough water treatment facilities to keep the little water that does remain in good quality.

Between three to five threatened species per sub-basin are found in many areas in the region including parts of the southern Black Sea coastal area, the middle Asi drainage (Karasu and Afrin Rivers), Lake Tuz (Cihanbeyli, Melendiz/Ihlara, and southern tributaries), Lake Burdur drainage, wider Lake Işıklı drainage, Lakes Eber, Çavuşcu (Ilgın), and Akşehir drainage, Lake Eğirdir drainage, lower Bakır River, middle and lower Gediz and Büyük Menderes Rivers, as well as the Köprü and Aksu Rivers in the Gulf of Antalya. Again, apart from along the Black Sea coast, water stress is the main driver of habitat loss of freshwater fishes. Many springs, streams, obruks (sinkholes), and small lakes have dried out in the last 20 years, for example in the Lake Tuz basin. The water level of Lake Burdur continues to decline, and pollution has severely impacted many of the rivers of the Aegean basin (such as the Gediz, the Bakır, and the Küçük Menderes).

Outside of Turkey the same number of threatened species (between three and five) per sub-basin are also found in the mainstream Tigris and Euphrates Rivers including lower parts of their tributaries and the marshes in Iraq and in adjacent Iran, the middle and lower Aras/Kura, upper Asi/Orontes, and Lake Kinneret and its catchment. In Central Anatolia and the Levant, local species richness is low and very few species occur within only one sub-basin (Figure 3.3), however a very high ratio of these have been assessed as threatened (Figure 3.4). The high numbers of threatened species along the Black and Caspian Sea coasts are not only due to the presence of local endemics such as the lamprey Lampetra lanceolata (EN), gobies Ponticola rizeensis (EN) and P. turani (VU), and the loach Cobitis splendens (CR) but also due to the occurrence of widespread but declining species such as the European eel Anguilla anguilla (CR) and several species of sturgeons (all CR), which may occasionally roam along these coasts and once spawned in the lower parts of the rivers as far upstream as the construction of dams allows them to go.

The sub-basin in the Euphrates and Tigris system with the highest number of threatened species (six) is situated at the middle Euphrates in Iraq. There, two subterranean cyprinid species are endemic to the Haditha karst system (Typhlogarra (now Garra) widdowsoni, Caecocypris basimi, both CR). These are found in the same sub-basin as Luciobarbus xanthopterus, L. esocinus, Carasobarbus kosswigi and Barbus grypus (now Arabibarbus) (all VU) which all occur in the adjacent, but hydrologically connected, Euphrates River. The subterranean species have been severely impacted by high levels of groundwater extraction, and the species in the Euphrates River are threatened by dams and overfishing.

\subsubsection{Restricted range and endemic species}

There are many range restricted and locally endemic species, which is reflected in the 58 species assessed as threatened under the restricted Extent of Occurrence (B1) Red List criteria. These are found mostly in Anatolia and the Levant, but also occur in

There are many freshwater fish species with tiny global ranges in the Eastern Mediterranean region. Aphanius transgrediens (CR) from a spring field in Central Anatolian Lake Acı is just one example. Photo @ Jörg Freyhof

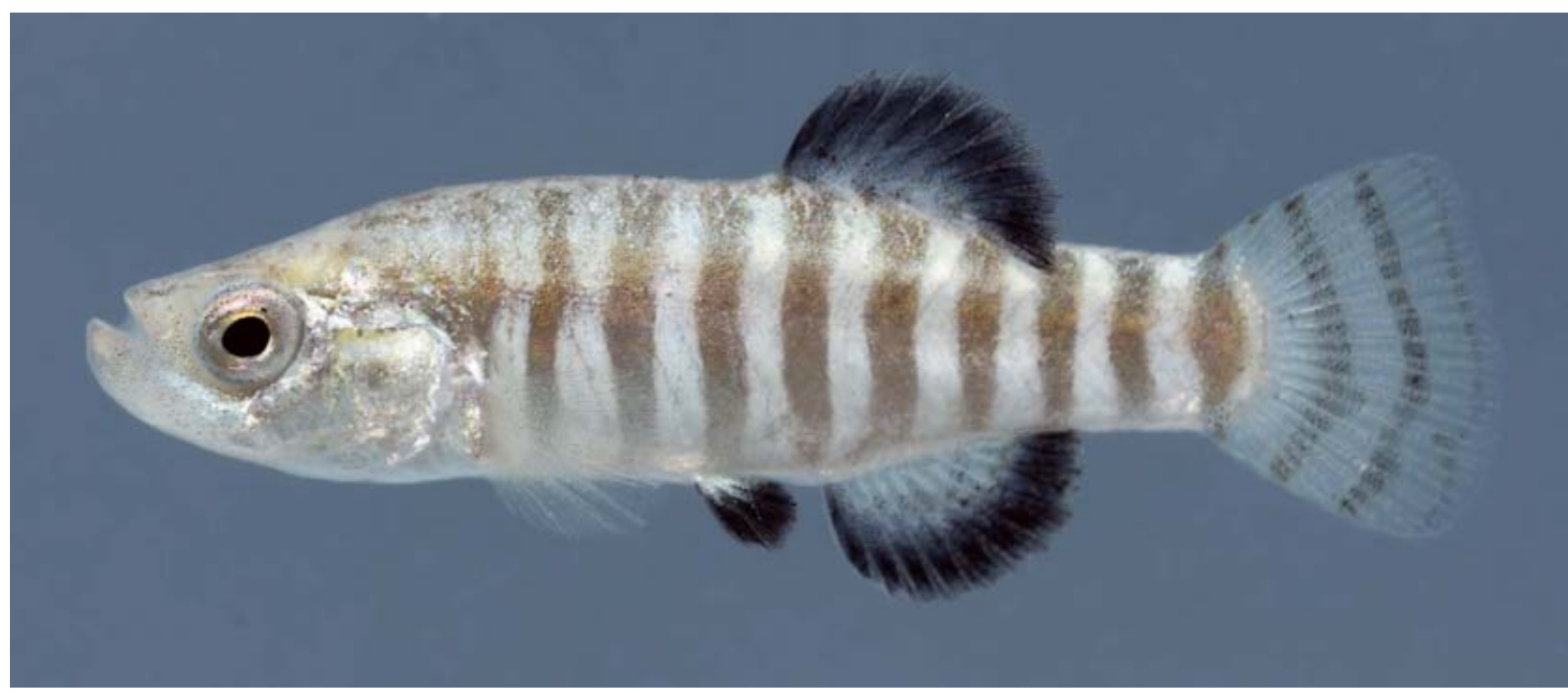


Mesopotamia and in the Caucasus, for example the endemic trout Salmo ischchan (CR draft assessment) in Lake Sevan in Armenia and two Pseudophoxinus (both CR) in springs in the Kura basin in Azerbaijan. In Anatolia, particularly along the Mediterranean coast and in Central Anatolia, many locally endemic species occur and this pattern of a high ratio of local or single catchment endemic species is found south to the Jordan River basin. In contrast, most species in Mesopotamia have large distribution ranges occurring throughout the Tigris/Euphrates system from Turkey south to Iraq, with several species also occurring in other tributaries of the Arabian / Persian Gulf. However, there are several genera, for example Oxynoemacheilus and Alburnoides, where species are very restricted and are found in just one or a few headwater streams of the Euphrates or the Tigris.

\subsubsection{Data Deficient species (DD)}

Sixteen species have been assessed as DD, 13 of them are endemic to the region. Seven are due to unresolved taxonomic problems and are likely to be synonyms of other species (Barbus ercisianus, Capoeta kosswigi, Gobio battalgilae, Luciobarbus kersin, Oxynoemacheilus cinicus, O. lenkoraensis, Vimba melanops). The distribution of Salmo tigridis (DD draft assessment) has been well studied in Turkey where it is highly restricted, however it is expected that the species is much more widespread in the Iranian Tigris, where Salmo species have not yet been studied, particularly on their taxonomy. Without this knowledge, the species' full range and therefore threats remain unknown. The other species assessed as DD are so poorly known that not enough information was available to assess their conservation status. Cobitis amphilekta has just recently (Vasil'eva and Vasil'ev 2012) been described based on old material (1937) from Azerbaijan, but there has been no targeted fieldwork to search for the species. Glyptothorax kurdistanicus, a species likely to be endemic to the Little Zab drainage in Iraq, has been just recently re-discovered but its wider range and threats are unknown. Oxynoemacheilus araxensis is still only known from a small tributary in the upper Euphrates from where it has been described (despite its name, the species does not occur in the Arax), but there are indications that the species may also be widespread in the adjacent Yeşilırmak drainage and its threats are unknown. Oxynoemacheilus ceyhanensis is known from one site only but is likely to be widespread in the adjacent Ceyhan drainage. Petroleuciscus kurui is only known from a small endorheic basin in the upper Tigris catchment in Turkey where the species has not been found since 1974. However, the area is difficult to visit and has not been surveyed since, therefore the species may be still in a good status, or may be highly threatened. Squalius seyhanensis was described in 2013 and not enough is known about its suspected wider distribution range and threats.

\subsubsection{Extinct (EX), Possibly Extinct (CR PE) and Extinct in the Wild (EW) species}

Extinction of freshwater fishes in the Eastern Mediterranean region, as in many parts of the world, is sadly on-going and largely un-noticed. Six species of freshwater fishes, all lake endemics, are assessed as Extinct (EX). Alburnus akili was endemic to Lake Beyşehir, Alburnus nicaeensis to Lake İznik, Aphanius splendens to Lake Gölcük, west of Isparta, and Pseudophoxinus handlirschi to Lake Eğirdir, all of them in Anatolia. Mirogrex hulensis was endemic to Lake Hula and Tristramella sacra to Lake Tiberias, both in Israel. All four extinct species from lakes in Turkey vanished due to the intentional stocking of alien fish species for fisheries purposes. While Lake Hula was drained, the reasons for the extinction of Tristramella sacra are not known, but it is thought to be due to the loss of its breeding grounds (marsh areas).

There are seven additional species which are assessed as Critically Endangered, Possibly Extinct (CR PE), meaning that they may be extinct but further research is required to confirm their status. These are Acanthobrama centisquama, a species once known from Lake Amik in the Asi drainage in Turkey. This species has not been found since 1977 and while the lake itself has since been drained, there is a small lake close by, Lake Gölbaşı, which may

Gobio battalgilae (DD) has been described as an endemic to Lake Beyşehir basin in Central Anatolia, however it may be a synonym of Gobio microlepidotus (VU). Photo $\odot$ Jörg Freyhof

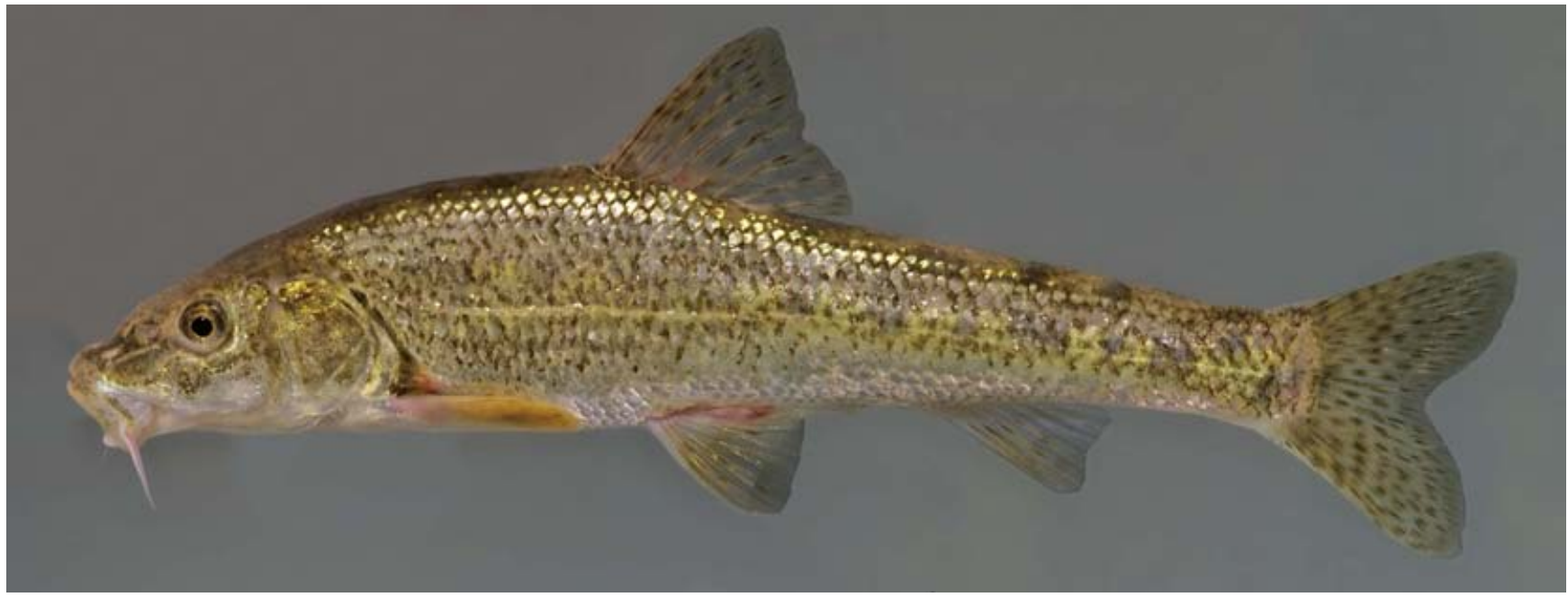


be inhabited by this species. Acanthobrama tricolor has not been found in the lower Barada River in Syria since 1908, but was recorded in the Golan Area of Separation in the late 1980s ( $\mathrm{H}$. Esterbauer pers. comm. 2008), the species needs further surveys to its status there. Caecocypris basimi is endemic to the Haditha karst in Iraq but has not been found since the 1980s, and while a survey in 2012 did not find it, the species may still exist in the subterranean waters which may be deep and inaccessible. Pseudophoxinus sojuchbulagi is a small cyprinid endemic to a small spring-stream system in the Kura drainage. It has not been found since the 1950s despite two recent expeditions (N. Bogutskaya pers. comm. 2014, B. Levin pers. comm. 2014). Cobitis kellei and Paraschistura chrysicristinae were found only once in 1974 in the upper Tigris drainage in Turkey but have not been found since, despite intensive research in the area (E. Ünlü pers. comm. 2014). Nevertheless, it cannot be excluded that a small population(s) may have survived somewhere close by. Pseudophoxinus syriacus was still present in 2008 in the very last remnants of the spring of the Barada River in Syria, where the species is endemic, however since then the spring has been almost fully drained and it is feared that the species may since have gone extinct. While writing this report, we learned (M. Bariche, pers. comm. 2014), that in the winter of 2013/14 and all of 2014 so far, there was no rainfall in the Ammiq marshes in Lebanon and the marshes may have dried. There is one endemic fish species, Tylognathus festai (now Garra), last seen in 2011, which therefore may have gone extinct this

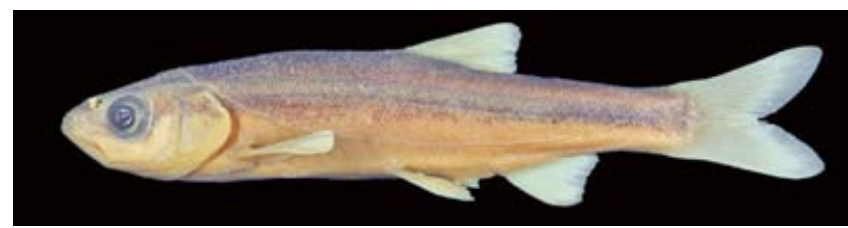

Pseudophoxinus handlirschi (EX) from Lake Eğirdir. One of the specialized lacustrine fish species which went extinct after the stocking of alien species. Photo $\odot$ Jörg Freyhof

year. The same could be true for Pseudophoxinus ninae, which is endemic to a single stream in Central Anatolia reported as being dry in 2013 and 2014 (G. Ekmekçi, own observations).

There is an additional species, Stenodus leucichthys, which is assessed as Extinct in the Wild, as dam construction has blocked access to the spawning grounds of the species in northern Caspian Sea drainages (the species spends the summer in the central and southern Caspian Sea). The species now only survives due to artificial breeding and stocking in the Volga drainage

\subsubsection{Regionally extirpated species}

As $87.7 \%$ of the threatened species are endemic to the Eastern Mediterranean region, only a few species are at risk of becoming regionally extirpated (i.e. extirpated from the Eastern

Once famous for its large amounts of cold and clear water, Barada spring in the Syrian Damascus basin was drained in 2008. The only endemic species of the spring, Pseudophoxinus syriacus (CR) might now be extinct. Photo $@$ Jörg Freyhof

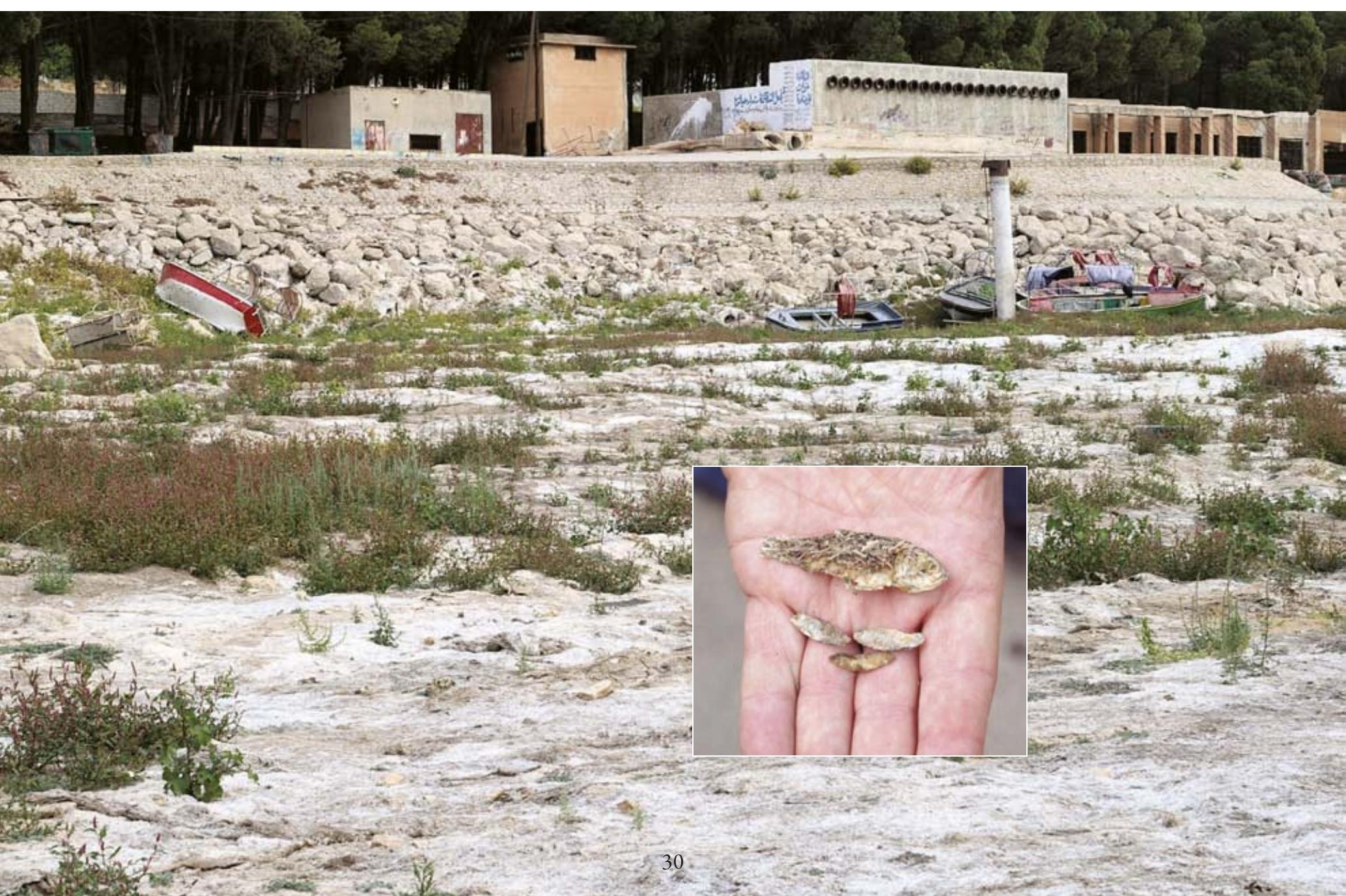


Mediterranean region, but extant elsewhere). The most critical examples are the sturgeons (all CR). There is no evidence that sturgeons still regularly reproduce in any of the rivers in the assessment region. The last populations of sturgeons in the Black and Caspian Sea basins are now restricted to European rivers such as the Danube, the Volga, and the Ural. In the Black Sea basin and outside Europe, the only remaining river regularly used for spawning is the Rioni in Georgia, which is outside of the area assessed for this study. Acipenser colchicus, which is now endemic to the Rioni along with Acipenser gueldenstaedtii, Acipenser stellatus, and Huso huso, still spawns in the Rioni. Acipenser nudiventris and $A$. sturio seem to be extirpated. Within the Eastern Mediterranean region the Iranian rivers and the Kura (of the Caspian basin) in Azerbaijan and the large southern Black Sea rivers, such as the Sakarya, Kızılırmak, Yeşilırmak and the Çoruh had all once been significant spawning rivers for sturgeons (Holč́k 1989), whereas now it is only very occasional. In Azerbaijan, Georgia, and Iran, there are large-scale fish farms, which produce sturgeons for stocking and also meat and caviar production. These activities are largely decoupled from restoration of wild stocks but may result in lower prices for sturgeons and therefore reduce the fishing pressure upon wild populations. However, great efforts need to be made to re-establish wild breeding populations that are fully independent from human activities such as artificial reproduction and stocking. There is a government led programme in Turkey to develop sturgeon brood stocks for reintroduction purposes into the Black Sea (Akbulut et al. 2011).

It should also be noted, that the European eel Anguilla anguilla (CR) has to be considered to be extirpated from large parts of its former range in the Black Sea and Eastern Mediterranean basin. While eels have experienced a very large decline in the late 20th century, they are still regularly found in the lower parts of rivers and streams close to the Mediterranean Sea in Anatolia and the Levant. Eels used to occur in all Mediterranean and Black Sea rivers, but are now mostly restricted to the lowest parts of the rivers due to many dams restricting their range.

\subsection{Major threats to freshwater fishes}

There are a number of pressures to freshwater fishes of the Eastern Mediterranean region, most of them a result of human development and climate change (Figure 3.5). These include increased water extraction and the development of dams (included under 'Natural system modifications' which impacts $90 \%$ of threatened and NT fish species), coupled with increasing frequency of droughts (under 'Climate change and severe weather' affecting 69\% threatened and NT fish species) which is leading to habitat loss, increased pollution of freshwater systems particularly from domestic/urban effluent and from local agricultural runoff (affecting $47 \%$ of threatened and NT fish species), and nonnative invasive species (affecting 21\% of threatened and NT fish species). These threats are unequally distributed over the Eastern Mediterranean region, with some threats being particularly intense in some parts of the region. As many species assessed as threatened have very small distribution ranges, even relatively low environmental stress on these small populations can significantly impact their global population and likelihood of survival.

\subsubsection{Water extraction and dams (natural system modification)}

\subsubsection{Surface and ground water extraction}

The Middle East is the first region of the world to effectively run out of water (Allan 2001). Surface and ground water are extracted in huge quantities throughout the dry parts of the Eastern Mediterranean region and extraction is rarely sustainable, making it the most important threat for many of the freshwater fishes in arid and semi-arid landscapes. These species survive in freshwater habitats that already have periods of low flow, and any additional extraction can easily result in significant loss of habitat, or even total desiccation. This assessment shows that $90 \%$ of the threatened and NT species are impacted by dams and water extraction.

Within the Eastern Mediterranean region, Central and Western Anatolia in Turkey, and the Levant are the areas most intensively impacted by water extraction where pumps abstract surface water from the streams and rivers. In smaller streams it is common practice to dig large holes in the streambed to allow the extraction of water even when the stream has almost fallen dry in late summer. Water is also widely extracted by pump-trucks and transported to more distant places.

All countries considered here have water policies but these are not always enforced in ways that sustain or protect biodiversity. Apart from Israel which introduced a 'water for biodiversity' policy in the early 2000s, we are not aware of any country where there is a water policy that aims to guarantee enough water remains in the lakes, marshes, streams, and rivers to sustain biodiversity's needs (Shacham 2003). In Israel seawater is increasingly desalinated in large amounts reducing stress on naturally available freshwater supplies, and studies show that streams and springs can rapidly return when the amount of water extracted is reduced (Shacham 2003). However, desalination is expensive, requires access to seawater and is powered by fossil fuels and should not be seen as the sole answer to the region's water needs. Allan (2001) pointed out that the rapidly growing water needs of many countries of the Eastern Mediterranean and the Middle East can no longer be met by further exploitation of water resources except through either the development of desalination facilities or the reallocation of water resources from agriculture. Great innovative efforts and financial support are needed to develop desalination systems powered by solar or wind energy not only to conserve freshwater biodiversity but also to benefit the other water needs of the Eastern Mediterranean.

As further evidence for the desperate state of the region's water resources, Voss et al. (2013) found that large parts of western Asia are losing groundwater reserves at an alarming rate, with 
the water deficit being one of the highest in the world, second only to India. The water demands for intensive agriculture and growing populations cannot be met by surface water sources alone. Large spring fed wetland complexes are therefore especially impacted by additional groundwater abstraction, for example the Turkish Sultan marshes, Eşmekaya marshes, Lakes Hotamış and Ac1, the Jordanian Azraq marshes and Lebanese Ammiq marshes have all almost or completely dried out. The lowering of water tables is impacting stream flows across the region with many having dried out, the Turkish Küçük Menderes River is one example. Another example is the loss of the Qweik River which once flowed through the Syrian city of Aleppo, but has now virtually vanished. Today only two very small headwater streams remain from this once large river leaving the only endemic fish species, the loach Oxynoemacheilus tigris (CR), on the border of extinction. Other examples include the once extensive spring areas at Ras Al Ain in northern Syria, which have almost completely dried out, as has the famous spring of the Barada River near Damascus along with almost the entire Damascus hydrological basin as most of the water is extracted for the city of Damascus.

\subsubsection{Dams}

It is impossible to determine the exact number of dams and weirs in the region, even for Turkey where information is available, different sources provide very different numbers. However, according to GegenStrömung (2011), Turkey has more than 2,000 dams and weirs and has plans to build an additional 1,700 within its borders, making it one of the most active dam building countries in the world and leaving hardly any river in the country unaffected (GegenStrömung 2011, International Rivers 2014). Some of the proposed dams - in particular Ilisu and Yusufeli - have triggered strong opposition (International Rivers 2014), and the lack of ESIAs (environmental and/or social impact assessments) for many of the recent dam developments mean that impacts to biodiversity and society remain largely undetermined (GegenStrömung 2011). In the Caucasus, many dams were built during the Soviet times but there is now a growing interest in exploiting rivers as hydropower resources. In the Levant and Mesopotamia dams are found on almost all suitable rivers, but political instability, especially in Iraq, has so far delayed the construction of new dams. The upper Tigris in Turkey as well as Iraqi Kurdistan are still places not impacted by dams, and have almost pristine rivers with rich freshwater biodiversity. However there are plans to build dams in this region; and the highly controversial Ilisu dam in the upper Tigris is the most prominent of several planned dams which would transfer considerable parts of the Tigris drainage into hydropower reservoirs.

While most rivers in the region are dammed, it is usually only a single dam or maybe a few rather than a 'cascade of dams', which essentially changes the river into a series of lakes. However, this is changing as many new dams and weirs are constructed across the region, and especially in Turkey. Construction of new dams, especially for hydropower, is a major concern for freshwater fish conservation across the region. Hydropower is widely presented as a 'green technology' leading many countries to aim towards exploitation of all their hydropower potential. As mentioned above, however, the environmental and social impacts of dams can be quite significant and far reaching. Large dams in Eastern Anatolia, for example, already impact water availability in Syria and Iraq (leading to political tension) and if the Ilisu dam on the Tigris becomes a reality another important part of the free flowing Tigris will be lost. Beyond Turkey, it is likely that other governments in the region will follow the same dam building strategy if political stability would allow them to do so. Several large dams have already been built in Syria and Iraq, massively impacting the biodiversity and hydrology of the Euphrates and Tigris; and their tributary mountain rivers in Iraq, such as the
Figure 3.5 Drivers of threats impacting threatened and Near Threatened freshwater fish species in the Eastern Mediterranean region.

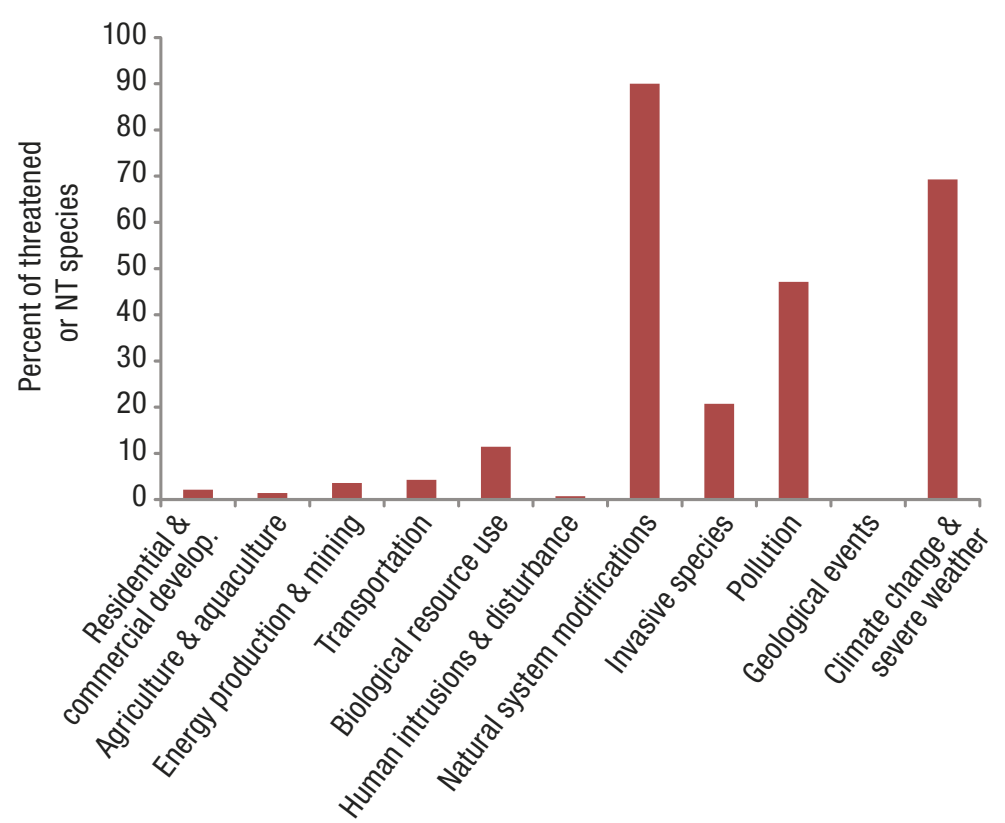




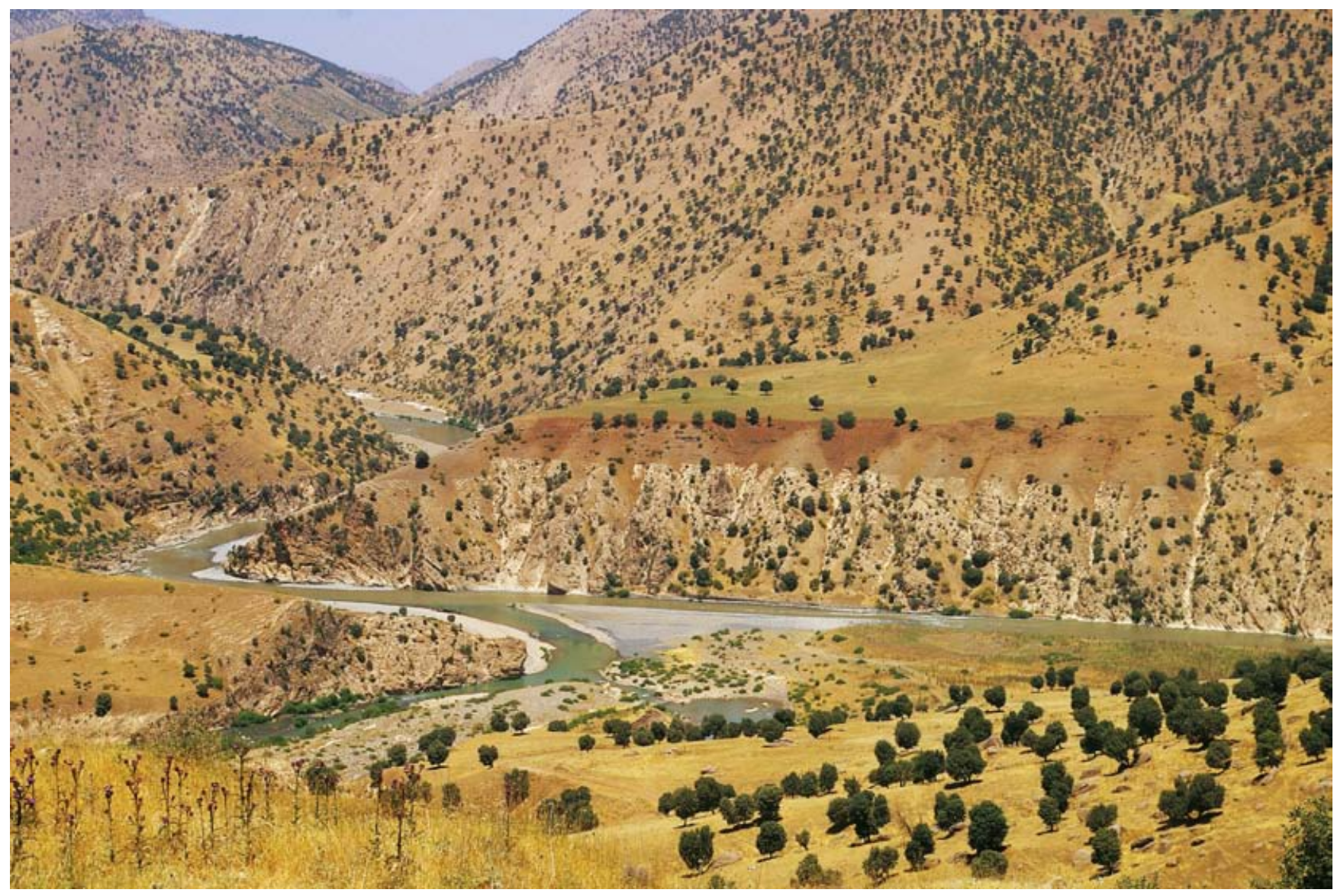

The Chorman River in Iraqi Kurdistan, a tributary to the Tigris, is a habitat of Barbus (now Arabibarbus) grypus and Carasobarbus kosswigi (both VU). This is one of very few rivers that have escaped major impacts and are of high conservation value in the Eastern Mediterranean region. Photo $($ Jörg Freyhof

Great and Little Zab Rivers, have a large hydropower potential which will likely also lead to their damming sooner or later. This will lead to a significant decline in all species (and associated human livelihoods) that depend on larger rivers and streams with a continuous flow of water. In addition, all existing (and proposed) dams along the Tigris and its tributaries are a threat to the recently restored marshes in lower Mesopotamia in Iraq, as they reduce the amount of freshwater reaching the marshes causing them to dry out or become saline as the brackish water borderline is moving northwards in the Shatt Al-Arab (Iraqi Ministry of Environment and Nature Iraq, in prep).

Dams and weirs for capturing runoff. In the Eastern Mediterranean region it is very common, and natural, for sections of streams and rivers to run dry in summer. However, capture dams and weirs which with hold water runoff that would otherwise be 'lost' to human use, leave little or no water to flow downstream. This reduces the habitat availability for freshwater fishes even in ecosystems which are adapted to seasonal droughts where the survival of fishes often relies upon small refuge pools. The continued over-abstraction of water, coupled with increasing frequency and severity of droughts, is leading to the desiccation of these refuge pools and to the extirpation (and extinction) of fishes. Many of the lakes in Central Anatolia that have dried out have done so because of high levels of water extraction from their tributaries and from their aquifers. The most famous (but not only) example are Lakes Burdur, Eber, and Akşehir which are currently in a critical ecological status as significant quantities of water are being extracted directly or retained by dams in their catchments (primary author's observations). The same is true for the former Ereğli marshes where, after building a dam on the İvriz stream and draining all the water for human use, the marshes dried out completely in the 1990s.

Dams as migration barriers. Freshwater fish species are often very sensitive to habitat alterations as many have complex life histories, relying upon seasonal changes in their environment such as flow regimes, and some need to perform long distance migrations in order to breed. No other ecological group of freshwater biodiversity shows higher threat levels than anadromous species (e.g. $85 \%$ of all sturgeon and paddlefish are threatened (IUCN 2014)), and as there are almost no rivers in the Eastern Mediterranean region which have not been impacted by dams the migration routes of many fishes have been blocked, or seriously compromised. This is a situation which can be partly mitigated by the installation of suitable fish ladders, allowing migratory fishes to pass dams and continue their migration upriver. However, the primary author is not aware of any river in the region, where effectively functioning fish ladders have been installed. Even where fish ladders are in place migratory fishes do not always find the habitats they need as once they negotiate a dam they often then enter impoundments (reservoirs) 


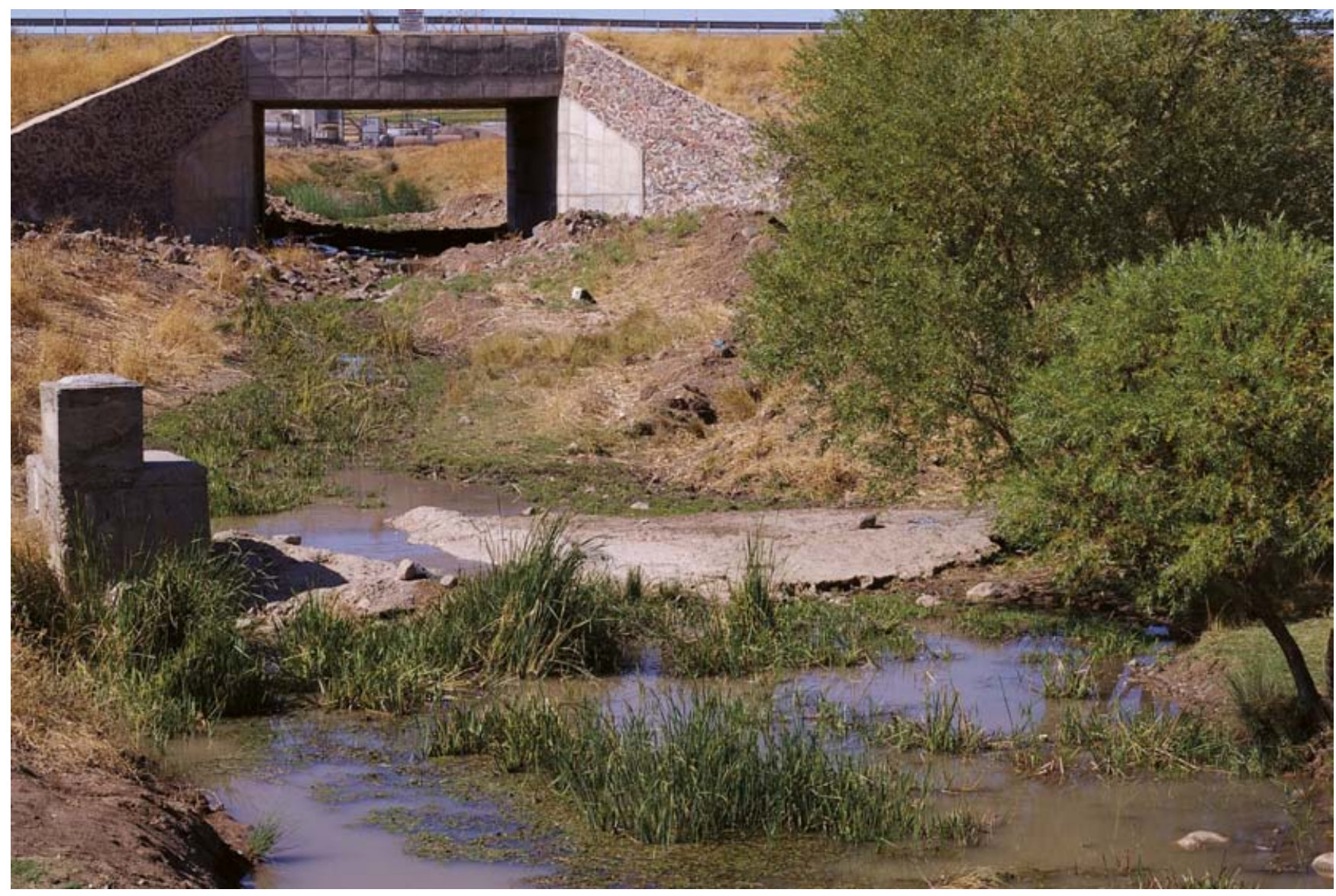

The last remains of a vanished river. The Sünnep in Turkey is one of two remaining small streams of the once large Qweik River which flowed through the city of Aleppo. The Sünnep is home to the last population of Oxynoemacheilus tigris (CR). Photo @ Jörg Freyhof

which have replaced their required riverine spawning habitats. Anadromous fish species not only need to find their way upriver they also need to travel downstream and the authors are not aware of any existing effective way to prevent fishes on their downstream migrations from swimming into the turbines of the dams and being killed or injured. Sadly, the first dam upstream from a river estuary effectively ends the migration for most anadromous species in the region, and all rivers have lost their stocks of sturgeons (all CR), and the once widespread European eel, Anguilla anguilla (CR), has lost major parts of its former range.

Hydropeaking and water level fluctuation. Primarily in the Caucasus and along the Black Sea coast, the outflow from dams is managed as regular flood pulses, creating a flash flood downstream every few hours or days; a situation that is devastating for most freshwater fishes leaving the rivers almost empty of fish life below the dam. While reservoirs are suitable habitats for some native fish species this large-scale water level fluctuation in reservoirs (known as hydropeaking) inhibits the formation of a suitable lacustrine environment by preventing establishment of marginal vegetation such as reed belts and submerged vegetation, as well as invertebrate communities. Therefore, reservoirs exhibiting significant fluctuations in water level are usually only inhabited by a tolerant fish community dominated by alien species and carps, most of which are stocked for fisheries.
Future scenarios. Sadly, the future does not look bright for freshwater fish species specialized for inhabiting larger rivers and streams. Within the past 30 years many dams have been built impacting river flows across the region and it is expected, at least in some areas, that the potential hydropower capacity will be fully exploited in the near future. Currently the Eastern Mediterranean region is an area of huge water deficit (Voss et al. 2013) and, if policies that govern water extraction and dam building and management do not change, conservation of the remaining fish species in the region will remain a major challenge.

\subsubsection{Pollution}

Across the Eastern Mediterranean region and especially adjacent to areas of urban development, pollution is a major driver of threat for freshwater fishes impacting just under half (47\%) of all threatened or Near Threatened species (Figure 3.5). Most rivers and streams are significantly polluted downstream of urban areas primarily by sewage, for example the Kura downstream of Tiblisi in Georgia, the Tigris downstream of Diyarbakir, and the Shatt Al-Arab River in Iraq (Saleem and Hussain 2013). However, it is in the rivers of western Anatolia such as the Bakır, Gediz, and the Küçük and Büyük Menderes where water pollution is at its most widespread and severe. The Küçük Menderes has virtually vanished and the lower part is filled by sewage from towns and industries, and the Gediz and Bakır are so heavily polluted that no fish seem to occur in the middle and lower 


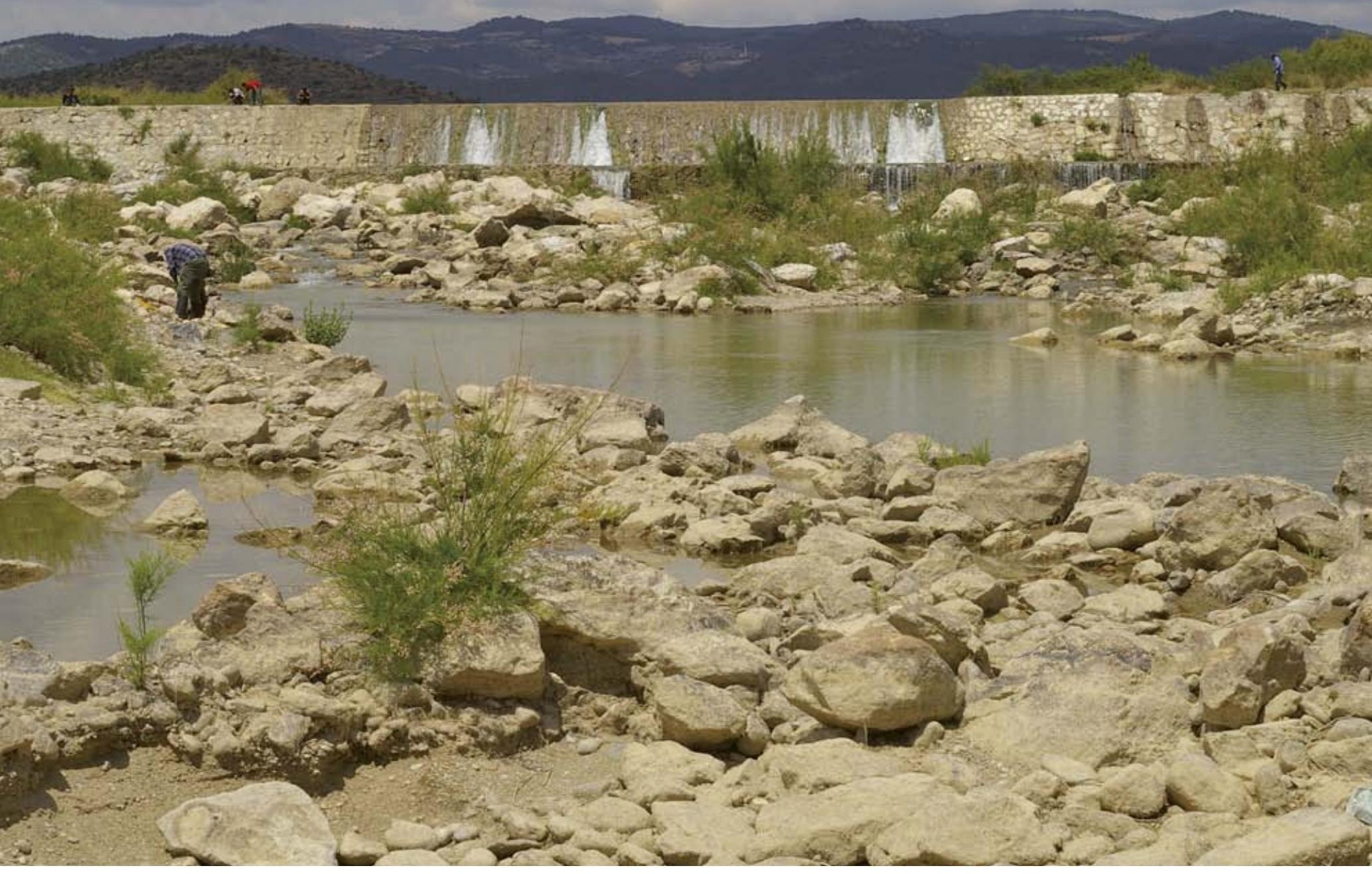

Small dams, such as this one in the Gediz drainage, capture runoff for irrigation and small weirs for flood control are found virtually everywhere in the Eastern Mediterranean region. During dry periods they often leave no water in downstream sections Photo @ Jörg Freyhof

parts of the main rivers. There are also high levels of pollution in many other areas, for example the upper Köprü River south of Isparta is flowing mostly with sewage, as is the Asi River and many coastal streams in Syria. However, data about chemical and biological water quality are sparse and there are few continuous monitoring programmes of open surface waters. Therefore, little is known about the extent and intensity of urban and agricultural pollution across the region. As part of the process towards its closer relations and future EU membership, Turkey is aiming to meet the requirements set out in the EU Water Framework Directive and the creation of a reliable inventory of water data and monitoring system is one of the major challenges it faces (Sumer and Mujuk 2011).

\subsubsection{Climate change and severe weather}

The Eastern Mediterranean region is predicted to become dryer and warmer, with a particular increase in the frequency of hot summer days and high temperature events (CEPF 2010) with reduced rainfall in all of Anatolia (except the northern coast) as well as in all of the Levant and the Mesopotamian region (Chenoweth et al. 2011). These scenarios suggest a bleak future for freshwater fishes in large parts of the region, as many areas have already dried out and many fish species, once widespread, are now restricted to small refuges. According to the research undertaken for this study $69 \%$ of all threatened or Near Threatened species are already being impacted by the effects of climate change (droughts) (Figure 3.5). The dramatic reduction in river flows (due to water abstraction and increased frequency of droughts) has led to considerable ecological, economic, and political problems that will increase in the future unless there is a radically different approach to water management across the region. A step in this direction has been taken in Israel, where large amounts of freshwater are now gained from seawater desalination. The effects of climate change to the unique and highly endemic freshwater fishes of the Eastern Mediterranean region are not difficult to imagine, as climate change will just speed up the on-going process of the drying out of springs, lakes, and streams in the region.

\subsubsection{Invasive alien species}

Over a fifth $(21 \%)$ of all threatened and Near Threatened freshwater fish species are currently being threatened by invasive alien species (Figure 3.5). At least 20 species of alien freshwater fish are introduced and established to the Eastern Mediterranean region. Species such as Carassius auratus, Carassius gibelio, Chelon haematocheilus, Gambusia holbrooki, Hemiculter leucisculus, Heteropneustes fossilis, Lepomis gibbosus, Poecilia latipinna, Pseudorasbora parva, and Rhinogobius similis are all invasive and have expanded their ranges within the region and are believed to negatively impact native fish communities where they exist. There are also a number of non-native species that do not yet seem to have become invasive, and are restricted to a few sites: 


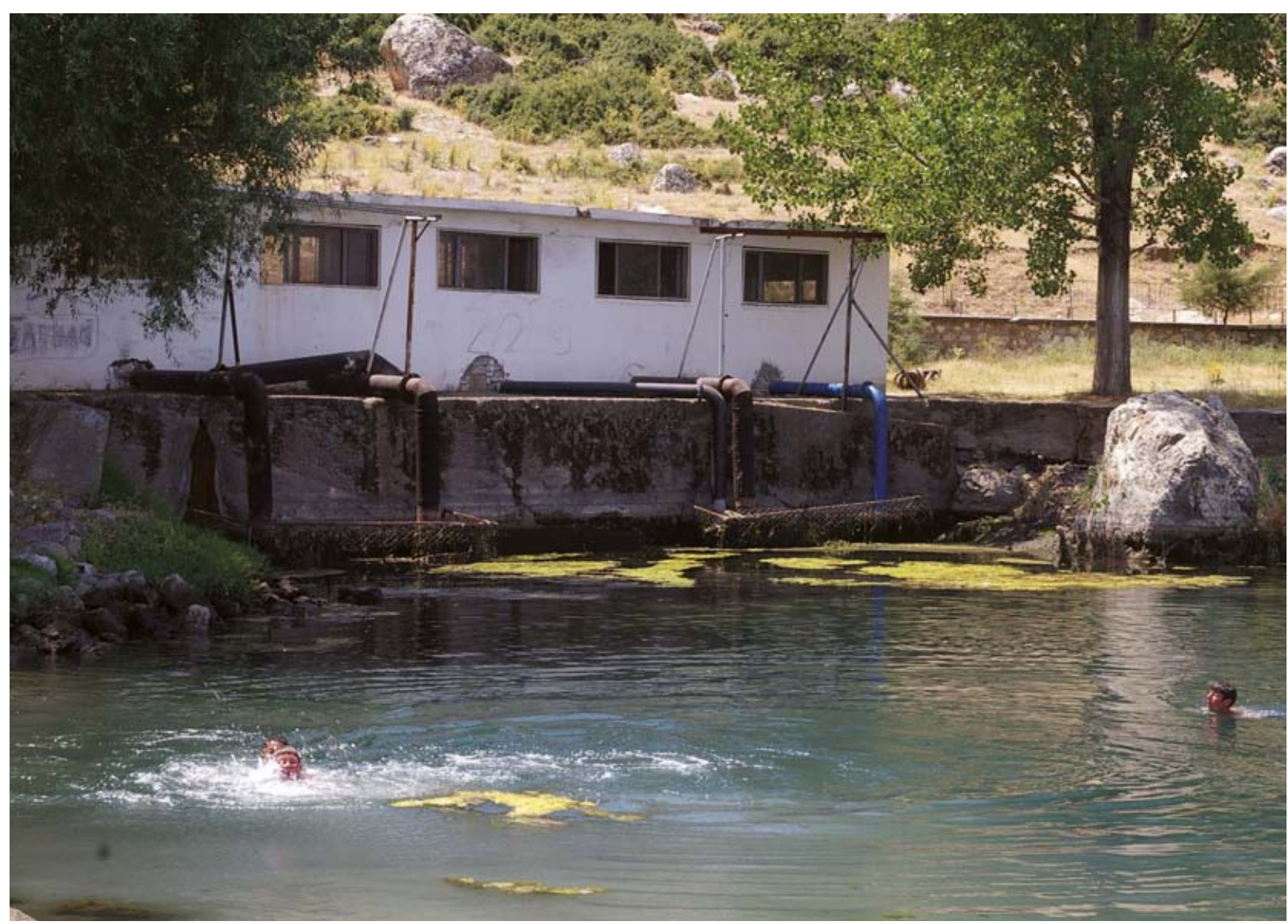

Spring at Gemiş in Lake Acı basin, Central Anatolia. While springs are the treasure box for freshwater fishes in the Eastern Mediterranean, the locally endemic killifish Aphanius transgrediens (CR) has vanished from this spring due to alien fish invasion. Note also the large pumping station taking water directly from the spring's source. Photo () Jörg Freyhof

Amatitlania nigrofasciata, Ameiurus melas, Coregonus ladogae, Lepomis macrochirus, Micropterus salmoides, Misgurnus anguillicaudatus, Oncorhynchus mykiss, Oryzias sinensis, and Poecilia reticulata. These non-native fish species have been released from aquaria, or have escaped from ornamental fish farms, intentionally introduced to improve fisheries, or have spread accidentally (as by-catch) with commercially introduced alien or native species. Five additional species, Acipenser baerii, Ctenopharyngodon idella, Hypophthalmichthys molitrix, Hypophthalmichthys nobilis, and Mylopharyngodon piceus are or have been stocked into waters of the Eastern Mediterranean region but have not formed self-sustaining populations.

The most common and widespread alien invasive species in the region are the cyprinids Carassius auratus and Pseudorasbora parva and the poecilid Gambusia holbrooki (Ekmekçi et al. 2013). These species occur almost everywhere in the Eastern Mediterranean region, and are known as 'global invaders' due to their widespread introductions across the world. An additional invasive species which is causing significant impacts as a competitor to native fishes is the East Asian cyprinid Hemiculter leucisculus. This cyprinid has reached Central Asia as a by-catch of Chinese carps and quickly established and spread in the Aral Sea basin. From there it reached, again as a by-catch with commercial species, the south-eastern Caspian basin and it is already widespread in the southern Caspian. Recently it made its way into the Tigris drainage where it has become established in several areas (Coad 2010). This very powerful invader is likely to follow the track of Pseudorasbora parva, which has spread across the complete Western Palearctic within 40 years.

Other major invasive species are native to parts of the Eastern Mediterranean region but have been introduced to other parts. The most famous example is the intentional introduction of predatory percid Sander lucioperca to the Central Anatolian Lakes Eğirdir and Beyşehir. Both lakes have a highly endemic fish fauna in which specialized predatory fishes were absent. Soon after the introduction of Sander in the 1950s, most native species declined sharply and in each lake one specialized open water lacustrine species went extinct (Alburnus akili in Lake Beyşehir; Pseudophoxinus handlirschi in Lake Eğirdir). Most native species are now restricted to lake tributaries, which are not inhabited by Sander. Other examples are cichlids (such as Coptodon zillii and Oreochromis aureus) and the catfish Clarias gariepinus, which are native to the Jordan basin, but have been introduced into the wider Levant and southern Anatolia. Coptodon zillii and Oreochromis aureus have been recently introduced to Iraq, where they have spread quickly and are 
already impacting fish communities in the marshes and the Shatt Al-Arab, the estuarine region of the Euphrates and Tigris, where they have become dominant in the fish communities (Mohamed, Hussein, and Lazem 2013, Falah M. Mutlak pers. comm. 2014). There are fears that the lower Euphrates, Tigris, and the Shatt Al-Arab and adjacent marshes will soon have fish communities that are dominated by alien species, at the expense of native species, especially the endemic herbivorous cyprinid Mesopotamichthys sharpeyi (VU), which seems to be the victim of the competition from alien herbivorous cichlids.

The most common alien invasive fish species in the Eastern Mediterranean region are the goldfish Carassius auratus and the common carp Cyprinus carpio, which occur virtually everywhere (Coad, 2010, Vilizzi, Tarkan, and Ekmekçi 2013). The common carp (itself a VU species) is native to the Black Sea and Caspian Sea basin where it is threatened due to habitat modification and the hybridization of the wild populations with domesticated forms. These domesticated carps have been introduced all over the region where they are particularly dominant in reservoirs. Although there are very few specific studies of the impacts of these alien species on the native fauna in the region, it seems that they out-compete native species, and the situation seems to be especially alarming in the lower Tigris and Euphrates. Research on the effects and distribution of alien species is strongly recommended to better understand their impacts, their behaviour, and how to limit their dispersal.

\subsubsection{Harvesting and research}

Relatively few native freshwater fish species are harvested in the Eastern Mediterranean region and this does not generally represent a significant threat, with only $11 \%$ of threatened or Near Threatened species impacted by overharvesting (Figure 3.5). It is common carp, Cyprinus carpio which is the major commercial species in large parts of the area including across its non-native range. It is along the Caspian coast and in the Caspian rivers where freshwater fishes are particularly harvested, where several Gobiids, Percids, Cyprinids, and Clupeids are of major commercial importance. In former times, sturgeons were also fished here during their spawning migrations but as sturgeons have now vanished from the rivers they are now harvested in the sea, but mostly from ranched stocks.

However, overfishing is a threat for several large barbels in the larger rivers of the Euphrates and Tigris drainage. Species such as Luciobarbus esocinus (VU), L. xanthopterus (VU), Mesopotamichthys sharpeyi (VU), and Barbus grypus (now Arabibarbus) (VU) all have high commercial value and are intensively exploited across their range, and available catch statistics suggest a considerable decline in the populations of these species. The only species of the genus Mesopotamichthys, M. sharpeyi, was once an important commercial catch especially in the marshes of southern Iraq and adjacent Iran, but in the last 10 years, the species has declined dramatically due to overfishing and most likely the impacts from alien invasive species. However, one mitigating factor for three of these species (L. esocinus, L. xanthopterus, and A. grypus) is that they benefit from the construction of large reservoirs, where they form large stocks and can migrate to inflowing rivers in spring to spawn. This at least partly offsets the massive losses due to overexploitation. The most important commercial wild and native freshwater fish species in Turkey is the cyprinid Alburnus tarichi (NT), which is endemic to Lake Van. This species was the victim of illegal overfishing, which now seems to be mostly under control. The Mesopotamian Luciobarbus subquincunciatus (CR) also grows to a considerable size, but does not inhabit reservoirs and is now almost extinct with accidental harvesting being a potential cause. In the Caspian basin, overexploitation is still a massive problem for all sturgeons and also for large cyprinids such as Luciobarbus brachycephalus (VU), a migratory species that is also found in the Aral Sea basin. This large barbel has lost access to almost all its spawning grounds in the Caspian basin and as the species is not ranched, it is now close to extirpation in the Caspian basin, where it seems to be restricted to one landlocked population in the Kura in Azerbaijan.

The effects of alien invasive species are often difficult to quantify as scientific data are lacking. The East Asian cyprinid Hemiculter leucisculus is an invasive species impacting the Eastern Mediterranean region. Photo $\odot$ Jörg Freyhof

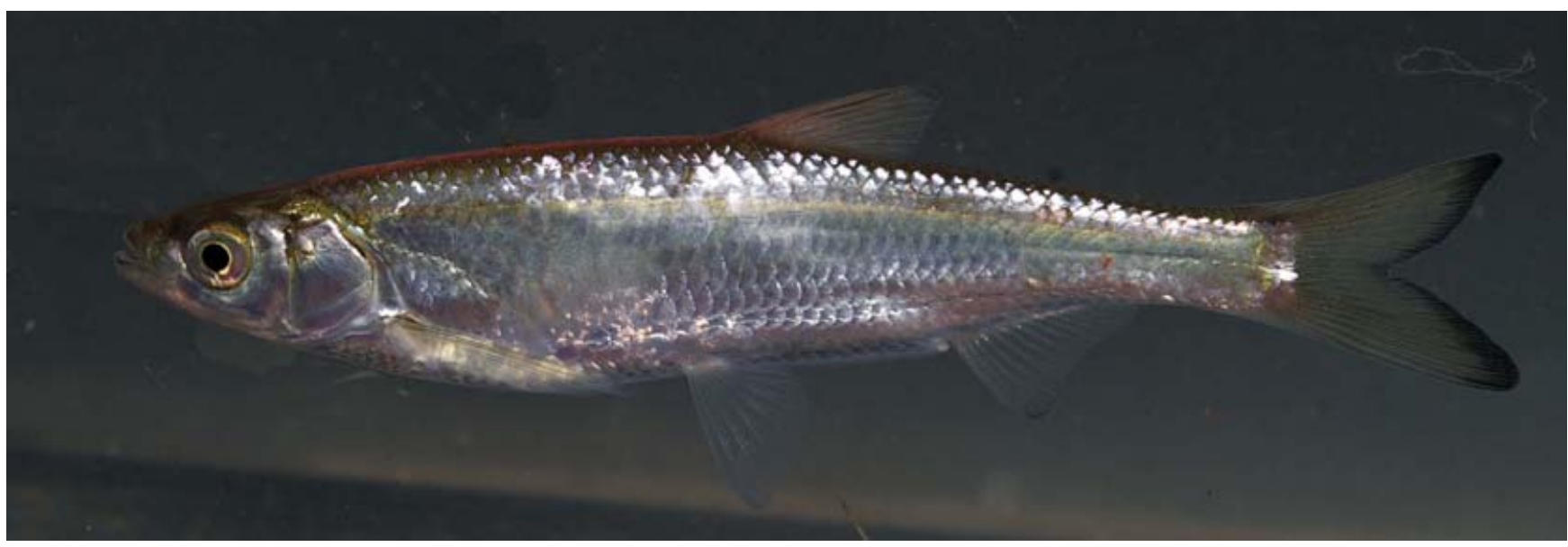




\subsection{Conservation actions and recommendations}

\subsubsection{Conservation actions in place}

There are very few in-situ conservation actions in place for the Eastern Mediterranean freshwater fish species assessed as threatened. The most significant are the re-introductions of the once Extinct in the Wild Acanthobrama telavivensis in Israel (now VU), and targeted conservation projects for Aphanius sirhani (CR) in Jordan run by the RSCN, and for Aphanius transgrediens (CR) in Turkey run by the Hacettepe University. Acanthobrama telavivensis survived only in captivity since its habitat dried up in 1999. Then in 2006, following stream restoration supported by changes in water policies in Israel, the species was reintroduced back into the wild where it now survives in self-sustaining populations (Goren 2014). Aphanius sirhani is endemic to the Azraq wetlands in Jordan which almost completely dried out in 1992. The species was taken from the wild and bred in captivity, and released back into the wetlands after partial restoration in 2000. The population is now stable, however the long term viability of the wetlands is wholly dependent on artificial water pumping as the wetlands natural water sources (springs) have dried up due to water extraction (Freyhof and Harrison 2014). Many other highly threatened species identified by this assessment would make good flagship species for habitat conservation as was seen in both these cases.

In Turkey, the Caucasus, and Iraq, there are many projects to breed and ranch commercially important fish species such as sturgeons, salmonids, and several cyprinids for fisheries purposes. For example, Iraq has a long tradition of producing large amounts of commercially important fishes such as Luciobarbus esocinus, L. xanthopterus, Mesopotamichthys sharpeyi, and Barbus grypus (now Arabibarbus) (all VU). Breeding facilities for salmonids are also widespread, again usually for commercial purposes, but rarely do these fish farms produce native fishes for stocking for conservation. However, ranching of fishes is no alternative to habitat conservation and restoration and should only be seen as a temporary solution. The ultimate goal must be to have self-sustaining wild fish populations that are independent from restocking. In large parts of Europe, ranching of salmonids has been successful to keep commercially high salmonid stocks in largely unsuitable habitats. Rehabilitation programmes for fishes, including salmonids, need to improve the habitats and other requirements of fishes and not just increase the number of fishes for anglers. While legal protection for freshwater fishes themselves is in place in most countries in the region, it does not help to protect freshwater fish habitats from the threats described above. Catch size limits are in place for commercially valuable species, which may address (if enforced) overfishing especially of large barbs in Mesopotamia. It is illegal to catch salmonids in some areas, and sturgeons are protected across the region, however, especially for the sturgeons, illegal fishing is still a considerable problem at least in the Caucasus. Except for salmonids and sturgeons, there are only two (known

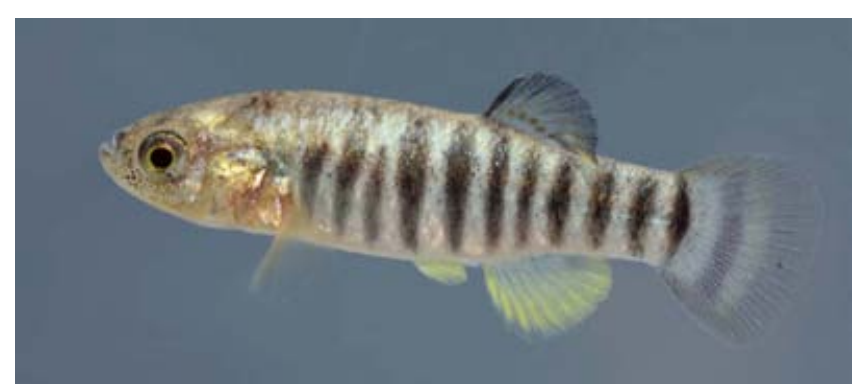

Fish first. The Azraq wetland in Jordan is the only known location for the killifish Aphanius sirhani (CR). The wetlands, which almost dried out completely in 1992 are now partially restored and have managed to save the killifish from extinction. Photo $\subset$ Jörg Freyhof

to the authors) coordinated ex-situ conservation breeding programmes in the countries of the Eastern Mediterranean region, Acanthobrama telavivensis and Aphanius sirhani (see above). Ex-situ conservation is usually only undertaken as the very last option to save a species at the very brink of extinction. In Turkey, there is a new and dedicated plan to conserve 100 selected species including 10 freshwater fishes, including Pseudophoxinus elizavetae, Aphanius transgrediens, Alburnus nasreddini, A. timarensis, and Capoeta pestai for priority conservation actions. Another project in Turkey will start in 2015 to breed Barbus (now Arabibarbus) grypus, Luciobarbus esocinus, L. subquincunciatus, Pseudophoxinus anatolicus, and Salmo coruhensis to balance over-exploitation. Also, it should be mentioned, that Turkey has adopted the EU Water Framework Directive and hopefully new data on freshwater fishes and water quality will soon become available, which will lead to a better understanding of the threats to fishes and also raise awareness for the often critical situation of their habitats.

\subsubsection{Recommendations}

This IUCN Red List assessment reveals how many gaps remain in the understanding of the freshwater fish fauna in the Eastern Mediterranean region. There are many endemic freshwater fish species in the area and most are still very poorly known highlighting the urgent need for more research. But more importantly there are only very few significant efforts to conserve this highly diverse and threatened group. While there are large-scale conservation efforts for some enigmatic, but widespread and non-threatened terrestrial vertebrates, freshwater fishes as a major component of the highly endemic fauna are mostly ignored in conservation plans and regulations in most countries. Many species assessed as threatened by this study are legally protected by national laws, however these laws are usually not implemented or enforced when it comes to habitat destruction, water extraction, or the construction of dams. The authors are not aware of any cases where threatened fishes have stopped a planned dam construction, or their needs for water have been considered when water is extracted from streams and springs. Water policies generally consider biodiversity needs but these have rarely been enforced. There is an urgent need to raise awareness for freshwater biodiversity 
conservation, especially for all the threatened species identified by this study. Significant efforts are needed to be undertaken in freshwater fish conservation and the targets cannot be achieved by breeding and stocking a few commercially important species or by size-regulations for anglers and fishermen. All countries in the study area have signed the Convention on Biological Diversity (CBD) which includes commitments (Aichi Targets) on improving the conservation status of threatened species, and production of national biodiversity strategies and action plans (NBSAPs). On the evidence found through this assessment major steps are needed if the region is to come close to achieving Aichi Target 12 which states 'By 2020 the extinction of known threatened species has been prevented and their conservation status, particularly of those most in decline, has been improved and sustained'...If we fail, more extinct species will undoubtedly be listed in future assessments.

\subsubsection{Field research and taxonomic studies}

Field surveying is essential in order to provide up-to-date knowledge on the overall distribution of species and their threats. We strongly recommend that fieldwork for national and collaborative international scientists, and projects that can help build regional scientific capacity are given more support from an administrative point of view (e.g. permits for research), and also that funding and resources are made available by national and international agencies. Incomplete knowledge of biodiversity due to taxonomic uncertainty remains a significant stumbling block for conservation planning. The taxonomy of several freshwater fish species needs to be resolved by applying an integrated molecular and morphological approach by welltrained taxonomists, which do not exist in all countries in the region. The large scale molecular study recently published by Geiger et al. (2014), considering almost all freshwater fishes of the Mediterranean Biodiversity Hotspot, is a major step forward in this field. Furthermore, targeted and publicly open national scientific collections should be set up to allow scientists to store their materials in a good order while allowing for the scientific intellectual property to remain within countries.

\subsubsection{Public data availability}

It is strongly recommended to bring together all site scale records as well as all monitoring time series of all Eastern Mediterranean region freshwater fish species in an open access online database like the Global Biodiversity Information Facility (GBIF), to make them available for analysis and all conservation activities and planning. We also encourage that data and metadata should be published in open access data journals. Positive steps have been taken, for example recently in Turkey the Ministry of Forestry and Water Affairs has established the National Water Information System which will include all monitoring data including biological data and will be freely available.

\subsubsection{Field guides}

The freshwater fish biodiversity of the Eastern Mediterranean region is poorly documented and much information is out-dated. As an addition to further ecological and taxonomic research, the publication of an (online and freely available) field guide of the freshwater fishes would be highly beneficial for scientists in the region. It would need to include pictures of fishes and sites, information about the distribution, ecology, identification characters, and threats. The online guide should be directly linked to GBIF, to have up-to-date distribution data, and the IUCN Red List to provide the conservation context. Furthermore, a citizen scientists recording system for freshwater fishes based on smartphone technologies would be useful, allowing local scientists and citizens to add their own data.

\subsubsection{Key Biodiversity Areas}

Building on the assessment information published in this report, and on the IUCN Red List the freshwater Key Biodiversity Areas (KBAs) of the Eastern Mediterranean region have been identified and validated through regional stakeholder workshops. The results of this work will be published in a separate report, Freshwater Key Biodiversity Areas in the Mediterranean Basin Hotspot (Darwall et al. 2014).

\subsubsection{Monitoring and ex-situ conservation}

We are not aware of a comprehensive freshwater fish monitoring programme within any of the countries in the Eastern Mediterranean. There are some more limited efforts, for example in Jordan, where Aphanius sirhani has been monitored at Azraq since 2000 and also fishes in the Mujib, and Southern Ghore are monitored. In Israel there is monitoring at a number of localities, and in Turkey and Iraq, fisheries data are collected. Critical sites for freshwater fish such as KBAs (and especially Alliance for Zero Extinction (AZE) sites) are a priority, and need to be monitored following standardized protocols. Such sites should be regularly visited to assess the population status of freshwater fishes and to collect long-term population and habitat quality trend data. Some considerable efforts are urgently needed, as a number of species are on the brink of becoming extinct and may not get the opportunity of last minute in-situ or even ex-situ conservation measures. We strongly recommend that fish breeding facilities, regional zoos, and aquaria engage with conservation biologists and assist in these often relatively expensive ex-situ actions. While there are capacities for exsitu conservation in several European and regional zoos, such facilities have yet to be established in Turkey as national laws hinder international cooperation.

A geographically distributed fish-monitoring network should be established engaging local experts to gather monitoring data and be able to react in the last moment before species go extinct. It is important to note that great care must be given to maintain genetic diversity in the captive brood stocks to avoid genetic bottlenecks in captive populations. Therefore, it is favourable to closely monitor the wild populations that are in immediate danger of extinction, and only when monitoring shows a fatal population decline, actions for ex-situ conservation should be taken. We recommend that these species are in urgent need of a monitoring programme, and some may possibly already require ex-situ conservation actions: Acanthobrama tricolor, 
Alburnus nasreddini, Aphanius danfordii, Aphanius fontinalis, Aphanius meridionalis, Aphanius richardsoni, Aphanius saldae, Aphanius sirbani, Aphanius transgrediens, Carasobarbus kosswigi, Chondrostoma fahirae, Chondrostoma holmwoodii, Chondrostoma kinzelbachi, Garra festai, Garra kemali, Garra widdowsoni, Gobio hettitorum, Gobio insuyanus, Luciobarbus subquincunciatus, Oxynoemacheilus galilaeus, Oxynoemacheilus panthera, Oxynoemacheilus phoxinoides, Oxynoemacheilus tigris, Pseudophoxinus alii, Pseudophoxinus anatolicus, Pseudophoxinus burduricus, Pseudophoxinus drusensis, Pseudophoxinus elizavetae, Pseudophoxinusevliyae, Pseudophoxinusfahrettini, Pseudophoxinus firati, Pseudophoxinus hasani, Pseudophoxinus hittitorum, Pseudophoxinus meandri, Pseudophoxinus maeandricus, Pseudophoxinus ninae, Pseudophoxinus syriacus, Pseudophoxinus atropatenus, and the undescribed species from Sultan marshes (Seminemacheilus sp., Oxynoemacheilus sp., and Cobitis sp.).

\subsubsection{Training and dissemination}

Often the relevant information is not provided in the right format or language to those who could potentially undertake monitoring or conservation actions on the ground. In the context ofbiodiversity conservation there is an urgent need to train specialists from the region in 'secondary' taxonomy. We need scientists able to train others (including researchers from other disciplines) in species identification, and to write local identification tools including their translation into local languages. Local awareness-raising, and conservation projects are also recommended, especially at key sites that contain small narrow endemic species such as in the Central Anatolian lakes and springs.

\subsection{Case study: The marshes of Mesopotamia}

Near the city of Basra in Iraq, the Euphrates and the Tigris form one of the most important natural and cultural sites on the planet - the marshes of Mesopotamia, known as the cradle of civilization. Until the early 1990s, these marshes were mostly intact. Each spring, the two rivers flooded and inundated an area the size of Belgium. However, dams upstream on the Euphrates in Turkey and Syria were built, significantly reducing the flow of water into the marshes. Then after the first Gulf War Saddam Hussein ordered the marshes to be drained as revenge for the Marsh Arabs' opposition to him, turning most of the remaining wetland area into desert. After Saddam's capture in 2003, local people destroyed dykes allowing the water to flow back into the areas once flooded. Today the reeds are growing again, wildlife is returning and more Marsh Arabs are returning, rebuilding their huts, raising cattle, and resuming their traditional way of life. It is estimated that $30-40 \%$ of the original wetlands have been restored, and further restoration projects are planned (Yeo 2013). In addition in 2013, Iraq's first national park was designated here covering $1,000 \mathrm{~km}^{2}$. Today this restored ecosystem and its future depends entirely upon water from the Tigris river. However, upstream dam projects in Turkey, Iraq, and Iran are planned which will hold back water in the Tigris river system especially in springtime, reducing the flow of water once again into the marshes and threatening its future.

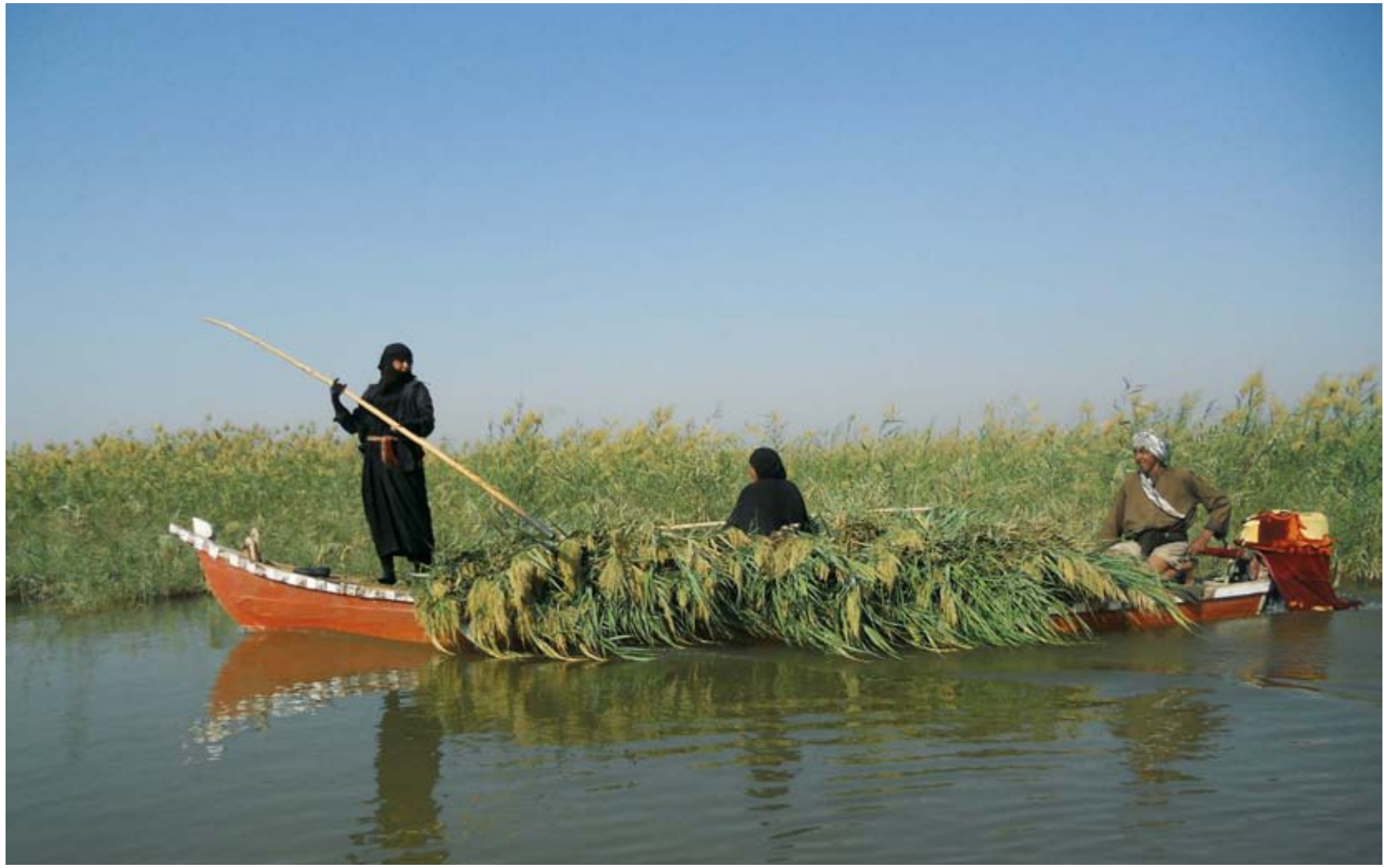




\subsection{Acknowledgements}

Special thanks are due to all colleagues, who assisted in compiling and reviewing the information on which the assessments are based. We are pleased to thank for this support: Erhan Ünlü, from Dicle University, Nina Bogutskaya, St Petersburg, Boris Levin, Borok, Michel Bariche and Nisreen Alvan from American University of Beirut, Davut Turan from Rize University, Hasan Musa Sarı from Ege University, Mustafa Sarı from Van Yil University, M. Altuğ Atalay from Directorate of Fisheries and Aquaculture, Menachem Goren from Tel Aviv, and Falah M. Mutlak from Basrah. Furthermore we thank H. Esterbauer (Vienna) for unpublished information.

This work (freshwater fish Red List assessments) was co-funded by the 'Biodiversity of Freshwater Ecosystems: Trends, Pressures and Conservation Priorities (BioFresh)' FP7 project funded by the European Union (Contract No. 226874). The views expressed herein can in no way be taken to reflect the official opinion of the European Union.

\subsection{References}

Abdoli, A. 2000. The Inland Water Fishes of Iran. Iranian Museum of Nature and Wildlife, Tehran, Iran [In Farsi].

Abell, R., Thieme, M., Revenga, C., Bryer, M., Kottelat, M., Bogutskaya, N., Coad, B., Mandrak, N., Contreras-Balderas, S., Bussing, W., Stiassny, M.L.J., Skelton, P., Allen, G.R., Unmack, P., Naseka, A., Ng, R., Sindorf, N., Robertson, J., Armijo, E., Higgins, J., Heibel, T.J., Wikramanayake, E., Olson, D., Lopez, H.L., Reis, R.E.D., Lundberg, J.G., Sabaj Perez, M.H. and Petry, P. 2008. Freshwater ecoregions of the world: A new map of biogeographic units for freshwater biodiversity conservation. BioScience 58:403-414.

Akbulut, B., Zengin, M., Çiftçi, Y., Ustaoğlu Tiril, S., Memis, D., Alkan, A., Çakmak, E., Kurtoğlu, İ.Z., Aydin, İ., Üstündağ, E., Eroğlu, O. and Serdar, S. 2011. Stimulating sturgeon conservation and rehabilitation measures in Turkey: an overview on major projects (2006-2009). Journal of Applied Ichthyology 27:415-419.

Allan, J.A. 2001. The Middle East Water Question: Hydropolitics and the Global Economy. I. B. Tauris, London, UK.

AQUASTAT. 2009. Asi-Orontes Basin. Aquastat. Food and Agricultural Organisation. http://www.fao.org/nr/water/aquastat/basins/asiorontes/index.stm

CEPF. 2010. Mediterranean Basin Biodiversity Hotspot: Ecosystem Profile. Critical Ecosystem Partnership Fund. http://www.cepf.net/ Documents/Mediterranean_EP_FINAL.pdf

Chenoweth J., Hadjinicolaou, P., Bruggeman, A., Lelieveld, J., Levin, Z., Lange, M.A., Xoplaki, E. and Hadjikakou, M. 2011. Impact of climate change on the water resources of the eastern Mediterranean and Middle East region: Modeled 21st century changes and implications. Water Resources Research 47, W06506, doi :10.1029/2010WR010269

Coad, B.W. 2010. Freshwater Fishes of Iraq. Pensoft Publishers, SofiaMoscow.

Darwall W., Carrizo S., Numa C., Barrios V., Freyhof J. and Smith K. 2014. Freshwater Key Biodiversity Areas in the Mediterranean Basin Hotspot. Informing species conservation and development planning in freshwater ecosystems. IUCN, Cambridge, UK and Malaga, Spain.

Darwall, W.R.T., Smith, K.G., Allen, D.J., Holland, R., Harrison, I. and Brooks, E. (eds). 2011. The diversity of life in African freshwaters: under water, under threat. An analysis of the status and distribution of freshwater species throughout mainland Africa. IUCN, Gland, Switzerland and Cambridge, UK.

Ekmekçi F.G., Kırankaya, Ş.G, Gençoğlu, L. and Yoğurtçuoğlu, B. 2013. Türkiye İçsularındaki İstilacı Balıkların Güncel Durumu ve İstilanın Etkilerinin Değerlendirilmesi. Present Status Of invasive fishes in inland waters of Turkey and assessment of the effects of invasion. Journal Of Fisheries and Aquatic Sciences 28:105-140.

Freyhof, J. and Brooks, E. 2011. European Red List of Freshwater Fishes. Publications Office of the European Union, Luxembourg.

Freyhof, J., Hamidan, N.A., Feulner, G.R., Tognelli, M. and Harrison, I. In prep. The Status and Distribution of Freshwater Fishes of the Arabian Peninsula.

Freyhof, J. and Harrison, I.J. 2014. Aphanius sirhani. The IUCN Red List of Threatened Species. Version 2014.2. www.iucnredlist.org. Downloaded on 27 October 2014.

Garcia, N., Cuttelod, A. and Abdul Malak, D. 2010. The status and distribution of freshwater biodiversity in northern Africa. Gland, Switzerland, Cambridge, UK, and Malaga, Spain: IUCN.

GegenStrömung. 2011. Dam construction in Turkey and its impact on economic, cultural and social rights: Parallel report in response to the Initial Report by the Republic of Turkey on the Implementation of the International Covenant On Economic, Social and Cultural Rights. Submission to the UN Committee on Economic, Social and Cultural Rights for its 46th Session, 2-20 May 2011. http://www2.ohchr.org/ english/bodies/cescr/docs/ngos/JointReport_Turkey46.pdf

Geiger, M.F., Herder, F. Monaghan, M.T. Almada, V., Barbieri, R. Bariche, M. Berrebi, P. Bohlen, J. Casal-Lopez, M., Delmastro, G.B., Denys, G.P.J., Dettai, A., Doadrio, I., Kalogianni, E., Kaerst, H., Kottelat, M., Kovacic, M., Laporte, M., Lorenzoni, M., Marcic, Z., Özulug, M., Perdices, A., Perea, S., Persat, H., Porcelotti, S., Puzzi, C., Robalo, J., Sanda, R., Schneider, M., Slechtova, V., Stoumboudi, M., Walter, S. and Freyhof, J. 2014. Spatial heterogeneity in the Mediterranean Biodiversity Hotspot affects barcoding accuracy of its freshwater fishes. Molecular Ecology Resources, DOI: 10.1111/1755-0998.12257.

Goren, M. 2014. Acanthobrama telavivensis. The IUCN Red List of Threatened Species. Version 2014.2. www.iucnredlist.org. Downloaded on 27 October 2014 .

Holčík, J. 1989. (ed.) The freshwater fishes of Europe. Vol. 1, Part II. General introduction to fishes - Acipenseriformes. Aula, Wiesbaden, Germany.

Holland, R., Darwall, W. and Smith, K. 2012. Conservation priorities for freshwater biodiversity: the Key Biodiversity Area approach refined and tested for continental Africa. Biological Conservation 148:167-179.

Hrbek, T., Stölting, K.N., Bardakçı, F., Küçük, F., Wildekamp, R.H., and Meyer, A. 2004. Plate tectonics and biogeographical patterns of the Pseudophoxinus (Pisces: Cypriniformes) species complex of central Anatolia, Turkey. Molecular Phylogenetics and Evolution 32:297-308.

Hussain, N.A., Rasen, A.K., Al-Kafiji, B.Y. and Coad, B.W. 2012. Occurrence of bull shark Carcharhinus leucas (Valenciennes, 1839) at the inland waters of southern Iraq. Journal of University of Dubok 15(1):140-143.

International Rivers. 2014. Turkey. http://www.internationalrivers.org/ campaigns/turkey. Accessed 13 October 2014

Iraqi Ministry of Environment and Nature Iraq. In prep. Inventory of Key Biodiversity Areas of Iraq. Iraqi Ministry of Environment \& Nature Iraq, Baghdad, Iraq.

IUCN. 2012. IUCN Red List Categories and Criteria: Version 3.1. Second edition. IUCN, Gland, Switzerland and Cambridge, UK.

IUCN. 2014. IUCN Red List of Threatened Species 2014.2. www. iucnredlist.org

Kottelat, M. and Freyhof, J. 2007. Handbook of European freshwater fishes. Kottelat, Cornol and Freyhof, Berlin, Germany.

Krupp, F. 1985. Systematik und Zoogeographie der Süsswasserfische des levantinischen Grabenbruchsystems und der Ostküste des Mittelmeers. Dissertation, Johannes Gutenberg Universität, Mainz, Germany.

Küçük, F., Turan, D., Şahin, C. and Gülle, I. 2009. Capoeta mauricii n. sp., a 
new species of cyprinid fish from Lake Beyşehir, Turkey (Osteichthyes: Cyprinidae). Zoology in the Middle East 47:71-82.

Küçük F., Atalay, M.A., Güçlü S.S. and Gülle, İ. 2012. The Morphological Characteristics of Pseudophoxinus (Teleostei: Cyprinidae) Species Distributed in Turkey and Zoogeographic Distribution. Süleyman Demirel Üniversitesi Eğirdir Su Ürünleri Fakültesi Dergisi 8:1-9. [Date of Publication: December 2013].

Küçük, F., Gülle, İ., Güçlü, S.S., Çiftçi, Y. and Erdoğan, Ö. 2013. A new Pseudophoxinus (Teleostei, Cyprinidae) species from Southwestern Anatolia, with remarks on the distribution of the genus in Western Anatolia. Zookeys 320:29-41.

Lehner, B. and Grill, G. 2013. Global river hydrography and network routing: baseline data and new approaches to study the world's large river systems. Hydrological Processes 27:2171-2186.

Levin, B.A., Freyhof, J., Lajbner, Z., Perea, S., Abdoli, A., Gaffaroglu, M., Özuluğ, M. Roubenyan, H.R. and Salnikov, V.B. 2012. Phylogenetic relationships of the algae scraping cyprinid genus Capoeta (Teleostei: Cyprinidae). Molecular Phylogenetics and Evolution 62:542-549.

Mohamed, A.R.M, Hussein, S.A. and Lazem, L.F. 2013. Spatiotemporal variability of fish assemblage in the Shatt Al-Arab River, Iraq. Basrah Journal of Agricultural Sciences 26:34-95.

Myers, N., Mittermeier, R.A., Mittermeier, C.G., da Fonseca, G.A.B. and Kent, J. 2000. Biodiversity Hotspots for conservation priorities. Nature 403:853-858.

Ozelkan, E., Avcı Uca D.Z. and Karaman, M. 2011. Investigation on draining of the Lake Amik and the related environmental changes, by using remote sensing technology. L. Halounová (ed.), Proceedings of the 31st EARSeL Symposium and 35th General Assembly 2011: 20-29.

Perea, S., Bohme, M., Zupancic, P., Freyhof, J., Sanda, R., Özuluğ, M., Abdoli, A. and Doadrio, I. 2010. Phylogenetic relationships and biogeographical patterns in Circum-Mediterranean Subfamily Leuciscinae (Teleostei, Cyprinidae) inferred from both mitochondrial and nuclear data. BMC Evolutionary Biology 10:265.

Ricketts, T.H., Dinerstein, E., Boucher, T., Brooks, T.M., Butchart, S.H.M., Hoffmann, M., Lamoreux, J.F., Morrison, J., Parr, M., Pilgrim, J.D., Rodrigues, A.S.L., Sechrest, W., Wallace, G.E., Berlin, K. Bielby, J., Burgess, N.D., Church, D.R., Cox, N., Knox, D., Loucks, C., Luck, G.W., Master, L.L., Moore, R., Naidoo, R., Ridgely, R., Schatz, G.E., Shire, G., Strand, H., Wettengel, W. and Wikramanayake, W. 2005. Pinpointing and preventing imminent extinctions. Proceedings of the National Academy of Sciences of the USA 102:18497-18501. Saleem,
F.M. and Hussain, N.A. 2013. Assessment of organic pollution levels in the northern and middle parts of Shatt Al-Arab River by applying modified organic pollution index (OPI). Basrah Journal of Agricultural Sciences 26:207-221 [in Arabic].

Shacham, G. 2003. Nature right for water: water allocation demands for water bodies and wet habitats - a policy statement document. Israel Ministry of the Environment and Israel Nature and Parks Authority [in Hebrew].

Sumer, V. and Mujuk, C. 2011. Challenges for Turkey to implement the EU Water Framework Directive. Turkey's Water Policy, 2011:43-67.

Turan, D., Kottelat, M. and Engin, S. 2009. Two new species of trouts, resident and migratory, sympatric in streams of northern Anatolia (Salmoniformes: Salmonidae). Ichthyological Exploration of Freshwaters 20:333-364.

Turan, D., Kottelat, M. and Bektaş, Y. 2011. Salmo tigridis, a new species of trout from the Tigris River, Turkey (Teleostei: Salmonidae). Zootaxa 2993:23-33.

Turan, D., Kottelat, M. and Engin, S. 2012. The trouts of the Mediterranean drainages of southern Anatolia, Turkey, with description of three new species (Teleostei: Salmonidae). Ichthyological Exploration of Freshwaters 23:219-236.

Vasil'eva, E.D. and Vasil'ev, V.P. 2012. Cobitis amphilekta sp. nova, a new species of spined loaches (Cobitidae, Cypriniformes) from the Caspian Sea basin. Journal of Ichthyology 52:200-206.

Vilizzi, L., Tarkan, A.S. and Ekmekçi, F.G. 2013. Stock characteristics and management insights for Common Carp (Cyprinus carpio) in Anatolia: A review of weight-length relationships and condition factors. Turkish Journal of Fisheries and Aquatic Sciences 13:759-775.

Voss, K.A., Famiglietti, J.S., Lo, M., de Linage, C., Rodell, M. and Swenson, S.C. 2013. Groundwater depletion in the Middle East from GRACE with implications for transboundary water management in the TigrisEuphrates-Western Iran region. Water Resources Research 49:904-914, doi:10.1002/wrcr.20078.

WWF/TNC. 2013. The Freshwater Ecoregions of the World. http://www. feow.org/

Yeo, J. 2013. Iraq's First National Park: A Story of Destruction and Restoration in the Mesopotamian Marshlands. Circle of Blue. Accessed 11/11/2014 http://www.circleofblue.org/waternews/2013/world/ iraqs-first-national-park-a-story-of-destruction-and-restoration-in-themesopotamian-marshlands/ 


\title{
Chapter 4. Freshwater molluscs
}

\author{
Mary B. Seddon', Ümit Kebapçı², Manuel Lopes-Lima³, Dirk van Damme ${ }^{4}$, and Kevin G. Smith ${ }^{5}$
}

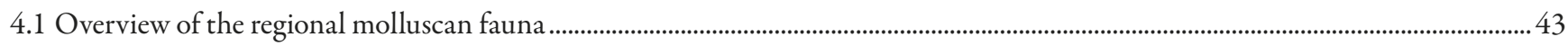

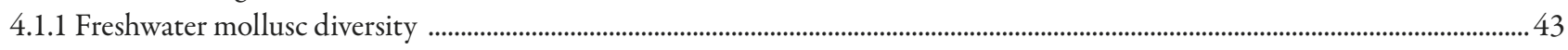

4.1.2 Geographical factors affecting the distribution of freshwater molluscs .......................................................................................... 46

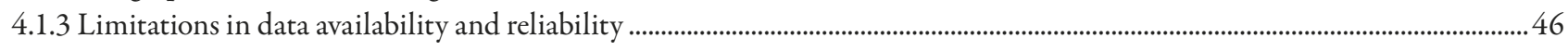

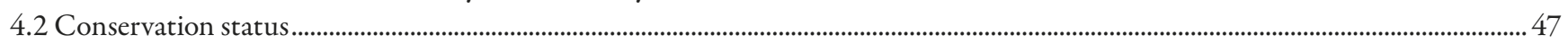

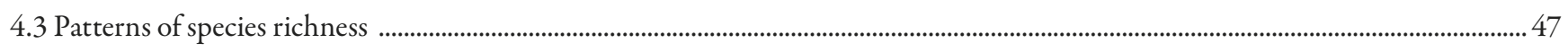

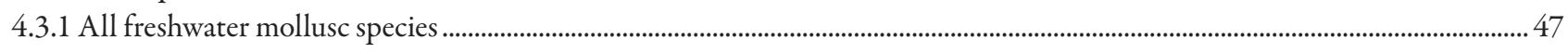

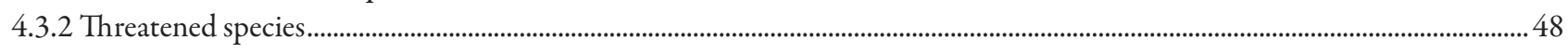

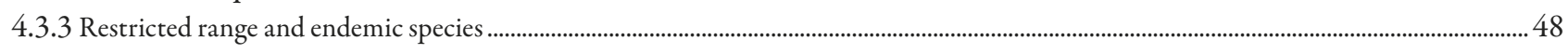

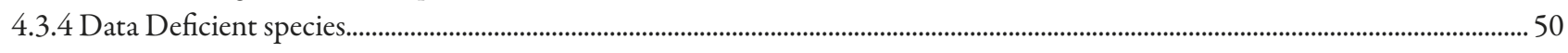

4.3.5 Possibly Extinct and locally extirpated species........................................................................................................................5

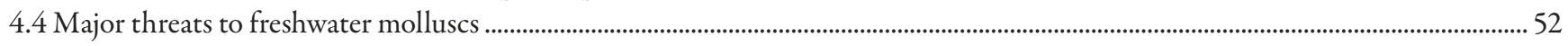

4.4.1 Water abstraction and dams (Natural system modifications) ................................................................................................... 52

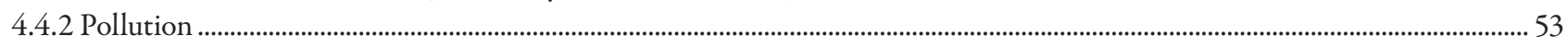

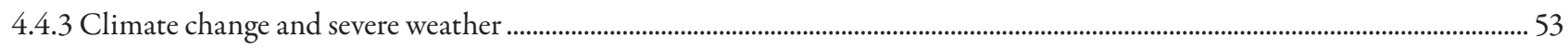

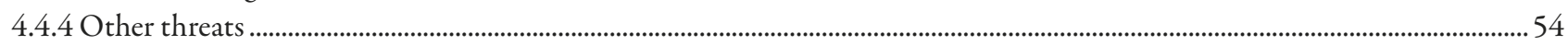

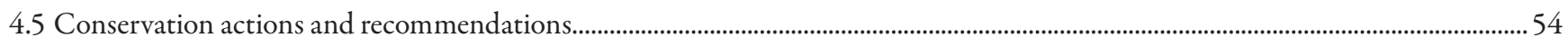

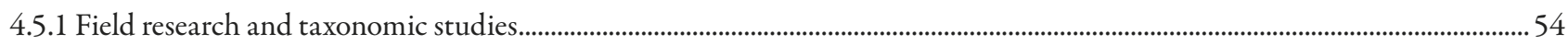

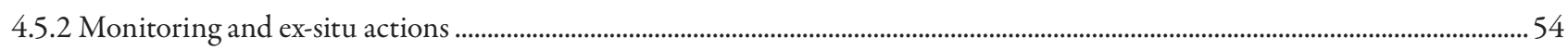

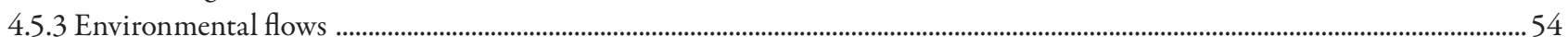

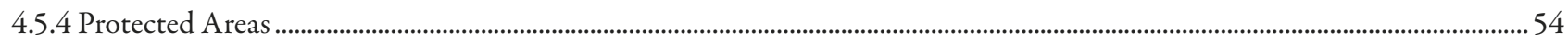

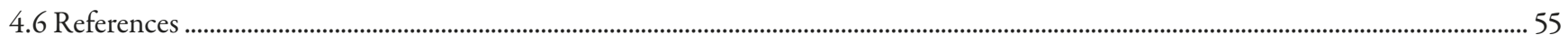

\subsection{Overview of the regional molluscan fauna}

\subsubsection{Freshwater mollusc diversity}

Freshwater molluscs fall into two main groups, the Bivalves and the Gastropods, and are found in a wide range of freshwater habitats, and have varied life-history strategies, with life-spans that vary from three months (pea-clams) to over 120 years (pearl mussels). They find their highest levels of endemism and diversity in ancient lakes, large river basins and artesian basins (Seddon 2000) and all of these habitats can be found within the Eastern Mediterranean region.
The geographic range of this study covers all of Turkey, the southern Caucasus, the Levant and Mesopotamia. It includes 14 freshwater ecoregions (Abell et al. 2008, WWF and TNC 2013): from Thrace in the West of Anatolia, east to the Kura-South Caspian ecoregion, and south to the Jordan River and Levant ecoregions in the west, and the Tigris- and Euphrates ecoregions in the east (see Chapter 1 Figure 1.2). This study completes the assessment of the circum-Mediterranean region, covering the large geographic gap between Europe, which has been assessed by Cuttelod, Seddon, and Neubert (2011), North Africa (Van Damme et al. 2010), and the Arabian Peninsula (Neubert, Zuhair, and Van Damme in prep).

Aquatic Ecology and Evolution, Interdisciplinary Centre of Marine and Environmental Research (CIIMAR/CIMAR), University of Porto, Portugal

Research Unit Paleontology, Geological Institute, Ghent University, Krijgslaan, 281, B9000, Ghent, Belgium

IUCN Global Species Programme, 219c Huntingdon Road, Cambridge, UK 
Unfortunately, much of the knowledge on the freshwater molluscan fauna of the Eastern Mediterranean is dated, with the only recent reviews for Turkey (Yildırım 1999, Yildırım et al. 2006a, 2006b, Yıldırım and Kebapçı 2009, 2012, 2012), Lebanon (Bößneck 2011) and Israel (Milstein, Mienis, and Rittner 2012). Knowledge for Syria and Jordan relies mostly on literature from the 1930s (Germain 1936, Pallary 1939). Schütt's (1983a, 1983b) and Kinzelbach's (1987, 1989) reviews of the region provide further data on the large river systems in Turkey, Syria, and Jordan. There are recent taxonomic revisions for some species groups in the Hydrobiidae, Bithyniidae (Glöer and Yıldırım 2006b), Lymnaeidae (Glöer and Yıldırım 2006a), Planorbidae (Glöer and Rahle 2009), and Acroloxidae (Shirokaya et al. 2012), revealing cryptic species lineages, and it is likely that further research will reveal more of these, especially with advances in molecular systematics.

In general the freshwater molluscs of the circum-Mediterranean are much more diverse than some continental faunas such as Africa with around 560 species (Seddon et al. 2011), and Europe with 856 species (Cuttelod, Seddon, and Neubert 2011). According to this study, 150 species of freshwater molluscs are present in the Eastern Mediterranean region, 94 of them endemic. This is a region of active malacological research, and hence this first assessment is likely to be outdated quickly, as taxonomic research and ongoing surveys in little-known areas continue (e.g. Glöer et al. 2014).

\subsubsection{Gastropods}

Within the region, the greatest diversity is seen in the freshwater gastropods with 123 species. The endemic species, of which there are 85, are found in the families Hydrobiidae, Bithyniidae, Neritidae, Melanopsidae, Cochliopidae, Assimineidae, Planorbidae, Lymnaeidae, and Acroloxidae. Within the families

There are at least 123 species of gastropods native to the Eastern Mediterranean region, found in a variety of habitats. A Melanopsis buccinoidea and six Theodoxus jordani at Banias springs in Israel. Photo $\left.{ }^{(}\right)$Anita Gould. Online image/Flickr under CC licence 2.0 by-nc

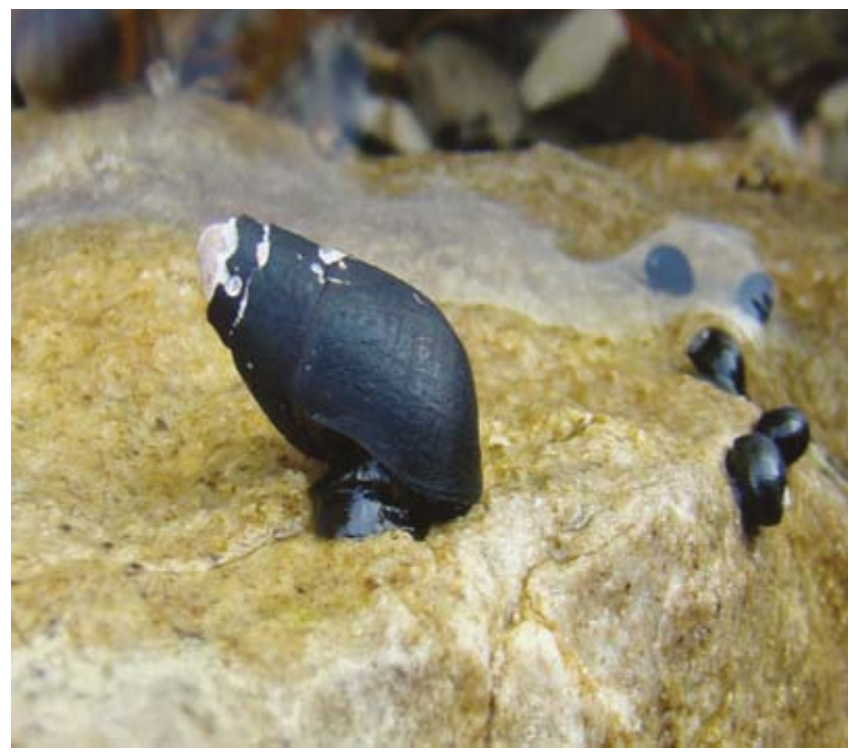

Hydrobiidae, Bithyniidae, Lymnaeidae and Planorbidae, many range restricted species have been found in the last 15 years, with new species described from Turkey, Lebanon, Jordan, Iraq, and Iran, as discussed above.

The freshwater gastropods are generally divided into two informal groups, the 'Prosobranchs' and the 'Pulmonates'. In many parts of the world, 'pulmonates' are associated with smaller water-bodies as they are tolerant of seasonal drying, whereas 'Prosobranchs' are generally more sensitive to desiccation and are usually found within permanent water bodies.

\section{Prosobranchs}

The highest levels of diversity and endemism are observed in the small 'spring-snail' species of the families Hydrobiidae and Cochliopidae, which occur throughout the region, but have the greatest diversity in Turkey.

The Hydrobiidae family is the most diverse group among freshwater molluscs and one of the major centres for diversity of this family is the Mediterranean region where an exceptionally high amount of crenobiont (found in springs) and stygobiont (subterranean) endemic species and genera occur. Within the Eastern Mediterranean region there are 48 species found in the many springs, wells, caves, and aquifers. The species from the recently recognized Bythinellidae family (included within Hydrobiidae in this assessment) are found in nutrient poor cold springs and small streams from Northern Africa to western Turkey. The Holarctic family Cochliopidae is represented in the study area by only three species, however their taxonomy is not fully resolved. There are 11 species of Bithyniidae in the region, and all are endemic. The Assimineidae is a family of mainly marine and brackish water species, represented by three species, one being endemic to the coastal Iraqi marshes. Although common in the fossil strata of the Levant, the cosmopolitan family Viviparidae is represented by two species which are found in lakes and marshes of Turkey and Southern Mesopotamia. Species of the cosmopolitan family Neritidae (10 species in the region) (Schütt and Sesen 1989, 1992) and the Mediterranean centred Melanopsidae (13 species) are mostly endemics of the study area, found in springs and lotic systems, with one species found in lakes (Theodoxus heldreichi). Diversified in the tropics, the family Thiaridae is presented with a single native and two introduced species. The holarctic ectobranch family Valvatidae can be found in many habitats. In the Levant the family is represented by only Valvata saulcyi, whilst in Turkey there are four additional species.

\section{Pulmonates}

Although relatively tolerant to harsh conditions and favouring passive dispersal, native representatives of the pulmonate families in the area have mainly Palearctic affinities and become rarer towards the south of the region. However, all existing groups in the area show cryptic speciation as demonstrated by recent studies (Glöer and Naser 2007, Yıldırım and Kebapçı, 2009, Shirokaya et al. 2012). 
Two lake-limpet species of the Holarctic family Acroloxidae are found in the region; one is relatively widespread, while the other is endemic to Turkey. These acroloxid limpets live on microalgae growing on rocks in clean lakes and springs. The cosmopolitan families Lymnaeidae (seven species) and Planorbidae (17 species) are species rich and representatives of these families are common across the area. Recent updates on the taxonomy of the genera Stagnicola (Lymnaeidae) and Gyraulus (Planorbidae) have revealed the presence of cryptic taxa, once believed to be belonging to common species. Populations of Lymnaeidae show a considerable degree of ecophenotypic shell plasticity, whilst intra- and interspecific variation is not very pronounced.

Some species of freshwater gastropods are known to be intermediate hosts for parasitic trematodes (flat worms) some of which are agents for important livestock and human diseases such as Schistosomiasis and Fascioliasis. These species are considered as dangerous pest species, and attempts are made to control their populations in order to limit the spread of the diseases. However, the molluscicides used are usually non-species specific, and often affect all molluscs.

The aquarium and garden centre trade can mediate rapid colonization of gastropod species into non-native areas, where they can cause significant impacts to native freshwater systems (Padilla and Williams 2004).

Many of the freshwater gastropods are hermaphroditic and self-fertilization occurs in some taxa. In general, gastropods prefer eutrophic habitats including ephemeral ponds and manmade habitats.

Melanoides tuberculata is the only native member of the Thiaridae family in the region, but has become an invasive species in many parts of the world. Photo $\odot$ AFPMB Online image/Flickr under CC licence 2.0 by-nc-nd

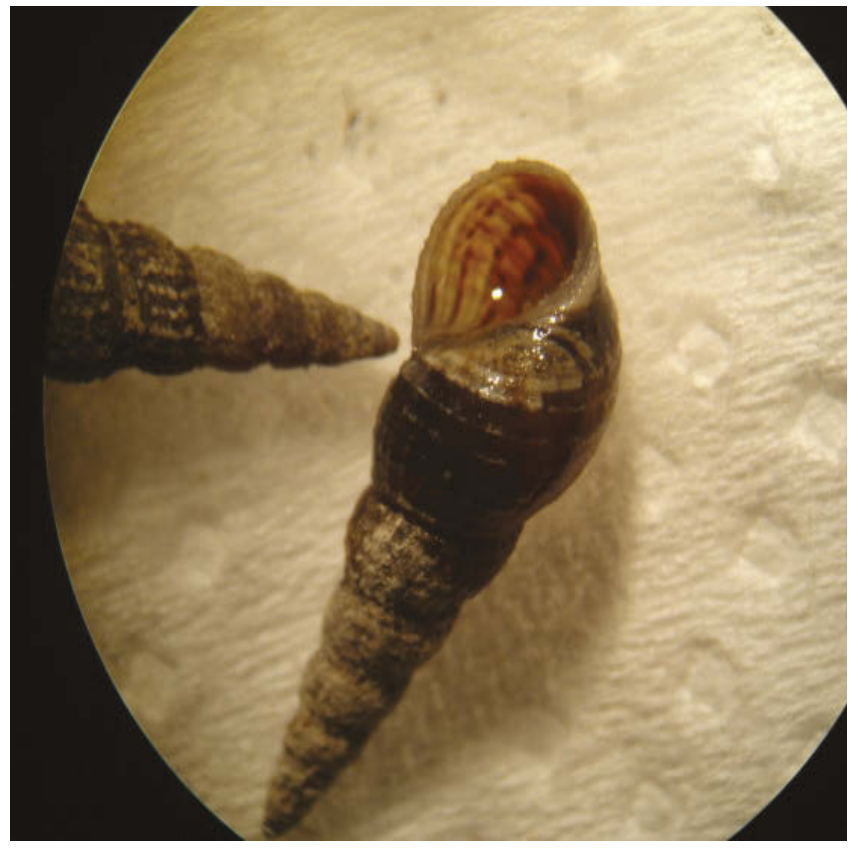

\subsubsection{Bivalves}

The freshwater bivalves are divided into two main groups, the larger freshwater mussels of the Unionoida and the smaller bivalves of the Veneroida. For the Veneroida three distinct families are present within the region, including the bysally attached Quagga and Zebra mussels (Dreissenidae) which are more common in lakes and the slower sections of large rivers, the basket clams (Cyrenidae) which include the freshwater clams of the genus Corbicula, and the minute fingernail clams (Sphaeriidae).

Most freshwater bivalves possess a common suite of adaptations to life in freshwater. These include larval brooding, and direct development, in the case of the sphaeriids and cyrenids, and, obligate larval parasitism on freshwater fishes, in the case of unionoid freshwater mussels (Wächtler et al. 2001, Cummings and Graf 2009). Despite these common characters derived from shared environmental pressures, these bivalve taxa represent different evolutionary lineages and, as a result of their disparate life histories, demonstrate a range of patterns of dispersal and abundance.

The traditional concepts of the western Palearctic bivalve genera and species are holdovers from the early 20th century which have only recently started to be re-evaluated using modern analytical methods and species concepts. This is likely to lead to the discovery of more cryptic taxa within the freshwater bivalves of the Eastern Mediterranean region than the 27 species presented here (M. Lopes-Lima pers. comm. 2014).

\section{Unionoida}

All unionoid species are strictly freshwater inhabitants, and in the Eastern Mediterranean these molluscs are often locally abundant inhabitants of both rivers and lakes.

At present the diversity of Mediterranean freshwater mussels is relatively low (with 13 species) compared to the North American and African fauna and slightly higher than the North and Central European (Bogan 2010). It lies largely in the genera Margaritifera, Unio, Anodonta, and Potomida.

The genus Margaritifera (Margaritiferidae) is widespread in the Holarctic region, where most species typically occur in oligotrophic streams and rivers. However some species are present at lower latitudes in Southeast Asia, in the southeast basins of North America, and in the Mediterranean area and have distinct habitat preferences for slow flowing lowland rivers. Within the Eastern Mediterranean region, only one species Margaritifera homsensis is present from the Margaritiferidae family.

Within the Unionidae family (12 species in the region) the genus Anodonta is a widespread Holarctic genus that, in the western Palearctic, reaches its southern limit in countries around the Mediterranean basin. The genus Unio is the more speciesrich with almost 20 species occurring in the Palearctic region 
from the Iberian Peninsula and Morocco in the west to the Transbaikal region in the east. Additional species of this genus occur in the Nile basin and in South Africa. As for Potomida, generally described as a monotypic genus, it is restricted to the Mediterranean area with a disjunct distribution in the Iberian Peninsula, northwest Africa, southern France, western Greece, southern Turkey, and the Levant, represented by distinct lineages (M. Lopes-Lima pers. comm. 2014).

\section{Veneroida}

Similarly, the Veneroida (14 species in the region) occupy a wide range of habitats, with the mussels from the Dreissenidae family present in brackish waters, freshwater lakes, and slow sections of rivers. Corbicula spp. (Cyrenidae), of which there is only $C$. fuminalis in the region (note: $C$. consobrina is treated as a synonym of $C$. Aluminalis), and is probably the dominant bivalve in the region, have a wider habitat plasticity, generally occupying the middle and lower sections of rivers and streams as well as pools, lakes, channels, reservoirs and other man-made structures, being also capable of withstanding higher levels of salinity. As for the pea or fingernail clams (Sphaeriidae), they are in general more cosmopolitan taxa, occurring in all types of aquatic environments that possess a high dispersal potential via attachment to other animals (insects, fish, amphibians, and mammals).

\subsubsection{Geographical factors affecting the distribution of freshwater molluscs}

The whole circum-Mediterranean region is geologically recent. During Late Miocene times (11.6-5.3 million years ago) the Mediterranean Sea extended over large parts of the adjacent lands, while most of eastern Europe and parts of Asiatic Russia and Turkey were covered by the Paratethys Sea, stretching out from the Rhône Basin in France to the Aral Sea and connected with the North Sea. During Mio-Pliocene times this vast but shallow sea was divided in basins that became brackish or fresh, such as the Pannonian basin system, the Euxinian lakes basin (presently the Black Sea), and the Caspian and Aral Sea basins. At the onset of the Pliocene (5.3 Ma) the Mediterranean was closed off from the Atlantic at Gibraltar and evaporated, leaving hypersaline to brackish lakes at the bottom.

For millions of years the molluscan fauna of the whole region has shown spectacular changes in composition and morphological evolution due to the existence of vast lakes with marked salinity gradients and fluctuations and the possibility of migration among these ecosystems (Werner et al. 2007, Wesselingh 2007). During Plio-Pleistocene times (c. 2.5 Ma) these large lakes and their freshwater malacofauna disappeared either due to tectonic uplift (Lake Pannon), marine invasion (Euxinian lakes) or increased salinity due to endorheism and desiccation/desertification (Caspian Sea and Aral Sea). During the Pleistocene, severe climate fluctuations created large arid areas, making many once habitable regions inhospitable for molluscs.
The modern malacological fauna of the Eastern Mediterranean region is a small relict of the Mio-Pliocene endemic one. However, the high species richness and degree of endemism in such families as the Hydrobiidae, Neritidae, Melanopsidae, and even in the Dreissenidae, and possibly in the Potamida group (Unionidae), is directly linked to the evolutionary radiation of saline tolerant freshwater taxa in the lakes that existed in former times.

An important part of the present fauna (e.g. Viviparidae, Bithyniidae, Valvatidae, Thiaridae, most pulmonate taxa, probably also Unio, Anodonta, Corbicula, and most Sphaeriidae) consist of geologically recent arrivals that either reached the region from the Palearctic through a narrow corridor west of the Euphrates (e.g. Valvata, Lymnaea, etc.) or from the east via the Tigris-Euphrates system (e.g. Bellamya, Corbicula). Taxa of the lakes in the Paratethyian region succeeded in extending their range as far east as the Euphrates (Dreissenidae) and west to Lake Tiberias/Sea of Galilee (Hydrobiidae). The Danubian fauna is represented in Lake Sapanca in northwestern Turkey (Schütt 1988).

Several Palearctic taxa presently occurring in northeastern Africa and the Lower Nile, such as the gastropods Valvata nilotica and Theodoxus niloticus, are morphologically near-identical to Levantine species and probably reached Africa from that region during Late Pleistocene-Holocene times (D. Van Damme pers. comm. 2014). Recent molecular research has equally proved a distinct relationship between Levantine Unio and the African representatives of the genus Unio (M. Lopes-Lima pers. comm. 2014). However, there is no evidence that Afrotropical elements reached the Levant (Sivan, Heller, and Van Damme 2006).

\subsubsection{Limitations in data availability and reliability}

Much of the knowledge of the freshwater molluscan fauna for the Eastern Mediterranean is dated, with recent reviews for only Turkey (Yıldırım and Kebapçı 2012), Lebanon (Bößneck 2011), and Israel (Milstein, Mienis, and Rittner 2012). Knowledge for Syria and Jordan relies on literature from the 1930s (Germain 1936, Pallary 1939). Schütt's (1965, 1983a, 1983b) and Kinzelbach's $(1987,1989)$ reviews of the region provide further data on the large river systems in Turkey, Syria, Lebanon, and Jordan. From the adjacent countries formerly of the Soviet Union, Zhadin (1952) and Kantor et al. (2010) provide lists of species and their distributions, and for Europe, Bank, von Proschwitz, and Falkner (2006) give lists for Greece. Some of the species in these lists, but not yet recorded from the Eastern Mediterranean as defined for this project, are likely to be discovered in the region in the future, as there are many areas with little survey effort. With few recent checklists to draw from, the compiling of the final species list for the region has been a difficult task and it is likely that a number of species may have been missed.

The taxonomy of most groups is either presently under revision or is in urgent need of revision. It is also likely that new species will be discovered, particularly with advances in molecular systematics, 
from the cryptic species lineages presented in recent taxonomic revisions for some species groups, namely the Bithyniidae (e.g. Glöer and Georgiev 2012), Lymnaeidae, and Planorbidae (Glöer, Falinioski, and Pesic 2010, Glöer and Georgiev 2012).

\subsection{Conservation status}

This IUCN Eastern Mediterranean project is the first study that provides a comprehensive overview of the conservation status of the region's freshwater molluscan fauna. In this project the conservation status of each species of freshwater mollusc was assessed by applying the IUCN Red List Categories and Criteria: Version 3.1 (IUCN 2012).

There are 145 species that have been identified and assessed for the Eastern Mediterranean region, however as discussed above (section 4.1.3) this will be an underestimate of true species diversity. There are an additional five species that were only recently identified to be in the region, but this was unfortunately too late to be included in this project, these are the gastropods Pseudobithynia saulyci, P. yildirimi, Pyrgorientalia zilchi, and Sadleriana minuta, and the bivalve Pisidium sogdianum. These species will be assessed by the IUCN SSC Mollusc Specialist Group for publication in the first IUCN Red List release of 2015. It is important to note that of the 145 species assessments, 14 species are classed as draft Red List assessments and still need to be independently reviewed. See Appendix 2 of the report for a full species list for the region.

Of extant species where there is sufficient information to identify an extinction risk $45.5 \%$ ( 55 species) are classed as threatened, an additional nine species (7.4\%) are considered Near Threatened, and just under half (57 species or $47.1 \%$ ) are Least Concern (Figure 4.1). There are an additional 24 species (16.6\% of all species in the region) that are assessed as Data Deficient,

Figure 4.1 Number of species of Eastern Mediterranean freshwater mollusc species in each IUCN Red List Category.

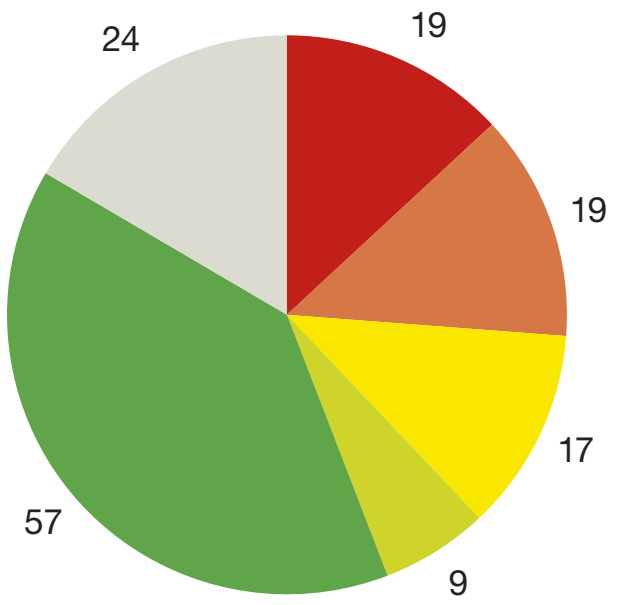

meaning there was insufficient information available to make an assessment of extinction risk, due to unresolved taxonomic problems or lack of information on current distribution. There are no species classed as Extinct or Extinct in the Wild.

Almost two thirds (94 species or 62.7\%) of the Eastern Mediterranean molluscan fauna is endemic to the region (note four of these are Not Assessed). Of the extant endemic species where there is sufficient information to identify a risk of extinction over three quarters (53 species or $76.8 \%$ ) are threatened, with $10.1 \%$ (seven species) Near Threatened, and only $13.0 \%$ (nine species) assessed as Least Concern (Figure 4.2). Of the 90 endemic species that were assessed, 21 species (23.3\%) are assessed as Data Deficient.

\subsection{Patterns of species richness}

Apparent regional variations in the distribution patterns of species and threatened species richness in part reflect regional differences in the status of taxonomic research, levels of survey work, and numbers of range restricted endemic species, which are often threatened. These factors should be taken into consideration when interpreting the species distribution maps.

\subsubsection{All freshwater mollusc species}

There is a general trend of increasing species richness towards the north and west due to the arid nature of the environment in the southern part of the region. Although representatives of the Palearctic fauna predominate across the Levant and Arabian Peninsula, there are immigrants from the Oriental fauna. The isolated position of Anatolia from the European mainland and the barrier provided by the Anatolian mountain belts may explain the general decrease in the number of species with Palearctic affinities as we move to the south of the region.

Figure 4.2 Number of species of Eastern Mediterranean endemic freshwater mollusc species in each IUCN Red List Category.

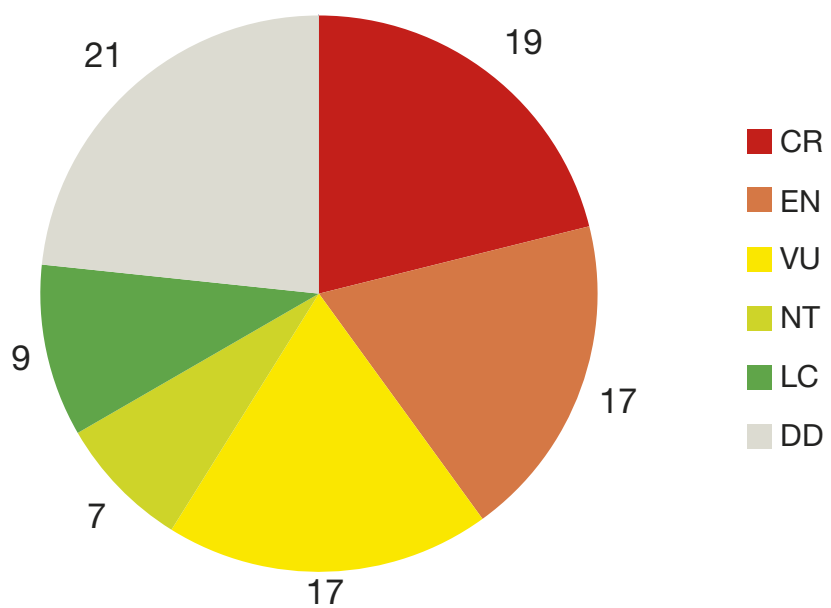


Figure 4.3 shows that the sub-basins with the highest species richness (22-26 species) are the Kırkgöz karst springs in Antalya, the lower Orontes in Turkey, and the Karasu River upstream of Amik Lake (including Gölbası Lake), and a river catchment and swamp area to the west of the Tarsus River in Turkey. Areas of high richness (17-21 species per sub-basin) are found in lower parts of rivers along the Mediterranean coast of Turkey, lakes Burdur, Eğridir, Beyş̧ehir, and Eber, the catchments of lakes Acı, Salda, Burdur, and Eğridir, and the Litani River basin including the Aammiq marshes.

\subsubsection{Threatened species}

The greatest diversity of freshwater molluscs is found in the spring snails. Apart from their tendency to be found in restricted habitats and their low dispersal abilities in general, they have a low tolerance to changes in environmental conditions which can rapidly lead to extinction. This is especially valid for restricted range species. Due to the abundance of single site species and widespread threats to freshwater habitats, threatened species are concentrated in the Lakes Region of Turkey (Figure 4.4). The sub-basins containing the highest number of threatened species are the Kırkgöz springs (seven threatened species) in Antalya, Turkey, which also contain the highest diversity of single site endemics in the region (six species), followed by Eğridir Lake in
Isparta, Turkey (five threatened species). Sub-basins containing between three and four threatened species are found in four general areas; Lakes Region of Turkey (Lake Beyşehir, and the catchments (springs) of lakes Acı, Işıklı, Burdur, and Eğridir) and the Küçük Menderes River; Gulf of Iskenderun in Turkey (in a river and marsh to the west of the Tarsus River, the lower Asi/Orontes, and the Karasu River above Amik Lake including Gölbası Lake); western Levant (Lake Homs in Syria and in the upper Asi River in Lebanon, the Nahr al Kabir on the border between Syria and Lebanon, the coastal rivers of Lebanon including the Litani, Lake Tiberias/Kinneret and its catchment, and the Zarqa River including the Rumeinin springs/waterfalls); and Ras al-Ain springs at the headwaters of the Khabour River (upper Euphrates) in northern Syria.

\subsubsection{Restricted range and endemic species}

In Anatolia, particularly along the Mediterranean coast and in Central Anatolia, some species reach the southern limit of their European range, but many locally endemic species also occur (Yıldırım and Karaşahin 2000). This high ratio of local or single catchment endemic species extends south to the Jordan basin. In contrast, most species in Mesopotamia have large distribution ranges occurring all over the Tigris-Euphrates system from Turkey south to Iraq.

Figure 4.3 Eastern Mediterranean freshwater mollusc species richness. Species richness = number of species per sub-basin (defined by HydroBASINS ‘Level 8’, Lehner and Grill 2013).

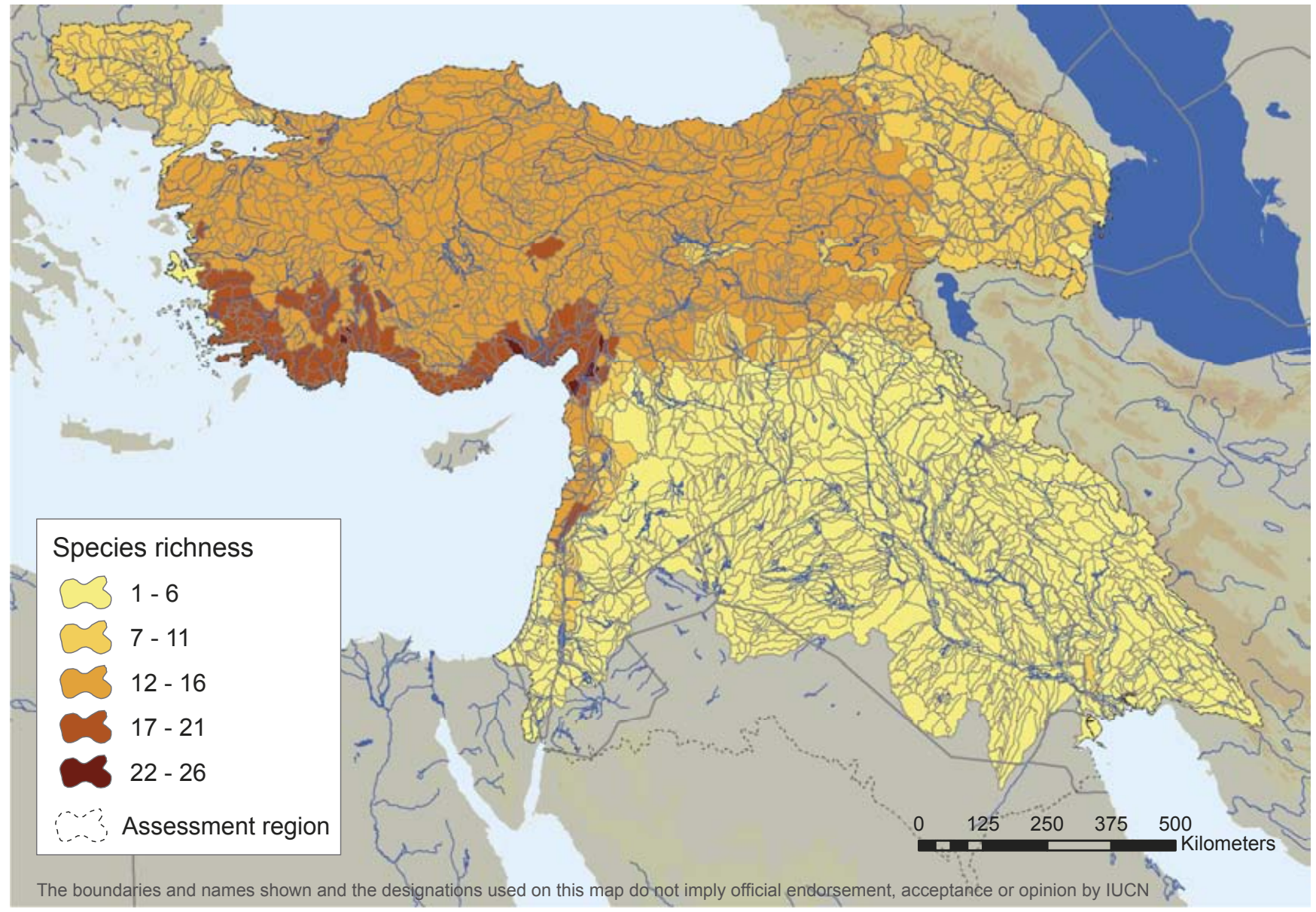




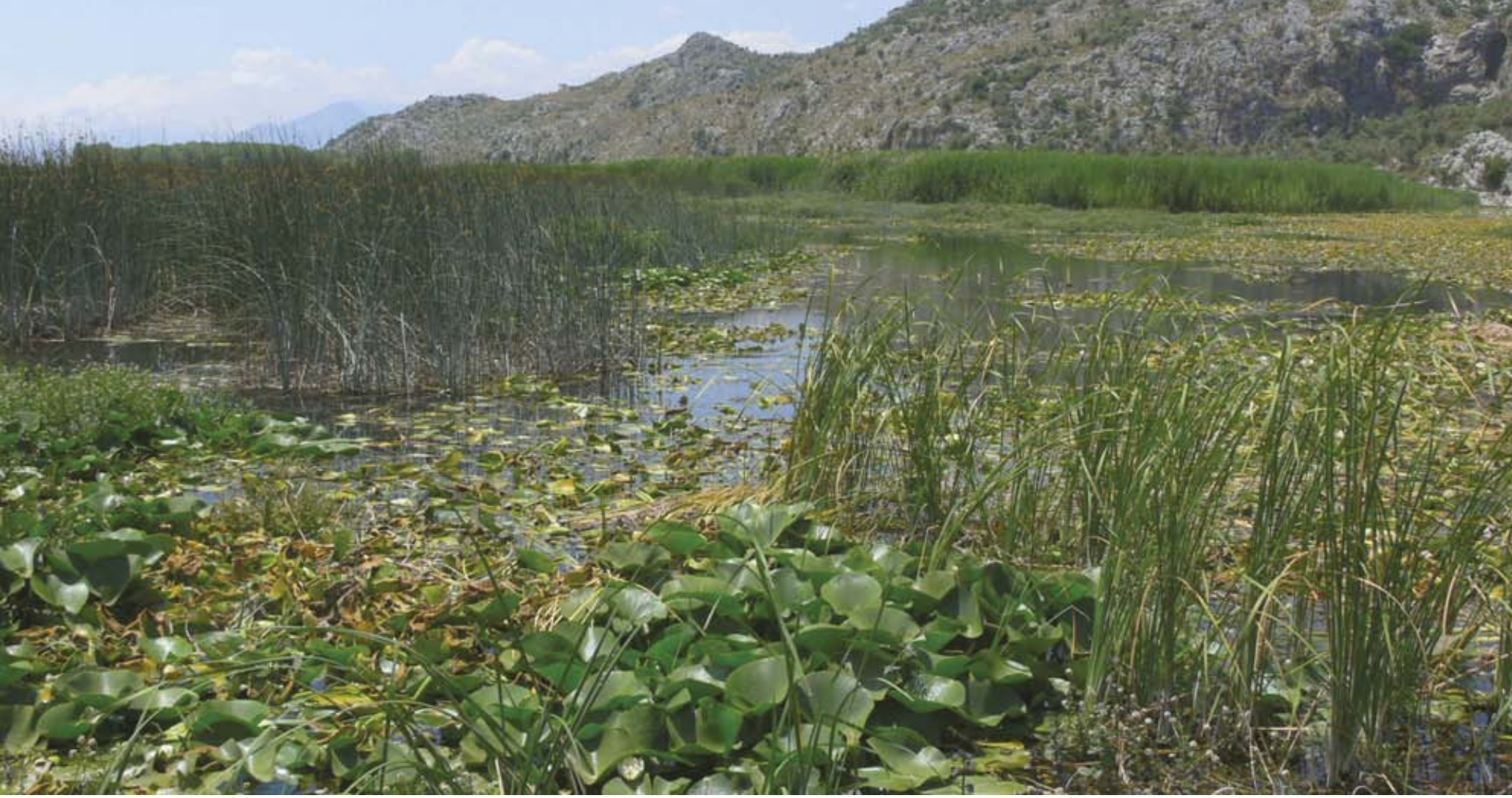

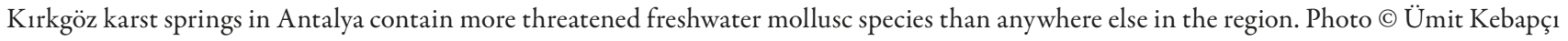

Figure 4.4 Eastern Mediterranean threatened freshwater mollusc species richness. Species richness = number of species per sub-basin (defined by HydroBASINS 'Level 8', Lehner and Grill 2013).

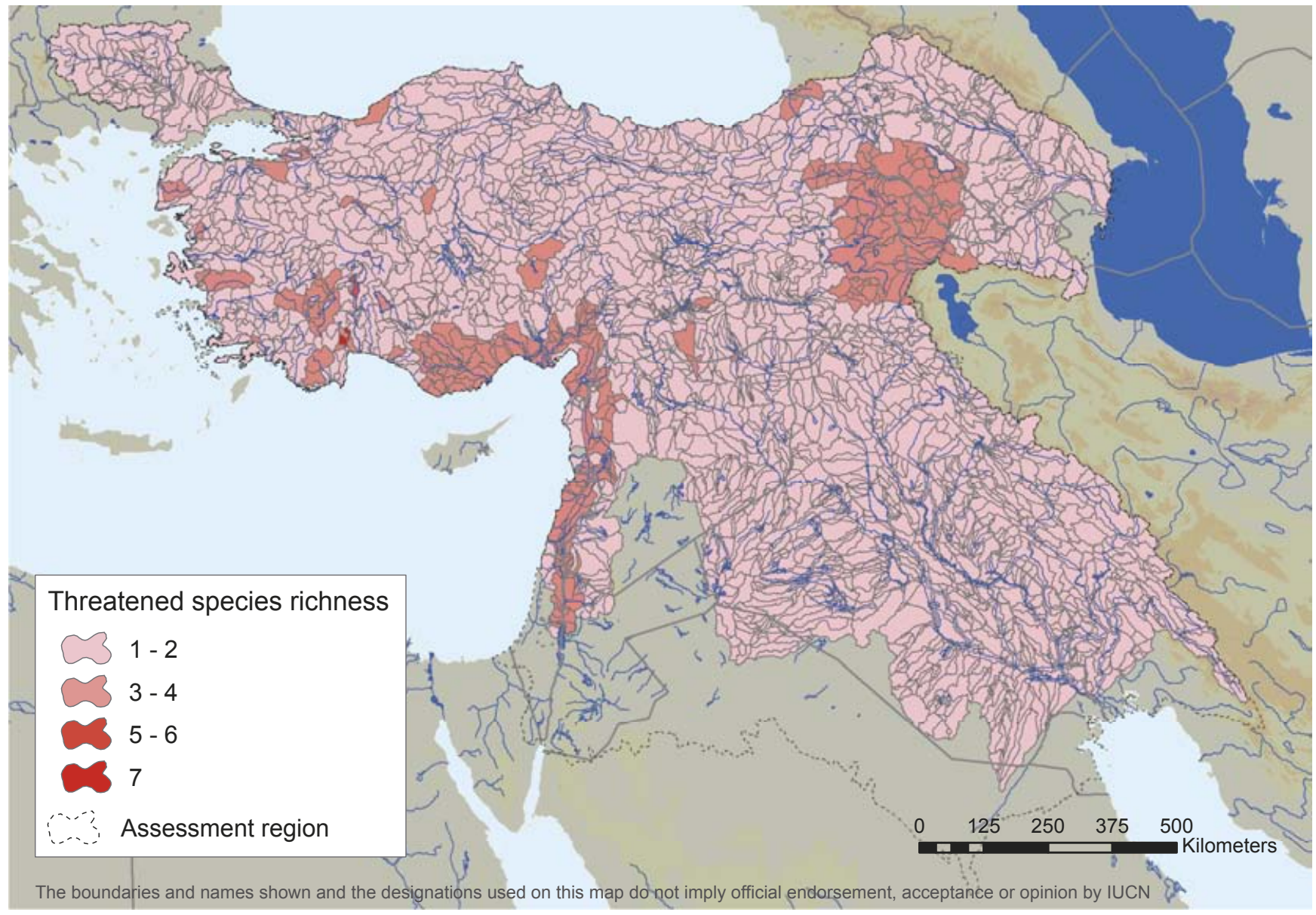




\section{River systems}

The Eastern Mediterranean contains several major river systems that have endemic species present in their catchment. The main endemism in the freshwater mussels is found in large rivers such as the Orontes, Jordan, and the Tigris-Euphrates. By contrast, most of the pea-clam species are more widespread with mainly pan-European distributions, reaching their eastern limit in the Eastern Mediterranean region. Some of the Dreissenid mussels are endemic to this region and are restricted to the large lakes and rivers in Turkey.

\section{Lakes}

The Eastern Mediterranean contains several important lake regions that have endemic species present in their catchment. These lakes vary in geological longevity and origin, and are fed by subterranean springs and intra-lacustrine springs within the lake complexes. Notable lakes in the region are Eğirdir, Beyşehir, Ac1, and Işıklı in southwestern Turkey. In northwestern Turkey, lakes Iznik and Sapanca with their catchments are important for freshwater gastropod biodiversity. The Gölbaşı lakes (in Adiyaman) are another lake system in eastern Turkey with a considerable level of freshwater mollusc endemism. Gölbaşı Lake (in Hatay, Turkey), Lake Homs (Syria), and Lake Tiberias/ Kinneret (Israel) are the other important lakes for gastropod diversity in the south.

Recent work on the taxonomy of species in the region has revealed the existence of many new cryptic species, providing a new insight into the degree of endemicity within the Turkish Lakes Region (Yıldırım and Kebapçı 2009).

\section{Springs and groundwaters}

Species with an extremely restricted range, sometimes of only a few square metres, are the Anatolian spring snails (e.g. Hydrobiids and Cochliopids) that exist in only one or two springs or wells. Although their range underground may be more extensive, they are assessed as threatened on a precautionary basis as the extent of their range in artesian aquifers is uncertain. Some species may be truly restricted to the wells whereas others, which are only found at outlets during flood events are likely to be distributed more widely in the aquifers supplying the outlets.

\subsubsection{Data Deficient species}

The two main reasons for Data Deficiency in molluscs are taxonomic uncertainty and poor geographic knowledge, making it impossible to map their distribution. There are species with little distribution data, beyond the information provided in their original descriptions, some dating back to the 19 th century. The regions with the highest proportion of Data Deficient species due to poor geographic knowledge are Syria, Jordan, and parts of Turkey and Lebanon.

In terms of taxonomic uncertainty, the high level of taxonomic confusion within the freshwater molluscs is largely a consequence of too many species being described by members of the 19th century French 'Ecole Nouvelle' and the competing German malacologists, which considered all morphologically differing populations as different species. Few recent taxonomic revisions have been made so that, for quite a number of species described between 1850 and 1920, there remains doubt as to their

Gölbaşı Lake (in Hatay, Turkey) is the remnant of the former Lake Amik on the Karasu River. Many freshwater species are now confined to this small lake. Photo (c) Manuel Lopes-Lima 


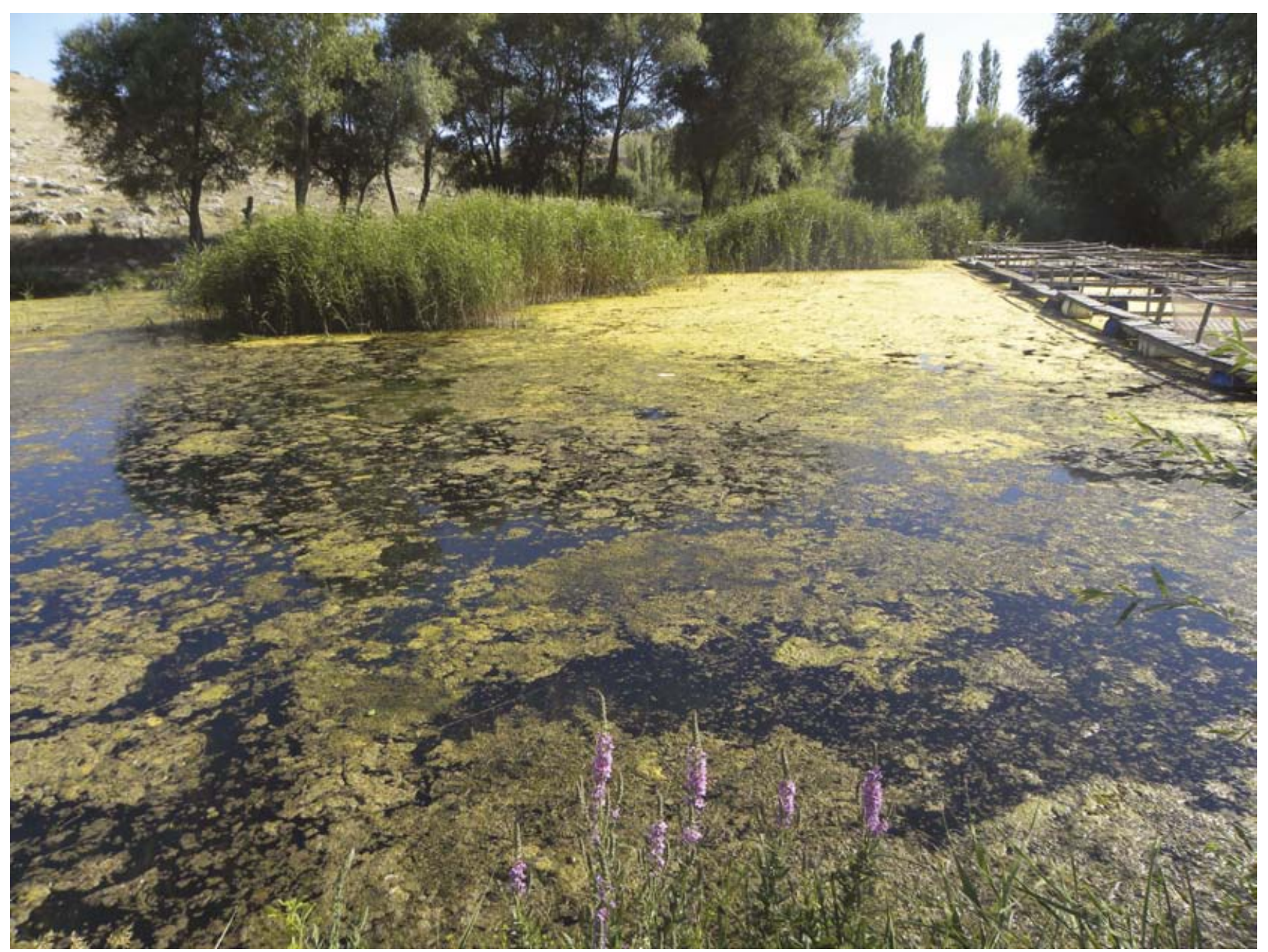

İncirlipınar springs in the headwaters of the Büyük Menderes River, Turkey, is the type locality for the EN gastropod Graecoanatolica dinarica. The springs are threatened by a fish farm and eutrophication. Photo @ Ümit Kebapçı

taxonomic validity. Conversely, due to the lack of distinctive morphological characters, traditional taxonomic techniques used to identify species have proven to be inadequate. The use of molecular markers has now proved that a high number of distinct but 'cryptic' species exist in the region, which were previously unrecognized (i.e. species that are morphologically very close but genetically highly distinct).

\subsubsection{Possibly Extinct and regionally extirpated species}

While no species have been confirmed as being Extinct, there are 11 species that have been assessed as Critically Endangered Possibly Extinct (CR PE). This means that further surveys are required to confirm whether the species is extinct. Most of the CR PE species come from the smaller spring-snails (Hydrobiidae) with a restricted range in Turkey: Hydrobia anatolica, Graecoanatolica conica, Graecoanatolica brevis, Falsiprygula beysehirana, Islamia pseudorientalica, Kirelia carinata, and Belgrandiella cavernica. The other CR PE species are all from the Melanopsidae family, and are restricted to karstic spring complexes in Syria and Turkey: Melanopsis germaini (stream species not springs), Melanopsis infracincta, Melanopsis khabourensis, and Melanopsispachya.

There are other gastropod species that have been extirpated from significant parts of their ranges: Graecoanatolica lacustristurca (EN) is considered extinct in Lake Beyşehir, but remains at other sites, Heleobia longiscata (DD) is extinct in Israel, and the subspecies Pseudorientalia natolica smyrnensis is no longer recorded from the İzmir area in Turkey.

All of the large bivalves (Unio terminalis, Potomida littoralis, Leguminaia saulcyi, and $L$. wheatleyi) are locally extinct in all of the Levant coastal rivers (in Israel, Lebanon, Syria, and Turkey) with the probable exception of Nahr al-Kabir which forms the Lebanese-Syrian border and is inaccessible to researchers (M. Lopes-Lima, pers. comm.).

There are also the mainly Palearctic species that extended their southern limit to the Levant, Ethiopian Highlands, and Maghreb during the (colder and wetter) early Holocene period and are now 
retreating to the north in the current warmer and drier climate (Pisidium milium, Segmentina nitida, Gyraulus crista, Gyraulus albus, Acroloxus lacustris (in Israel), Valvata cristata (in the Lakes Region of Turkey), all LC species).

\subsection{Major threats to freshwater molluscs}

There are multiple drivers of threat to freshwater molluscs in the Eastern Mediterranean region, and in the majority of cases it is usually a combination of threats that lead to declining populations. Figure 4.5 shows that the major threats are water abstraction for domestic supplies and agriculture, and dams (all included under 'Natural system modification') which affect $68.8 \%$ of threatened and Near Threatened species, water pollution from agricultural and urban areas which impacts $56.3 \%$, followed by climate change leading to increasing droughts (29.7\%). The loss of habitats due to urban and agricultural expansion is also a threat to freshwater molluscs, affecting $20.3 \%$ and $14.1 \%$ of threatened and Near Threatened species respectively.

\subsubsection{Water abstraction and dams (Natural system modifications)}

The threat category Natural system modifications includes water abstraction and dams, and impacts over two thirds (68.8\%) of the threatened and NT freshwater molluscs. Surface and ground water are abstracted in huge quantities throughout the arid parts of the Eastern Mediterranean region and abstraction is rarely sustainable, leading to an alarming reduction in groundwater levels (Voss et al. 2013). The exact number of dams in the region is unknown, however Turkey is one of the most active dam building nations in the world with more than 2,000 dams and weirs already constructed, with plans to build an additional 1,700 , including the controversial Ilısu dam (GegenStrömung 2011, International Rivers 2014).

Throughout the Mediterranean region, including Turkey and the countries of the Levant, the human needs for water are already higher than the available water resources. The water demands for intensive agriculture and growing populations

Many rivers in the region now have intermittent flows due to dams holding back water and water abstraction. Left: The Karasu River below the Tahtaköprü dam. Right: The Tahtaköprü dam reservoir, both photos @ Jörg Freyhof
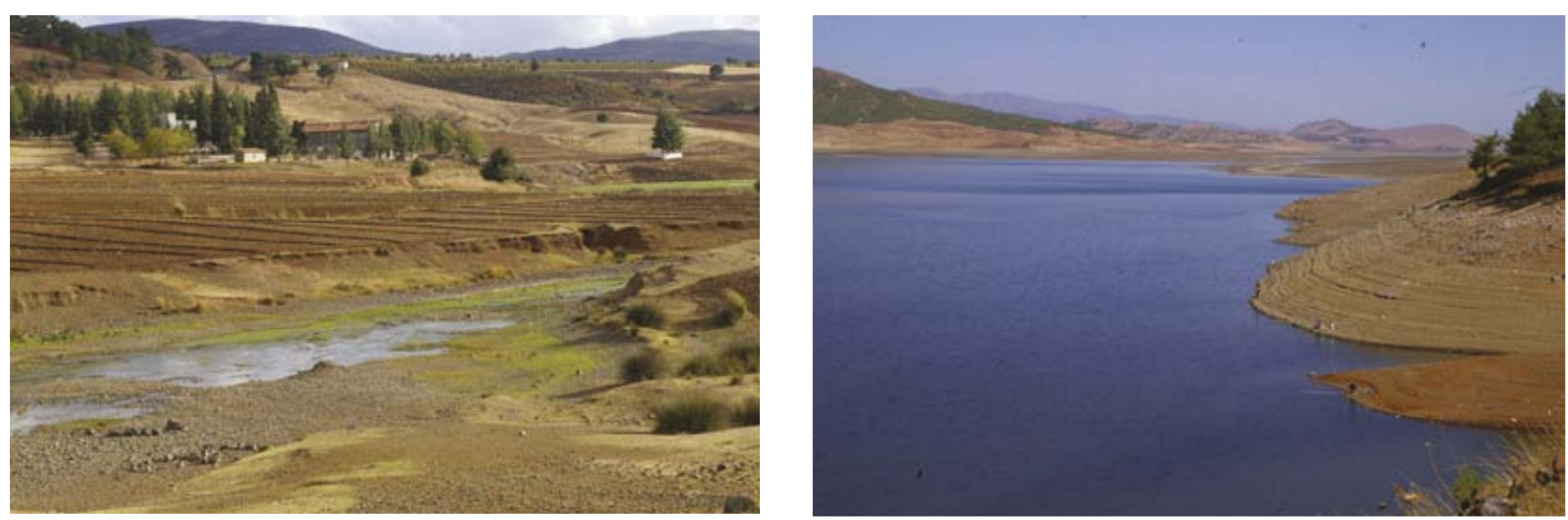

Figure 4.5 Drivers of threats impacting threatened and Near Threatened freshwater mollusc species in the Eastern Mediterranean region.

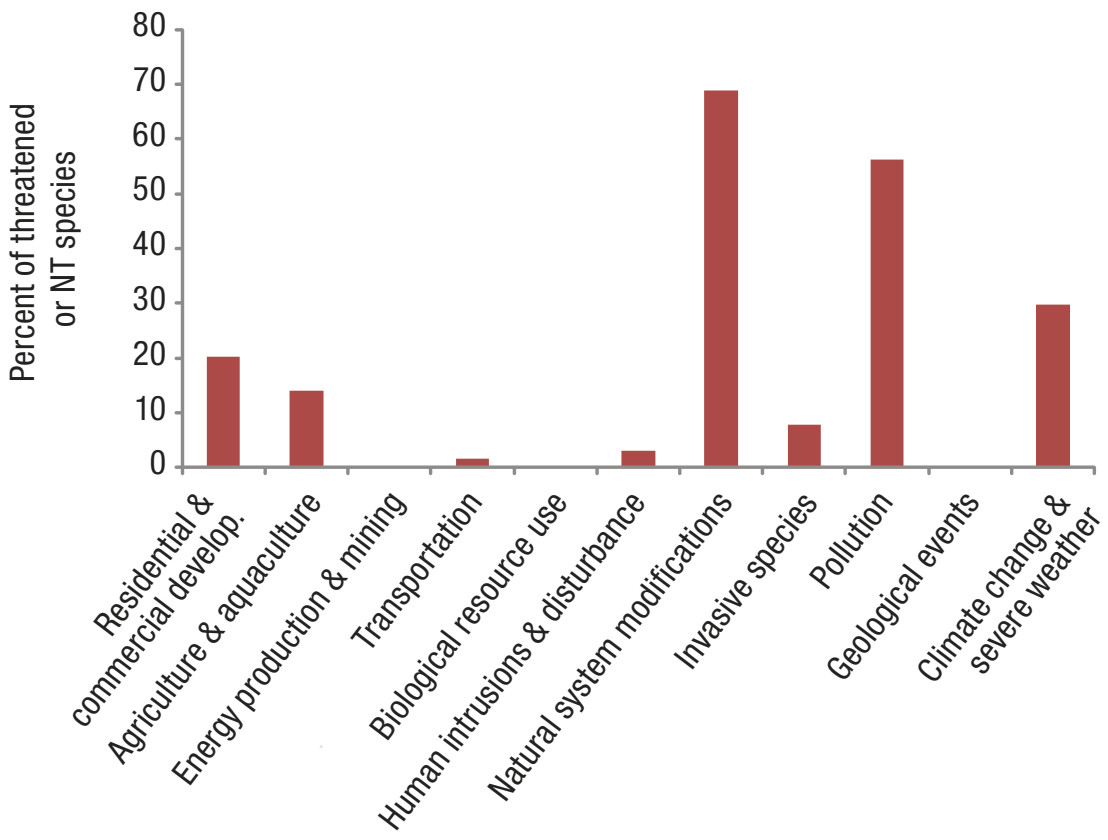


cannot be satisfied by extraction from surface waters alone. In many areas, large spring-fed wetlands have been severely impacted by groundwater extraction and withholding water by dams, for example the Amik Lake wetlands in Turkey (now drained), the Turkish Sultan marshes, lakes Avlan, Hotamıs, and Acs, the Jordanian Azraq wetlands, the Hula marshes in Israel, and the Mesopotamian marshes in Iraq, which almost completely dried out. This loss of wetlands has massively impacted freshwater mollusc populations across the region. Spring-snail species have declined or even been lost from headwaters as they are often 'sanitized' and 'improved' for water abstraction purposes, destroying habitats and lowering the water table to such an extent that springs no longer flow. The lowering of groundwater tables is impacting stream flows across the region and many have dried out, for example the Qweik River, which once flowed through the Syrian city of Aleppo and now is just an intermittent and highly polluted stream (UN-ESCWA and BGR 2013), and also many of the formerly permanent Levantine coastal streams from Israel to Turkey. This reduction in freshwater flow in rivers and streams is also leading to increased salinity in the lower parts of rivers, making these areas uninhabitable for many mollusc species.

Furthermore, the damming of rivers also impacts bivalve species through the blocking of their migratory fish hosts from reaching the mussel beds within the rivers upstream of dams.

\subsubsection{Pollution}

In many areas the impact of reduced flows in river and stream systems caused by over-abstraction (4.4.1) is compounded by pollution and nutrient enrichment from urban and agriculture effluents, transforming what flow remains into hypertrophic streams. This situation can also be seen in the bigger river systems, such as the Orontes River where large sections of the middle and lower part of the river are almost devoid of freshwater life due to excessive inputs of urban and agriculture runoff, and also in the downstream parts of the Jordan River which is heavily polluted and almost no water reaches the Dead Sea (Barinova et al. 2010, UN-ESCWA and BGR 2013).

Across the Eastern Mediterranean region and especially adjacent to areas of urban development, pollution is a major threat to freshwater molluscs, and impacts $56.3 \%$ of all threatened or Near Threatened species (Figure 4.5). Within the Eastern Mediterranean region, Western Anatolia (Turkey) is acutely impacted by water pollution, here all major rivers, such as the Bakır, Gediz, and the Küçük and Büyük Menderes, are heavily polluted. The upper parts of the Küçük Menderes have virtually vanished as all tributaries have dried out due to water extraction and the remaining lower part of the river is filled by untreated sewage from towns and industries. The Gediz and Bakır are also so polluted that little freshwater life can survive in the middle and lower parts.
Despite the scale of pollution in the region, little is known about the true extent and intensity of pollution, particularly from agricultural and industrial sources. Comprehensive data on chemical and biological water quality in the Eastern Mediterranean region is lacking, and with the exception of Israel, there are no country-wide surface water quality monitoring systems in place.

\subsubsection{Climate change and severe weather}

Due to the impacts of climate change the Eastern Mediterranean region is predicted to become dryer and warmer, with a particular increase in the frequency of hot summer days and high temperature events (CEPF 2010) with reduced rainfall in all of Anatolia (except the northern coast) as well as in all of the Levant and the Mesopotamian region (Chenoweth et al. 2011).

This changing climate is compounding already reduced water flows due to over-abstraction, and is impacting almost one third (29.7\%) of threatened and NT species (Figure 4.5). The future, especially for the local spring endemic species, is looking bleak as there have already been a number of local and possible global extinctions of freshwater molluscs due to reduced water levels (see the Possibly Extinct spring snails in section 4.3.5).

Within parts of the Mediterranean, reduced rainfall and water abstraction has impacted the Orontes/Asi and the Jordan river systems, and severely affected the coastal streams of the Levant, many of which are almost gone (Ü. Kebapçı and M. Lopes-Lima pers. obs. 2013). Also within the Lakes Region of Turkey, six lakes (lakes Pınarbaşı, Kestel, Gencali, Avlan, Söğüt, Karagöl) are largely dried out. Unfortunately, the freshwater mollusc fauna was recorded in only three of these lakes (Avlan, Söğüt, Karagöl), therefore it is likely that a number of species, unknown to science, have been lost (Kebapçı and Yıldırım 2010, Ü. Kebapçı pers. comm. 2014). It is a similar situation for the marshlands of Turkey, where the Eşmekaya marshes (in Aksaray), Ereğli marshes (Konya), and Gavur Lake (Kahramanmaraş) have all been severely reduced in size, and none of them had undergone malacological surveys.

The Orontes River is impacted by water abstraction and pollution, but has lots of mussels in localized stretches. Orontes River on the Turkey-Syrian border. Photo (c) Manuel Lopes-Lima

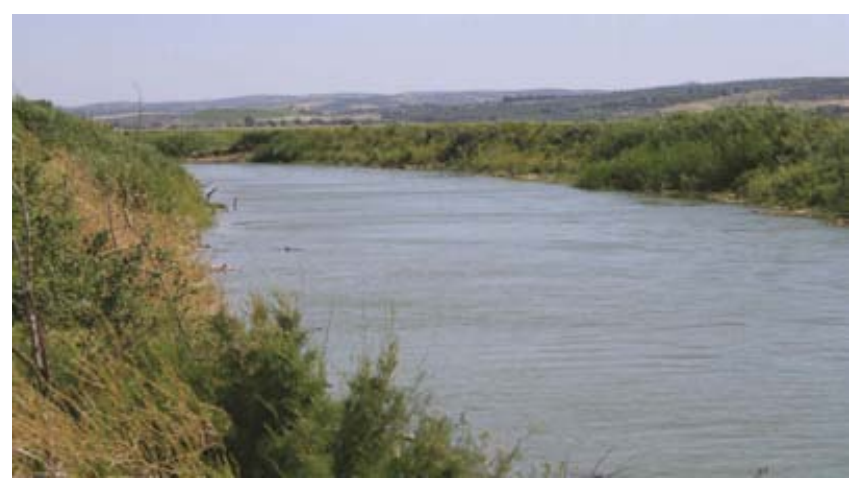


It is therefore difficult to establish the likely degree of loss of the freshwater molluscs that would have been present and lost at these sites. Such marshland reductions have also been recorded around the Sea of Galilee/Kinneret with reported localized extinctions (H. Mienis pers. comm. 2012).

\subsubsection{Other threats}

The major widespread threats to the region's freshwater molluscs are discussed above, however it is worth noting that some areas, particularly along the coastal regions of Turkey, are suffering from a loss of wetland habitats due to development (impacting $20 \%$ of threatened and NT species), primarily for tourism.

Invasive mollusc species are also present in the region and are believed to be impacting a number of threatened and NT species (7.8\%, see Figure 4.5). However, while new records of invasive snail species are increasingly being published, for example Nasarat, Amr, and Neubert (2014) who report two new invasive species in Jordan, the impact upon native species is yet to be documented.

\subsection{Conservation actions and recommendations}

This assessment has revealed many gaps remaining in the exploration and understanding of the freshwater molluscan fauna of the Eastern Mediterranean region. While almost two thirds of the freshwater mollusc species are endemic to the region, most are still very poorly known, highlighting the urgent need for more research. However, more importantly, there exists no comprehensive government supported initiative for the conservation of this highly diverse and threatened group. Whilst large-scale conservation efforts for widespread and unthreatened vertebrates exist, freshwater molluscs are frequently considered as pests that require extermination rather than as a major component of the endemic fauna providing ecosystem services vital to maintaining the health of river systems. Consequently molluscs are largely ignored in conservation planning and legislation in most countries in the region.

\subsubsection{Field research and taxonomic studies}

Field surveying is essential in order to provide up-to-date information on the overall distribution of species, their threats, and the abundance of sub-populations and the connectivity between them. While the region has been a focus of small research projects which have demonstrated the levels of endemicity reported here, further data is required on many species' distribution, growth, life span, age of maturity, and dispersal ability which are all crucial to inform effective conservation planning and management. In addition, in light of the cryptic lineages already identified within the region, in particular for the large mussel species that maintain healthy river systems, taxonomic research is urgently needed, as well as data on geographic genetic diversity patterns, evolutionarily significant units (ESUs) and/or management units (MUs).

We strongly recommend an increase in field surveys and taxonomic research, particularly through further cooperation projects for national and international scientists, as these will help build regional scientific capacity. This will require further investment from national agencies, including funding, administrative assistance with research permits and other resources.

\subsubsection{Monitoring and ex-situ actions}

Anecdotal information suggests that in all countries in this region there has been a substantial decline in the quality and extent of freshwater habitats since the 1980s, and that mollusc populations have been declining over the past 10 to 30 years. Monitoring programmes are urgently required to track the population trends of many of the threatened species, and especially for those with highly restricted range which are susceptible to the lowering of water tables and reduced flows, some of which are already possibly extinct. Such projects will need to adopt strict monitoring protocols so that ex-situ conservation actions can be taken before further species become extinct.

\subsubsection{Environmental flows}

In many regions, there is a lack of basic data about the levels of ongoing water abstraction and its impact upon native species. The environmental flows, including the quality, quantity, and timing of water flows, required to maintain the highly endemic and threatened mollusc species, need to be identified, and incorporated into the decisions that govern water management in the region. However, this will require significant changes in current water use policy across the region. Hence there is an urgent need to raise awareness across different sectors and stakeholder groups on the importance of freshwater molluscs and their conservation status.

\subsubsection{Protected Areas}

Building on the IUCN Red List assessment information published in this report, the freshwater Key Biodiversity Areas (KBAs) of the Eastern Mediterranean region (including for molluscs) have been identified and validated through regional stakeholder workshops. The results of this work are published in a separate report, Freshwater Key Biodiversity Areas in the Mediterranean Basin Hotspot (Darwall et al. 2014). A network of protected areas needs to be established using the results of these Key Biodiversity Areas (KBAs), and managed appropriately; for freshwater species this means using integrated river basin management approaches. In addition, management of the existing protected areas across the region needs to ensure that actions are taken to conserve the freshwater biodiversity within them, as they are often focused upon only terrestrial mega fauna. The high level of endemicity and range restricted species especially within the Levant, where water 


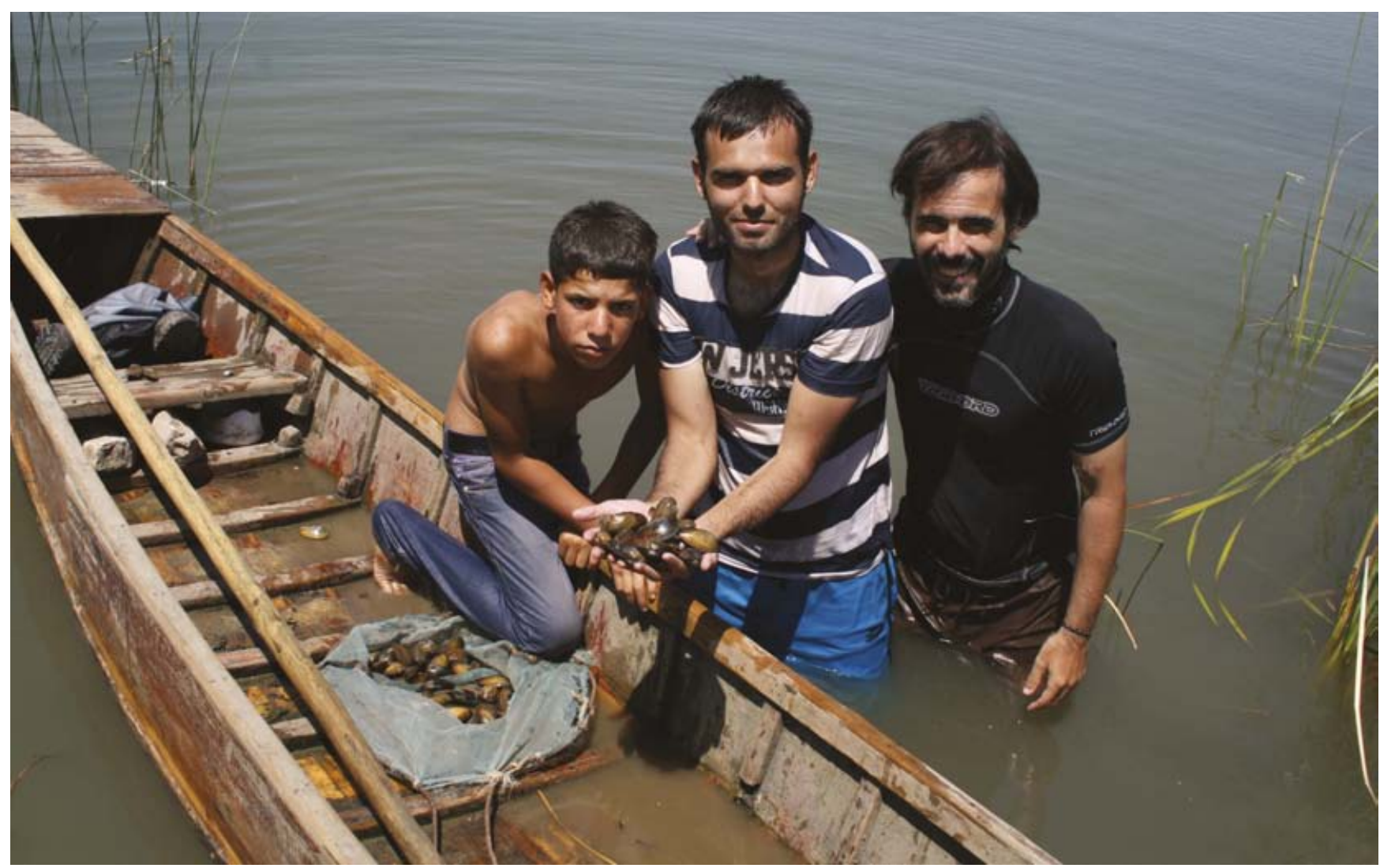

Field surveys are urgently required as much of the data on the region's freshwater molluscs are outdated. Manuel Lopes-Lima with local fishermen surveying bivalves in Gölbaşı Lake (in Hatay, Turkey). Photo @ Manuel Lopes-Lima

resources are already extremely low and urban development is still growing, means such a network of protected areas, if effectively managed, will be vital for conserving freshwater mollusc species.

\subsection{References}

Abell, R., Thieme, M., Revenga, C., Bryer, M., Kottelat, M., Bogutskaya, N., Coad, B., Mandrak, N., Contreras-Balderas, S., Bussing, W., Stiassny, M., Skelton, P., Allen, G. Unmack, P., Naseka, A., Ng, R., Sindorf, N., Robertson, J., Armijo, E., Higgins, J., Heibel, T., Wikramanayake, E., Olson, D., Lopez, H., Reis, R., Lundberg, J., Sabaj Perez, M. and Petry, P. 2008. Freshwater ecoregions of the world: A new map of biogeographic units for freshwater biodiversity conservation. BioScience 58:403-414.

Bank, R., von Proschwitz, T. and Falkner, G. 2006. Unpublished manuscript of the mollusca section of the Fauna Europea web-site (http://www.faunaeur.org). Available at: http://www.faunaeur.org

Barinova, S., Tavassi, M., Glassman, H. and Nevo, E. 2010. Algal indication of pollution in the lower Jordan River, Israel. Applied Ecology and Environmental Research 8(1):19-38.

Bogan, A.E. 2010. Mollusca-Bivalvia checklist. Freshwater Animal Diversity Project. http://fada.biodiversity.be

Bößneck, U. 2011. New records of freshwater and land molluscs from Lebanon (Mollusca: Gastropoda \& Bivalvia). Zoology in the Middle East 54: 35-52.

CEPF. 2010. Mediterranean Basin Biodiversity Hotspot: Ecosystem Profile. Critical Ecosystem Partnership Fund. http://www.cepf.net/ Documents/Mediterranean_EP_FINAL.pdf
Chenoweth, J., Hadjinicolaou, P., Bruggeman, A., Lelieveld, J., Levin, Z., Lange, M.A., Xoplaki, E. and Hadjikakou, M. 2011. Impact of climate change on the water resources of the eastern Mediterranean and Middle East region: Modeled 21st century changes and implications. Water Resources Research 47: doi:10.1029/2010WR010269. issn: 0043-1397.

Cummings, K.S. and Graf, D.L. 2009. Mollusca: Bivalvia. In: J.H. Thorp and A.P. Covich (eds.). Ecology and Classification of North American Freshwater Invertebrates, 3rd edition. Academic Press-Elsevier, New York, USA: 309-384.

Cuttelod, A., Seddon, M. and Neubert, E. 2011. European Red List of Non-marine Molluscs. Publications Office of the European Union, Luxembourg.

Darwall, W., Carrizo, S., Numa, C., Barrios, V., Freyhof, J. and Smith, K. 2014. Freshwater Key Biodiversity Areas in the Mediterranean Basin Hotspot. Informing species conservation and development planning in freshwater ecosystems. IUCN, Cambridge, UK and Malaga, Spain.

GegenStrömung. 2011. Dam construction in Turkey and its impact on economic, cultural and social rights: Parallel report in response to the Initial Report by the Republic of Turkey on the Implementation of the International Covenant on Economic, Social and Cultural Rights. Submission to the UN Committee on Economic, Social and Cultural Rights for its 46th Session, 2-20 May 2011. http://www2.ohchr.org/ english/bodies/cescr/docs/ngos/JointReport_Turkey46.pdf

Germain, L. 1936. Les Mollusques terrestres et fluviatiles de l'Asie antérieure. (Voyage H. Gadeau de Kerville). Paris, France.

Glöer, P., Falinioski, A. and Pesic, V. 2010. The Bithyniidae of Greece (Gastropoda: Bithyniidae). Journal of Conchology 40(2):179-187.

Glöer, P. and Georgiev, D. 2012. Three new gastropod species from Greece and Turkey (Mollusca: Gastropoda: Rissooidea) with notes on the anatomy of Bythinella charpentieri cabitius Reischütz 1988. NorthWestern Journal of Zoology 8:278-282. 
Glöer, P., Gürlek, M.E. and Kara, C. 2014. New Pseudamnicola species of Turkey (Mollusca: Gastropoda: Hydrobiidae). Ecologica Montenegrina 1:103-108.

Glöer, P. and Naser, M.D. 2007. Gyraulus huwaizahensis n. sp. - a new species from Mesopotamia, Iraq (Mollusca: Gastropoda: Planorbidae). Mollusca, 25(2):147-152.

Glöer, P. and Rähle, W. 2009. Gyrauluspamphylicus n. sp. a new species from Turkey (Mollusca: Gastropoda: Planorbidae). Mollusca, 27(1):57-60.

Glöer, P. and Yıldırım, M.Z. 2006a. Stagnicola records from Turkey with the description of two new species (Gastropoda: Lymnaeidae). Journal of Conchology, 39:85-89.

Glöer, P. and Yildırım, M.Z. 2006b. Some records of Bithyniidae from Turkey with the description of Bithynia pesicii n.sp. (Gastropoda: Bithyniidae). Malakologische Abhandlungen. Dresden, 24:37-42.

International Rivers. 2014. Turkey. Accessed 13 October 2014. http:// www.internationalrivers.org/campaigns/turkey

IUCN. 2012. IUCN Red List Categories and Criteria: Version 3.1. Second edition. IUCN, Gland, Switzerland and Cambridge, UK.

Kantor, Y.I., Vinarski, M.V., Schileyko, A.A. and Sysoev A.V. 2010. Catalogue of the continental mollusks of Russia and adjacent territories [Electronic resource]: Version 2.3.1. Accessed 20/11/2014 http://www.ruthenica. com/documents/Continental_Russian_molluscs_ver2-3-1.pdf

Kebapçı, Ü. and Yıldırım, M.Z. 2010. Freshwater Gastropods in the Lakes Region (Turkey). Muzeul Olteniei Craiova. Oltenia. Studii si comunicftri. Ştiintele Naturii Tom. 26(2):75-83.

Kinzelbach, R. 1987. Faunal history of some freshwater invertebrates of the northern Levant (Mollusca, Crustacea). In: Proceedings of the symposium on the fauna and zoogeography of the Middle East. Mainz: Beihefte zum TAVO A 28: 40-61.

Kinzelbach R. 1989. Freshwater mussels (genus Anodonta) from Anatolia and adjacent areas (Bivalvia, Unionidae). Zoology in the Middle East 3(1):59-72.

Lehner, B. and Grill, G. 2013. Global river hydrography and network routing: baseline data and new approaches to study the world's large river systems. Hydrological Processes 27:2171-2186.

Milstein, D., Mienis, H.K. and Rittner, O. 2012. A field Guide to the Molluscs of inland Waters of the Land of Israel. Israel Nature and Parks Authority, Israel.

Nasarat, H., Amr, Z. and Neubert, E. 2014. Two invasive freshwater snails new to Jordan (Mollusca: Gastropoda). Zoology in the Middle East 60:46-49.

Neubert, E., Zuhair, Z. and Van Damme, D. In prep. Chapter 4. The status and distribution of freshwater molluscs in the Arabian Peninsula. In: The freshwater fauna of the Arabian Peninsula. IUCN.

Padilla, D. and Williams, S. 2004. Beyond ballast water: aquarium and ornamental trades as sources of invasive species in aquatic ecosystems. Frontiers in Ecology and Environment 2(3):131-138.

Pallary, P. 1939. Deuxième addition à la faune malacologique de la Syrie. Mémoires de l'Institut d'Égypte 39:1-143.

Schütt, H. 1965. Zur Systematik und Okologie Turkischer Susswasserprosobranchier. Zoologische Mededelingen 41:43-71.

Schütt, H. 1983a. Die Molluskenfauna der Susswasser im Einzugsgebiet des Orontes unter Berucksichtigung benachbarter Flusssysteme. Archiv fur Molluskenkunde 113:17-91, 225-228.

Schütt, H. 1983b. Die bisher aus Jordanien bekannten süßwasser - und landbewohnenden Mollusken anhand der Aufsammlungen von Dr. Bandel 1978. Natur und Mensch, Jahresmitteilungen der Naturhist. Ges. 49-64.

Schütt, H. 1988. The Danubian character of the Mollusc fauna of the Sapanca Gölü (Marmara region, Turkey). Zoology in the Middle East 2:79-85.

Schütt, H. and Sesen, N.R. 1989. Theodoxus in SE-Anatolia. Turkey (Gastropoda Prosobranchia. Neritidae). Basteria 53:39-46.

Schütt, H. and Sesen, N.R. 1992. The genus Theodoxus in South-western Anatolia, Turkey (Gastropoda, Prosobranchia: Neritidae). Zoology in the Middle East 6:63-67.
Seddon, M. 2000. Molluscan biodiversity and the impact of large dams (Thematic Review II. I prepared as an input to the World Commission on Dams). World Commission on Dams, Cape Town, South Africa.

Seddon, M., Appleton, C., Van Damme, D. and Graf, D. 2011. Freshwater molluscs of Africa: diversity, distribution, and conservation. In: W.R.T. Darwall, K.G. Smith, D.J. Allen, R.A. Holland, I.J. Harrison, and E.G.E. Brooks, (eds.). The Diversity of Life in African Freshwaters: Under Water, Under Threat. An analysis of the status and distribution of freshwater species throughout mainland Africa. IUCN, Cambridge, United Kingdom and Gland, Switzerland.

Shirokaya, A., Kebapçı, Ü., Hauffe, T. and Albrecht, C. 2012. Unrecognized biodiversity in an old lake: a new species of Acroloxus Beck, 1837 (Pulmonata, Hygrophila, Acroloxidae) from Lake Eğirdir, Turkey. Zoosystematics and Evolution 88:159-170.

Sivan, N., Heller, J. and Van Damme, D. 2006. Fossil Viviparidae (Mollusca: Gastropoda) of the Levant. Journal of Conchology 39(2):207-220.

UN-ESCWA and BGR (United Nations Economic and Social Commission for Western Asia; Bundesanstalt für Geowissenschaften und Rohstoffe). 2013. Inventory of Shared Water Resources in Western Asia. Beirut, Lebanon.

Van Damme, D., Ghamizi, M., Soliman, G., McIvor, A. and Seddon, M.B. 2010. The status and distribution of freshwater molluscs. In: N. García, , A. Cuttelod, and D. Abdul Malak (eds.) The Status and Distribution of Freshwater Biodiversity in Northern Africa. IUCN, Gland, Switzerland, Cambridge, UK, and Malaga, Spain.

Voss, K.A., Famiglietti, J.S., Lo, M., Linage, C., Rodell, M. and Swenseon, S.C. 2013. Groundwater depletion in the Middle East from GRACE with implications for transboundary water management in the TigrisEuphrates-Western Iran region. Water Resources Research 49(2):904914.

Wächtler, K., Dreher-Mansur, M.C. and Richter, T. 2001. Larval types and early postlarval biology in naiads (Unionoida). In: G. Bauer, and K. Wächtler (eds). Ecology and evolution of the freshwater mussels Unionoida. Springer-Verlag, Heidelberg, Germany: 93-125.

Werner, E., Piller, W., Harzhauser, M. and Mandic, O. 2007. Miocene Central Paratethys stratigraphy - current status and future directions. Stratigraphy 4(2/3):151-168.

Wesselingh, F. 2007. Long-Lived Lake Molluscs as Island Faunas: A Bivalve Perspective. In: W. Renema, (ed.). Biogeography, Time, and Place: Distributions, Barriers, and Islands, Springer Verlag, Germany: 275314.

WWF/TNC. 2013. The Freshwater Ecoregions of the World. http://www. feow.org/

Yildırım, M.Z. 1999. Prosobranchia (Gastropoda: Mollusca) Species and their Zoogeographic Distribution, 1. Fresh and Brackish Waters. Turkish Journal of Zoology 23:877-900.

Yıldırım, M.Z., Bahadir Koca, S. and Kebapçı, Ü.2006a. Supplement to the Prosobranchia (Mollusca: Gastropoda) Fauna of Fresh and Brackish Waters of Turkey. Turkish Journal of Zoology 30:197-204.

Yıldırım, M.Z., Gümüş B.A., Kebapçı, Ü., and Bahadır Koca, S. 2006b. The Basommatophoran Pulmonate Species (Mollusca: Gastropoda) of Turkey. Turkish Journal of Zoology 30:445-458.

Yıldırım, M.Z. and Karaşahin, B. 2000. The Gastropoda species that are distributed in fresh waters of Antalya Vicinity. SDU. Fen Bilimleri Enstitusu Dergisi 4:199-207.

Yıldırım, M.Z. and Kebapçı, Ü. 2009. Endemism of Land and Freshwater Gastropods in the Lakes Region (Turkey). Muzeul Olteniei Craiova. Oltenia. Studii si comunicftri. Stiintele Naturii, 25:55-59.

Yıldırım, M.Z. and Kebapçı, Ü., 2012. Extinction in land and freshwater snails in Lakes Region (Turkey). 'Annual Zoological Congress of "Grigore Antipa” Museum (CZGA 2012)' 21-23 November 2012, Bucharest, Romania.

Zhadin, V.I. 1952. Molluscs of Fresh and Brackish Waters of USSR. Israel Program for Scientific Translations Ltd., Israel. 


\section{Chapter 5. Odonata (dragonflies and damselflies)}

Jean-Pierre Boudot ${ }^{1}$ and Vincent J. Kalkman²

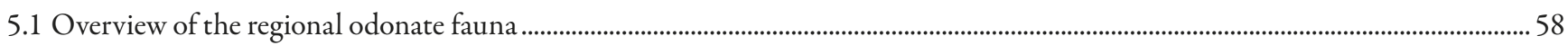

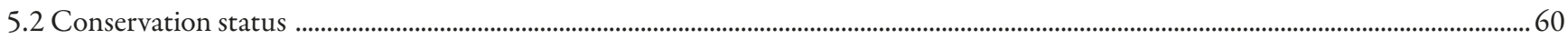

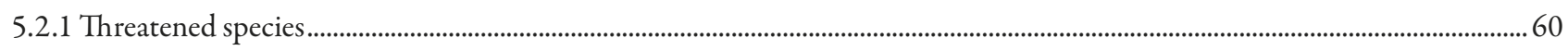

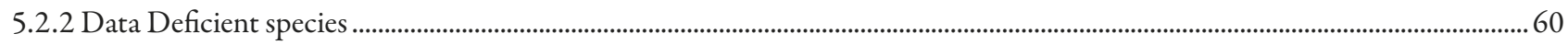

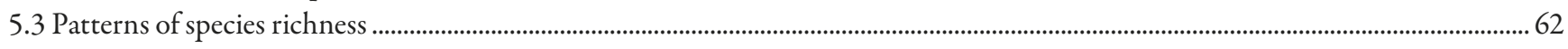

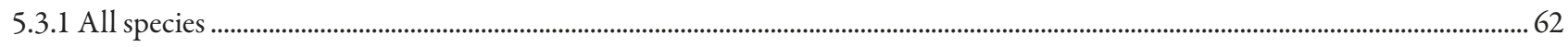

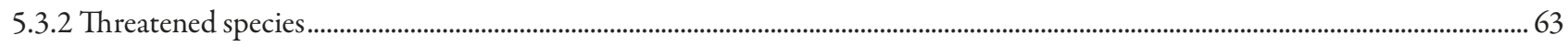

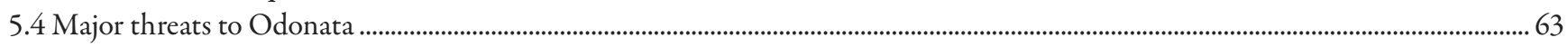

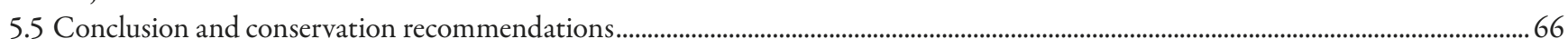

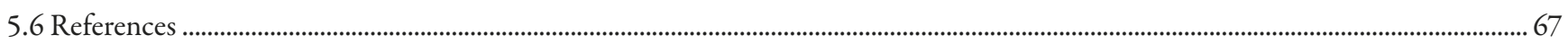

${ }^{1}$ Immeuble Orphée, Ludres, France. Email: jean.pierre.boudot@numericable.fr

${ }^{2}$ Naturalis Biodiversity Centre, Leiden, Netherlands

Red-veined Dropwing (Trithemis arteriosa) a LC species found across Africa, and the Levant. Photo @ Jean-Pierre Boudot 


\subsection{Overview of the regional odonate fauna ${ }^{1}$}

The first significant contribution to our understanding of the Odonata fauna in the Eastern Mediterranean was made by W.G. Schneider, who described five new species from southern Turkey in 1845. Some decades later Selys (1887) in his seminal work on Asia Minor, gave an updated picture of the regional fauna and compared it to that of surrounding regions. Subsequent decisive works were presented, in several country-related papers for Turkey (Morton 1914, Schmidt 1953, 1954a, Dumont 1974a, 1977, Dumont, Demirsoy, and Verschuren 1987, Dumont, Borisov, and Seidenbusch 1995, Schneider 1983, 1984a, 1985a, 1986a), Iraq and surrounding areas (Morton 1919, 1920a,b, 1921, Sage 1960a,b, Asahina 1973, 1974), what was then referred to as Palestine, and now as Israel and Palestine (Morton 1924, Schmidt 1938), South Caucasus countries (Akramowski 1948, 1964, 1975, Shengelia 1975), Iran (Schmidt 1954b, Blom 1982, Hacet and Aktaç 1997, Lohmann 1990, 1992, 1993), the Levant (Dumont 1974b, 1991, Schneider 1981a,b,c, 1982a,b, 1984b, 1985b, 1986b, 1987a,b, 1995), the Near East (Schneider 1985c,d) and Lebanon (Schneider and Moubayed 1985). More recent records and syntheses appeared after the turn of the millennium, dealing with Lebanon (Dia and Dumont 2011), Iran (Heidari and Dumont 2002, Sadeghi and Dumont 2004, Kiany and Minaei 2009, Sadeghi and Mohammadalizadeh 2009, Sadeghi and Kiany 2012, Ghahari et al. 2012), the South Caucasus countries (Dumont 2004, Tailly, Ananian and Dumont 2004, Tailly and Tabarroni 2006, Schröter 2010, Ananian 2012, Ananian and Tailly 2012), Turkey (Kalkman, Wasscher, and Van Pelt 2003, Kalkam et al. 2004, Kalkman, Lopau, and Van Pelt 2004, Van Pelt 2004; Kalkman 2006, Kalkman and Van Pelt 2006, Hacet and Aktaç 2004, 2006, 2008, 2009, Salur and Özsaraç 2004, Salur and Kiyak 2000, 2006, 2007, Pisica and Popescu-Mirceni 2008, Hacet, 2009a,b, 2010, Ayten and Özgökçe 2009, Miroglu and Kartal 2008, Miroglu 2011, Miroglu, Katal, and Salur 2011, Salur, Dogan, and Yagiz 2012, Salur, Miroglu, and Okçu 2012, Olthoff and Ikemeyer 2012), Jordan (Katbeh-Bader, Amr, and Schneider 2002, Katbeh-Bader, Amr, and Abu Baker 2004), Syria (Mousatat et al. 2010), and the overall Mediterranean Basin (Boudot et al. 2009).

Whereas many papers dealt with the descriptions of new species (e.g. Marinov 2001 who described a new Corduliidae species from the Eastern Rhodope), others pointed to the dramatic degradation of the hydrological systems with respect to their Odonata fauna in the Eastern Mediterranean region, a process which is particularly extreme from southern Turkey to the whole Levant and Mesopotamia (Schneider 1982b, Dumont, Demirsoy,

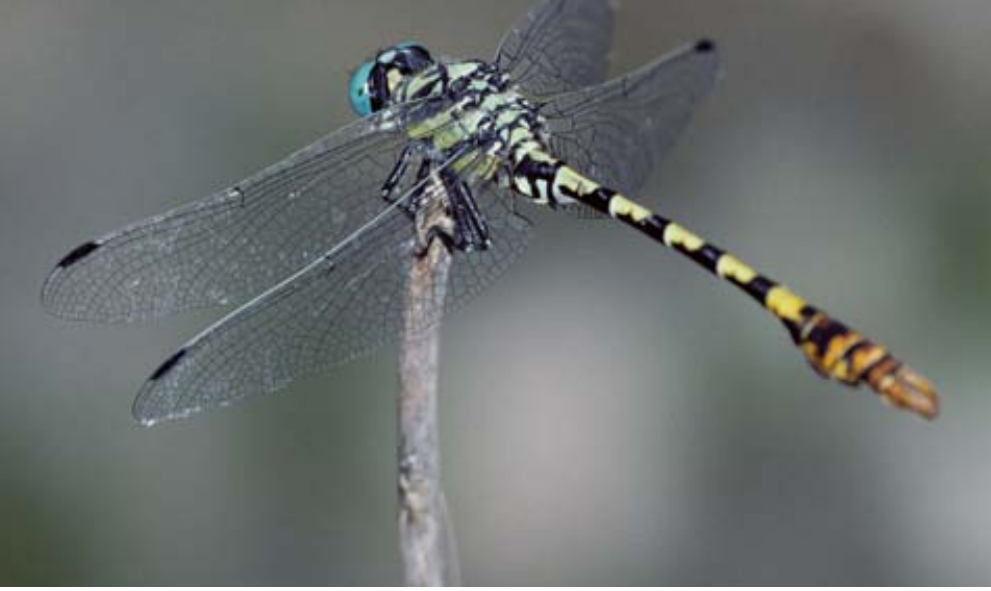

Onychogomphus assimilis, one of the species described by W.G. Schneider in 1845, now threatened (VU) due to habitat loss from urbanization, tourism development, and gravel mining from streams. Photo (C) Jean-Pierre Boudot

and Mertens 1988, Seidenbusch 2001, Herkenrath and Evans 2002, Mousatat et al. 2010, Schneider and Schneider 2010, Dia and Dumont 2011).

The Eastern Mediterranean is a transition region covering parts of both the West and East Palearctic, linking the western and south-western Asian fauna to the African and the European. There are 124 Odonata species in the region, 96 of them are Palearctic species (77.4\%) (including several subspecies or local forms of which the systematics is still unclear) (Figure 5.1). Due to paleotropical inputs, the remaining taxa includes 17 (14\%) Afrotropical species and six (5\%) Indomalayan. Four species are cosmopolitan to subcosmopolitan, as their ranges encompasses several biogeographic realms (these are Pantala flavescens [a neo- and paleotropical migrant with local/sporadic reproduction in the Palearctic and the Nearctic], Sympetrum fonscolombii and Anax imperator [widespread in Africa and Europe, more regional in central and south-western Asia], and Ischnura senegalensis [almost the whole Paleotropics]). While Agriocnemis sania is restricted to the north of Africa and the Levant, it may pertain to the $A$. pygmaea complex, widespread throughout the Indomalayan area with significant regional variations of which the systematic value is poorly known.

Turkish Anatolia and the South Caucasus countries share a lot of species and show some homogeneity in the composition of their Odonata fauna. The Levant (Syria-Lebanon-IsraelJordan-Palestine) and southern Turkey harbour a distinctive

\footnotetext{
1 Taxonomic notes: The poorly known Coenagrion vanbrinkae Lohmann 1993 is considered here as at most a subspecies of C. ornatum (Selys, 1850 ) and is treated with the latter. Calopteryx waterstoni Schneider, 1984, endemic from the North-east Anatolia, is similarly treated as a member of the C. splendens complex, although assessing it at the full species rank would be equally justified. Coenagrion persicum Lohmann 1993 is treated with reserves as a valid species but more knowledge is needed to know whether it should be treated as a synonym of C.pulchellum or not. Agriocnemis sania Nielsen, 1959 is considered distinct from A.pygmaea (Rambur, 1842) but this should deserve more attention by additional researches as both taxa are closely related and the later shows significant regional variations (Pinhey, 1974). Cordulegaster mzymtae Bartenef, 1929 is considered as a subspecies of $C$. insignis Schneider, 1845 due to the existence of probable hybrids. Further researches are needed to know whether this is justified or not. Crocothemis erythraea chaldaeorum Morton, 1920 is maintained at the subspecific rank and is treated with the nominotypical subspecies although further researches are needed about this poorly known taxon.
} 
Odonata fauna which includes a fairly high number of Eastern Mediterranean endemics (see below). The number of species recorded from each country (or part of country) included in the region is shown in Table 5.1. It shows that the greatest number of species (based on the up-to-date distributional data), almost 100 , is found in Turkey, followed by a number of countries with similar diversity (50-60s); including Syria, Israel, Armenia, and the parts of Bulgaria and Georgia that fall within the region. The countries with relatively low diversity are Iraq, Jordan and Lebanon (41-47 species), and Palestine (25) and Kuwait (11) support the fewest species.

The 124 species of Eastern Mediterranean Odonata are found within 10 families, five pertaining to the Zygoptera (damselflies) suborder and five to the Anisoptera (dragonfly) suborder (Table 5.2). There are almost two Anisoptera species for every one Zygoptera, and the Libellulidae (skimmers) is clearly the best represented family containing one third of all the regional

Table 5.1 Number of Odonata species in each country (or part of each country) in the East Mediterranean region. The table shows two figures for each country: 'Red List' presents the number of species from the region coded to each country according to their IUCN Red List assessment; 'Distribution Data' presents data from an up-to-date distribution database held by the authors. As some species assessments are five years old, the distribution data represents a more accurate figure of true diversity for each country.

* indicates those countries that are only partially within the region.

\begin{tabular}{|lcc|}
\hline Countries & $\begin{array}{c}\text { Number of } \\
\text { species } \\
\text { (Red List) }\end{array}$ & $\begin{array}{c}\text { Number } \\
\text { of species } \\
\text { (distribution } \\
\text { data) }\end{array}$ \\
\hline Armenia & 50 & 60 \\
\hline Azerbaijan & 49 & 56 \\
\hline Bulgaria* & N/A & 64 \\
\hline Georgia* & 53 & 62 \\
\hline Greece* & N/A & 55 \\
\hline Iran* & 66 & 52 \\
\hline Iraq & 38 & 41 \\
\hline Israel & 56 & 64 \\
\hline Jordan & 41 & 44 \\
\hline Kuwait & 10 & 11 \\
\hline Lebanon & 41 & 47 \\
\hline Palestine & 28 & 25 \\
\hline Saudi Arabia* & N/A & 39 \\
\hline Syria & 55 & 67 \\
\hline Turkey & 96 & 69 \\
\hline
\end{tabular}

Odonata species. Eleven species are strictly endemic to the region (six Zygoptera and five Anisoptera) and are found in the Calopterygidae, Coenagrionidae, Platycnemididae, Gomphidae, and Libellulidae families. The Zygoptera have twice the proportion of regional endemics ( $14 \%$ species are endemic to the region) compared to the Anisoptera (6.2\%).

The endemic species are particularly concentrated in the Levant and southern Turkey (Calopteryx hyalina, C. syriaca, Coenagrion syriacum, Pseudagrion syriacum, Onychogomphus macrodon, and Gomphus davidi), with others in Anatolia, Iraq, and Iran, some with a relatively large range (Platycnemis kervillei, Libellula pontica, and Brachythemis fuscopalliata), and some with a smaller range (Gomphus kinzelbachi and Coenagrion persicum). Near regional endemics that have restricted ranges are known from the Balkans (e.g. Somatochlora borisi which is found in the Eastern Rhodope area in Bulgaria, Greece, and Turkish Thrace, extending out of the Eastern Mediterranean region as defined for

Table 5.2 Number of total and endemic Odonata species within each family.

\begin{tabular}{|c|c|c|c|}
\hline Suborder & Family & $\begin{array}{c}\text { Number of } \\
\text { species }\end{array}$ & $\begin{array}{l}\text { Number } \\
\text { of regional } \\
\text { endemics }\end{array}$ \\
\hline \multirow[t]{5}{*}{ Zygoptera } & Calopterygidae & 4 & 2 \\
\hline & Coenagrionidae & 26 & 3 \\
\hline & Euphaeidae & 1 & 0 \\
\hline & Lestidae & 9 & 0 \\
\hline & Platycnemididae & 3 & 1 \\
\hline \multicolumn{2}{|c|}{ Total Zygoptera (Damselflies) } & 43 & 6 \\
\hline \multirow{5}{*}{ Anisoptera } & Aeshnidae & 12 & 0 \\
\hline & Cordulegastridae & 5 & 0 \\
\hline & Corduliidae & 5 & 0 \\
\hline & Gomphidae & 17 & 3 \\
\hline & Libellulidae & 42 & 2 \\
\hline \multicolumn{2}{|c|}{ Total Anisoptera (Dragonflies) } & 81 & 5 \\
\hline \multicolumn{2}{|c|}{ Total Odonata } & 124 & 11 \\
\hline
\end{tabular}

Figure 5.1 Zoogeographic origin of the Eastern Mediterranean Odonata fauna.

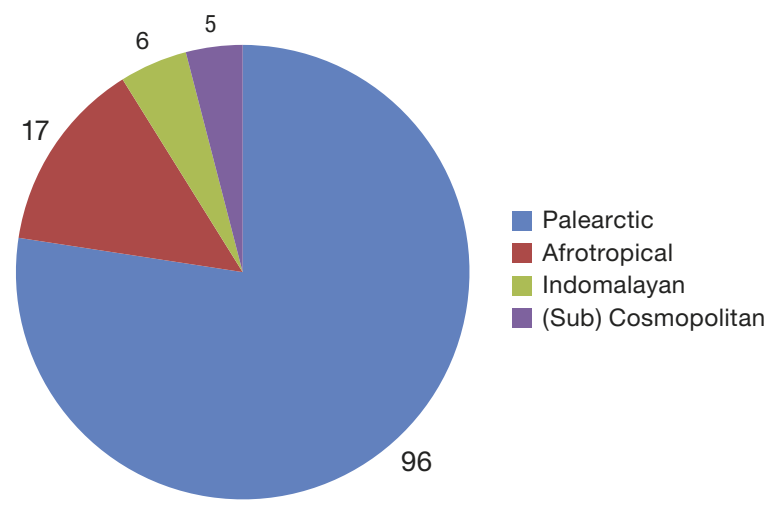


this project by just $35 \mathrm{~km}$ or less) and the eastern shores of the Black Sea (e.g. Coenagrion ponticum from Turkey, Georgia, and south-west Russia).

\subsection{Conservation status}

\subsubsection{Threatened species}

The application of the IUCN Red List Categories and Criteria (IUCN 2012) shows that of the 124 species (listed in Appendix 2), eight (6.7\%) are threatened, and are assessed as Endangered (EN) or Vulnerable (VU), with no species assessed as Critically Endangered (the highest threat category). A further six species (4.8\%) are close to meeting the thresholds for a threatened category, and are therefore assessed as Near Threatened (NT) (Tables 5.3 and 5.4, Figure 5.2). The majority (88.3\%) of the Eastern Mediterranean species are not threatened or Near Threatened at the global scale (although some of them are declining within the region, see Appendix 2).

However, the proportion of threatened (and Near Threatened) species increases dramatically when only the endemic species are considered (Tables 5.3 and 5.4, Figure 5.3). Four (44.4\%) of the nine endemic species that can be assigned a threat category, are threatened, with an additional two species being Near Threatened and three species Least Concern, showing that the endemics are significantly impacted by the regional pressures to freshwater systems and are threatened at the global scale. Among the six threatened and Near Threatened endemics, several are confined to the Levant and southern Turkey, a region in which hydrological systems and water bodies have suffered significantly from very rapid degradation.

\subsubsection{Data Deficient species}

Four species, two being endemics (Coenagrion persicum, Gomphus kinzelbachi), are poorly known and are assessed as Data Deficient (DD) (Table 5.4, Figures 5.2 and 5.3). Cordulegaster vanbrinkae was described in 1993 from the Elburz Mountains in northern Iran (outside the region) where it was only recorded again in 2013 (Schneider et al. 2014). It has also been recently discovered in two new localities within the Eastern Mediterranean region, including two nearby forest streams in south-east Armenia in 2010 (Ananian and Tailly 2012), an additional site was discovered in south-east Azerbaijan in 2012 and 2013 just outside the Eastern Mediterranean region (Skvortsov and Snegovaya 2014). More information is needed on the species' range, and on the threats to the sites in the South Caucasian countries and northern Iran. Coenagrion persicum is an Iranian taxa described in 1993 from one single male and one exuvia. It was found to be closely related to $C$. pulchellum but additional studies are needed to identify its systematic position. Gomphus ubadschii extends from western Anatolia to Central Asia. It is separated from the closely related $G$. flavipes by the Marmara Straight, the Black Sea, and the Caucasus range. In Central Asia a gap seems to exist between these two species in Kazakhstan, with G. ubadschii south of the Balkhach Lake and G. flavipes to the north. G. ubadschii seems to be scattered across the Eastern Mediterranean region but most records date from before 1996. Accordingly, its present conservation status is poorly known as since this date several Anatolian rivers have been degraded and

The threatened (VU) Turkish Red Damsel (Ceriagrion georgifreyi) is restricted to a narrow strip of coast from Israel to southwest Turkey and three Greek islands, where it is impacted by increasing levels of drought. Photo $\odot$ Jean-Pierre Boudot 
Table 5.3 Threatened and Near Threatened Odonata species in the Eastern Mediterranean region.

\begin{tabular}{|c|c|c|c|c|}
\hline Family & Scientific name & Common name & $\begin{array}{c}\text { IUCN } \\
\text { Red List } \\
\text { Category }\end{array}$ & $\begin{array}{c}\text { Endemic to the } \\
\text { East Mediterranean } \\
\text { region }\end{array}$ \\
\hline Calopterygidae & Calopteryx hyalina & Clear-winged Demoiselle & $\mathrm{EN}$ & Yes \\
\hline Calopterygidae & Calopteryx syriaca & Syrian Demoiselle & EN & Yes \\
\hline Coenagrionidae & Ceriagrion georgifreyi & Turkish Red Damsel & VU & \\
\hline Gomphidae & Onychogomphus assimilis & Dark Pincertail & VU & \\
\hline Gomphidae & Onychogomphusflexuosus & Waved Pincertail & VU & \\
\hline Gomphidae & Onychogomphus macrodon & Levant Pincertail & VU & Yes \\
\hline Corduliidae & Somatochlora borisi & Bulgarian Emerald & VU & \\
\hline Libellulidae & Brachythemis fuscopalliata & Dark-winged Groundling & VU & Yes \\
\hline Coenagrionidae & Coenagrion syriacum & Syrian Bluet & NT & Yes \\
\hline Coenagrionidae & Ischnura intermedia & Dumont's Bluetail & NT & \\
\hline Gomphidae & Anormogomphus kiritshenkoi & & NT & \\
\hline Cordulegastridae & Cordulegaster bidentata & Sombre Goldenring & NT & \\
\hline Cordulegastridae & Cordulegaster heros & Balkan Goldenring & NT & \\
\hline Libellulidae & Libellula pontica & Red Chaser & NT & Yes \\
\hline
\end{tabular}

Figure 5.2 Number of Eastern Mediterranean Odonata species in each IUCN Red List Category.

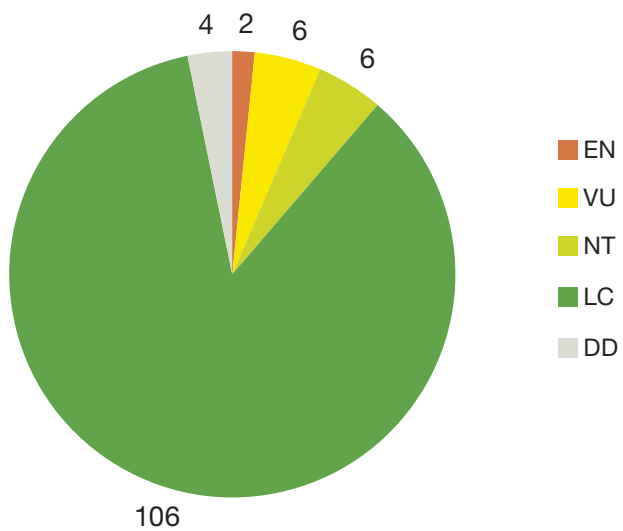

Figure 5.3 Number of Eastern Mediterranean endemic Odonata species in each IUCN Red List Category.

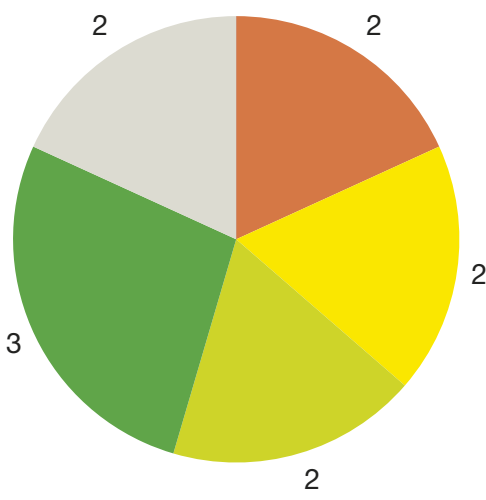

EN

VU

NT

LC

DD
Table 5.4 Number of Odonata species in each Red List Category in the Eastern Mediterranean region.

\begin{tabular}{|lrr|}
$\begin{array}{l}\text { IUCN } \\
\text { Red List Category }\end{array}$ & $\begin{array}{r}\text { Number } \\
\text { and \% of all } \\
\text { species }\end{array}$ & $\begin{array}{r}\text { Number and \% } \\
\text { of all regional } \\
\text { endemics }\end{array}$ \\
\hline Extinct & $0(0 \%)$ & $0(0 \%)$ \\
\hline Extinct in the Wild & $0(0 \%)$ & $0(0 \%)$ \\
\hline Critically Endangered (CR) & $0(0 \%)$ & $0(0 \%)$ \\
\hline Endangered (EN) & $2(1.6 \%)$ & $2(18.2 \%)$ \\
\hline Vulnerable (VU) & $6(4.8 \%)$ & $2(18.2 \%)$ \\
\hline Near Threatened (NT) & $6(4.8 \%)$ & $2(18.2 \%)$ \\
\hline Least Concern (LC) & $106(85.5 \%)$ & $3(27.3 \%)$ \\
\hline Data Deficient (DD) & $4(3.2 \%)$ & $2(18.2 \%)$ \\
\hline Total number of taxa assessed & $\mathbf{1 2 4}$ & $\mathbf{1 1}$
\end{tabular}

The Dark-winged Groundling (Brachythemis fuscopalliata VU) is endemic to the Eastern Mediterranean region where its populations are declining due to pollution and habitat loss. Photo $\odot$ Jean-Pierre Boudot

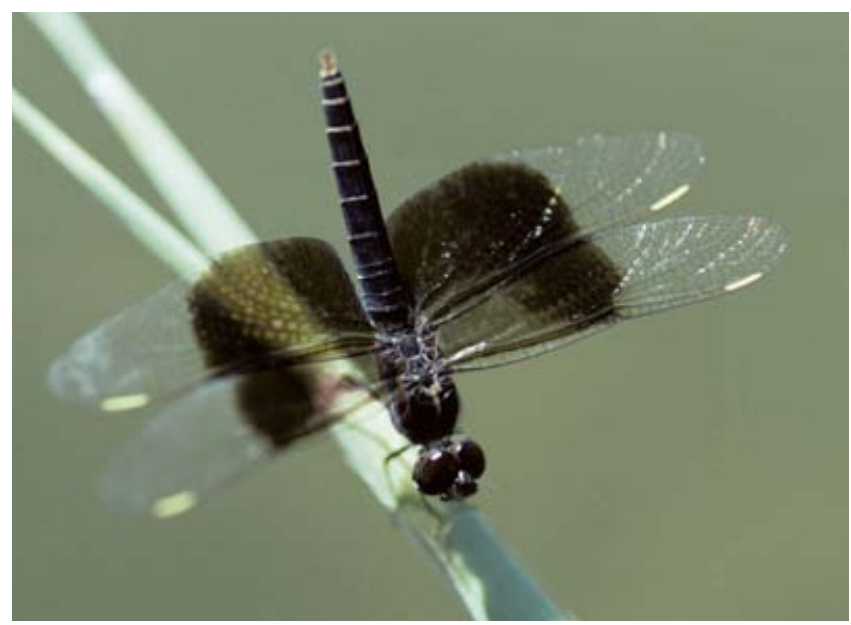




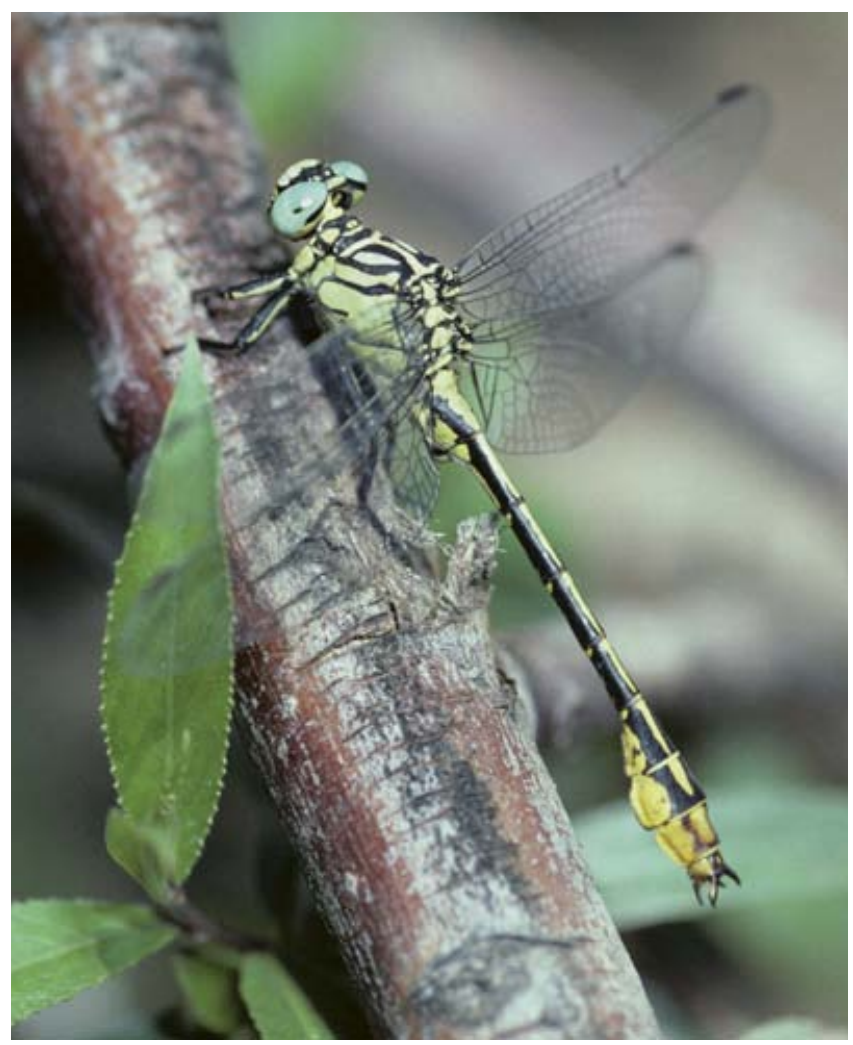

The Syrian Clubtail (Gomphus ubadschii) is a DD species due to a lack of information on its status in the eastern parts of its range in Central Asia. Photo @ Jean-Pierre Boudot the impacts to the species is therefore unknown, it is likely that the species is at least Near Threatened. Gomphus kinzelbachi is a rare endemic from eastern Iraq and western Iran. Only five records exist, ranging from 1937 to 2002, and therefore more surveys are required to understand the conservation status of this species.

\subsection{Patterns of species richness}

\subsubsection{All species}

The odonate species of Turkey, Levant, Bulgaria, and Armenia have been relatively well studied during the past 30 years, allowing for an accurate picture of species distribution. However, field inventories in Georgia, Azerbaijan, western Iran, Iraq, and northern Saudi Arabia are much rarer and often old. Based on the collected data, comprehensively compiled and mapped to subbasins (see Chapter 2), the areas holding the highest numbers of species (between 41 and 50 species) are primarily along the coast of southern Turkey from the Sandras Mountains and Köyceğiz Lake through the Dalaman Plain, Fethiye Bay to the Esen River catchment, and the coastal areas south of Alanya; the upper Hula Valley in Israel and Lebanon; forested areas near Bolu in north-western Turkey; forests to the west of Tbilisi in Georgia (upper Kura catchment); and the Biala Reka (Bulgaria), Oreinis

Toparlar stream is within the Köyceğiz catchment, one of the sub-basins with the highest diversity of Odonata in the region. However while the upper reaches are in good condition, as the stream descends into the alluvial coastal plain water is extracted to such an extent that the stream is dry. Photo (c) Jean-Pierre Boudot

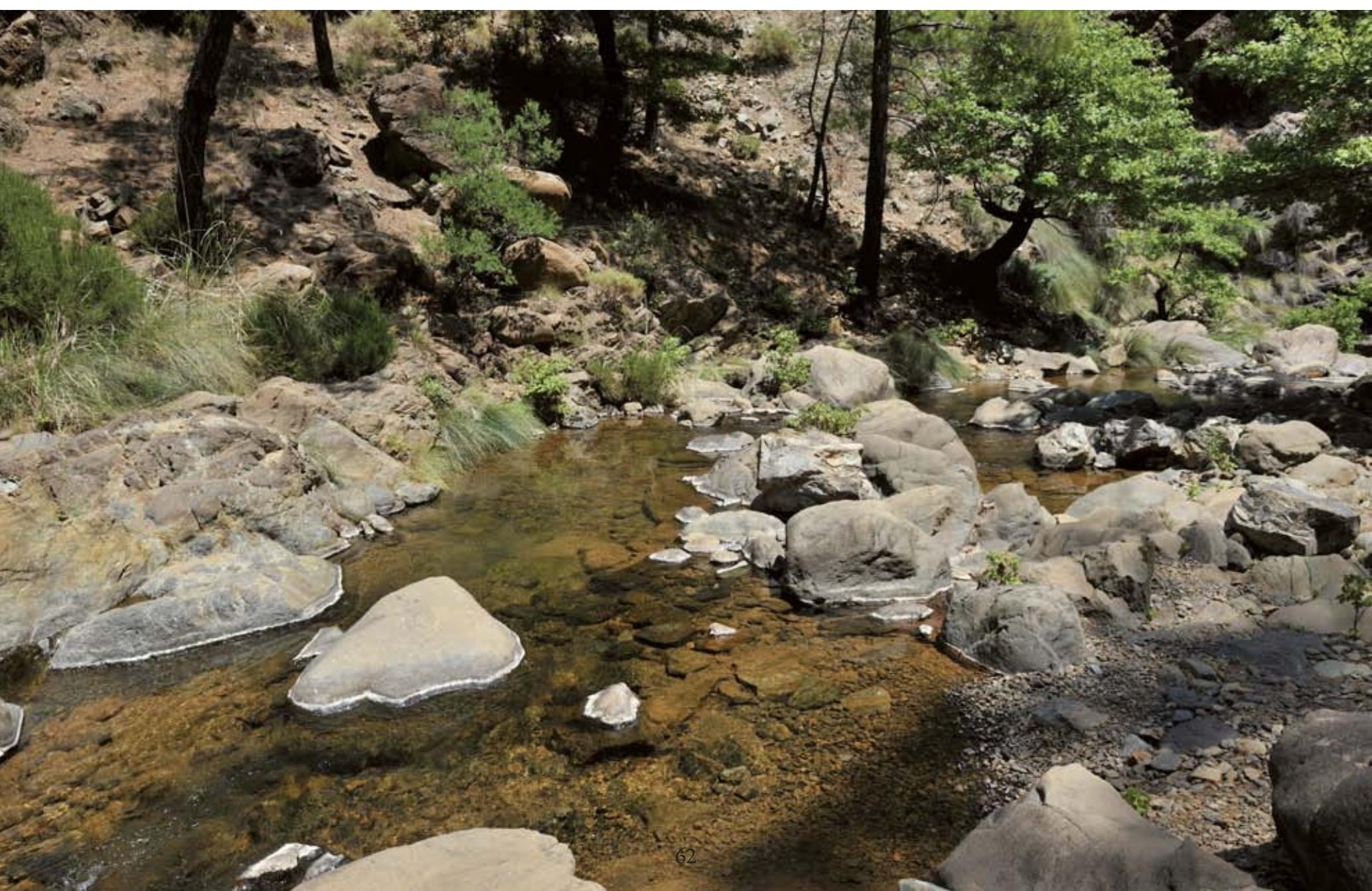




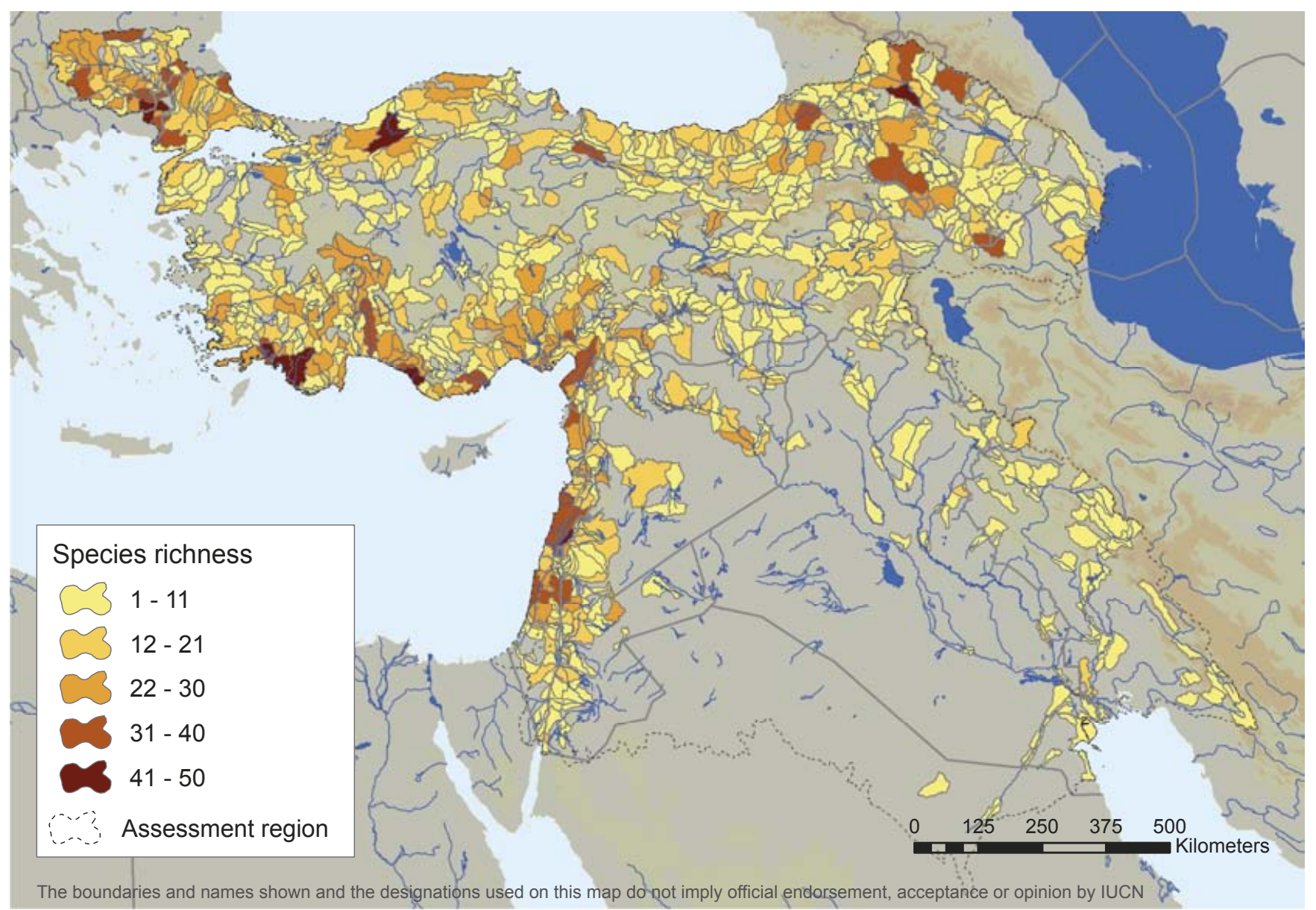

Figure 5.4 Eastern Mediterranean Odonata species richness. Species richness = number of species per sub-basin (defined by HydroBASINS 'Level 8', Lehner and Grill 2013).

Evros, and Poilia Wildlife Refuge (Greece) in the upper Evros Catchment (see Figure 5.4).

Areas of high species richness (31-40 species per sub-basin), include the Jordan River Valley in Israel and Jordan; coastal Israel north of Tel Aviv to Haifa; coastal Lebanon and the Litani River; the Karasu River and Amanos Mountains on the Gulf of İskenderun, Turkey; lower Göksu River and its delta, the Köprü River valley, both in southern coastal Turkey; many subbasins of the Evros River in Turkey, Greece, and Bulgaria; Kelkit River valley in Tokat, northern Turkey; upper Çoruh River in the Yalnizcam Mountains in north-eastern Turkey, southern Caucasus mountains in Georgia (Kura catchment); and the Aras River valley in Armenia.

\subsubsection{Threatened species}

There are only eight threatened odonate species in the region (Near Threatened not included), but the vast majority of the areas containing these species are along the Mediterranean coasts of southern Turkey and the Levant, with a few threatened species found in the upper Euphrates (Syria) and the Kura/Aras River catchments in Armenia and Georgia (Figure 5.5). The two subbasins containing the highest number of threatened species in the region (four species) are found in the middle Asi/Orontes in Syria and the Hula valley in Israel and Lebanon. In both these areas the threatened species found are Brachythemis fuscopalliata (VU), Calopteryx hyalina (EN), C. syriaca (EN), and Onychogomphus macrodon (VU). Three threatened species are found in the lower Ceyhan River in south-eastern Turkey on the Gulf of İskenderun (B. fuscopalliata (VU), O. flexuosus (VU), O. macrodon (VU)), and the coastal rivers of Lebanon (C. hyalina (EN), C. syriaca (EN), and O. macrodon (VU)).

\subsection{Major threats to Odonata}

The major threats to the Eastern Mediterranean Odonata species are from the loss and physical degradation of aquatic habitats, due to wetland drainage for development, high levels of water extraction, water pollution, and climate change (Dumont, Demirsoy and Mertens 1988, Seidenbusch 2001, Bou Zeid and El Fadel 2002, Dia and Dumont 2011, Mousatat et al. 2011) (Table 5.5). The Red List assessment data shows that natural system modifications (i.e. water abstraction and dams) and pollution are the two most significant drivers of threat to Odonata in the region, impacting $79 \%$ and $71 \%$ of threatened and NT species respectively (Figure 5.6), and both residential and commercial development and climate change and severe weather both affect half of all threatened and NT species. 
The destruction of swamps, marshes, and lakes by large scale drainage has historically impacted Middle Eastern benthic fauna. Examples include the drainage of Amik Lake and its marshes in southern Turkey, Antakya province, which was initiated in 1940 to develop cotton culture, and the destruction of the Hula Lake ecosystem in northern Israel from 1951 to 1958 . Both resulted in a severe decline in water resources, and the extinction of several endemic species. Attempts at rehabilitation and reconstruction have since been developed in the Hula Lake area, by re-flooding parts of the Hula depression. More recently, the destruction of

Figure 5.5 Eastern Mediterranean threatened Odonata species richness. Species richness = number of species per sub-basin (defined by HydroBASINS Level 8, Lehner and Grill 2013).

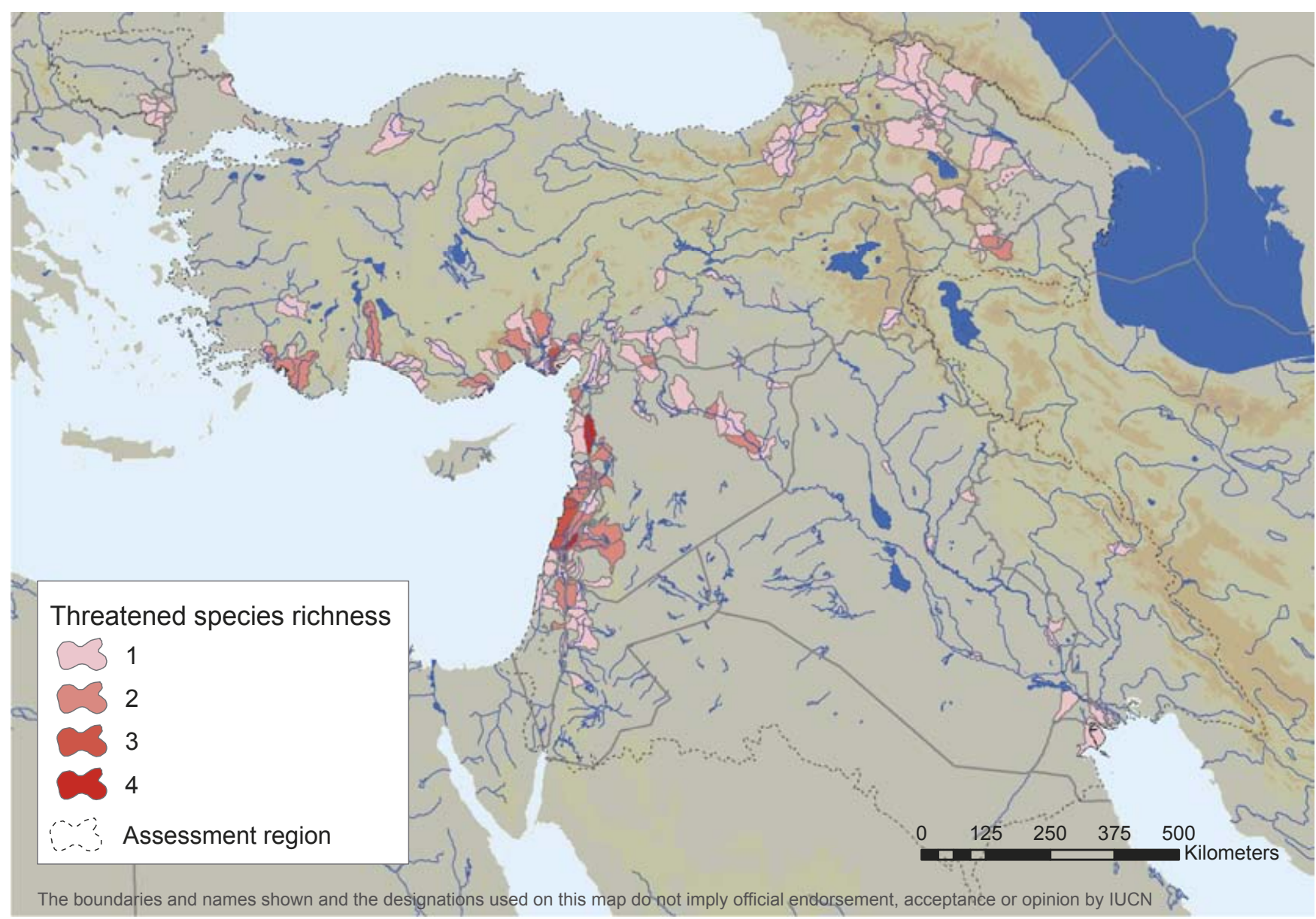

Figure 5.6 Drivers of threats impacting threatened and Near Threatened odonate species in the Eastern Mediterranean region.

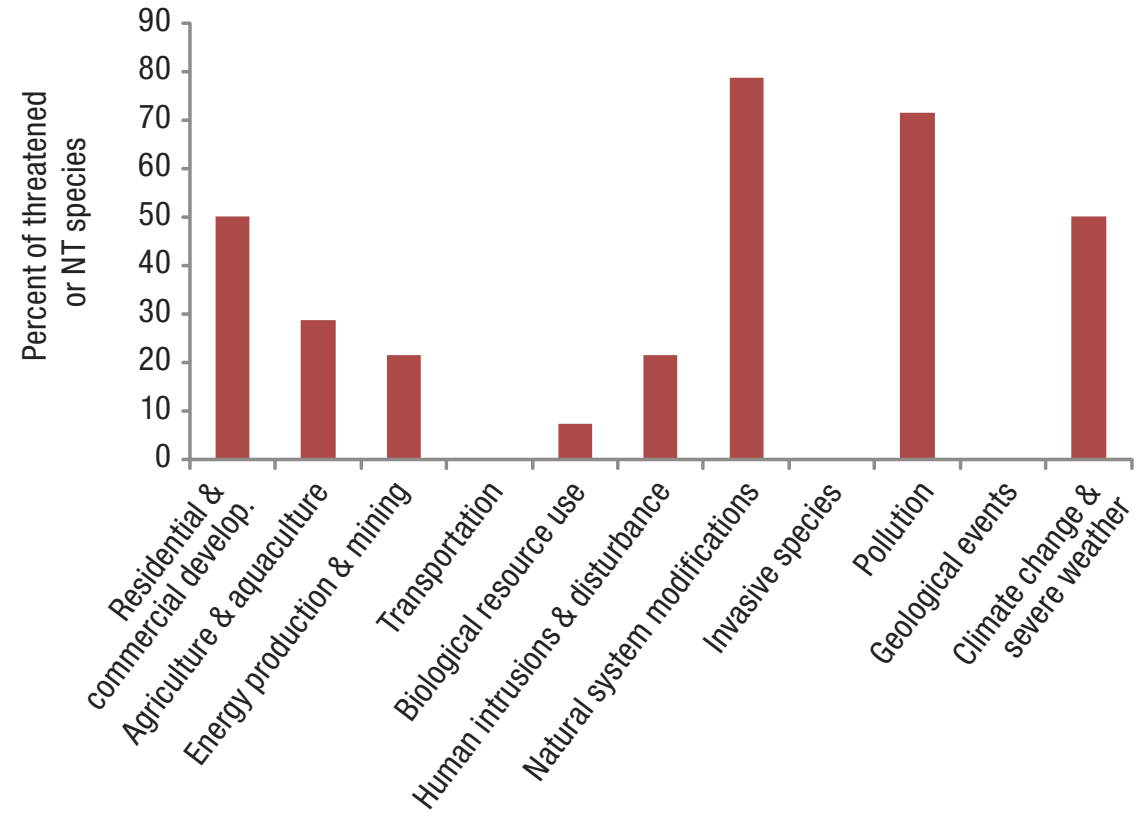


the lower Euphrates marshes for political reasons between the two Iraq wars resulted in the near extinction of many of the dependent species, among which was Brachythemis fuscopalliata (VU), a well-known Middle East endemic.

Many formerly permanent streams in the East Mediterranean region have become intermittent, becoming fully dry in the summer. Thishasbeen caused by achange in climate compounding already severe water shortages due to increasing levels of ground and surface water (at springs) extraction primarily for irrigation, and the channelization of rivers and brooks in agricultural areas. Dam construction is also increasing throughout the whole region, especially in Turkey, and has resulted in the loss of

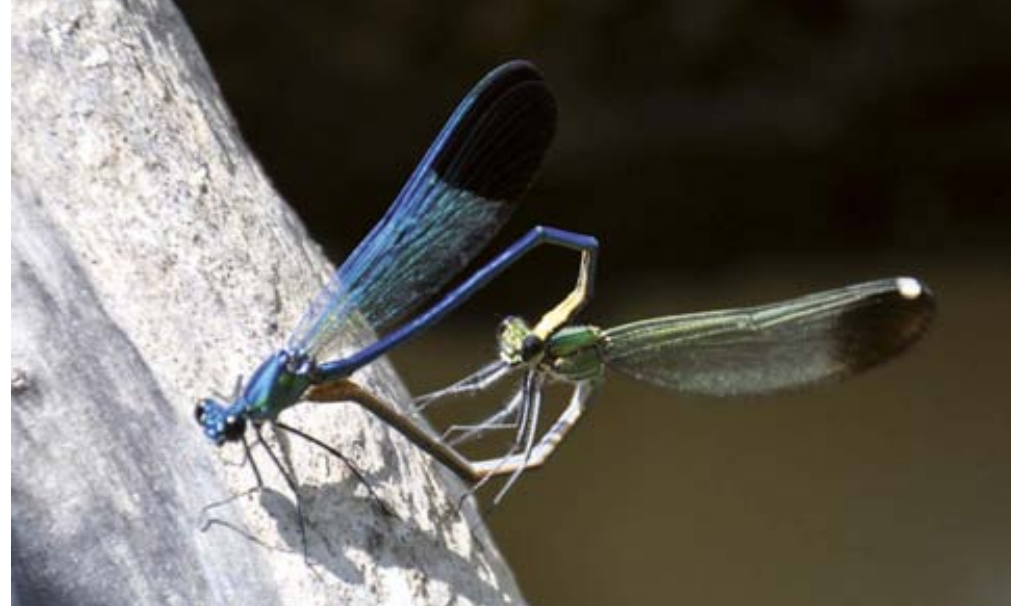

The Syrian Demoiselle (Calopteryx syriaca) an EN species endemic to the southern Levant where it is impacted by water extraction and drought. Photo $\odot$ Izhar Laufer online image under Creative Commons 2.0 licence by-nc-nd

Table 5.5 Main threats and conservation status of the Eastern Mediterranean endemic species.

\begin{tabular}{|c|c|c|c|}
\hline Family & Species & Main threats & $\begin{array}{l}\text { IUCN Red List } \\
\text { Category (global) }\end{array}$ \\
\hline Calopterygidae & Calopteryx hyalina & Water extraction, dams, channelization, water pollution, drought & EN \\
\hline Calopterygidae & Calopteryx syriaca & Water extraction, dams, channelization, water pollution, drought & EN \\
\hline Gomphidae & Onychogomphus macrodon & Water extraction, dams, channelization, water pollution, drought & VU \\
\hline Libellulidae & Brachythemis fuscopalliata & Water extraction, dams, channelization, water pollution & VU \\
\hline Coenagrionidae & Coenagrion syriacum & Water extraction, dams, channelization, water pollution, drought & NT \\
\hline Libellulidae & Libellula pontica & Water extraction, dams, channelization, water pollution & NT \\
\hline Coenagrionidae & Coenagrion persicum & Unknown & DD \\
\hline Gomphidae & Gomphuskinzelbachi & Water extraction, dams, channelization, water pollution & DD \\
\hline Coenagrionidae & Pseudagrion syriacum & Water extraction, dams, channelization, drought & LC \\
\hline Platycnemididae & Platycnemis kervillei & Water extraction & $\mathrm{LC}$ \\
\hline Gomphidae & Gomphus davidi & Water extraction, dams, channelization, water pollution & $\mathrm{LC}$ \\
\hline
\end{tabular}

The Euphrates River in southern Turkey, taken in 1993, now submerged by the reservoir of the Birecik irrigation and hydropower dam. Photo (C) Jean-Pierre Boudot

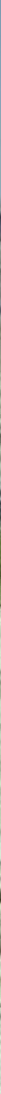


flourishing populations of regional endemic species, which are often replaced by more ubiquitous ones.

Agricultural, domestic, and industrial pollution affects virtually all of the inland water systems in the region. It is expected that this will increase in line with development, leading to increasing pressure on benthic organisms such as odonates. Pollution is severe in some stretches of major large rivers in Anatolia, the lower Ceyhan River and Adana Peninsular being one of the most serious examples of a former endemic-rich habitat now largely devastated due to pollution, in this case by uncontrolled oil discharges and other industrial and agricultural effluents. Regional endemics such as Brachythemis fuscopalliata (VU) have been extirpated from the Adana Peninsula, an area of intensive cotton production, due to the continued use of fertilizers and pesticides (Dumont, Demirsoy, and Mertens 1988). Gravel mining of river beds is also a threat to odonates, as it destroys benthic habitats and has led to the loss of huge populations of the Southwest Asian Onychogomphus assimilis $(\mathrm{VU})$ in southern Anatolia.

\subsection{Conclusion and conservation recommendations}

The freshwater ecosystems in the Eastern Mediterranean region have been under significant pressure over the past century. This has led to a serious situation for the endemic odonate species, with more than half (six species) assessed as threatened or Near Threatened. Most of these are confined to the Levant and the southern coast of Anatolia, an area where human pressure is high and political instability often makes successful conservation action difficult. The main threats are associated with habitat loss and physical destruction of wetland habitats (mostly due to water abstraction, draining of wetlands, and dams) but pollution and increasing rainfall deficit due to climate change are also significant pressures. It is also important to note that the four Data Deficient species identified in this study, two of which are endemic, may well become threatened species when more information is available.

Long-term conservation of the Odonata fauna in the Eastern Mediterranean region depends upon the conservation of the

The Blue-eyed Goldenring (Cordulegaster insignis) is a widespread but localised LC species, restricted to seepage springs and headwaters in hilly and mountainous areas which are threatened by water extraction and drought. Photo $\odot$ Jean-Pierre Boudot

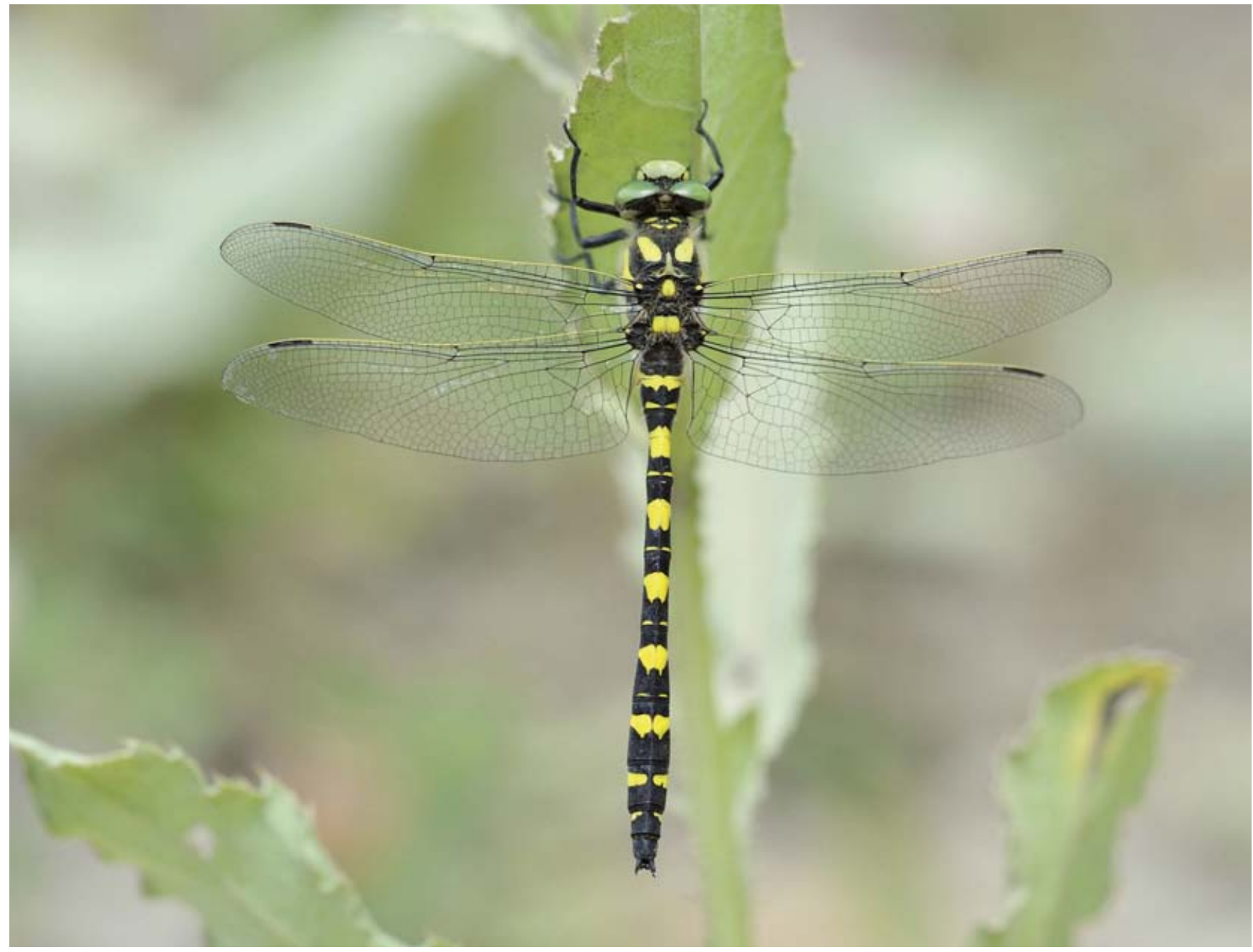


remaining standing water and rivers under a low level of pollution and relatively natural flow regimes (i.e. no channelization, no drainage, no dam construction). Seepage springs and headwaters in mountains and hilly regions are particularly important and need protection as they harbour highly specialized species which cannot live in other habitats (e.g. Sympetrum haritonovi (LC) which has lost some of its rare known localities in the past two decades due to mountain agriculture and road construction; also Cordulegaster insignis (LC) which is threatened by the drying up of its spring habitats). Restoration and rehabilitation of formerly destroyed or degraded marshes should be undertaken whenever possible.

Lastly, it is important to make sure that the threatened and endemic species are monitored in the field and regularly reassessed for the IUCN Red List as threats in the region are changing rapidly.

\subsection{References}

Akramowski, N.N. 1948. The Dragonfly fauna of the Soviet Armenia. Zoologicheskii Sbornik, Akademya Nauk Armyanskoi SSR, 5:117-188.

Akramowski, N.N. 1964. Supplement to the dragonfly fauna of Eastern Transcaucasia. Izv. Akad. Nauk Armenian SSR, 17:99-101.

Akramowski, N.N. 1975. Some Dragonfly species of special interest from the Caucasus and Transcaucasia and proposals for their protection. In: On insect protection, proceedings of the 2 nd conference. Ministry of Agriculture of the Armenian SSR and Academy of Sciences of the Armenian SSR, Yerevan, Armenia.

Ananian, V. 2012. New finds of 'critical' species of Odonata in Armenia Onychogomphus assimilis and Libellula pontica. Brachytron, 15(1):3642.

Ananian, V. and Tailly, M. 2012. Cordulegaster vanbrinkae Lohmann, 1993 (Odonata: Anisoptera) discovered in Armenia. International Dragonfly Fund Report 46:1-11.

Asahina, S. 1973. The Odonata of Iraq. Japanese Journal of Zoology 17:1736.

Asahina, S. 1974. An additional note to the Odonata of Iraq. Konty $\hat{u}$, Tokyo 42(2):107-109.

Ayten, Y. and Özgökçe, M.S. 2009. Odonata species, their distribution and habitats in Van province. Yüzüncü Yil Üniversitesi Tarim Bilimleri Dergisi 19:1-9.

Blom, W.L. 1982. List of Odonata collected during various lepidopterological trips in Iran (1971-1974). Notulae odonatologicae, 1(9):150-151.

Boudot, J.-P., Kalkman, V.J., Azpilicueta Amorín, M., Bogdanović, T., Cordero Rivera, A., Degabriele, G., Dommanget, J.-L., Ferreira, S., Garrigós, B., Jović, M., Kotarac, M., Lopau, W., Marinov, M., Mihoković, N., Riservato, E., Samraoui B. and Schneider, W. 2009. Atlas of the Odonata of the Mediterranean and North Africa. Libellula Supplement 9:1-256.

Bou Zeid, E. and El Fadel. M. 2002. Climate change and water resources in Lebanon in the Middle East. Journal of Water Resource Planning and Management 128:343-355.

Dia, A. and Dumont, H.J. 2011. The Odonata of Lebanon. Zoology in the Middle East 52:63-70.

Dumont, H.J. 1974a. Ischnura intermedia spec. nov. from Turkey, and its relations to I. forcipata Morton, 1907 and I. pumilio (Charpentier, 1825) (Anisoptera: Coenagrionidae). Odonatologica 3(3):153-165.

Dumont, H.J. 1974b. Agriocnemis sania Nielsen, 1959 (Odonata:
Zygoptera), with a redescription of the species and distributional and ecological notes. Israel Journal of Zoology 23:125-134.

Dumont, H.J. 1977. A review of the dragonfly faune of Turkey and adjacent Mediterranean islands. Bull. Ann. Soc. Roy. Belge Ent. 113:119-171.

Dumont, H.J. 1991. Odonata of the Levant. In: F.D. Por (ed.), Fauna Palestina, Insecta, $V$. The Israel Academy of Sciences and Humanities, Jerusalem, Israel.

Dumont, H.J. 2004. Dragonflies from Azerbaijan. Zoology in the MiddleEast 31:87-92.

Dumont, H.J., Borisov, S.N. and Seidenbusch, R. 1995. Redescription and geographic range of Sympetrum haritonovi, Borisov, 1983 (Odonata, Libellulidae), with notes on its habitat and ecology. Bulletin et Annales de la Société royale belge d'Entomologie 131:65-74.

Dumont, H.J., Demirsoy, A. and Mertens, J. 1988. Odonata from South-East Anatolia (Turkey) collected in spring 1988. Notulae Odonatologicae 3(2):17-36.

Dumont, H.J., Demirsoy, A. and Verschuren, D. 1987. Breaking the Calopteryx-bottleneck: taxonomy and range of Calopteryx splendens waterstoni Schneider, 1984 and of C. splendens tschaldirica Bartenef, 1909 (Zygoptera: Calopterygidae). Odonatologica 16(3):239-247.

Ghahari, H., Thipaksorn, H., Naderian, H., Sakenin, H. and Tajali, A.A. 2012. A faunistic study on the Odonata (Insecta) from Kurdistan province and vicinity, western Iran. Linzer biologische Beiträge 44(2):1079-1085.

Hacet, N. 2009a. Odonata of the western Black Sea region of Turkey, with taxonomic notes and species list of the region. Odonatologica 38(4):293-306.

Hacet, N. 2009b. The easternmost record of Somatochlora borisi Marinov, 2001 from Turkish Thrace, with a zoogeographic assessment on the distribution of the species (Odonata: Corduliidae). Journal of the Entomological Research Society 11(2):51-56.

Hacet, N. 2010. Notes on flight periods and distributions of some dragonflies in Turkey. Munis Entomology and Zoology, 5(1):158-162.

Hacet, N. and Aktaç, N. 1997. Odonata fauna of Istranca Mountains. Turkish Journal of Zoology 21(3):275-289.

Hacet, N. and Aktaç, N. 2004. Considerations on the odonate fauna of Turkish Thrace, with some taxonomic notes. Odonatologica 33(3):253270.

Hacet, N. and Aktaç, N. 2006. The Odonata of Gökçeada Island, Turkey: a biogeographical assessment. Entomological News 117(4):357-368.

Hacet, N. and Aktaç, N. 2008. Two new records of Odonata (Gomphidae) for Turkey, Gomphus flavipes (Charpentier, 1825) and Ophiogomphus cecilia (Geoffroy in Fourcroy, 1785), with distributional notes on G. flavipes and G. ubadschii Schmidt, 1953. Entomological News 119(1):81-89.

Hacet, N. and Aktaç, N. 2009. Contribution to the knowledge of Odonata fauna of Southern Marmara Region of Turkey. Turkiye Entomoloji Dergisi 33(3):171-178.

Heidari, H. and Dumont, H.J. 2002. An annotated check-list of the Odonata of Iran. Zoology in the Middle East 26:133-150.

Herkenrath, P. and Evans, M. 2002. Die Mesopotamischen Sümpfe -eine unbemerkte Tragödie. Berichte zum Vogelschutz 38:157-161.

IUCN. 2012. IUCN Red List Categories and Criteria. Version 3.1. Second Edition. IUCN, Gland, Switzerland and Cambridge, UK.

Kalkman, V.J. 2006. Key to the dragonflies of Turkey, including species known from Greece, Bulgaria, Lebanon, Syria, the Trans-Caucasus and Iran. Brachytron 10:3-82.

Kalkman, V.J., Kop, A., Wasscher, M. and Van Pelt, G.J. 2004. The dragonflies of the surroundings of Lake Köycegiz and the River Esen, Mugla province, SW Turkey (Odonata). Libellula Supplement 5:3963.

Kalkman, V.J., Lopau, W. and Van Pelt, G.J. 2004. Hitherto unpublished records of dragonflies from Turkey (Odonata). Libellula Supplement 5:65-166.

Kalkman, V.J. and Van Pelt, G.J. 2006. The distribution and flight period of the dragonflies of Turkey. Brachytron 10:83-153. 
Kalkman, V.J., Wasscher, M. and Van Pelt, G.J. 2003. An annotated checklist of the Odonata of Turkey. Odonatologica 32:215-236.

Katbeh-Bader, A., Amr, Z. and Schneider, W. 2002. Odonata of Jordan. Fragmenta Entomologica 34:147-170.

Katbeh-Bader, A., Amr, Z., Abu Baker, M. and Mahasneh, A. 2004. The dragonflies (Insecta: Odonata) of Jordan. Denisia 14:309-317.

Kiany, M. and Minaei, K. 2009. The dragonfly family Libellulidae (Insecta: Odonata: Anisoptera) of Shiraz and its vicinity (Fars Province, Iran). Iran Agricultural Research, 27/28:65-78.

Lohmann, H. 1990. Anax immaculifrons Rambur, 1842 in Iran (Odonata: Aeshnidae). Opusc. Zool. Flumin. 54:9-10.

Lohmann, H. 1992. Gomphhus kinzelbachi Schneider in Iran (Anisoptera: Gomphidae). Notulae Odonatologicae 3(10):169.

Lohmann, H. 1993. Coenagrion vanbrinki spec. nov. und C. persicum spec. nov. aus Vorderasien (Zygoptera: Coenagrionidae). Odonatologica 22(2):203-211.

Marinov, M. 2001. Somatochlora borisi spec. nov., a new European dragonfly species from Bulgaria (Anisoptera: Corduliidae). International Dragonfly Fund Report 3:46-53.

Miroglu, A. 2011. First record of the Black Darter, Sympetrum danae (Sulzer, 1776) (Odonata: Libellulidae), from Turkey. Zoology in the Middle East 53:129.

Miroglu, A. and Kartal, V. 2008. Additional Notes on the Odonata Fauna of Kurupelit (Samsun, Turkey). Turkish Journal of Zoology 32:33-41.

Miroglu, A., Kartal, V. and Salur, A. 2011. Odonata of the eastern Black Sea region of Turkey, with some taxonomic notes. Odonatologica 40(2):105-122.

Morton, K.J. 1914. Notes on a collection of Odonata from Van, Turkey in Asia. The Entomologist's Monthly Magazine 50:56-59.

Morton, K.J. 1919. Odonata from Mesopotamia. Entomologist's Monthly Magazine 55:143-151, 183-196.

Morton, K.J. 1920a. Odonata collected in Mesopotamia by the late Major R. Brewitt-Taylor, R.A.M.C. Annals and Magazine of Natural History 9(5):293-303.

Morton, K.J. 1920b. Odonata collected in north-western Persia and Mesopotamia by Captain P.A. Buxton, R.A.M.C. Entomologist's Monthly Magazine 56:82-87.

Morton, K.J. 1921. Neuroptera, Mecoptera, and Odonata from Mesopotamia and Persia. Entomologist's Monthly Magazine 57:213225.

Morton, K.J. 1924. The dragonflies (Odonata) of Palestine, based primarily on collections made by Dr. P.A. Buxton, with notes on the species of the adjacent regions. Transactions of the Entomological Society of London $1924(1 / 2): 25-44$.

Mousatat, F., Dumont, H.J., Karrom, M., and Ali, N.M. 2010. Dragonflies from northern Syria. Zoology in the Middle East 51:105-112.

Olthoff, M. and Ikemeyer, D. 2012. Dragonflies of a peat bog in northwestern Turkey (Odonata: Anisoptera, Zygoptera). Zoology in the Middle-East 57:142-146.

Pinhey, E.C.G. 1974. A revision of the African Agriocnemis Selys and Mortonagrion Fraser (Odonata: Coenagrionidae). Occasional papers of the National Museums of Rhodesia (B), 5(4):171-278.

Pisica, E.I. and Popescu-Mirceni, R. 2008. Data on some dragonflies (insecta: odonata) from western turkey. Travaux du Muséum National d'Histoire Naturelle Grigore Antipa 51:335-344.

Sadeghi, S. and Dumont, H. 2004. First record of Libellula fulva pontica Selys, 1887 (Odonata, Anisoptera) from Iran. Zoology in the Middle East 32:116-117.

Sadeghi, S. and Kiany, M. 2012. Wing shape variation in Calopteryx splendens (Harris) populations in the Zagros mountains, Iran (Zygoptera: Calopterygidae). Odonatologica 41(2):123-134.

Sadeghi, S. and Mohammadalizadeh, J. 2009. Additions to the Odonata Fauna of Iran. Iranian Journal of Science and Technology 33(A4):355359.

Sage, B.L. 1960a. Notes on the odonata of Iraq. Iraq Natural History Museum Publication 18:1-11.
Sage, B.L. 1960b. Notes on the odonata of Iraq. The Entomologist 93:118125.

Salur, A., Dogan, Ö. and Yagiz, Y. 2012. Odonata Fauna of Pülümür (Turkey: Tunceli prov.). Munis Entomology and Zoology 7(1):359-362.

Salur, A. and Kiyak, S. 2000. On the Systematic and Faunistic Studies of Anisoptera Species (Insecta: Odonata) of Kizilirmak River Basin (Kayseri Province). Gazi Üniversitesi Fen Bilimleri Enstitüsü Dergisi 13(3):829-841.

Salur, A. and Kiyak, S. 2006. Additional records for the Odonata fauna of east Mediterranean region of Turkey. Munis Entomology and Zoology 1:239-252.

Salur, A. and Kiyak, S. 2007. Additional records for the Odonata fauna of south-western Anatolia - Part I: Anisoptera. Munis Entomology and Zoology 2:63-78.

Salur, A., Miroglu, A. and Okçu, B. 2012. Odonata fauna of Tokat province (Turkey). Munis Entomology and Zoology, 7(1):339-343.

Salur, A. and Özsaraç, Ö. 2004. Additional notes on the Odonata fauna of Çiçekdagi (Kirsehir), Turkey. G.U. Journal of Science 17(1):11-19.

Schmidt, E. 1938. Odonaten aus Syrien und Palästina. Sitzungsberichte Österreichische Akademie der Wissenschaften. MathematischNaturwissenschaftliche Klasse, Wien, Abt I, 147(5-10): 135-150.

Schmidt, E. 1953. Zwei neue Libellen aus dem Nahen Osten. Mitteilungen der Münchner Entomologischen Gesellschaft 63:1-9.

Schmidt, E. 1954a. Auf der Spur von Kellenmisch. Entomologische Zeitschrift 64(5):49-62; 65-72; 74-86; 92-93.

Schmidt, E. 1954b. Die Libellen Irans. Sitzungsberichte Österreichische Akademie der Wissenschaften. MathematischNaturwissenschaftliche Klasse, Wien, Abt I, 163(4-5):233-260.

Schneider, T. and Schneider, J. 2010. Occurrence, behaviour, and habitat preference of the Levant Pincertail, Onychogomphus macrodon Selys, 1887 in Turkey. Zoology in the Middle East 49:79-88.

Schneider, T., Schneider, E., Schneider,J. and Müller, O. 2014. Rediscovery of Cordulegaster vanbrinkae in Iran (Odonata: Cordulegastridae). Odonatologica 43(1/2):25-34.

Schneider, W. 1981a. Eine Massenwanderung von Selysiothemis nigra (Vander Linden, 1825) (Odonata: Macrodiplactidae) und Lindenia tetraphylla (Vander Linden, 1825) (Odonata: Gomphidae) in Südjordanien. Entomologische Zeitschrift 91(9):97-102.

Schneider, W. 1981b. Neue Funde von Pseudagrion syriacum (Selys, 1887) in der nördlichen Levante (Odonata: Zygoptera: Coenagrionidae). Entomologische Zeitschrift 91(13):145-150.

Schneider, W. 1981c. On a dragonfly collection from Syria. Odonatologica 10(2):131-145.

Schneider, W. 1982a. Crocothemis sanguinolenta arabica n. subsp. (Odonata: Anisoptera: Libellulidae), ein afrikanisches Relikt in der südlichen Levante. Entomologische Zeitschrift 92(3):25-31.

Schneider, W. 1982b. Man-induced changes in the dragonfly fauna of the Jordan valley. Advances in Odonatology 1:244-249.

Schneider, W. 1983. The larva of Gomphus davidi Selys, 1887. Hydrobiologia, 98:245-248.

Schneider, W. 1984a. Description of Calopteryx waterstoni spec. nov. from northeastern Turkey (Zygoptera: Calopterygidae). Odonatologica 13(2):281-286.

Schneider, W. 1984b. Beschreibung von Gomphus kinzelbachi n. sp. aus dem Iraq (Odonata: Anisoptera: Gomphidae). Entomologische Zeitschrift 94:1-16.

Schneider, W. 1985a. Dragonfly records from SE-Turkey (Insecta: Odonata). Senckenbergiana Biol. 66(1/3):67-78.

Schneider, W. 1985b. Wiederbeschreibung von Erythromma viridulum orientale Schmidt, 1960 aus dem östlichen Mittelmeerraum. Senckenbergiana Biol. 66(1/3):89-95.

Schneider, W. 1985c. Die Gattung Crocothemis Brauer, 1868 im Nahen Osten. Senckenbergiana Biol. 66(1/3):79-88.

Schneider, W. 1985d. The genus Pseudagrion Selys, 1876 in the Middle East - A zoogeographic outline (Insecta: Odonata: Coenagrionidae). 
In: F. Krupp, W. Schneider and R. Kinzelbach (eds), Proceedings on the Symposium on the Fauna and Zoogeography of the Middle East, Mainz. Beibefte zum TAVO A28 (1987) pp. 114-125.

Schneider, W. 1986a. Erstnachweis von Cordulia aenea (Linnaeus, 1758) für die Türkei (Odonata: Anisoptera: Corduliidae). Entomologische Zeitschrift 96:92-93.

Schneider, W. 1986b. Systematik und Zoogeographie der Odonata der Levante unter besonderer Berücksichtigung der Zygoptera. Dissertation, Universität Mainz, Germany.

Schneider, W. 1987a. Die Verbreitung von Onychogomphusmacrodon Selys, 1887, mit der Beschreibung des bisher unbekannten Weibchens und einer Wiederbeschreibung des Männchens (Odonata: Gomphidae). Opuscula Zoologica Fluminensia 13:1-12.

Schneider, W. 1987b. The genus Pseudagrion Selys, 1876 in the Middle East. A zoogeographic outline (Insecta: Odonata: Coenagrionidae). In: F. Krupp, W. Schneider, and R. Kinzelbach (eds.), Proc. Symp. Fauna Zoogeogr. Middle East, Mainz, 1985, Beihefte zum TAVO A 28:114-123.

Schneider, W. 1995. Die Verbreitung von Pseudagrion syriacum Selys 1887 und Erstnachweis der Art für die Türkei (Odonata: Zygoptera: Coenagrionidae). Entomologische Zeitschrift 105(9):161-180.

Schneider, W. and Moubayed, Z. 1985. Beitrag zur Kenntnis der Odonata des Libanon. Entomologische Zeitschrift 95:183-192.

Schneider, W.G. 1845. Verzeichnis der von Herrn Prof. Dr. Loew im Sommer 1842 in der Türkei und Kleinasien gesammelten Neuroptera, nebst kurzer Beschreibung der neuen Arten. Stettiner entomologische Zeitung 6:110-116, 153-155.

Schröter, A. 2010. On a collection of dragonflies from eastern Georgia, with the first record of Sympetrum arenicolor (Odonata: Libellulidae). Libellula 29(3/4):209-222.

Seidenbusch, R. 2001. Decay and degeneration of lotic habitats in southern Turkey. Reasons and solutions. Sulzbach-Rosenberg Libellenrundbriefe 12:24-29.

Selys-Longchamps, E. de, 1887. Odonates de l'Asie Mineure et révision de ceux des autres parties de la faune dite européenne. Ann. Soc. Ent. Belg. 31:1-85.

Shengelia, E.S. 1975. Dragonflies of Georgia. In: Materialy k Faune Gruzii 5, Tbilisi, Georgia.

Skvortsov, V.E. and Snegovaya, N.Y. 2014. Additions to the knowledge of the Odonata fauna of Azerbaijan, with six new records. Notulae Odonatologicae 8(3):67-76.

Tailly, M., Ananian, V. and Dumont, H.J. 2004. Recent Dragonfly observations in Armenia, with an updated checklist. Zoology in the Middle East 31:93-102.

Tailly, M. and Tabarroni, A. 2006. Crocothemis servilia (Dru.) added to the Armenian fauna and new records of Lindenia tetraphylla (Vander L.) and Selysiothemis nigra (Vander L.) from Azerbaijan (Anisoptera: Gomphidae, Libellulidae). Notulae Odonatologicae 6:93-95.

Van Pelt, G.J. 2004. New records of dragonflies from Turkey (Odonata). Libellula Supplement 5:3-38. 


\title{
Chapter 6. Freshwater plants
}

\author{
Richard V. Lansdown ${ }^{1}$, Ahmad Houri², Salih Kavak ${ }^{3}$, Nisrine Machaka-Houri ${ }^{4}$, and Kevin G. Smith ${ }^{5}$
}

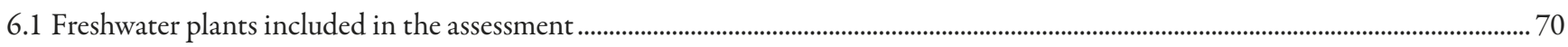

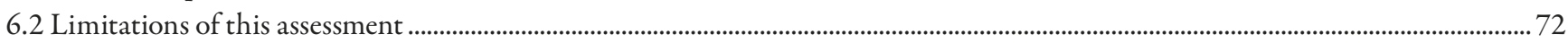

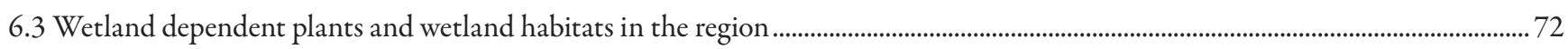

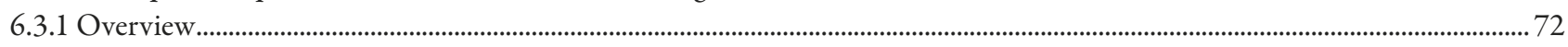

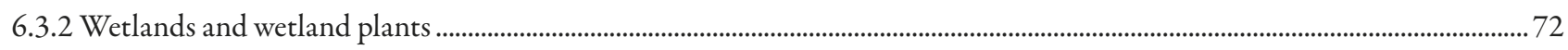

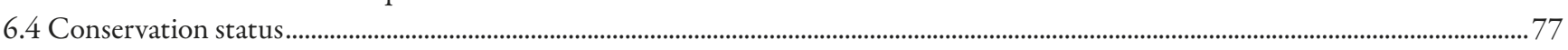

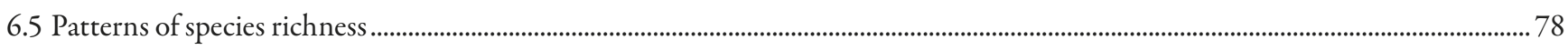

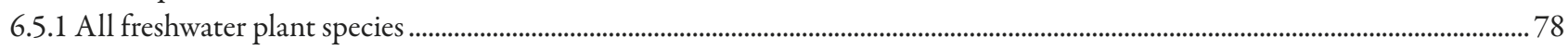

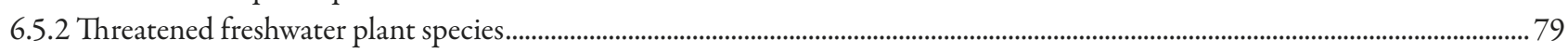

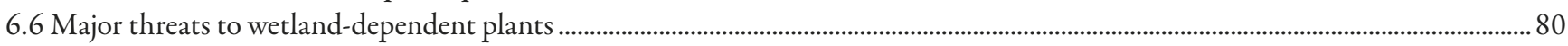

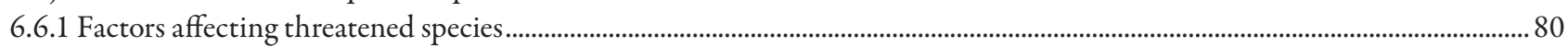

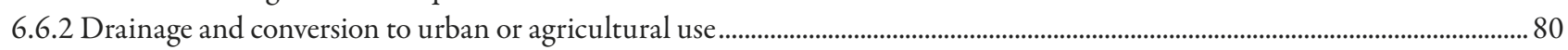

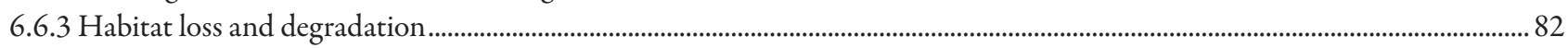

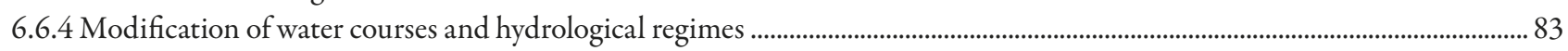

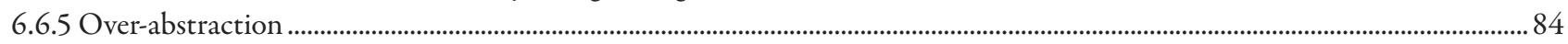

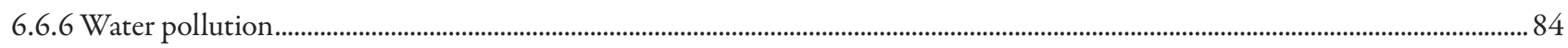

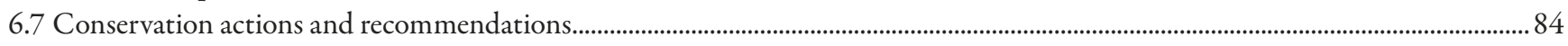

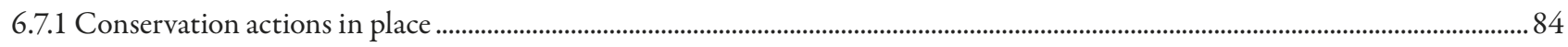

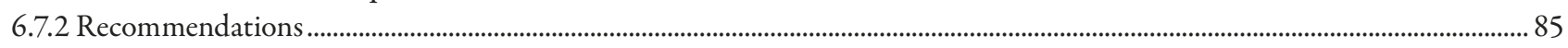

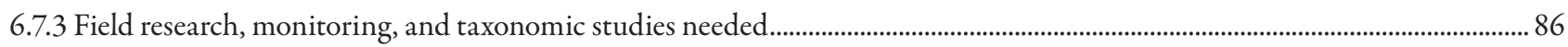

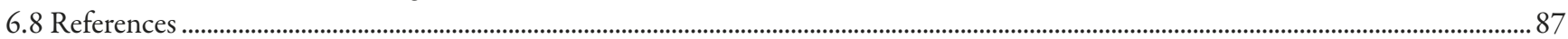

\subsection{Freshwater plants included in the assessment}

Wetland-dependent plants provide a wide range of functions in freshwater ecosystems. They supply water with oxygen, fix atmospheric carbon, recycle nutrients, regulate water temperature and light, as well as protecting against erosion. They also provide vital habitats and food for fishes and aquatic invertebrates, which themselves support other animals and humans. Many species of wetland-dependent plants, such as rice (Oryza sativa) and water-chestnut (Trapa natans) are eaten by people, while others have been used for a variety of other purposes, such as papyrus (Cyperus papyrus) for writing and Saccharum ravennae which is now widely cultivated as an ornamental plant. Some species are used for construction, such as common reed (Phragmites australis) which is used for thatching roofs, erosion control, making furniture, and as an ornament. Plants that are dependent upon wetlands are vulnerable to many anthropogenic pressures, from direct habitat loss through drainage and conversion to other land uses, to pollution and the secondary effects of hypereutrophication such as algal blooms.

Important wetlands in the region include rivers such as the Euphrates, Tigris, Orontes, Jordan, and the Litani, many of which have played a significant role in the development of human civilization, as well as supporting a wide range of aquatic plant, fish, and bird diversity, providing significant ecosystem services to the communities that protect them (Carp 1980). The wetland communities known as Ma'adans have lived near, and have depended for their livelihood on the wetlands of southern Iraq, fed by the Tigris and Euphrates for over 5,000 years. Reed beds in the area provide these people with a source of income and are used for boat and house construction. The lakes are an important fishing ground and provide them with food, and other human activities across the wetlands include bird hunting and raising buffalos. These isolated communities maintain a culture and way of life that has changed little for hundreds of years, their symbiosis with wetlands is remarkable.

\footnotetext{
Chair IUCN SSC Freshwater Plant Specialist Group, Ardeola Environmental Services, Stroud, UK. Email: rlansdown@ardeola.demon.co.uk

Department of Natural Sciences, Lebanese American University, Beirut, Lebanon.

Çukurova Üniversitesi, Fen Edebiyat Fakültesi, Biyoloji Bölümü, 01330, Adana, Turkey.

Environmental Scientist, Beirut, Lebanon.

Programme Officer, Freshwater Biodiversity Unit, Global Species Programme, IUCN, 219c Huntingdon Road, Cambridge, UK.
} 


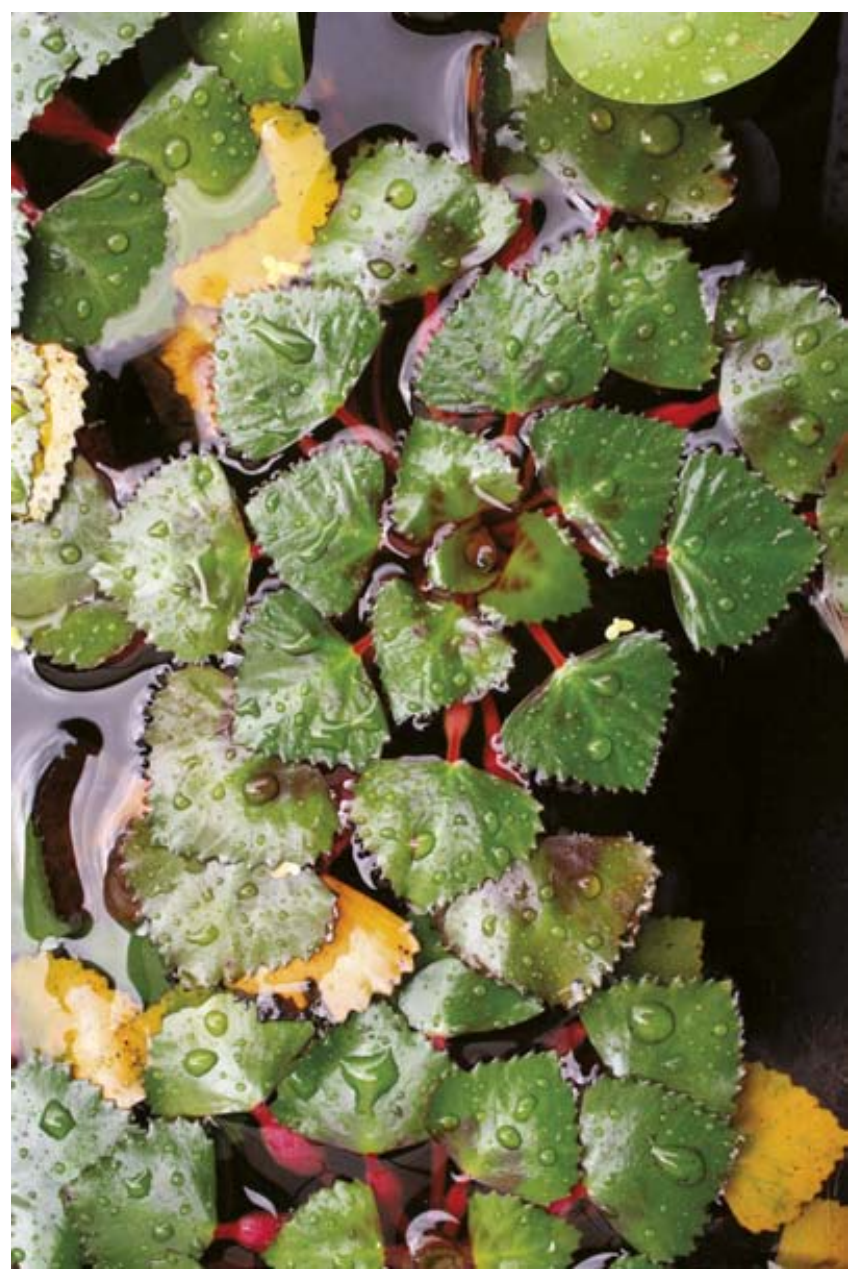

Trapa natans formerly an important crop throughout its native range. Photo $($ C R.V. Lansdown

The aim of this project was to assess the conservation status of vascular plant species occurring in wetlands in the Eastern Mediterranean region (see Chapter 2, Figure 2.1); no taxa below species level were assessed separately nor were hybrid combinations. The definition of which plants may be considered aquatic is not straightforward. The following definition is considered the most clear and unambiguous available: 'Vascular aquatic plants are interpreted as all Pteridophytina and Spermatophytina whose photosynthetically active parts are permanently or, at least, for several months each year submerged in water or float on the surface of water' (Cook 1996). However, not only is little known about the tolerance or requirements of many plants (for example some 'photosynthetically active parts' such as the leaves of many Rubus species may remain submerged for several months but they would never be considered 'aquatic' in a strict sense) but the duration of tolerance of inundation is unknown. In addition, there are plants which often germinate in temporary water bodies after the water has dried out (for example Cyperus fuscus) but which rarely, if ever grow in water. Therefore, the decision was taken to extend the range of taxa included to cover species such as Phyla nodiflora, which is restricted to the edge of shallow semi-permanent and permanent water courses, as well as Isoetes olympica which is capable of growing in shallow, seasonally inundated depressions (and has even been found in a wet corner of a vineyard). Thus, the aim of the project was to consider the conservation requirements of all plants occurring in the Eastern Mediterranean region which can be considered to be dependent upon wetlands; that is species which would not occur if there were no wetlands.

A fundamental principle of these assessments was not to pre-judge the conservation condition, such as by selecting species known or believed to be of conservation concern, as this approach is likely to support existing areas of concern, but overlook taxa which are not already known to be at risk.

The vascular plant taxa covered by this assessment can be grouped as follows:

- Species which are always completely submerged (obligate submerged aquatics) such as the naiads (Najadaceae).

- Species which are always submerged with sexually reproductive parts emergent (held above the water or at the surface), such as Stuckenia amblyophylla or Groenlandia densa.

- Species which are always emergent, the roots and base of the plant are submerged, but some photosynthetic parts and sexually reproductive parts are held above the water, such as Eleocharis, Schoenoplectus, and Typha species.

- Species which are always floating, without roots or with roots hanging in the water column, such as hornworts (Ceratophyllum sp.) and duckweeds (Lemnaceae).

- Species which are always amphibious, growing from the land over the water or adopting a variety of the above forms, such as some Persicaria species.

- Species which always grow on the margins of wetlands and those associated with ephemeral wetlands.

The following were excluded from the assessment:

- Taxa known or suspected not to be native to the region. However, this distinction is not always straightforward, particularly when considering long established cultivated plants, such as Acorus calamus and Nymphaea species.

- Hybrids and taxa below species level.

- Strict halophytes, again this involves a degree of judgement, there are large areas of the Near and Middle East in which most of the plants of seasonal and some permanent wetlands must be tolerant of quite high salt levels. However, to have included all wetland-dependent vascular plant species, therefore including both coastal and inland halophytes would have significantly increased the number of species beyond the capacity of the project.

There are areas of taxonomic uncertainty affecting wetlanddependent plants, in particular, the taxonomy of Ranunculus subgenus Batrachium is very poorly elucidated and the subject of a number of different concurrent treatments (Lansdown 2007). Equally, there are specimens of a Callitriche from Israel, identified as $C$. mouterdei, which are clearly one of the $C$. hermaphroditica group but not $C$. truncata. No other member of the $C$. hermaphroditica group has been recorded from the region and this is either an undescribed species or a significant 


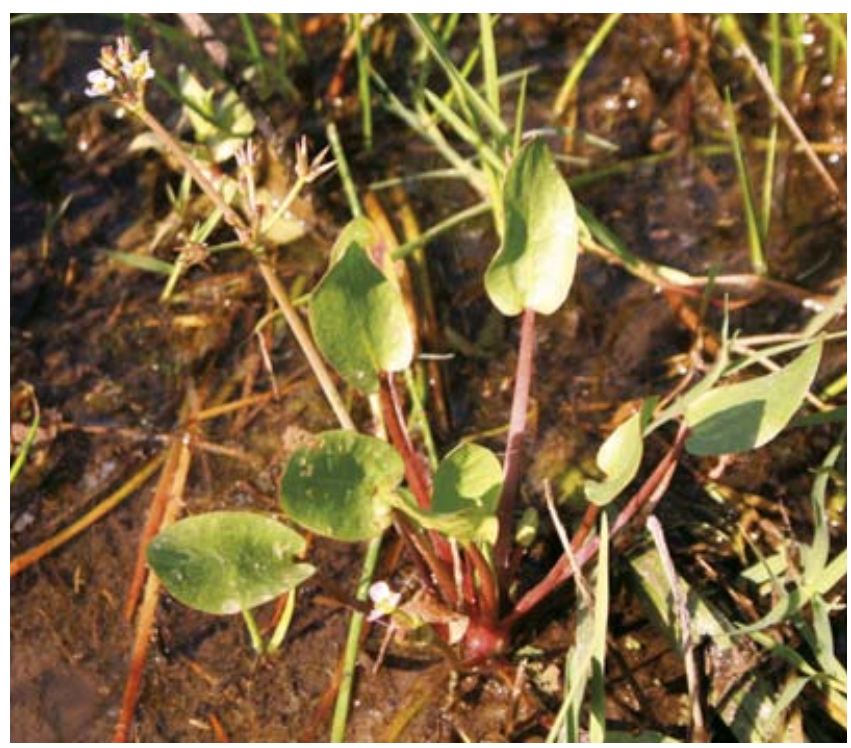

Damasonium bourgaei is widespread throughout the region in suitable habitat, but is not well distinguished from other taxa. Photo $\odot$ R.V. Lansdown

extension in the range of another species. It is also certain that more than one species of Damasonium occurs in the region. There are credible records of $D$. bourgaei from Turkey east to Iran and all previous records of D. alisma appear to refer to this species. However, records of $D$. alisma from inland waters and at medium to high altitude are likely to be of a different species. In the Ceyhan Delta in southern Turkey, D. bourgaei occurred with another unidentified Damasonium species (A.J. Byfield pers. comm.). An unconfirmed record of $D$. polyspermum from the Homs area in Syria (Ewald et al. 2010) would represent a massive range extension for the species and needs to be confirmed before it can be accepted.

\subsection{Limitations of this assessment}

The assessment presented here is a major step forward in gaining an understanding of the conservation status of freshwater plants in the Eastern Mediterranean. However, it is important to note that the information on plants in the region is not uniform and the involvement of regional specialists in the project was in some cases affected by the political instability. Therefore to identify all freshwater plant species for the region, particularly for some lesser studied habitats, taxa, and countries, would involve a considerable amount of time and money far beyond the scope of this project, involving a review of herbaria and a much wider review of literature and engagement with species experts (if political stability allows). As a result, there are a number of areas of bias in this assessment, in particular species from Turkey, and within Turkey, from the coast of the Sea of Marmara have been treated in more detail, and freshwater plants from some habitats and countries have not been fully represented in this assessment. As the project progressed, particularly in the production of this report, a lot of information became available on wetlanddependent plants in the region but too late to be included in the actual Red List assessments.
Therefore the assessment has better representation of species from lowland habitats and countries that are politically stable, and are likely to be relatively common species, or those more restricted range species that are better studied. In addition, a lot of the information (species distribution in particular) may post-date significant levels of wetland modification across lowland areas in the region. Due to these reasons, it is likely that this assessment under-represents the true level of species diversity and threat in the region.

A key recommendation coming from this work is that an additional freshwater plant project is undertaken to fill in the species, habitats, and geographic gaps that exist in this assessment.

\subsection{Wetland dependent plants and wetland habitats in the region}

\subsubsection{Overview}

The region covered by this report extends from the Mediterranean coast to the mountains which straddle the borders of southeastern Turkey, Iran, and Armenia with the highest peak, Mount Ararat (A ğr1 Dağı), exceeding 5,000 m altitude. The northern and eastern parts of the region are dominated by mountains which extend from the Taurus mountains in south-western Turkey, eastward into Armenia and Azerbeijan, and then southeastwards through Iraq to the Persian Gulf (see Figure 2.1). There is a second mountain range which runs along the eastern Mediterranean coast through Syria and Lebanon, south through Mount Hermon on the border between Lebanon and Syria, to Khalil governorate in Palestine. The eastern part of the region is dominated by the floodplains of the Tigris and Euphrates, which arise in the Anti-Taurus Mountains of central Turkey and flow southwards eventually to meet in the marshes of southern Iraq. Most of the region is characterized by dry arid climate, with extensive deserts. The extreme altitudinal range and relationship with the major water bodies: the Mediterranean, the Black Sea, the Caspian Sea, and the Persian Gulf, influence the climate, with consequences for the distribution and extent of wetland habitats. In particular, whilst annual rainfall throughout the region is mainly less than $500 \mathrm{~mm}$, it rises to $2,500 \mathrm{~mm}$ on the Black Sea coast of Turkey. Available information suggests that of the 31 types of natural wetland of the Ramsar Convention classification, the region includes all except three (non-forested peatlands, forested peatlands, and tundra wetlands) (Mirabzadeh 1999). The topography and related elements of the climate drive the nature and distribution of wetland habitats throughout the region, these are described below.

\subsubsection{Wetlands and wetland plants}

High altitude wetlands in the region are mainly represented by wet flushes, seepages, wet peaty depressions or saddle wetlands, and alpine lakes, whilst at the highest levels, nivation (late snowlie) hollows support a range of wetland-dependent bryophytes 
and in the mountains of Lebanon the endemic Ranunculus schweinfurthii (VU) (Rhazi et al. 2010). The highest lakes and tarns typically support few plants, although charophytes, as well as a range of pondweeds, including occasional Stuckenia amblyophylla may occur in deeper water. These water bodies generally also have sparse vegetation on the margins, but occasionally support more diverse vegetation which is usually dominated by Eleocharis palustris (Parolly 2004). Montane lakes and those at medium altitude such as Beyşehir Gölü, Karamik Gölü, Karadiken Gölü, Akşehir, and Eber Gölleri, and in the mountain ranges of Kılıç Dağı, Tecer Dağları, and Munzur Dağları in Turkey support a number of notable species including Baldellia ranunculoides (NT), Salvinia natans, and Thermopsis turcica (CR) (Seçmen and Leblebici 1984, Byfield, Atay, and Özhatay 2010). Montane lakes elsewhere in the region such as Gahar and Neor in Iran probably support a similar range of species, but are poorly known.

Much of the vegetated habitat above the tree line, as well as in open areas in high altitude coniferous woodland is characterized by wet meadows and pasture, dominated by grasses and sedges. In mountain areas such as Sultan Dağları, Kaz Dağı, Silphan Dağı, Ispiriz Dağı, and Yüksekova in Turkey and east into northern Iran these habitats support a wide range of species in swards which can, in places, be remarkably species-rich (Byfield, Atay, and Özhatay 2010). In wetter flushed areas, along the sides of streams and in pools, more wetland-dependent species may also occur (Sharifi $e t$ al. 2014). These nutrient-rich pastures, hay meadows, lawns, wet anthropogenic grasslands and carpet-turfs of wet or periodically flooded sites are broken up by springs and flushes which are often dominated by or have a high representation of bryophytes.

Seepages, springs and the overflows from tarns in the high mountains coalesce to form streams which are initially fastflowing and steep, cutting through rock to form gorges and steep-sided valleys. These are typically dominated by bryophytes, although some vascular plants can also exploit these conditions. Along rivers flowing into the Caspian Sea, the steep rocks and high moisture along deep valleys and gorges support shade tolerant species, particularly ferns (Akhani et al. 2010). Wherever there is a decrease in slope, flow rates in rivers decline and allow the development of sedge and rush dominated marshy habitats (Parolly 2004). As streams become larger, they remain flashy, rising and falling dramatically in response to rainfall and snowmelt, but they begin to develop a wider range of channel habitats, including cobble and pebble bars and islands, eroding banks and cliffs which support diverse acrocarpous moss and liverwort stands, as well as backwaters sheltered from the flow by rock outcrops and bars. In the fastest flowing water courses, it is the backwaters which often support the only populations of obligate aquatic plants.

Shaded wetlands typically support fewer aquatic plants but Alchemilla bursensis (NT) occurs along the margins of streams

Baldellia ranunculoides (NT) is threatened by drainage and destruction of wetlands throughout its range. Photo (c) R.V. Lansdown

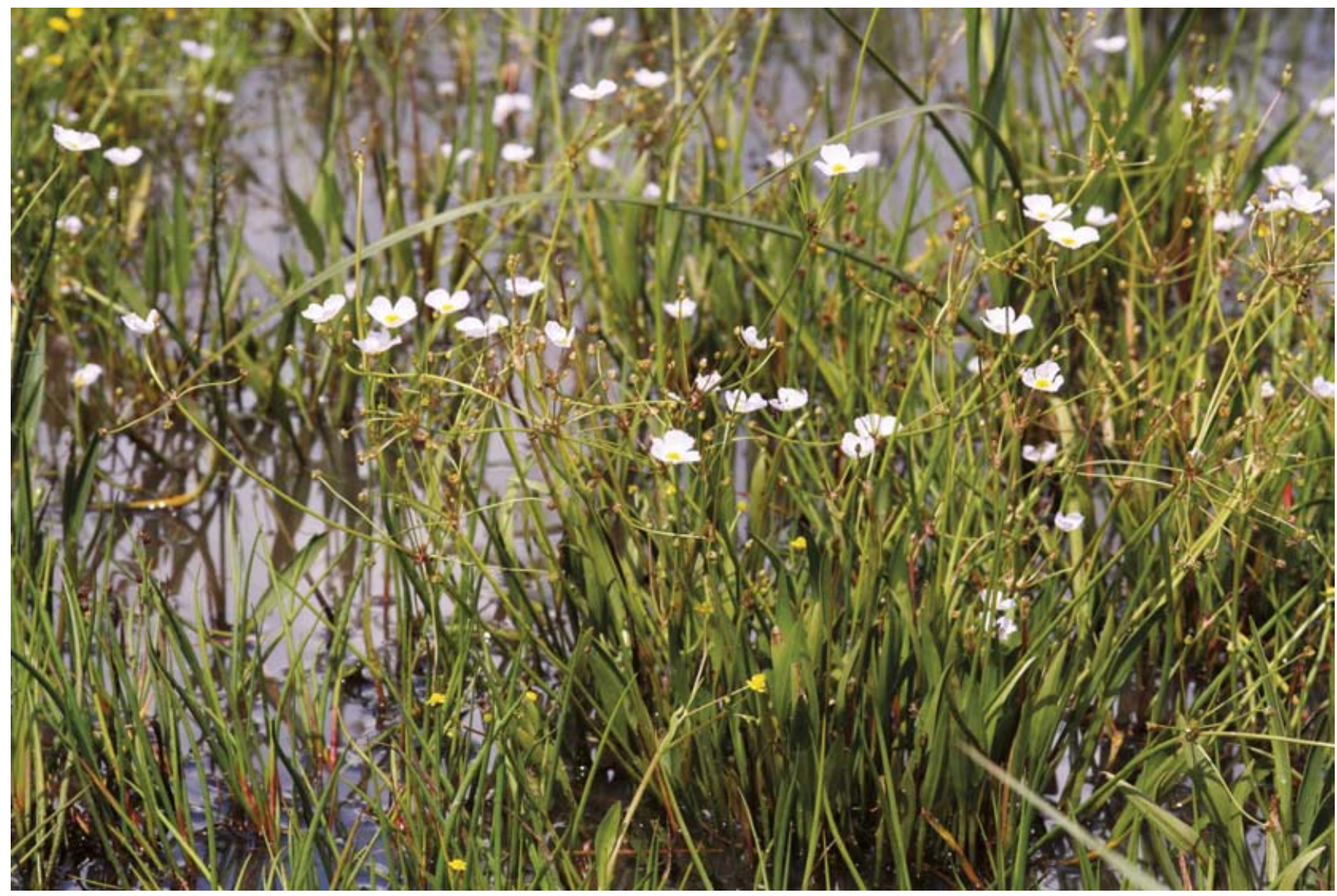




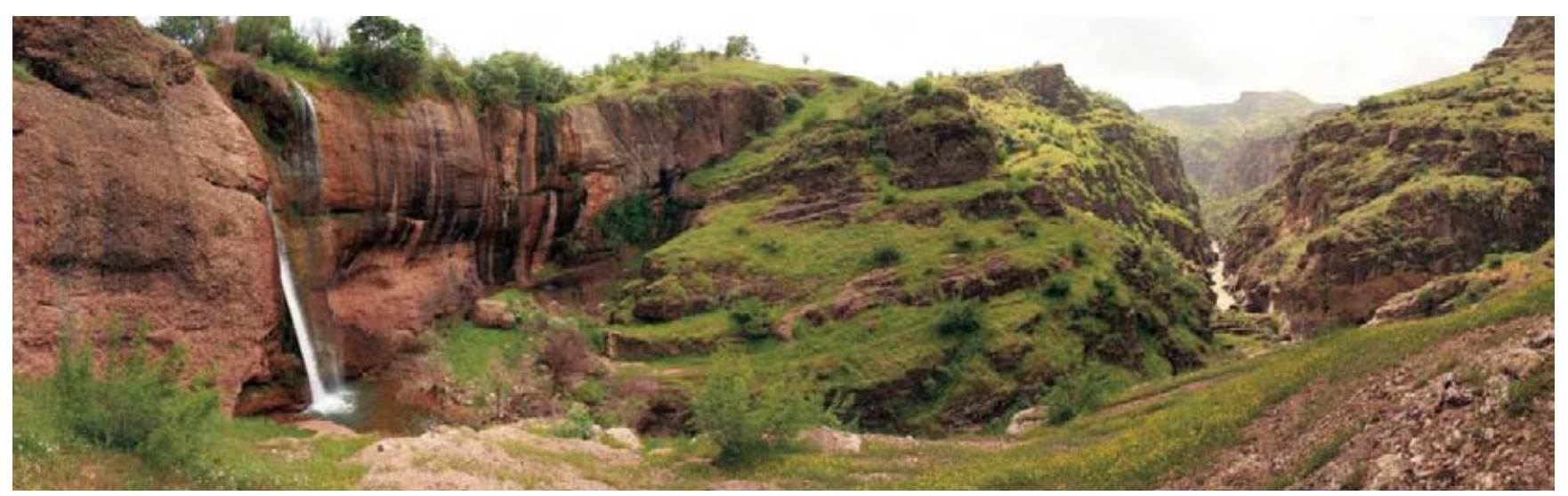

Mawat Gorge in Iraq. Photo $@$ Anna Bachmann

and in bogs in Fagus forest at medium to high altitude in the Amanos Dağları (Mountains) while streams and pools in Pinus nigra forest in Turkey support a variety of wetland species (Kargıoglu 2003). Where there is a build-up of peat at medium to high altitude, wetlands may support a very wide range of wetland-dependent plants, such as in the Sabalan Mountains of north-west Iran (Sharifi et al. 2014) and Akdağ in Turkey. Wherever there are streams or areas of open water in valley bottoms marshes and inundated habitats become more frequent. Extensive peatlands occur in the upper forest zone in the extensive Karadeniz area in north-eastern Turkey (Doğu Karadeniz Dağları) and support a highly diverse range of wetland-dependent species (Byfield, Atay, and Özhatay 2010).

Lakes at medium and low altitude may support beds of submerged and floating vegetation in open water. Most lowland lakes support species-poor associations dominated by $C$. demersum and M. spicatum, with few other species (Akhani et al. 2010, Naqinezhad 2012). Marginal vegetation is often dominated by tall monocots, with a range of smaller species in gaps (Scott 1995). Where the topography allows, marginal vegetation grades through marshes into wet meadows which support a wide range of species. In the richest areas, such as at Yukarı Gerede Vadisi in Turkey, a combination of topography and geology allows development of a wide range of habitats which support a similarly wide range of vegetation associations, including

Mountain riverine habitat in Gali Balnda, Iraq. Photo $\odot$ S. Abdulrahman

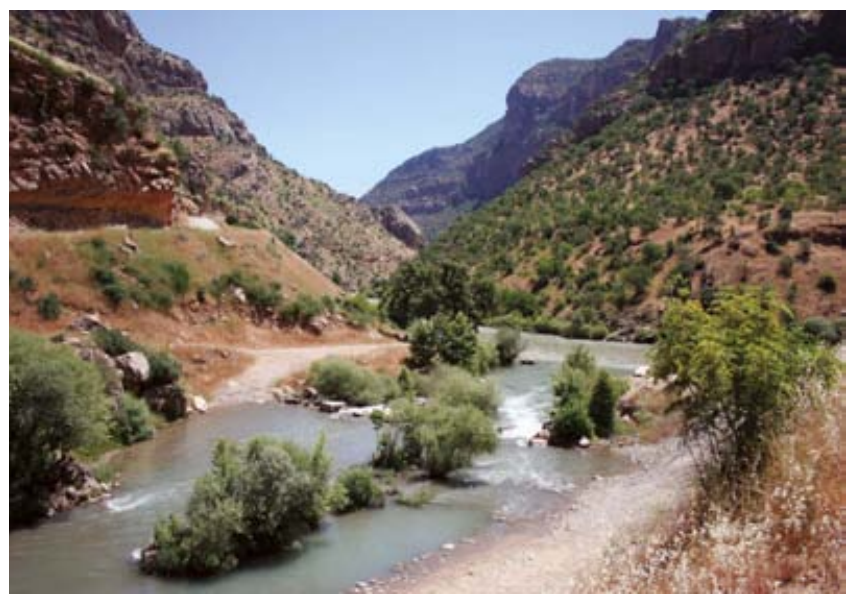

springhead communities, marshes, rich sedge flushes, tussock fen, short sedge fen, and swamp (Byfield, Atay, and Özhatay 2010). The drawdown zones of such lakes may also support diverse wetland-dependent vegetation, such as at Yeniçağa Gölü in Turkey. Lowland marshes support a range of restricted range species including Iris xanthospuria which is endemic to Turkey and has only been confirmed from the marshes of Dalaman Ovas1, although there are unconfirmed reports from Hatay Province. The most abundant plant in wetlands throughout the region is Phragmites australis which may occur as a narrow fringe along streams and rivers, or can form immense beds in places such as Aammiq Wetlands in Lebanon and parts of the restored Mesopotamian marshes. At a smaller scale, marshes occur throughout the region, associated with rivers, streams, lakes, and ponds or simply with impeded drainage resulting from natural topography or human activities.

As slopes become more gentle, river valley sides become less steep and the channels support more vascular plants. Large lowland river systems often include a wide range of habitats for wetland plants, including major marshlands, marginal and floodplain wetlands, oxbow lakes, seasonal peripheral habitats such as pools created by scour during seasonal high flows, as well as riparian and gallery woodland. Lowland rivers also support a wide range of vegetation along their margins. Seasonally flooded sand and gravel banks, such as in

Wad Qana, a permanent stream with rich vegetation, Palestine. Photo (c) B. Al-Sheikh

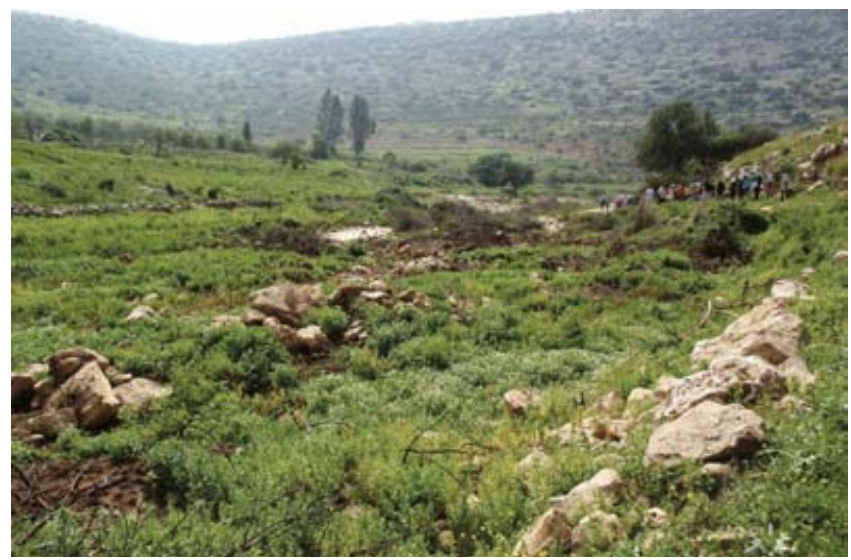


the Yeş1lırmak Delta in Turkey, may support a wide range of species, particularly Cyperaceae.

Ephemeral pools are a vital habitat for wetland plants throughout the region, from the Mediterranean coast where they may occur in dune slacks, in the upper reaches of deltaic systems, and in depressions over less permeable rocks, to upland desertic or steppic habitats. Some originate as stock watering ponds, whilst others are a consequence of impeded drainage or perched water tables. Throughout the region, although they may share some species with the drawdown zones of permanent lakes and ponds, such as Baldellia ranunculoides (NT) and Elatine alsinastrum, (NT) they also support a range of species which are restricted to this habitat, including annual Lythrum species, Ranunculus lateriflorus, and Myosurus minimus. A complex of pools near Homs in Syria and a second site near Biqaa in Lebanon have both been identified as Important Areas for Ponds (IAPs) (Ewald et al. 2010). Two particularly threatened taxa which are dependent upon ephemeral wetlands are Isoetes olympica (CR) and Pilularia minuta (EN). The area supporting Isoetes olympica in Lebanon is Jabal al Arab (also known as Jebel Druze) which is listed as an Important Plant Area (IPA) (Radford, Catullo, and de Montmollin 2011). The IPA is a convex volcanic massif reaching $1800 \mathrm{~m}$ and includes a number of permanent and seasonal pools. The site is threatened by over-exploitation of natural resources, tourism development, and urbanization (Radford, Catullo, and de Montmollin 2011). In contrast to ephemeral pools, most wadis typically only support wetland-dependent plants where they contain pools or lakes. In most cases, they do not hold water frequently enough or for long enough to be important for wetland plants.

Deltas generally represent complex wetland habitats, showing gradation from saline or brackish habitats nearest to the coast, to freshwater marshes inland. However, these systems are often further complicated by braided channels of large rivers which cut through the associated wetlands, providing even greater habitat diversity. Important deltaic systems in the region include those on the Kızılırmak, Yeşılırmak, Büyük Menderes, Göksu, Ceyhan, and Seyhan rivers in Turkey (Byfield, Atay, and Özhatay 2010) and the Shadegan Marshes and tidal mud-flats of Khor-al Amaya and Khor Musa in Iran (Carp 1980).

Habitat of Isoetes olympica in a vineyard near Kfar Noun, northern Lebanon, Inset. I. olympica. Photo (C) L.J. Musselman

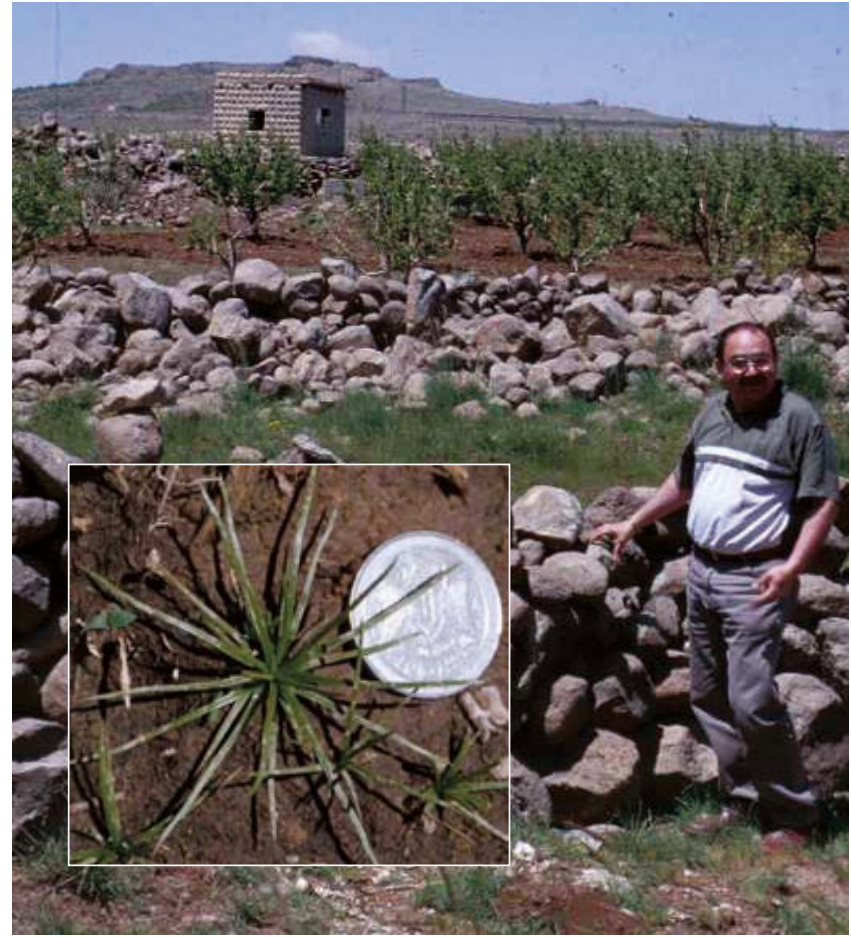

Aammiq Wetlands, Lebanon. Photo $\odot$ Ahmad Houri \& Nisrine Machaka-Houri

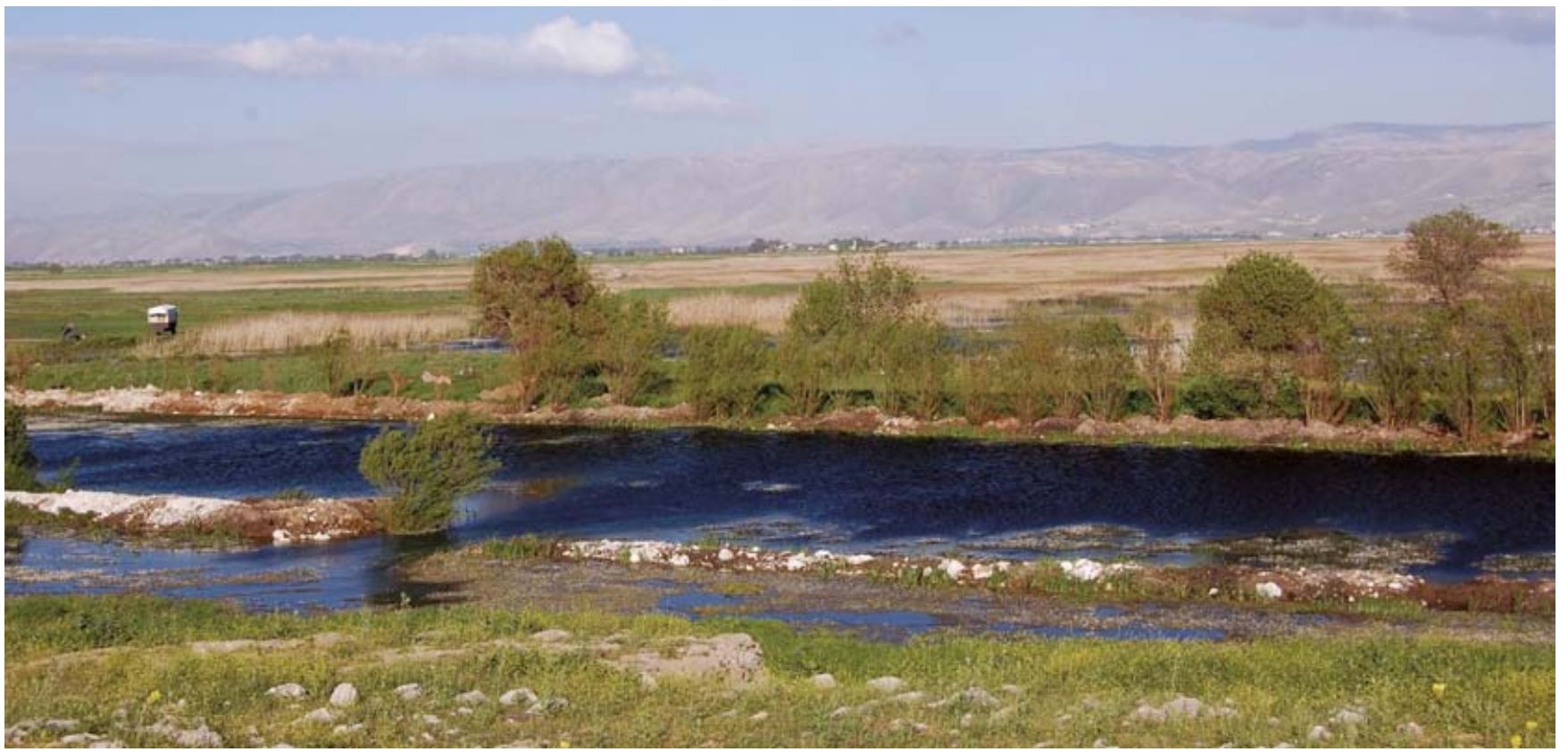




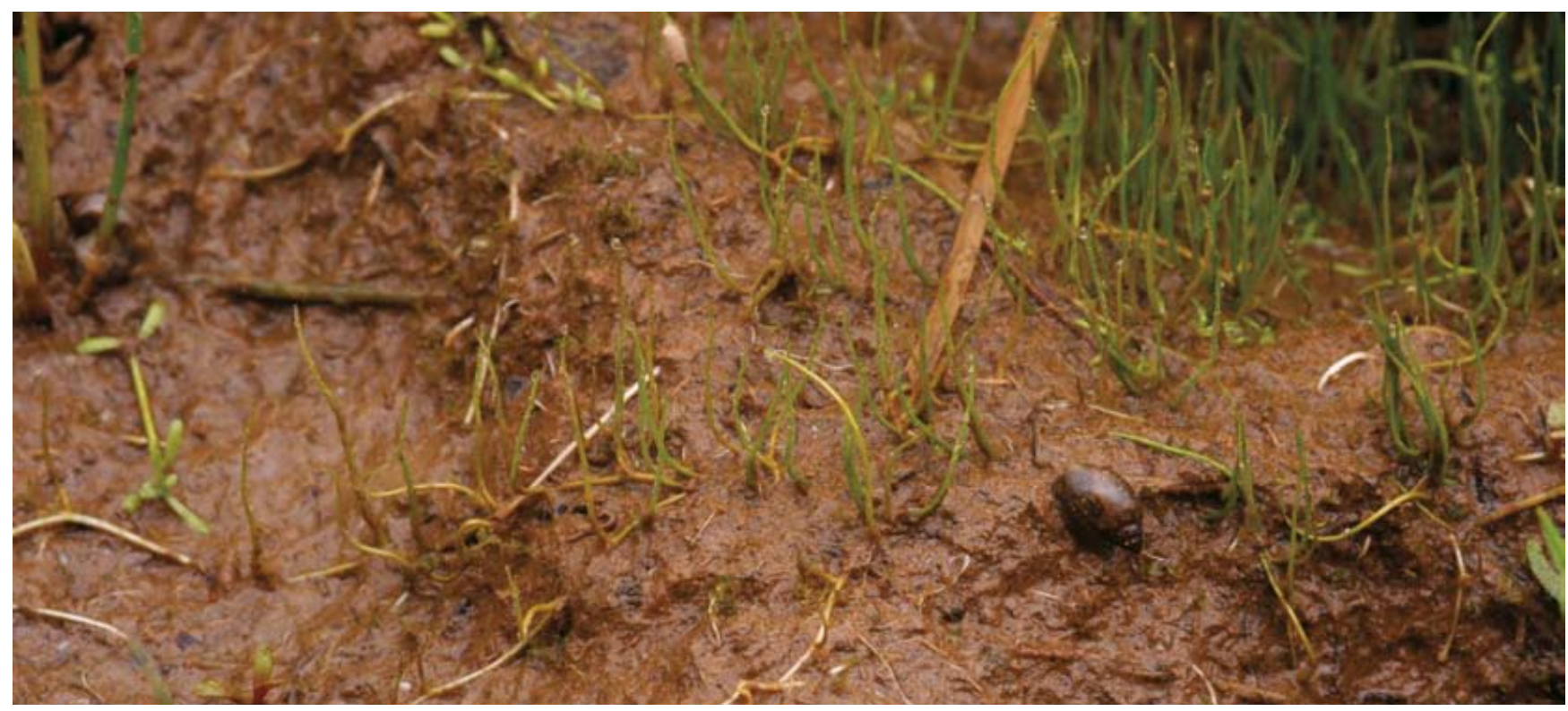

Pilularia minuta $(\mathrm{EN})$ which is threatened throughout its range by destruction of ephemeral wetlands. Photo $\odot$ R.V. Lansdown

It is impossible to draw a clear line between freshwater and saline habitats in the region. Rivers lying in enclosed drainage basins terminate in saline wetlands which are subject to wide fluctuations in water level, often drying out completely. Extensive fresh to brackish marshes occur where rivers and spring-fed streams enter these salt lakes, such as the wetlands of the Sabkat al Jabboul in Syria and the Dead Sea in Palestine, Israel, and Jordan.

As is the case with freshwater lakes, both inland and coastal saline and brackish lakes are often associated with fringing beds of Phragmites australis and other tall monocots. Ruppia maritima and Ceratophyllum demersum are characteristic components of aquatic plant associations in the marshes along inland salt lakes (Al-Jaboul) in Syria, while R. maritima is associated with Arundo donax and Scirpus littoralis in Al-Jaboul Lake (Al-Oudat and Qadir 2011).

Given the long history of human influence in the region, it is not surprising that many artificial wetlands support important plant diversity. In fact in areas such as the Mesopotamian marshes, before the drainage of large areas, human activity was an integral part of the ecology of the wetlands. In other areas, reservoirs and 'artificialized' wetlands (e.g. where water levels have been stabilized by damming) mimic the ecology of natural

Stuckenia pectinata, widespread and abundant in fresh, brackish, and saline wetlands throughout the region. Photo @ R.V. Lansdown

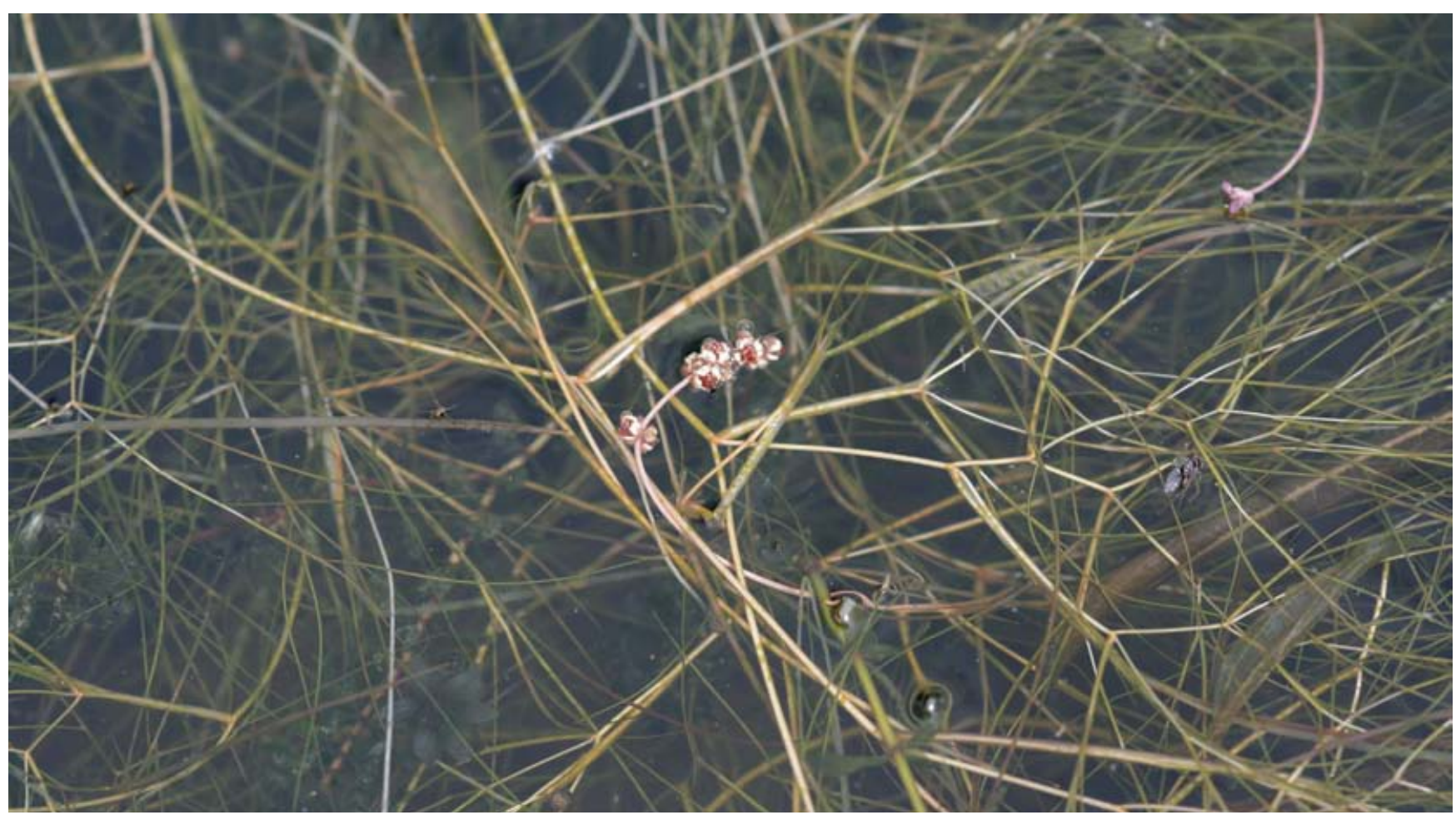


lakes, supporting similar vegetation, with extensive associated seasonally flooded pools, marshes, and seepages such as at Omerli Havzası in Turkey, which supports important populations of Amsonia orientalis and Eleocharis carniolica (Byfield, Atay, and Özhatay 2010). Many reservoirs support very little aquatic or wetland-dependent vegetation because they typically involve drowned steep-sided valleys and are consequently both deep and with very little gradation from adjacent terrestrial habitats to deep water. Occasionally, particularly around the tail of the reservoir, there may be marshy or seasonally inundated habitats supporting wetland plants, or where seepages occurred before flooding, these may survive and support diverse wetlanddependent plant associations.

Throughout the Mediterranean region and east through Asia, rice field systems and their associated irrigation and drainage canals and ditches can also represent important habitats for wetland plants, supporting a wide range of native species as well as non-native species such as Eclipta prostrata, Heteranthera limosa, and H. reniformis. However the weed flora of rice fields is typically dominated by members of the Poaceae and Cyperaceae (Marnotte et al. 2006). Rice field systems can occasionally also support plants of conservation importance such as Baldellia ranunculoides (NT).

Many wetland-dependent plant species are able to survive in wet hollows and other seasonally wet habitats associated with human settlements and agricultural systems. Most of these species are very tolerant and consequently tend to be widespread and abundant; however in some cases where such habitats are associated with long-standing traditional agricultural practices, they may include rare species such as Isoetes olympica (Musselman 2002).

\subsection{Conservation status}

Through this project 364 wetland dependent plants occurring in the Eastern Mediterranean region have been assessed. However, as discussed above (section 6.2) this is a significant underrepresentation of the region's true diversity. Of the extant species where there is sufficient information to identify an extinction risk, only $2.5 \%$ (nine species) are classed as threatened (Figure 6.1). There are an additional five species that are classed as Near Threatened, but no species are classed as Extinct or Extinct in the Wild. For the full list of species assessed, along with their Red List Category see Appendix 2.

The vast majority of the wetland dependent plants assessed (96.1\% / 342 species) are not thought to be close to meeting the criteria for a threatened category and they were therefore assessed as Least Concern. Eight species did not have enough information to be able to identify their level of threat, and were assessed as Data Deficient. It is important to note that the DD species should not be considered as not threatened; the Data Deficient status indicates that more information is needed before their conservation status can be assessed. The likelihood is that some and possibly all may be threatened, which makes the need for more information urgent, for example Lythrum anatolicum which is endemic to Turkey was collected from a single site, Bolu in Düzce Province, south of Efteni (Melen) Lake by E. Leblebici in 1985 and has not been recorded since (Seçmen and Leblebici 1997). There is an urgent need for more information on its population size, the habitat where it was recorded and any threats to the species or the site. If the species still occurs at the site then there is a need for site protection.

Of the species assessed, 20 (5.5\%) are strictly endemic to the region, and if only these species are used, the overall level of threat rises to $31.2 \%$ (five species) (Figure 6.2). However, while Amsonia orientalis is not endemic to the region, the species is possibly extirpated from its only location outside of the Eastern Mediterranean in Greece (Kavak 2014a). Of the endemics exactly half of the species (eight) are assessed as LC, compared to $96.1 \%$ of all species. Four of the eight DD species, and three of the five NT species, are also endemic to the region.

Figure 6.1 Number of species of Eastern Mediterranean wetland dependent plant species in each IUCN Red List Category.

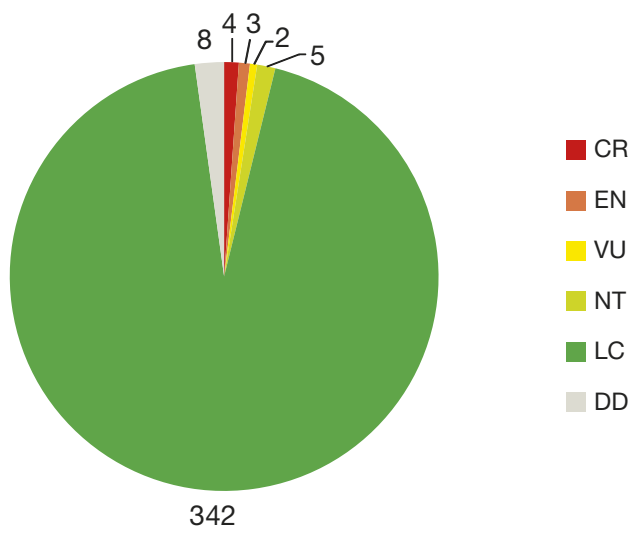

Figure 6.2 Number of species of Eastern Mediterranean endemic wetland dependent plant species in each IUCN Red List Category.

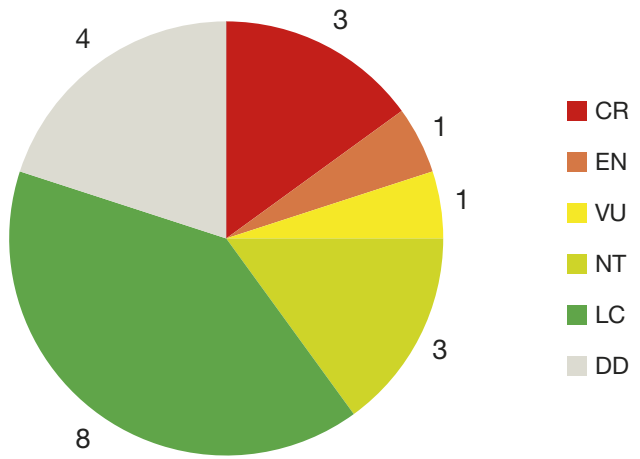


The range of taxa assessed was strongly biased by the dominance of Turkey, both in terms of the proportion of the region that it occupies and because of the availability of information on Turkish plants. Turkey supports most of the threatened and NT species (13 of 14), with four of them being endemic to Turkey and one additional species which is possibly endemic (Table 6.1). Lebanon is the only other country in the region to contain an endemic threatened wetland dependent species. Syria supports one threatened species (Isoetes olympica) and Iraq, Armenia, Azerbaijan, and Georgia all support one NT species. Iran also supports one threatened species (Calamagrostis parsana, also found in Turkey), though its Iranian location is outside the assessment region (Figure 2.1).

\subsection{Patterns of species richness}

Due to the lack of readily available information on the distribution of wetland dependent plant species within the region, the majority of species could not be mapped to sub-basins and have been mapped to countries of occurrence. Only the threatened and Near Threatened species could be linked to more precise localities allowing them to be mapped to sub-basins. In addition these results need to be viewed in light of the limitations of the assessment (see section 6.2), meaning that all figures presented in this section are an under-representation of true species diversity.

\subsubsection{All freshwater plant species}

Turkey has by far the highest proportion of the wetland dependent plant species assessed within the region, with 306 species. However it is important to note that only parts of Iran and Georgia, with 156 and 150 species (second and third highest), were included in the assessment so these countries (particularly Iran) will have a much higher number of species than is reported here. All the countries of the Levant possess a similar level of richness, all having between 57 (Jordan) and 114 (Lebanon). Iraq supports 105 wetland dependent plant species, and Azerbaijan and Armenia support 73 and 76 species respectively.

Table 6.1 The Threatened and Near Threatened wetland dependent plant species of the Eastern Mediterranean region.

\begin{tabular}{|c|c|c|c|c|}
\hline Family & Species & $\begin{array}{l}\text { RL } \\
\text { Cat. }\end{array}$ & Distribution & Key Threats \\
\hline Apocynaceae & Amsonia orientalis & $\mathrm{CR}$ & Turkey and Greece (possibly extinct) & $\begin{array}{l}\text { Over-harvesting } \\
\text { Urban development }\end{array}$ \\
\hline Compositae & Sonchus erzincanicus & $\mathrm{CR}$ & Turkey & $\begin{array}{l}\text { Droughts } \\
\text { Grazing } \\
\text { Urban development and pollution }\end{array}$ \\
\hline Isoetaceae & Isoetes olympica & $\mathrm{CR}$ & Syria and Turkey (possibly extinct) & $\begin{array}{l}\text { Agricultural expansion } \\
\text { Grazing } \\
\text { Tourism development }\end{array}$ \\
\hline Leguminosae & Thermopsis turcica & $\mathrm{CR}$ & Turkey & $\begin{array}{l}\text { Agricultural expansion } \\
\text { Grazing } \\
\text { Water abstraction }\end{array}$ \\
\hline Gramineae & Calamagrostis parsana & EN & Iran and Turkey & Grazing \\
\hline Marsileaceae & Pilularia minuta & EN & Mediterranean wide (incl. Turkey) & $\begin{array}{l}\text { Agricultural expansion } \\
\text { Grazing } \\
\text { Urban development }\end{array}$ \\
\hline Polygonaceae & Rumex bithynicus & EN & Turkey & $\begin{array}{l}\text { Dams } \\
\text { Fire management (reeds) } \\
\text { Pollution (agriculture and urban) }\end{array}$ \\
\hline Ranunculaceae & Ranunculus schweinfurthii & $\mathrm{VU}$ & Lebanon & Tourism development and activities \\
\hline Ranunculaceae & Ranunculus thracicus & $\mathrm{VU}^{*}$ & Greece and Turkey & $\begin{array}{l}\text { Forestry } \\
\text { Urban development and pollution } \\
\text { Tourism development }\end{array}$ \\
\hline Alismataceae & Baldellia ranunculoides & NT & Europe, North Africa, and Turkey & $\begin{array}{l}\text { Agricultural expansion and pollution } \\
\text { Urban development }\end{array}$ \\
\hline Cyperaceae & Carex iraqensis & NT & Iraq and Turkey & Grazing (possible threat) \\
\hline Elatinaceae & Elatine alsinastrum & NT & Europe to Asia (incl. Israel and Turkey) & $\begin{array}{l}\text { Agricultural expansion } \\
\text { Ecosystem modifications }\end{array}$ \\
\hline Orchidaceae & Dactylorhiza euxina & NT & Armenia, Azerbaijan, Georgia, and Turkey & Overharvesting \\
\hline Rosaceae & Alchemilla bursensis & NT & Turkey & $\begin{array}{l}\text { Deforestation } \\
\text { Climate change }\end{array}$ \\
\hline
\end{tabular}

* Indicates that the Red List category assigned to the species is based on a draft assessment and may change before it is published. 


\subsubsection{Threatened freshwater plant species}

Of the nine threatened wetland dependent plant species assessed, four occur in areas surrounding the Sea of Marmara in northwestern Turkey and the Ömerli Basin, east of Istanbul is the only sub-basin in the region to contain more than one threatened species (Figure 6.3). Amsonia orientalis (Blue star) (CR) has been recorded from one locality in Greece, and a number of locations in Turkey, however its status in Greece is now uncertain and it has been extirpated through over-harvesting for ornamental use combined with habitat loss and degradation from all but one location in the Ömerli Basin (Kavak 2014a). The other threatened species found in the Ömerli Basin is Ranunculus thracicus (VU draft Red List assessment) which is only known from four localities around Istanbul, and a restricted number of locations in Greece. It is threatened in Turkey by afforestation of its seasonally flooded habitats and by urban development (Kavak in prep.). The two other species found around the Sea of Marmara are Rumex bithynicus (EN), endemic to Turkey, with three records in northwestern Turkey including Lake Iznik but also a record from the Ceyhan Delta in southern Turkey, and Isoetes olympica (CR) which is known only from Mount Olympus where it is possibly extinct, and another distant location in the Jabal Al-Arab (Jebel Druze) in southern Syria. Rumex bithynicus is threatened by agricultural and urban pollution and possibly also by the Hersek
Dam, and impacts of reed bed burning (Kavak 2014b). Isoetes olympica is likely to have been lost from Mount Olympia due to ski resort developments, and is affected by grazing at Jabal AlArab (Jebel Druze) in Syria (Daoud-Bouattour et al. 2010).

Two threatened species occur in eastern Anatolia, Turkey: Calamagrostis parsana (EN) is only known from two sites in the south-eastern Taurus Mountains of Turkey and four sites in the Alborz Mountains in northern Iran (outside the assessment region). Although this species is affected by intensive grazing pressure it is likely to be more widespread and under-recorded (Akhani 2014). Sonchus erzincanicus (CR) is endemic to a single marsh site at Erzincan where it is affected by a number of threats including urban and agricultural pollution, as well as droughts (Kavak 2014c). Thermopsis turcica (CR) is endemic to marshy habitats on the shores of two close lakes in western Central Anatolia, Eber, and Akşehir, where it is threatened by water abstraction and the conversion of wetland habitats for agriculture (Kavak 2014d). Pilularia minuta (EN) is widespread across the Mediterranean, with its only population within the Eastern Mediterranean being close to Izmir in the Aegean Region of Turkey. It has a very localized and fragmented distribution and is declining due to the vulnerability of its low elevation temporary pools habitats which are often drained for agriculture or urban development. The western slopes of the Lebanese mountains

Figure 6.3 Eastern Mediterranean threatened freshwater plant species richness. Species richness = number of species per subbasin (defined by HydroBASINS ‘Level 8', Lehner and Grill 2013).

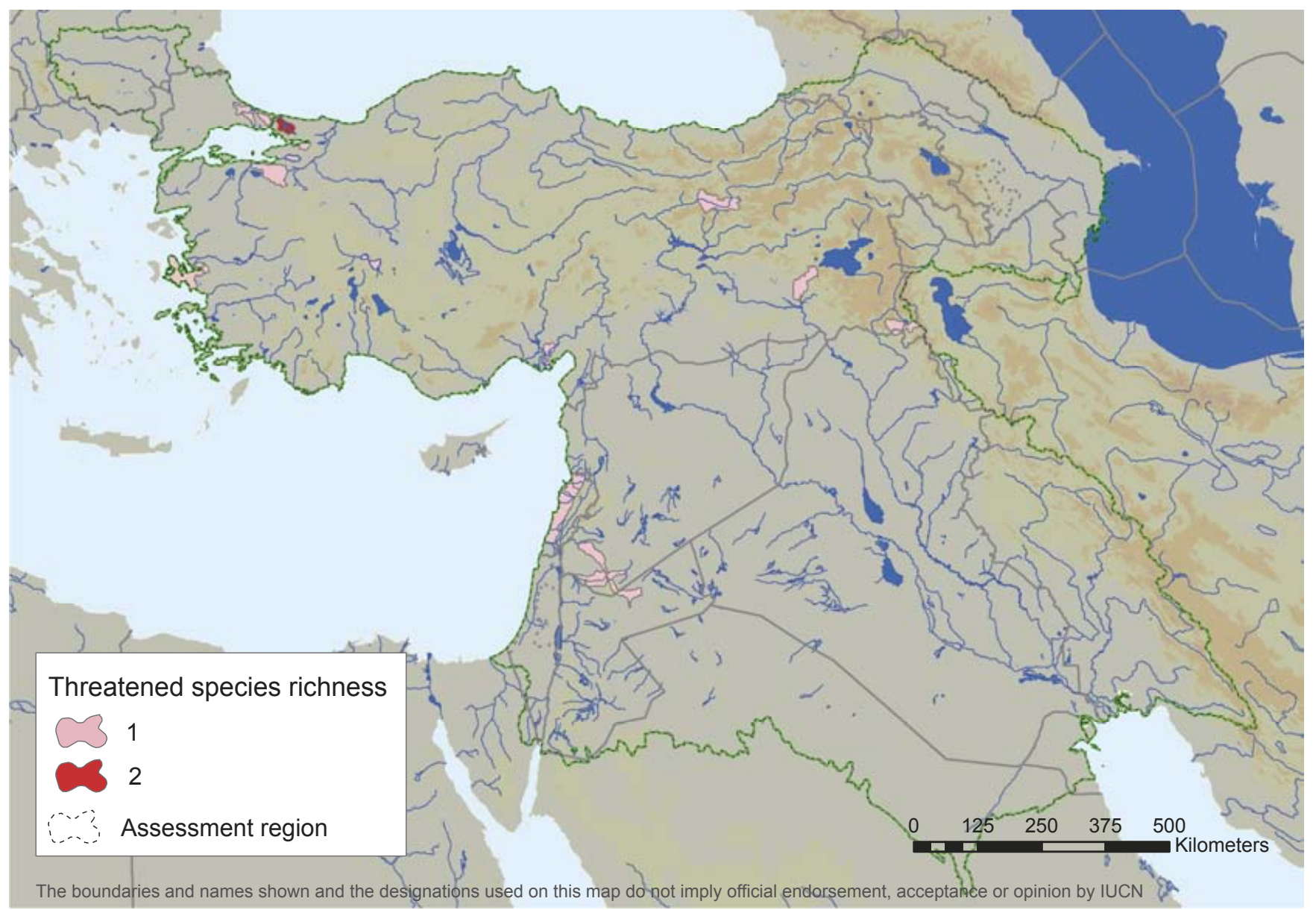


are the only other area in the region to support a threatened wetland dependent plant species, Ranunculus schweinfurthii (VU). This species is endemic to Lebanon and known from only four locations/sub-populations, which are thought to be in a good and stable condition but are highly susceptible to tourist developments in the area (Rhazi et al. 2010).

\subsection{Major threats to wetland-dependent plants}

\subsubsection{Factors affecting threatened species}

The IUCN Red List uses a standardized classification of threats (for more information see http://www.iucnredlist.org/technicaldocuments/classification-schemes, and Salafskyetal.2008), based on these results, the main threats affecting the most threatened and Near Threatened wetland-dependent plant species are urban development (50\% of species) and agricultural expansion (64\% of species) (Figure 6.4). Biological resource use (over-harvesting), disturbance from humans (e.g. tourist activities), natural system modifications (fire regimes, or dams and water abstraction), and pollution all affect between $20 \%$ and $30 \%$ of threatened and NT species. Whilst it is certain that agricultural expansion is a significant threat to wetlands throughout the region, the reason for the high importance of urban development is because a high proportion of the threatened species occur around the Sea of Marmara which is undergoing significant urban expansion.

The main threats to wetland-dependent plants species are described below. In addition to these, parts of the region have suffered internal or international conflict for decades and there is no prospect of an end to this in the foreseeable future. Such conflict has dramatic and far-reaching impacts on wildlife, over and above the human impacts (Dudley et al. 2002). Not only does conflict risk weakening or negating any site management and protection, but pressure on human populations forces people to prioritize survival over conservation considerations. Movement of armaments and bombardment can eliminate important sites for conservation and much of the infrastructure controlling pollution breaks down. At the time of writing, there are refugee camps in many areas providing some shelter for refugees from conflict in Syria, those in the Biqaa region are very likely to be destroying the complexes of ponds identified as an IAP (Ewald et al. 2010). Obviously, human needs should and do take priority, but the impact on wildlife must be recognized and if possible mitigated.

\subsubsection{Drainage and conversion to urban or agricultural use}

Historically, this region has possibly seen the longest relationship between settled human communities and wetlands. Whilst this has led to the development of unintensive traditional exploitation of wetland resources, it has also seen a very long history of their modification and exploitation. Since the start of the 20th century, there has been an increase in both the level and the rate of destruction of semi-natural habitats throughout the region (e.g. see Davidson 2014). The massive destruction and degradation of the Mesopotamian marshes during the regime of Saddam Hussein is well known, however, recent work monitoring the recovery of vegetation (Alwan 2006, Hamdan et al. 2010) suggests that whilst reasonably diverse, the marshes supported no threatened plant species before drainage, and also that more than half of the species recorded prior to the draining have either survived or re-colonized.
Figure 6.4 Drivers of threats affecting threatened and Near Threatened freshwater plant species of the Eastern Mediterranean region.

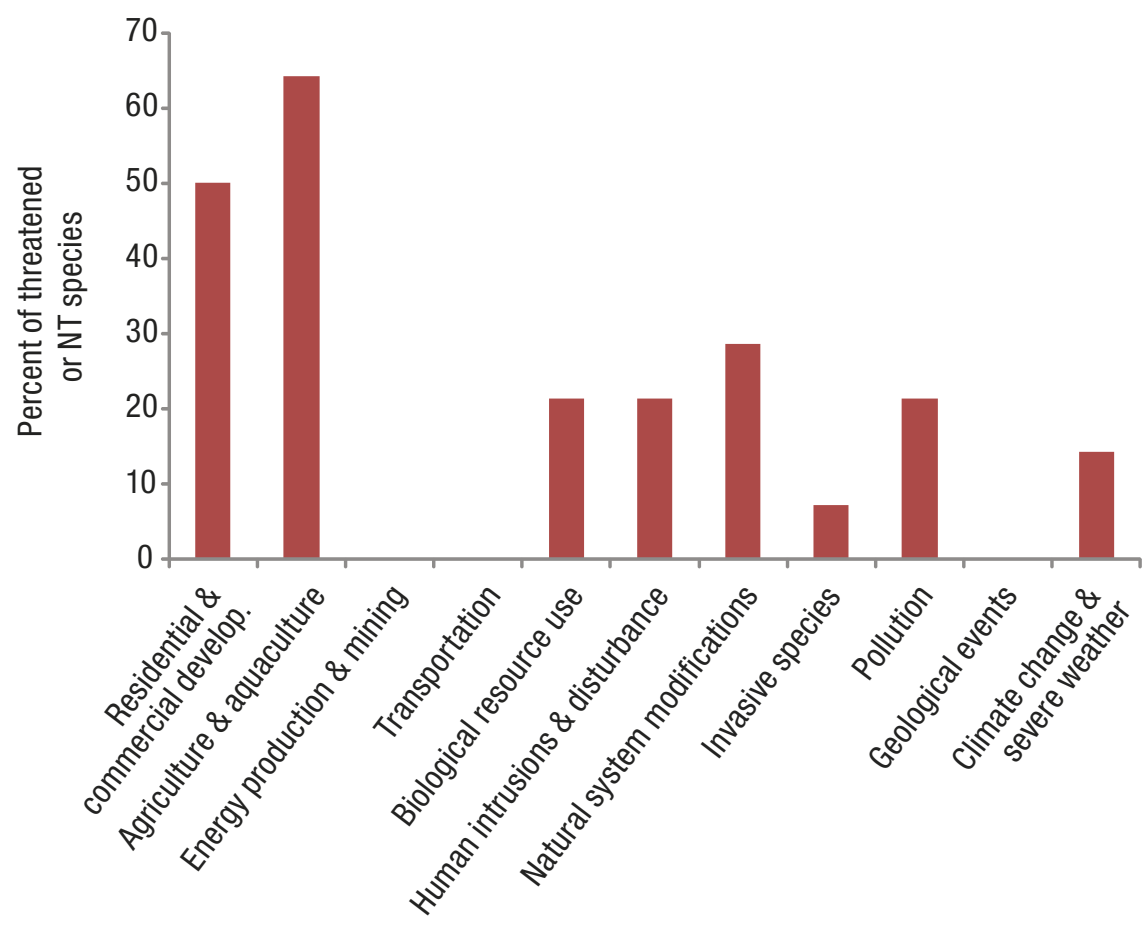


Drainage of massive wetland systems in the region has not been limited to the Mesopotamian marshes. The northern end of the rift valley runs from East Africa up the eastern coast of the Mediterranean into Turkey, creating large, low-lying areas. Historically, these included some of the most important wetland complexes in the region. In Turkey the most significant of these was the Amik Lake and its related wetlands (see Kilic et al. 2006, Çalişkan 2008, Lansdown 2010, Ozelkan, Avci, and Karaman 2011) which covered an area of approximately $53 \mathrm{~km}^{2}$ in 1972 , which increased during flood periods and was surrounded by extensive marshland created by episodic floods and silting up of the outlet to the Orontes River. In the past, it provided food security and construction materials and supported livelihoods for local communities. A major drainage project, channelling the lake's tributary rivers directly to the Orontes was undertaken from 1966 by the State Hydraulic Works, with further works completed by the early 1970 s. Draining and reclamation of areas around the lake commenced in 1940 and by the early 1970s most of the lake had been drained with only isolated fragments remaining, and by 2007 Hatay Airport had been constructed in the centre of the former lakebed. The drainage has had only limited success, with frequent flooding (including some leading to closure of the airport) and salinization of land converted to cotton production. The destruction of the Amik Lake and its related wetlands has led to the loss of vital ecosystem goods and services, and biodiversity (Kilic et al. 2006). While the remnant fragments of Amik Lake (known as Gölbaşı Lake) still support some wetland plant diversity and provide habitat for migrating birds, searches in recent years have failed to find any of the endemic taxa, all of which are thought to be extinct. The site now supports a wide range of non-native plants probably introduced by local people. In spite of the significant losses, restoration work

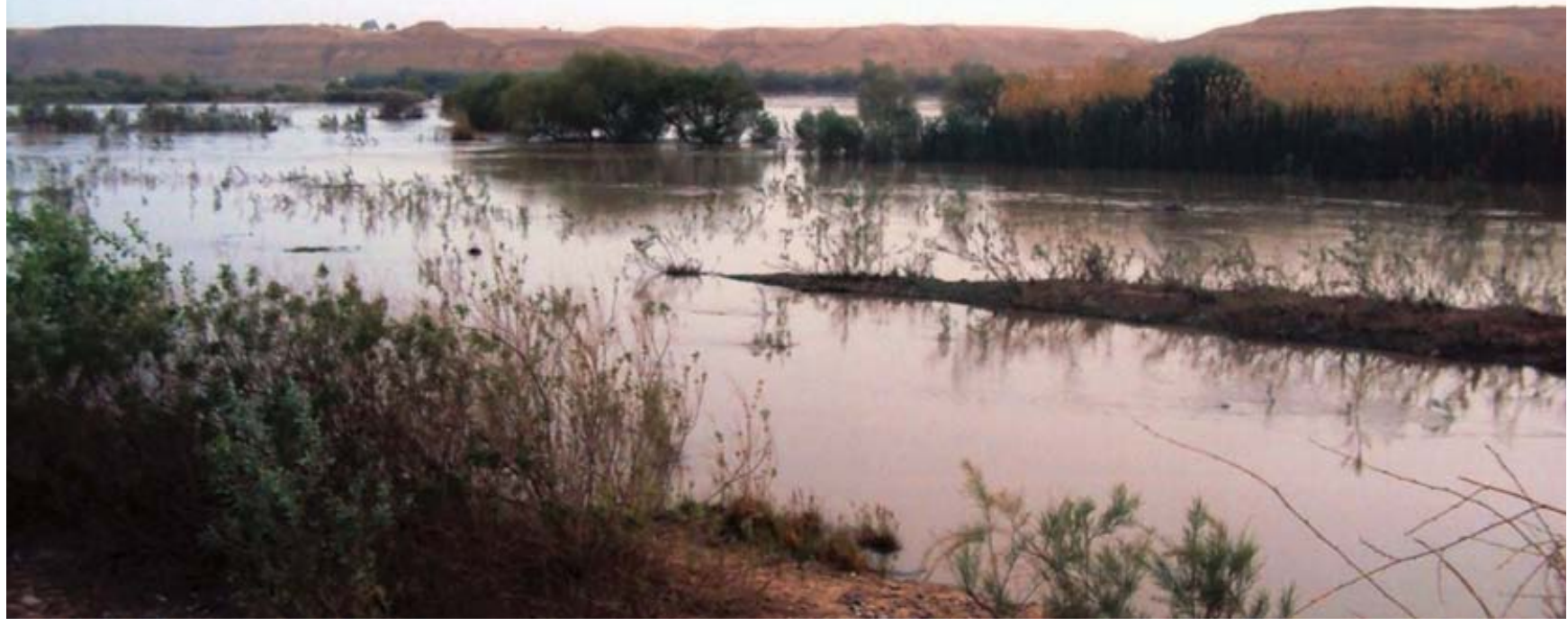

Seasonal wetlands at Pano Teeb in the Mesopotamian Marshes in Iraq. Photo ( ) M.A. Salim

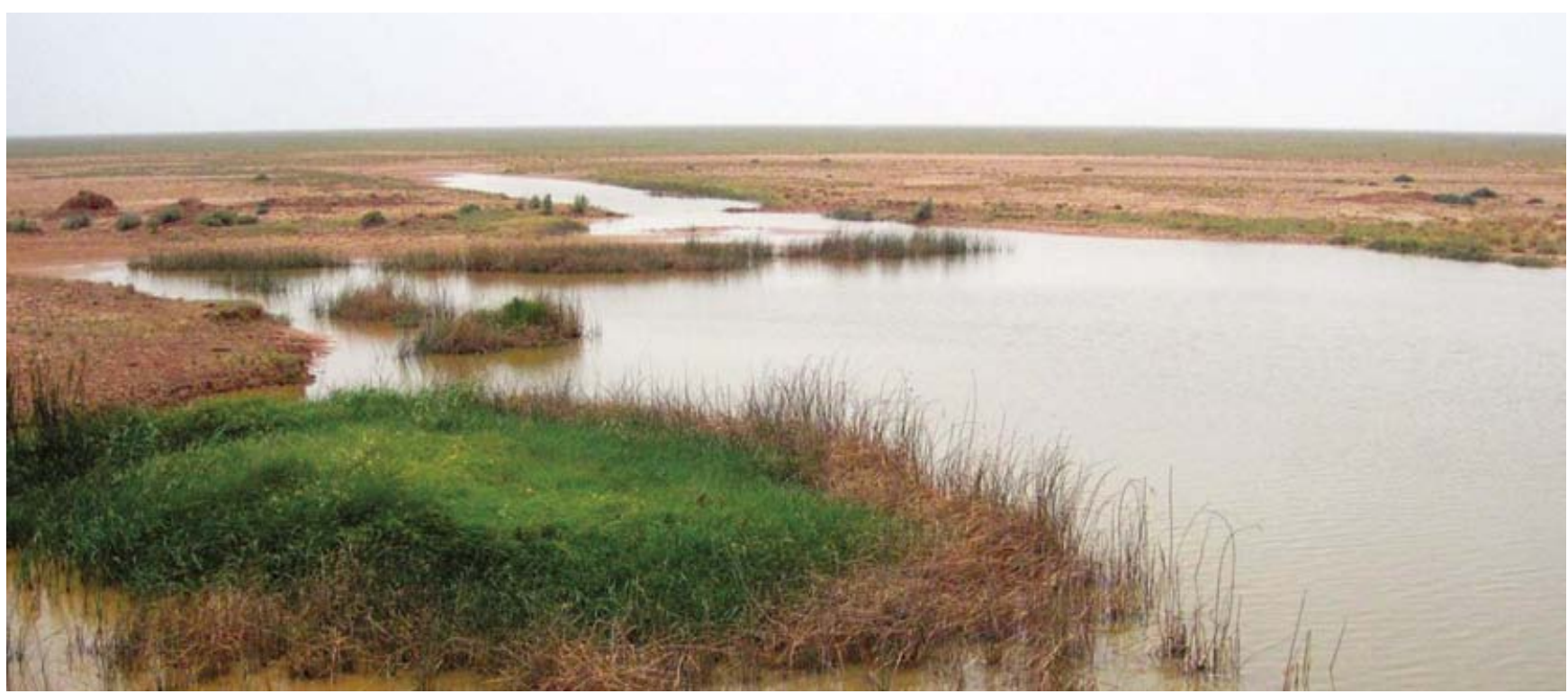




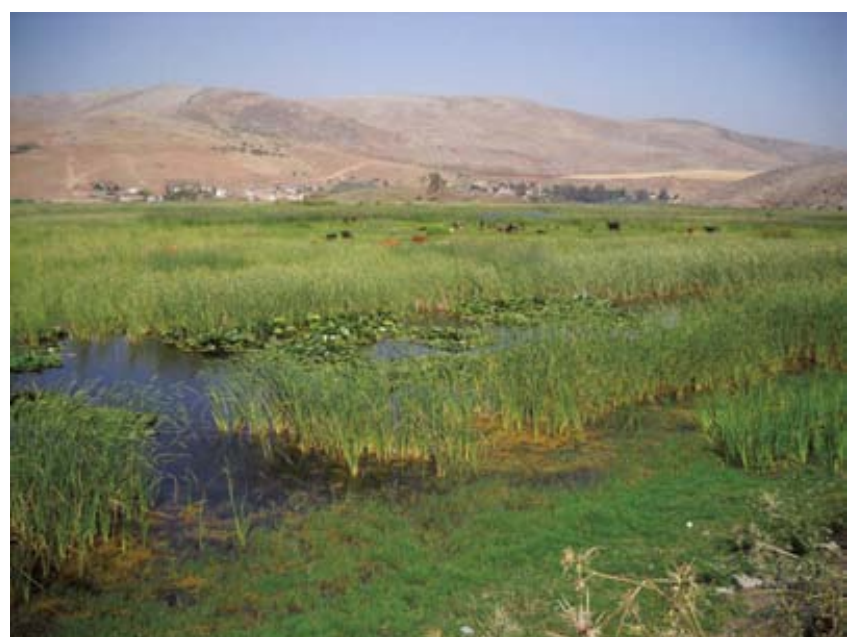

Gölbaşı Lake, a small remnant of the former Amik Lake in Hatay Province, Turkey. Photo $\odot$ M. Çenet

could re-create a complex of marshes and other wetland habitats which could both be of international conservation value and provide significant income from eco-tourism.

Further south along the rift valley in northern Israel, Lake Hula and its wetlands were also drained in the 1950s and 1960s. Massive wetland areas were lost with the extinction from Israel of a number of wetland plant species, including Berula erecta, Marsilea minuta, and Nymphaea alba (Radford, Catullo, and de Montmollin 2011). As is the case with the former Amik Lake, marginal springs still flow and retain some wetland plant diversity. In recent years, extensive wetlands have been restored in the Hula Valley which has led to the return of large numbers of common crane (Grus grus). However a number of wetland plants such as Butomus umbellatus, Nymphaea alba, and Utricularia australis have failed to recolonize, in particular, reintroduction attempts have so far failed to restore Marsilea minuta or Utricularia australis (Hamdan et al. 2010).

\subsubsection{Habitat loss and degradation}

Throughout the long history of human activity in the region there has always been some loss and modification of wetland habitats, but in general humans typically exploited wetlands and the species that they supported without destroying them. Since the start of the 20th century massive wetland drainage and destruction has occurred in a number of areas. There is still a significant level of wetland degradation and modification, such as construction of dams on rivers and the expansion of urban and agricultural land use. It is equally true that throughout much of the region, wetlands are perceived as wasted land and there is a greater tendency for efforts to focus on reducing these habitats to the smallest possible area, rather than their protection or even low-intensity exploitation. There is also a general lack of awareness of the importance of wetlands and the ecosystem services they provide. This lack of awareness is shown by the significant amounts of discharged untreated waste water and nutrient-rich run-off from agricultural land into water bodies across the region and the effects of uncontrolled tourism and associated development. For example, it is common for people to picnic along the edges of the Aammiq wetland in Lebanon, where they often use trees to shelter fires from the wind for cooking and in many cases, the fires have slowly but steadily eaten through the bark of the trees, weakening and sometimes killing them (see photo).

In Turkey the uncontrolled movement of people in areas supporting threatened plants has resulted in the overexploitation of plants for sale for ornamental use or food, which has had a significant effect on some species, including Amsonia orientalis. In addition, around many wetlands such as Sultan Marshes, and lakes Eber and Akşehir, reeds have been seen as a constraint on the expansion of agriculture and they are often cut or burnt. Throughout the region there is still extensive use of tall wetland monocots such as Phragmites australis and Typha species for house construction and in places this can lead to the degradation of beds of tall monocots. Another aspect of this lack of awareness can be seen by the burning of reed beds to flush out birds for hunting. Massive bird hunting in Aammiq resulted in the proliferation of snakes in the wetland in unprecedented scale; the balance was fortunately restored when a strict hunting ban was enforced a few years ago, after the area was declared a

Tree burnt by fires, Aammiq Wetland, Lebanon. Photo $\odot$ Ahmad Houri \& Nisrine Machaka-Houri

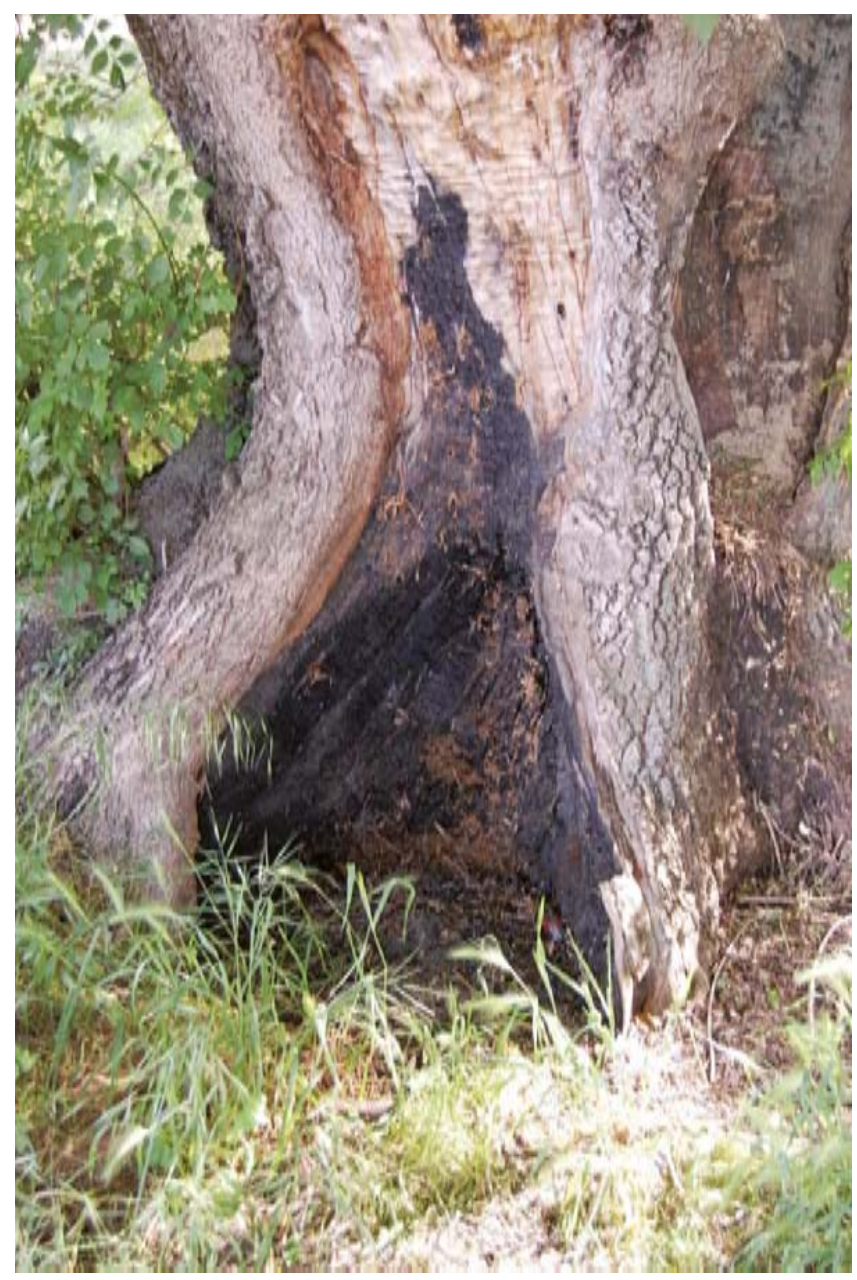


reserve. This has not always been the case in other wetlands in the region where elimination of birds has had a direct impact on the insect population with consequent knock-on effects on plant pollination and propagation. A lack of, or poor implementation of, planning controls has also allowed the casual destruction and degradation of wetlands. In many areas, private landowners have been able to modify their land through construction, farming, grazing, and other activities with little or no state control.

Overgrazing is one of the most important threats to the wetland ecosystems since the abundance of water and the associated plants provide an extremely suitable habitat to an otherwise water-poor region. In fact historic and ongoing over-grazing has completely altered the character of much of the region, increasing desertification to the extent that vast areas are more or less bare. The lack of relevant protective laws and their enforcement, has contributed to this problem. Climate change has resulted in reduced levels of rainfall in the Eastern Mediterranean. This has applied additional pressure to already over-stretched water resources, with the needs of settlements, industry, and agriculture taking priority over conservation, even though conservation of natural wetlands can significantly improve water quality. Many wetlands throughout the region also support large populations of non-native aquatic plants. It is likely that humans have modified the vegetation of water bodies in the region for millennia, to the extent that it is impossible to establish the true native distribution of some taxa, such as Acorus calamus and some Nymphaea species. Most water bodies support some aliens and it is notable that nonnative aquatic plants occurred in the Mesopotamian marshes both before drainage and after restoration. Some invasive species such as Azolla filiculoides are very widespread and cover entire water bodies excluding light to submerged plants, however this is generally a relatively short-lived phenomenon. In contrast the invasion of Ludwigia grandiflora, which is present in

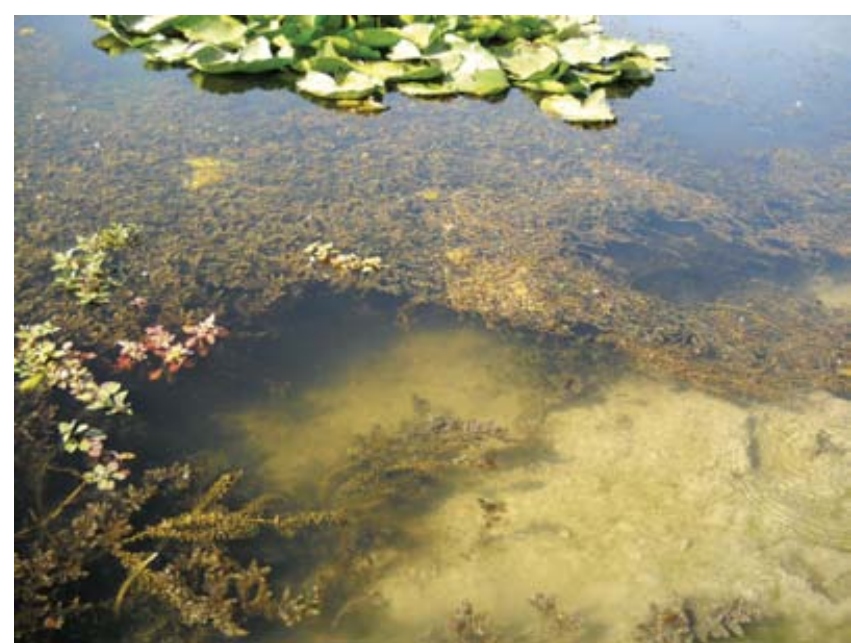

Non-native species in a remnant of Amik Lake in Hatay Province, Turkey, including Hydrilla verticillata, Ludwigia grandiflora, and a Nymphaea cultivar. Photo $\odot \mathrm{M}$. Çenet

Gölbaşı Lake in Hatay Province in Turkey, can lead to a longterm modification of wetland vegetation and processes.

\subsubsection{Modification of water courses and hydrological regimes}

Apart from simple drainage or infilling of standing waters, the modification of wetland regimes falls into three classes:

- Construction of weirs and dams across rivers, resulting in conversion of parts of the flowing system to a standing system, eliminating or modifying the seasonal amplitude in variation of flows and levels, disrupting erosion-deposition processes and interrupting transport of propagules (potentially both downstream with flow and upstream in the digestive systems

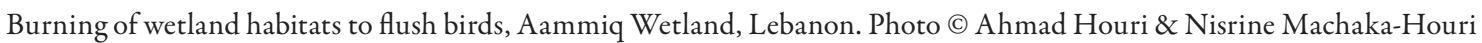

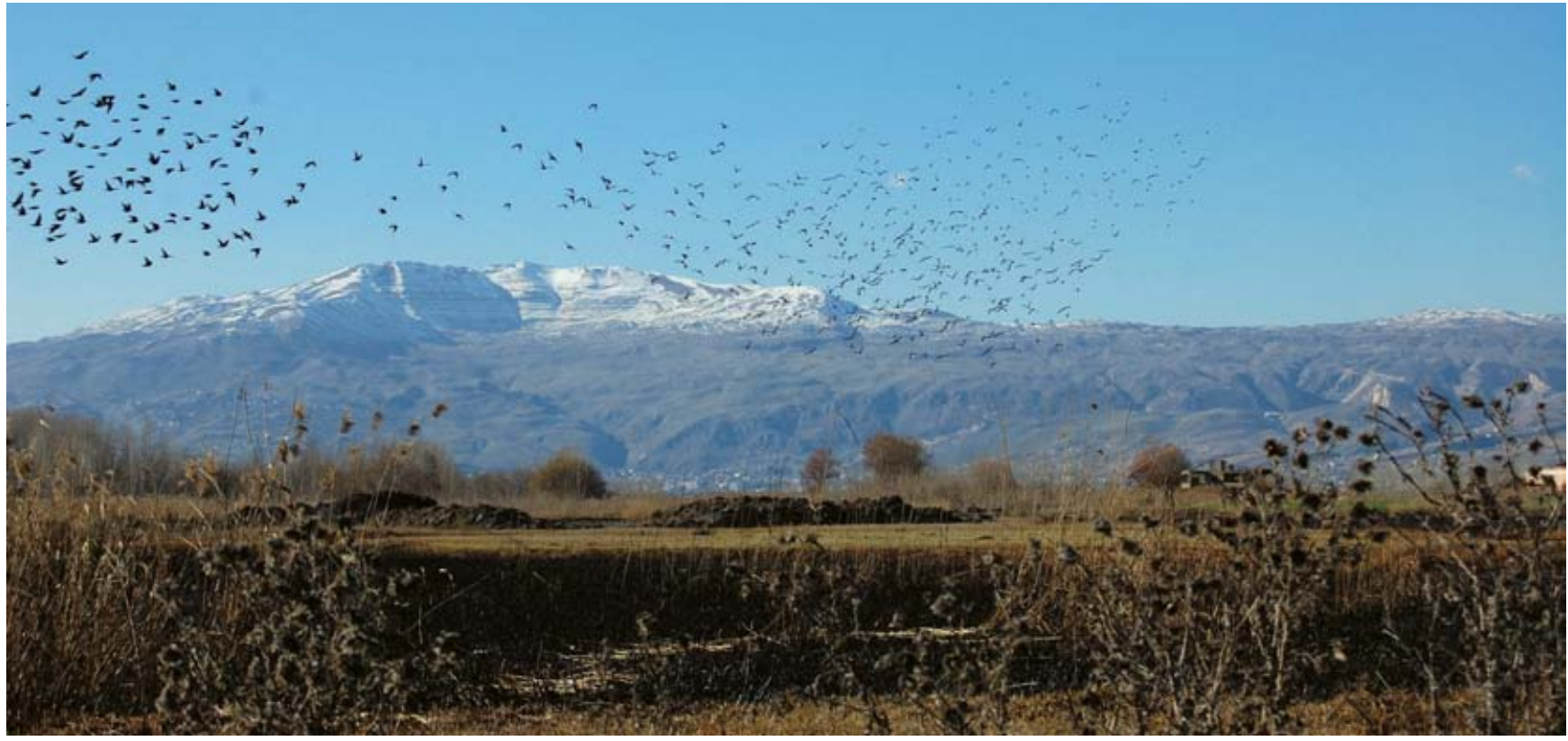


of fish). The Orontes, Jordan, Tigris, and Euphrates river basins have all been heavily dammed and the water diverted for agricultural needs (see AQUASTAT 2009).

- Stabilization of the hydrological regimes resulting in the conversion of seasonal or ephemeral pools to permanent ponds and reservoirs. This is one of the actions which has the most severe impacts on wetland-dependent plant species' diversity throughout the world, because it results in the replacement of diverse specialist associations which are driven by varying inundation duration and able to compete with more aggressive perennial plants due to extreme conditions, with a combination of true aquatics and perennial marginal plants.

- Channelization, diversion, and replacement of natural channels with artificial substrates. The most frequent effect of these actions is to reduce habitat diversity for wetland plants by destroying marginal wetlands, such as backwaters, oxbows, seasonally inundated habitats associated with river channels and floodplain wetlands. For example, flow diversion has drastically reduced the flow into Aammiq Wetland in Lebanon and directed the water directly into the main Litani River.

\subsubsection{Over-abstraction}

The Azraq Wetland in Jordan is another example of dramatic loss and degradation of a wetland in the region. This was an oasis with extensive marshland and natural water that formed 'glittering pools and streams'. Excessive pumping of water from the oasis to large urban areas and the illegal drilling of artesian wells for agricultural purposes has caused water levels to drop over the last 50 years, starting in the early 1980s. This overabstraction has led to extreme depletion of the oasis, drying up massive areas of wetlands. With international support, the Royal Society for the Conservation of Nature (RSCN) began a rescue effort in 1994, managing to restore a significant portion of the wetland and aims to restore depleted water levels by $10 \%$. So far, this target has not been achieved because of continued water pumping, and only $5.5 \%$ of the original wetland has been

Part of Wadi Elmalih, Palestine which has been reduced to a trickle due to over-abstraction. Photo $\odot$ B. Al-Sheikh

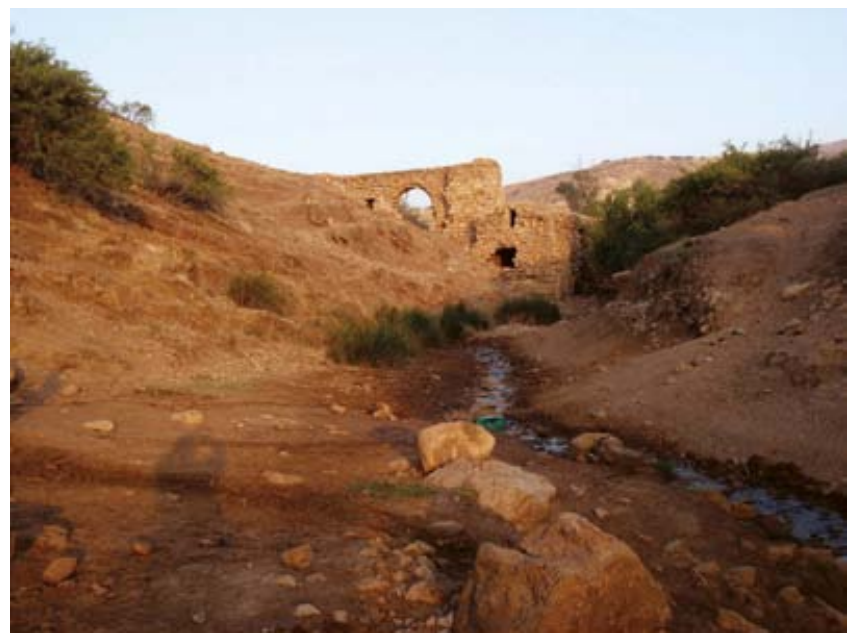

restored (Freyhof and Harrison 2014). Aammiq is probably the most important wetland area in Lebanon and its area has been greatly reduced by water abstraction to supply an ever increasing population and more intensive agricultural activities. This wetland used to spread over a large part of the Biqaa area but is now mostly dry for a large part of the year. A number of wells are pumping water from ground water sources and a major spring which supported the wetlands has been diverted for drinking water. In another area, slightly north of Aammiq, another wetland exists in Kfarzabad which is also under similar threats. Similarly, in Palestine, tributaries of the Jordan River and a number of springs have dried out as a result of over-abstraction; these springs and tributaries only flow when there is heavy continuous rain for days.

\subsubsection{Water pollution}

As a result of the high population density in the region, inadequate treatment, and the generally weak sewer networks, water bodies in general, and wetlands in particular, suffer from severe pollution from sewage, industrial wastewater discharge, and often diffuse run-off from agriculture involving fertilizer, pesticides, and sediment (Jurdi et al 2002, Houri and El Jeblawi 2007). Hyper-eutrophication of water courses is frequent throughout the region as pollution increases and fresh water replenishment decreases. Many wetlands also suffer from the disposal of solid waste resulting from uncontrolled tourism.

\subsection{Conservation actions and recommendations}

\subsubsection{Conservation actions in place}

Most countries in the region are signatories to international conventions, such as the Barcelona Agreement (1981), Paris Agreement (1983), Bern Agreement (1984), Ramsar Convention (1994), Convention on Biological Diversity (1992), and

Dense growth of filamentous green algae, caused by hypereutrophication, Oustouan River, Lebanon. Photo (c) Ahmad Houri \& Nisrine Machaka-Houri

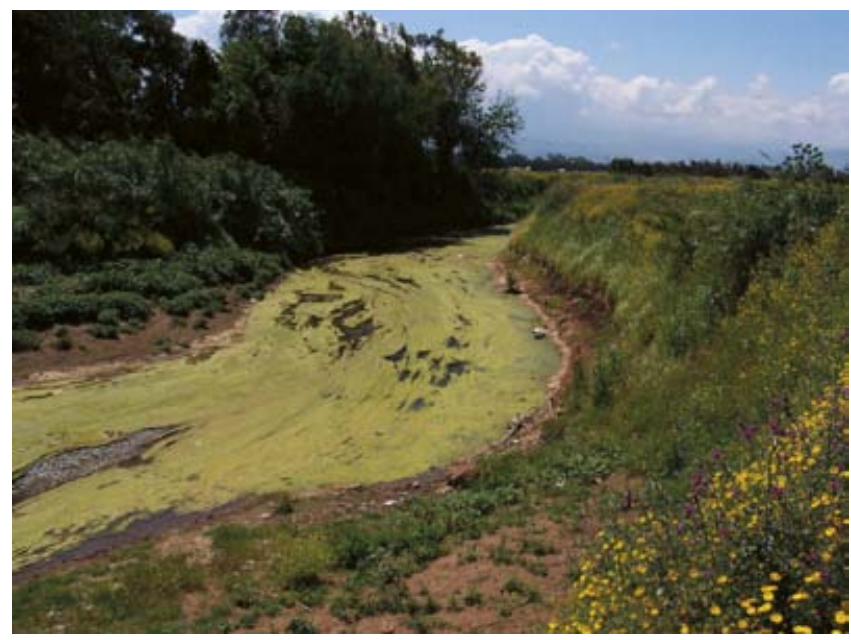




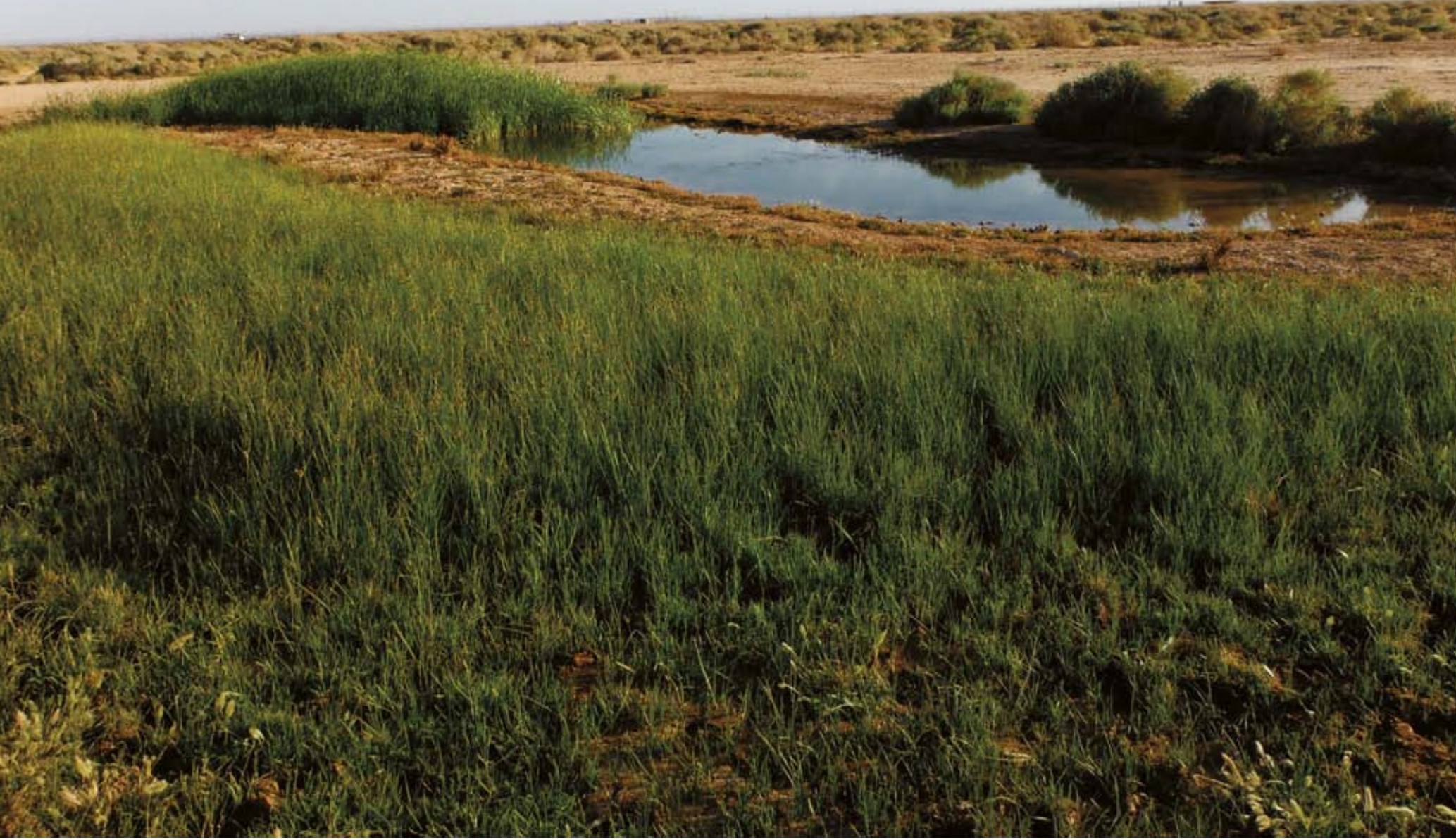

Small artificial pool in Wadi Rum where livestock grazing is precluded. Photo @ R.V. Lansdown

European Landscape Convention (2003) (Karadeniz, Tiril, and Bayland 2009). In addition, a wide range of initiatives documenting natural habitats, including wetlands, are under way in the region, for example a collaboration between the Ministry of Environment and Nature Iraq is in the process of publishing an account of Key Biodiversity Areas of Iraq (Iraq Ministry of Environment and Nature Iraq In prep), Important Plant Areas have been identified for most countries in the region (Byfield, Atay, and Özhatay 2010, Radford, Catullo, and de Montmollin 2011) and Important Areas for Ponds have been identified in Israel, Lebanon, and Syria (Ewald et al. 2010). Also freshwater Key Biodiversity Areas have been identified for the whole Eastern Mediterranean region and wider Mediterranean Basin Hotspot through this project (Darwall et al. 2014). All of these combine to help inform conservation of wetland dependent plants and site protection, as well as often enabling or informing the infrastructure necessary to establish protected areas.

All countries in the region have protected wetland areas for conservation, for example in Turkey the Regulation for Protection of the Wetlands was published in 2002 and revised in 2005, defining different zones of protection (Karadeniz, Tiril, and Baylan 2009), and most other countries have similar structures in place.

There are also a large number of NGOs and many governmental bodies actively working for conservation in the region. For example, Nature Iraq has been active in the preparation of the KBA report and in restoration of the Mesopotamian marshes, in collaboration with many other organizations. Similarly, in Lebanon, A Rocha has been working on introducing improved management techniques which helped reduce the threats of agricultural expansion and water extraction and stop habitat reduction of the wetland (Yazbek et al. 2010), and the Society for the Protection of Nature in Lebanon (SPNL), has been involved in habitat restoration of the Kfarzabad wetlands. In Turkey, the Nezahat Gökyiğit Botanical Garden in İstanbul has established ex-situ conservation for Thermopsis turcica, whilst in-situ conservation is being implemented by the General Directorate of Nature Conservation and National Parks and a new conservation action plan for the species will be implemented between 2014 and 2024 by the Republic of Turkey Ministry of Water Affairs and Forestry. In Jordan, work undertaken at Wadi Rum has shown that reduction of grazing pressure can lead to dramatic development of vegetation over otherwise bare areas, leading to increased humidity and the development of wetlands. This work is now being expanded by raising awareness among nomadic herders and has potential to dramatically alter the current distribution and character of wetlands.

\subsubsection{Recommendations}

The most important steps to address the conservation needs of wetland-dependent plants in the region are to complete the Red List assessments for wetland-dependent plants in the region, by preparing assessments for all the taxa not included in this project and then to use those data to produce a conservation action plan for wetland-dependent plants in the region. Without 
these two actions, the information provided by IUCN Red List assessments to inform conservation of wetland plants in the region will be limited.

Other actions in the region which are clearly needed include increasing the network of wetland sites which are protected for conservation of wetland plants using sources such as the KBA for Iraq (Iraqi Ministry of Environment and Nature Iraq In prep), the IPAs for the south and east Mediterranean region (Radford, Catullo, and de Montmollin 2010), Turkey (Byfield, Atay, and Özhatay 2010) and Lebanon (Yazbek et al. 2010), the IAP for the Mediterranean and Alpine Arc (Ewald et al. 2010), and the freshwater KBAs for the Mediterranean Basin Hotspot (Darwall et al. 2014). This protection needs to be backed by national legislation, it needs to involve local communities with re-allocation of land rights if necessary, and needs to include the creation of protected buffer zones to provide physical and chemical protection to the areas of greatest importance and vulnerability.

There is also a need for further work on habitat restoration. In particular, restoration of parts of the former Amik Lake could still enable recovery of important wetland plant associations, whilst the potential diversity of many other sites in the region could probably still be restored. One of the major problems with wetland conservation in the region is lack of awareness of the values of wetlands across stakeholder groups, who often see wetlands as wasted ground, the potential source of problems such as mosquitoes, and as a suitable repository for waste water and other waste products. This attitude can only be changed through increasing the awareness of the benefits of clean, healthy wetland systems, in particular emphasis on the health benefits of access to clean water without the need for expensive treatment. This awareness raising needs to engage with all groups, including women and children, for example through educational visits to wetlands such as those that happen at Azraq Wetland Reserve in Jordan.

It is widely accepted that ecotourism, when well-managed, can provide benefits to local communities at the sites involved, as opposed to the small number of affluent individuals who tend to benefit from the destruction of wetlands. However, there is a need to inform ecotourism through the publication of identification guides and other interpretation materials, such as the guides to the wild flowers of the Lebanon (Houri and Machaka-Houri 2001, Houri and Machaka-Houri 2008).

Any initiatives to conserve wetland-dependent plants in the region will need funding and would benefit from access to the best available knowledge and experience in the subject. Support for capacity building by international funding organizations will be fundamental if these actions are to have any real impact.

\subsubsection{Field research, monitoring, and taxonomic studies needed}

Wetlands in the region suffer from a lack of thorough and systematic research into their flora and fauna and there are still many taxonomic questions to be answered. Field research should be the basis for determining the conservation status of wetlands and the species which they support as well as potential to improve this status. The number of unconfirmed records of wetland dependent plants across the region shows that there is a need for long term surveys by competent specialists. These

Part of the Azraq Wetland Reserve, showing access facilities for tourists and environmental education, Jordan. Photo $\odot$ R.V. Lansdown

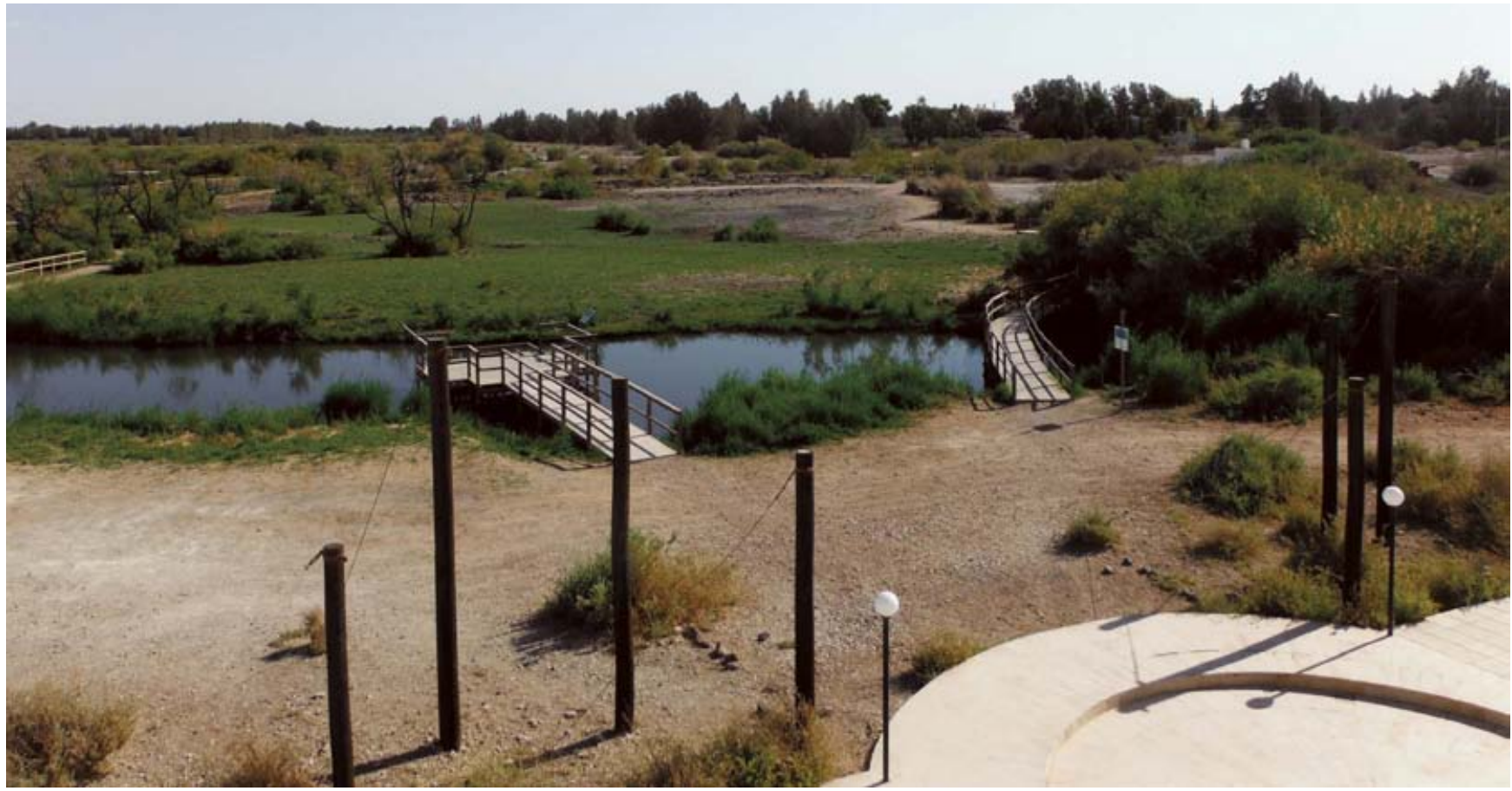


studies should also focus on the ecological linkages between water availability, plant, and animal population in a quantitative and qualitative way.

\section{Acknowledgements}

The authors would like to thank the following people for their help with this report: Nabeel Abduhasan, Haifaa Abdulhalim, Ioannis Bazos Halil Çakan, and Sabina Knees for background information, Banan Al-Sheikh for comments on an earlier draft, Sema Atay for the generous gift of a copy of the Turkish IPA, Anna Bachmann for her valuable help in many ways, including providing access to images, as well as Lytton John Musselman and Menderes Çenet for allowing us to use their images.

\subsection{References}

Akhani, H. 2014. Calamagrostisparsana. The IUCN Red List of Threatened Species. Version 2014.2. <www.iucnredlist.org>. Downloaded on 10 September 2014.

Akhani, H., Djamali, M., Ghorbanalizadehi, A and Ramezani, E. 2010 Plant biodiversity of hyrcanian relict forests, N. Iran: An overview of the flora, vegetation, palaeoecology and conservation. Pakistan Journal of Botany Special Issue (S.I. Ali memorial) 42: 231-258.

Al-Oudat, M. and Qadir, M. 2011 The halophyticflora of Syria. International Center for Agricultural Research in the Dry Areas, Aleppo, Syria.

Alwan, A.R.A. 2006 Past and present status of the aquatic plants of the marshlands of Iraq. Marsh Bulletin 1(2): 160-172.

AQUASTAT. 2009. Irrigation in the Middle East region in figures. Frenken K. (ed.) AQUASTAT Survey 2008. FAO Water Reports \#34, Rome, Italy.

Byfield, A., Atay, S. and Özhatay, N. 2010. Important Plant Areas in Turkey: 122 Key Turkish Botanical Sites. WWF Turkey, Istanbul, Turkey.

Çalişkan, V. 2008. Human-Induced Wetland Degradation: A case study of Lake Amik (Southern Turkey). BALWOIS 2008 Ohrid, Republic of Macedonia.

Carp, E. 1980. A Directory of Western Palearctic Wetlands. UNEP, Nairobi, Kenya and IUCN, Gland, Switzerland.

Cook, C.D.K. 1996. Aquatic and wetland plants of India. Oxford University Press, Oxford, UK.

Daoud-Bouattour, A., Gammar-Ghrabi, Z., Limam-Ben Saad, S. and Muller, S.D. 2010. Isoetes olympica. The IUCN Red List of Threatened Species. Version 2014.2. <www.iucnredlist.org>. Downloaded on 10 September 2014.

Darwall W., Carrizo S., Numa C., Barrios V., Freyhof J. and Smith K. 2014. Freshwater Key Biodiversity Areas in the Mediterranean Basin Hotspot. Informing species conservation and development planning in freshwater ecosystems. IUCN, Cambridge, UK and Malaga, Spain.

Davidson, N.C. 2014. How much wetland has the world lost? Long-term and recent trends in global wetland area. Marine and Freshwater Research 65(10):934-941.

Dudley, J.P., Ginsber, J.R., Plumtre, A.J., Hart, J.A. and Campos, L.C. 2002. Effects of war and civil strife on wildlife and wildlife habitats. Conservation Biology, 16(1):319-329.

Ewald, N., Nicolet, P., Oertli, B., Della Bella, V., Rhazi, L., Reymond, A.S., Minssieux, E., Saber, E., Rhazi, M., Biggs,, J., Bressi, N., Cereghino, R., Grillas, P., Kalettka, T., Hull, A., Scher, O. and Serrano, L. 2010. A preliminary assessment of Important Areas for Ponds (IAPs) in the Mediterranean and Alpine Arc. IAP Site Profiles. EPCN, Geneva, Switzerland.
Freyhof, J. and Harrison, I.J. 2014. Aphanius sirhani. The IUCN Red List of Threatened Species. Version 2014.3. www.iucnredlist.org.

Hamdan, M.A., Sada, T., Hassan, F.M., Warner, B.G., Douabul, A., Al-Hilli, M.R.A. and Alwan, A.A. 2010. Vegetation response to reflooding in the Mesopotamian Wetlands, Southern Iraq. Wetlands 30: 177-188.

Houri, A. and El Jeblawi S. 2007. Water quality assessment of Lebanese coastal rivers during dry season and pollution load into the Mediterranean Sea. Journal of Water and Health 5(4):615-623.

Houri, A. and Machaka-Houri, N. 2001. Photographic guide to wild flowers of Lebanon. Self-published, Beirut, Lebanon.

Houri, A. and Machaka-Houri, N. 2008. Photographic guide to wild flowers of Lebanon. Vol. 2. Self-published, Beirut, Lebanon.

Iraqi Ministry of Environment and Nature Iraq. In prep. Inventory of Key Biodiversity Areas of Iraq. Iraqi Ministry of Environment \& Nature Iraq, Baghdad, Iraq.

Jurdi, M., Korfali, S.I., Karahagopian, Y., and Davies, B.E. 2002. Evaluation of water quality of the Qaraaoun Reservoir, Lebanon: Suitability for multipurpose usage. Environmental Monitoring and Assessment 77(1): $11-30$.

Karadeniz, N., Tiril, A. and Baylan, E. 2009. Wetland management in Turkey: Problems, achievements and perspectives, African Journal of Agricultural Research 4(11):1106-1119.

Kargığlu, M. 2003. The Flora of Ahırdağ ${ }_{1}$ (Afyonkarahisar) and its Environs. Turkish Journal of Botany 27:357-381.

Kavak, S. 2014a. Amsonia orientalis. The IUCN Red List of Threatened Species. Version 2014.2. <www.iucnredlist.org>. Downloaded on 10 September 2014.

Kavak, S. 2014b. Rumex bithynicus. The IUCN Red List of Threatened Species. Version 2014.2. <www.iucnredlist.org>. Downloaded on 10 September 2014.

Kavak, S. 2014c. Sonchus erzincanicus. The IUCN Red List of Threatened Species. Version 2014.2. <www.iucnredlist.org>. Downloaded on 10 September 2014.

Kavak, S. 2014d. Thermopsis turcica. The IUCN Red List of Threatened Species. Version 2014.2. <www.iucnredlist.org>. Downloaded on 10 September 2014.

Kavak, S. In prep. Ranunculus thracicus. The IUCN Red List of Threatened Species. <www.iucnredlist.org>

Kilic, S., Evrendilek, F., Berberoglu, S. and Demirkesen, A.C. 2006 Environmental Monitoring of Land-Use and Land-Cover Changes in a Mediterranean Region of Turkey. Environmental Monitoring and Assessment 114(1-3):157-168.

Lansdown, R.V. 2007. The identity of Ranunculus subgenus Batrachium in the River Itchen. Environment Agency, Southern Region.

Lansdown, R.V. 2010. Search for Callitriche mouterdei Schotsm. and vegetation surveys in the former Amouk (Amik) marshes and Gölbaşı Gölü, to the north and east of Kırıkhan, Hatay Province in South Anatolia, Turkey. Unpublished Report to the Botanical Research Fund, British Museum (Natural History), London.

Marnotte, P., Carrara, A., Dominati, E. and Girardot, F. 2006. Plantes des rizières de Camargue. Cirad, Montpellier, France.

Mirabzadeh, P.A. 1999. Wetlands in Western Asia. Background text from Ramsar brochure "Conservation and wise use of wetlands in western Asia”. Ramsar Bureau, Gland, Switzerland.

Musselman, L.J. 2002. The only quillwort (Isoetes olympica A.A.Braun) in Syria is threatened with extirpation. The Fern Gazette 16(6, 7, 8):324329.

Naqinezhad, A. 2012. A Physiognomic-Ecological Vegetation Mapping of Boujagh National Park, the first Marine-land National Park in Iran. Advances in Bioresearch 3(1):37-42

Ozelkan, E., Avci, Z.D.I. and Karaman, M. 2011. Investigation on draining of the Lake Amik and the related environmental changes, by using remote sensing technology. Remote Sensing and Geoinformation not only for Scientific Cooperation. Proceedings of the 31st EARSeL Symposium Prague, 30 May - 2 June 2011, 20-29. 
Parolly, G. 2004. The High Mountain Vegetation of Turkey - a State of the Art Report, including a First Annotated Conspectus of the Major Syntaxa. Turkish Journal of Botany 28:39-63.

Radford, E.A., Catullo, G. and de Montmollin, B. (eds.) 2011. Important Plant Areas of the south and east Mediterranean region: Priority sites for conservation. IUCN, Gland, Switzerland and Malaga, Spain.

Rhazi, L., Grillas, P., Rhazi, M. and Flanagan, D. 2010. Ranunculus schweinfurthii. The IUCN Red List of Threatened Species. Version 2014.2. <www.iucnredlist.org>. Downloaded on 10 September 2014. Salafsky, N., Salzer, D., Stattersfield, A.J., Hilton-Taylor, C., Neugarten, R., Butchart, S.H.M., Collen, B., Cox, N., Master, L.L., O’Connor, S. and Wilkie, D. 2008. A standard lexicon for biodiversity conservation:
Unified classifications of threats and actions. Conservation Biology 22:897-911.

Scott D.A. 1995 Directory of Middle East Wetlands. Wetlands International, Wageningen, Netherlands.

Seçmen, O. and Leblebici, E. 1984. Aquatic flora of Western Anatolia. Willdenowia 14:165-178.

Sharifi, J., Jalili, A., Ghasemov, S. and Esfahan, E.S. 2014. Alpine wetland flora, species life forms and chorology of the Sabalan Mountain-Iran. Journal of Biodiversity and Environmental Sciences 5(2):173-180.

Yazbek M., Machaka-Houri N., Al-Zein M.S., Safi S., Sinno N. and Talhouk S. 2010. Important Plant Areas of Lebanon. ISBAR (AUB)/ IUCN. 


\section{Chapter 7. Synthesis for all taxa}

Kevin G. Smith ${ }^{1}$, William R.T. Darwall ${ }^{1}$, Savrina F. Carrizo', Violeta Barrios ${ }^{2}$, Catherine Numa², and Süreyya Isfendiyaroğlu ${ }^{3}$

7.1 Introduction and inclusion of additional taxa.

7.2 Red List status

7.3 Patterns of species richness.

7.3.1 Species numbers by country.

7.3.2 Species numbers by Hotspot within the Eastern Mediterranean ............................................................................................. 93

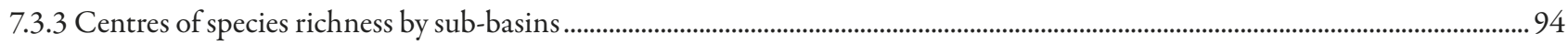

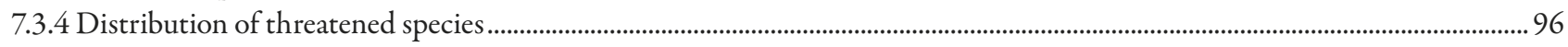

7.3.5 Sub-basins containing high proportions of species and threatened species for all taxonomic groups ......................................... 98

7.4 Important habitats supporting freshwater biodiversity in the Eastern Mediterranean .......................................................................... 100

7.5 Threats to freshwater biodiversity in the Eastern Mediterranean....................................................................................................... 102

7.6 Provisioning ecosystem services and freshwater biodiversity of the Eastern Mediterranean................................................................. 105

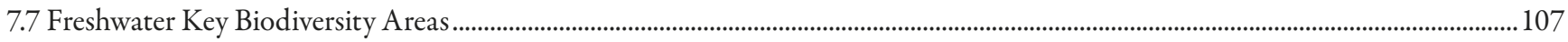

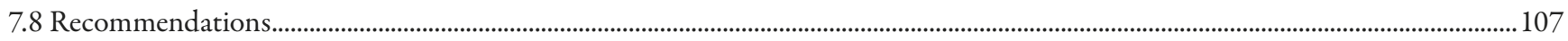

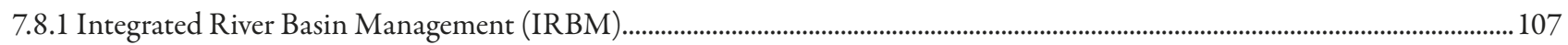

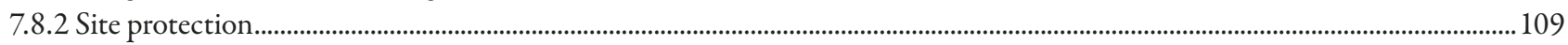

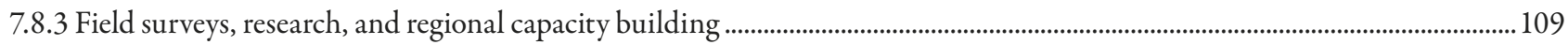

7.8.4 Enforcement of existing legislation and government awareness .................................................................................................. 109

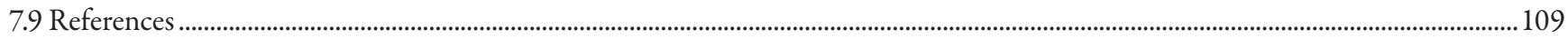

The upper Tarsus River in southern Turkey is one of the most species-rich rivers in the Eastern Mediterranean region. Photo $\odot$ Manuel Lopes-Lima

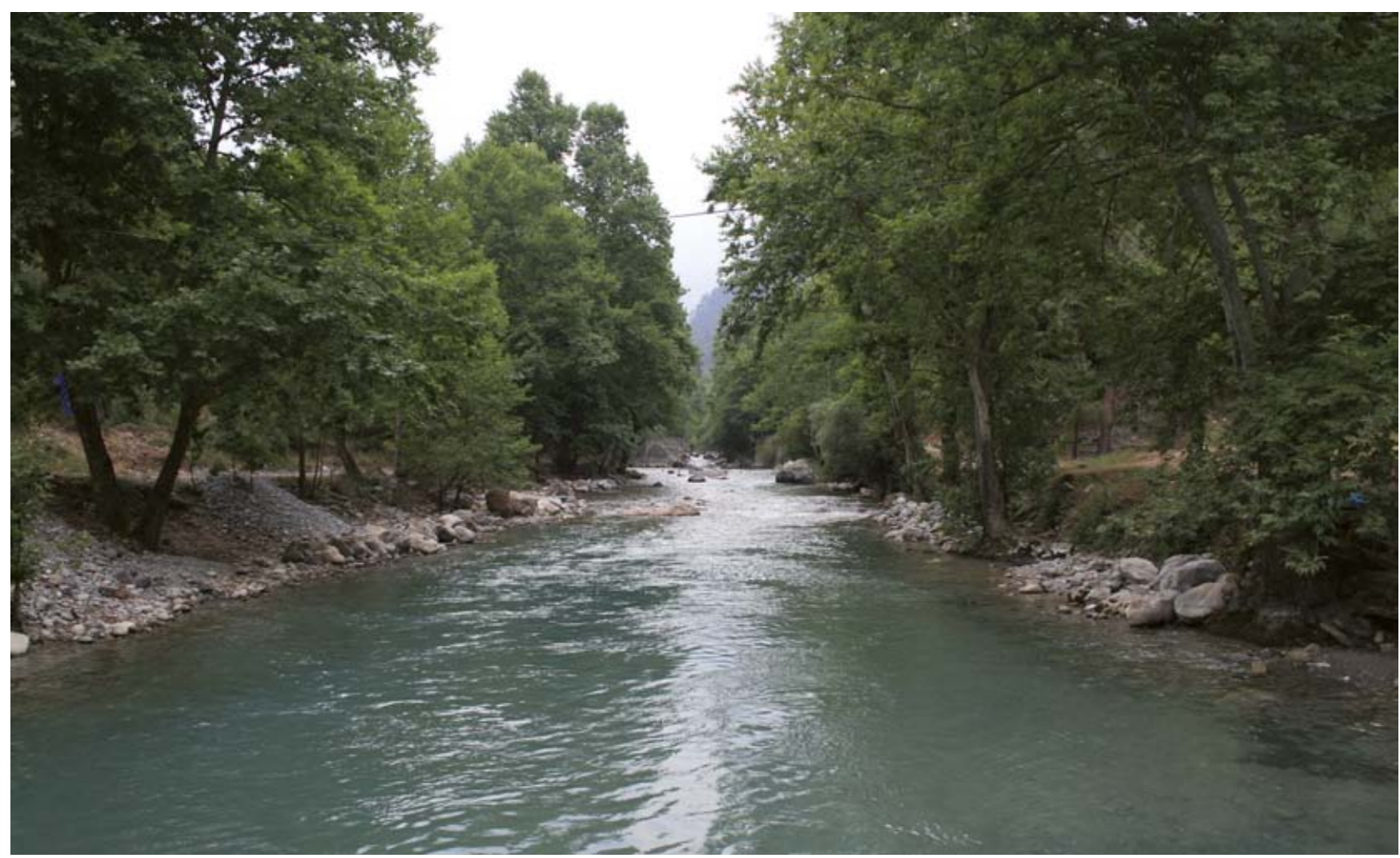

${ }^{1}$ IUCN Global Species Programme, 219c Huntingdon Road, Cambridge, UK. Email: Kevin.Smith@iucn.org

${ }^{2}$ IUCN Centre for Mediterranean Cooperation, Marie Curie 22, 29590 Málaga, Spain

${ }^{3}$ Doga Dernegi, Kültür Mahallesi, Doktor Mediha Eldem Sokak, $70 \backslash 10$ Çankaya, Ankara, Turkey 


\subsection{Introduction and inclusion of additional taxa}

In this synthesis chapter we combine all the data sets from Chapters 3 to 6 (freshwater fishes, molluscs, odonates, and plants) with existing data on freshwater species of birds, mammals, amphibians, and decapods, and consider the status of freshwater biodiversity across the Eastern Mediterranean region. Here, we present combined species richness, and threatened species richness across the region. The types of factors driving threats to the freshwater species are quantified and discussed along with the identification of human use of species. The objective of this analysis (and the accompanying data) is to provide outputs to help inform conservation and development planning for wetland ecosystems and species at the national, state, catchment, and site scales.

As all birds, amphibians, mammals, and freshwater decapods (crabs, crayfish, and shrimps) have been globally assessed on the IUCN Red List, the freshwater/wetland species from these groups that are present within the region (referred to as the 'additional taxa') can be included in the analysis. To identify the species within the region a GIS overlay selection using the Eastern Mediterranean region was undertaken on the additional taxa distribution maps, and then filtered to only include those species coded as found within the 'freshwater' system on the IUCN Red List. The species and their Red List categories are shown in Appendix 2 along with the freshwater taxa from this report.

\subsection{Red List status}

While the Eastern Mediterranean region covers just less than $1.5 \%\left(<2\right.$ million $\mathrm{km}^{2}$ ) of the Earth's land surface, and large parts are classed as arid and semi-arid, it supports a higher proportion (1.9\%) of species dependent upon freshwater habitats (Table 7.1). The region contains over $2 \%$ of the world's freshwater fishes and odonates, $3 \%$ of the world's freshwater mollusc species, and over $5 \%$ of the mammals and almost $10 \%$ of the birds that are dependent upon freshwater systems. However, it is important to note that the number of species in the region, especially for the molluscs and plants, are likely to be significant underestimates and true diversity is likely to be much higher (see individual taxa chapters).

When the Red List assessments for the freshwater groups assessed in this report (fishes, molluscs, odonates, and plants) are combined with the additional comprehensively assessed groups (freshwater species of birds, mammals, amphibians, and decapods) $19.2 \%$ (224 species) of extant species for which sufficient data are available are threatened with extinction (Table 7.2 and Figure 7.1). Six species, all fishes, are considered to have become Extinct (EX) and 18 species (seven fishes and 11 molluscs) are assessed as Critically Endangered Possibly Extinct, which means that urgent surveys are required to confirm whether the species are still extant or have become extinct (see Chapters 3 and 5 for details). When compared to the globally assessed animal groups, such as the amphibians with $41.2 \%$ threatened species, mammals with $25.9 \%$, and birds with $13.4 \%$ threatened (IUCN 2014), the level of threat may seem relatively low. However, when compared to the other regional freshwater multi-taxa studies undertaken so far by IUCN, the level of threat to freshwater biodiversity in the Eastern Mediterranean is high, with only Africa containing a (slightly) higher proportion of threatened species (Eastern Himalaya 7.2\% threatened (Allen, Molur, and Daniel, 2011), Indo-Burma 13.2\% threatened (Allen, Smith, and Darwall 2012), Western Ghats of India $17.8 \%$ threatened (Molur et al. 2011), and Africa 21\% threatened (Darwall et al. 2011)).

Of the freshwater groups in the Eastern Mediterranean, three groups have exceptionally high levels of threat, the molluscs (45.8\%), decapods (44.4\%), and fishes (41.0\%), reflecting their limited dispersal ability and high proportion of restricted range species (Table 7.2; Figure 7.1). The mammals and amphibians both have around one third of their species assessed as threatened, and then the remaining groups (plants, odonates, and birds) all have between $2.5-6.7 \%$ of their species assessed as threatened.

Almost one third (29.8\%) of the Eastern Mediterranean freshwater species are endemic to the region (Table 7.3). These endemic species do not have populations outside the region to influence their Red List conservation status. When only these species are used, the level of threat (of extant species for which sufficient data are available that are threatened with extinction) increases to $58.2 \%$ (Table 7.3 and Figure 7.2). The fishes have the highest number of endemic threatened species at 108 , but

Table 7.1 Estimated numbers of extant inland waterdependent species by major taxonomic groups.

\begin{tabular}{|c|c|c|c|}
\hline Taxon & $\begin{array}{c}\text { Global } \\
\text { number } \\
\text { of } \\
\text { described } \\
\text { species }\end{array}$ & $\begin{array}{c}\text { Number } \\
\text { of species } \\
\text { in Eastern } \\
\text { Mediterranean } \\
\text { assessment } \\
\text { region }\end{array}$ & $\begin{array}{c}\% \text { of species } \\
\text { found in } \\
\text { Eastern } \\
\text { Mediterranean } \\
\text { assessment } \\
\text { region }\end{array}$ \\
\hline Fishes & $>15,000^{1}$ & $3,22^{4}$ & $2.15 \%$ \\
\hline Molluscs & $>5,000^{1}$ & $1,50^{4}$ & $3.00 \%$ \\
\hline Odonates & $5,680^{1}$ & $1,24^{4}$ & $2.18 \%$ \\
\hline Plants & $30,000^{2}$ & $3,64^{4}$ & $1.21 \%$ \\
\hline Birds & $2,283^{3}$ & $2,25^{5}$ & $9.86 \%$ \\
\hline Mammals & $1,45^{3}$ & $8^{5}$ & $5.52 \%$ \\
\hline Amphibians & $4,330^{3}$ & $31^{5}$ & $0.72 \%$ \\
\hline Decapods & $2,628^{3}$ & $12^{5}$ & $0.46 \%$ \\
\hline All groups & 65,066 & 1,236 & $1.90 \%$ \\
\hline
\end{tabular}

Data sources: ${ }^{1}$ Balian et al. $2008 ;{ }^{2}$ Estimate by R. Lansdown, chair of the IUCN Freshwater Plant Specialist Group; 32014. ${ }^{2}$ IUCN Red List, filtered by 'system = freshwater'; ${ }^{4}$ Species lists generated by experts for this project; ${ }^{5}$ Based on GIS analysis using the Red List species distributions. 
the group (with more than one endemic species in the region) with the highest level of threat is the molluscs, at 76.8\% (53 species) threatened, followed by the decapods $(75 \%$ or three species), fishes (55.1\% or 108 species), amphibians (50\% or 10 species), odonates ( $44.4 \%$ or four species), and then plants (31.2\% or five species).

\subsection{Patterns of species richness}

\subsubsection{Species numbers by country}

The IUCN Red List species assessments are coded to countries of occurrence, it is therefore possible to identify the number of

Table 7.2 Number of Eastern Mediterranean freshwater species within each IUCN Red List Category for each taxonomic group.

\begin{tabular}{|c|c|c|c|c|c|c|c|c|c|c|c|}
\hline \multirow[b]{2}{*}{ Freshwater group } & \multicolumn{9}{|c|}{ IUCN Red List Category } & \multirow[b]{2}{*}{ Total species } & \multirow[b]{2}{*}{$\%$ Threatened } \\
\hline & EX & EW & $\mathrm{CR}$ & $\mathrm{EN}$ & VU & NT & LC & DD & NA & & \\
\hline Fishes & 6 & 0 & 39 & 53 & 31 & 20 & 157 & 16 & 0 & 322 & 41.0 \\
\hline Molluscs & 0 & 0 & 19 & 19 & 17 & 9 & 57 & 24 & 5 & 150 & 45.5 \\
\hline Odonata & 0 & 0 & 0 & 2 & 6 & 6 & 106 & 4 & 0 & 124 & 6.7 \\
\hline Plants & 0 & 0 & 4 & 3 & 2 & 5 & 342 & 8 & 0 & 364 & 2.5 \\
\hline Birds & 0 & 0 & 1 & 6 & 5 & 7 & 206 & 0 & 0 & 225 & 5.3 \\
\hline Mammals & 0 & 0 & 0 & 2 & 1 & 1 & 4 & 0 & 0 & 8 & 37.5 \\
\hline Amphibians & 0 & 0 & 5 & 1 & 4 & 5 & 15 & 1 & 0 & 31 & 33.3 \\
\hline Decapods & 0 & 0 & 1 & 2 & 1 & 0 & 5 & 3 & 0 & 12 & 44.4 \\
\hline All groups & 6 & 0 & 69 & 88 & 67 & 53 & 892 & 56 & 5 & 1,236 & 19.2 \\
\hline
\end{tabular}

Those Categories shown in colour are known as the 'Threatened' Categories IUCN Red List Categories:

EX - Extinct, EW - Extinct in the Wild, CR - Critically Endangered, EN - Endangered, VU - Vulnerable, NT - Near Threatened, LC - Least Concern, DD - Data Deficient, NA - Not Assessed.

Almost a half of all decapod species in the region, such as this freshwater crab (Potamon spp.) from Turkey, are assessed as threatened. Photo $($ ) Jean-Pierre Boudot

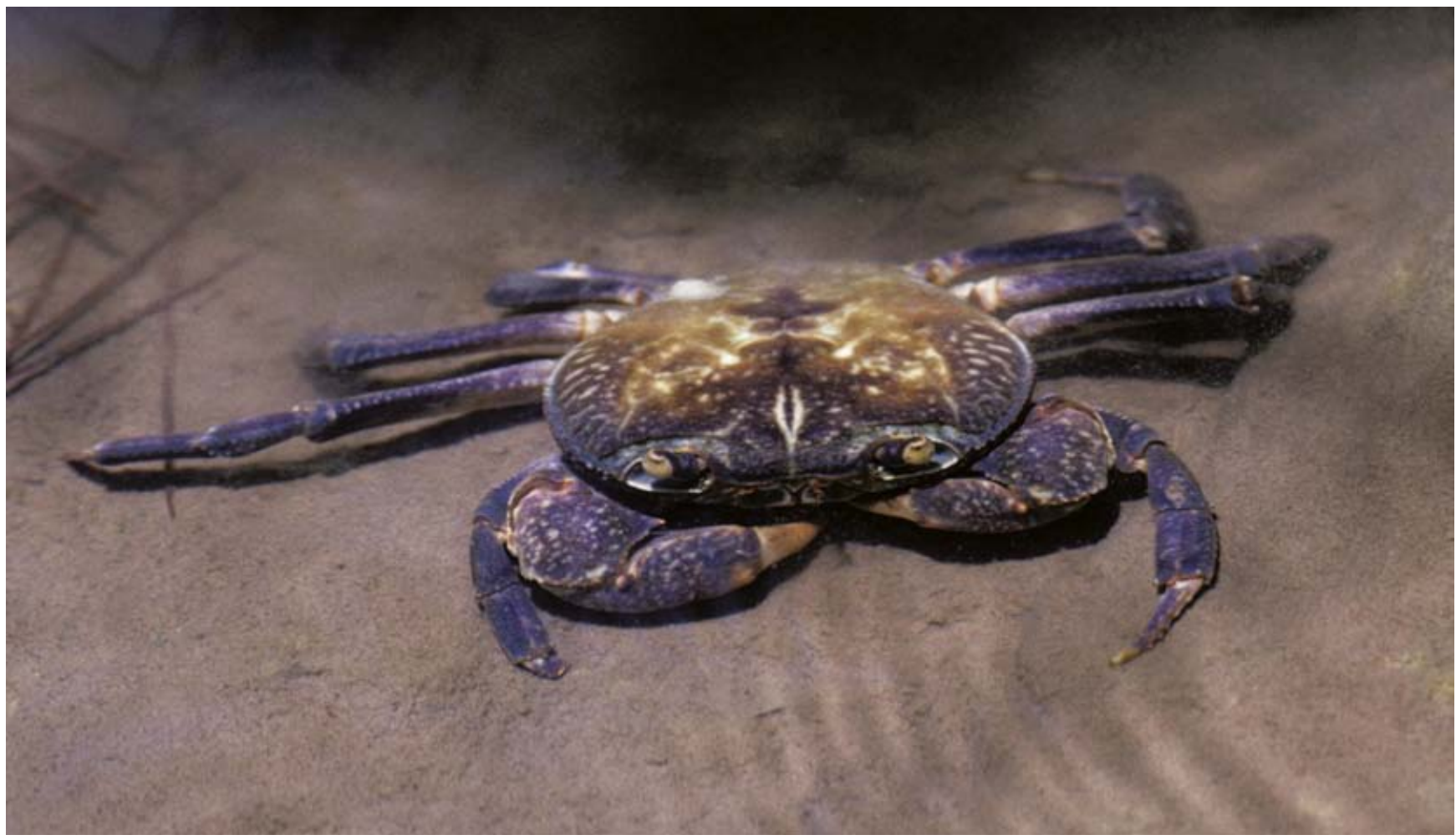


Table 7.3 Number of Eastern Mediterranean endemic freshwater species within each IUCN Red List Category for each taxonomic group.

\begin{tabular}{|l|c|c|c|c|c|c|c|c|c|c|c|}
\hline & \multicolumn{9}{|l|}{ IUCN Red List Category } \\
\hline & EX & EW & CR & EN & VU & NT & LC & DD & NA & Total species & \% Threatened \\
\hline Freshwater group & 6 & 0 & 32 & 49 & 27 & 16 & 72 & 13 & 0 & 215 & 55.1 \\
\hline Fishes & 0 & 0 & 19 & 17 & 17 & 7 & 9 & 21 & 4 & 94 & 76.8 \\
\hline Odluscs & 0 & 0 & 0 & 2 & 2 & 2 & 3 & 2 & 0 & 11 & 44.4 \\
\hline Plants & 0 & 0 & 3 & 1 & 1 & 3 & 8 & 4 & 0 & 20 & 31.2 \\
\hline Birds & 0 & 0 & 0 & 0 & 0 & 0 & 1 & 0 & 0 & 1 & 0 \\
\hline Mammats & 0 & 0 & 0 & 1 & 0 & 0 & 0 & 0 & 0 & 1 & 100 \\
\hline Amphibians & 0 & 0 & 5 & 1 & 4 & 5 & 5 & 0 & 0 & 20 & 5 \\
\hline Decapods & 0 & 0 & 1 & 2 & 0 & 0 & 1 & 2 & 0 & 6 & 50 \\
\hline All groups & 6 & 0 & 60 & 73 & 51 & 33 & 99 & 42 & 4 & 368 & 75 \\
\hline
\end{tabular}

Those Categories shown in colour are known as the 'Threatened' Categories IUCN Red List Categories:

EX - Extinct, EW - Extinct in the Wild, CR - Critically Endangered, EN - Endangered, VU - Vulnerable, NT - Near Threatened, LC - Least Concern, DD - Data Deficient, NA - Not Assessed.

Figure 7.1 Proportion of Eastern Mediterranean freshwater species within each IUCN Red List Category for each taxonomic group. IUCN Red List Categories: EX - Extinct, EW - Extinct in the Wild, CR - Critically Endangered, EN - Endangered, VU - Vulnerable, NT - Near Threatened, LC - Least Concern, DD - Data Deficient, NA - Not Assessed.

Figure 7.2 Proportion of Eastern

Mediterranean endemic freshwater species within each IUCN Red List Category for each taxonomic group. IUCN Red List Categories: EX - Extinct, EW - Extinct in the Wild, CR - Critically Endangered, EN - Endangered, VU - Vulnerable, NT - Near Threatened, LC - Least Concern, DD - Data Deficient, NA - Not Assessed.
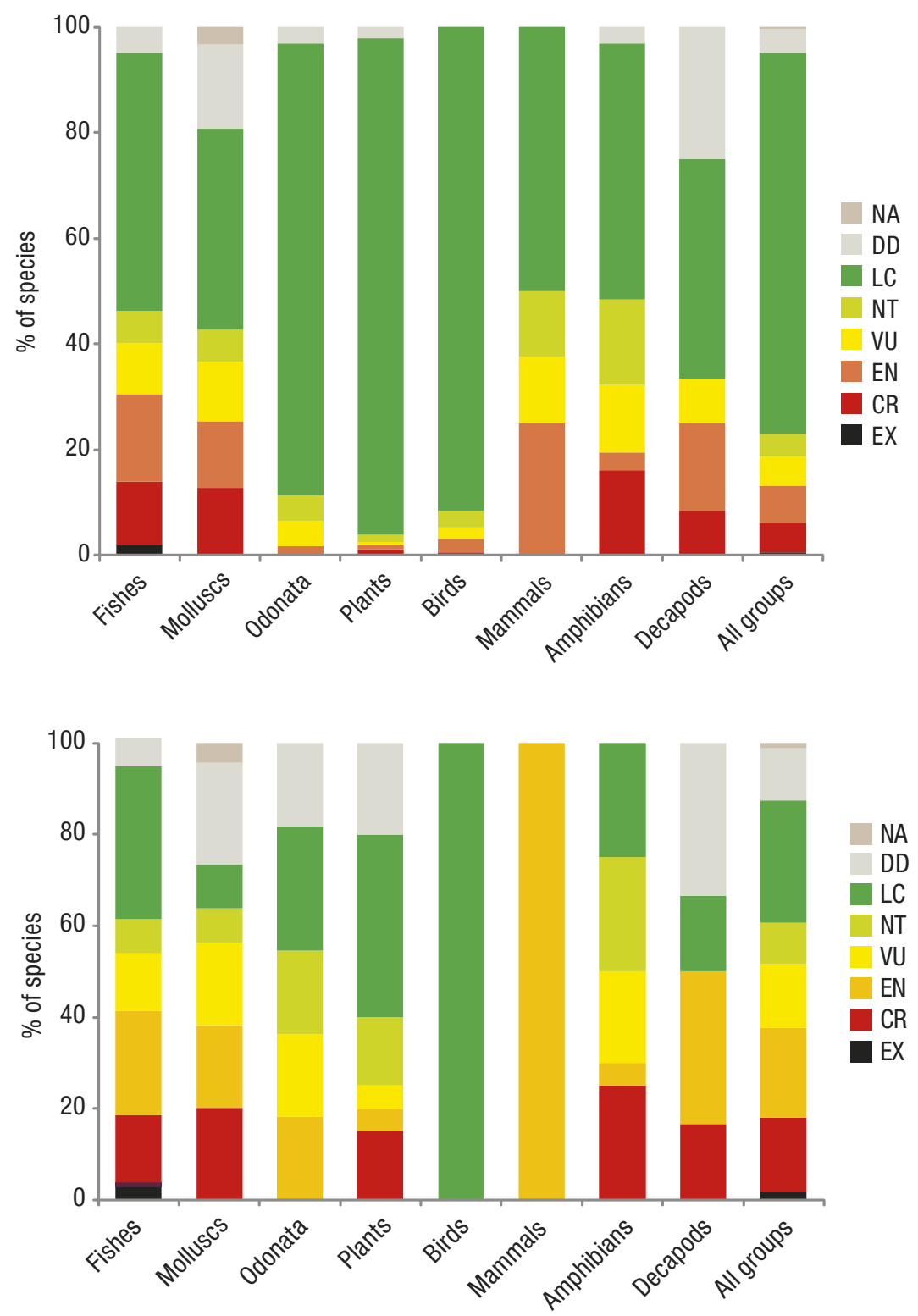
freshwater species that are found within each country of the Eastern Mediterranean region. Figure 7.3 shows that Turkey, which is the largest country in the Eastern Mediterranean region, supports the highest diversity of freshwater species with almost 1,000, however it also contains the highest proportion of threatened species (18\% of extant species for which sufficient data are available are threatened with extinction) and also the highest number (four) of Extinct or Extinct in the Wild species, all of which are fishes (see Chapter 3). Iran contains the second highest number of freshwater species with 562, (7.0\% threatened), even though this only relates to a small portion of the territory of Iran, therefore the figure for Iran as a whole will be much higher. Syria is notable in terms of the proportion of its freshwater species that are threatened, being the second highest in the region with $11.8 \%$; this is also likely to be an underestimate due to the lack of recent information available for this country. See Appendix 3 for a species breakdown for each country by taxonomic group. The country with the highest number (and proportion) of DD species is Turkey with 37 (3.7\%), followed by Iran with 15 species (2.7\%), Iraq with 10 species (2.5\%), and Syria with 10 species (2.3\%).

Table 7.4 shows the number of species that have become extirpated from each country (note this does not necessarily mean the species is extinct, just no longer found within the country). It shows that while Turkey has the greatest number of extirpated species with 17 (1.7\% of all freshwater species assessed), it is Israel which has the highest proportion of extirpated species at $3.8 \%$ ( 15 species), followed by Syria with $2.9 \%$ (13 species) (compared to Turkey 1.7\%).

\subsubsection{Species numbers by Hotspot within the Eastern Mediterranean}

Using the species distribution maps, the number of freshwater animal species and threatened species mapped to the sub-basins that overlap the three biodiversity Hotspots that are found in the Eastern Mediterranean region (see Figure 1.1) can be identified. Note that plants were not included as only the threatened species were mapped to sub-basins. Also, these figures represent the number of species for each Hotspot within the region only, and not for the entire Hotspots which all extend beyond the Eastern Mediterranean region.

The Mediterranean Basin hotspot supports the greatest number of freshwater species with 641 species, 159 of which are threatened. One third of its freshwater animal species are fishes, and it is the only Hotspot where fish species outnumber birds (Figure 7.4 and Table 7.5). The Mediterranean Basin Hotspot also has a significantly higher proportion of molluscs than

Table 7.4 Number of freshwater species that are recorded as being extirpated/possibly extirpated from a country of the Eastern Mediterranean region. *denotes those countries where only a part of their territory is included in the analysis (see Figure 2.1).

\begin{tabular}{|c|c|c|c|c|c|c|c|c|c|c|c|c|}
\hline & 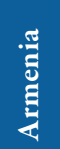 & 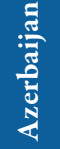 & 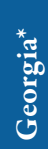 & 苞 & 丞 & 氶 & 离 & 苞 & 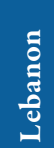 & 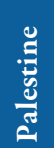 & हึ & 気 \\
\hline Number of species extirpated/possibly extirpated & 1 & 1 & 0 & 2 & 3 & 15 & 4 & 0 & 2 & 3 & 13 & 17 \\
\hline $\begin{array}{l}\% \text { of all freshwater species that are extirpated/ } \\
\text { possibly extirpated }\end{array}$ & 0.3 & 0.3 & 0.0 & 0.4 & 0.7 & 3.8 & 1.4 & 0.0 & 0.6 & 1.0 & 2.9 & 1.7 \\
\hline
\end{tabular}

Figure 7.3 Total number of freshwater species (fishes, molluscs, odonates, plants, birds, mammals, amphibians, decapods) by country of the Eastern Mediterranean region.

* denotes those countries where only a part of their territory is included in the analysis (see Figure 2.1)

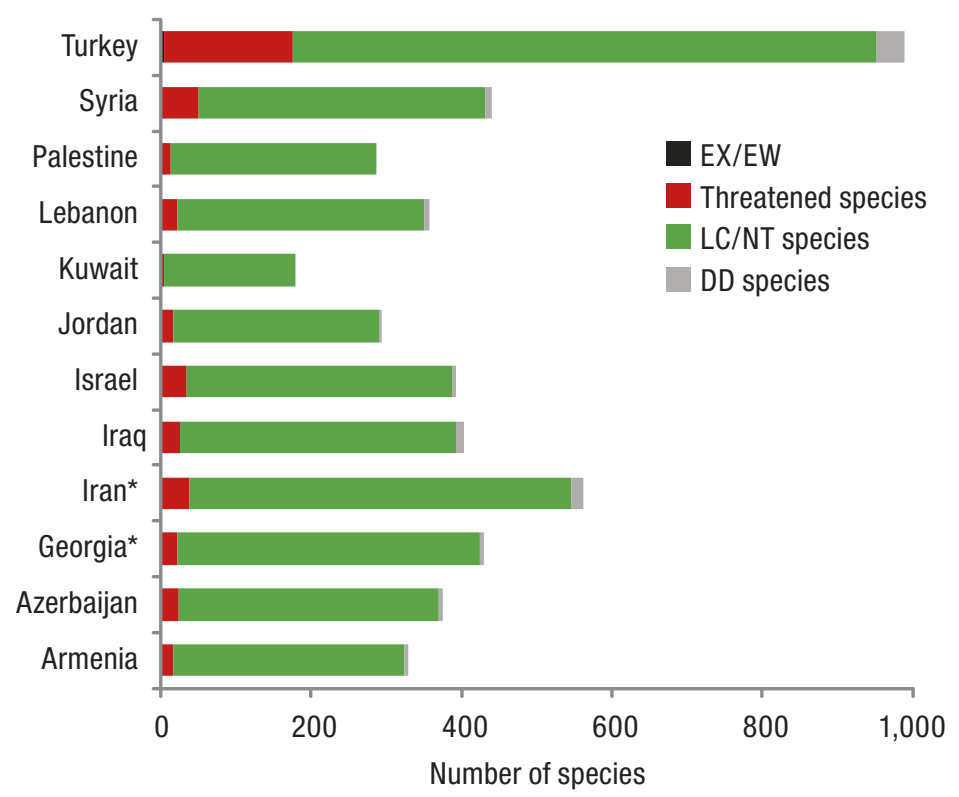


the other Hotspots, with $15.6 \%$ (100 species), compared to $9 \%$ ( 47 species) for the Irano-Anatolian and 4.7\% (18 species) for the Caucasus Hotspot. It is not surprising that the Caucasus Hotspot supports the fewest number of freshwater species, as it covers only a small part of the region (north-eastern Turkey, Georgia, and Azerbaijan), but it has a higher proportion of its freshwater animal species being birds (44.3\%) than the other Hotspots (Mediterranean Basin 31\%; Irano-Anatolian 38\%).

Just over one quarter of all freshwater animal species $(25.9 \%$ or 159 species) in the Mediterranean Basin Hotspot are threatened, which is the highest level of threat for the three Hotspots (IranoAnatolian $17.2 \%$ or 87 species; Caucasus $8.9 \%$ or 33 species), and significantly higher than the Eastern Mediterranean region as a whole (19.2\%) indicating that the freshwater systems of this Hotspot may be under greater pressure than the others within the region (Figure 7.4 and Table 7.5). In terms of threatened freshwater species composition for each Hotspot, the fishes make up the largest proportion for each, with $48.4 \%$ for the Caucasus, $62.1 \%$ for the Irano-Anatolian, and $55.3 \%$ for the Mediterranean Basin. The taxa making up the second largest proportion of threatened species differs for each Hotspot, for the Caucasus $30.3 \%$ of all threatened freshwater species are birds, for the Irano-Anatolian both the birds and molluscs each represent around $12 \%$ (12.6\% and $11.5 \%$ respectively), and for the Mediterranean basin it is the molluscs at $29.6 \%$.

For species that are extirpated from each region (note this does not mean globally Extinct), the Irano-Anatolian and the Mediterranean Hotspots contain the highest numbers with 14 and 17 respectively, representing $2.7 \%$ of all freshwater species in each Hotspot.

\subsubsection{Centres of species richness by sub-basins}

Species richness is presented here as the number of native species contained within river sub-basins, derived from the HydroBASINS hydrographic data (Lehner and Grill 2013) and has been mapped to include all the species groups assessed through this project. As only the threatened and NT plant species have been mapped to river sub-basins (the remainder are mapped to countries, see Chapter 6 for more details), the plants are not included in the species richness analysis (Figures 7.5, 7.7, and 7.8) but are included in the threatened species richness analysis (Figure 7.6).

As with many species richness maps, they have the potential to be biased by sampling intensity and mapping methodology. Some parts of the region may have benefited from much more intense survey and taxonomic study either historically or by more recent workers, or because they happen to be close to research centres. Conversely, some areas are likely to have higher species richness than is shown in this report as they have been historically under-surveyed, often because of political instability or actual difficulty of access.

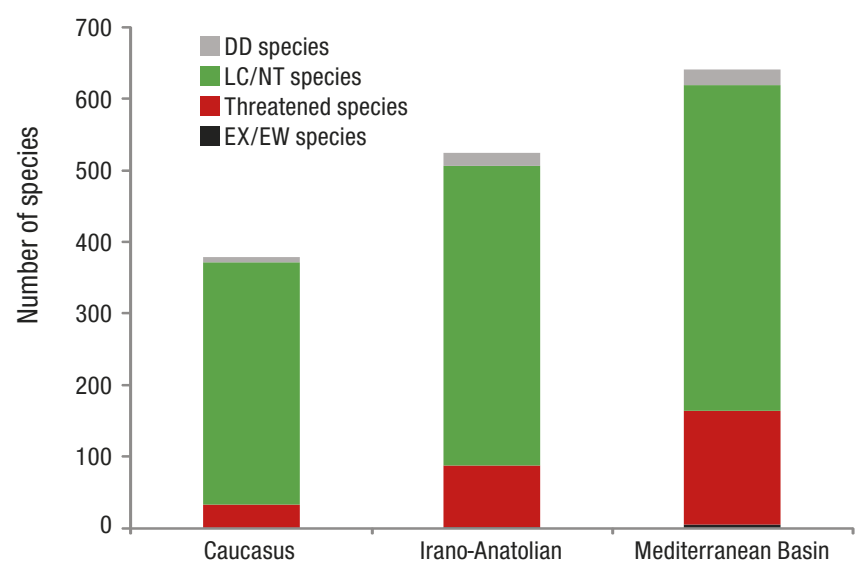

Figure 7.4 Number of freshwater animal species and threatened species found within each biodiversity Hotspot within the Eastern Mediterranean region.

The groups assessed through this project (fishes, molluscs, odonates, threatened plant species) and the freshwater shrimps have all been mapped directly to the HydroBASINS sub-basin layer. However the birds, mammals, amphibians, and remaining decapods originally were mapped to polygons representing the species extent of range which have then been translated across to the HydroBASINS sub-basin layer. This means that there is likely to be some commissioning errors for the additional groups (i.e. where a species is recorded as being present within a sub-basin when it should be recorded as absent), and is particularly the case for the widespread bird species. The results of this can be seen in the Arabian Desert in the south of the region, which shows species and threatened species presence (Figures 7.5 and 7.6). The original bird distribution polygons were provided by BirdLife International (BirdLife International and NatureServe 2012).

Figure 7.5 shows that the highest levels of species richness (between 177-217 species per sub-basin) are found along the Mediterranean coasts of the Levant (Jordan River, coastal Israel, Litani River) and Turkey (Gulfof İskenderun rivers, Köprü River, Köyceğiz Lake catchment, lower Büyük Menderes), Sea of Marmara catchments, Black Sea coast of Turkey (Çoruh River), and also within the Aras/Kura catchment in Georgia, Azerbaijan, and Armenia. The Jordan River is a good example, supporting an amazing array of freshwater biodiversity (185 freshwater animal species are mapped to the sub-basin) including: the Palestine loach (Oxynoemacheilus insignis) a NT fish species endemic to the Levant; the Jordan barbel (Luciobarbus longiceps) an EN fish species endemic to the Jordan watershed; Unio terminalis, a VU species of bivalve endemic to the Levant; the Syrian demoiselle (Calopteryx syriaca) an EN species of damselfly only found along the river systems in the Levant; the Levant waterfrog (Pelophylax bedriagae) a LC species found across the eastern Mediterranean; the Black stork (Ciconia nigra) a LC bird species that migrates along the Jordan Valley, with some spending the winter; and Atyaephyra orientalis a LC freshwater shrimp species endemic to the Middle East. 
Table 7.5 The number of freshwater species and threatened species by each taxonomic group found within each biodiversity Hotspot within the Eastern Mediterranean region. ${ }^{*}$ Note that plant total species richness could not be included as only the threatened plant species were mapped to sub-basin.

\begin{tabular}{|c|c|c|c|c|}
\hline & & Caucasus & Irano-Anatolian & Mediterranean Basin \\
\hline \multirow[t]{8}{*}{ All animal groups } & Total richness & 379 & 524 & 641 \\
\hline & Threatened species & 33 & 87 & 159 \\
\hline & DD species & 7 & 18 & 22 \\
\hline & EX/EW species & 0 & 1 & 5 \\
\hline & $\mathrm{LC} / \mathrm{NT}$ species & 339 & 418 & 455 \\
\hline & Extirpated & 0 & 1 & 5 \\
\hline & $\%$ Threatened & 8.9 & 17.2 & 25.9 \\
\hline & \% Extirpated & 0.5 & 2.7 & 2.7 \\
\hline \multirow[t]{5}{*}{ Fishes } & All species & 104 & 160 & 217 \\
\hline & Threatened species & 16 & 54 & 88 \\
\hline & DD species & 5 & 9 & 4 \\
\hline & EX/EW species & 0 & 1 & 5 \\
\hline & Extirpated from Hotspot & 2 & 10 & 14 \\
\hline \multirow[t]{5}{*}{ Odonata } & All species & 69 & 87 & 100 \\
\hline & Threatened species & 2 & 4 & 6 \\
\hline & DD species & 1 & 3 & 1 \\
\hline & EX/EW species & 0 & 0 & 0 \\
\hline & Extirpated from Hotspot & 0 & 0 & 2 \\
\hline \multirow[t]{5}{*}{ Molluscs } & All species & 18 & 47 & 100 \\
\hline & Threatened species & 3 & 10 & 47 \\
\hline & DD species & 0 & 4 & 14 \\
\hline & $\mathrm{EX} / \mathrm{EW}$ species & 0 & 0 & 0 \\
\hline & Extirpated from Hotspot & 0 & 3 & 0 \\
\hline \multirow[t]{5}{*}{ Decapods } & All species & 1 & 6 & 8 \\
\hline & Threatened species & 0 & 1 & 3 \\
\hline & DD species & 0 & 1 & 2 \\
\hline & EX/EW species & 0 & 0 & 0 \\
\hline & Extirpated from Hotspot & 0 & 0 & 0 \\
\hline \multirow[t]{5}{*}{ Birds } & All species & 168 & 193 & 192 \\
\hline & Threatened species & 10 & 11 & 10 \\
\hline & DD species & 0 & 0 & 0 \\
\hline & EX/EW species & 0 & 0 & 0 \\
\hline & Extirpated from Hotspot & 0 & 1 & 0 \\
\hline \multirow[t]{5}{*}{ Mammals } & All species & 3 & 5 & 3 \\
\hline & Threatened species & 0 & 1 & 0 \\
\hline & DD species & 0 & 0 & 0 \\
\hline & EX/EW species & 0 & 0 & 0 \\
\hline & Extirpated from Hotspot & 0 & 0 & 0 \\
\hline \multirow[t]{5}{*}{ Amphibians } & All species & 16 & 26 & 21 \\
\hline & Threatened species & 2 & 6 & 5 \\
\hline & DD species & 1 & 1 & 1 \\
\hline & EX/EW species & 0 & 0 & 0 \\
\hline & Extirpated from Hotspot & 0 & 0 & 1 \\
\hline Plants* & Threatened species & 0 & 3 & 7 \\
\hline
\end{tabular}


Areas of high species richness (136-176 species per sub-basin) are found in the Euphrates and Tigris plains in central and southern Iraq, many coastal rivers of the Levant, Turkey (Mediterranean, Marmara, and Black seas), and a number of inland lake catchments and rivers in Turkey (including the Akar River that drains into Lake Akşehir, the lakes Eğirdir and Burdur catchments, and Sultan Marshes). The areas of low species richness, is a reflection on the lack of availability of permanent water, with most water sources being intermittent or seasonal.

\subsubsection{Distribution of threatened species}

In general the pattern of threatened species richness (Figure 7.6) reflects that of species richness (Figure 7.5). The greatest numbers of globally threatened freshwater species (between 18-20 species per sub-basin) (Figure 7.6) are found in the lower Orontes/Asi catchment in Turkey, the lower and middle Tigris/Euphrates including the Hammar marshes, the Shatt al Arab River, Ras alAin spring area and outflowing Khabur/Khabour River (part of the Euphrates catchment) in northern Syria, and the lower Aras/ Kura River in Azerbaijan.

The Ras al-Ain (Arabaic for 'head of the spring') spring complex and Khabur River in Syria typifies the situation of many springs (and spring-fed rivers and wetlands) across the region. Over- exploitation of groundwater resources (there are an estimated 6,000 wells in the aquifer) combined with periods of extreme drought have resulted in the intermittent drying out of the springs (which used to supply $87 \%$ of the total discharge from the aquifer) which has also caused the flows in Khabur River to be drastically reduced impacting downstream communities (UN-ESCWA and BGR 2013, Van Damme and Kebapçı 2014). The intermittent desiccation of the springs and outflowing river is disastrous for the species that survive there, one of which, the CR freshwater snail Melanopsis khabourensis is endemic to the Ras al-Ain spring complex. Other threatened species found in the Ras al-Ain and Khabur river system include a freshwater snail (Melanopsis infracincta CR) which is only found in one additional site, the Ayn al-'Arus spring at the head of the connected Balikh River (Van Damme, Seddon, and Kebapçı 2014), the Leopard barbel (Luciobarbus subquincunciatus CR) once common in the 1980s but is now thought to be extirpated from the Khabur River (Freyhof 2014a) and Palaemonetes mesopotamicus (CR) a species of freshwater shrimp known only from the Khabur River and the Orontes River, though its status in Syria is unknown and is suspected to be extirpated (De Grave 2013).

Areas that contain high levels of threatened freshwater species (between 14-17 species per sub-basin) are found within six distinct areas within the region: the coastal Levant and Gulf

Figure 7.5 Distribution of all freshwater species of fishes, molluscs, odonates, birds, mammals, amphibians, and decapods in the Eastern Mediterranean project area.

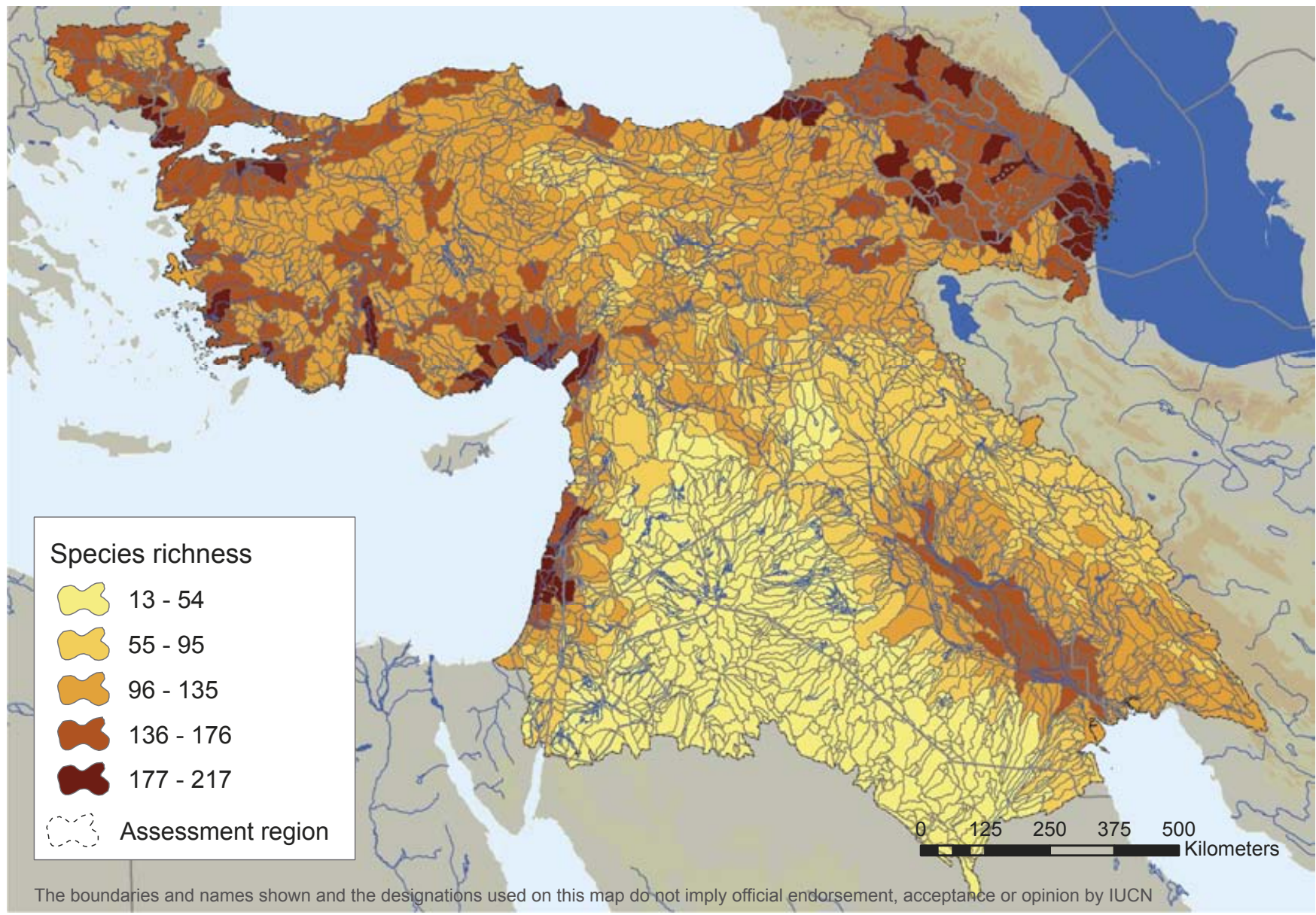




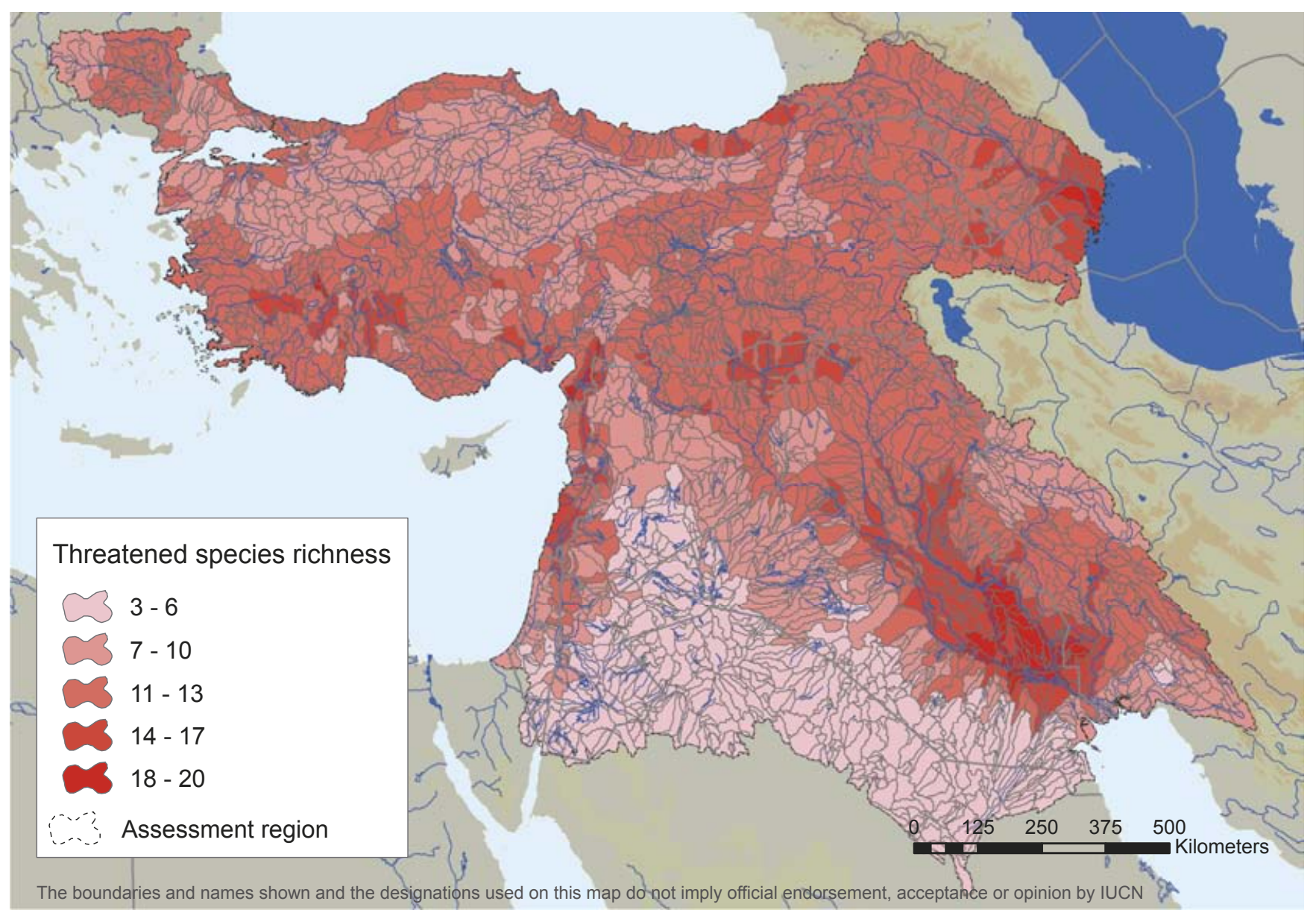

Figure 7.6 Distribution of all threatened (CR, EN, and VU) freshwater species of fishes, molluscs, odonates, plants, birds, mammals, amphibians, and decapods in the Eastern Mediterranean project area.

The Ras al-Ain springs in Syria, which are threatened by ground water extraction and now intermittently dry out, typify the status of springs across the region. Photo $\odot$ Jörg Freyhof

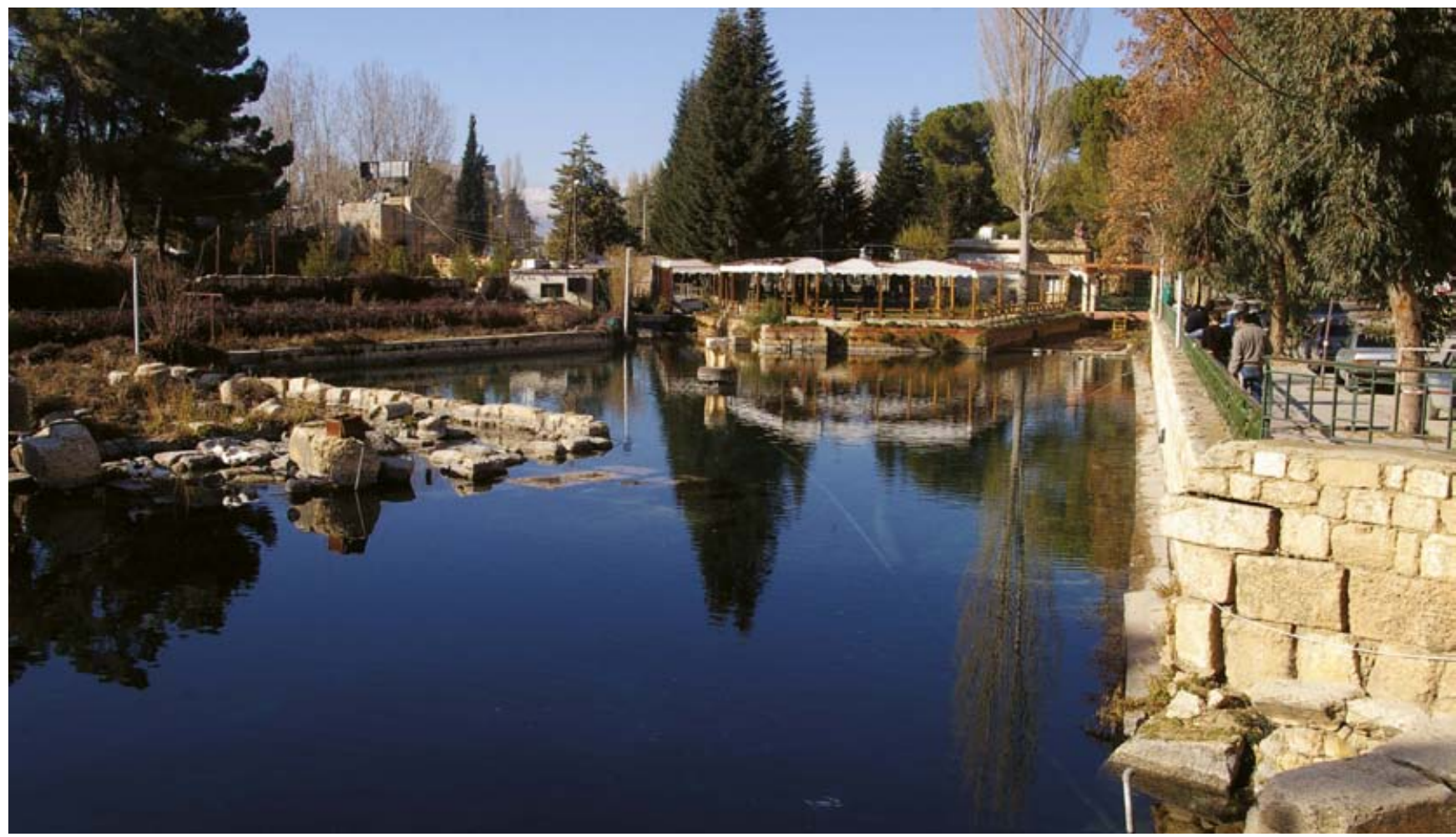


of İskenderun catchments (Orontes/Asi catchment from the lower parts in Turkey all the way through Syria to Lake Homs, the Kebir/Nahr al Kabir on the Lebanon/Syria border, coastal catchments of Lebanon including the Litani River, Upper Hula basin, and Lake Kinneret/Sea of Galilee); the wider Tigris and Euphrates lower plains including the Hawizah marshes up to the Diyala River in Iraq and lower Karoun in Iran; the Khabur River (Euphrates catchment) in northern Syria; the Lakes Region of Turkey (the catchments of lakes Burdur, Işıklı, Eğirdir, and Beyşehir , and lakes Eğirdir and Beyşehir themselves; the upper Büyük Menderes, the Köprü River, and Kırkgöz Springs); the lower Çoruh River and other Black Sea catchments in northeastern Turkey; and the lower Aras/Kura River in Azerbaijan and southern Armenia.

\subsubsection{Sub-basins containing high proportions of species and threatened species for all taxonomic groups}

While the total species and threatened species richness figures above (7.5 and 7.6) present those areas containing the highest number of freshwater species and threatened species, they are biased towards the speciose groups of the fishes, molluscs, and birds. Therefore, to ensure each taxonomic group has an equal weighting, those sub-basins that contain high proportions (at least $10 \%$ ) of the total known species numbers for each animal taxonomic group have been identified (Figure 7.7). Only one subbasin contains $10 \%$ of species for all the seven groups, a tributary to the Simav/Susurluk River which flows into the Sea of Marmara in north-western Turkey.

There are many sub-basins that contain at least $10 \%$ of species for six of the groups, but they are found clustered together: primarily from the Central Anatolian Lakes Region (Akşehir, Burdur, and Eğirdir catchments, Lake Beyşehir, etc.) along the coastal Mediterranean rivers of Turkey (including the Ceyhan, Seyhan, Tarsus, Göksu, Köprü , Eşen, and Büyük Menderes) to the lower Orontes/Asi River. There are also sub-basins within this category ( $10 \%$ of species for six groups) in north-western Turkey including the catchment of Lake İznik, and lower Sakarya River, the lower Çoruh River in north-eastern Turkey, and the lower Aras/Kura River in Azerbaijan.

Figure 7.8 shows that there are no sub-basins that contain a high proportion (at least 5\%) of threatened species for all seven, or even six of the taxonomic groups. Only one sub-basin, the lower Orontes/Asi in Turkey contains $5 \%$ of threatened species for five groups, it is also the sub-basin that contains the highest total number of threatened species in the entire region $(20$ species, Figure 7.6). Three sub-basins contain $5 \%$ of threatened species

Figure 7.7 Sub-basins containing high proportions of species from across all animal taxonomic groups (fishes, molluscs, odonates, birds, mammals, amphibians, and decapods). The map represents the number of taxonomic groups for which at least $10 \%$ of their total known species from the Eastern Mediterranean region are mapped to the sub-basin.

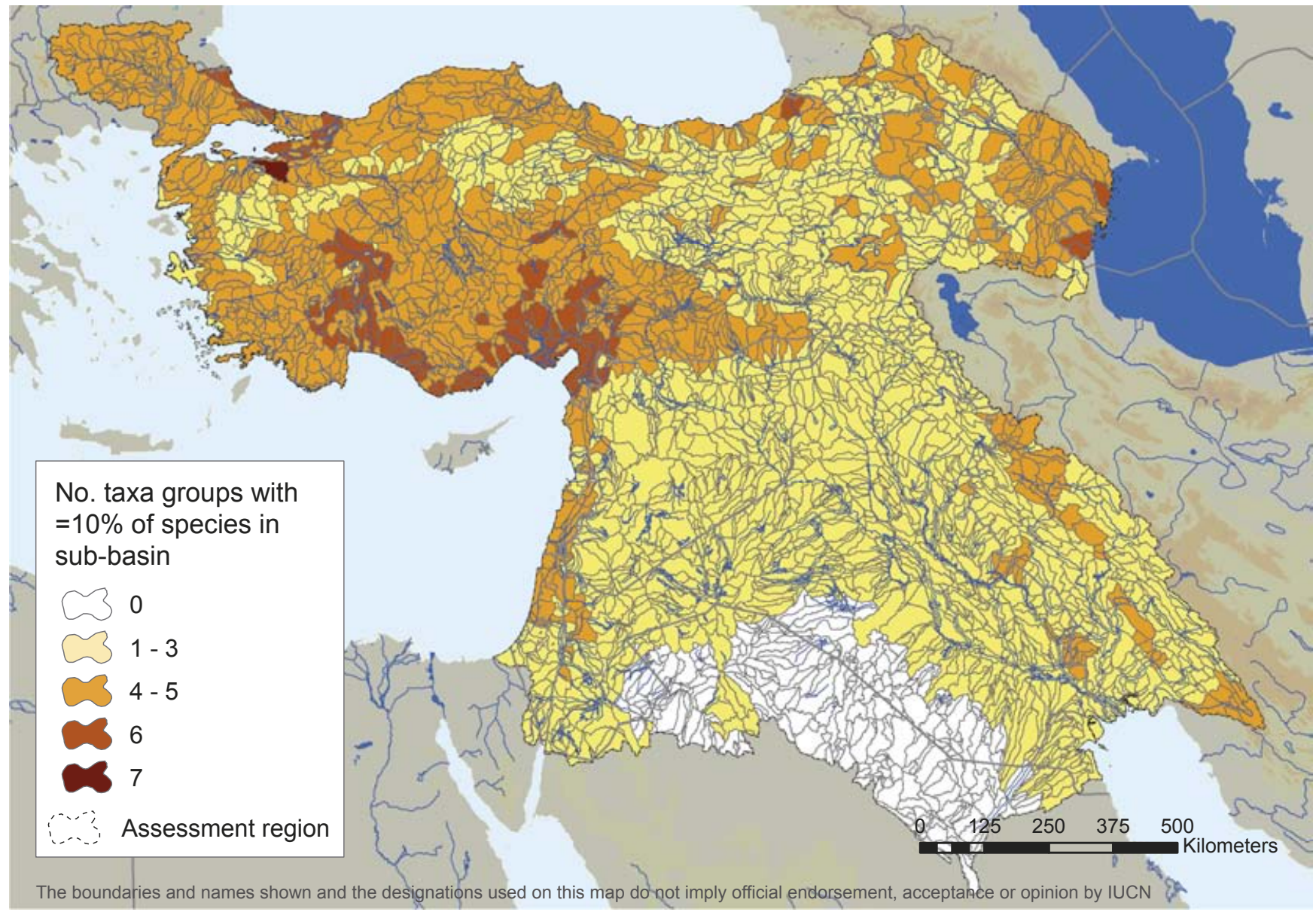




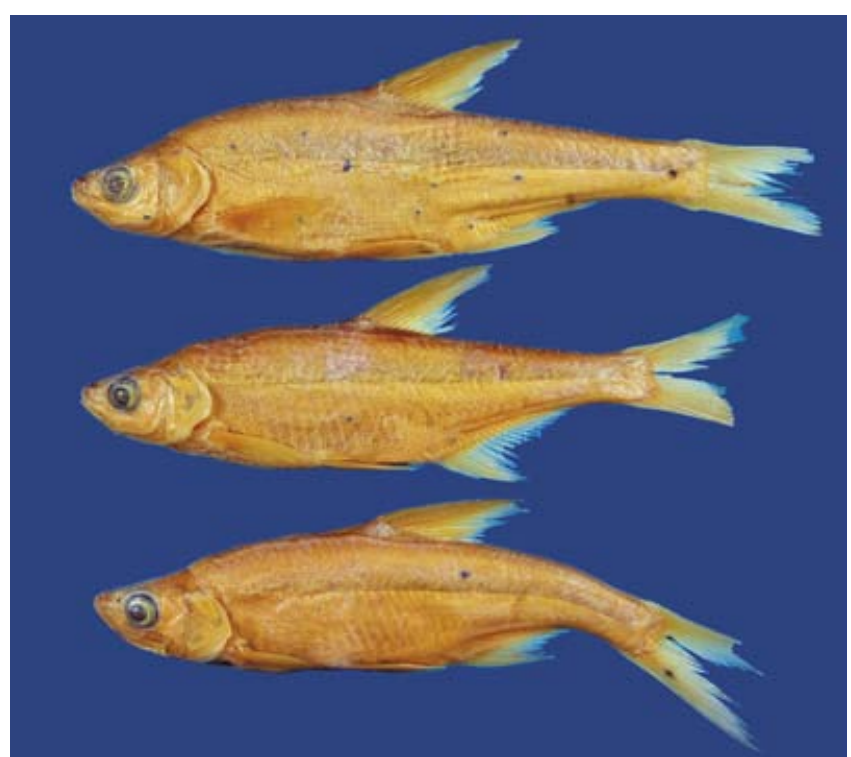

The CR Possibly Extinct Acanthobrama centisquama known only from former lakes Amik (Turkey) and al-Gab (Syria) both in the Orontes/Asi system. Photo @ Jörg Freyhof

for four groups: Lake Kinneret/Sea of Galilee in Israel; Ras al-Ain springs/river in northern Syria; and the Karasu River (including Lake Gölbaşı) that flows into the now drained Amik Lake and lower Orontes/Asi River.
The lower Orontes/Asi system including former Amik Lake, and the Karasu and Afrin river catchments (Turkey and Syria border) are clearly a priority in terms of threatened freshwater biodiversity. The Afrin River is polluted and has almost dried out in its upper parts (J. Freyhof pers. comm. 2014), but the Karasu in general has good water quality, however this deteriorates in the middle and lower reaches due to urban, agricultural, and industrial pollution. In Syria the Asi/Orontes is considered one of the most disturbed hydrological ecosystems, and in Turkey the lower Orontes is affected by salinity and phosphates (UN-ESCWA and BGR 2013). While the main channel is often heavily polluted, the tributaries originating from springs in the mountains and the springs in the river bed itself (both in the upper and middle catchment) can be clean and are of conservation importance. There is also heavy exploitation of water resources across the catchment, the system is dammed and water flow is managed to provide water primarily for irrigation which has resulted in the lowering of the water table, and there are additional plans for irrigation and dam projects which will further threaten the basin's sustainability (UN-ESCWA and BGR 2013). These pressures have had significant impacts to freshwater biodiversity in this system, for example the Long-spined bream (Acanthobrama centisquama) is a CR fish species known only from former lakes Amik (Turkey) and al-Gab (Syria) both in the Orontes/Asi system, and is now classed as Possibly Extinct (Freyhof 2014b).

Figure 7.8 Sub-basins containing high proportions of threatened species from across all animal taxonomic groups (fishes, molluscs, odonates, birds, mammals, amphibians, and decapods). The map represents the number of taxonomic groups for which at least 5\% of their total numbers of threatened species from the Eastern Mediterranean region are mapped to the sub-basin.

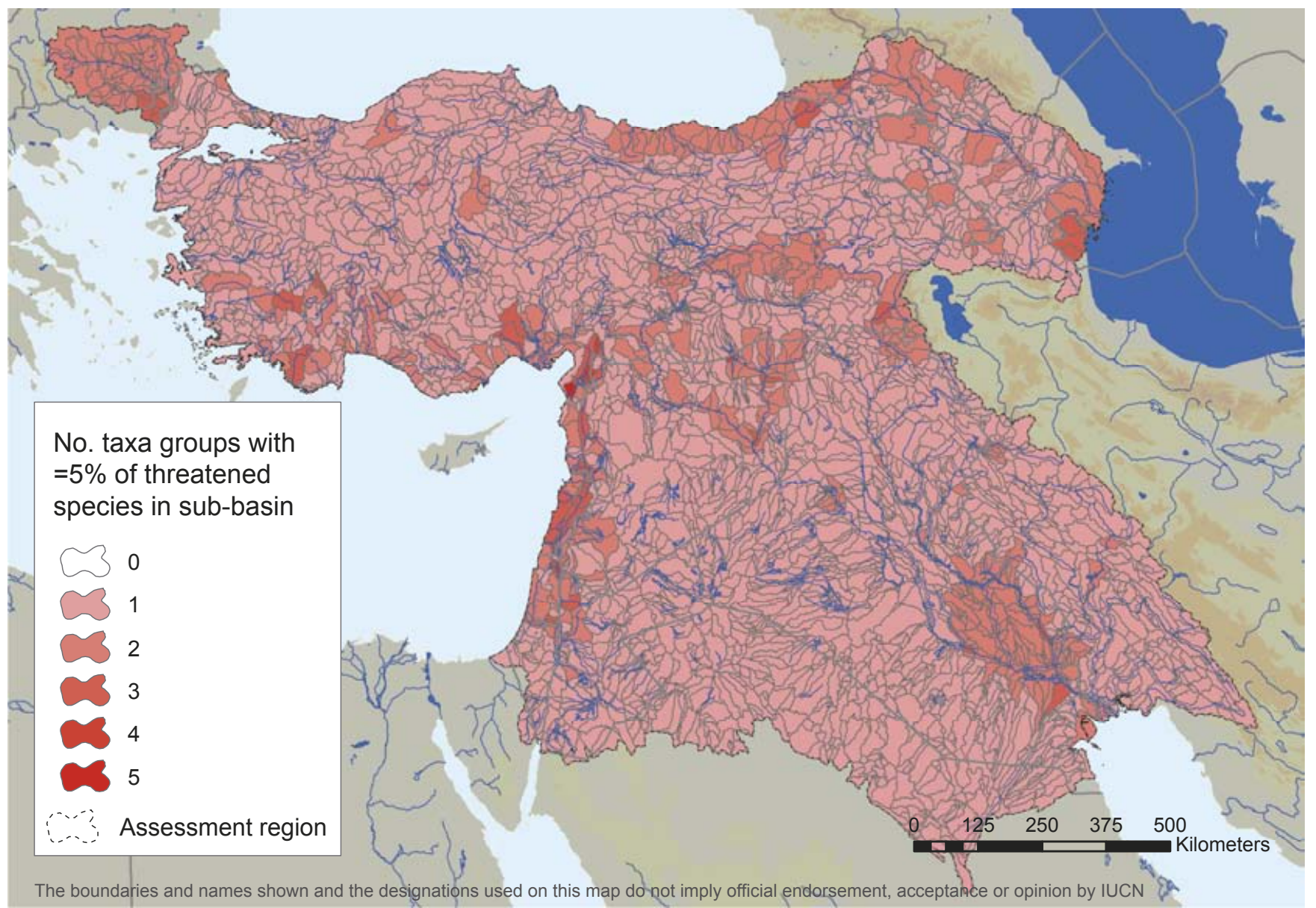




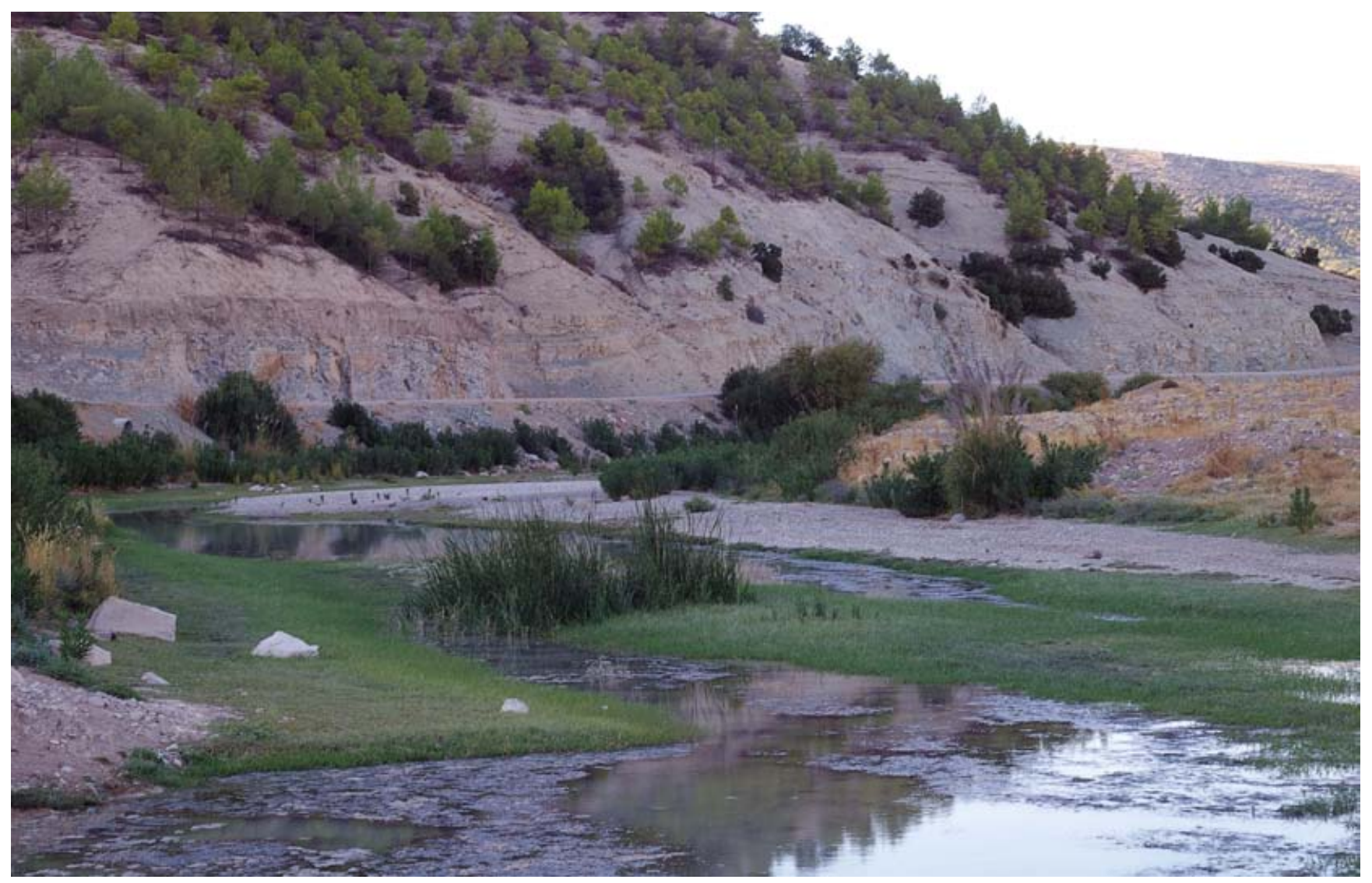

The River Afrin, a tributary to the lower Asi/Orontes River is one of the few rivers that support a large proportion of threatened freshwater species for a number of different taxonomic groups. Photo $\odot$ Jörg Freyhof

Amik Lake was drained between the 1940s and 1970s, and the al-Gab lake was drained earlier, however the species may still be present in Lake Gölbaşı, just upstream of where Amik Lake used to be, but is itself impacted by pollution and water abstraction. The Orontes sportive loach (Oxynoemacheilus hamwii) and the Levantine Nase (Chondrostoma kinzelbachi) are both EN fishes, restricted to the lower Orontes system in Turkey having become extirpated from the Orontes in Syria (Freyhof 2014c, d). The Orontes scraper (Capoeta barroisi), also EN, was once widespread across the Orontes system (where it is endemic) but it is thought now to only exist in the lower Orontes and Afrin in Turkey, and in Lake Qattinah in southern Syria (Freyhof 2014e). Leguminaia saulcyi is a CR species of freshwater mussel now thought to be restricted to the Orontes, as it has become extirpated from Israel and from the coastal plain rivers of the Levant (Lopes-Lima and Seddon 2014a). Anodonta pseudodopsis is another threatened (EN) species of mussel, only known from the Orontes with recent records only from Lake Gölbaşı. It is possible that the species is still present in Lake Homs and other connected lakes in the Orontes, and also in the Nahr al-Kabir River in Lebanon and Syria (Lopes-Lima and Seddon 2014b). Palaemonetes mesopotamicus a CR species of freshwater shrimp is only known from one location in the lower Orontes despite widespread surveys across the Turkish part of the Orontes system, though old records for the species exist from Syria (the Khabur River) it is thought to be extirpated from there (De Grave 2013).

\subsection{Important habitats supporting freshwater biodiversity in the Eastern Mediterranean}

Using the IUCN Red List species assessments which code suitable habitats for the species, and also those which are of a major importance (meaning the habitat is required by the species to complete its life cycle, or is the primary habitat type), it is possible to identify which habitat types are the most important and threatened for freshwater biodiversity in the Eastern Mediterranean region. Figure 7.9 shows that permanent rivers is the most utilized habitat by freshwater biodiversity, supporting $64 \%$ (785 species) of the 1,230 species for which there are Red List assessments (Figure 7.6). This is followed by permanent lakes (over $8 \mathrm{ha}$ ) which provide a habitat for $44 \%$ of species ( 547 species), permanent marshes and pools (under $8 \mathrm{ha}$ ) (39\% or 476 species), and bogs, marshes, and swamps (38\% or 467 species). Freshwater springs and oases, and the seasonal/intermittent habitats (rivers, lakes, and marshes/pools) are also important habitat types, each supporting between $16-22 \%$ of all species.

In terms of threatened species, permanent rivers support the most with $61 \%$ (or 137) of all threatened species (a similar proportion to all species found in permanent rivers). This is followed by freshwater springs and oases (32\% or 71 species) and permanent freshwater lakes (29\% or 65 species). However, if the proportion 
of threatened species supported by each habitat is identified, karst systems are the most threatened habitat type with six of the eight species assessed as threatened. The second most threatened habitat type are the freshwater springs and oases which have $29 \%$ of its species assessed as threatened, which is followed by permanent rivers (17\%).

Figure 7.10 presents the habitats coded as of major importance for threatened species. It shows that permanent rivers are of major importance for the survival of almost half of all threatened species in the region (111 species) more than any other habitat type. This is followed by freshwater springs and oases (25\% or 56 species) and permanent freshwater lakes (22\% or 49 species). However if this is looked at in terms of the proportion of all species supported by each habitat type, karst systems and freshwater springs and oases again come out on top. Fifty per cent of all species supported by karst systems (four species) are threatened and have coded karst as a 'major importance'. For freshwater springs and oases, this figure is $23 \%$ ( 56 species out of a total of 245 ), and for permanent rivers it is $14 \%$ (111 species out of a total of 785 ).

Permanent rivers, often fed by springs, are a key habitat for freshwater biodiversity in the region. However they are under great pressure (see individual taxa chapters) from a multitude of threats primarily from water abstraction, dams, increasing severity of droughts, and pollution. This is leading to many, once permanent, rivers becoming degraded, fragmented, and seasonal, with some becoming totally dry. One example of this is the Qweik River, a closed basin which rises in Turkey and flows into northern Syria where it was once the primary water source for the city of Aleppo. However, due to high levels of water abstraction the springs that fed the river are now dry and the river itself is intermittent and heavily polluted (UN-ESCWA and BGR 2013). The Halep loach (Oxynoemacheilus tigris) a CR fish
Figure 7.9 Habitats coded against all freshwater species (fishes, molluscs, odonates, plants, birds, mammals, amphibians, and decapods). Note species can have more than one habitat coded, and some habitat types (e.g. Tundra) are not found within the Eastern Mediterranean region but are coded in the species Red List assessment as the species will be found in these habitat types outside the region.

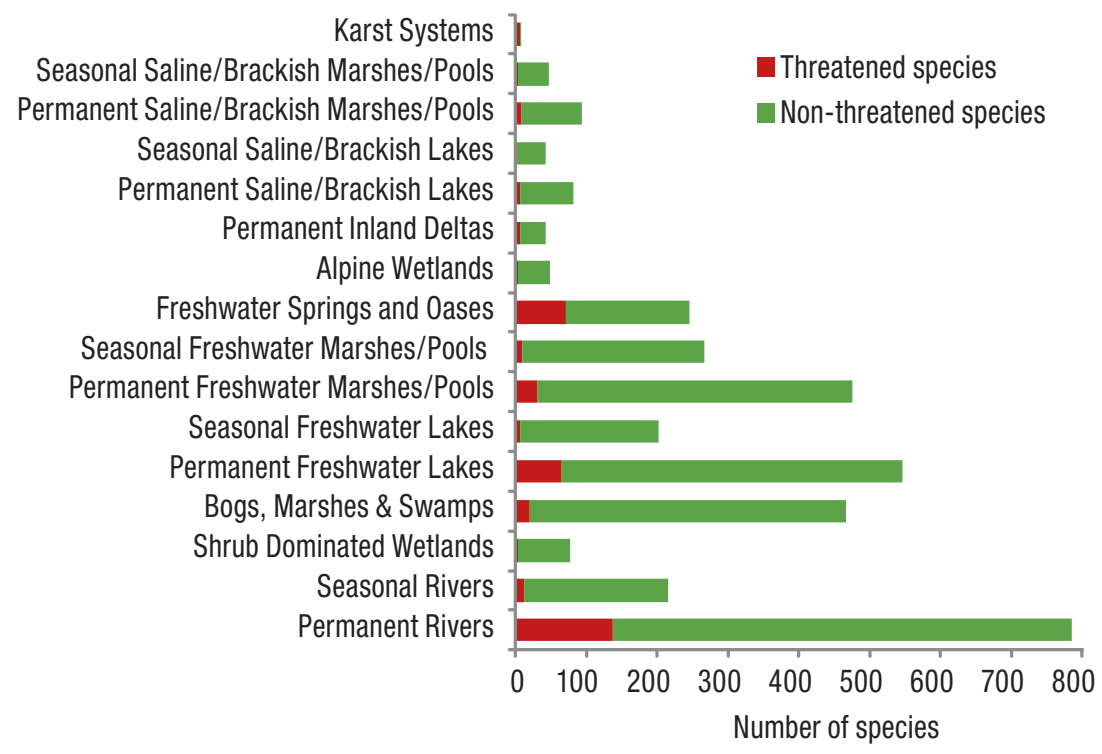

Figure 7.10 Habitats coded as 'major importance' for threatened freshwater species (fishes, molluscs, odonates, plants, birds, mammals, amphibians, and decapods).

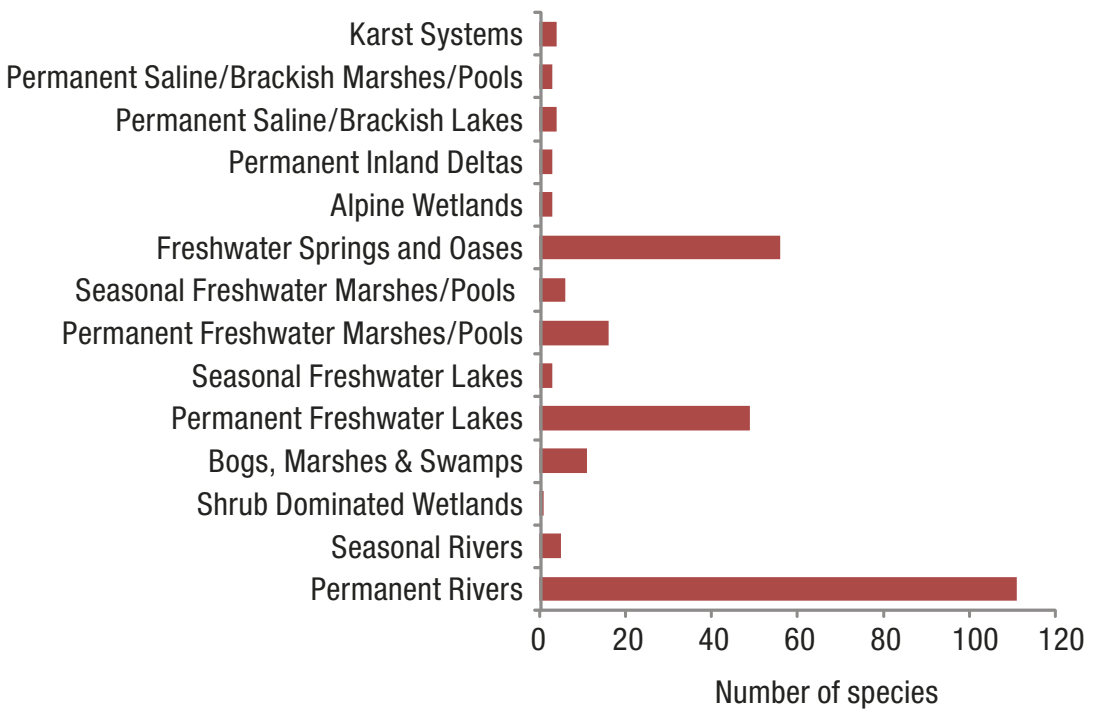




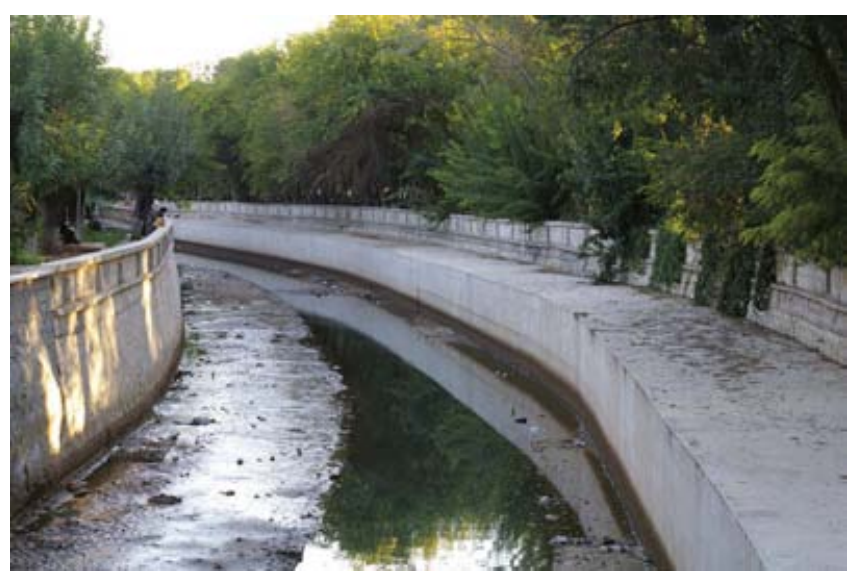

The Qweik River was once the primary water source for the city of Aleppo, Syria, but like many over-abstracted rivers in the region, now only flows intermittently and is heavily polluted. Photo @ Jörg Freyhof

species, was once widespread across the Qweik drainage, but now due to the loss of water in large parts of the river, the species is now known from just one stream in Turkey, which is only a few hundred metres long and flows into a reservoir (Freyhof 2014f).

The section above on Ras al-Ain springs (7.3.4) details the common plight of springs across the region, which are being threatened by water abstraction exacerbated by an increasing severity of droughts. Azraq Oasis, a Ramsar site in Jordan, is another similar situation, where the springs that fed a large permanent wetland (with extended seasonal flats) ran dry in 1992 due to excessive groundwater abstraction. Azraq Oasis is the only known site for the Azraq toothcarp (Aphanius sirhani, now CR), which was taken into captive breeding facilities. Since then, the wetlands have been partially restored (to $5.5 \%$ of their former size), however large scale water abstraction continues (much of it illegal), and the wetlands are wholly reliant upon artificial water supply provided by the government as the springs are still dry. The Azraq toothcarp has since been successfully re-introduced into the wetlands, though there is an additional threat from introduced invasive fish species (Freyhof and Harrison 2014).

Karst systems are widely found in the Mediterranean part of Anatolia and they occur in the majority of the Taurus Mountains Range, where limestone deposits originating from various geological ages are found together. The middle and western parts of the range, for example Teke Peninsula, Lakes Region, and Taseli Plateau, contain significant areas of complex karstic

The Haditha cave garra (Typhlogarra widdowsoni), a CR fish species endemic to the Haditha karst system in Iraq. Photo @ Jörg Freyhof

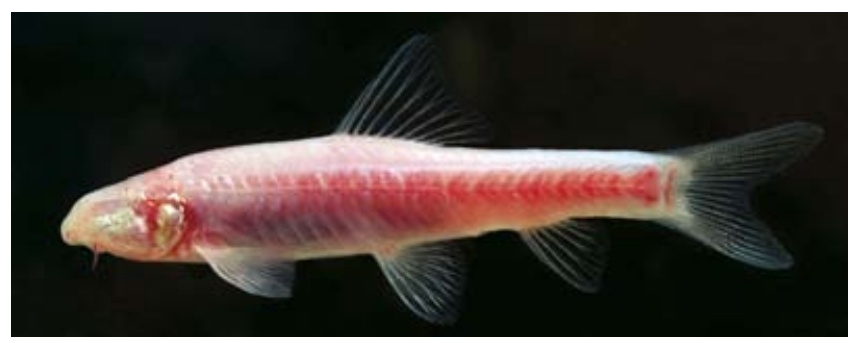

systems (Atalay 1997). However the fauna of Turkish karst systems is poorly known. The very recently discovered (2014), and therefore not yet assessed, cave loach species Cobitis damlae is the only known cave fish in Turkey. The species was discovered in the upper streams of the Dalaman River after a flood, where the Keloglan cave is found (Erk'akan, and Özdemir 2014). The Haditha karst system is found in western Iraq (within the Euphrates catchment), and supports two endemic CR cave fishes: the Haditha cave fish (Caecocypris basimi) and the Haditha cave garra (Typhlogarra widdowsoni). Falling groundwater levels are the major threat to the system, which is due to water abstraction and hydrological modifications of the water layers by the construction of a large dam close by on the Euphrates. The Haditha cave garra was once so abundant it was harvested and sold as an ornamental fish, though a survey in 2012 found that its two known cave sites were massively impacted by water abstraction, with one site totally dry (Freyhof 2014g). The Haditha cave fish was last recorded from a well in 1983, but the same 2012 survey failed to find the species (Freyhof 2014h). However, due to the nature of karst systems, their presence elsewhere within the karst cannot be ruled out.

\subsection{Threats to freshwater biodiversity in the Eastern Mediterranean}

For each species in the IUCN Red List assessment the direct threats that have impacted, are impacting, or may impact the species are coded against the IUCN-CMP Unified Classification of Direct Threats and Actions ver. 3.2 (for more information see http://www.iucnredlist.org/technical-documents/classificationschemes, and Salafsky et al. 2008). This allows for the major threatening processes to freshwater biodiversity to be identified. The previous chapters in this report discuss the threats to individual taxon groups in more detail, and in the context of each group's specific life histories. In summary, the taxon chapters show how unique and irreplaceable the freshwater biodiversity in the Eastern Mediterranean region is, and how it is being put under

The widespread abstraction of water is leading to the reduction of ground waters at an alarming rate. Azraq Oasis springs in Jordan are a classic example of how excessive levels of groundwater extraction can leave wetlands dry. Photo (c) Kevin Smith

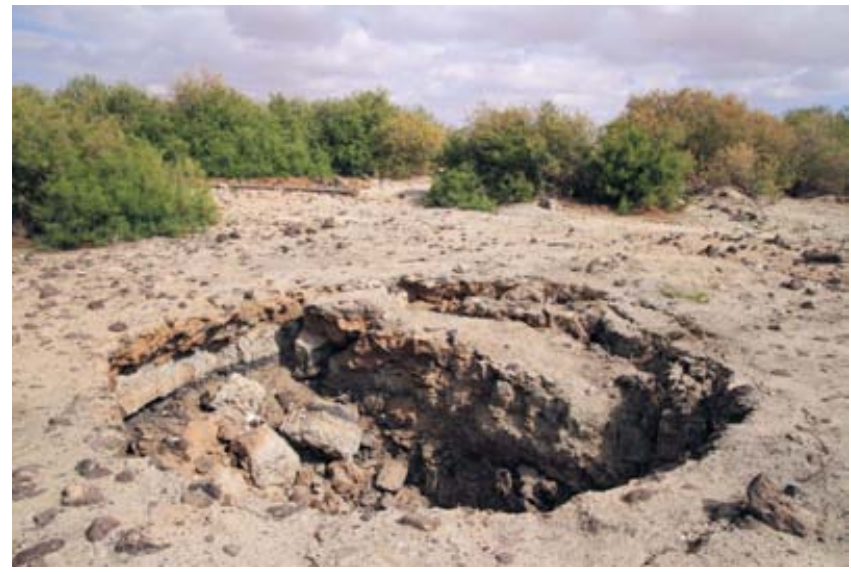


Natural system modifications, such as by dams, represent one of the greatest threats to freshwater biodiversity in the Eastern Mediterranean. Oymapinar hydro-electric dam on the Manavgat River, Antalya, Turkey is one such example. Photo @ Jörg Freyhof

severe pressure due to rapid economic development impacting the region's water resources. The widespread abstraction of water (primarily for agricultural irrigation), coupled with the damming of rivers (for hydropower and water storage), is compounded by increasing severity of droughts leading to reduced flows in rivers, in some cases leaving rivers and wetlands totally dry and a reduction of ground waters at an alarming rate (AQUASTAT
2009, Voss et al. 2013). Not only is this unsustainable level of extraction threatening freshwater biodiversity but it also threatens the long-term water security of the region (UNEP 2008). To make matters worse, freshwater habitats such as deltas and marshes are widely considered as vacant or worthless land often being converted for more 'productive' uses such as for agriculture, urban expansion, and industrial developments such

Table 7.6 Major ongoing threats to each taxon group in the Eastern Mediterranean. The percentage of threatened and NT freshwater species within each taxon group is shown for each of the IUCN threat categories (for both ongoing and/or future threats).

\begin{tabular}{|c|c|c|c|c|c|c|c|c|}
\hline Threat Category & $\begin{array}{l}\frac{d}{E} \\
\frac{E}{E}\end{array}$ & $\frac{\mathscr{U}}{\frac{8}{0}}$ & 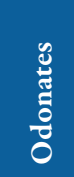 & $\begin{array}{l}\frac{8}{0} \\
\frac{0}{0} \\
\frac{0}{2}\end{array}$ & 竞 & 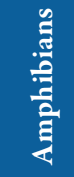 & 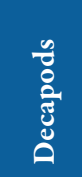 & 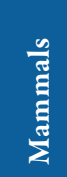 \\
\hline Residential \& commercial development & 50.0 & 2.1 & 50.0 & 20.3 & 26.3 & 33.3 & 0.0 & 50.0 \\
\hline Agriculture \& aquaculture & 64.3 & 1.4 & 28.6 & 14.1 & 78.9 & 66.7 & 0.0 & 75.0 \\
\hline Energy production $\&$ mining & 0.0 & 3.6 & 21.4 & 0.0 & 31.6 & 0.0 & 0.0 & 25.0 \\
\hline Transportation & 0.0 & 4.3 & 0.0 & 1.6 & 21.1 & 20.0 & 0.0 & 75.0 \\
\hline Biological resource use & 21.4 & 11.4 & 7.1 & 0.0 & 78.9 & 73.3 & 25.0 & 75.0 \\
\hline Human disturbance & 21.4 & 0.7 & 21.4 & 3.1 & 47.4 & 6.7 & 0.0 & 75.0 \\
\hline Natural system modifications & 28.6 & 90.0 & 78.6 & 68.8 & 52.6 & 40.0 & 100.0 & 75.0 \\
\hline Invasive species, genes, \& diseases & 7.1 & 20.7 & 0.0 & 7.8 & 36.8 & 40.0 & 25.0 & 75.0 \\
\hline Pollution & 21.4 & 47.1 & 71.4 & 56.3 & 36.8 & 66.7 & 25.0 & 75.0 \\
\hline Climate change $\&$ severe weather & 14.3 & 69.3 & 50.0 & 29.7 & 47.4 & 20.0 & 0.0 & 25.0 \\
\hline
\end{tabular}


as power plants and oil refineries. Freshwater habitats are also heavily degraded by pollution, particularly adjacent to urban areas and intensive agriculture.

The proportions of threatened and NT species within each taxon group that are impacted by the various categories of threat are presented in Table 7.6. The major threat to freshwater plants is agriculture and aquaculture (impacting 64.3\% of threatened and NT species), followed by residential and commercial development (50\% of species impacted). The greatest threat to threatened and NT fishes is natural system modifications (90\% of species impacted), followed by climate change and severe weather (69\% of species impacted). The odonates and molluscs are both most heavily impacted by natural system modifications (79\%, 69\% of species impacted, respectively), followed by pollution ( $71 \%$, $56 \%$ of species impacted, respectively). Wetland birds are most impacted by agriculture and aquaculture and biological resource use equally (79\% of species impacted), with natural system modifications also affecting just over a half of threatened and NT species (53\% of species impacted). Biological resource use is also the major threat to amphibians ( $73 \%$ of species impacted), followed by agriculture and aquaculture and pollution (both impacting $67 \%$ of species). All species of threatened or NT freshwater decapod species (of which there are only four) are threatened by natural system modifications, with biological resource use, invasive and other problematic species, and pollution each affecting one species. Three of the four threatened or NT freshwater dependent mammal species are widely impacted by almost all threat categories.

The average proportion of threatened and NT species, for all the taxon groups combined, impacted by each category of threat is presented in Figure 7.11. Natural system modifications, pollution, and agriculture and aquaculture are the dominant threats to freshwater biodiversity in the Eastern Mediterranean region, affecting on average $67 \%, 50 \%$, and $41 \%$ of the threatened and NT species, respectively.

The IUCN threat classification system is multi-levelled, in that more specific threat classifications are nested under each of the top level categories. A breakdown according to the second level threat classifications for the two greatest threats, natural system modifications and pollution is presented in figures 7.12 and 7.13, respectively. Figure 7.12 shows that dams and water managemen. and use are a major pressure to freshwater biodiversity within the Eastern Mediterranean region, affecting a large proportion o: threatened and NT species from each of the taxon groups, namely $90 \%$ of fishes, $71 \%$ of odonates, $66 \%$ of molluscs, $42 \%$ of birds $40 \%$ of amphibians, $75 \%$ of mammals, and $100 \%$ of decapods Under the major threat heading of pollution, agricultural effuent. present the greatest source of pollution for plants (impacting 14\% of threatened or NT species), odonates (64\%), molluscs (42\%) birds (31\%), and amphibians (53\%), whereas domestic and urbar. waste water is the major source of pollution impacting freshwates fishes (43\%) (Figure 7.13).

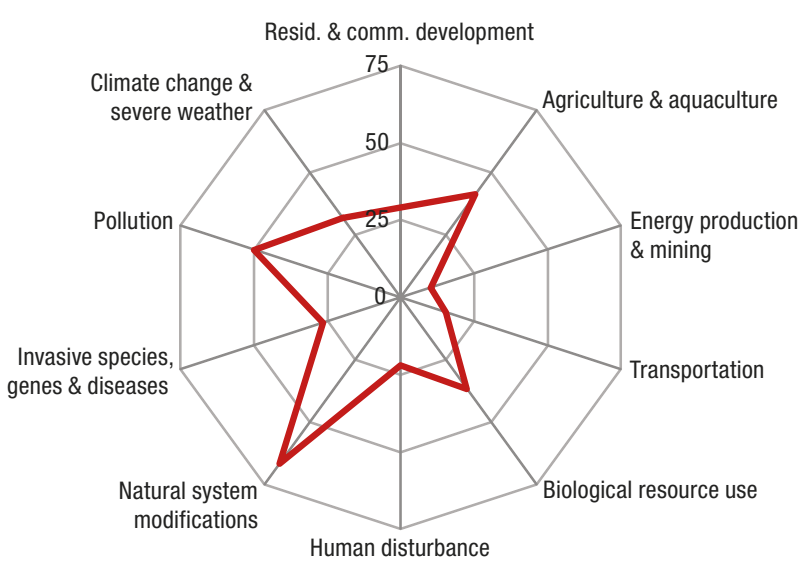

Figure 7.11 Major ongoing threats to freshwater biodiversity in the Eastern Mediterranean. The chart shows the average percentage of threatened and NT species for all taxon groups combined (fishes, molluscs, odonates, plants, birds, mammals, amphibians, and decapods) impacted by each of the main IUCN threat categories (for both ongoing and/or future threats).

Figure 7.12 Impact of sub-categories of threat within the threat category 'Natural System Modifications' for each of the taxon groups.

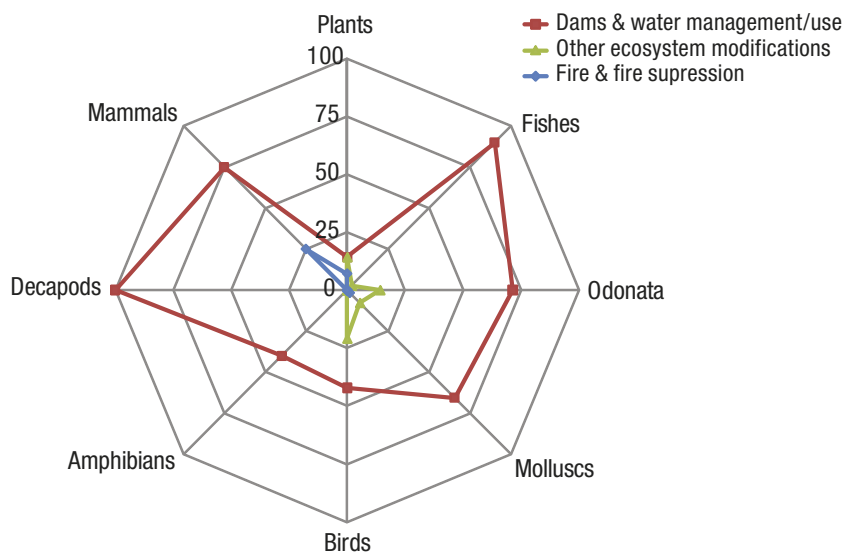

Figure 7.13 Impact of sub-categories of threat within the threat category 'Pollution' for each of the taxon groups.

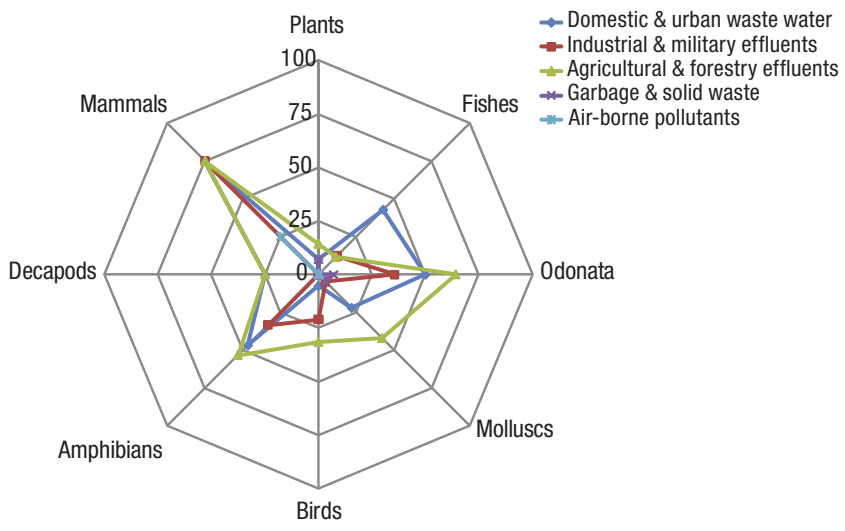




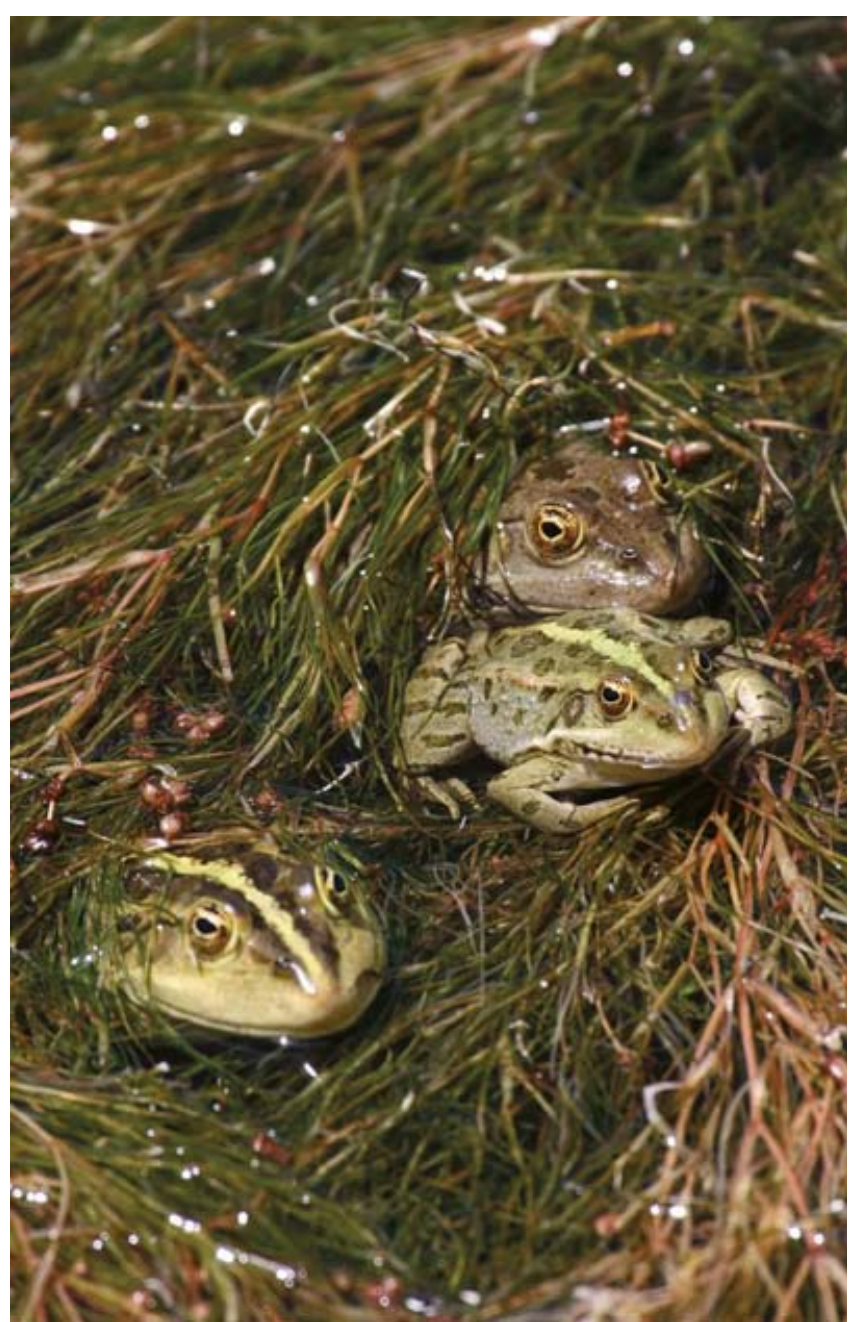

A number of frog species are harvested for food and export in the Eastern Mediterranean region. Eurasian Marsh Frogs in Sultan Marshes, Turkey. Photo @ Jan Stefka. Online image/Flickr under CC licence 2.0 by-nc-sa

\subsection{Provisioning ecosystem services and freshwater biodiversity of the Eastern Mediterranean}

Within each species Red List assessment its human use and trade are recorded. Based on this information the freshwater species found in the Eastern Mediterranean that directly contribute to provisioning ecosystem services (e.g. food, medicine, fodder etc.) can be identified. It is important to note that if a species has been identified as providing some kind of provisioning service it does not mean that the harvesting of the species is a threat. If harvesting is a threat, it will be recorded under biological resource use in the threats classification scheme (section 7.5). Also, many of the species (in particular plants and birds) occur outside the Eastern Mediterranean region and their human use information in the Red List assessment may relate to harvesting activities not within the Eastern Mediterranean region.

The results show that the plants have by far the most diverse set of use purposes, with species being utilized in almost every category, though they are predominantly used as medicine, food and for humans and in horticulture (Figure 7.14). Almost a fifth of all freshwater plants $(18.4 \%, 67$ species) are harvested for medicinal use, whereas $11 \%$ ( 40 species) and 12.6\% ( 46 species) are used as food for humans and in horticulture respectively. An example is the plant Amsonia orientalis (CR), known as 'blue star', which has cardioactive and anticancer characteristics and shows broad antimicrobial activity, and is also found in horticulture due to its purple star-shaped flowers. The species, only known from seasonal wetlands in Greece and northwest Turkey, was previously thought likely to be extirpated from Turkey, but it has been found within a very narrow area in the Ömerli Basin (Kavak 2014).
Figure 7.14 Proportion of freshwater species for each taxonomic group (fishes, molluscs, plants, birds, amphibians, mammals, and decapods) utilized for different purposes (this data excludes those species that are sourced from captive bred or horticulture). Note that no species of odonates were utilized for any purpose.

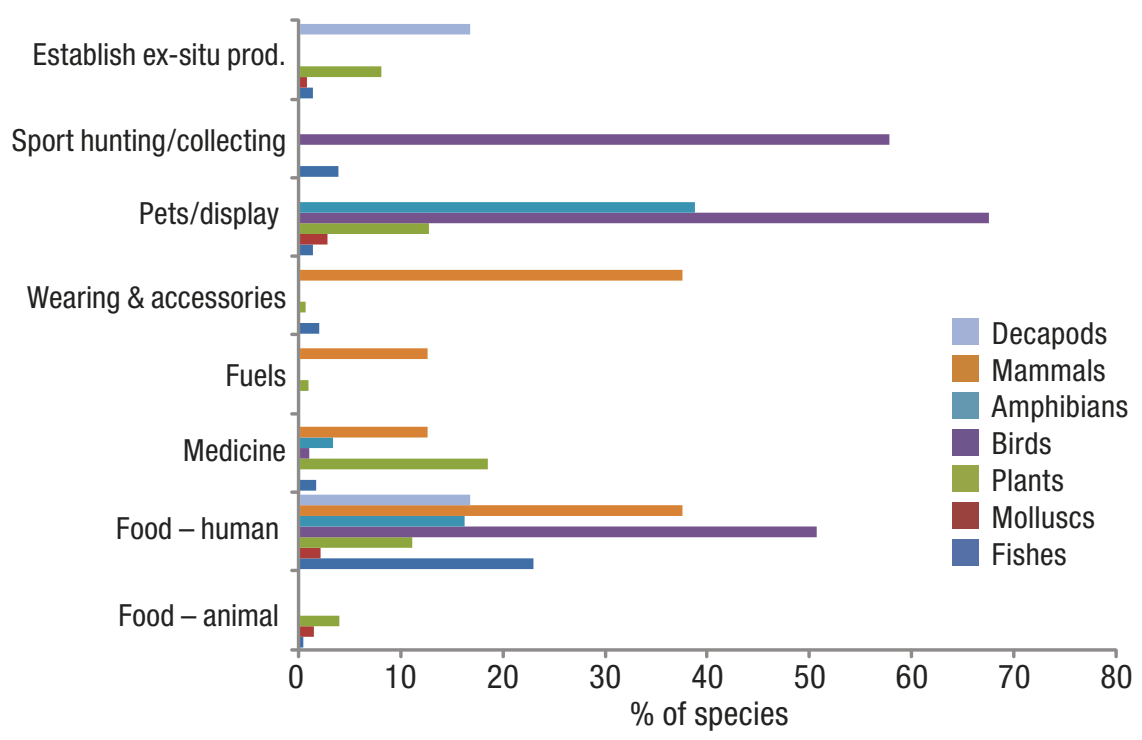


Almost one quarter of freshwater fishes assessed in this study (22.9\% or 73 species) are harvested for human food, and $3.8 \%$ (12 species) are utilized in sport bunting. An example is the Shabout (Barbus grypus), a Vulnerable species which is of high commercial importance and a major target species in all larger rivers, marshes, and reservoirs within its range (Euphrates and Tigris catchments from southern Anatolia south to Shatt AlArab, it is also in rivers of the Persian Gulf of Iran) and is heavily overfished (Freyhof 2014i).

Large numbers of wetland birds, for example the Eurasian Wigeon (Mareca penelope) and Common coot (Fulica atra), are harvested from the wild either for human food (50.7\% or 144 species), pets/ display animals (67.6\% or 152 species), or for sport hunting $(57.8 \%$ or 130 species). The region has a long history of bird hunting, and hundreds of thousands of people are still involved in the activity today. Many of the waterfowl and songbirds that are hunted in the region are migrants, and it is an important socio-economic activity across the region, involving large numbers of people particularly in rural areas (e.g. in Syria there are an estimated 400,000 sport hunters, 200-300 falcon trappers and 20,000 people who hunt for a living) (BirdLife International 2010). This harvesting (in the Middle East and North Africa) is often excessive and indiscriminate and is a threat to many migratory bird species in the region (BirdLife International 2008).

The major human uses for the few amphibian species found in the Eastern Mediterranean region is for human food $(16.1 \%$ or five species) and for pets/display animals (38.7\% or 12 species). An example is the Near Threatened Pelophylax caralitanus, the largest edible frog from Turkey (where it is endemic to the Lakes District in southwestern Anatolia) and is harvested to export for food in France, Italy, and Switzerland (Ŏz et al. 2009).

The freshwater dependent mammals are primarily utilized for human food (37.5\% or three species), and wearing apparel, accessories (37.5\% or three species). An example is the Smoothcoated Otter (Lutrogale perspicillata) a VU species found across South and Southeast Asia, with an isolated population in Iraq (the sub-species L. p. maxwelli). This sub-species, which is endemic to Iraq, and the Eurasian otter (Lutra lutra) are both hunted in large numbers for their pelts, and the level of harvest alongside persecution due to conflict with fishermen is thought to be a significant threat to the species (Al-Sheikhly and Nader 2013).

The decapods are only harvested (16.7\% or two species) from the wild for human food (or establishing ex-situ populations for food). For example the long-clawed crayfish (Astacus leptodactylus), which is a LC species widespread across Europe, Middle East, and Russia, is commercially harvested for food. However, in Turkey there have been fluctuations in the harvest of this species over the years, showing an increasing trend since 1995, with a significant decline since 2005 (the trend is unknown after 2007). The reason for this apparent decline is not clear and there is no indication that it is related to crayfish plague, though

Integrated River Basin Management is especially important for transboundary rivers such as the Tigris, pictured here at Hasankeyf in Turkey. Photo $($ Travel Aficionado. Online image/Flickr under CC licence 2.0 by-nc

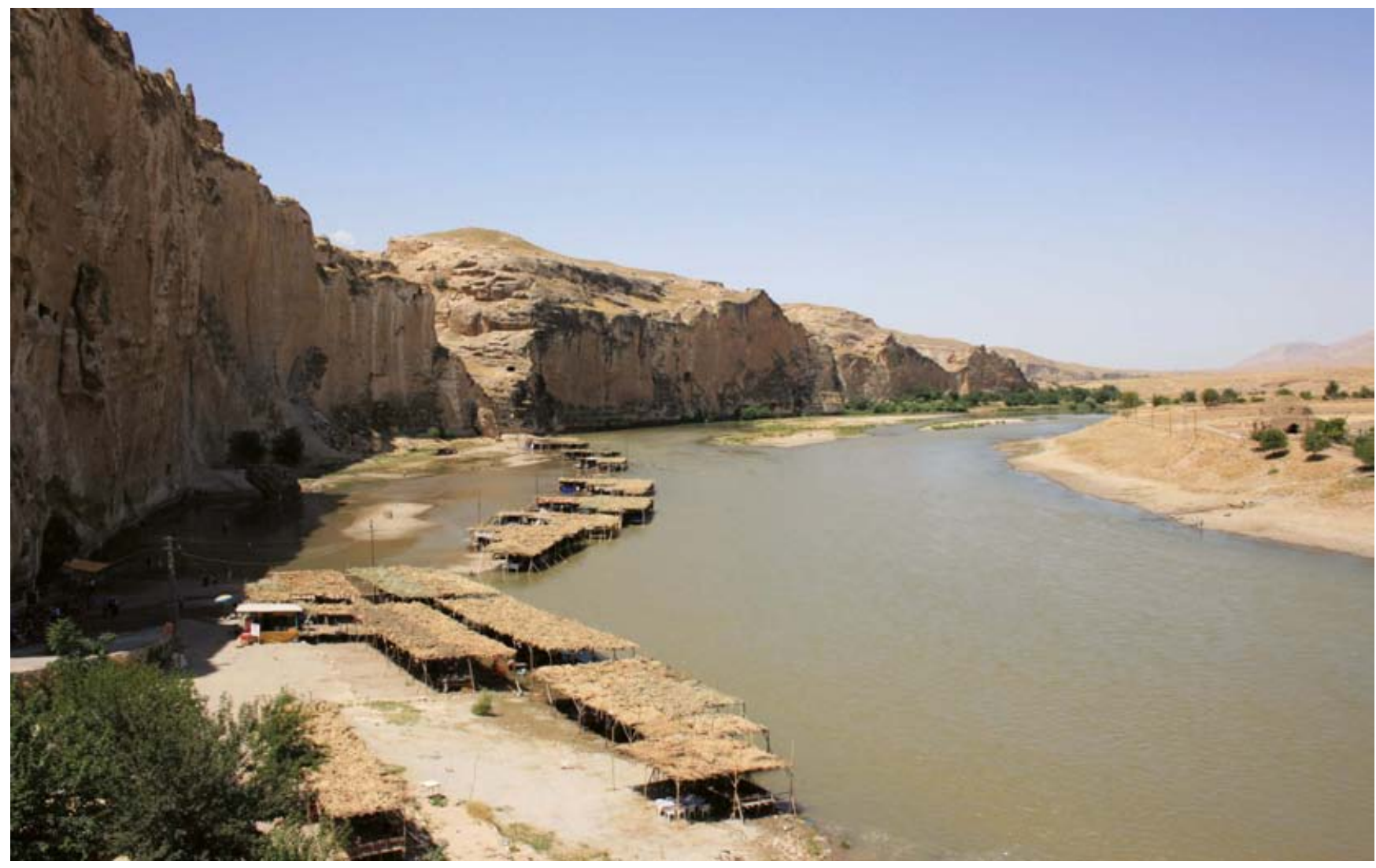


over-harvesting is thought to be a contributing factor (Gherardi and Souty-Grosset 2010).

\subsection{Freshwater Key Biodiversity Areas}

Freshwater Key Biodiversity Areas (KBAs) are globally significant areas for the persistence of biodiversity (Eken et al. 2004, Langhammer et al. 2007, Holland, Darwall, and Smith 2011), and can guide the selection of new protected areas or the expansion of existing site networks. Building on the IUCN Red List assessment information collated through this project, the freshwater KBAs for the Mediterranean Basin have been identified through a regional stakeholder consultation process. The results of this are presented in an associated report 'Freshwater Key Biodiversity Areas in the Mediterranean Basin Hotspot' (Darwall et al. 2014) which can be accessed on the IUCN website.

In addition the Iraqi Ministry of Environment and Nature Iraq has recently identified a total of $82 \mathrm{KBAs}$. Thirty-nine of these KBAs are triggered by non-avian vertebrates, 67 by birds (IBAs), and 73 by plants (IPAs), covering 4.3\%, 6.3\%, and $5.6 \%$ of Iraq respectively. The non-avian vertebrate KBAs include a number of freshwater trigger species: the Smoothcoated otter Lutrogale perspicillata (VU); two newt species Neurergus derjugini [N. microspilotus in this assessment] (CR) and Neurergus crocatus (VU); and four fish species, the Orontes Scraper Capoeta barroisi (EN), the Leopard Barbel Luciobarbus subquincunciatus (CR), and the Haditha Karst system endemics Haditha Cave garra Typhlogarra widdowsoni (CR), and Haditha Cave fish Caecocypris basimi (CR). The results of this work are presented in the 'Key Biodiversity Areas of Iraq: Priority Sites for Conservation and Protection' report (Iraqi Ministry of Environment \& Nature Iraq in prep).

\subsection{Recommendations}

This section builds on and summarizes the conservation recommendations presented in each of the preceding chapters, and incorporates an analysis of IUCN Red List species assessments (Table 7.7) for which 'conservation actions needed' for each species are coded against the IUCN-CMP Unified Classification of Direct Threats and Actions ver. 3.2 (see http:// www.iucnredlist.org/technical-documents/classificationschemes, and Salafsky et al. 2008 for more information).

\subsubsection{Integrated River Basin Management (IRBM)}

The primary conservation action required for freshwater biodiversity in the region is site/area management which is recommended for $56.1 \%$ of all threatened freshwater species (Table 7.7). The recommended approach is for application of Integrated River Basin Management (IRBM). IRBM is the process of coordinating conservation, management, and

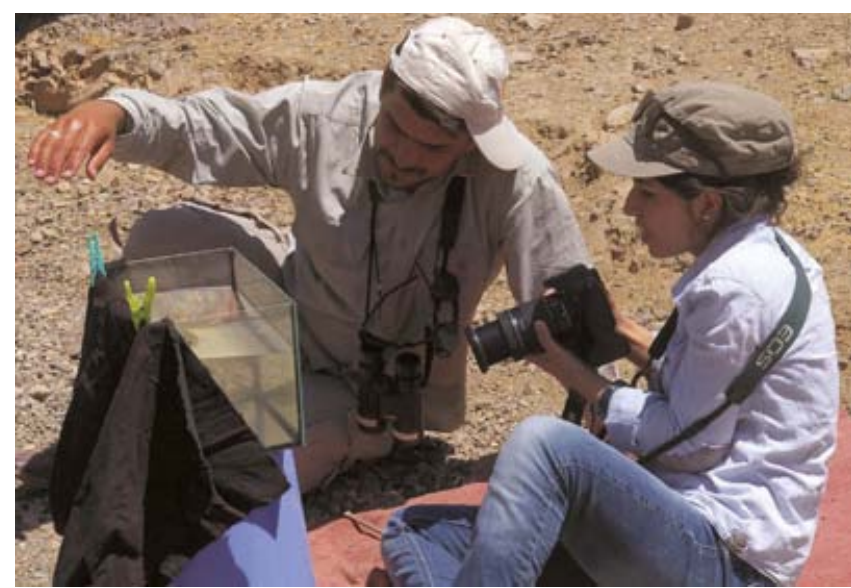

Field surveys and monitoring are a priority for many of the threatened species in the region in order to build a better understanding of the species requirements and to identify suitable cases for ex-situ conservation. Photo $@$ Jörg Freyhof

development of water, land, and related resources across sectors within a given river basin, in order to maximize the economic and social benefits derived from water resources in an equitable manner while preserving and, where necessary, restoring freshwater ecosystems (WWF 2014, adapted from Global Water Partnership 2000). Catchment wide management plans are particularly recommended for those that contain freshwater Key Biodiversity Areas (see Section 7.7). Such plans will likely need to include the restoration of natural flow regimes working with stakeholders such as dam operators and those involved in water extraction (note: $32.6 \%$ of threatened species require Habitat \& natural process restoration), and the incorporation of biodiversity requirements within decisions for water allocation across sectors. In many cases it will be hard to achieve the recommended habitat restoration without a reduction in the levels of water abstraction, especially in the face of a changing climate which is likely to lead to even more severe and prolonged periods of drought across the region. In order to develop an effective IRBM plan the key threats to freshwater biodiversity (e.g. pollution, invasive species, and over-harvesting), and their drivers, will need to be identified and managed through a multi-stakeholder engagement process. The need for IRBM is particularly important for many of the regions' transboundary catchments (Voss et al. 2013). One international policy instrument that has recently (August 2014) come into force and which may provide useful guidance and support is the UN Watercourse Convention (UNWC). The UNWC is focused on the economic, social, and environmental uses of international watercourses including water provision, and fisheries. Of great significance is the convention text identifying a requirement to protect and maintain watercourses in their natural state, as part of securing equitable use of these resources, and that economic needs (e.g. power supply, water provision) may not, by default, be assumed to be more important than social or environmental needs (Loures and Harrison 2014). To date, 35 countries have ratified the convention, including Iraq, Jordan, Lebanon, and Syria. For more information on the UNWC, please see www. unwatercoursesconvention.org. 
Table 7.7 'Conservation actions needed' as coded within the IUCN Red List assessments for all freshwater species (fishes, molluscs, odonates, plants, birds, mammals, amphibians, and decapods), showing the proportions of all freshwater species, and all threatened species for which each type of conservation action is recommended.

\begin{tabular}{|c|c|c|c|}
\hline & Conservation action needed & $\%$ of all species & $\%$ of threatened species \\
\hline 1 & Land/water protection & 16.7 & 52.5 \\
\hline 1.1 & Site/area protection & 14.3 & 45.7 \\
\hline 1.2 & Resource \& habitat protection & 11.6 & 35.3 \\
\hline 2 & Land/water management & 18.1 & 61.1 \\
\hline 2.1 & Site/area management & 16.4 & 56.1 \\
\hline 2.2 & Invasive/problematic species control & 2.9 & 10.9 \\
\hline 2.3 & Habitat $\&$ natural process restoration & 9.2 & 32.6 \\
\hline 3 & Species management & 5.0 & 15.8 \\
\hline 3.1 & Species management & 2.3 & 7.2 \\
\hline 3.1 .1 & Harvest management & 2.0 & 5.9 \\
\hline 3.1 .2 & Trade management & 1.3 & 3.6 \\
\hline 3.1 .3 & Limiting population growth & 0.3 & 0.5 \\
\hline 3.2 & Species recovery & 0.7 & 2.3 \\
\hline 3.2 .1 & Reintroduction & 0.3 & 0.5 \\
\hline 3.2 .2 & Benign introduction & 0.5 & 2.3 \\
\hline 3.3 & Species re-introduction & 0.8 & 2.7 \\
\hline 3.4 & Ex-situ conservation & 2.8 & 11.3 \\
\hline 3.4 .1 & Captive breeding/artificial propagation & 2.1 & 10.9 \\
\hline 3.4 .2 & Genome resource bank & 0.9 & 1.4 \\
\hline 4 & Education $\&$ awareness & 12.7 & 43.9 \\
\hline 4.1 & Formal education & 1.6 & 4.1 \\
\hline 4.2 & Training & 1.6 & 5.4 \\
\hline 4.3 & Awareness \& communications & 12.6 & 43.9 \\
\hline 5 & Law \& policy & 10.4 & 38.0 \\
\hline 5.1 & Legislation & 9.2 & 36.7 \\
\hline 5.1 .1 & International level & 2.9 & 10.9 \\
\hline 5.1 .2 & National level & 7.5 & 24.4 \\
\hline 5.1 .3 & Sub-national level & 4.6 & 14.5 \\
\hline 5.1 .4 & Scale unspecified & 0.2 & 0.5 \\
\hline 5.2 & Policies and regulations & 1.3 & 5.0 \\
\hline 5.3 & Private sector standards and codes & 0.0 & 0.0 \\
\hline 5.4 & Compliance and enforcement & 4.5 & 16.3 \\
\hline 5.4 .1 & International level & 2.0 & 8.1 \\
\hline 5.4 .2 & National level & 3.5 & 10.4 \\
\hline 5.4 .3 & Sub-national level & 0.7 & 0.0 \\
\hline 5.4 .4 & Scale unspecified & 0.2 & 0.9 \\
\hline 6 & Livelihood, economic, \& other incentives & 0.3 & 0.9 \\
\hline 6.1 & Linked enterprises \& livelihood alternatives & 0.3 & 1.4 \\
\hline 6.2 & Substitution & 0.0 & 0.0 \\
\hline 6.3 & Market forces & 0.0 & 0.0 \\
\hline 6.4 & Conservation payments & 0.2 & 0.0 \\
\hline 6.5 & Non-monetary values & 0.0 & 0.0 \\
\hline
\end{tabular}




\subsubsection{Site protection}

A number of species require some degree of site protection below the spatial scale of the river basin (as recommended for $45.7 \%$ of threatened freshwater species). This is especially true for habitats that are essential for a species, for example spawning areas, or those species that are highly restricted to distinct habitats, such as springs and seepages, that could be quickly impacted by localized threats. It is important to note that for most freshwater species any site scale protection needs to be done in addition to a wider IRBM approach. For those few species that occur within existing protected areas, management actions are required to specifically target freshwater biodiversity as, in many cases, protected areas are not designated or managed for freshwater biodiversity. In cases where sites that require protection are not within existing protected areas, the freshwater Key Biodiversity Areas identified (see Section 7.7) may be used to inform new protected area establishment, delineation, and management.

\subsubsection{Field surveys, research, and regional capacity building}

A recommendation common to all taxon groups is the need for more field research particularly for the threatened species using modern standardized monitoring protocols. This will require an increase in collaborative research projects between regional and international scientists to help build capacity within the region. To make this achievable additional funding and ease of access to research licences are required. With many species on the brink of extinction within the region an immediate increase in field research and monitoring is critical to help identify if and when ex-situ conservation measures should be taken to ensure no more species are lost $(11.3 \%$ of threatened species are recommended for ex-situ conservation). Capacity building within the region should also focus on inclusion of modern taxonomic research and species identification methods, and the publication of national field guides and checklists in the languages of the region.

\subsubsection{Enforcement of existing legislation and government awareness}

Capacity within many of the regions' national governments and their agencies is currently not sufficient to enforce compliance with existing legislation for the protection of freshwater biodiversity. More than $16 \%$ of threatened species are reported to potentially benefit from better compliance and enforcement of existing legislation, and this includes legislation for management of resource exploitation (e.g. fisheries), water extraction, pollution, and requirements for Environmental Impact Assessments (EIAs) for development projects, such as dam construction and management. Building capacity within government bodies (national to local) and raising awareness of the conservation needs of freshwater biodiversity and the benefits to people of healthy freshwater systems is an urgent need. Finally, and perhaps most important of all, legislation for the management of water resources across the region needs to ensure adequate water flows remain for maintaining ecological functions within all inland waters.

\subsection{References}

Allen, D.J., Molur, S. and Daniel, B.A. 2011. The status and distribution of freshwater biodiversity in the Eastern Himalaya. IUCN, Cambridge, UK and Gland, Switzerland, and Zoo Outreach Organisation, Coimbatore, India.

Allen,D.J.,Smith, K.G. and Darwall, W.R.T.2012. Thestatus and distribution of freshwater biodiversity in Indo-Burma. IUCN, Cambridge, UK and Gland, Switzerland.

Al-Sheikhly, O.F. and Nader, I.A. 2013. The Status of Iraq Smooth-Coated Otter Lutrogale perspicillata maxwelli Hayman 1956 and Eurasian Otter Lutra lutra Linnaeus 1758 in Iraq. IUCN Otter Specialist Group Bulletin 30(1):18-30.

AQUASTAT. 2009. Irrigation in the Middle East region in figures. Frenken K. (ed.) AQUASTAT Survey 2008. FAO Water Reports \#34, Rome, Italy.

Atalay, I. 1997. Red Mediterranean soils in some karstic regions of Taurus mountains, Turkey. Catena 28(3-4):247-260.

Balian, E.V., Lévêque, C., Segers, H. and Martens, K. 2008. The freshwater animal diversity assessment. Hydrobiologia, $\mathbf{5 9 5}$.

BirdLife International. 2008. Migrating birds know no boundaries. Presented as part of the BirdLife State of the world's birds website. Accessed 19/11/2014 http://www.birdlife.org/datazone/sowb/ casestudy/73

BirdLife International. 2010. Towards sustainable hunting in the Middle East. Presented as part of the BirdLife State of the world's birds website. Accessed 19/11/2014 http://www.birdlife.org/datazone/sowb/ casestudy/35

BirdLife International and NatureServe. 2012. Bird species distribution maps of the world. BirdLife International, Cambridge, UK and NatureServe, Arlington, USA.

Darwall W., Carrizo S., Numa C., Barrios V., Freyhof J. and Smith K. 2014. Freshwater Key Biodiversity Areas in the Mediterranean Basin Hotspot. Informing species conservation and development planning in freshwater ecosystems. IUCN, Cambridge, UK and Malaga, Spain.

Darwall, W.R.T., Smith, K.G., Allen, D.J., Holland, R.A, Harrison, I.J., and Brooks, E.G.E. (eds.). 2011. The Diversity of Life in African Freshwaters: Under Water, Under Threat. An analysis of the status and distribution of freshwater species throughout mainland Africa. IUCN, Cambridge, United Kingdom and Gland, Switzerland.

De Grave, S. 2013. Palaemonetes mesopotamicus. The IUCN Red List of Threatened Species. Version 2014.2. www.iucnredlist.org

Eken, G., Bennun, L., Brooks, T.M., Darwall, W.R.T., Fishpool, L., Foster, M., Knox, D., Langhammer, P., Matiku, P., Radford, E., Salaman, P., Sechrest, W., Smith, M., Spector, S. and Tordoff, A. 2004. Key Biodiversity Areas as site conservation targets. Bioscience 54(12):11101118.

Erk'akan, F. and Özdemir, F. 2014. The first new cave fish species, Cobitis damlae (Teleostei: Cobitidae) from Turkey. Hacettepe Journal of Biology \& Chemistry 42(2):275-279.

Freyhof, J. 2014a. Luciobarbus subquincunciatus. The IUCN Red List of Threatened Species. Version 2014.2. www.iucnredlist.org

Freyhof, J. 2014b. Acanthobrama centisquama. The IUCN Red List of Threatened Species. Version 2014.2. www.iucnredlist.org

Freyhof, J. 2014c. Oxynoemacheilus hamwii. The IUCN Red List of Threatened Species. Version 2014.2. www.iucnredlist.org

Freyhof, J. 2014d. Chondrostoma kinzelbachi. The IUCN Red List of Threatened Species. Version 2014.2. www.iucnredlist.org

Freyhof, J. 2014e. Capoeta barroisi. The IUCN Red List of Threatened Species. Version 2014.2. www.iucnredlist.org 
Freyhof, J. 2014f. Oxynoemacheilus tigris. The IUCN Red List of Threatened Species. Version 2014.3. www.iucnredlist.org

Freyhof, J. 2014g. Typhlogarra widdowsoni. The IUCN Red List of Threatened Species. Version 2014.3. www.iucnredlist.org

Freyhof, J. 2014h. Caecocypris basimi. The IUCN Red List of Threatened Species. Version 2014.3. www.iucnredlist.org

Freyhof, J. 2014i. Barbus grypus. The IUCN Red List of Threatened Species. Version 2014.2. www.iucnredlist.org

Freyhof, J. \& Harrison, I.J. 2014. Aphanius sirhani. The IUCN Red List of Threatened Species. Version 2014.2. www.iucnredlist.org

Gherardi, F. \& Souty-Grosset, C. 2010. Astacus leptodactylus. The IUCN Red List of Threatened Species. Version 2014.2. www.iucnredlist.org

Holland, R.A., Darwall, W.R.T. and Smith, K.G. 2012. Conservation priorities for freshwater

biodiversity: The Key Biodiversity Area approach refined and tested for continental Africa. Biological Conservation 148(1):167-179.

Iraqi Ministry of Environment and Nature Iraq. In prep. Inventory of Key Biodiversity Areas of Iraq. Iraqi Ministry of Environment and Nature Iraq, Baghdad, Iraq.

IUCN. 2014. The IUCN Red List of Threatened Species. Version 2014.3. www.iucnredlist.org

Kavak, S. 2014. Amsonia orientalis. The IUCN Red List of Threatened Species. Version 2014.2. www.iucnredlist.org

Langhammer, P.F., Bakarr, M.I., Bennun, L.A., Brooks, T.M., Clay, R.P., Darwall, W., De Silva, N., Edgar, G., Eken, G., Fishpool, L., Fonseca, G.A.B. da, Foster, M., Knox, D.H., Matiku, P., Radford, E.A., Rodrigues, A.S.L., Salaman, P., Sechrest, W., and Tordoff, A. 2007. Identification and gap analysis of Key Biodiversity Areas as targets for comprehensive protected area systems. IUCN, Gland, Switzerland.

Lehner, B. and Grill, G. 2013. Global river hydrography and network routing: baseline data and new approaches to study the world's large river systems. Hydrological Processes 27:2171-2186.

Lopes-Lima, M. and Seddon, M.B. 2014a. Leguminaia saulcyi. The IUCN Red List of Threatened Species. Version 2014.3. www.iucnredlist.org

Lopes-Lima, M. and Seddon, M.B.2014b. Anodontapseudodopsis. The IUCN Red List of Threatened Species. Version 2014.2. www.iucnredlist.org
Loures, F.R and Harrison, I. 2014. The UN Watercourses Convention in force: what's in it for aquatic ecosystems? Newsletter of the IUCN SSC/ WI Freshwater Fish Specialist Group 6:12-17.

Molur, S., Smith, K.G., Daniel, B.A. and Darwall, W.R.T. 2011. The status and distribution of freshwater biodiversity in the Western Ghats, India. IUCN, Cambridge, UK and Zoo Outreach Organisation, Coimbatore, India.

Ŏz, M., Kaska, Y., Kumlutaş, Y., Kaya, U., Avci, A., Üzüm, N., Yeniyurt, C., Akarsu, F. and Kasparek, M. 2009. Pelophylax caralitanus. The IUCN Red List of Threatened Species. Version 2014.2. www.iucnredlist.org

Salafsky, N., Salzer, D., Stattersfield, A.J., Hilton-Taylor, C., Neugarten, R., Butchart, S.H.M., Collen, B., Cox., N., Master, L.L., O’Connor, S. and Wilkie, D. 2008. A standard lexicon for biodiversity conservation: Unified classifications of threats and actions. Conservation Biology 22:897-911.

UNEP. 2008. Vital Water Graphics - An Overview of the State of the World's Fresh and Marine Waters. 2nd Edition. UNEP, Nairobi, Kenya.

UN-ESCWA and BGR (United Nations Economic and Social Commission for Western Asia; Bundesanstalt für Geowissenschaften und Rohstoffe). 2013. Inventory of Shared Water Resources in Western Asia. Beirut, Lebanon.

Van Damme, D. and Kebapçı, U. 2014. Melanopsis khabourensis. The IUCN Red List of Threatened Species. Version 2014.2. www.iucnredlist.org

Van Damme, D., Seddon, M.B. and Kebapçı, U. 2014. Melanopsis infracincta. The IUCN Red List of Threatened Species. Version 2014.3. www.iucnredlist.org

Voss, K.A., Famiglietti, J.S., Lo, M., Linage, C., Rodell, M. and Swenseon, S.C. 2013. Groundwater depletion in the Middle East from GRACE with implications for transboundary water management in the TigrisEuphrates-Western Iran region. Water Resources Research 49(2):904914.

WWF. 2014. Integrated river basin management (IRBM). Accessed 14/11/2014 http://wwf.panda.org/about_our_earth/about freshwater/rivers/irbm 


\title{
Appendix 1. Example of a species Red List assessment
}

\author{
Oxynoemacheilus hamwii - (Krupp \& Schneider, 1991)
}

ANIMALIA - CHORDATA - ACTINOPTERYGII - CYPRINIFORMES - BALITORIDAE - Oxynoemacheilus - hamwii Common Names: Orontes Sportive Loach (English)

Synonyms: Nemacheilus hamwii Krupp \& Schneider, 1991

Red List Status

EN - Endangered, B2ab(i,ii,iii,iv,v) (IUCN version 3.1)

\section{Red List Assessment}

\section{Assessment Information}

Date of Assessment: 2013-01-10

\begin{tabular}{|l|l|l|l|l|}
\hline Reviewed? & Date of Review: & Status: & Reasons for Rejection: & Improvements Needed: \\
\hline true & $2014-02-03$ & Passed & - & - \\
\hline
\end{tabular}

Assessor(s): Freyhof, J.

Reviewer(s): Ekmekçi, F., Özuluğ, M. \& Smith, K.

Regions: Global

\section{Assessment Rationale}

This species was known from the headwaters in the Asi drainage in Turkey and northern Syria (it is now extirpated from Syria). It is now only left in the northern Asi drainage in three streams, the Yildırım (2-5 km), Buyuk Karacay (3-5 km), and Kucuk Karacay (3-5 km) flowing to the lower Asi in Turkey, and the upper Afrin (10 km) which flows into Syria. Other records are misidentifications or thought to now be extirpated. The upper Afrin is already heavily impacted by human activities, especially by water abstraction. The species seems to be quite sensitive to pollution and has most likely vanished from the Syrian part of the Afrin. Water abstraction in the Afrin will increase in the near future due to population growth and climate change and this will lead to a continuous decline and possible extinction of this species. Due to the small distribution range of the species (area of occupancy estimated $50 \mathrm{~km}^{2}$ ), only four sites (locations) remaining, and the ongoing and expected future decline in habitat area and quality, this species is assessed as Endangered.

\section{Distribution}

\section{Geographic Range}

The species was known from the headwaters in the Asi drainage in Turkey and northern Syria (it is now extirpated from Syria). It is now only left in the northern Asi drainage in three streams, the Yildırım (2-5 km), Buyuk Karacay (3-5 km), and Kucuk Karacay $(3-5 \mathrm{~km})$ flowing to the lower Asi in Turkey, and the upper Afrin $(10 \mathrm{~km})$ which flows into Syria. Other records are misidentifications or are thought to now be extirpated.

\section{Biogeographic Realms}

Biogeographic Realm: Palearctic 
Occurrence

Countries of Occurrence

\begin{tabular}{|lllll|}
\hline Country & Presence & Origin & Formerly Bred & Seasonality \\
\hline Syrian Arab Republic & Possibly Extinct & Native & Yes & Resident \\
\hline Turkey & Extant & Native & - & Resident \\
\hline Turkey $\rightarrow$ Turkey-in-Asia & Extant & Native & - & Resident \\
\hline
\end{tabular}

\section{Population}

This species was widespread within its range in the late 20 th century but seems to have lost most of its populations since.

\section{Population Information}

Current Population Trend: Decreasing

\begin{tabular}{|l|l|l|}
\hline Continuing decline in mature individuals? & Qualifier & Justification \\
\hline Yes & Observed & - \\
\hline
\end{tabular}

\section{Habitats and Ecology}

Moderately fast flowing waters of streams and rivers with mud or gravel substrate and low pollution level.

\section{IUCN Habitats Classification Scheme}

\begin{tabular}{|l|l|l|l|}
\hline Habitat & Season & Suitability & Major Importance? \\
\hline $\begin{array}{l}\text { 5.1. Wetlands (inland) -> Wetlands (inland) - Permanent Rivers/Streams/Creeks } \\
\text { (includes waterfalls) }\end{array}$ & resident & Suitable & Yes \\
\hline
\end{tabular}

\section{Continuing Decline in Habitat}

\begin{tabular}{|l|l|l|}
\hline Continuing decline in area, extent and/or quality of habitat? & Qualifier & Justification \\
\hline Yes & Observed & - \\
\hline
\end{tabular}

\section{Movement Patterns}

Movement Patterns: Not a Migrant

\section{Systems}

System: Freshwater (=Inland waters)

\section{Use and Trade}

General Use and Trade Information

This species is not directly used by humans. 


\section{Threats}

Large levels of water abstraction and pollution are the major threads within the Asi drainage and for this species. While the population in the Yildırım is in a good shape, this stream is very small and depends on a spring coming from the mountains. Less rainfall due to climate change might lessen the amount of water in this stream in the future. In the upper Afrin, water abstraction and pollution is a major problem and water levels are already very low in late summer. Often dams in Syria stop all water flow into Turkey in the Asi. Less rainfall due to climate change as well as increased exploitation of the water resources in upper Afrin very seriously threaten this population.

\section{Threats Classification Scheme}

\begin{tabular}{|c|c|c|c|c|}
\hline Threat & Timing & Scope & Severity & $\begin{array}{l}\text { Impact } \\
\text { Score }\end{array}$ \\
\hline $\begin{array}{l}\text { 7.2.1. Natural system modifications }->\text { Dams \& water management/ } \\
\text { use }->\text { Abstraction of surface water (domestic use) }\end{array}$ & Ongoing & $\begin{array}{l}\text { Majority } \\
(50-90 \%)\end{array}$ & $\begin{array}{l}\text { Slow, Significant } \\
\text { Declines }\end{array}$ & $\begin{array}{l}\text { Medium } \\
\text { Impact: } 6\end{array}$ \\
\hline $\begin{array}{l}\text { 7.2.3. Natural system modifications }->\text { Dams } \& \text { water management/ } \\
\text { use }->\text { Abstraction of surface water (agricultural use) }\end{array}$ & Ongoing & $\begin{array}{l}\text { Majority } \\
(50-90 \%)\end{array}$ & $\begin{array}{l}\text { Slow, Significant } \\
\text { Declines }\end{array}$ & $\begin{array}{l}\text { Medium } \\
\text { Impact: } 6\end{array}$ \\
\hline $\begin{array}{l}\text { 7.2.5. Natural system modifications }->\text { Dams \& water management/ } \\
\text { use }->\text { Abstraction of ground water (domestic use) }\end{array}$ & Ongoing & $\begin{array}{l}\text { Majority } \\
(50-90 \%)\end{array}$ & $\begin{array}{l}\text { Slow, Significant } \\
\text { Declines }\end{array}$ & $\begin{array}{l}\text { Medium } \\
\text { Impact: } 6\end{array}$ \\
\hline $\begin{array}{l}\text { 7.2.7. Natural system modifications }->\text { Dams \& water management/ } \\
\text { use }->\text { Abstraction of ground water (agricultural use) }\end{array}$ & Ongoing & $\begin{array}{l}\text { Majority } \\
(50-90 \%)\end{array}$ & $\begin{array}{l}\text { Slow, Significant } \\
\text { Declines }\end{array}$ & $\begin{array}{l}\text { Medium } \\
\text { Impact: } 6\end{array}$ \\
\hline 9.1.1. Pollution $\rightarrow$ Domestic \& urban waste water $\rightarrow$ Sewage & Ongoing & $\begin{array}{l}\text { Majority } \\
(50-90 \%)\end{array}$ & $\begin{array}{l}\text { Slow, Significant } \\
\text { Declines }\end{array}$ & $\begin{array}{l}\text { Medium } \\
\text { Impact: } 6\end{array}$ \\
\hline
\end{tabular}

\section{Conservation}

There are no conservation actions in place for this species. A real action plan is recommended for this species and other freshwater biodiversity in Asi drainage and especially in Afrin subdrainage. The status of $O$. hamwii should be carefully monitored and even ex situ conservation should be taken into account.

\section{Bibliography}

IUCN. 2014. The IUCN Red List of Threatened Species. Version 2014.1. Available at: www.iucnredlist.org. (Accessed: 12 June 2014).

Krupp, F. and Schneider, W. 1991. Two new species of Nemacheilus Bleeker, 1863 from the Orontes River drainage basin of Lebanon, Syria and Turkey. (Pisces, Osteichthyes: Balitoridae). Senckenbergiana Biol. 71: 23-34. 


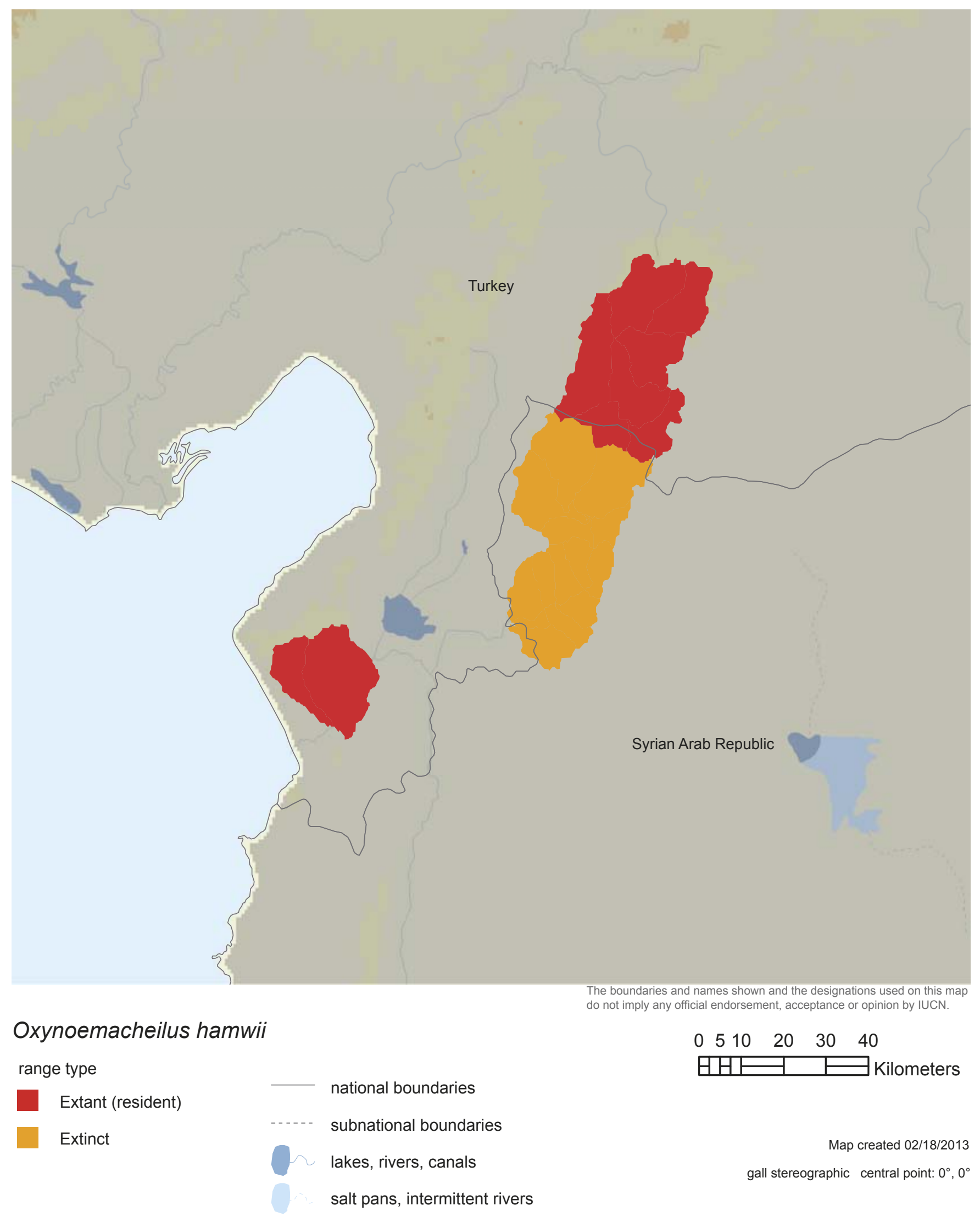




\section{Appendix 2. Species lists}

The species lists for each taxonomic group are listed below in order of the chapters in this report. Please see the IUCN Red List of Threatened Species website (www.iucnredlist.org) for more information on the species.

$\mathrm{RL}=$ The Red List Category for the species. These are: EX - Extinct, EW - Extinct in the Wild, CR - Critically Endangered (CR PE - Possibly Extinct), EN - Endangered, VU - Vulnerable, NT - Near Threatened, LC - Least Concern, DD - Data Deficient, NA - Not Assessed.

* = An asterisk next to the RL category indicates the species is endemic to the Eastern Mediterranean region.

2.1 Freshwater fishes 115

2.2 Freshwater molluscs

2.3 Odonata.

2.4 Freshwater plants.

2.5 Freshwater birds.

2.6 Freshwater amphibians

2.7 Freshwater mammals.

2.8 Freshwater decapods.

\subsection{Freshwater fishes}

\begin{tabular}{|l|l|l|}
\hline Class & Actinopterygii & \\
\hline Order & Acipenseriformes & \\
Family & Species & $\mathrm{RL}$ \\
\hline Acipenseridae & Acipenser gueldenstaedtii & $\mathrm{CR}$ \\
\hline Acipenseridae & Acipenser nudiventris & $\mathrm{CR}$ \\
\hline Acipenseridae & Acipenserpersicus & $\mathrm{CR}$ \\
\hline Acipenseridae & Acipenserstellatus & $\mathrm{CR}$ \\
\hline Acipenseridae & Acipensersturio & $\mathrm{CR}$ \\
\hline Acipenseridae & Huso huso & $\mathrm{CR}$ \\
\hline
\end{tabular}

\begin{tabular}{|c|c|c|}
\hline Order & Anguilliformes & \\
\hline Family & Species & RL \\
\hline Anguillidae & Anguilla anguilla & CR \\
\hline Order & Atheriniformes & \\
\hline Family & Species & $\mathrm{RL}$ \\
\hline Atherinidae & Atherina boyeri & LC \\
\hline
\end{tabular}

\begin{tabular}{|l|l|l|}
\hline $\begin{array}{l}\text { Order } \\
\text { Family }\end{array}$ & $\begin{array}{l}\text { Clupeiformes } \\
\text { Species }\end{array}$ & RL \\
\hline Clupeidae & Alosa caspia & LC \\
\hline Clupeidae & Alosafallax & LC \\
\hline Clupeidae & Alosa kessleri & LC \\
\hline Clupeidae & Alosa maeotica & LC \\
\hline Clupeidae & Alosa volgensis & EN \\
\hline Clupeidae & Clupeonella caspia & LC \\
\hline Clupeidae & Clupeonellacultriventris & LC \\
\hline Clupeidae & Tenualosa ilisha & LC \\
\hline
\end{tabular}

\begin{tabular}{|l|l|l|}
\hline $\begin{array}{l}\text { Order } \\
\text { Family }\end{array}$ & $\begin{array}{l}\text { Cypriniformes } \\
\text { Species }\end{array}$ & $\mathrm{RL}$ \\
\hline Balitoridae & Oxynoemacheilus anatolicus & $\mathrm{EN}^{*}$ \\
\hline Balitoridae & Oxynoemacheilus angorae & $\mathrm{LC}^{*}$ \\
\hline Balitoridae & Oxynoemacheilus araxensis & $\mathrm{DD}^{*}$ \\
\hline Balitoridae & Oxynoemacheilus argyrogramma & $\mathrm{LC}^{*}$ \\
\hline Balitoridae & Oxynoemacheilus atili & $\mathrm{NT}^{*}$ \\
\hline Balitoridae & Oxynoemacheilus banarescui & $\mathrm{NT}^{*}$ \\
\hline & & \\
\hline
\end{tabular}

\begin{tabular}{|c|c|c|}
\hline Balitoridae & Oxynoemacheilus bergianus & LC \\
\hline Balitoridae & Oxynoemacheilus brandtii & LC \\
\hline Balitoridae & Oxynoemacheilus ceybanensis & $\mathrm{DD}^{*}$ \\
\hline Balitoridae & Oxynoemacheilus cinicus & $\mathrm{DD}^{*}$ \\
\hline Balitoridae & Oxynoemacheilus cyri & $\mathrm{LC}^{*}$ \\
\hline Balitoridae & Oxynoemacheilus ercisianus & $\mathrm{EN}^{*}$ \\
\hline Balitoridae & Oxynoemacheilus eregliensis & VU* \\
\hline Balitoridae & Oxynoemacheilus evreni & $\mathrm{LC}^{*}$ \\
\hline Balitoridae & Oxynoemacheilus frenatus & $\mathrm{LC}^{*}$ \\
\hline Balitoridae & Oxynoemacheilus galilaeus & $\mathrm{CR}^{*}$ \\
\hline Balitoridae & Oxynoemacheilus germencicus & $\mathrm{VU}^{*}$ \\
\hline Balitoridae & Oxynoemacheilus hamwii & $\mathrm{EN}^{*}$ \\
\hline Balitoridae & Oxynoemacheilus insignis & $\mathrm{NT}^{*}$ \\
\hline Balitoridae & Oxynoemacheilus kaynaki & $\mathrm{LC}^{*}$ \\
\hline Balitoridae & Oxynoemacheiluskosswigi & $\mathrm{LC}^{*}$ \\
\hline Balitoridae & Oxynoemacheilus lenkoranensis & $\mathrm{DD}^{*}$ \\
\hline Balitoridae & Oxynoemacheilus leontinae & $\mathrm{LC}^{*}$ \\
\hline Balitoridae & Oxynoemacheilus mediterraneus & $\mathrm{LC}^{*}$ \\
\hline Balitoridae & Oxynoemacheilus mesudae & $\mathrm{EN}^{*}$ \\
\hline Balitoridae & Oxynoemacheilus namiri & $\mathrm{LC}^{*}$ \\
\hline Balitoridae & Oxynoemacheiluspanthera & $\mathrm{EN}^{*}$ \\
\hline Balitoridae & Oxynoemacheilus paucilepis & $\mathrm{EN}^{*}$ \\
\hline Balitoridae & Oxynoemacheilusphoxinoides & $\mathrm{CR}^{*}$ \\
\hline Balitoridae & Oxynoemacheilus samanticus & $\mathrm{LC}^{*}$ \\
\hline Balitoridae & Oxynoemacheilus seyhanensis & $\mathrm{CR}^{*}$ \\
\hline Balitoridae & Oxynoemacheilus seyhanicola & $\mathrm{EN}^{*}$ \\
\hline Balitoridae & Oxynoemacheilus theophilii & LC \\
\hline Balitoridae & Oxynoemacheilus tigris & $\mathrm{CR}^{*}$ \\
\hline Balitoridae & Paraschistura chrysicristinae & CR PE* \\
\hline Balitoridae & Seminemacheilus ispartensis & $\mathrm{VU}^{*}$ \\
\hline Balitoridae & Seminemacheilus lendlii & $\mathrm{VU}^{*}$ \\
\hline Balitoridae & Turcinoemacheilus kosswigi & $\mathrm{LC}^{*}$ \\
\hline Cobitidae & Cobitis amphilekta & $\mathrm{DD}^{*}$ \\
\hline Cobitidae & Cobitis battalgili & $\mathrm{EN}^{*}$ \\
\hline Cobitidae & Cobitis bilseli & $\mathrm{EN}^{*}$ \\
\hline Cobitidae & Cobitis elazigensis & $\mathrm{LC}^{*}$ \\
\hline Cobitidae & Cobitis evreni & $\mathrm{EN}^{*}$ \\
\hline
\end{tabular}


Appendix 2.1 cont'd, Freshwater fishes

\begin{tabular}{|c|c|c|c|c|c|}
\hline Cobitidae & Cobitisfabireae & $\mathrm{LC}^{*}$ & Cyprinidae & Capoeta damascina & $\mathrm{LC}^{*}$ \\
\hline Cobitidae & Cobitiskellei & CR PE* & Cyprinidae & Capoeta ekmekciae & NT \\
\hline Cobitidae & Cobitis levantina & $\mathrm{EN}^{*}$ & Cyprinidae & Capoeta erhani & $\mathrm{LC}^{*}$ \\
\hline Cobitidae & Cobitisphrygica & $\mathrm{EN}^{*}$ & Cyprinidae & Capoeta kosswigi & $\mathrm{DD}^{*}$ \\
\hline Cobitidae & Cobitispontica & LC & Cyprinidae & Capoeta mauricii & $\mathrm{EN}^{*}$ \\
\hline Cobitidae & Cobitispuncticulata & EN & Cyprinidae & Capoeta pestai & $\mathrm{CR}^{*}$ \\
\hline Cobitidae & Cobitissatunini & $\mathrm{LC}^{*}$ & Cyprinidae & Capoeta sieboldii & $\mathrm{LC}^{*}$ \\
\hline Cobitidae & Cobitis simplicispina & $\mathrm{LC}^{*}$ & Cyprinidae & Capoeta tinca & $\mathrm{LC}^{*}$ \\
\hline Cobitidae & Cobitis splendens & $\mathrm{CR}^{*}$ & Cyprinidae & Capoeta trutta & $\mathrm{LC}^{*}$ \\
\hline Cobitidae & Cobitisstrumicae & LC & Cyprinidae & Capoeta turani & $\mathrm{NT}^{*}$ \\
\hline Cobitidae & Cobitis turcica & $\mathrm{EN}^{*}$ & Cyprinidae & Capoeta umbla & $\mathrm{LC}^{*}$ \\
\hline Cobitidae & Sabanejewia aurata & LC & Cyprinidae & Carasobarbus canis & $\mathrm{NT}^{*}$ \\
\hline Cobitidae & Sabanejewia balcanica & LC & Cyprinidae & Carasobarbus chantrei & $\mathrm{NT}^{*}$ \\
\hline Cyprinidae & Abramis brama & LC & Cyprinidae & Carasobarbus kosswigi & $\mathrm{VU}^{*}$ \\
\hline Cyprinidae & Acanthobrama centisquama & $\mathrm{CRPE}^{*}$ & Cyprinidae & Carasobarbus luteus & $\mathrm{LC}^{*}$ \\
\hline Cyprinidae & Acanthobramalissneri & $\mathrm{NT}^{*}$ & Cyprinidae & Carassius carassius & LC \\
\hline Cyprinidae & Acanthobrama marmid & $\mathrm{LC}^{*}$ & Cyprinidae & Chondrostoma angorense & $\mathrm{LC}^{*}$ \\
\hline Cyprinidae & Acanthobrama microlepis & LC & Cyprinidae & Chondrostoma beysehirense & $\mathrm{EN}^{*}$ \\
\hline Cyprinidae & Acanthobrama telavivensis & $\mathrm{VU}^{*}$ & Cyprinidae & Chondrostoma colchicum & LC \\
\hline Cyprinidae & Acanthobrama tricolor & CR PE* & Cyprinidae & Chondrostoma cyri & $\mathrm{LC}^{*}$ \\
\hline Cyprinidae & Alburnoides eichwaldii & LC & Cyprinidae & Chondrostoma fahirae & $\mathrm{EN}^{*}$ \\
\hline Cyprinidae & Alburnoides fasciatus & LC & Cyprinidae & Chondrostoma holmwoodii & $\mathrm{VU}^{*}$ \\
\hline Cyprinidae & Alburnoides manyasensis & $\mathrm{LC}^{*}$ & Cyprinidae & Chondrostoma kinzelbachi & $\mathrm{EN}^{*}$ \\
\hline Cyprinidae & Alburnus akili & $\mathrm{EX}^{*}$ & Cyprinidae & Chondrostoma meandrense & $\mathrm{VU}^{*}$ \\
\hline Cyprinidae & Alburnus alburnus & LC & Cyprinidae & Chondrostoma regium & $\mathrm{LC}^{*}$ \\
\hline Cyprinidae & Alburnus attalus & $\mathrm{EN}^{*}$ & Cyprinidae & Chondrostoma vardarense & NT \\
\hline Cyprinidae & Alburnus baliki & $\mathrm{EN}^{*}$ & Cyprinidae & Crossocheilus klatti & $\mathrm{EN}^{*}$ \\
\hline Cyprinidae & Alburnus battalgilae & $\mathrm{VU}^{*}$ & Cyprinidae & Cyprinion kais & $\mathrm{LC}^{*}$ \\
\hline Cyprinidae & Alburnus caeruleus & $\mathrm{LC}^{*}$ & Cyprinidae & Cyprinion macrostomum & $\mathrm{LC}^{*}$ \\
\hline Cyprinidae & Alburnus carinatus & $\mathrm{EN}^{*}$ & Cyprinidae & Cyprinus carpio & $\mathrm{VU}$ \\
\hline Cyprinidae & Alburnus chalcoides & LC & Cyprinidae & Garraghorensis & $\mathrm{EN}^{*}$ \\
\hline Cyprinidae & Alburnus demiri & $\mathrm{VU}^{*}$ & Cyprinidae & Garrarufa & LC \\
\hline Cyprinidae & Alburnus derjugini & LC & Cyprinidae & Garra variabilis & $\mathrm{LC}^{*}$ \\
\hline Cyprinidae & Alburnus escherichii & $\mathrm{LC}^{*}$ & Cyprinidae & Gobio battalgilae & $\mathrm{DD}^{*}$ \\
\hline Cyprinidae & Alburnus filippii & LC & Cyprinidae & Gobio bulgaricus & LC \\
\hline Cyprinidae & Alburnus heckeli & $\mathrm{LC}^{*}$ & Cyprinidae & Gobio caucasicus & LC \\
\hline Cyprinidae & Alburnus istanbulensis & $\mathrm{LC}^{*}$ & Cyprinidae & Gobiogymnostethus & $\mathrm{CR}^{*}$ \\
\hline Cyprinidae & Alburnuskotschyi & $\mathrm{LC}^{*}$ & Cyprinidae & Gobio hettitorum & $\mathrm{CR}^{*}$ \\
\hline Cyprinidae & Alburnus nasreddini & $\mathrm{CR}^{*}$ & Cyprinidae & Gobio insuyanus & $\mathrm{CR}^{*}$ \\
\hline Cyprinidae & Alburnus nicaeensis & $\mathrm{EX}^{*}$ & Cyprinidae & Gobio intermedius & $\mathrm{EN}^{*}$ \\
\hline Cyprinidae & Alburnus orontis & $\mathrm{VU}^{*}$ & Cyprinidae & Gobio maeandricus & $\mathrm{EN}^{*}$ \\
\hline Cyprinidae & Alburnus qalilus & $\mathrm{EN}^{*}$ & Cyprinidae & Gobio microlepidotus & $\mathrm{VU}^{*}$ \\
\hline Cyprinidae & Alburnus schischkovi & EN & Cyprinidae & Gobio sakaryaensis & $\mathrm{LC}^{*}$ \\
\hline Cyprinidae & Alburnus sellal & LC & Cyprinidae & Hemigrammocapoeta caudomaculata & LC $^{*}$ \\
\hline Cyprinidae & Alburnus tarichi & $\mathrm{NT}^{*}$ & Cyprinidae & Hemigrammocapoeta culiciphaga & LC $^{*}$ \\
\hline Cyprinidae & Alburnus timarensis & $\mathrm{CR}^{*}$ & Cyprinidae & Hemigrammocapoeta elegans & $\mathrm{LC}^{*}$ \\
\hline Cyprinidae & Aspius aspius & LC & Cyprinidae & Hemigrammocapoeta kemali & $\mathrm{EN}^{*}$ \\
\hline Cyprinidae & Barbuscyclolepis & LC & Cyprinidae & Hemigrammocapoeta nana & $\mathrm{NT}^{*}$ \\
\hline Cyprinidae & Barbusercisianus & $\mathrm{DD}^{*}$ & Cyprinidae & Ladigesocyprisirideus & $\mathrm{NT}^{*}$ \\
\hline Cyprinidae & Barbus escherichii & $\mathrm{LC}^{*}$ & Cyprinidae & Leucalburnus satunini & LC $^{*}$ \\
\hline Cyprinidae & Barbus grypus & VU & Cyprinidae & Leucaspius delineatus & LC \\
\hline Cyprinidae & Barbus lacerta & $\mathrm{LC}^{*}$ & Cyprinidae & Leuciscus vorax & $\mathrm{LC}^{*}$ \\
\hline Cyprinidae & Barbus niluferensis & $\mathrm{NT}^{*}$ & Cyprinidae & Luciobarbus brachycephalus & VU \\
\hline Cyprinidae & Barbus oligolepis & $\mathrm{LC}^{*}$ & Cyprinidae & Luciobarbus capito & VU \\
\hline Cyprinidae & Barbuspergamonensis & LC & Cyprinidae & Luciobarbus esocinus & $\mathrm{VU}^{*}$ \\
\hline Cyprinidae & Barilius mesopotamicus & LC & Cyprinidae & Luciobarbus kersin & $\mathrm{DD}^{*}$ \\
\hline Cyprinidae & Blicca bjoerkna & LC & Cyprinidae & Luciobarbuskottelati & $\mathrm{VU}^{*}$ \\
\hline Cyprinidae & Caecocypris basimi & $\mathrm{CRPE}^{*}$ & Cyprinidae & Luciobarbus longiceps & $\mathrm{EN}^{*}$ \\
\hline Cyprinidae & Capoeta antalyensis & $\mathrm{VU}^{*}$ & Cyprinidae & Luciobarbuslydianus & LC $^{*}$ \\
\hline Cyprinidae & Capoeta baliki & $\mathrm{LC}^{*}$ & Cyprinidae & Luciobarbusmursa & LC \\
\hline Cyprinidae & Capoeta banarescui & $\mathrm{LC}^{*}$ & Cyprinidae & Luciobarbuspectoralis & $\mathrm{LC}^{*}$ \\
\hline Cyprinidae & Capoeta barroisi & $\mathrm{EN}^{*}$ & Cyprinidae & Luciobarbus subquincunciatus & $\mathrm{CR}^{*}$ \\
\hline Cyprinidae & Capoeta bergamae & $\mathrm{NT}^{*}$ & Cyprinidae & Luciobarbusxanthopterus & $\mathrm{VU}^{*}$ \\
\hline Cyprinidae & Capoeta caelestis & $\mathrm{LC}^{*}$ & Cyprinidae & Mesopotamichthys sharpeyi & $\mathrm{VU}^{*}$ \\
\hline Cyprinidae & Capoeta capoeta & LC & Cyprinidae & Mirogrex bulensis & $\mathrm{EX}^{*}$ \\
\hline
\end{tabular}


Appendix 2.1 cont'd, Freshwater fishes

\begin{tabular}{|c|c|c|}
\hline Cyprinidae & Mirogrex terraesanctae & $\mathrm{LC}^{*}$ \\
\hline Cyprinidae & Pelecus cultratus & LC \\
\hline Cyprinidae & Petroleuciscus borysthenicus & LC \\
\hline Cyprinidae & Petroleuciscuskurui & $\mathrm{DD}^{*}$ \\
\hline Cyprinidae & Petroleuciscus smyrnaeus & LC \\
\hline Cyprinidae & Phoxinus colchicus & LC \\
\hline Cyprinidae & Phoxinus strandjae & EN \\
\hline Cyprinidae & Pseudophoxinus alii & $\mathrm{EN}^{*}$ \\
\hline Cyprinidae & Pseudophoxinus anatolicus & $\mathrm{EN}^{*}$ \\
\hline Cyprinidae & Pseudophoxinus antalyae & $\mathrm{VU}^{*}$ \\
\hline Cyprinidae & Pseudophoxinus atropatenus & $\mathrm{CR}^{*}$ \\
\hline Cyprinidae & Pseudophoxinus battalgili & $\mathrm{LC}^{*}$ \\
\hline Cyprinidae & Pseudophoxinus burduricus & $\mathrm{EN}^{*}$ \\
\hline Cyprinidae & Pseudophoxinus crassus & $\mathrm{EN}^{*}$ \\
\hline Cyprinidae & Pseudophoxinus drusensis & $\mathrm{EN}^{*}$ \\
\hline Cyprinidae & Pseudophoxinus egridiri & $\mathrm{EN}^{*}$ \\
\hline Cyprinidae & Pseudophoxinus elizavetae & $\mathrm{CR}^{*}$ \\
\hline Cyprinidae & Pseudophoxinus evliyae & $\mathrm{EN}^{*}$ \\
\hline Cyprinidae & Pseudophoxinusfabrettini & $\mathrm{EN}^{*}$ \\
\hline Cyprinidae & Pseudophoxinus firati & $\mathrm{EN}^{*}$ \\
\hline Cyprinidae & Pseudophoxinus handlirschi & $\mathrm{EX}^{*}$ \\
\hline Cyprinidae & Pseudophoxinus hasani & $\mathrm{CR}^{*}$ \\
\hline Cyprinidae & Pseudophoxinus hittitorum & $\mathrm{EN}^{*}$ \\
\hline Cyprinidae & Pseudophoxinus maeandri & $\mathrm{EN}^{*}$ \\
\hline Cyprinidae & Pseudophoxinus maeandricus & $\mathrm{CR}^{*}$ \\
\hline Cyprinidae & Pseudophoxinus ninae & $\mathrm{CR}^{*}$ \\
\hline Cyprinidae & Pseudophoxinus sojuchbulagi & CR PE* \\
\hline Cyprinidae & Pseudophoxinus syriacus & $\mathrm{CRPE}^{*}$ \\
\hline Cyprinidae & Pseudophoxinus zekayi & $\mathrm{VU}^{*}$ \\
\hline Cyprinidae & Pseudophoxinus zeregi & $\mathrm{LC}^{*}$ \\
\hline Cyprinidae & Rhodeus amarus & LC \\
\hline Cyprinidae & Romanogobio macropterus & $\mathrm{LC}^{*}$ \\
\hline Cyprinidae & Rutilus frisii & LC \\
\hline Cyprinidae & Rutilus heckelii & LC \\
\hline Cyprinidae & Rutilus rutilus & LC \\
\hline Cyprinidae & Scardinius elmaliensis & $\mathrm{EN}^{*}$ \\
\hline Cyprinidae & Scardinius erythrophthalmus & LC \\
\hline Cyprinidae & Squalius adanaensis & $\mathrm{NT}^{*}$ \\
\hline Cyprinidae & Squalius anatolicus & $\mathrm{LC}^{*}$ \\
\hline Cyprinidae & Squalius aristotelis & $\mathrm{LC}^{*}$ \\
\hline Cyprinidae & Squalius berak & $\mathrm{LC}^{*}$ \\
\hline Cyprinidae & Squalius cappadocicus & $\mathrm{CR}^{*}$ \\
\hline Cyprinidae & Squalius carinus & $\mathrm{EN}^{*}$ \\
\hline Cyprinidae & Squalius cephaloides & $\mathrm{VU}^{*}$ \\
\hline Cyprinidae & Squalius cephalus & LC \\
\hline Cyprinidae & Squalius cii & $\mathrm{LC}^{*}$ \\
\hline Cyprinidae & Squalius fellowesii & $\mathrm{LC}^{*}$ \\
\hline Cyprinidae & Squalius kosswigi & $\mathrm{EN}^{*}$ \\
\hline Cyprinidae & Squalius kottelati & $\mathrm{NT}^{*}$ \\
\hline Cyprinidae & Squalius lepidus & $\mathrm{LC}^{*}$ \\
\hline Cyprinidae & Squalius orpheus & LC \\
\hline Cyprinidae & Squaliuspursakensis & $\mathrm{LC}^{*}$ \\
\hline Cyprinidae & Squalius recurvirostris & $\mathrm{VU}^{*}$ \\
\hline Cyprinidae & Squalius seyhanensis & $\mathrm{DD}^{*}$ \\
\hline Cyprinidae & Squalius turcicus & $\mathrm{LC}^{*}$ \\
\hline Cyprinidae & Tinca tinca & LC \\
\hline Cyprinidae & Tylognathus festai & $\mathrm{CR}^{*}$ \\
\hline Cyprinidae & Typhlogarra widdowsoni & $\mathrm{CR}^{*}$ \\
\hline Cyprinidae & Vimba melanops & DD \\
\hline Cyprinidae & Vimba mirabilis & $\mathrm{LC}^{*}$ \\
\hline Cyprinidae & Vimba vimba & LC \\
\hline
\end{tabular}

\begin{tabular}{|l|l|l|}
\hline $\begin{array}{l}\text { Order } \\
\text { Family }\end{array}$ & $\begin{array}{l}\text { Cyprinodontiformes } \\
\text { Species }\end{array}$ & $\mathrm{RL}$ \\
\hline Cyprinodontidae & Aphanius anatoliae & $\mathrm{NT}^{*}$ \\
\hline Cyprinodontidae & Aphanius asquamatus & $\mathrm{LC}^{*}$ \\
\hline Cyprinodontidae & Aphanius danfordii & $\mathrm{CR}^{*}$ \\
\hline Cyprinodontidae & Aphanius dispar & $\mathrm{LC}$ \\
\hline Cyprinodontidae & Aphanius disparssp. Richardsoni & $\mathrm{EN}{ }^{*}$ \\
\hline Cyprinodontidae & Aphaniusfasciatus & $\mathrm{LC}^{*}$ \\
\hline Cyprinodontidae & Aphanius mento & $\mathrm{LC}^{*}$ \\
\hline Cyprinodontidae & Aphanius sirhani & $\mathrm{CR}^{*}$ \\
\hline Cyprinodontidae & Aphaniussplendens & $\mathrm{EX}^{*}$ \\
\hline Cyprinodontidae & Aphaniussureyanus & $\mathrm{EN}^{*}$ \\
\hline Cyprinodontidae & Aphanius transgrediens & $\mathrm{CR}^{*}$ \\
\hline Cyprinodontidae & Aphanius villwocki & $\mathrm{LC}^{*}$ \\
\hline
\end{tabular}

\begin{tabular}{|l|l|l|}
\hline $\begin{array}{l}\text { Order } \\
\text { Family }\end{array}$ & $\begin{array}{l}\text { Esociformes } \\
\text { Species }\end{array}$ & RL \\
\hline Esocidae & Esoxlucius & LC \\
\hline
\end{tabular}

\begin{tabular}{|c|c|c|}
\hline Order & Gadiformes & \\
\hline Family & Species & RL \\
\hline Lotidae & Lota lota & LC \\
\hline
\end{tabular}

\begin{tabular}{|l|l|l|}
\hline Order & Gasterosteiformes & \\
Family & Species & RL \\
\hline Gasterosteidae & Gasterosteus aculeatus & LC \\
\hline Gasterosteidae & Gasterosteus gymnurus & LC \\
\hline Gasterosteidae & Pungitiusplatygaster & LC \\
\hline
\end{tabular}

\begin{tabular}{|l|l|l|}
\hline $\begin{array}{l}\text { Order } \\
\text { Family }\end{array}$ & $\begin{array}{l}\text { Mugiliformes } \\
\text { Species }\end{array}$ & RL \\
\hline Mugilidae & Chelon labrosus & LC \\
\hline Mugilidae & Ellochelon vaigiensis & LC \\
\hline Mugilidae & Lizaabu & LC \\
\hline Mugilidae & Liza aurata & LC \\
\hline Mugilidae & Lizaramada & LC \\
\hline Mugilidae & Liza saliens & LC \\
\hline Mugilidae & Mugilcephalus & LC \\
\hline & & \\
\hline
\end{tabular}

\begin{tabular}{|c|c|c|}
\hline Order & Perciformes & \\
\hline Family & Species & $\mathrm{RL}$ \\
\hline Cichlidae & Coptodon zillii & LC (draft) \\
\hline Cichlidae & Haplochromis flaviijosephi & $\mathrm{VU}^{*}$ \\
\hline Cichlidae & Oreochromis aureus & LC (draft) \\
\hline Cichlidae & Oreochromis niloticus & LC (draft) \\
\hline Cichlidae & Sarotherodon galilaeus & LC (draft) \\
\hline Cichlidae & Tristramella sacra & $\mathrm{EX}^{*}$ \\
\hline Cichlidae & Tristramella simonis & VU* \\
\hline Gobiidae & Babka gymnotrachelus & LC \\
\hline Gobiidae & Knipowitschia byblisia & $\mathrm{LC}^{*}$ \\
\hline Gobiidae & Knipowitschia caucasica & LC \\
\hline Gobiidae & Knipowitschia caunosi & $\mathrm{LC}^{*}$ \\
\hline Gobiidae & Knipowitschia ephesi & $\mathrm{CR}^{*}$ \\
\hline Gobiidae & Knipowitschia mermere & VU* \\
\hline Gobiidae & Mesogobius batrachocephalus & LC \\
\hline Gobiidae & Neogobiusfluviatilis & LC \\
\hline Gobiidae & Neogobius melanostomus & LC \\
\hline Gobiidae & Neogobiuspallasi & LC \\
\hline Gobiidae & Ponticola cyrius & LC \\
\hline Gobiidae & Ponticola gorlap & LC \\
\hline Gobiidae & Ponticola rizensis & $\mathrm{EN}^{*}$ \\
\hline Gobiidae & Ponticola syrman & LC \\
\hline Gobiidae & Ponticola turani & $\mathrm{VU}^{*}$ \\
\hline
\end{tabular}


Appendix 2.1 cont'd, Freshwater fishes

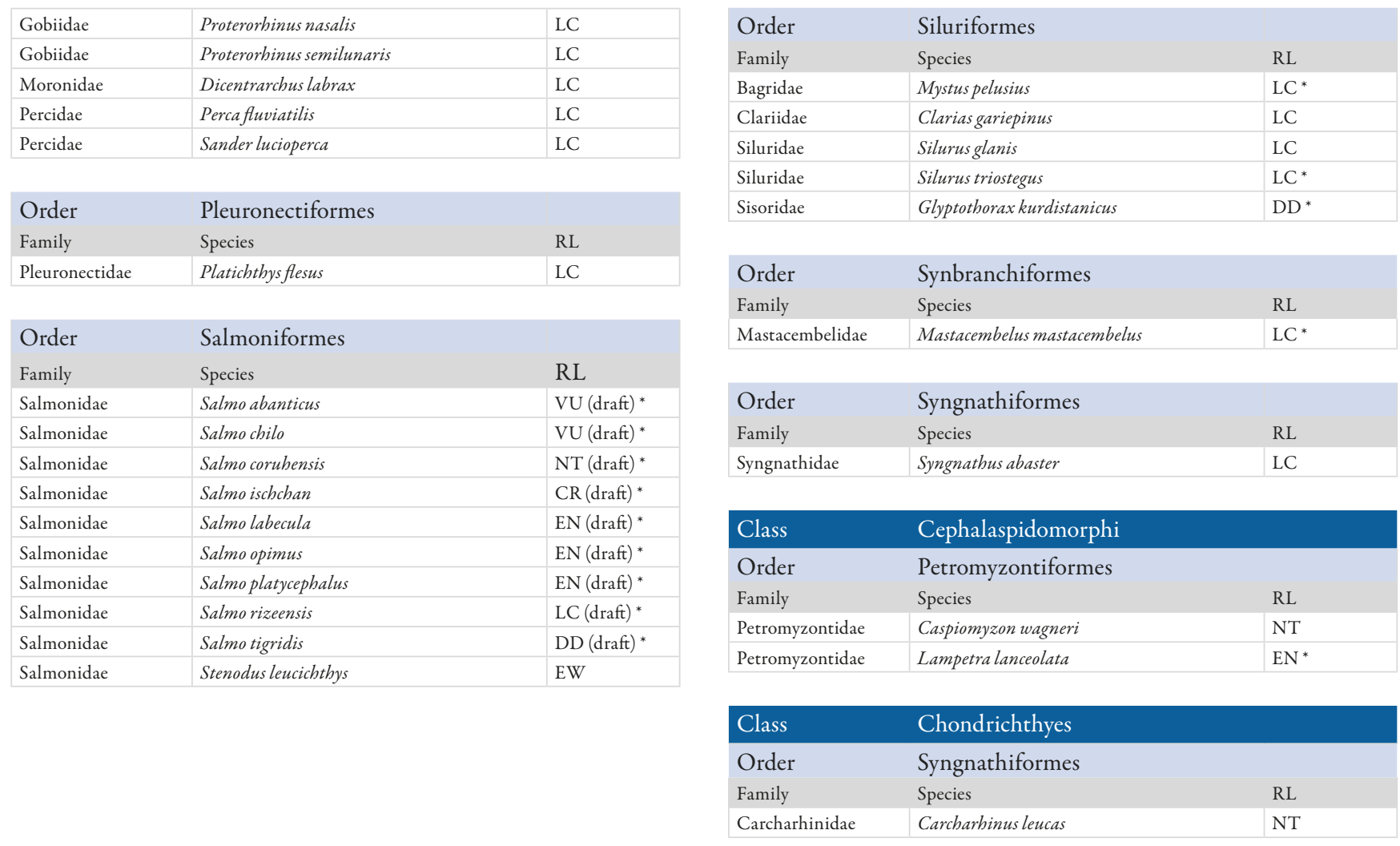

\subsection{Freshwater molluscs}

\begin{tabular}{|c|c|c|}
\hline Class & Bivalvia & \\
\hline Order & Unionoida & \\
\hline Family & Species & $\mathrm{RL}$ \\
\hline Margaritiferidae & Margaritifera homsensis & $\mathrm{EN}^{*}$ \\
\hline Unionidae & Anodonta anatina & LC \\
\hline Unionidae & Anodonta cygnea & LC \\
\hline Unionidae & Anodonta pseudodopsis & $\mathrm{EN}^{*}$ \\
\hline Unionidae & Anodonta vescoiana & $\mathrm{NT}^{*}$ \\
\hline Unionidae & Leguminaia saulcyi & $\mathrm{CR}^{*}$ \\
\hline Unionidae & Leguminaia wheatleyi & $\mathrm{NT}^{*}$ \\
\hline Unionidae & Potomida littoralis & EN \\
\hline Unionidae & Pseudodontopsis euphratica & NT $(\text { draft })^{*}$ \\
\hline Unionidae & Unio crassus & EN \\
\hline Unionidae & Unio mancus & NT \\
\hline Unionidae & Unio terminalis & $\mathrm{VU}^{*}$ \\
\hline Unionidae & Unio tigridis & $\mathrm{LC}^{*}$ \\
\hline
\end{tabular}

\begin{tabular}{|l|l|l|}
\hline Sphaeriidae & Pisidium moitessierianum & LC (draft) \\
\hline Sphaeriidae & Pisidium personatum & LC (draft) \\
\hline Sphaeriidae & Pisidium sogdianum & NA ? \\
\hline Sphaeriidae & Pisidium subtruncatum & LC (draft) \\
\hline Sphaeriidae & Pisidium tenuilineatum & LC (draft) \\
\hline Class & Gastropoda & \\
\hline Order & Allogastropoda & \\
\hline Family & Species & RL \\
\hline Valvatidae & Borysthenia naticina & LC \\
\hline Valvatidae & Valvata cristata & LC (draft) \\
\hline Valvatidae & Valvata macrostoma & LC \\
\hline Valvatidae & Valvata piscinalis & LC \\
\hline Valvatidae & Valvata saulcyi & LC \\
\hline
\end{tabular}

\begin{tabular}{|c|c|c|c|c|c|}
\hline & \\
\hline & \multirow{2}{*}{\multicolumn{2}{|c|}{ Veneroida }} & Family & Species & $\mathrm{RL}$ \\
\hline Order & & & Viviparidae & Viviparus contectus & LC \\
\hline Family & \multicolumn{2}{|l|}{ Species } & \multirow[t]{2}{*}{ Viviparidae } & \multirow[t]{2}{*}{ Viviparus viviparus } & \multirow{2}{*}{ LC } \\
\hline Cyrenidae & Corbicula fluminalis & LC & & & \\
\hline Dreissenidae & Dreissena caputlacus & EN (draft) ${ }^{*}$ & \multirow{2}{*}{$\begin{array}{l}\text { Order } \\
\text { Family }\end{array}$} & \multirow{2}{*}{$\begin{array}{l}\text { Cycloneritimorpha } \\
\text { Species }\end{array}$} & \multirow[b]{2}{*}{ RL } \\
\hline Dreissenidae & Dreissenaiconica & $\mathrm{DD}^{*}$ & & & \\
\hline Dreissenidae & Dreissena polymorpha & LC & \multirow{2}{*}{\begin{tabular}{|l|} 
Neritidae \\
Neritidae \\
\end{tabular}} & Theodoxus altenai & $\mathrm{CR}^{*}$ \\
\hline Sphaeriidae & Musculium lacustre & LC & & Theodoxus anatolicus & NT \\
\hline Sphaeriidae & Pisidium amnicum & LC (draft) & \multirow{2}{*}{\begin{tabular}{|l|} 
Neritidae \\
Neritidae \\
\end{tabular}} & Theodoxus cinctellus & $\mathrm{DD}^{*}$ \\
\hline Sphaeriidae & Pisidium casertanum & LC & & Theodoxus euphraticus & $\mathrm{DD}^{*}$ \\
\hline Sphaeriidae & Pisidium henslowanum & LC & \multirow[t]{2}{*}{ Neritidae } & \multirow[t]{2}{*}{ Theodoxus euxinus } & \multirow[t]{2}{*}{ LC (draft) } \\
\hline Sphaeriidae & Pisidium milium & LC (draft) & & & \\
\hline
\end{tabular}


Appendix 2.2 cont'd, Freshwater molluscs

\begin{tabular}{|l|l|l|}
\hline Neritidae & Theodoxus heldreichi & LC $^{*}$ \\
\hline Neritidae & Theodoxusjordani & LC $^{*}$ \\
\hline Neritidae & Theodoxuspallasi & DD \\
\hline Neritidae & Theodoxus subthermalis & LC \\
\hline Neritidae & Theodoxus syriacus & DD \\
\hline
\end{tabular}

\begin{tabular}{|c|c|c|}
\hline Order & Hygrophila & \\
\hline Family & Species & RL \\
\hline Acroloxidae & Acroloxus egirdirensis & $V U^{*}$ \\
\hline Acroloxidae & Acroloxus lacustris & LC \\
\hline Lymnaeidae & Galba truncatula & LC \\
\hline Lymnaeidae & Lymnaea schirazensis & LC \\
\hline Lymnaeidae & Lymnaea stagnalis & LC \\
\hline Lymnaeidae & Radix auricularia & LC \\
\hline Lymnaeidae & Radix balthica & LC \\
\hline Lymnaeidae & Stagnicola kayseris & $\operatorname{EN}(\text { draft })^{*}$ \\
\hline Lymnaeidae & Stagnicola tekecus & $\mathrm{DD}$ (draft) * \\
\hline Planorbidae & Ancylus fluviatilis & LC \\
\hline Planorbidae & Bathyomphalus contortus & $\mathrm{LC}$ \\
\hline Planorbidae & Gyraulus albus & LC \\
\hline Planorbidae & Gyraulus argaeicus & $\mathrm{VU}^{*}$ \\
\hline Planorbidae & Gyraulus bekaensis & $\mathrm{VU}^{*}$ \\
\hline Planorbidae & Gyraulus convexiusculus & LC \\
\hline Planorbidae & Gyraulus crista & LC \\
\hline Planorbidae & Gyraulus egirdirensis & $\mathrm{DD}^{*}$ \\
\hline Planorbidae & Gyraulus hebraicus & $\mathrm{LC}^{*}$ \\
\hline Planorbidae & Gyraulus huwaizahensis & $\mathrm{DD}^{*}$ \\
\hline Planorbidae & Gyraulus nedyalkovi & $\mathrm{VU}^{*}$ \\
\hline Planorbidae & Gyraulus pamphylicus & $\mathrm{VU}^{*}$ \\
\hline Planorbidae & Gyraulus taseviensis & $\mathrm{DD}^{*}$ \\
\hline Planorbidae & Planorbarius corneus & $\mathrm{LC}$ \\
\hline Planorbidae & Planorbis carinatus & LC (draft) \\
\hline Planorbidae & Planorbis planorbis & LC \\
\hline Planorbidae & Segmentina nitida & LC (draft) \\
\hline
\end{tabular}

\begin{tabular}{|c|c|c|}
\hline Hydrobiidae & Falsipyrgula barroisi & $\mathrm{EN}^{*}$ \\
\hline Hydrobiidae & Falsipyrgula beysehirana & $\mathrm{CR} \mathrm{PE}^{*}$ \\
\hline Hydrobiidae & Falsipyrgula pfeiferi & $\mathrm{EN}^{*}$ \\
\hline Hydrobiidae & Globuliana gaillardotii & LC \\
\hline Hydrobiidae & Graecoanatolica brevis & CR PE* \\
\hline Hydrobiidae & Graecoanatolica conica & CR PE* \\
\hline Hydrobiidae & Graecoanatolica dinarica & $\mathrm{EN}^{*}$ \\
\hline Hydrobiidae & Graecoanatolica kocapinarica & $\mathrm{VU}^{*}$ \\
\hline Hydrobiidae & Graecoanatolica lacustristurca & $\mathrm{EN}^{*}$ \\
\hline Hydrobiidae & Graecoanatolica pamphylica & $\mathrm{EN}^{*}$ \\
\hline Hydrobiidae & Graecoanatolica tenuis & $\mathrm{EN}(\mathrm{draft})^{*}$ \\
\hline Hydrobiidae & Horatia parvula & $\mathrm{DD}^{*}$ \\
\hline Hydrobiidae & Hydrobia acuta & LC \\
\hline Hydrobiidae & Hydrobia anatolica & CR PE* \\
\hline Hydrobiidae & Hydrobia soosi & $\mathrm{DD}^{*}$ \\
\hline Hydrobiidae & Hydrobia ventrosa & LC \\
\hline Hydrobiidae & Islamia anatolica & $\mathrm{CR}(\mathrm{draft})^{*}$ \\
\hline Hydrobiidae & Islamia bunarbasa & $\mathrm{CR}^{*}$ \\
\hline Hydrobiidae & Islamia pseudorientalica & CR PE* \\
\hline Hydrobiidae & Kirelia carinata & CR PE* \\
\hline Hydrobiidae & Kirelia murtici & $\mathrm{CR}^{*}$ \\
\hline Hydrobiidae & Peringia ulvae & LC (draft) \\
\hline Hydrobiidae & Pseudamnicola bilgini & $\mathrm{LC}^{*}$ \\
\hline Hydrobiidae & Pseudamnicola geldiayana & $\mathrm{EN}^{*}$ \\
\hline Hydrobiidae & Pseudamnicola intranodosa & $\mathrm{VU}^{*}$ \\
\hline Hydrobiidae & Pseudamnicola macrostoma & DD \\
\hline Hydrobiidae & Pseudamnicola solitaria & $\mathrm{EN}^{*}$ \\
\hline Hydrobiidae & Pseudamnicola vinarskii & $\mathrm{DD}^{*}$ \\
\hline Hydrobiidae & Pseudorientalia natolica & EN (draft) * \\
\hline Hydrobiidae & Pyrgorientalia zilchi & NA? \\
\hline Hydrobiidae & Radomaniola caputlacus & $\mathrm{NT}^{*}$ \\
\hline Hydrobiidae & Radomaniola gaillardoti & DD \\
\hline Hydrobiidae & Sadleriana affinis & $\mathrm{DD}^{*}$ \\
\hline Hydrobiidae & Sadleriana byzanthina & $\mathrm{DD}^{*}$ \\
\hline Hydrobiidae & Sadleriana fluminensis & LC \\
\hline Hydrobiidae & Sadleriana minuta & NA? \\
\hline Hydrobiidae & Sheitanok amidicus & $\mathrm{NT}^{*}$ \\
\hline Hydrobiidae & Tefennia tefennica & $\mathrm{VU}^{*}$ \\
\hline Hydrobiidae & Torosia proschwitzi & $\mathrm{DD}^{*}$ \\
\hline Hydrobiidae & Turcorientalia anatolica & $\mathrm{VU}^{*}$ \\
\hline
\end{tabular}

\begin{tabular}{|c|c|c|}
\hline Order & Littorinimorpha & \\
\hline Family & Species & $\mathrm{RL}$ \\
\hline Assimineidae & Assiminea mesopotamica & $\mathrm{DD}^{*}$ \\
\hline Assimineidae & Paludinella littorina & LC \\
\hline Assimineidae & Paludinella sicana & LC \\
\hline Bithyniidae & Bithynia hareerensis & $\mathrm{DD}^{*}$ \\
\hline Bithyniidae & Bithynia pesicii & $\mathrm{EN}^{*}$ \\
\hline Bithyniidae & Bithynia phialensis & $\mathrm{LC}^{*}$ \\
\hline Bithyniidae & Bithynia pseudemmericia & $\mathrm{VU}^{*}$ \\
\hline Bithyniidae & Bithynia yildirimii sp. Nov. & $\mathrm{VU}^{*}$ \\
\hline Bithyniidae & Pseudobithynia hamicensis & LC (draft) ${ }^{*}$ \\
\hline Bithyniidae & Pseudobithynia kathrinae & $\mathrm{CR}^{*}$ \\
\hline Bithyniidae & Pseudobithynia levantica & $\mathrm{EN}^{*}$ \\
\hline Bithyniidae & Pseudobithynia pentheri & $\mathrm{NT}^{*}$ \\
\hline Bithyniidae & Pseudobithynia saulyci & NA? \\
\hline Bithyniidae & Pseudobithynia yildirimi & NA? \\
\hline Cochliopidae & Heleobia contempta & $\mathrm{DD}$ (draft)* \\
\hline Cochliopidae & Heleobia galilaea & $\mathrm{VU}^{*}$ \\
\hline Cochliopidae & Heleobia longiscata & $\mathrm{DD}^{*}$ \\
\hline Hydrobiidae & Belgrandiella adsharica & $\mathrm{EN}^{*}$ \\
\hline Hydrobiidae & Belgrandiella cavernica & CR PE* \\
\hline Hydrobiidae & Belgrandiella edessana & $\mathrm{VU}^{*}$ \\
\hline Hydrobiidae & Belgrandiella libanica & $\mathrm{NT}^{*}$ \\
\hline Hydrobiidae & Bythinella kazdaghensis & $\mathrm{VU}^{*}$ \\
\hline Hydrobiidae & Bythinella occasiuncula & $\mathrm{VU}^{*}$ \\
\hline Hydrobiidae & Bythinella turca & $\mathrm{CR}^{*}$ \\
\hline Hydrobiidae & Falsibelgrandiella bunarica & $\mathrm{DD}^{*}$ \\
\hline
\end{tabular}

\begin{tabular}{|c|c|c|}
\hline Order & Sorbeoconcha & \\
\hline Family & Species & RL \\
\hline Melanopsidae & Esperiana sangarica & $\mathrm{VU}^{*}$ \\
\hline Melanopsidae & Melanopsis ammonis & $\mathrm{CR}^{*}$ \\
\hline Melanopsidae & Melanopsis buccinoidea & LC \\
\hline Melanopsidae & Melanopsis denegabilis & $\mathrm{DD}^{*}$ \\
\hline Melanopsidae & Melanopsis dircaena & $\mathrm{EN}^{*}$ \\
\hline Melanopsidae & Melanopsis doriae & LC \\
\hline Melanopsidae & Melanopsis germaini & CR PE* \\
\hline Melanopsidae & Melanopsis infracincta & CR PE* \\
\hline Melanopsidae & Melanopsis khabourensis & CR PE* \\
\hline Melanopsidae & Melanopsis meiostoma & $\mathrm{DD}^{*}$ \\
\hline Melanopsidae & Melanopsis nodosa & $\mathrm{LC}^{*}$ \\
\hline Melanopsidae & Melanopsispachya & CR PE* \\
\hline Melanopsidae & Melanopsis saulcyi & $\mathrm{LC}^{*}$ \\
\hline Thiaridae & Melanoides tuberculata & LC \\
\hline Order & Stylommatophora & \\
\hline Family & Species & RL \\
\hline Succineidae & Oxyloma elegans & LC (draft) * \\
\hline
\end{tabular}




\subsection{Odonata}

\begin{tabular}{|c|c|c|c|c|c|}
\hline Suborder & Anisoptera & & Libellulidae & Sympetrum arenicolor & LC \\
\hline Family & Species & RL & Libellulidae & Sympetrum danae & LC (draft) \\
\hline Aeshnidae & Aeshna affinis & LC & Libellulidae & Sympetrum depressiusculum & LC (draft) \\
\hline Aeshnidae & Aeshna cyanea & LC & Libellulidae & Sympetrum flaveolum & LC \\
\hline Aeshnidae & Aeshna isoceles & LC & Libellulidae & Sympetrum fonscolombii & LC \\
\hline Aeshnidae & Aeshnajuncea & LC & Libellulidae & Sympetrum haritonovi & LC \\
\hline Aeshnidae & Aeshna mixta & LC & Libellulidae & Sympetrum meridionale & LC \\
\hline Aeshnidae & Aeshna serrata & LC & Libellulidae & Sympetrum pedemontanum & LC \\
\hline Aeshnidae & Anax ephippiger & LC & Libellulidae & Sympetrum sanguineum & LC \\
\hline Aeshnidae & Anax immaculifrons & LC & Libellulidae & Sympetrum sinaiticum & LC \\
\hline Aeshnidae & Anax imperator & LC & Libellulidae & Sympetrum striolatum & LC \\
\hline Aeshnidae & Anaxparthenope & LC & Libellulidae & Sympetrum vulgatum & LC \\
\hline Aeshnidae & Brachytron pratense & LC & Libellulidae & Trithemis annulata & LC \\
\hline Aeshnidae & Caliaeschna microstigma & LC & Libellulidae & Trithemis arteriosa & LC \\
\hline Cordulegastridae & Cordulegaster bidentata & NT & Libellulidae & Trithemisfestiva & LC \\
\hline Cordulegastridae & Cordulegaster heros & NT & Libellulidae & Trithemis kirbyi & LC \\
\hline Cordulegastridae & Cordulegaster insignis & LC & Libellulidae & Urothemis edwardsii & LC \\
\hline Cordulegastridae & Cordulegaster picta & LC & Libellulidae & Zygonyx torridus & LC \\
\hline Cordulegastridae & Cordulegaster vanbrinkae & DD & & & \\
\hline Corduliidae & Cordulia aenea & LC & Suborder & Zygoptera & \\
\hline Corduliidae & Somatochlora borisi & VU & Family & Species & $\mathrm{RL}$ \\
\hline Corduliidae & Somatochlora flavomaculata & LC & Calopterygidae & Calopteryx hyalina & $\mathrm{EN}^{*}$ \\
\hline Corduliidae & Somatochlora meridionalis & LC & Calopterygidae & Calopteryx splendens & LC \\
\hline Corduliidae & Somatochlora metallica & LC & Calopterygidae & Calopteryx syriaca & $\mathrm{EN}^{*}$ \\
\hline Gomphidae & Anormogomphus kiritshenkoi & NT & Calopterygidae & Calopteryx virgo & LC \\
\hline Gomphidae & Gomphus davidi & $\mathrm{LC}^{*}$ & Coenagrionidae & Agriocnemissania & LC \\
\hline Gomphidae & Gomphus flavipes & LC & Coenagrionidae & Ceriagrion georgifreyi & VU \\
\hline Gomphidae & Gomphuskinzelbachi & $\mathrm{DD}^{*}$ & Coenagrionidae & Coenagrion armatum & LC \\
\hline Gomphidae & Gomphus schneiderii & LC & Coenagrionidae & Coenagrion hastulatum & LC \\
\hline Gomphidae & Gomphus ubadschii & DD & Coenagrionidae & Coenagrion lunulatum & LC (draft) \\
\hline Gomphidae & Gomphus vulgatissimus & LC & Coenagrionidae & Coenagrion ornatum & LC \\
\hline Gomphidae & Lindenia tetraphylla & LC & Coenagrionidae & Coenagrion persicum & $\mathrm{DD}^{*}$ \\
\hline Gomphidae & Onychogomphus assimilis & VU & Coenagrionidae & Coenagrion ponticum & LC \\
\hline Gomphidae & Onychogomphusflexuosus & VU & Coenagrionidae & Coenagrion puella & LC \\
\hline Gomphidae & Onychogomphus forcipatus & LC & Coenagrionidae & Coenagrion pulchellum & LC \\
\hline Gomphidae & Onychogomphus lefebvrii & LC & Coenagrionidae & Coenagrion scitulum & LC \\
\hline Gomphidae & Onychogomphus macrodon & $\mathrm{VU}^{*}$ & Coenagrionidae & Coenagrion syriacum & $\mathrm{NT}^{*}$ \\
\hline Gomphidae & Ophiogomphuscecilia & LC & Coenagrionidae & Enallagma cyathigerum & LC \\
\hline Gomphidae & Ophiogomphus reductus & LC & Coenagrionidae & Erythromma lindenii & LC \\
\hline Gomphidae & Paragomphus genei & LC & Coenagrionidae & Erythromma najas & LC (draft) \\
\hline Gomphidae & Paragomphus lineatus & LC & Coenagrionidae & Erythromma viridulum & LC \\
\hline Libellulidae & Brachythemis fuscopalliata & $\mathrm{VU}^{*}$ & Coenagrionidae & Ischnura elegans & LC \\
\hline Libellulidae & Brachythemis impartita & LC & Coenagrionidae & Ischnura evansi & LC \\
\hline Libellulidae & Crocothemis erythraea & LC & Coenagrionidae & Ischnura fountaineae & LC \\
\hline Libellulidae & Crocothemis sanguinolenta & LC & Coenagrionidae & Ischnura intermedia & NT \\
\hline Libellulidae & Crocothemis servilia & LC & Coenagrionidae & Ischnura pumilio & $\mathrm{LC}$ \\
\hline Libellulidae & Diplacodes lefeburii & LC & Coenagrionidae & Ischnura senegalensis & LC \\
\hline Libellulidae & Leucorrbinia pectoralis & LC & Coenagrionidae & Pseudagrion sublacteum & LC \\
\hline Libellulidae & Libellula depressa & LC & Coenagrionidae & Pseudagrion syriacum & $\mathrm{LC}^{*}$ \\
\hline Libellulidae & Libellula fulva & LC & Coenagrionidae & Pseudagrion torridum & LC \\
\hline Libellulidae & Libellula pontica & $\mathrm{NT}^{*}$ & Coenagrionidae & Pyrrhosoma nymphula & LC \\
\hline Libellulidae & Libellula quadrimaculata & LC & Euphaeidae & Epallage fatime & LC \\
\hline Libellulidae & Orthetrum abbotti & LC & Lestidae & Chalcolestes parvidens & LC \\
\hline Libellulidae & Orthetrum albistylum & LC & Lestidae & Chalcolestes viridis & LC \\
\hline Libellulidae & Orthetrum brunneum & LC & Lestidae & Lestes barbarus & LC \\
\hline Libellulidae & Orthetrum cancellatum & LC & Lestidae & Lestes dryas & LC \\
\hline Libellulidae & Orthetrum chrysostigma & LC & Lestidae & Lestes macrostigma & LC \\
\hline Libellulidae & Orthetrum coerulescens & LC & Lestidae & Lestes sponsa & LC \\
\hline Libellulidae & Orthetrum ransonnetii & LC & Lestidae & Lestes virens & LC \\
\hline Libellulidae & Orthetrum sabina & LC & Lestidae & Sympecma fusca & LC \\
\hline Libellulidae & Orthetrum taeniolatum & LC & Lestidae & Sympecma paedisca & LC \\
\hline Libellulidae & Orthetrum trinacria & LC & Platycnemididae & Platycnemis dealbata & LC \\
\hline Libellulidae & Pantala flavescens & LC & Platycnemididae & Platycnemis kervillei & $\mathrm{LC}^{*}$ \\
\hline Libellulidae & Rhyothemis semibyalina & LC & Platycnemididae & Platycnemis pennipes & LC \\
\hline
\end{tabular}




\subsection{Freshwater plants}

\begin{tabular}{|c|c|c|}
\hline Phylum & Tracheophyta & \\
\hline Class & Equisetopsida & \\
\hline Order & Equisetales & \\
\hline Family & Species & RL \\
\hline Equisetaceae & Equisetum fluviatile & LC \\
\hline Equisetaceae & Equisetum giganteum & LC \\
\hline Equisetaceae & Equisetum byemale & LC \\
\hline Equisetaceae & Equisetum palustre & LC \\
\hline Equisetaceae & Equisetum telmateia & LC \\
\hline
\end{tabular}

\begin{tabular}{|c|c|c|}
\hline Class & Isoetopsida & \\
\hline Order & Isoetales & \\
\hline Family & Species & $\mathrm{RL}$ \\
\hline Isoetaceae & Isoetes olympica & $\mathrm{CR}^{*}$ \\
\hline
\end{tabular}

\begin{tabular}{|l|l|l|}
\hline Class & Liliopsida & \\
\hline $\begin{array}{l}\text { Order } \\
\text { Family }\end{array}$ & $\begin{array}{l}\text { Alismatales } \\
\text { Species }\end{array}$ & RL \\
\hline Alismataceae & Alismagramineum & DD \\
\hline Alismataceae & Alismalanceolatum & LC \\
\hline Alismataceae & Alismaplantago-aquatica & LC \\
\hline Alismataceae & Baldellia ranunculoides & NT \\
\hline Alismataceae & Damasonium bourgaei & LC \\
\hline Alismataceae & Sagittaria sagittifolia & LC \\
\hline Butomaceae & Butomusumbellatus & LC \\
\hline Order & & \\
\hline Family & $\begin{array}{l}\text { Arales } \\
\text { Species }\end{array}$ & \\
\hline Acoraceae & Acoruscalamus & RL \\
\hline Araceae & Callapalustris & LC \\
\hline Lemnaceae & Lemnagibba & LC \\
\hline Lemnaceae & Lemna minor & LC \\
\hline Lemnaceae & Lemnatrisulca & LC \\
\hline Lemnaceae & Lemnaturionifera & LC \\
\hline Lemnaceae & Spirodelapolyrbiza & LC \\
\hline & & LC \\
\hline
\end{tabular}

\begin{tabular}{|l|l|l|}
\hline $\begin{array}{l}\text { Order } \\
\text { Family }\end{array}$ & $\begin{array}{l}\text { Cyperales } \\
\text { Species }\end{array}$ & RL \\
\hline Cyperaceae & Blysmus compressus & LC \\
\hline Cyperaceae & Bolboschoenus glaucus & LC \\
\hline Cyperaceae & Bolboschoenus laticarpus & LC \\
\hline Cyperaceae & Bolboschoenus maritimus & LC \\
\hline Cyperaceae & Carex acuta & LC \\
\hline Cyperaceae & Carex acutiformis & LC \\
\hline Cyperaceae & Carexappropinquata & LC \\
\hline Cyperaceae & Carexatherodes & LC \\
\hline Cyperaceae & Carex caespitosa & LC \\
\hline Cyperaceae & Carex canescens & LC \\
\hline Cyperaceae & Carex cilicica & LC \\
\hline Cyperaceae & Carex davalliana & LC \\
\hline Cyperaceae & Carex diandra & LC \\
\hline Cyperaceae & Carex diluta & LC \\
\hline Cyperaceae & Carex distans & LC \\
\hline Cyperaceae & Carex divisa & LC \\
\hline Cyperaceae & Carex elata & LC \\
\hline Cyperaceae & Carex extensa & LC \\
\hline Cyperaceae & Carex flava & LC \\
\hline Cyperaceae & Carex iraqensis & NT \\
\hline Cyperaceae & Carex lasiocarpa & LC \\
\hline Cyperaceae & Carex limosa & LC \\
\hline Cyperaceae & Carex melanorrhyncha & LD \\
\hline Cyperaceae & & \\
\hline & & Canica \\
\hline
\end{tabular}

\begin{tabular}{|c|c|c|}
\hline Cyperaceae & Carex microglochin & LC \\
\hline Cyperaceae & Carex nigra & LC \\
\hline Cyperaceae & Carex orbicularis & LC \\
\hline Cyperaceae & Carex otrubae & LC \\
\hline Cyperaceae & Carexpaniculata & LC \\
\hline Cyperaceae & Carexpseudocyperus & LC \\
\hline Cyperaceae & Carexpseudofoetida & LC \\
\hline Cyperaceae & Carexpunctata & LC \\
\hline Cyperaceae & Carex riparia & LC \\
\hline Cyperaceae & Carex rostrata & LC \\
\hline Cyperaceae & Carex songorica & LC \\
\hline Cyperaceae & Carex umbrosa & LC \\
\hline Cyperaceae & Carex vesicaria & LC \\
\hline Cyperaceae & Cladium mariscus & LC \\
\hline Cyperaceae & Cyperus difformis & LC \\
\hline Cyperaceae & Cyperus fuscus & LC \\
\hline Cyperaceae & Cyperus glaber & LC \\
\hline Cyperaceae & Cyperus glomeratus & LC \\
\hline Cyperaceae & Cyperus hamulosus & LC \\
\hline Cyperaceae & Cyperusiria & LC \\
\hline Cyperaceae & Cyperus laevigatus & LC \\
\hline Cyperaceae & Cyperus longus & LC \\
\hline Cyperaceae & Cyperusmichelianus & LC \\
\hline Cyperaceae & Cyperus rotundus & LC \\
\hline Cyperaceae & Eleocharis acicularis & LC \\
\hline Cyperaceae & Eleocharis argyrolepis & LC \\
\hline Cyperaceae & Eleocharis atropurpurea & LC \\
\hline Cyperaceae & Eleocharis carniolica & LC \\
\hline Cyperaceae & Eleocharis macrantha & $\mathrm{LC}^{*}$ \\
\hline Cyperaceae & Eleocharis mitracarpa & LC \\
\hline Cyperaceae & Eleocharispalustris & LC \\
\hline Cyperaceae & Eleocharis quinqueflora & LC \\
\hline Cyperaceae & Eleocharis uniglumis & LC \\
\hline Cyperaceae & Eriophorum angustifolium & LC \\
\hline Cyperaceae & Eriophorum latifolium & LC \\
\hline Cyperaceae & Fimbristylis bisumbellata & LC \\
\hline Cyperaceae & Fimbristylis dichotoma & LC \\
\hline Cyperaceae & Fimbristylisferruginea & LC \\
\hline Cyperaceae & Fimbristylis littoralis & LC \\
\hline Cyperaceae & Fimbristylis quinquangularis & LC \\
\hline Cyperaceae & Fuirenapubescens & LC \\
\hline Cyperaceae & Isolepis cernua & LC \\
\hline Cyperaceae & Isolepis setacea & $\mathrm{LC}$ \\
\hline Cyperaceae & Kobresia simpliciuscula & LC \\
\hline Cyperaceae & Kyllinga brevifolia & LC \\
\hline Cyperaceae & Pycreusflavescens & LC \\
\hline Cyperaceae & Pycreus flavidus & LC \\
\hline Cyperaceae & Pycreus sanguinolentus & LC \\
\hline Cyperaceae & Rhynchospora alba & $\mathrm{LC}$ \\
\hline Cyperaceae & Schoenoplectiella roylei & LC \\
\hline Cyperaceae & Schoenoplectiella supina & LC \\
\hline Cyperaceae & Schoenoplectus lacustris & LC \\
\hline Cyperaceae & Schoenoplectus litoralis & LC \\
\hline Cyperaceae & Schoenoplectus mucronatus & LC \\
\hline Cyperaceae & Schoenoplectus tabernaemontani & LC \\
\hline Cyperaceae & Schoenoplectus triqueter & LC \\
\hline Cyperaceae & Schoenus nigricans & LC \\
\hline Cyperaceae & Scirpoides holoschoenus & LC \\
\hline Cyperaceae & Scirpus sylvaticus & LC \\
\hline Gramineae & Agrostis canina & LC \\
\hline Gramineae & Agrostis stolonifera & LC \\
\hline Gramineae & Alopecurus aequalis & LC \\
\hline Gramineae & Alopecurus arundinaceus & LC \\
\hline Gramineae & Alopecurus creticus & LC \\
\hline
\end{tabular}


Appendix 2.4 cont'd, Freshwater plants

\begin{tabular}{|l|l|l|}
\hline Gramineae & Alopecurus setarioides & LC \\
\hline Gramineae & Beckmannia eruciformis & LC \\
\hline Gramineae & Brachiaria eruciformis & LC \\
\hline Gramineae & Calamagrostisparsana & EN \\
\hline Gramineae & Calamagrostispseudophragmites & LC \\
\hline Gramineae & Catabrosa aquatica & LC \\
\hline Gramineae & Crypsis alopecuroides & LC \\
\hline Gramineae & Crypsis schoenoides & LC \\
\hline Gramineae & Echinochloa crusgalli & LC \\
\hline Gramineae & Eleusine indica & LC \\
\hline Gramineae & Glyceria arundinacea & LC \\
\hline Gramineae & Glyceria fuitans & LC \\
\hline Gramineae & Glyceria maxima & LC \\
\hline Gramineae & Glyceria nemoralis & LC \\
\hline Gramineae & Glyceria notata & LC \\
\hline Gramineae & Hemarthria altissima & LC \\
\hline Gramineae & Panicum repens & LC \\
\hline Gramineae & Phalaris arundinacea & LC \\
\hline Gramineae & Phragmites australis & LC \\
\hline Gramineae & Polypogon monspeliensis & LC \\
\hline Gramineae & Polypogon viridis & LC \\
\hline Gramineae & Scolochloafestucacea & LC \\
\hline Gramineae & Zingeria biebersteiniana & LC \\
\hline Gramineae & LC \\
\hline & \\
\hline
\end{tabular}

\begin{tabular}{|l|l|l|}
\hline $\begin{array}{l}\text { Order } \\
\text { Family }\end{array}$ & $\begin{array}{l}\text { Hydrocharitales } \\
\text { Species }\end{array}$ & RL \\
\hline Hydrocharitaceae & Hydrocharismorsus-ranae & LC \\
\hline Hydrocharitaceae & Najasgraminea & LC \\
\hline Hydrocharitaceae & Najasmarina & LC \\
\hline Hydrocharitaceae & Najasminor & LC \\
\hline Hydrocharitaceae & Stratiotesaloides & LC \\
\hline Hydrocharitaceae & Vallisneriaspiralis & LC \\
\hline
\end{tabular}

\begin{tabular}{|l|l|l|}
\hline $\begin{array}{l}\text { Order } \\
\text { Family }\end{array}$ & $\begin{array}{l}\text { Najadales } \\
\text { Species }\end{array}$ & RL \\
\hline Juncaginaceae & Triglochin bulbosa & LC \\
\hline Juncaginaceae & Triglochin palustris & LC \\
\hline Potamogetonaceae & Groenlandia densa & LC \\
\hline Potamogetonaceae & Potamogeton alpinus & LC \\
\hline Potamogetonaceae & Potamogeton berchtoldii & LC \\
\hline Potamogetonaceae & Potamogeton coloratus & LC \\
\hline Potamogetonaceae & Potamogeton crispus & LC \\
\hline Potamogetonaceae & Potamogeton gramineus & LC \\
\hline Potamogetonaceae & Potamogeton lucens & LC \\
\hline Potamogetonaceae & Potamogeton natans & LC \\
\hline Potamogetonaceae & Potamogeton nodosus & LC \\
\hline Potamogetonaceae & Potamogeton perfoliatus & LC \\
\hline Potamogetonaceae & Potamogeton praelongus & LC \\
\hline Potamogetonaceae & Potamogeton pusillus & LC \\
\hline Potamogetonaceae & Potamogeton trichoides & LC \\
\hline Potamogetonaceae & Stuckenia amblyophyla & LC \\
\hline Potamogetonaceae & Stuckeniapectinata & LC \\
\hline Potamogetonaceae & Zannichelliapalustris & LC \\
\hline Potamogetonaceae & Zannichellia peltata & LC \\
\hline & & \\
\hline
\end{tabular}

\begin{tabular}{|l|l|l|}
$\begin{array}{l}\text { Order } \\
\text { Family }\end{array}$ & $\begin{array}{l}\text { Orchidales } \\
\text { Species }\end{array}$ & RL \\
\hline Orchidaceae & Anacamptispalustris & LC \\
\hline Orchidaceae & Dactylorhiza euxina & NT \\
\hline Orchidaceae & Epipactispalustris & LC \\
\hline Orchidaceae & Epipactis veratrifolia & LC \\
\hline Orchidaceae & Spiranthes sinensis & LC \\
\hline & & \\
\hline
\end{tabular}

\begin{tabular}{|l|l|l|}
\hline $\begin{array}{l}\text { Order } \\
\text { Family }\end{array}$ & $\begin{array}{l}\text { Typhales } \\
\text { Species }\end{array}$ & RL \\
\hline Typhaceae & Sparganium angustifolium & LC \\
\hline Typhaceae & Sparganium emersum & LC \\
\hline Typhaceae & Sparganium erectum & LC \\
\hline Typhaceae & Sparganium natans & LC \\
\hline Typhaceae & Typha angustifolia & LC \\
\hline Typhaceae & Typhadomingensis & LC \\
\hline Typhaceae & Typhalatifolia & LC \\
\hline Typhaceae & Typhalaxmannii & LC \\
\hline Typhaceae & Typhaminima & LC \\
\hline
\end{tabular}

\begin{tabular}{|l|l|l|}
$\begin{array}{l}\text { Order } \\
\text { Family }\end{array}$ & $\begin{array}{l}\text { Juncales } \\
\text { Species }\end{array}$ & RL \\
\hline Juncaceae & Juncus acutus & LC \\
\hline Juncaceae & Juncus alpinoarticulatus & LC \\
\hline Juncaceae & Juncus articulatus & LC \\
\hline Juncaceae & Juncus bufonius & LC \\
\hline Juncaceae & Juncus bulbosus & LC \\
\hline Juncaceae & Juncus compressus & LC \\
\hline Juncaceae & Juncus conglomeratus & LC \\
\hline Juncaceae & Juncus effusus & LC \\
\hline Juncaceae & Juncus filiformis & LC \\
\hline Juncaceae & Juncus fontanesii & LC \\
\hline Juncaceae & Juncus heldreichianus & LC \\
\hline Juncaceae & Juncus hybridus & LC \\
\hline Juncaceae & Juncus inflexus & LC \\
\hline Juncaceae & Juncus minutulus & LC \\
\hline Juncaceae & Juncus rigidus & LC \\
\hline Juncaceae & Juncusstriatus & LC \\
\hline Juncaceae & Juncus subnodulosus & LC \\
\hline Juncaceae & Juncussubulatus & LC \\
\hline Juncaceae & Juncustenageia & LC \\
\hline & & \\
\hline
\end{tabular}

\begin{tabular}{|l|l|l|}
\hline $\begin{array}{l}\text { Order } \\
\text { Family }\end{array}$ & $\begin{array}{l}\text { Liliales } \\
\text { Species }\end{array}$ & RL \\
\hline Amaryllidaceae & Leucojum aestivum & LC \\
\hline Iridaceae & Irispseudacorus & LC \\
\hline Iridaceae & Irisspuria & LC \\
\hline Melanthiaceae & Narthecium balansae & DD \\
\hline
\end{tabular}

\begin{tabular}{|c|c|c|}
\hline Class & Lycopodiopsida & \\
\hline Order & Lycopodiales & \\
\hline Family & Species & $\mathrm{RL}$ \\
\hline Lycopodiaceae & Lycopodiella inundata & LC \\
\hline
\end{tabular}

\begin{tabular}{|l|l|l|}
\hline Class & Magnoliopsida & \\
\hline Order & $\begin{array}{l}\text { Apiales } \\
\text { Family }\end{array}$ & RL \\
\hline Umbelliferae & Angelica sylvestris & LC \\
\hline Umbelliferae & Apium graveolens & LC \\
\hline Umbelliferae & Berula erecta & LC \\
\hline Umbelliferae & Cicuta virosa & LC \\
\hline Umbelliferae & Hydrocotyle vulgaris & LC \\
\hline Umbelliferae & Oenanthe aquatica & LC \\
\hline Umbelliferae & Oenanthe fistulosa & LC \\
\hline Umbelliferae & Oenanthe silaifolia & LC \\
\hline Umbelliferae & Sium sisaroideum & LC \\
\hline
\end{tabular}


Appendix 2.4 cont'd, Freshwater plants

\begin{tabular}{|l|l|l|}
\hline $\begin{array}{l}\text { Order } \\
\text { Family }\end{array}$ & $\begin{array}{l}\text { Asterales } \\
\text { Species }\end{array}$ & RL \\
\hline Compositae & Bidenscernua & LC \\
\hline Compositae & Bidenstripartita & LC \\
\hline Compositae & Ecliptaprostrata & DD \\
\hline Compositae & Inula acaulis & LC* \\
\hline Compositae & Pulicaria sicula & LC \\
\hline Compositae & Pulicaria vulgaris & LC \\
\hline Compositae & Senecio aquaticus & LC \\
\hline Compositae & Sonchuserzincanicus & CR \\
\hline Compositae & Sonchuspalustris & LC \\
\hline & & \\
\hline
\end{tabular}

\begin{tabular}{|l|l|l|}
\hline Gentianaceae & Swertia iberica & LC \\
\hline Gentianaceae & Swertia longifolia & LC \\
\hline
\end{tabular}

\begin{tabular}{|l|l|l|}
\hline $\begin{array}{l}\text { Order } \\
\text { Family }\end{array}$ & $\begin{array}{l}\text { Callitrichales } \\
\text { Species }\end{array}$ & RL \\
\hline Callitrichaceae & Callitriche brutia & LC \\
\hline Callitrichaceae & Callitrichelenisulca & LC \\
\hline Callitrichaceae & Callitriche mouterdei & DD * \\
\hline Callitrichaceae & Callitriche stagnalis & LC \\
\hline Callitrichaceae & Callitriche truncata & LC \\
\hline Hippuridaceae & Hippuris vulgaris & LC \\
\hline
\end{tabular}

\begin{tabular}{|c|c|c|}
\hline Order & Campanulales & \\
\hline Family & Species & RL \\
\hline Campanulaceae & Sphenoclea zeylanica & LC \\
\hline
\end{tabular}

\begin{tabular}{|l|l|l|}
\hline $\begin{array}{l}\text { Order } \\
\text { Family }\end{array}$ & $\begin{array}{l}\text { Capparales } \\
\text { Species }\end{array}$ & RL \\
\hline Cruciferae & Barbarea integrifolia & LC* \\
\hline Cruciferae & Barbarea plantaginea & LC \\
\hline Cruciferae & Barbarea vulgaris & LC \\
\hline Cruciferae & Cardamine uliginosa & LC \\
\hline Cruciferae & Nasturtium officinale & LC \\
\hline Cruciferae & Rorippa amphibia & LC \\
\hline Cruciferae & Rorippa aurea & LC \\
\hline Cruciferae & Rorippa austriaca & LC \\
\hline Cruciferae & Rorippa islandica & LC \\
\hline Cruciferae & Rorippa microphylla & LC \\
\hline Cruciferae & Rorippa sylvestris & LC \\
\hline
\end{tabular}

\begin{tabular}{|l|l|l|}
$\begin{array}{l}\text { Order } \\
\text { Family }\end{array}$ & $\begin{array}{l}\text { Caryophyllales } \\
\text { Species }\end{array}$ & RL \\
\hline Amaranthaceae & Alternanthera sessilis & LC \\
\hline Caryophyllaceae & Spergularia bocconei & LC \\
\hline Caryophyllaceae & Spergulariamarina & LC \\
\hline Caryophyllaceae & Spergulariamedia & LC \\
\hline Portulacaceae & Montiafontana & LC \\
\hline
\end{tabular}

\begin{tabular}{|l|l|l|}
\hline $\begin{array}{l}\text { Order } \\
\text { Family }\end{array}$ & $\begin{array}{l}\text { Euphorbiales } \\
\text { Species }\end{array}$ & RL \\
\hline Euphorbiaceae & Euphorbiapalustris & LC \\
\hline Order & $\begin{array}{l}\text { Fabales } \\
\text { Species }\end{array}$ & \\
\hline Family & Lathyruspalustris & RL \\
\hline Leguminosae & Lotuspalustris & LC \\
\hline Leguminosae & Tetragonolobusmaritimus & LC \\
\hline Leguminosae & Thermopsisturcica & LC \\
\hline Leguminosae & CR \\
\hline
\end{tabular}

\begin{tabular}{|l|l|l|}
\hline $\begin{array}{l}\text { Order } \\
\text { Family }\end{array}$ & $\begin{array}{l}\text { Gentianales } \\
\text { Species }\end{array}$ \\
\hline Apocynaceae & Amsonia orientalis & RL \\
\hline Asclepiadaceae & Cynanchum acutum & LC \\
\hline Asclepiadaceae & Oxystelma esculentum & LC \\
\hline
\end{tabular}

\begin{tabular}{|l|l|l|}
\hline $\begin{array}{l}\text { Order } \\
\text { Family }\end{array}$ & $\begin{array}{l}\text { Haloragales } \\
\text { Species }\end{array}$ & RL \\
\hline Haloragaceae & Myriophyllum spicatum & LC \\
\hline Haloragaceae & Myriophyllum verticillatum & LC \\
\hline
\end{tabular}

\begin{tabular}{|l|l|l|}
\hline $\begin{array}{l}\text { Order } \\
\text { Family }\end{array}$ & $\begin{array}{l}\text { Lamiales } \\
\text { Species }\end{array}$ & RL \\
\hline Boraginaceae & $\begin{array}{l}\text { Myosotis laxa } \\
\text { Lycopus europaeus }\end{array}$ & LC \\
\hline Labiatae & Mentha aquatica & LC \\
\hline Labiatae & Mentha longifolia & LC \\
\hline Labiatae & Menthapulegium & LC \\
\hline Labiatae & Mentha spicata & LC \\
\hline Labiatae & Mentha suaveolens & LC \\
\hline Labiatae & Scutellariagalericulata & LC \\
\hline Labiatae & Stachyspalustris & LC \\
\hline Labiatae & Phyla nodiflora & LC \\
\hline Verbenaceae & & LC \\
\hline
\end{tabular}

\begin{tabular}{|c|c|c|}
\hline Order & Malvales & \\
\hline Family & Species & RL \\
\hline Malvaceae & Kosteletzkya pentacarpos & LC \\
\hline
\end{tabular}

\begin{tabular}{|l|l|l|}
\hline $\begin{array}{l}\text { Order } \\
\text { Family }\end{array}$ & $\begin{array}{l}\text { Myrtales } \\
\text { Species }\end{array}$ & RL \\
\hline Lythraceae & Ammannia baccifera & LC \\
\hline Lythraceae & Ammannia multiflora & LC \\
\hline Lythraceae & Ammannia verticillata & LC \\
\hline Lythraceae & Lythrum anatolicum & DD \\
\hline Lythraceae & Lythrum borysthenicum & LC \\
\hline Lythraceae & Lythrum hyssopifolia & LC \\
\hline Lythraceae & Lythrum junceum & LC \\
\hline Lythraceae & Lythrumportula & LC \\
\hline Lythraceae & Lythrum salicaria & LC \\
\hline Lythraceae & Lythrum thymifolia & LC \\
\hline Lythraceae & Lythrum tribracteatum & LC \\
\hline Onagraceae & Epilobium anatolicum & LC \\
\hline Onagraceae & Epilobium confusum & LC \\
\hline Onagraceae & Epilobium hirsutum & LC \\
\hline Onagraceae & Epilobium minutiflorum & LC \\
\hline Onagraceae & Epilobiumpalustre & LC \\
\hline Onagraceae & Epilobiumparviflorum & LC \\
\hline Onagraceae & Ludwigia palustris & LC \\
\hline Onagraceae & Ludwigia stolonifera & LC \\
\hline Trapaceae & Trapanatans & LC \\
\hline & & \\
\hline
\end{tabular}

\begin{tabular}{|l|l|l|}
\hline $\begin{array}{l}\text { Order } \\
\text { Family }\end{array}$ & $\begin{array}{l}\text { Nymphaeales } \\
\text { Species }\end{array}$ & RL \\
\hline Ceratophyllaceae & Ceratophyllum demersum & LC \\
\hline Ceratophyllaceae & Ceratophyllum muricatum & LC \\
\hline Ceratophyllaceae & Ceratophyllum submersum & LC \\
\hline Nymphaeaceae & Nupharlutea & LC \\
\hline Nymphaeaceae & Nymphaea alba & LC \\
\hline
\end{tabular}

\begin{tabular}{|l|l|l|}
\hline $\begin{array}{l}\text { Order } \\
\text { Family }\end{array}$ & $\begin{array}{l}\text { Polygonales } \\
\text { Species }\end{array}$ & RL \\
\hline Polygonaceae & Persicaria amphibia & LC \\
\hline Polygonaceae & Persicaria hydropiper & LC \\
\hline Polygonaceae & Persicaria salicifolia & LC \\
\hline Polygonaceae & Polygonum cappadocium & DD \\
\hline Polygonaceae & Rumex bithynicus & EN $^{*}$ \\
\hline
\end{tabular}


Appendix 2.4 cont'd, Freshwater plants

\begin{tabular}{|l|l|l|}
\hline Polygonaceae & Rumexhydrolapathum & LC \\
\hline Polygonaceae & Rumexpalustris & LC \\
\hline $\begin{array}{l}\text { Order } \\
\text { Family }\end{array}$ & $\begin{array}{l}\text { Primulales } \\
\text { Species }\end{array}$ \\
\hline Primulaceae & Hottoniapalustris & RL \\
\hline Primulaceae & Lysimachia dubia & LC \\
\hline Primulaceae & Lysimachia nummularia & LC \\
\hline Primulaceae & Lysimachiapunctata & LC \\
\hline Primulaceae & Lysimachia vulgaris & LC \\
\hline Primulaceae & Primula auriculata & LC \\
\hline Primulaceae & Samolus valerandi & LC \\
\hline
\end{tabular}

\begin{tabular}{|l|l|l|}
\hline $\begin{array}{l}\text { Order } \\
\text { Family }\end{array}$ & $\begin{array}{l}\text { Ranunculales } \\
\text { Species }\end{array}$ & RL \\
\hline Ranunculaceae & Calthapalustris & LC \\
\hline Ranunculaceae & Ranunculus aquatilis & LC \\
\hline Ranunculaceae & Ranunculus cornutus & LC \\
\hline Ranunculaceae & Ranunculusflammula & LC \\
\hline Ranunculaceae & Ranunculus lateriflorus & LC \\
\hline Ranunculaceae & Ranunculus lingua & LC \\
\hline Ranunculaceae & Ranunculus ophioglossifolius & LC \\
\hline Ranunculaceae & Ranunculuspeltatus & LC \\
\hline Ranunculaceae & Ranunculus rionii & LC \\
\hline Ranunculaceae & Ranunculussaniculifolius & LC \\
\hline Ranunculaceae & Ranunculusschweinfurthii & VU * \\
\hline Ranunculaceae & Ranunculus sphaerospermus & LC \\
\hline Ranunculaceae & Ranunculus thracicus & VU (draft) \\
\hline Ranunculaceae & Ranunculus trichophyllus & LC \\
\hline & & \\
\hline
\end{tabular}

\begin{tabular}{|l|l|l|}
$\begin{array}{l}\text { Order } \\
\text { Family }\end{array}$ & $\begin{array}{l}\text { Rosales } \\
\text { Species }\end{array}$ & RL \\
\hline Parnassiaceae & Parnassia palustris & LC \\
\hline Rosaceae & Alchemilla bursensis & NT $^{*}$ \\
\hline Rosaceae & Alchemilla stricta & LC $^{*}$ \\
\hline Rosaceae & Filipendula ulmaria & LC \\
\hline Rosaceae & Potentilla palustris & LC \\
\hline Rosaceae & Potentilla supina & LC \\
\hline
\end{tabular}

\begin{tabular}{|l|l|l|}
\hline $\begin{array}{l}\text { Order } \\
\text { Family }\end{array}$ & $\begin{array}{l}\text { Rubiales } \\
\text { Species }\end{array}$ & RL \\
\hline Rubiaceae & Galium debile & LC \\
\hline Rubiaceae & Galium palustre & LC \\
\hline Rubiaceae & Galium uliginosum & LC \\
\hline Rubiaceae & Oldenlandiacapensis & LC \\
\hline
\end{tabular}

\begin{tabular}{|l|l|l|}
$\begin{array}{l}\text { Order } \\
\text { Family }\end{array}$ & $\begin{array}{l}\text { Salicales } \\
\text { Species }\end{array}$ & RL \\
\hline Salicaceae & Salixalba & LC \\
\hline Salicaceae & Salix amplexicaulis & LC \\
\hline Salicaceae & Salix cinerea & LC \\
\hline Salicaceae & Salix excelsa & LC \\
\hline Order & Sapindales & \\
\hline Family & Species & RL \\
\hline Zygophyllaceae & Nitrariaschoberi & LC \\
\hline
\end{tabular}

\begin{tabular}{|l|l|l|}
$\begin{array}{l}\text { Order } \\
\text { Family }\end{array}$ & $\begin{array}{l}\text { Scrophulariales } \\
\text { Species }\end{array}$ & RL \\
\hline Lentibulariaceae & Utricularia australis & LC \\
\hline Lentibulariaceae & Utriculariagibba & LC \\
\hline Lentibulariaceae & Utriculariaminor & LC \\
\hline Lentibulariaceae & Utricularia vulgaris & LC \\
\hline Scrophulariaceae & Gratiola officinalis & LC \\
\hline Scrophulariaceae & Limnophila indica & LC \\
\hline Scrophulariaceae & Limosella aquatica & LC \\
\hline Scrophulariaceae & Lindernia diffusa & LC \\
\hline Scrophulariaceae & Lindernia procumbens & LC \\
\hline Scrophulariaceae & Pedicularispalustris & LC \\
\hline Scrophulariaceae & Rhamphicarpamedwedewii & DD \\
\hline Scrophulariaceae & Scrophularia umbrosa & LC \\
\hline Scrophulariaceae & Veronica anagallis-aquatica & LC \\
\hline Scrophulariaceae & Veronica anagalloides & LC \\
\hline Scrophulariaceae & Veronica beccabunga & LC \\
\hline Scrophulariaceae & Veronica catenata & LC \\
\hline Scrophulariaceae & Veronicascutellata & LC \\
\hline
\end{tabular}

\begin{tabular}{|l|l|l|}
\hline $\begin{array}{l}\text { Order } \\
\text { Family }\end{array}$ & $\begin{array}{l}\text { Solanales } \\
\text { Species }\end{array}$ & RL \\
\hline Menyanthaceae & Menyanthes trifoliata & LC \\
\hline Menyanthaceae & Nymphoidesindica & LC \\
\hline Menyanthaceae & Nymphoidespeltata & LC \\
\hline
\end{tabular}

\begin{tabular}{|l|l|l|}
\hline $\begin{array}{l}\text { Order } \\
\text { Family }\end{array}$ & $\begin{array}{l}\text { Theales } \\
\text { Species }\end{array}$ & RL \\
\hline Elatinaceae & Elatine alsinastrum & NT \\
\hline Elatinaceae & Elatine ambigua & LC \\
\hline Elatinaceae & Elatine macropoda & LC \\
\hline
\end{tabular}

\begin{tabular}{|c|c|c|}
\hline Order & Violales & \\
\hline Family & Species & RL \\
\hline Tamaricaceae & Tamarix kotschyi & LC \\
\hline Tamaricaceae & Tamarix mascatensis & LC \\
\hline Tamaricaceae & Tamarix nilotica & LC \\
\hline Tamaricaceae & Tamarix octandra & LC \\
\hline Tamaricaceae & Tamarix parviflora & LC \\
\hline Tamaricaceae & Tamarix ramosissima & LC \\
\hline Tamaricaceae & Tamarix tetragyna & LC \\
\hline Tamaricaceae & Tamarix tetrandra & LC \\
\hline Class & Polypodiopsida & \\
\hline Order & Osmundales & \\
\hline Family & Species & RL \\
\hline Osmundaceae & Osmunda regalis & LC \\
\hline Order & Polypodiales & \\
\hline Family & Species & $\mathrm{RL}$ \\
\hline Thelypteridaceae & Thelypteris palustris & LC \\
\hline Order & Salviniales & \\
\hline Family & Species & $R L$ \\
\hline Marsileaceae & Marsilea quadrifolia & LC \\
\hline Marsileaceae & Pilularia minuta & EN \\
\hline Salviniaceae & Salvinia natans & LC \\
\hline
\end{tabular}




\subsection{Freshwater birds}

\begin{tabular}{|l|l|l|}
\hline $\begin{array}{l}\text { Order } \\
\text { Family }\end{array}$ & $\begin{array}{l}\text { Accipitriformes } \\
\text { Species }\end{array}$ & RL \\
\hline Accipitridae & Accipiter brevipes & LC \\
\hline Accipitridae & Accipiternisus & LC \\
\hline Accipitridae & Aquila fasciata & LC \\
\hline Accipitridae & Aquila beliaca & VU \\
\hline Accipitridae & Buteo buteo & LC \\
\hline Accipitridae & Buteo lagopus & LC \\
\hline Accipitridae & Circus aeruginosus & LC \\
\hline Accipitridae & Circus cyaneus & LC \\
\hline Accipitridae & Circus macrourus & NT \\
\hline Accipitridae & Circuspygargus & LC \\
\hline Accipitridae & Clangaclanga & VU \\
\hline Accipitridae & Haliaeetus albicilla & LC \\
\hline Accipitridae & Milvus migrans & LC \\
\hline Accipitridae & Neophron percnopterus & EN \\
\hline Pandionidae & Pandion haliaetus & LC \\
\hline
\end{tabular}

\begin{tabular}{|c|c|c|}
\hline Order & Anseriformes & \\
\hline Family & Species & RL \\
\hline Anatidae & Anas crecca & LC \\
\hline Anatidae & Anasplatyrhynchos & LC \\
\hline Anatidae & Anser anser & LC \\
\hline Anatidae & Anser erythropus & $\mathrm{VU}$ \\
\hline Anatidae & Anserfabalis & LC \\
\hline Anatidae & Aythya ferina & LC \\
\hline Anatidae & Aythya fuligula & LC \\
\hline Anatidae & Aythya marila & LC \\
\hline Anatidae & Aythya nyroca & NT \\
\hline Anatidae & Branta ruficollis & EN \\
\hline Anatidae & Bucephala clangula & LC \\
\hline Anatidae & Cygnus columbianus & LC \\
\hline Anatidae & Cygnus cygnus & LC \\
\hline Anatidae & Cygnus olor & LC \\
\hline Anatidae & Marecapenelope & LC \\
\hline Anatidae & Mareca strepera & LC \\
\hline Anatidae & Marmaronetta angustirostris & VU \\
\hline Anatidae & Melanitta fusca & EN \\
\hline Anatidae & Mergellus albellus & LC \\
\hline Anatidae & Mergus merganser & LC \\
\hline Anatidae & Mergus serrator & LC \\
\hline Anatidae & Netta rufina & LC \\
\hline Anatidae & Oxyura leucocephala & EN \\
\hline Anatidae & Spatula querquedula & LC \\
\hline Anatidae & Tadorna ferruginea & LC \\
\hline Anatidae & Tadorna tadorna & LC \\
\hline
\end{tabular}

\begin{tabular}{|c|c|c|}
\hline Order & Caprimulgiformes & \\
\hline Family & Species & RL \\
\hline Apodidae & Apus apus & LC \\
\hline Apodidae & Tachymarptis melba & LC \\
\hline Caprimulgidae & Caprimulgus nubicus & LC \\
\hline
\end{tabular}

\begin{tabular}{|c|c|c|}
\hline Charadriidae & Vanellusspinosus & LC \\
\hline Glareolidae & Glareola nordmanni & NT \\
\hline Glareolidae & Glareola pratincola & LC \\
\hline Haematopodidae & Haematopus ostralegus & LC \\
\hline Laridae & Chlidonias hybrida & LC \\
\hline Laridae & Chlidonias leucopterus & LC \\
\hline Laridae & Chlidoniasniger & LC \\
\hline Laridae & Gelochelidon nilotica & LC \\
\hline Laridae & Hydrocoloeus minutus & LC \\
\hline Laridae & Hydroprogne caspia & LC \\
\hline Laridae & Larus argentatus & LC \\
\hline Laridae & Larus cachinnans & LC \\
\hline Laridae & Larus canus & LC \\
\hline Laridae & Larusgenei & LC \\
\hline Laridae & Larusichthyaetus & LC \\
\hline Laridae & Larus melanocephalus & LC \\
\hline Laridae & Larus michahellis & LC \\
\hline Laridae & Larus ridibundus & LC \\
\hline Laridae & Sterna birundo & LC \\
\hline Laridae & Sternula albifrons & LC \\
\hline Recurvirostridae & Himantopus himantopus & LC \\
\hline Recurvirostridae & Recurvirostra avosetta & LC \\
\hline Rostratulidae & Rostratula benghalensis & LC \\
\hline Scolopacidae & Actitis hypoleucos & LC \\
\hline Scolopacidae & Arenaria interpres & LC \\
\hline Scolopacidae & Calidris alba & LC \\
\hline Scolopacidae & Calidris alpina & LC \\
\hline Scolopacidae & Calidrisferruginea & LC \\
\hline Scolopacidae & Calidris minuta & LC \\
\hline Scolopacidae & Calidris temminckii & LC \\
\hline Scolopacidae & Gallinago media & NT \\
\hline Scolopacidae & Limosa lapponica & LC \\
\hline Scolopacidae & Limosa limosa & NT \\
\hline Scolopacidae & Lymnocryptes minimus & LC \\
\hline Scolopacidae & Numenius arquata & NT \\
\hline Scolopacidae & Numenius phaeopus & LC \\
\hline Scolopacidae & Numenius tenuirostris & CR \\
\hline Scolopacidae & Steganopus tricolor & LC \\
\hline Scolopacidae & Tringa erythropus & LC \\
\hline Scolopacidae & Tringa nebularia & LC \\
\hline Scolopacidae & Tringa ochropus & LC \\
\hline Scolopacidae & Tringa stagnatilis & LC \\
\hline Scolopacidae & Tringa totanus & LC \\
\hline
\end{tabular}

\begin{tabular}{|c|c|c|}
\hline Order & Ciconiiformes & \\
\hline Family & Species & RL \\
\hline Ciconiidae & Ciconia ciconia & LC \\
\hline Ciconiidae & Ciconia nigra & LC \\
\hline
\end{tabular}

\begin{tabular}{|c|c|c|}
\hline Order & Columbiformes & \\
\hline Family & Species & RL \\
\hline Columbidae & Spilopelia senegalensis & LC \\
\hline
\end{tabular}

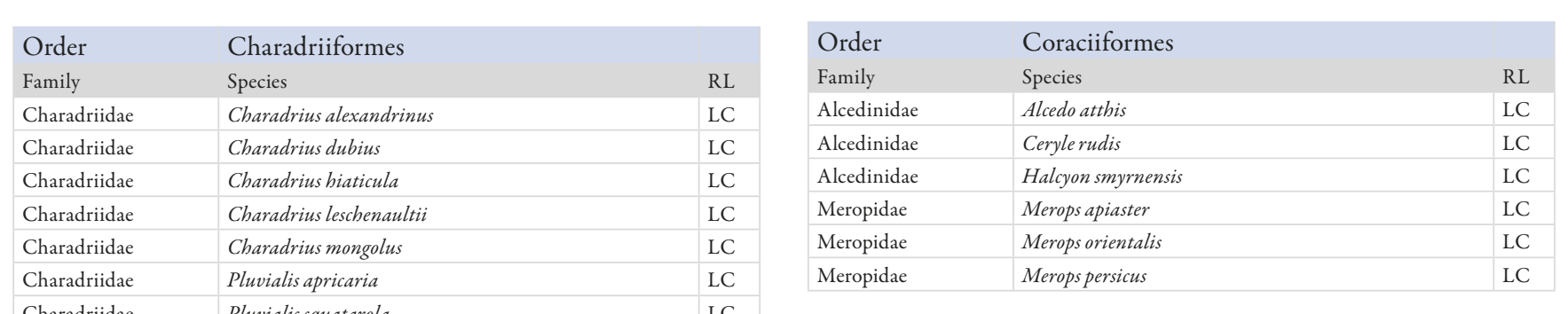


Appendix 2.5 cont'd, Freshwater birds

\begin{tabular}{|c|c|c|}
\hline Order & Cuculiformes & \\
\hline Family & Species & RL \\
\hline Cuculidae & Clamatorglandarius & LC \\
\hline Cuculidae & Cuculus canorus & LC \\
\hline
\end{tabular}

\begin{tabular}{|l|l|l|}
\hline $\begin{array}{l}\text { Order } \\
\text { Family }\end{array}$ & $\begin{array}{l}\text { Falconiformes } \\
\text { Species }\end{array}$ & RL \\
\hline Falconidae & Falco cherrug & EN \\
\hline Falconidae & Falco peregrinus & LC \\
\hline Falconidae & Falco subbuteo & LC \\
\hline Falconidae & Falco vespertinus & NT \\
\hline
\end{tabular}

\begin{tabular}{|c|c|c|}
\hline Order & Gaviiformes & \\
\hline Family & Species & RL \\
\hline Gaviidae & Gavia arctica & LC \\
\hline Gaviidae & Gavia stellata & LC \\
\hline
\end{tabular}

\begin{tabular}{|l|l|l|}
\hline $\begin{array}{l}\text { Order } \\
\text { Family }\end{array}$ & $\begin{array}{l}\text { Gruiformes } \\
\text { Species }\end{array}$ & RL \\
\hline Gruidae & Anthropoides virgo & LC \\
\hline Gruidae & Grusgrus & LC \\
\hline Rallidae & Crexcrex & LC \\
\hline Rallidae & Fulicaatra & LC \\
\hline Rallidae & Gallinulachloropus & LC \\
\hline Rallidae & Porphyrioporphyrio & LC \\
\hline Rallidae & Porzanaporzana & LC \\
\hline Rallidae & Rallusaquaticus & LC \\
\hline Rallidae & Zaporniaparva & LC \\
\hline Rallidae & Zaporniapusilla & LC \\
\hline
\end{tabular}

\begin{tabular}{|c|c|c|}
\hline Order & Passeriformes & \\
\hline Family & Species & RL \\
\hline Aegithalidae & Aegithalos caudatus & LC \\
\hline Alaudidae & Alauda arvensis & LC \\
\hline Alaudidae & Alauda gulgula & LC \\
\hline Alaudidae & Eremalauda dunni & LC \\
\hline Cinclidae & Cinclus cinclus & LC \\
\hline Cisticolidae & Cisticola juncidis & LC \\
\hline Cisticolidae & Scotocerca inquieta & LC \\
\hline Corvidae & Corvus corone & LC \\
\hline Corvidae & Corvus rhipidurus & LC \\
\hline Corvidae & Corvus ruficollis & LC \\
\hline Emberizidae & Emberiza schoeniclus & LC \\
\hline Fringillidae & Carduelis carduelis & LC \\
\hline Fringillidae & Carpodacus erythrinus & LC \\
\hline Hirundinidae & Delichon urbicum & LC \\
\hline Hirundinidae & Hirundo daurica & LC \\
\hline Hirundinidae & Hirundo obsoleta & LC \\
\hline Hirundinidae & Hirundo rupestris & LC \\
\hline Hirundinidae & Hirundo rustica & LC \\
\hline Hirundinidae & Riparia riparia & LC \\
\hline Laniidae & Lanius collurio & LC \\
\hline Laniidae & Lanius excubitor & LC \\
\hline Laniidae & Lanius isabellinus & LC \\
\hline Motacillidae & Anthus cervinus & LC \\
\hline Motacillidae & Anthus pratensis & LC \\
\hline Motacillidae & Anthus spinoletta & LC \\
\hline Motacillidae & Motacilla alba & LC \\
\hline Motacillidae & Motacilla cinerea & LC \\
\hline Motacillidae & Motacilla citreola & LC \\
\hline Motacillidae & Motacilla flava & LC \\
\hline Muscicapidae & Erythropygia galactotes & LC \\
\hline Muscicapidae & Luscinia luscinia & LC \\
\hline Muscicapidae & Luscinia svecica & LC \\
\hline
\end{tabular}

\begin{tabular}{|c|c|c|}
\hline Muscicapidae & Oenanthe chrysopygia & LC \\
\hline Muscicapidae & Oenanthe moesta & LC \\
\hline Muscicapidae & Oenanthe monacha & LC \\
\hline Muscicapidae & Oenanthe oenanthe & LC \\
\hline Muscicapidae & Saxicola torquatus & LC \\
\hline Nectariniidae & Nectarinia osea & LC \\
\hline Paridae & Parus montanus & LC \\
\hline Paridae & Paruspalustris & LC \\
\hline Passeridae & Passer moabiticus & LC \\
\hline Pycnonotidae & Pycnonotus leucotis & LC \\
\hline Pycnonotidae & Pycnonotusxanthopygos & LC \\
\hline Remizidae & Remizpendulinus & LC \\
\hline Sittidae & Sitta tephronota & LC \\
\hline Sylviidae & Acrocephalus agricola & LC \\
\hline Sylviidae & Acrocephalus arundinaceus & LC \\
\hline Sylviidae & Acrocephalus dumetorum & LC \\
\hline Sylviidae & Acrocephalus griseldis & EN \\
\hline Sylviidae & Acrocephalus melanopogon & LC \\
\hline Sylviidae & Acrocephalus palustris & LC \\
\hline Sylviidae & Acrocephalus schoenobaenus & LC \\
\hline Sylviidae & Acrocephalus scirpaceus & LC \\
\hline Sylviidae & Acrocephalus stentoreus & LC \\
\hline Sylviidae & Cettia cetti & LC \\
\hline Sylviidae & Hippolais rama & LC \\
\hline Sylviidae & Locustella fluviatilis & LC \\
\hline Sylviidae & Locustella luscinioides & LC \\
\hline Sylviidae & Locustella naevia & LC \\
\hline Sylviidae & Phylloscopus sindianus & LC \\
\hline Sylviidae & Phylloscopus trochiloides & LC \\
\hline Sylviidae & Phylloscopus trochilus & LC \\
\hline Sylviidae & Sylvia conspicillata & LC \\
\hline Sylviidae & Sylvia curruca & LC \\
\hline Timaliidae & Panurus biarmicus & LC \\
\hline Timaliidae & Turdoides altirostris & $\mathrm{LC}^{*}$ \\
\hline
\end{tabular}

\begin{tabular}{|l|l|l|}
\hline $\begin{array}{l}\text { Order } \\
\text { Family }\end{array}$ & $\begin{array}{l}\text { Pelecaniformes } \\
\text { Species }\end{array}$ & RL \\
\hline Ardeidae & Ardea alba & LC \\
\hline Ardeidae & Ardea cinerea & LC \\
\hline Ardeidae & Ardeagoliath & LC \\
\hline Ardeidae & Ardea purpurea & LC \\
\hline Ardeidae & Ardeolaralloides & LC \\
\hline Ardeidae & Botaurus stellaris & LC \\
\hline Ardeidae & Bubulcusibis & LC \\
\hline Ardeidae & Egrettagarzetta & LC \\
\hline Ardeidae & Egrettagularis & LC \\
\hline Ardeidae & Ixobrychus minutus & LC \\
\hline Ardeidae & Nycticoraxnycticorax & LC \\
\hline Pelecanidae & Pelecanus crispus & VU \\
\hline Pelecanidae & Pelecanus onocrotalus & LC \\
\hline Threskiornithidae & Platalealeucorodia & LC \\
\hline Threskiornithidae & Plegadisfalcinellus & LC \\
\hline Threskiornithidae & Threskiornis aethiopicus & LC \\
\hline
\end{tabular}

\begin{tabular}{|l|l|l|}
\hline $\begin{array}{l}\text { Order } \\
\text { Family }\end{array}$ & $\begin{array}{l}\text { Phoenicopteriformes } \\
\text { Species }\end{array}$ & RL \\
\hline Phoenicopteridae & Phoenicopterus roseus & LC \\
\hline & Piciformes & \\
\hline $\begin{array}{l}\text { Order } \\
\text { Family }\end{array}$ & Species & RL \\
\hline Picidae & Dendrocoposleucotos & LC \\
\hline Picidae & Dryobatesminor & LC \\
\hline
\end{tabular}


Appendix 2.5 cont'd, Freshwater birds

\begin{tabular}{|l|l|l|}
\hline $\begin{array}{l}\text { Order } \\
\text { Family }\end{array}$ & $\begin{array}{l}\text { Podicipediformes } \\
\text { Species }\end{array}$ & RL \\
\hline Podicipedidae & Podiceps auritus & LC \\
\hline Podicipedidae & Podiceps cristatus & LC \\
\hline Podicipedidae & Podiceps grisegena & LC \\
\hline Podicipedidae & Podiceps nigricollis & LC \\
\hline Podicipedidae & Tachybaptus ruficollis & LC \\
\hline $\begin{array}{l}\text { Order } \\
\text { Family }\end{array}$ & $\begin{array}{l}\text { Psittaciformes } \\
\text { Psittacidae }\end{array}$ & Psittaculakrameri \\
\hline $\begin{array}{l}\text { Order } \\
\text { Family }\end{array}$ & $\begin{array}{l}\text { Pterocliformes } \\
\text { Species }\end{array}$ & RL \\
\hline Pteroclidae & Pterocleslichtensteinii & LC \\
\hline Pteroclidae & Pterocles senegallus & RL \\
\hline
\end{tabular}

\begin{tabular}{|l|l|l|}
\hline $\begin{array}{l}\text { Order } \\
\text { Family }\end{array}$ & $\begin{array}{l}\text { Strigiformes } \\
\text { Species }\end{array}$ & RL \\
\hline Strigidae & Asioflammeus & LC \\
\hline Strigidae & Bubo ascalaphus & LC \\
\hline Strigidae & Glaucidiumpasserinum & LC \\
\hline Strigidae & Ketupa zeylonensis & LC \\
\hline Tytonidae & Tyto alba & LC \\
\hline
\end{tabular}

\begin{tabular}{|c|c|c|}
\hline Order & Suliformes & \\
\hline Family & Species & RL \\
\hline Anhingidae & Anbinga rufa & LC \\
\hline Phalacrocoracidae & Microcarbo pygmaeus & LC \\
\hline Phalacrocoracidae & Phalacrocorax aristotelis & LC \\
\hline Phalacrocoracidae & Phalacrocorax carbo & LC \\
\hline
\end{tabular}

\subsection{Freshwater amphibians}

\begin{tabular}{|l|l|l|}
\hline $\begin{array}{l}\text { Order } \\
\text { Family }\end{array}$ & $\begin{array}{l}\text { Anura } \\
\text { Species }\end{array}$ & RL \\
\hline Alytidae & Latonia nigriventer & CR \\
\hline Bombinatoridae & Bombina bombina & LC \\
\hline Bufonidae & Bufo bufo & LC \\
\hline Bufonidae & Bufo eichwaldi & VU \\
\hline Bufonidae & Bufo verrucosissimus & NT \\
\hline Bufonidae & Pseudepidalea luristanica & LC \\
\hline Bufonidae & Pseudepidalea surda & LC \\
\hline Bufonidae & Pseudepidalea variabilis & DD \\
\hline Hylidae & Hyla arborea & LC \\
\hline Hylidae & Hyla beinzsteinitzi & CR* \\
\hline Hylidae & Hyla savignyi & LC \\
\hline Pelobatidae & Pelobates syriacus & LC \\
\hline Pelodytidae & Pelodytes caucasicus & NT \\
\hline Ranidae & Pelophylaxbedriagae & LC \\
\hline Ranidae & Pelophylaxcaralitanus & NT ${ }^{*}$ \\
\hline Ranidae & Pelophylax ridibundus & LC \\
\hline
\end{tabular}

\begin{tabular}{|c|c|c|}
\hline Ranidae & Rana dalmatina & LC \\
\hline Ranidae & Rana holtzi & $\mathrm{CR}^{*}$ \\
\hline Ranidae & Rana macrocnemis & LC \\
\hline Ranidae & Ranapseudodalmatina & LC \\
\hline Ranidae & Rana tavasensis & $\mathrm{EN}^{*}$ \\
\hline Order & Caudata & \\
\hline Family & Species & $\mathrm{RL}$ \\
\hline Salamandridae & Lissotriton vulgaris & LC \\
\hline Salamandridae & Mertensiella caucasica & $\mathrm{VU}^{*}$ \\
\hline Salamandridae & Neurergus crocatus & $\mathrm{VU}^{*}$ \\
\hline Salamandridae & Neurerguskaiseri & $\mathrm{CR}^{*}$ \\
\hline Salamandridae & Neurergus microspilotus & $\mathrm{CR}^{*}$ \\
\hline Salamandridae & Neurergus strauchii & $\mathrm{VU}^{*}$ \\
\hline Salamandridae & Ommatotriton ophryticus & NT \\
\hline Salamandridae & Ommatotriton vittatus & $\mathrm{LC}^{*}$ \\
\hline Salamandridae & Salamandra infraimmaculata & $\mathrm{NT}^{*}$ \\
\hline Salamandridae & Triturus karelinii & LC \\
\hline
\end{tabular}

\subsection{Freshwater mammals}

\subsection{Freshwater decapods}

\begin{tabular}{|l|l|l|}
\hline $\begin{array}{l}\text { Order } \\
\text { Family }\end{array}$ & $\begin{array}{l}\text { Carnivora } \\
\text { Species }\end{array}$ & RL \\
\hline Mustelidae & Lutralutra & NT \\
\hline Mustelidae & Lutrogaleperspicillata & VU \\
\hline Phocidae & Pusacaspica & EN \\
\hline $\begin{array}{l}\text { Order } \\
\text { Family }\end{array}$ & $\begin{array}{l}\text { Eulipotyphla } \\
\text { Species }\end{array}$ & \\
\hline Soricidae & Neomys anomalus & RL \\
\hline Soricidae & Neomysfodiens & LC \\
\hline Soricidae & Neomysteres & LC \\
\hline $\begin{array}{l}\text { Order } \\
\text { Family }\end{array}$ & $\begin{array}{l}\text { Rodentia } \\
\text { Species }\end{array}$ \\
\hline Cricetidae & Arvicola amphibius & LC \\
\hline Muridae & Nesokiabunnii & RL \\
\hline
\end{tabular}

\begin{tabular}{|l|l|l|}
\hline $\begin{array}{l}\text { Order } \\
\text { Family }\end{array}$ & $\begin{array}{l}\text { Decapoda } \\
\text { Species }\end{array}$ & RL \\
\hline Astacidae & Astacus astacus & VU \\
\hline Astacidae & Astacusleptodactylus & LC \\
\hline Astacidae & Austropotamobius torrentium & DD \\
\hline Atyidae & Atyaephyra orientalis & LC \\
\hline Atyidae & Atyaephyra tuerkayi & DD \\
\hline Atyidae & Caridina babaulti & LC \\
\hline Atyidae & Caridina fossarum & LC \\
\hline Palaemonidae & Palaemonetes antennarius & LC \\
\hline Palaemonidae & Palaemonetes mesopotamicus & $\mathrm{CR}^{*}$ \\
\hline Palaemonidae & Palaemonetes turcorum & $\mathrm{DD}^{*}$ \\
\hline Typhlocarididae & Typhlocaris ayyaloni & $\mathrm{EN}^{*}$ \\
\hline Typhlocarididae & Typhlocaris galilea & $\mathrm{EN}^{*}$ \\
\hline
\end{tabular}




\section{Appendix 3. Number of freshwater species for each taxonomic group by country of the Eastern Mediterranean region}

Note: The numbers excludes cases where a species is recorded as Origin Introduced or Vagrant. Also, these numbers are likely to be an underestimate of true diversity of freshwater species in each country, they are taken from the IUCN Red List assessment classification schemes included within each species Red List assessment (see www.iucnredlist.org).

* Denotes those countries where only a part of their territory is included in the analysis (see Figure 2.1).

\begin{tabular}{|c|c|c|c|c|c|c|c|c|c|c|c|c|c|}
\hline & & 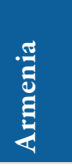 & 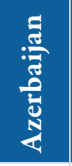 & 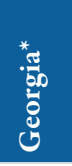 & 泀 & 焉 & অ & 胥 & 言 & 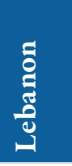 & $\frac{\mathscr{E}}{\frac{\mathscr{J}}{\tilde{E}}}$ & 今 & 尊 \\
\hline \multirow[t]{10}{*}{ All species } & All species & 329 & 376 & 430 & 562 & 403 & 392 & 294 & 180 & 358 & 287 & 441 & 989 \\
\hline & Threatened species & 18 & 24 & 22 & 38 & 26 & 33 & 17 & 5 & 23 & 13 & 51 & 171 \\
\hline & DD species & 5 & 6 & 5 & 15 & 10 & 5 & 3 & 0 & 7 & 0 & 10 & 37 \\
\hline & EX/EW species & 0 & 1 & 0 & 1 & 0 & 2 & 0 & 0 & 0 & 0 & 0 & 4 \\
\hline & LC/NT species & 306 & 345 & 403 & 508 & 367 & 352 & 274 & 175 & 328 & 274 & 380 & 777 \\
\hline & EX/EW species & 0 & 1 & 0 & 1 & 0 & 2 & 0 & 0 & 0 & 0 & 0 & 4 \\
\hline & $\begin{array}{l}\text { \% Threatened (of extant \& } \\
\text { suff. Info species) }\end{array}$ & 5.6 & 6.5 & 5.2 & 7.0 & 6.6 & 8.6 & 5.8 & 2.8 & 6.6 & 4.5 & 11.8 & 18.0 \\
\hline & \% DD (of all species) & 1.5 & 1.6 & 1.2 & 2.7 & 2.5 & 1.3 & 1.0 & 0.0 & 2.0 & 0.0 & 2.3 & 3.7 \\
\hline & $\begin{array}{l}\text { Extinct or Poss Extinct from } \\
\text { the country }\end{array}$ & 1 & 1 & 0 & 2 & 3 & 15 & 4 & 0 & 2 & 3 & 13 & 17 \\
\hline & $\%$ extirpated (of all species) & 0.3 & 0.3 & 0.0 & 0.4 & 0.7 & 3.8 & 1.4 & 0.0 & 0.6 & 1.0 & 2.9 & 1.7 \\
\hline \multirow[t]{5}{*}{ Fishes } & All species & 29 & 54 & 61 & 84 & 39 & 36 & 14 & 3 & 20 & 17 & 75 & 265 \\
\hline & Threatened species & 4 & 10 & 7 & 15 & 8 & 9 & 4 & 0 & 3 & 0 & 24 & 98 \\
\hline & DD species & 0 & 2 & 0 & 2 & 1 & 0 & 0 & 0 & 0 & 0 & 1 & 11 \\
\hline & EX/EW species & 0 & 1 & 0 & 1 & 0 & 2 & 0 & 0 & 0 & 0 & 0 & 4 \\
\hline & $\begin{array}{l}\text { Extinct or Poss Extinct from } \\
\text { the country }\end{array}$ & 1 & 1 & 0 & 1 & 1 & 4 & 0 & 0 & 0 & 0 & 7 & 8 \\
\hline \multirow[t]{5}{*}{ Plants } & All species & 76 & 73 & 150 & 156 & 105 & 82 & 57 & 10 & 114 & 93 & 93 & 306 \\
\hline & Threatened species & 0 & 0 & 0 & 1 & 0 & 0 & 0 & 0 & 1 & 0 & 1 & 7 \\
\hline & DD species & 1 & 1 & 3 & 0 & 0 & 1 & 0 & 0 & 1 & 0 & 1 & 6 \\
\hline & EX/EW species & 0 & 0 & 0 & 0 & 0 & 0 & 0 & 0 & 0 & 0 & 0 & 0 \\
\hline & $\begin{array}{l}\text { Extinct or Poss Extinct from } \\
\text { the country }\end{array}$ & 0 & 0 & 0 & 0 & 0 & 0 & 0 & 0 & 0 & 0 & 0 & 2 \\
\hline \multirow[t]{5}{*}{ Odonata } & All species & 50 & 49 & 53 & 66 & 38 & 56 & 41 & 10 & 41 & 28 & 55 & 96 \\
\hline & Threatened species & 2 & 1 & 2 & 3 & 2 & 6 & 3 & 0 & 5 & 3 & 6 & 6 \\
\hline & DD species & 2 & 1 & 1 & 4 & 3 & 0 & 0 & 0 & 1 & & 1 & 3 \\
\hline & EX/EW species & 0 & 0 & 0 & 0 & 0 & 0 & 0 & 0 & 0 & 0 & 0 & 0 \\
\hline & $\begin{array}{l}\text { Extinct or Poss Extinct from } \\
\text { the country }\end{array}$ & 0 & 0 & 0 & 1 & 1 & 3 & 0 & 0 & 0 & 1 & 2 & 0 \\
\hline
\end{tabular}




\begin{tabular}{|c|c|c|c|c|c|c|c|c|c|c|c|c|c|}
\hline & & 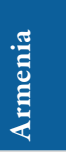 & 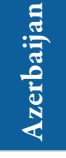 & 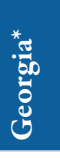 & $\stackrel{*}{\Xi}$ & 焉 & 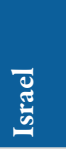 & 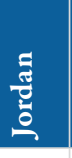 & 苋 & 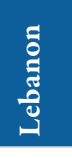 & 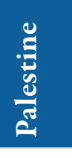 & हूँ & 绨 \\
\hline \multirow[t]{5}{*}{ Molluscs } & All species & 9 & 8 & 10 & 23 & 14 & 22 & 14 & 1 & 27 & 7 & 32 & 93 \\
\hline & Threatened species & 2 & 1 & 2 & 1 & 1 & 6 & 5 & 0 & 8 & 3 & 10 & 42 \\
\hline & DD species & 1 & 1 & 0 & 8 & 5 & 3 & 2 & 0 & 3 & 0 & 5 & 14 \\
\hline & EX/EW species & 0 & 0 & 0 & 0 & 0 & 0 & 0 & 0 & 0 & 0 & 0 & 0 \\
\hline & $\begin{array}{l}\text { Extinct or Poss Extinct from } \\
\text { the country }\end{array}$ & 0 & 0 & 0 & 0 & 0 & 5 & 0 & 0 & 1 & 1 & 2 & 6 \\
\hline \multirow[t]{5}{*}{ Birds } & All species & 153 & 176 & 139 & 207 & 192 & 182 & 161 & 156 & 146 & 140 & 174 & 194 \\
\hline & Threatened species & 10 & 10 & 9 & 12 & 11 & 8 & 5 & 5 & 6 & 6 & 9 & 11 \\
\hline & DD species & 0 & 0 & 0 & 0 & 0 & 0 & 0 & 0 & 0 & 0 & 0 & 0 \\
\hline & EX/EW species & 0 & 0 & 0 & 0 & 0 & 0 & 0 & 0 & 0 & 0 & 0 & 0 \\
\hline & $\begin{array}{l}\text { Extinct or Poss Extinct from } \\
\text { the country }\end{array}$ & 0 & 0 & 0 & 0 & 1 & 2 & 3 & 0 & 1 & 0 & 2 & 1 \\
\hline \multirow[t]{5}{*}{ Mammals } & All species & 3 & 4 & 3 & 6 & 4 & 2 & 1 & 0 & 1 & 0 & 2 & 5 \\
\hline & Threatened species & 0 & 1 & 0 & 2 & 2 & 0 & 0 & 0 & 0 & 0 & 0 & 0 \\
\hline & DD species & 0 & 0 & 0 & 0 & 0 & 0 & 0 & 0 & 0 & 0 & 0 & 0 \\
\hline & EX/EW species & 0 & 0 & 0 & 0 & 0 & 0 & 0 & 0 & 0 & 0 & 0 & 0 \\
\hline & $\begin{array}{l}\text { Extinct or Poss Extinct from } \\
\text { the country }\end{array}$ & 0 & 0 & 0 & 0 & 0 & 0 & 0 & 0 & 0 & 0 & 0 & 0 \\
\hline \multirow[t]{5}{*}{ Amphibians } & All species & 9 & 11 & 12 & 16 & 9 & 8 & 5 & 0 & 7 & 2 & 7 & 24 \\
\hline & Threatened species & 0 & 1 & 1 & 4 & 2 & 2 & 0 & 0 & 0 & 1 & 0 & 6 \\
\hline & DD species & 1 & 1 & 1 & 1 & 1 & 1 & 1 & 0 & 1 & 0 & 1 & 1 \\
\hline & EX/EW species & 0 & 0 & 0 & 0 & 0 & 0 & 0 & 0 & 0 & 0 & 0 & 0 \\
\hline & $\begin{array}{l}\text { Extinct or Poss Extinct from } \\
\text { the country }\end{array}$ & 0 & 0 & 0 & 0 & 0 & 1 & 1 & 0 & 0 & 1 & 0 & 0 \\
\hline \multirow[t]{5}{*}{ Decapods } & All species & 0 & 1 & 2 & 4 & 2 & 4 & 1 & 0 & 2 & 0 & 3 & 6 \\
\hline & Threatened species & 0 & 0 & 1 & 0 & 0 & 2 & 0 & 0 & 0 & 0 & 1 & 1 \\
\hline & DD species & 0 & 0 & 0 & 0 & 0 & 0 & 0 & 0 & 1 & 0 & 1 & 2 \\
\hline & EX/EW species & 0 & 0 & 0 & 0 & 0 & 0 & 0 & 0 & 0 & 0 & 0 & 0 \\
\hline & $\begin{array}{l}\text { Extinct or Poss Extinct from } \\
\text { the country }\end{array}$ & 0 & 0 & 0 & 0 & 0 & 0 & 0 & 0 & 0 & 0 & 0 & 0 \\
\hline
\end{tabular}




\section{Freshwater Africa}

The Status and Distribution of Freshwater Biodiversity in Eastern Africa. Compiled by W.R.T. Darwall, K.G. Smith, T. Lowe, and J.-C. Vie. 2005.

The Status and Distribution of Freshwater Biodiversity in Southern Africa. Compiled by W.R.T. Darwall, K.G. Smith, D. Tweddle, and P. Skelton, 2009.

The Status and Distribution of Freshwater Biodiversity in Western Africa. Compiled by K.G. Smith, M.D. Diop, M. Niane, and W.R.T. Darwall. 2009.

The Status and Distribution of Freshwater Biodiversity in Northern Africa. Compiled by N. Garcia, A Cuttelod, and D.A. Malak. 2010

The Status and Distribution of Freshwater Biodiversity in Central Africa. Compiled by D.J. Allen, E.G.E. Brooks, and W.T. Darwall. 2010.

The Diversity of Life in African Freshwaters: Underwater; Under Threat. An Analysis of the Status and Distribution of Freshwater Species throughout Mainland Africa. Edited by W.R.T. Darwall, K.G. Smith, D.J. Allen, R.A. Holland, I.J. Harrison, and E.G.E. Brooks. 2011.

\section{Freshwater Asia}

The Status and Distribution of Freshwater Biodiversity in the Eastern Himalaya. Compiled by D.J. Allen, S. Molur, and B.A. Daniel. 2010.

The Status and Distribution of Freshwater Biodiversity in the Western Ghats. Compiled by S. Molur, K.G., Smith, B.A. Daniel, and W.R.T Darwall. 2011.

The Status and Distribution of Freshwater Biodiversity in Indo-Burma. Compiled by D.J. Allen, K.G. Smith, and W.R.T Darwall. 2012.

\section{Mediterranean}

The Status and Distribution of Freshwater Fish Endemic to the Mediterranean Basin. Compiled by K.G. Smith and W.R.T. Darwall. 2006.

The Status and Distribution of Reptiles and Amphibians of the Mediterranean Basin. Compiled by N. Cox, J. Chanson, and S. Stuart. 2006

Overview of the Cartilaginous Fishes (Chondrichthyans) in the Mediterranean Sea. Compiled by R.D. Cavanagh and C Gibson. 2007.

The Mediterranean: A Biodiversity Hotspot under Threat. A. Cuttelod, N. Garcia, D.A. Malak, H. Temple, and V. Katariya. 2008.

The Status and Distribution of Dragonflies of the Mediterranean Basin. Compiled by E. Riservato, J.-P. Boudot, S. Ferreira, M. Jovic, V.J. Kalkman, W. Schneider, and B. Samraoui. 2009.

The Status and Distribution of Mediterranean Mammals. Compiled by H.J. Temple and A. Cuttelod. 2009.

Overview of the Conservation Status of the Marine Fishes of the Mediterranean Sea. Compiled by D.A. Malak, S.R. Livingstone, D. Pollard, B.A. Polidoro, A. Cuttelod, M. Bariche, M. Bilecenoglu, K.E. Carpenter, B.B. Collette, P. Francour, M. Goren, M.H. Kara, E. Massutí, C. Papaconstantinou, and L. Tunesi. 2011.

Marine Mammals and Sea Turtles of the Mediterranean and Black Seas. IUCN. 2012.

\section{Europe}

The Status and Distribution of European Mammals. Compiled by H.J. Temple and A. Terry. 2007.

European Red List of Amphibians. Compiled by H.J. Temple and N. Cox. 2009.

European Red List of Reptiles. Compiled by N. Cox and H.J. Temple. 2009.

European Red List of Saproxylic Beetles. Compiled by A. Nieto and K.N.A. Alexander. 2010.

European Red List of Butterflies. Compiled by C. van Swaay, A. Cuttelod, S. Collins, D. Maes, M.L. Munguira, M. Šašić, J. Settele, R. Verovnik, T. Verstrael, M. Warren, M. Wiemers, and I. Wynhoff. 2010.

European Red List of Dragonflies. Compiled by V.J. Kalkman, J.-P. Boudot, R. Bernard, K.-J. Conze, G. De Knijf, E. Dyatlova, S. Ferreira, M. Jović, J. Ott, E. Riservato, and G. Sahlen. 2010.

European Red List of Vascular Plants. Compiled by M. Bilz, S.P. Kell, N. Maxted, and R.V. Lansdown. 2011.

European Red List of Non-marine Molluscs. Compiled by A. Cuttelod, M. Seddon, and E. Neubert. 2011.

European Red List of Freshwater Fishes. J. Freyhof, and E. Brooks. 2011. 


\section{9:: \\ (C) RIST}

THE IUCN RED LST

OF THREATENED SPECIES

INTERNATIONAL UNION FOR CONSERVATION OF NATURE

WORLD HEADQUARTERS

Rue Mauverney 28

1196 Gland

Switzerland

Tel: + 41229990000

Fax: +41229990020

www.iucn.org/species

www.iucnredlist.org
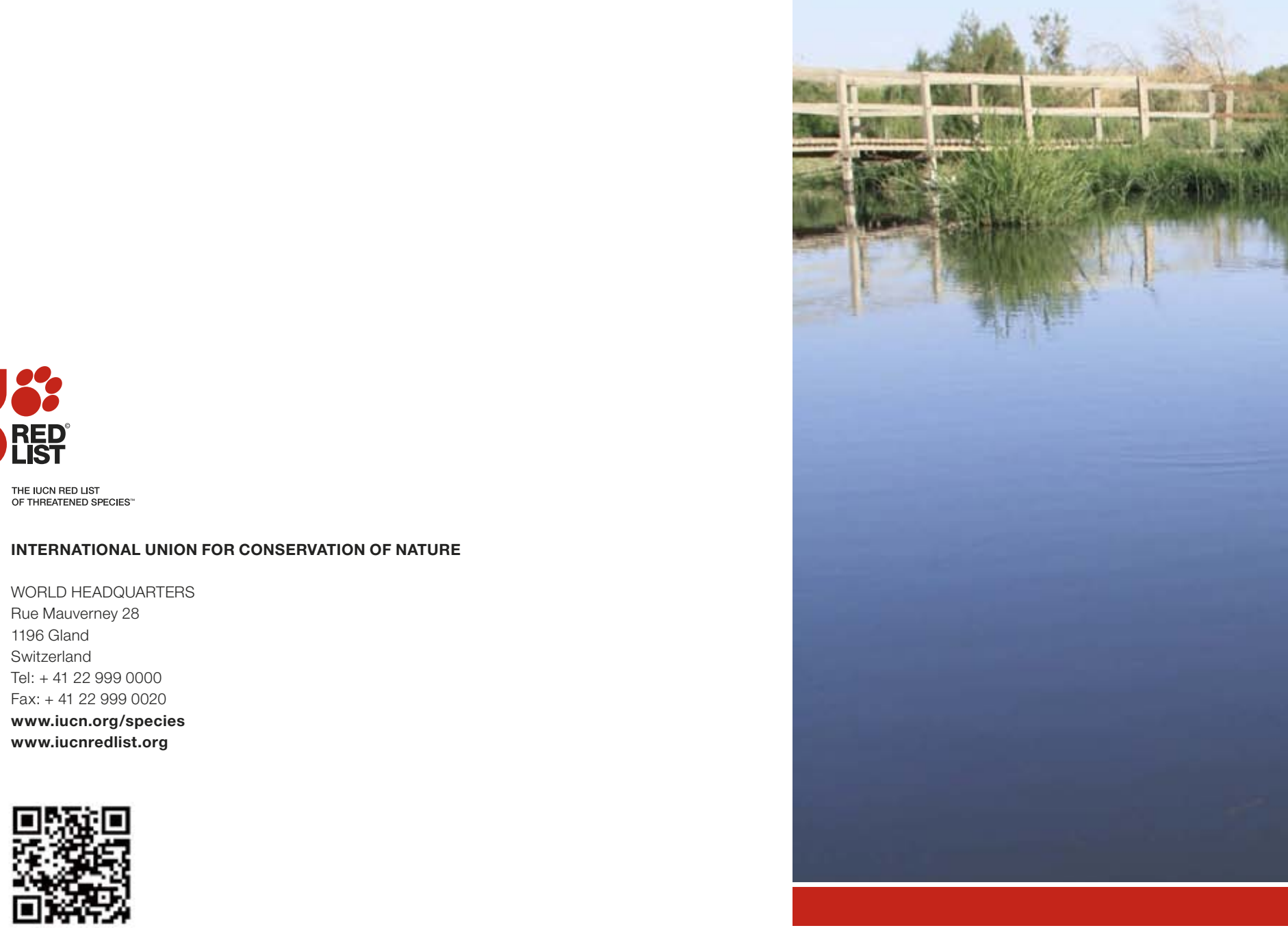